Universidad Nacional de La Plata

FACULTAD DE HUMANIDADES Y CiENCIAS DE LA EDUCACIÓN SeCRETARÍA de Posgrado

Inmigración, política y memoria.

La Fiesta Provincial del Inmigrante (Berisso, 1978-2015): un ritual conmemorativo a través del cual la comunidad se imagina a sí misma

Herrera Nicolás

Tesis para optar por el grado de Doctor en Ciencias Sociales

Directora Patricia Flier, FaHCE-UNLP

La Plata, 01 de Diciembre de 2017 


\section{Índice}

Agradecimientos.

Páginas 4-6)

Resumen y palabras claves

(Página 7)

Introducción

(Paginas 8 - 17)

1. Objeto, tema y objetivo general de la investigación: un recorrido personal hasta ellos

2. Estructura de la tesis

\section{Primera Parte}

1. Marco Teórico: Rituales conmemorativos, comunidad e imaginarios sociales (Páginas 18 - 45)

1.1. Irracionalidad, sentidos y orden social

1.2. Ritual y reproducción social

1.3. Ritual y cambio social

1.4. La fiesta en clave ritual

1.5. Críticas a la visión dicotómica

1.6. Rituales conmemorativos, comunidad e imaginarios sociales

1.7. Una toma de postura y su caracterización: nociones fuertes, débiles, seculares y religiosas del ritual

2. Estado de la Cuestión: un recorrido por los antecedentes................................................ (Páginas 46 - 60)

2.1. El campo de los estudios migratorios de la Argentina: inmigración y memoria

2.2. La fiesta como objeto de investigación en el campo de los estudios migratorios de la Argentina

2.3. La fiesta como objeto de investigación en el campo historiográfico de la Argentina

3. Estrategia Metodológica: entre lo cualitativo y lo cuantitativo (Páginas 61 - 67)

3.1. Recorte espacio/temporal y ejes de investigación

3.2. La metodología elegida, las técnicas utilizadas y las fuentes consultadas

3.3. Consideraciones sobre la ética en la investigación

\section{Reflexiones finales}




\section{Segunda Parte}

Capítulo № 1: Inmigración y Estado en la Argentina (Páginas 69 - 81)

1. Inmigración y Estado en la Argentina: cuatro grandes períodos

1.1. 1830-1880: El inicio de un largo y sostenido proceso de inmigración europea hacia la Argentina

1.2. 1880-1914: El período de la inmigración masiva

1.3. 1918-1960: El descenso de los flujos migratorios hacia la Argentina

1.4. 1960-2010: La visibilización de la inmigración latinoamericana

2. Reflexiones finales

Capítulo № 2: Berisso: Inmigración, asociacionismo étnico, trabajo e identidad política.

(Páginas 82 - 103)

1. Berisso: inmigración, trabajo y política

1.1. 1871-1936: La proliferación de identificaciones étnico-nacionales

1.2. 1936-1955: La proliferación de identificaciones político-clasistas

1.3. 1955-1983: El declive de identificaciones político-clasistas y el renacer de identificaciones étnico-nacionales

1.4. 1983-2015: Continuidad en las identificaciones políticas y cambios en las dinámicas migratorias

2. Reflexiones finales

Capítulo No 3 El origen de la Fiesta Provincial del Inmigrante. Recuerdos, olvidos y silencios de un pasado en disputa. (Páginas 104 - 122)

1. Disputas por el origen: ¿Cuándo, quiénes y por qué participaron en el origen de la fiesta?

2. ¿Qué debía ser conmemorado (recordado/olvidado)? imaginar la comunidad a partir de sus recuerdos y olvidos

3. Sobre los silencios

4. Reflexiones finales

Capítulo $\mathrm{N}^{\circ}$ 4: Memoria escrita, sentidos conmemorativos e imaginarios sobre la comunidad. Un análisis de las Gacetillas Oficiales de la Fiesta Provincial del Inmigrante. (Páginas 123 - 140)

1. Las editoriales publicadas en las Gacetillas Oficiales de la fiesta

1.1. La última dictadura cívico-militar: entre septiembre de 1980 y septiembre de 1983

1.2. El restablecimiento democrático: entre septiembre de 1984 y septiembre de 1989

1.3. Los años 90: entre septiembre de 1990 y septiembre del 2002

1.4. Post crisis del año 2001: entre septiembre del 2003 y septiembre del 2015 
2. Reflexiones finales

Capítulo No 5: La Fiesta Provincial del Inmigrante (2010-2015): la reconstrucción de un imaginario armónico, acrisolado y peronista

(Páginas 141 - 180)

1. Celebración Litúrgica Ecuménica: la misa

2. Encendido de la Lámpara Votiva y Posta del Inmigrante

3. Desembarco Simbólico: el puerto

4. Sobre el Centro Cívico: monumentos, bustos, murales y la Carpa de las Colectividades

5. Desfile de Clausura

6. Reflexiones finales

Excurso No 1: El Aniversario de Berisso

(Páginas 181 - 183)

Capítulo No 6: La Fiesta Provincial del Inmigrante (2010-2015): disputas, exclusiones y conflictos

.(Páginas 184 - 219)

1. Disputas: caboverdeanos

1.1. "Es un quilombo, pero no pueden irse"

1.2. "Lo que costo entrar, las que sufrimos acá"

1.3. Ser parte de, sin ser lo mismo que: usos del pasado y tradiciones culturales

2. Exclusiones: inmigrantes latinoamericanos

2.1. "Queremos que esto se revierta"

3. Conflictos: partidos políticos y ambientalistas

3.1 "A donde está, a dónde está, la democracia de Slezack"

4. Reflexiones finales

Excurso № 2: El equívoco de María (Páginas 220 - 222)

Conclusiones. .(Páginas 223 - 235)

Bibliografía ..(Páginas 236 - 268)

Anexos

(Páginas 269 - 317)

1. Anexo $\mathrm{N}^{\circ} 1$ : Berisso, ubicación geográfica y barrios de la ciudad

2. Anexo $\mathrm{N}^{\circ}$ 2: Asociaciones étnicas, calles y lugares históricos de Berisso

3. Anexo No 3: Población extranjera en Berisso (censos, 1991, 2001, 2010)

4. Anexo $\mathrm{N}^{\circ} 4$ : Georreferenciación de la población de origen extranjero residente en Berisso (censo del 2010)

5. Anexo $N^{\circ}$ 5: Asociación de Entidades Extranjeras (AEE)

6. Anexo $\mathrm{N}^{\circ}$ 6: Bandera y Escudo de Berisso

7. Anexo $N^{\circ} 7$ : Fotográfico de la Fiesta Provincial del Inmigrante 


\section{Agradecimientos}

Como toda construcción social, la del conocimiento científico nunca es una tarea individual. Es por esto que quisiera agradecer a las instituciones y personas que me brindaron su apoyo para realizar esta tesis.

En términos institucionales la tesis fue posible gracias a los conocimientos aprehendidos a lo largo del Doctorado en Ciencias Sociales y el financiamiento que me otorgaron la UNLP y el CONICET a través de distintas becas de formación. Dentro de ese marco institucional quisiera agradecer particularmente a Juan Ignacio Piovani, director del mencionado posgrado (en el cual trabajé como secretario), co-director de mis becas UNLP y CONICET, co-director en mi tesina de Licenciatura en Sociología, director de los proyectos de investigación en los que participé durante muchos años y quién me brindó la posibilidad de comenzar mi formación docente siendo adscripto en uno de los seminario de grado que dictaba en la FaHCE-UNLP. Su generosidad, inteligencia y honestidad intelectual son características que pocas veces aparecen conjugadas en una sola persona. Un lugar especial en estos agradecimientos ocupan dos docentes del Doctorado en Ciencias Sociales, quienes en los seminarios de tesis I y II me ayudaron a comprender cuál era el centro de mi investigación (Sebastián Benítez Larghi) y me incentivaron a terminarla (Leticia Muñiz Terra). Finalmente quisiera agradecerles a algunos de mis compañeros, con quienes no solo compartimos muchas horas de cursada sino otras tantas leyendo los textos de cada seminario y escribiendo los trabajos finales: Nicolás Aliano, Martín Castilla, Andrés Stefoni.

Quisiera hacer una mención al CIMeCS (FaHCE-UNLP/IdHICS-CONICET) y en especial a su directora, Amalia Eguía. Dicho centro de investigación fue el lugar en el cual pude compartir y discutir los avances de mi trabajo de campo con total libertad, rodeado de todos los insumos necesarios. Nunca faltó nada: ni libros, ni computadoras, ni fotocopiadoras, ni scaner. Ni mate. Tampoco faltó el buen clima de trabajo. Ni los almuerzos en los que parecía existir una implícita regla de convivencia que prohibía continuar hablando de trabajo. A veces me faltó el silencio, pero por suerte Amalia había conseguido que el CIMeCS tuviera dos oficinas. Entré como becario a dicho centro de investigación cuando ella era su directora y desarrollé toda mi formación de posgrado durante su gestión. No solo estuvo atenta a preguntarme (asiduamente) "cómo iba" con mi trabajo, sino que además siempre se brindó con total amabilidad e inteligencia ante cualquier consulta que le formulara. $Y$ no fueron pocas. Sinceramente, ha sido un placer trabajar en un centro de investigación dirigido por ella. 
Amalia además leyó uno de los capítulos centrales de esta tesis, haciéndome sugerencias, correcciones y aportes de sumo valor. Lo mismo vale para Andrés Bisso y Emmanuel Kahan, a quienes hago extensivo mi agradecimiento por leer de manera atenta, incisiva y creativa algunas partes de la tesis. En esta línea agradezco a los compañeros y compañeras del proyecto de investigación que dirige Patricia Flier, quienes se encargaron de comentar y discutir algunos de mis borradores iniciales en un clima de absoluta cordialidad. En este marco un lugar destacado ocupa Patricia Flier. No quisiera abundar en elogios sobre su rol como directora, simplemente señalar que sin su apoyo personal e institucional esta tesis no habría sido entregada en este momento. No solo me dijo "qué era lo que tenía que hacer" para cerrar la tesis, sino que supo escuchar "qué era lo que yo quería hacer" con la tesis. Nunca me frenó el desarrollo de la escritura, con esas posturas tan habituales en nuestro medio académico a partir de las cuales alguien te señala "lo que le falta a tu trabajo" sin darte las herramientas para poder solucionarlo. Frente a esos posicionamientos paralizantes, centrados en la falta, la carencia o la ausencia, Patricia apostó a que continuara solidificando lo que mi trabajo tenía. Tampoco lo midió con la regla de su formación disciplinar, historiográfica, sino que en todo momento respetó mi formación sociológica e incentivó el diálogo interdisciplinar. Por todo lo anterior, por haber creado un espacio institucional como el PIEMER (Programa Interinstitucional de Estudios sobre Migraciones, Exilios y Refugios, IdHICS/CONICET-UNLP) y seguir apostando al desarrollo de mi carrera académica, muchas gracias.

Quiero agradecerles también a las antropólogas Marta Maffia y Paola Monkevicius, quienes dirigieron mi tesis de Maestría en Sociología de la Cultura (IDAES-UNSAM). Trabajo que constituyó un piso (muy alto) a partir del cual proyectarme hacia la instancia doctoral. Haciendo que ese pasaje fuera menos costoso. Por otra parte quiero agradecerles a todas las personas que durante el proceso de investigación me brindaron información de sumo valor y, centralmente, su tiempo. Los miembros de la colectividad caboverdeana de Ensenada, personas que organizaron las primeras ediciones de la Fiesta Provincial del Inmigrante, empleados de la Dirección de Estadística de la Provincia de Buenos Aires y algunos colegas/amigos fueron fundamentales para construir, completar, procesar, editar, graficar y georreferenciar el material de la tesis. A todos ellos, pero especialmente a Santiago Sosa, Luis Sosa, Javier Botana, Stella Loholaberry, Paula Celestino, Martín Urtasum y Lucas Alzugaray, muchísimas gracias.

Finalmente, y no por eso menos importante, quisiera agradecerles a mis afectos más cercanos: a Leyla (y toda su familia), a Roberto, Analía, Francisco, Claudia, Ava, 
Lito y Mafalda. A mis tíos y primos (de La Plata, Tandil y Necochea) por acompañarme desde el cariño y alentarme para que finalizara la tesis. A mis amigos, Faca, Pedro, Pato, Tato, Hernán, Leandro y Nahuel, por escucharme decir (muchas veces) que estaba realmente complicado con la tesis y responderme (siempre) que me dejara de "molestar" con la tesis. Gracias. 


\section{Resumen}

Influidas por distintas teorías antropológicas del ritual, la historia y la sociología encontraron en las fiestas conmemorativas un objeto de estudio privilegiado a la hora de analizar el modo en que las sociedades -al dramatizar sus mitos de origenreconstruyen un imaginario sobre sí mismas. Asumiendo que la dramaturgia del poder no es ajena a su funcionamiento, el estudio de las fiestas conmemorativas ha constituido una vía de acceso para conocer cómo la apelación a ciertos hechos del pasado forma parte de las estrategias a través de las cuales los actores disputan un conjunto de recursos simbólicos ligados a la estructuración social del presente: prestigio, legitimidad, reconocimiento, honor, respeto, etc. Así, y lejos de ser una instancia de ocio improductivo en la cual se desarrollarían prácticas lúdicas o irreflexivas, las fiestas conmemorativas permiten comprender cómo se representan -en el plano simbólico- las desigualdades sociales.

Siguiendo esta línea de interrogación, la Fiesta Provincial del Inmigrante (Berisso, 1978-2015) ha sido el objeto de investigación elegido a partir del cual analizaremos cómo los descendientes de inmigrantes ultramarinos reunidos en las asociaciones étnicas locales y los intendentes municipales que gobernaron la ciudad, reconstruyeron un imaginario armónico sobre Berisso. Así, la Fiesta Provincial del Inmigrante será entendida como un ritual conmemorativo a través del cual la comunidad berissense, al imaginarse, se produce a sí misma. Un contexto donde dichos actores apelan a hechos del pasado local para recordar, silenciar $u$ olvidar sus dos mitos de origen: un origen mítico de la comunidad ligado a la inmigración europea y el rol que ella habría jugado en los orígenes míticos del peronismo. Ese será el tema de investigación dentro del cual se inserta la tesis: la constitución imaginaria de la sociedad a través de sus fiestas. Formas de representar lo social que encierran, lógicamente, procesos de reproducción y cambio del orden social. Disputas, exclusiones, conflictos. En este marco temático y contextual, el objetivo general de la tesis es comprender el rol que juega el pasado en la producción de un imaginario sobre Berisso: ¿qué lugar ocupa, cómo es utilizado, en qué soportes se materializa, a través de qué canales se lo exterioriza, a quiénes se recuerda u olvida, qué hechos son rememorados, qué recursos simbólicos se disputan a través de él y qué procesos sociales del presente orientan su utilización?

Palabras claves: Berisso, Fiesta, Inmigración, Memoria, Comunidad, Imaginarios 


\section{Introducción}

\section{Objeto, tema y objetivo general de la investigación: un recorrido personal hasta ellos}

Influidas por distintas teorías antropológicas del ritual, la historia y la sociología encontraron en las fiestas conmemorativas un objeto de estudio privilegiado a la hora de analizar el modo en que las sociedades -al dramatizar sus mitos de origenreconstruyen un imaginario sobre sí mismas. Asumiendo que la dramaturgia del poder no es ajena a su funcionamiento, el estudio de las fiestas conmemorativas ha constituido una vía de acceso para conocer cómo la apelación a ciertos hechos del pasado forma parte de las estrategias a través de las cuales los actores disputan un conjunto de recursos simbólicos ligados a la estructuración social del presente: prestigio, legitimidad, reconocimiento, honor, respeto, etc. Así, y lejos de ser una instancia de ocio improductivo en la cual se desarrollarían prácticas lúdicas o irreflexivas, las fiestas conmemorativas permiten comprender cómo se representan -en el plano simbólico- las desigualdades sociales.

Siguiendo esta línea de interrogación, la Fiesta Provincial del Inmigrante (Berisso, 1978-2015) ha sido el objeto de investigación elegido a partir del cual analizaremos cómo los descendientes de inmigrantes ultramarinos reunidos en las asociaciones étnicas locales y los intendentes municipales que gobernaron la ciudad, reconstruyeron un imaginario armónico sobre Berisso. Así, la Fiesta Provincial del Inmigrante será entendida como un ritual conmemorativo a través del cual la comunidad berissense, al imaginarse, se produce a sí misma. Un contexto donde dichos actores apelan a hechos del pasado local para recordar, silenciar u olvidar sus dos mitos de origen: un origen mítico de la comunidad ligado a la inmigración europea y el rol que ella habría jugado en los orígenes míticos del peronismo. Ese será el tema de investigación dentro del cual se inserta la tesis: la constitución imaginaria de la sociedad a través de sus fiestas. Formas de representar lo social que encierran, lógicamente, procesos de reproducción y cambio del orden social. Disputas, exclusiones, conflictos.

En este marco temático y contextual, el objetivo general de la tesis es comprender el rol que juega el pasado en la producción de un imaginario sobre Berisso: ¿qué lugar ocupa, cómo es utilizado, en qué soportes se materializa, a través de qué canales se lo exterioriza, a quiénes se recuerda u olvida, qué hechos son 
rememorados, qué recursos simbólicos se disputan a través de él y qué procesos sociales del presente orientan su utilización?

Antes de ingresar en los ejes centrales de la tesis, nos parece fundamental señalar que esta investigación es producto de la confluencia entre un conjunto de perspectivas teórico-metodológicas aprehendidas a lo largo de mi trayectoria académica y distintas experiencias personales. Experiencias que al ser ordenadas intelectualmente por dichas perspectivas se volvieron fundamentales en la construcción del conocimiento sociológico que sostiene la tesis. Como sabemos la relación entre el conocimiento científico y la experiencia personal de quien lo construye está lejos de ser una novedad: el primer texto que leí como alumno de la Licenciatura en Sociología (FaHCE-UNLP) -y desde hace algunos años enseño como docente de esa carrera- lo planteaba claramente. Allí, en La imaginación sociológica, Mills [1959 (1994: 206-207, 6)] señalaba que los sociólogos más reconocidos no "separaban sus trabajos de sus vidas. Parecen tomar ambas cosas demasiado en serio para permitirse tal disociación y desean emplear cada una de ellas para enriquecer a la otra". Las preocupaciones de esos sociólogos (y las del propio Mills) se ubicaban en el punto exacto donde la historia y la biografía convergen, en el lugar donde las "preocupaciones personales del ambiente" se cruzan con "las cuestiones públicas de la estructuración social". Así, Mills les recomendaba a los futuros sociólogos que aprendieran a usar sus experiencias personales para la producción intelectual, examinándola e interpretándola sin cesar.

Cuando a principios del año 2009 me mude a Berisso ${ }^{1}$ lo primero que llamó mi atención fue la enorme cantidad de relatos que unían la historia de la ciudad con la llegada de inmigrantes ultramarinos y el surgimiento del peronismo. En pocas cuadras era posible ver varios bustos de Juan Domingo Perón y Eva Duarte de Perón, murales con imágenes y frases icónicas de la simbología peronista y placas recordatorias que definían a Berisso como la "Capital del Peronismo", su "Km. 0", señalando que desde ese "histórico lugar" habían partido "las primeras columnas de trabajadores argentinos que liberaron al Coronel Juan Domingo Perón en su glorioso 17 de octubre de 1945".

\footnotetext{
${ }^{1}$ Exactamente a Villa Argüello, uno de los barrios de la periferia sur de Berisso (ver Anexo № 1, “Berisso, ubicación geográfica y barrios de la ciudad").
} 


\section{Marcas territoriales de la memoria ligadas al Peronismo (bustos, murales y placas)}
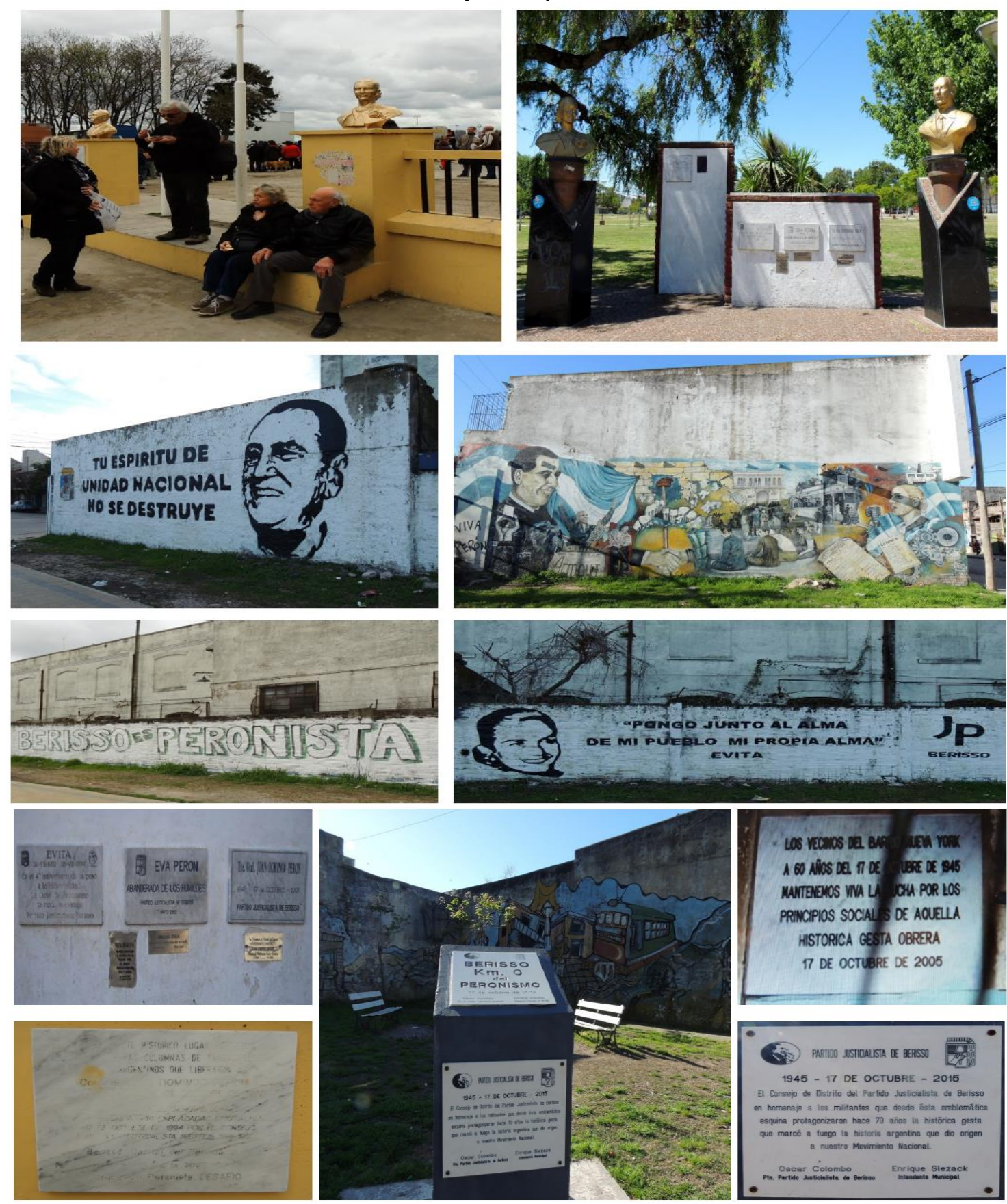

Fuente: propia

Pero a la vez, durante el mismo recorrido era imposible dejar de ver los murales y monumentos que recordaban el arribo de inmigrantes ultramarinos al puerto local, carteles viales que definían a Berisso como la "Capital Provincial del Inmigrante", anclas situadas en distintos espacios públicos que recordaban el origen ultramarino de la comunidad, personas vestidas con los "trajes típicos" de distintas nacionalidades y una enorme cantidad de asociaciones étnicas funcionando en un espacio limitado de su territorio. Recorrido que a su vez me llevaba por calles cuyos nombres remitían a 
ciudades y países extranjeros: Nueva York, Marsella, Londres, Constantinopla, Atenas, Cádiz, Hamburgo, Génova, Lisboa, Bilbao, Belfast, Italia, Polonia, República Árabe Unida, Grecia, República del Líbano, Yugoslavia, Albania, Rumania, Portugal, etc. $^{2}$

\section{Marcas territoriales ligadas a la Inmigración ultramarina (monumentos, anclas, carteles, murales)}
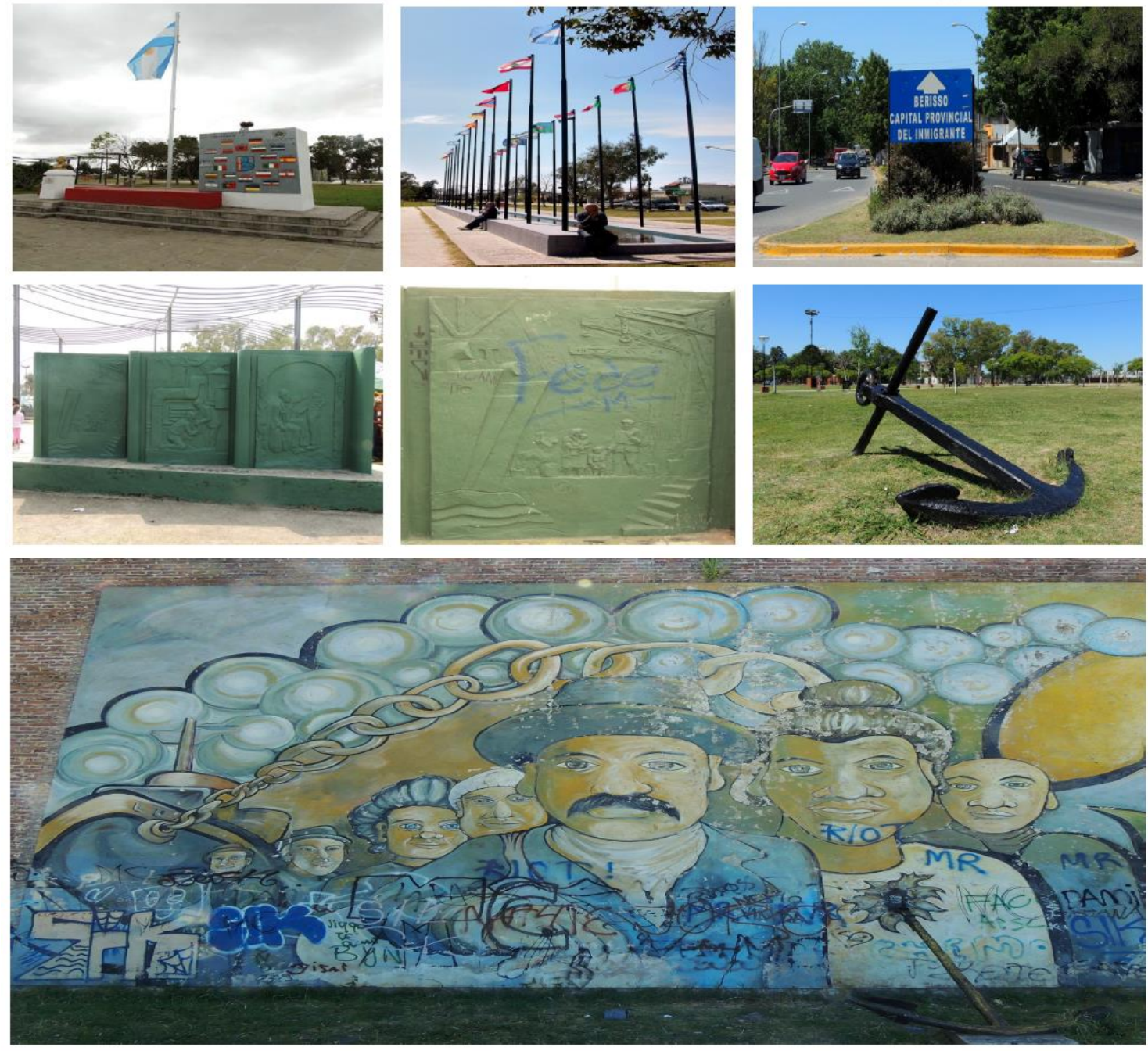

Fuente: propia

Lejos de agotarse ahí -en estas marcas territoriales de la memoria (Jelin y Langland, 2003; Messina, 2011)- las referencias hacia la inmigración ultramarina y el peronismo surgían en las charlas que mantenía con mis vecinos. Al preguntarles sobre la historia de la ciudad me señalaban que ella había sido "la cuna del peronismo" y luego de narrar distintas anécdotas donde "los polacos", los "turcos", "los tanos", "los gallegos", etc. tenían un lugar central- afirmaban que Berisso era la "capital provincial

\footnotetext{
${ }^{2}$ Para ver una representación social del espacio en la cual están señaladas las asociaciones étnicas que participan de la Fiesta Provincial del Inmigrante y los nombres de las calles de Berisso, ver Anexo № 2: "Asociaciones Étnicas, calles y lugares históricos de Berisso".
} 
del inmigrante". No solo la comunidad se narraba a sí misma recordando al peronismo y a la inmigración ultramarina sino que para estos actores, identificarse como berissenses, implicaba realizar un trabajo de memoria (Jelin, 2002a).

Por suerte, la singularidad y extensión de estos procesos habían llamado la atención de otros cientistas sociales. Al trabajar sobre la memoria de los pobladores locales Lobato (2004) advirtió que no solo existía en Berisso una práctica social de conmemoración articulada por la llegada de inmigrantes ultramarinos y el surgimiento del peronismo, sino que dicha práctica constituía un elemento clave del proceso a través del cual la comunidad se re-construía a sí misma:

"En las evocaciones (no importa si históricas o míticas), Berisso se había estructurado como comunidad a partir del trabajo y la lucha de una población que había parido al peronismo en la movilización del 17 de octubre de 1945, así como alrededor del esfuerzo de los inmigrantes que llegaron al lugar en las primeras décadas del siglo XX. (...) Ambas construcciones se enlazan y enfrentaban operando simultáneamente sobre la población local." (Lobato, 2004: 14)

Revisando la bibliografía especializada sobre Berisso noté que su vínculo con los orígenes del peronismo y las prácticas conmemorativas a través de las cuales la comunidad se imaginaba a sí misma apelando a dicho pasado, habían sido extensamente estudiados (Germani, 1968; Mora y Araujo y Llorente, 1980; Del Campo, 1983; James y Wolfson, 1987; Torre, 1988, 1990, 1995; Lobato, 2004; James, 2004; González, 2010; lucci, 2012, 2015; Bretal, 2014; entre otros). Sin embargo la historia inmigratoria de Berisso -ciudad que a principios del siglo XX llegó a estar compuesta en un $60 \%$ por extranjeros- y las prácticas conmemorativas a través de las cuales la comunidad era imaginada mediante la apelación a este pasado, habían sido escasamente indagadas. Investigaciones que además, al estar centradas en la construcción de memorias étnicas al interior de una colectividad en particular (Zubrzycki, 2001, 2002; Ballina, 2005, 2006; Monkevicius, 2009, 2011), no habían analizado aquellas prácticas de recordación vinculadas al pasado inmigratorio de la ciudad que estuvieran articuladas por varias asociaciones étnicas. Fue así que decidí, inicialmente, direccionar mis preocupaciones académicas hacía la historia de la inmigración en Berisso.

Al preguntarme dónde estaban esos inmigrantes a los cuales mis vecinos hacian referencia, comencé a notar que los mismos se encontraban presentes (como mínimo) en sus relatos orales, en los monumentos y en los murales de la ciudad. Y si bien allí se los recordaba en tiempo pasado, habitualmente se los mencionaba en tiempo presente. Habían estado ahí y de alguna manera seguían estando. Con el correr de 
los meses noté que las referencias hacia "los inmigrantes" se volvían habituales y diariamente veía gente caminando por la ciudad con los "trajes típicos" de distintas nacionalidades. Finalmente, hacia mediados del año 2009 decidí preguntarle a mis vecinos si "eso" era parte de mis percepciones o efectivamente "pasaba algo": la sorpresa con la que me respondieron que sí, que efectivamente sucedía algo, no solo me informó que en pocas semanas comenzaba una nueva edición de la Fiesta Provincial del Inmigrante sino que ellos daban por descontado que yo debía saberlo. Al parecer nadie que viviera en la ciudad o quisiera conocer algo de su historia inmigratoria podía desconocer la existencia de "La Fiesta". Evidentemente, si quería analizar alguna dimensión significativa de la relación que existía entre Berisso y la inmigración debía ir a "La Fiesta". Y no solo por mi pretensión de conocimiento sino porque para los propios actores ahí se jugaba algo.

Así, la lectura de aquella bibliografía y los hechos narrados anteriormente fueron centrales para que decidiera centrar mi investigación en una práctica social de conmemoración a través de la cual un conjunto de actores institucionales reponen un imaginario sobre la comunidad apelando a su origen inmigratorio: la Fiesta Provincial del Inmigrante. Un ritual conmemorativo en el cual los descendientes de inmigrantes ultramarinos reunidos en las asociaciones étnicas locales y los representantes de la intendencia municipal ponen en circulación un conjunto de relatos sobre el pasado de Berisso. Una fiesta organizada por actores que no transitaron por la experiencia migratoria. Argentinos, descendientes de inmigrantes, que acceden y se vinculan con dicho pasado (un pasado trasmitido) mediante una representación simbólica, un acto de memoria. De esta manera, sin ser una tesis sobre el origen inmigratorio de la sociedad berissense, nos interesa analizar cómo la apelación a dicho mito de origen forma parte de los recursos mnemónicos a través de los cuales estos actores construyen un imaginario que les permite intervenir en el presente. Un pasado a partir del cual demarcan y definen "lo auténticamente berissense". Un origen que insnstituye, a la vez, un eje de agregación social y un recurso fundamental para la construcción de su propia legitimidad, prestigio y reconocimiento social.

\section{Estructura de la tesis}

Hemos dividido la tesis en dos grandes partes. La primera reúne el Marco Teórico, el Estado de la Cuestión y la Estrategia Metodológica. La segunda -dividida a su vez en seis capítulos- está íntegramente dedicada a describir, analizar y comprender un conjunto de dimensiones centrales del tema y el objeto de estudio. El diálogo entre 
ambas partes es fundamental para alcanzar el objetivo general que nos hemos planteado y responder algunas de las preguntas que guiaron la investigación: ¿A través de qué prácticas una sociedad representa sus propios orígenes? ¿Qué lugar ocupan los rituales conmemorativos en esa dinámica? ¿Cuál es el rol que tienen estos rituales en los procesos de reproducción y cambio social? ¿Qué forma de comunidad invoca, actualiza o instaura la Fiesta Provincial del Inmigrante? ¿Quiénes participan de ella? ¿Qué hechos y actores del pasado se recuerdan? ¿Cómo se incorporan esos hechos y actores a la versión oficial del pasado local? ¿A quiénes incluye/excluye? ¿A través de qué prácticas la memoria escenificada en la fiesta valida la estructuración social del presente? ¿Qué disputas, silencios y conflictos habilita dicha conmemoración? ¿Cómo se expresan en ella las memorias subalternas? ¿Existe homogeneidad en los sentidos otorgados a lo conmemorado o la conmemoración se vuelve el espacio en el cual se disputan sentidos sobre lo conmemorado? Y finalmente ¿cuáles son los procesos sociales del presente que orientan la representación ritual del pasado?

Respecto a la primera parte de la tesis, en el Marco Teórico abordamos un conjunto de teorías socio-antropológicas del ritual que al haber enmarcado el estudio empírico del fenómeno festivo, nos permitirán definir a la Fiesta Provincial del Inmigrante como un ritual conmemorativo. Luego de repasar la perspectiva teórica de algunos autores que analizaron la relación entre ritual e irracionalidad, vinculamos nuestra investigación con autores que (distanciándose de la perspectiva anterior) analizaron la relación entre ritual y estructuración social. Si bien esta relación mayoritariamente fue indagada en términos dicotómicos (entre quienes vieron en el ritual un modo de reproducir el orden social y quienes vieron en él un modo de subvertirlo) adoptamos la perspectiva teórica de autores que superaron dicha dicotomía postulando la existencia simultánea -es decir, en un mismo contexto ritualde prácticas tendientes a la reproducción y al cambio de la estructuración social.

Seguidamente, partiendo del carácter conmemorativo del ritual analizado, abordamos la relación entre ritual y memoria preguntándonos por el rol que juega el pasado en aquellas prácticas sociales a través de las cuales una comunidad se imagina a sí misma. En ese marco presentamos la perspectiva teórica de Weber (1998 [1922]) sobre el concepto de comunidad y el modo en que según Anderson (2007) ellas, para constituirse, deben imaginarse. Así, ritual conmemorativo, comunidad e imaginarios sociales serán los conceptos teóricos a partir de los cuales analizaremos a la Fiesta Provincial del Inmigrante. Pese a ser un apartado puramente teórico, el recorrido propuesto pretende alejarse del "fetichismo teoricista" que aísla la 
construcción conceptual del análisis empírico (Bourdieu y Wacquant, 2008). Frente a él buscaremos mostrar el valor heurístico que dichos conceptos tienen a la hora de estudiar empíricamente una festividad (Muir, 2001).

Teniendo en cuenta que el pasado inmigratorio de Berisso se vuelve un elemento constitutivo del imaginario dramatizado anualmente en la fiesta, hemos decidido insertar nuestra tesis dentro del campo de los estudios migratorios de la Argentina. Sin embargo lo haremos desde un objeto de estudio con escasos antecedentes en él: las fiestas conmemorativas desarrolladas por descendientes de inmigrantes ultramarinos. Así, con el objetivo de poner en diálogo nuestra investigación con trabajos afines, en el Estado de la Cuestión recorremos un conjunto de antecedentes que indagaron temáticas similares. De manera subsidiaria abordamos algunos trabajos del campo historiográfico de la Argentina que nos aportaron significativas líneas de interrogación sobre el modo en que las fiestas patrias repusieron, en la esfera pública, distintos mitos sobre el origen de nuestra nacionalidad. La primera parte de la tesis se cierra con una presentación de la Estrategia Metodológica utilizada a lo largo de nuestra investigación. Allí no solo describimos las técnicas utilizadas y las fuentes consultadas, sino que además presentamos algunas reflexiones sobre la ética en el proceso de investigación.

Como dijimos anteriormente, la segunda parte de la tesis está íntegramente dedicada a describir, analizar y comprender un conjunto de dimensiones centrales del tema y el objeto de nuestra investigación. Así, en el primer capítulo reconstruimos sintéticamente los ejes centrales de la historia inmigratoria de la Argentina. Utilizando fuentes secundarias y adoptando una periodización que se ha vuelto canónica dentro del campo de los estudios migratorios, ese capítulo tiene como objetivo específico brindarnos un marco general a partir del cual -en el segundo capítulocontextualizaremos las dinámicas migratorias que caracterizaron a la ciudad de Berisso a lo largo de todo un siglo (1909-2010). Pasando de la escala nacional a la escala local, en dicho capítulo analizaremos el surgimiento, la consolidación y la decadencia del asociacionismo étnico y el sistema fabril berissense, haciendo énfasis en las tensiones que a lo largo del siglo $X X$ se produjeron entre las identificaciones étnicas y las identificaciones políticas. Este análisis será fundamental para comprender -en los capítulos siguientes- la construcción de memorias oficiales y los usos sociales del pasado que realizaron los descendientes de inmigrantes ultramarinos reunidos en las asociaciones étnicas locales y los representantes de la intendencia municipal durante las distintas ediciones de la Fiesta Provincial del Inmigrante (1978-2015). 
En el tercer capítulo contextualizamos el origen de esta fiesta durante la última dictadura, analizando el rol que en ese proceso fundacional tuvieron el intendente de Berisso y algunos miembros de las asociaciones étnicas locales. A partir de testimonios orales y textos escritos por algunos de los actores que participaron del origen de la fiesta, la segunda parte del capítulo está dedicada a analizar cómo dicho pasado se ha vuelto objeto de reinterpretaciones y disputas. Las fechas, los contextos, los motivos por los cuales fue sido creada y los actores señalados como centrales en ese proceso fundacional se encuentran atravesados por diferentes lecturas sobre su origen.

Tomando como corpus de análisis las Gacetillas Oficial de la fiesta publicadas entre 1980 y 2015, el cuarto capítulo está dedicado a analizar diacrónicamente los sentidos que los representantes de las asociaciones étnicas locales y los intendentes municipales le otorgaron la fiesta. Este soporte de la memoria escrita no solo conforma un archivo en el cual quedan depositadas representaciones y sentidos sobre el pasado de Berisso, sino que constituye un canal privilegiado para trasmitirlos hacia la esfera pública durante el contexto festivo. En ese marco veremos cómo dichos actores institucionales construyeron un imaginario sobre la comunidad berissense apelando a su propio pasado. Así, nos interesa preguntarnos qué hechos del pasado son seleccionados y traídos al presente en cada edición de la fiesta y cómo operan esos recuerdos en la construcción de un imaginario sobre la comunidad.

Los capítulos cinco y seis contienen los resultados de una etnografía elaborada en La Fiesta Provincial del Inmigrante durante el período 2010-2015. Siguiendo el marco teórico elegido, la decisión de dividir el material de campo en dos capítulos se corresponde con la necesidad de analizar empíricamente la existencia de prácticas tendientes a la reproducción y al cambio de la estructuración social en un mismo ritual. Teniendo en claro que en la práctica estos procesos no se encuentran separados (sin justamente tensionados), a los fines analíticos y expositivos de nuestro argumento fue necesario diferenciarlos en dos capítulos diferentes.

Así, en el quinto capítulo analizamos las prácticas y discurso orales mediante las cuales los descendientes de inmigrantes ultramarinos reunidos en las asociaciones étnicas locales y los representantes de la intendencia municipal construyeron un imaginario sobre la comunidad berissense apelando a hechos de su propio pasado. Imaginario que -dramatizado a partir de escenificación pública de la memoria oficialles permite reproducir los elementos simbólicos de la estructuración social. En tal sentido mostraremos el modo en que estos actores apelan a un conjunto de hechos 
del pasado (representando los orígenes étnicos/políticos de la comunidad) para construir un imaginario acrisolado y peronista que los sitúa en el centro de su historia. Al describir etnográficamente los cinco actos de la fiesta veremos cómo la selección de hechos del pasado permite dramatizar el pretendido origen ultramarino de una comunidad que, a su vez, habría dado origen al peronismo. El mito del crisol de razas (europeas/blancas) y las jornadas míticas del peronismo (17 de octubre) se volverán elementos centrales a partir de los cuales elaborar una lectura sobre la comunidad berissense que legitime las posiciones sociales de dichos actores.

Luego de haber resaltado la capacidad que posee la fiesta para construir un imaginario armónico, acrisolado y peronista sobre la comunidad berissense reproduciendo elementos simbólicos de su estructuración social mediante el uso de la memoria oficial- en el sexto capítulo llevamos a cabo un análisis de las disputas, exclusiones y conflictos que se expresaron en ella. En tal sentido daremos cuenta de las prácticas que desarrollan los descendientes de inmigrantes africanos (reunidos en la colectividad caboverdeana) para disputar visibilidad étnica. Asimismo describimos los conflictos desatados a partir de la negativa de los organizadores de la fiesta para permitirles el ingreso a las colectividades que reúnen a los inmigrantes latinoamericanos. Ambos actores, a través de distintas prácticas, cuestionarán los fundamentos (blancos/europeístas) del mito del crisol de razas a través del cual la comunidad es representada en contexto festivo. Finalmente presentamos algunos registros de campo sobre la irrupción de distintos partidos políticos y movimientos ambientalistas que cuestionaron, en contexto festivo, la legitimidad de una gestión municipal a cargo de peronismo.

Finalmente presentamos las conclusiones más significativas que se desprenden del contenido de la tesis, las cuales no pretenden resumir lo expuesto en cada uno de los capítulos sino reconstruir una mirada general sobre los procesos sociales que el estudio de la Fiesta Provincial del Inmigrante nos permitió comprender: la reproducción de un imaginario sobre la comunidad berissense y el rol que juega el pasado en las disputas de presente. Asimismo presentamos en dicho apartado algunos de los aportes que la investigación realiza al cruce entre inmigración, memoria e imaginarios sociales. Temas de investigación alrededor de los cuales se han constituidos sólidos campos académicos que no siempre dialogan entre sí. 


\section{Primer Parte}

\section{Marco Teórico: Rituales conmemorativos, comunidad e imaginarios sociales}

Al acercarnos al estudio de la fiesta, el recorrido por la bibliografía especializada nos mostró que la mayor parte de las investigaciones empíricas dialogan a nivel teórico con diversas teorías socio-antropológicas del ritual. De hecho, tal y como señalan Sevilla y Portal (2005), es frecuente encontrar un uso indistinto de "lo ritual" y "lo festivo" al interior de esa bibliografía. Debido a que nuestra tesis no pretende innovar en el uso de estos marcos teóricos y cada teoría del ritual ha influido de manera distinta en el estudio de la fiesta, consideramos necesario presentar un recorrido por ellas a fin de indicar cuáles fueron los temas y preguntas que, atravesándolas, aparecerán articulando el estudio empírico del fenómeno festivo.

\subsection{Irracionalidad, sentidos y orden social}

Al interior de los estudios sobre magia y religión realizados en sociedades tradicionales, la antropología victoriana y sus sucesores neotylorianos del siglo XX vieron en las prácticas rituales un modo de analizar las supuestas limitaciones y fantasías del -así llamado- "irracional pensamiento primitivo" (Díaz Cruz,1998). Tanto para Tylor como para Frazer

"los rituales son pensamientos actuados, creencias volcadas en acciones. No cualquier clase de creencia: les interesaron aquellas creencias primitivas no fundadas en razones objetivas y falsas por añadidura, pero que tienen el propósito, según ellos, de explicar, controlar y predecir el mundo" (Díaz Cruz, 1998: 26).

Influida por los descubrimientos de las ciencias naturales de mediados del siglo XIX, la naciente antropología buscó sustentar su legitimidad académica en la formulación de leyes universales que lograra describir el desarrollo evolutivo de la historia humana y, de ser posible, su sentido (Guber, 2009). Para esto adoptó un modelo explicativo de tipo evolucionista que -según ella- permitía analizar la existencia de un desarrollo histórico cuyo avance se produciría por estadios generalizables a toda la especie humana. Como bien señaló Evans-Pritchard (2006 [1962]), para construir leyes científicas y probar la existencia del progreso humano los antropólogos configuraron una hipotética escala del desarrollo social donde en uno de los extremos 
de la cronología histórica ubicaron a las sociedades denominadas primitivas y del otro, a las civilizadas. Así, con el pasaje de las formas primitivas a las modernas pretendieron demostrar la existencia de un progreso evolutivo en la racionalidad humana en el cual las prácticas indicadas como irracionales -entre ellas el ritual- irían perdiendo sus antiguas funciones sociales.

Mostrando que dicha perspectiva no estaba circunscripta a las filas de la antropología victoriana, Muir (2001) señaló que los grandes pensadores del modernismo -entre quienes reúne a Herbert Spencer, Max Weber y Edward Shilsentendían que el comportamiento ritual era incompatible con los valores modernos (racionalidad, individualismo, progreso) y por lo tanto ese comportamiento iría desapareciendo en la medida en que las sociedades europeas avanzaran hacia la modernidad. En el mismo gesto que empoderaba de plena racionalidad al observador neutral y despojaba de toda reflexividad al sujeto ritual ${ }^{3}$, el etnocentrismo de estas miradas pretendía comprobar la evolución de la racionalidad humana señalando la supuesta ausencia de rituales en la sociedad moderna: hijas del avance de la razón, las sociedades industriales irían eliminado de sí el error del pensamiento salvaje, y con él, al ritual.

Durante el siglo $\mathrm{XX}$ un conjunto de cientistas sociales provenientes de distintas corrientes teóricas buscaron alejarse de los postulados centrales de la perspectiva anterior. Sus renovadas claves de lectura no solo ayudaron a romper el vínculo que unía al ritual con lo irracional, sino además, a preguntarse por la relación que el ritual establece con la estructuración social. En este camino Malinowski (1986 [1922]) dio cuenta del sentido plenamente racional que había en la producción e intercambio ritual del Kula, y Geertz (2006a [1957]) explicó el sistema de apuestas que rodeaba a las riñas de gallos balinesas como una búsqueda plenamente racional de prestigio social. Asimismo, mientras Durkheim (2007 [1912]) había logrado describir la capacidad que los rituales totémicos tenían para cohesionar e integrar a los individuos -cumpliendo una función central en la reproducción del orden social-, Van Gennep (2008 [1908]) y Turner $(2008,1969$ [1967, 1988]) vieron en la instancia liminar del ritual la posibilidad de indagar el cambio, el tránsito entre instancias de socialización y el cuestionamiento al orden social.

Varios autores (Velasco, 1986; Ariño, 1996; Jaume, 2000; Muir, 2001; De Giorgi, 2014) señalan que una vez roto el vínculo entre ritual e irracionalidad la pregunta por

\footnotetext{
${ }^{3}$ Al respecto Díaz Cruz (1998:42) señala que tanto para Frazer como para Tylor los sujetos rituales no poseen la capacidad de diferenciar un objeto de su representación.
} 
la relación que el ritual establece con el orden social organizó las teorías dedicadas a su estudio en dos grandes tradiciones enfrentadas: mientras una de ellas vio en el ritual un mecanismo a través del cual la estructura social se ordena, repone jerárquicamente y cohesiona, la otra postuló que el ritual es una práctica social a través de la cual los actores cuestionan, revierten o disuelven momentáneamente la estructura social. Teniendo en cuenta que la pregunta por la relación entre ritual y estructuración social es la que organiza de manera tensionada las teorías que se ocupan actualmente de su estudio (ritual y reproducción versus ritual y cambio) y dicha tensión se vuelve constitutiva para las preguntas que le haremos a nuestro caso empírico, a continuación desarrollamos este vínculo con mayor detalle.

\subsection{Ritual y reproducción social}

Sin dudas el origen de la concepción teórica del ritual que dio prioridad a sus funciones integradoras -analizando en él la capacidad de contribuir a la estabilidad social y el equilibrio estructural- se encuentra en Durkheim. Para este autor los rituales permiten trasladar hacia el individuo un conjunto de normas, valores y sentimientos colectivos; articulando y cohesionando a la sociedad en torno a ellos. Según este autor los rituales contribuyen a prevenir, regular o reparar conflictos y desviaciones a las normas colectivas, promoviendo la homogeneización moral entre los individuos. En tal sentido la función de los rituales será mantener y reproducir la estructuración del orden social, ligando la conciencia individual a una identidad compartida. Como indica Segalen (2011: 20) Durkheim será el origen de una serie de trabajos para los cuales el ritual "tienen como efecto reforzar los sentimientos de pertenencia colectiva y de dependencia a un orden moral superior, que rescatan a los individuos del caos y el desorden". El énfasis durkheimiano está puesto en entender al ritual como un sistema de equilibrio, productor de homeostasis social, que le permite al individuo interpretarse como miembro de una existencia colectiva que lo comprehende y supera moralmente.

\footnotetext{
${ }^{4}$ Si bien no será la postura que seguiremos es necesario reconocer que Díaz Cruz (1998) propone una clave de lectura distinta para organizar las teorías del ritual. Señala que los autores clásicos de las ciencias sociales dedicados a su estudio (Frazer, Tylor, Durkheim, Gluckman, Turner y Leach) pueden ser separados dicotómicamente en dos grupos, atravesados en su interior por una pregunta oposicional que los sitúa en uno u otro extremo de ellos. Mientras en el primer grupo encontraríamos a los autores que se preguntaron por la relación que el ritual establece/disuelve entre creencias y acciones, en el segundo estarían los que se preguntaron por la relación que el ritual establece/disuelve entre el decir y el hacer. Así, mientras el primer grupo instauró una dicotomía entre creencias y acciones que "los rituales tienen la capacidad de disolver" -volviéndose "acciones pensadas o pensamientos actuados"-; el segundo grupo de autores habría planteado una división entre "el decir y el hacer -entre legomenon y dromedon, entre mito y rito, entre la comunicación verbal y la no verbal, que los rituales se encargan también de congregar" (Díaz Cruz, 1998:307).
} 
En palabras de Geertz, Durkheim "pone el énfasis en la manera en que las creencias y particularmente los ritos refuerzan los tradicionales vínculos sociales entre los individuos; hace resaltar el modo en que la estructura social de un grupo se ve fortalecida y perpetuada por la simbolización ritual o mística de los valores sociales subyacentes en que ella descansa" (Geertz, 2006a:131).

El hecho de encontrar en el ritual una función social (crear solidaridad, re-ligar lo que aparece disperso, introyectar en el individuo la norma colectiva, promover la cohesión social) y sugerir la plena racionalidad del actor que participa en él, llevo a Durkheim a concluir que

"No puede haber sociedad que no sienta la necesidad de conservar y reafirmar, a intervalos regulares, los sentimientos e ideas colectivos que le proporcionan su unidad y personalidad. Pues bien, no se puede conseguir esta reconstrucción moral más que por medio de reuniones, asambleas, congregaciones en las que los individuos, estrechamente unidos, reafirmen en común sus comunes sentimientos" (Durkheim, 2007: 397).

Con el correr de los años la potencia del análisis durkheimiano conformaría escuelas de seguidores que trasladaron los fundamentos de su concepción teórica al estudio de los rituales que se desarrollaban en las sociedades industriales. Entre los años 50 y los años 80 del siglo $X X$ se inició en Inglaterra una escuela ritualista neodurkheimiana que buscó analizar, por ejemplo, el modo en que un conjunto de rituales seculares habían servido para reafirmar y unificar los valores morales de la sociedad inglesa en torno a los símbolos de la monarquía; mostrando en la esfera pública la importancia que este régimen de gobierno tenía para la integración social de aquel país. Por su parte la sociología funcionalista norteamericana desarrolló entre mediados de los años 50 y fines de los 70 una tendencia interpretativa similar: consideró que la integración del sistema social norteamericano -como comunidad ideológica- encontraba su fundamento en la existencia de una religión civil construida en torno al estilo de vida norteamericano. Estilo de vida que, por ejemplo, era reproducido mediante una serie de rituales seculares como el Memorial Day, el 4 de julio, el Día de los Veteranos y el Día de Acción de Gracias ${ }^{5}$.

Al volver la mirada hacia la propia sociedad y enfocar el análisis del ritual en los elementos seculares de la misma, la escuela neodurkheimiana y la sociología funcionalista abrieron el camino para un conjunto de investigaciones que se preguntaron por los mecanismos a través de los cuales el Estado legitima y refuerza su autoridad. De esta manera el ritual se volvió un objeto de estudio privilegiado para

\footnotetext{
${ }^{5}$ Para un análisis detallado de estos trabajos ver Ariño (1992b).
} 
comprender cómo los Estados modernos dramatizan en la esfera pública la unidad simbólica de la Nación.

Sin dejar de notar los aportes sustantivos que esta tradición hizo a los estudios del ritual, las críticas a ella no se hicieron esperar. Mientras algunos autores cuestionaron su visión simplista respecto a la integración social o su resolución optimista de las contradicciones simbólicas, otros autores criticaron la insuficiente evidencia empírica sobre la que asentó sus interpretaciones, la escasa valoración de los conflictos existentes en cualquier sociedad, el desconocimiento del carácter "enmascarador" de la dominación ideológica, etc. (Moore y Myeroff, 1977; Geertz, 2006a). La tendencia a caracterizar al ritual como un elemento funcional al ordenamiento social, armonizador e integrador, imposibilitó que estas investigaciones pudieran explicar la disputa política, la variación histórica y el cambio social (Segura, 2004).

\subsection{Ritual y cambio social}

Situándose frente a las posturas teóricas que vieron en el ritual un modo de reproducir la estructuración social, los trabajos de Van Gennep y Turner vieron en él una práctica que cuestiona o subvierte sus elementos centrales. Enfocados en un conjunto de prácticas que le permiten al sujeto ritual transitar de un status comunitario a otro -y por lo tanto suspender momentáneamente los fundamentos que sostienen la jerarquización social y la estabilidad identitaria- estos autores afirmaron que el ritual regenera la vida comunitaria cambiando algo de ella.

La definición de Turner (2008) sobre los rituales -"ocasiones no dominadas por la rutina tecnológica"- quedará reflejada en su posterior caracterización de los momentos liminares de la ritualidad como instancias anti-estructurales (Turner, 1988). Según este autor el desarrollo social puede definirse como un proceso estructura-communitasestructura en el cual las instancias polares señalan fases diferenciadas, desiguales y de posiciones tan jerárquicas como institucionalizadas, mientras la communitas designa un momento de homogeneidad entre los individuos en el cual se suspenden las jerarquías sociales. Así, en sintonía con Van Gennep (1908), Turner vio en los rituales una instancia -entre dos momentos estructurales- en la cual los elementos constitutivos del ordenamiento social quedan suspendidos y los actores reviven la experiencia originaria del convivir (vivir con otros) sin distinciones sociales.

Del mismo modo que la mirada teórica de Durkheim generó escuelas de seguidores, las propuestas teóricas de Van Gennep y Turner influyeron de manera 
decisiva en autores que, como Balandier (1990 [1988]), vieron en los rituales un momento donde "las relaciones de dominación quedan subvertidas momentáneamente y se produce una inversión entre los papeles de sometedores y sometidos (...) [quebrando] un medio-ambiente marcado por la estratificación y la jerarquización" (en Cruells, 2006:8).

En síntesis, como hemos dicho anteriormente, la pregunta sobre la relación entre ritual y estructuración social separó en dos grandes campos dicotómicos las teorías ocupadas de su estudio: mientras una corriente entendió que el ritual cumple su función al reafirmar el orden social -por reforzar los lazos comunitarios, contener amenazas de caos, reafirmar las jerarquías del poder o las estratificaciones clasistas-, la otra corriente entendió que el ritual regenera la vida social cuestionando o subvirtiendo dicho orden -por suponer el tránsito de un status social a otro, suspender las jerarquías sociales, etc.-.

La constitución de este ordenamiento dicotómico entre ambas posturas ha sido tan potente que al mirar la entrada ritual del Diccionario de Antropología editado por Barfield (2000: 451-452) leemos: "Buena parte del estudio antropológico del ritual se ha ocupado de su función, de la medida en la que el ritual sostiene y reproduce el orden social". Haciendo notar la generación de sentimientos de pertenencia y su capacidad para sostener la solidaridad comunitaria, esta mirada postuló que a través del ritual los individuos reconocen "concretamente la legitimidad del orden establecido" porque su estructura simbólica "tiende a reflejar y reforzar las distinciones sociales". Así, "tanto en su contenido como en su forma el ritual tiende a exhibir y legitimar la estructura social". Frente a este modo de concebir al ritual el editor afirma que existe una mirada opuesta: aquella que vio en él "un foro importante para quienes querrían cambiar el orden social".

A partir del recorrido hecho hasta aquí, mostraremos a continuación la influencia que dichas teorías del ritual han tenido sobre el estudio de la fiesta, trasladando sus perspectivas y preguntas analíticas.

\subsection{La fiesta en clave ritual}

Las teorías del ritual anteriormente comentadas han funcionado de manera hegemónica como marco analítico para el estudio empírico de distintas fiestas. Su influencia llega a tal punto que el vínculo entre ritual e irracionalidad y la pregunta por 
la relación que el ritual establece con la estructuración social, se trasladaron de manera lineal al estudio del fenómeno festivo.

En diálogo crítico con lo manifestado por la antropología victoriana y los grandes pensadores del modernismo (respecto a que el ritual era una práctica social irracional e incompatible con los valores modernos) Martín (1997) señaló que el proceso de racionalización iniciado a mediados del siglo XIX priorizó y valorizó los ámbitos de la vida social ligados únicamente a la técnica y la economía. Esta situación derivó en la constitución de un modelo de éxito -centrado en el individuo racional- que situó a la fiesta en las antípodas de la productividad y la relevancia social. Al separar y oponer lo entretenido a lo productivo, lo cómico a lo profundo, el artista al espectador, lo material y sensible a lo espiritual y lógico; la racionalidad moderna vio en las fiestas un absurdo que encarnaba la sublimación irracional del ocio improductivo (Martín, 1997). En esta misma línea otras investigadoras argentinas (Da Orden, 1991; Giorgis, 2004; Lacarrieu, 2013) señalaron que hasta hace pocas décadas la fiesta fue vinculada con un supuesto ámbito irreflexivo de la realidad social. En ella se expresarían un conjunto de prácticas lúdicas, desproblematizadas, pintorescas, anecdóticas, carentes de sentido y ociosas que progresivamente irían perdiendo su rol en la sociedad moderna. Si recordamos las palabras de Schultz (1993:14) respecto a que en la fiesta el hombre se acerca a su "dimensión animal, entregándose a lo irracional"; la caracterización de Pieper (2006:29) en torno a que la fiesta es aquella dimensión lúdica de la vida donde la contemplación ociosa se mezcla con "el derroche absurdo y excesivo que supera toda racionalidad"; o la afirmación de Caillois (1963: 97-109) acerca de que las fiestas "favorecen eminentemente el nacimiento y el contagio de una exaltación que se agota en gritos y gestos, que incita a abandonarse sin trabas a los impulsos más irreflexivos", difícilmente podamos estar en desacuerdo respecto a que el vínculo entre ritual e irracionalidad se trasladó al estudio empírico de la fiesta.

Frente a esta postura, señalamientos como los de Elías (2011: 201 [1939]) acerca de que "son precisamente estas manifestaciones [festivas], aparentemente insignificantes, las que a menudo nos revelan aspectos de la estructura social y de la evolución espiritual que aquellas otras manifestaciones [el arte, la ciencia, la economía, la política], en cambio, no nos permiten ver con claridad", ayudaron a que el fenómeno festivo comenzara a ser interrogado desde la pregunta por su relación con la estructuración social. $Y$ aquí la postura dicotómica con que se pensó la relación entre ritual y estructuración social se trasladó al estudio del fenómeno festivo de manera directa: mientras algunos autores vieron en las fiestas del poder un mecanismo que reproduce la estructuración social, los autores centrados en las fiestas 
populares hicieron énfasis en mostrar cómo ellas habilitan un espacio en el cual distintos actores cuestionan los fundamentos de dicha reproducción.

Luego de que Rousseau (1967) afirmara que las fiestas cívicas crean y reproducen un conjunto de los lazos de placer, felicidad y compromiso ciudadano para mantener unida a la comunidad ${ }^{6}$; será el pensamiento durkheimiano el que ejerza una notable influencia sobre los autores que ligaron fiesta y reproducción del orden social. Trasladando este nexo entre fiesta, poder y ciudadanía hacia el rol del Estado, autores como Cohn [1983] (2002), Vovelle (1985), Cohn and Dirks (1988), Ozouf (1988 y 1989), Heers (1988), Geertz (1994) y Chartier (1995) hicieron énfasis en mostrar el papel que desempeñan las fiestas patrias en la representación y comunicación de una determinada imagen del orden social. Buena parte de la relevancia académica de estos trabajos está dada porque permitieron comprender cómo la Nación se representa y legitima a sí misma mediante la escenificación de un mito de origen que, a su vez, confirma jerarquías sociales, modos de exclusión y proyectos políticos de un grupo social particular.

Influidos por el pensamiento de Turner y Van Gennep, los autores enfocados en las fiestas populares hicieron énfasis en las dimensiones festivas que permiten romper/cuestionar/subvertir las distancias sociales y sus posiciones jerárquicas (Cox, 1983; Bajtin, 1994 [1987]; Da Matta, 2002; Cruells, 2006) habilitando un espacio/tiempo por fuera de la condición social ordinaria (Caillois, 1963; Vernes, 1978; Cardini, 1984) en el cual los actores liberan los impulsos, emociones y energías reprimidas durante la normatividad cotidiana (Freud, 1972; Duvignaud, 1989 y 1997; Maisonneuve, 2005). Sin buscar descansar en el glosado de citas, a continuación recorremos esta perspectiva con cierto grado detalle.

Desde el campo de la antropología Da Matta (2002) señaló que la mayor parte de los estudios sobre el ritual han olvidado -en su afán reproductivista- preguntarse por todo lo que el carnaval toma en cuenta para inventar un mundo nuevo. En este sentido consideró que

"En el carnaval dejamos de lado nuestra sociedad jerarquizada y represiva y tratamos de vivir con más libertad e individualidad [haciendo] que los 'pobres' se vuelvan 'ricos' durante cuatro días al año" (Da Matta, 2002: 52).

\footnotetext{
${ }^{6}$ Es sumamente interesante recordar el vínculo que Jean-Jacques Rousseau entablaba entre fiesta, pasado y presente. Como bien señalan Bisso y Kahan, Rousseau llegó a recomendarle al gobierno polaco que cada década instituyera "la celebración de un festejo público en torno a un monumento con inspiraciones alusivas a grandes acontecimientos del pasado. Habría que inventar juegos, festejos y ceremonias con el fin de que el pueblo pudiera imbuirse de la virtud del patriotismo" (Bisso y Kahan, 2014: 12).
} 
Da Matta reforzará la concepción de Turner y Van Gennep sobre el momento liminar del proceso ritual afirmando que durante el carnaval "la sociedad se descentraliza" produciendo la "suspensión temporal de las reglas de una jerarquización represora" (Da Matta, 2002: 58 y 59 respectivamente). En el campo de las letras Bajtin ha sido otro de los autores que indagaron el carnaval desde esta perspectiva teórica. Como señala Carolina Crespo

"Lejos de enfatizar su rol conservador y su manipulación por parte de sectores hegemónicos, Bajtin focaliza su atención en el aspecto emergente, cuestionador y regenerativo que ha tenido esta manifestación simbólica en la cultura cómica popular de la Edad Media y el Renacimiento (...) en el carnaval se transmitía la abolición de la jerarquía y la consagración de la igualdad. La lógica de esta fiesta popular era la lógica de las cosas 'contradictorias' y 'al revés', de las permutaciones de lo alto y lo bajo, de la eliminación de ciertas reglas y tabúes, de la parodia de la vida ordinaria." (Crespo, 2004: 1-2)

Por su parte, y desde el campo de la historiografía, Cardini afirmó que

"En la fiesta se deja en suspenso el existir diario que está sujeto a la corrupción y la destrucción: y se retorna al tempus illud, al modelo primordial (...) en orden de poder reemprender, renovados, a la senda de lo diario; a poder afrontar, con fuerzas recuperadas, el desgaste del tiempo. El retorno al tempus illud se manifiesta en la irrupción de las fuerzas del caos en la sociedad, esas fuerzas que durante el tiempo cotidiano se encontraban severamente reprimidas por cuanto entonces habrían sido disgregadoras y destructivas, es decir, orgía de alimentos y de sensualidad, trastrocamiento de los valores sociales, incluso de los determinados en las leyes de la naturaleza (así, por ejemplo, pájaros que nadan bajo el agua y peces que vuelan), abolición de las jerarquías efectivas y creación de jerarquías ficticias (...). Triunfan los oratas, los pobres, los niños, los animales, es decir, los que a diario se hallan marginados u obligados a la subordinación" (Cardini, 1984: 41-42).

Para estos autores la fiesta se vuelve una instancia que permite salir del ordenamiento jerarquizado que de vida cotidiana, romper con él, cuestionarlo, suspenderlo y entregarse libidinalmente a la pérdida del Yo social. Así Maisonneuve afirma que

"la fiesta se expresa naturalmente como una suerte de desorden generalizado: ruptura de las normas y de las prohibiciones (específicamente sexuales), excesos (comilonas y borracheras), inversión de los roles y de los atributos (en materia de poder y de vestido), anulación y parodia de la autoridad y de la virtud, despilfarros de todo tipo." (Maisonneuve, 2005: 43)

Desde el campo de la psicología Freud caracterizó a la fiesta como una instancia social opuesta a la represión normativa que rige la cotidianeidad; instituyendo un momento en el cual las personas liberan sus impulsos, emociones y energías. Así, la fiesta será 
"un exceso permitido, y hasta ordenado, una violación solemne de una prohibición. Pero el exceso no depende del alegre estado de ánimo de los hombres, nacido de una prescripción determinada, sino que reposa en la naturaleza de la fiesta, y la alegría es producida por la libertad de realizar lo que en tiempos normales se halla rigurosamente prohibido." (Freud, 1972: 184)

Por su parte el campo de la sociología tuvo en Jean Duvignaud (1989 y 1997) uno de los autores que entendió a la fiesta como una forma de subversión, una manifestación destructora de las sociedades, un acontecimiento a-estructural que escapa a toda institución y permite disolver la individualidad del Yo, ser cualquier Otro que se quiera ser. En la fiesta "la incesante modelación social que mezcla a los seres vivientes en el seno de una misma estructura y, en esa estructura, en el seno de las instituciones o las organizaciones, parece interrumpirse" (Jean Duvignaud, 1997:28).

Mostrando la excepcionalidad temporal que implica la fiesta Caillois (1963: 97) señala que ésta será la antítesis de la normalidad cotidiana: "la vida normal, ocupada en los trabajos cotidianos, apacibles, encajada en un sistema de prohibiciones cauto, donde la máxima 'quieta non movere' mantiene el orden del mundo, se opone la efervescencia de la fiesta". En tal sentido, cuando la "fiesta se ha terminado el orden queda nuevamente instituido" (Caillois, 1963: 125).

Por último, para acercarnos geográfica y temporalmente hacia nosotros, no quisiéramos dejar de señalar la influencia que esta mirada teórica ha tenido en algunas investigaciones locales. En la ya citada investigación de Martín sobre el carnaval porteño leemos que esta festividad "propone en la mascarada la confusión de los lugares sociales. Humanos disfrazados de animales, hombres transformados en mujeres, sirvientas vestidas como princesas. El carnaval suspende las reglas de comprensión del mundo alterando la lógica burguesa. De allí su carácter subversivo" (Martín, 1997:10). En la misma línea se expresa César (2005), quien en su estudio del carnaval de Buenos Aires durante el período 1770-1850, señala:

"En realidad, el carnaval es el poros o pasaje mismo, todo él umbral por el que puede producirse lo otro que lo habitual, el excluido... Para su festejo, las 'murallas', que configuran, organizan y transforman el espacio de la ciudad en un territorio social y políticamente ordenado, se abren transitoriamente. Por él irrumpe, de manera pasajera, ¡lo de afuera', desconocido y temido. ... una quiebra del ordenamiento en lugares públicos y privados convirtiéndolos en un espacio 'urbano'...pero extraordinario y efímero." (César, 2005: 214-215). 
Y también lo hace Geler (2011) quien -focalizando su mirada en el lugar que ocuparon "los negros" en el carnaval porteño- afirma

"Con todo, la fiesta no dejaría de presentar características de rito colectivo durante gran parte del siglo $\mathrm{xx}$, como un momento que quebraba el tiempo cotidiano y que ponía en relación específica de sincronía a segmentos, clases, grupos y categorías sociales, permitiendo la creación de una mirada de la sociedad sobre sí misma y proyectando otras. En este sentido, interesa la visión de Víctor Turner, para quien en todos los rituales cíclicos que permiten la acción reflexiva y colectiva, como el carnaval, surge un momento de liminalidad." (Geler, 2011: 186-187)

Siguiendo esta línea, en los trabajos compilados por Scribano podemos leer que la "fiesta puede caracterizare por, al menos, tres rasgos: es un corte tiempo-espacio en la vida vivida, es una alteración temporal del orden y es una inversión 'contingente' de las jerarquías" (2012:31). Por su parte, enfocado en las fiestas marianas organizadas por inmigrantes paraguayos en la ciudad de Rosario, el trabajo de Granero (2016: 101) adopta la perspectiva teórica de Van Gennep para distinguir en ellas la consecución de fases pre-liminares, liminares y pos-liminares. Bajo este marco conceptual la autora afirma que la fase intermedia transforma el espacio barrial en un escenario ritual donde las relaciones asimétricas entre inmigrantes y nativos se vuelven simétricas: así, los inmigrantes se representarían, demandarían y experimentarían en el "ritual la inversión de las relaciones efectivamente dadas e inscriptas en el marco societario". Finalmente -y sin ser los únicos trabajos locales en que vemos adoptados los elementos centrales de esta propuesta teórica- cabe mencionar el trabajo de Mallimaci (2016:12), para quien la Fiesta de la Virgen de Urkupiña "subvierte el orden de la visibilidad" urbana en la ciudad de Ushuaia haciendo que los inmigrantes bolivianos se hagan presentes en un espacio público acostumbrado a ver turistas y fueguinos nativos.

Al utilizar aquellas teorías socio-antropológicas que se preguntaron por la relación entre ritual y estructuración social, los estudios de la fiesta se vieron tensionados por la resolución dicotómica con la cual dicho vínculo había sido presentado. Esquema de resolución que, como veremos a continuación, encierra un conjunto de limitaciones a ser superadas. 


\subsection{Críticas a la visión dicotómica}

Como hemos visto en los apartados anteriores, las respuestas que los investigadores dieron a la relación entre ritual y estructuración social se trasladaron de manera dicotómica al estudio de distintas fiestas. Pese a haber investigadores que postularon la existencia de ambas dimensiones, el hecho de afirmar que las fiestas pueden hacer una cosa o la otra (sin pensarlas en simultáneo, en su tensión y dinámica) los mantuvo encerrados en dicha dicotomía. Esto les sucede a destacados investigadores europeos como Moreno Navarro, para quien las fiestas son

"un fiel reflejo de la estructura social, una simbolización directa, más o menos ritualizada (...) de la realidad social y de los valores dominantes, o constituyen una negación simbólica de esa misma realidad social" (1982: 74, resaltado nuestro).

\section{Y a Delgado Ruiz, quien afirma que la fiesta}

"Puede ser formalizadora, es decir puede dotar de forma un contenido cualquiera, haciendo que un magma social en principio informe cobre un perfil y se arrogue unos determinados contenidos legitimadores. Pero también puede hacer todo lo contrario (...) Puede deformar lo que se suponía estructurado, desfigurar cualquier realidad social presuntamente sólida hasta hacerla irreconocible, una masa sin rasgos precisos, sin rostro. (...) Es en ese orden de cosas que la fiesta es una máquina que puede ser dispuesta para proclamar una identidad personal o colectiva cualquiera, o para disolverla; para que los individuos afirmen quienes son o para que lo olviden. La fiesta puede anular las diferencias y hacer que, de pronto, aparezca no importa qué unidad. Pero también puede multiplicar -o dividir- hasta el infinito esas mismas diferencias." (2000: 81-82, resaltado nuestro).

Si bien este recurso argumental logró sintetizar y ordenar dicotómicamente la discusión teórica, entendemos ha empobrecido su abordaje empírico ${ }^{7}$. En esta línea el gran historiador de la fiesta en Francia, Vovelle (1985: 197) señaló que poner de un lado a "la fiesta como liturgia institucionalizada, reglamentada, que se apoya en la ficción unanimista de la comunión sin fallas de una comunidad" y del otro a la fiesta como "estructura que brota de la inversión y la contestación", ha limitado su estudio. Sin ir tan lejos, entre nosotros Bisso (2013) afirmó que la rigidez en "mostrar a estas expresiones [festivas] precisamente en las antípodas, según su condición de

\footnotetext{
${ }^{7}$ Somos conscientes que el esquematismo con que esta discusión ha sido presentada puede responder a objetivos tipológicos, pero así y todo estamos convencidos de que el modo dicotómico con el que se abordó la relación entre ritual/fiesta y estructuración social repone una herencia problemática de las ciencias sociales. Nos referimos a su compulsión para construir objetos de estudio mediante pares conceptuales opuestos: material/ideal, objetivo/subjetivo, colectivo/individual, estructura/agencia u orden/caos. En tal sentido coincidimos con Corcuff (2013: 19) cuando señala que estos pareid concepts nos llevan a ver el mundo de manera dicotómica "al invitaros a elegir un frente (lo colectivo en contra de lo individual, o lo subjetivo en contra de lo objetivo)".
} 
'reproductoras' o 'cuestionadoras' del orden social (...) puede dar lugar a cuestionamientos" porque dicha "dicotomía (...) tiende a limitar más que a expandir las posibilidades de análisis".

Llegados a este punto algunos investigadores del fenómeno festivo nos preguntamos con qué recursos analíticos salir de aquella dicotomía sin resignar la posibilidad de responder empíricamente la pregunta teórica por la relación entre fiesta y estructuración social. Cómo no podía ser de otra manera -ha sido nuestra hipótesis de lectura hasta aquí- los aportes que Geertz (2006a), Bourdieu (2001a) y otros autores $^{8}$ hicieron al estudio del ritual permitieron superar las limitaciones y profundizar los aportes de Durkheim, Turner y Van Gennep. Dicho en otros términos, estos autores han logrado responder empíricamente -desde tradiciones teóricas muy distintas- la pregunta sobre cómo, en un mismo ritual, actores con plena capacidad reflexiva conjugan simultánea y conflictivamente prácticas tendientes a la reproducción y al cambio de la estructuración social.

Partiendo de una crítica radical al funcionalismo durkheimiano, Geertz (2006a) logró explicar el cambio social, la variación histórica y la disputa simbólica sin necesidad de ver en los rituales un elemento que subvierta la estructura social. Desde dicha crítica mostró empíricamente cómo la conjunción entre la participación reflexiva de agentes diversos y con recursos culturales desiguales, el cambio profundo del contexto histórico, las disputas de poder, la urbanización de áreas rurales y una variación en la conformación simbólica, eran cambios en la trama cultural javanesa que podían ser leídos en sus rituales. Así, se negó a ver en el ritual una práctica estática, integradora y meramente reproductivista sin necesidad de afirmar que el mismo subvierte la estructura social.

Por el camino inverso Bourdieu (2001a) elaboró una crítica a la postura de Turner y Van Gennep sin necesidad de caer en los males del funcionalismo durkheimiano. Para Bourdieu el ritual no constituye una instancia de paso sino que su función es marcar el límite, instituirlo y definir claramente a través de él quién puede y quién no, quién posee y quién no. Al analizar la línea que gobierna el paso de un estado a otro (en el modelo liminar de Turner y Van Gennep) Bourdieu indagó la constitución de poder que el límite instaura. Lo importante no será el paso de un estado a otro sino la

\footnotetext{
${ }^{8}$ Nos referimos específicamente a Kertzer (1988). Este autor plantea que las prácticas rituales son cruciales tanto para las elites gobernantes que busque reproducir el orden existente, como para los actores que promuevan el cambio político y social. Para Kertzer el ritual es un campo de confrontación y lucha donde su función esencial es la de crear una imagen (simbólica) y una experiencia (práctica) de solidaridad en ausencia de consenso.
} 
línea que reinstala la separación entre dos grupos preexistentes. Línea que no implica la suspensión de las jerarquías sociales -un quiebre momentáneo del orden socialsino que constituye el mecanismo que las instituye: el rito ya no será de paso sino de legitimación, consagración o institución. Buscando dar cuenta de la dinámica social este autor consideró que el límite instaurado no solo es provisorio, sino que además está sujeto a disputa: es la disputa por el capital existente en cada campo la que lleva a los actores interesados en él a realizar estrategias de conservación o herejía para dirimir el lugar y la función del límite ${ }^{9}$. En otras palabras, la posibilidad ritual de instituir un límite se encuentra supeditada a la obtención o conservación del capital que rija la dinámica del campo.

Situándose en la tensión entre estructura y agencia para comprender la dinámica social, estos autores son quienes (a nuestro entender) mejor abordaron el estudio empírico del ritual, manteniendo la pregunta por su relación con la estructuración social sin caer en ninguno de los polos dicotómicos. Son ellos quienes -reiteramoslograron explicar en un mismo ritual la dinámica entre actores reflexivos que conjugan, de manera simultánea y conflictiva, prácticas tendientes a la reproducción y al cambio de la estructuración social. La potencialidad de esta mirada teórica ha llevado a que algunos investigadores -entre quienes nos situaremos- la adoptaran como marco para el estudio empírico del fenómeno festivo. Así, por ejemplo, al abordar las prácticas a través de las cuales las sociedades reinterpretan y recrean sus formas de existencia, Silla (2011: 214) señaló la importancia de analizar simultáneamente las dimensiones del conflicto y la armonía social que se encuentran presentes en el fenómeno festivo. En esta misma línea, leemos en una compilación de trabajos reunidos bajo el título de "El origen de las fiestas patrias", que:

"estas fiestas y ceremonias constituyen la hegemonía de la monarquía en América, consagran sus instituciones, cimientan lugares de memoria, legitiman sus autoridades, reafirman identidades corporativas de la ciudad y reanudan las interdependencias de los cuerpos (...) pero indefectiblemente dejan lugar a la contra-hegemonía en un particular diálogo entre sectores dominantes y subalternos. En efecto, toda fiesta del poder encierra la posibilidad de contestación no solo por los sectores subalternos sino también por conflictos intra-elites" (Ortemberg, 2013:19, cursivas del autor).

Por su parte Homobono Martínez -sociólogo español destacado en el estudio del fenómeno festivo y uno de los que mejor ha dialogado con las teorías del ritual presentadas anteriormente- señaló hace varias década que

\footnotetext{
9 Para un recorrido más detallado por los conceptos de capital, campo e illusio, y las prácticas de conservación o herejía, ver: Bourdieu (2000), Gutiérrez (1997), Costa (1997).
} 
"Además de esta función integradora y reproductora que les asigna una concepción de origen durkheimiano, [las fiestas] también pueden contribuir a la transformación del sistema social a través de un proceso dialéctico con dos fases sucesivas de interacción social: estructura y communitas, estadio este último durante el que la propia identidad se diluye y se hace irrelevante" (Homobono Martínez, 1990: 4, cursivas nuestras).

Por considerar que esta mirada posee las herramientas teóricas más relevantes para describir y analizar nuestro caso empírico, es que abordamos a partir de ella el estudio de la Fiesta Provincial del Inmigrante. En otros términos, utilizaremos esta mirada teórica del ritual para analizar empíricamente la existencia simultánea y conflictiva de prácticas orientadas hacia la reproducción y el cuestionamiento de un imaginario sobre Berisso: aquel que instaura un origen comunitario ligado (centralmente) a la llegada de inmigrantes ultramarinos y (de manera subsidiaria) con el surgimiento del peronismo. Ahora bien, ¿qué características tienen los rituales conmemorativos? ¿Qué implica conmemorar? ¿Por qué definimos a la Fiesta Provincial del Inmigrante como un ritual conmemorativo a través del cual la comunidad se imagina a sí misma?

\subsection{Rituales conmemorativos, comunidad e imaginarios sociales}

La proliferación de estudios sobre el pasado reciente llevó a que durante las últimas décadas algunos cientistas sociales afirmaran que nuestra contemporaneidad debería ser caracterizada como una era de las conmemoraciones (y también una era del testigo) donde la pasión archivística, la obsesión, el exceso, la sobreabundancia o el abuso de la memoria se han vuelto moneda corriente (Nora, 1992, 1993; Maier, 1993; Wieviorka, 1998; Todorov, 2000; Eiss, 2005). Sin buscar ahondar en los vínculos entre Historia y Memoria que las ciencias sociales han venido tensionado desde mediados de los años 60 (Traverso, 2007; Jelin, 2017; Flier y Kahan, en prensa) nos interesa rescatar de esa producción una idea general sobre los rituales conmemorativos: ellos suponen una forma específica de relación con el pasado donde la memoria oficial es reconstruida, escenificada y disputada reiteradamente (Pollak, 1989; Connerton, [1989] 1993; Olick, 2003; Fernández, 2007) ${ }^{10}$.

\footnotetext{
${ }^{10}$ La escasa traducción de los aportes europeos y norteamericanos dificulta la reconstrucción de un estado de la cuestión sobre el estudio de las conmemoraciones. En tal sentido agradezco el invalorable gesto del Mag. Daniel Badenes para facilitarme el acceso a dichos materiales y, en particular, al exhaustivo repaso que realiza Olábarri (1996) sobre un conjunto de textos elaborados en Estados Unidos, Alemania y Francia de escasa circulación en nuestro medio.
} 
Si bien el nominador de la sociología y referente clave del positivismo (Augusto Comte, a él nos referimos) consideró extremadamente importante la glorificación del pasado y ponderó las ventajas de los aniversarios y las conmemoraciones públicas para "desarrollar profundamente, en la generación actual, el espíritu histórico y el sentimiento de continuidad" (en Candau, 2001:144), ha sido Durkheim quien posteriormente hizo de estas temáticas una de sus preocupaciones centrales. En su definición de los rituales conmemorativos afirmó que una de sus características centrales es que ellos logran insertar en la diacronía del tiempo histórico, diversos referentes mitológicos que no encuentran un recipiente temporal sincrónico ${ }^{11}$. Al dramatizar episodios mitológicos, el ritual conmemorativo actualiza un relato de origen o creación comunitaria ${ }^{12}$ :

"Todo transcurre en representaciones cuyo único destino posible es actualizar el pasado mítico del clan. Pero la mitología de un grupo constituye el conjunto de sus creencias comunes. Lo que expresan las tradiciones cuyo recuerdo se perpetúa es el modo en que la sociedad concibe al hombre y al mundo; es una moral y una cosmología, a la vez que una historia. El rito, pues, no sirve ni puede servir más que para mantener la vitalidad de esas creencias, para impedir que se borren de la memoria, es decir, en suma, para reavivar los elementos más esenciales de la conciencia colectiva. Por medio de él, el grupo reanimará la conciencia de sí mismo y de su unidad; a la vez, los individuos resultan reafirmados en su naturaleza de seres sociales" (Durkheim, 2007:350).

Esta visión funcionalista de los rituales conmemorativos postuló que recordar hechos y personajes del pasado permite salvaguardar la fisonomía moral de la colectividad, revitalizando elementos esenciales de la conciencia colectiva frente al poder destructor del olvido. La función mnemónica de los rituales conmemorativos recrea la conciencia del grupo y su unidad, reafirmando a los individuos como parte de un sistema social (Zerubavel, 2007; Monkevicius, 2009). De esta manera las prácticas conmemorativas se vuelven un canal privilegiado para mantener la continuidad de la vida social y la identidad de una comunidad (Schwartz, 1992; Connerton, 1993). Como afirma Montesperelli (2004: 40):

"Mediante la conmemoración del pasado, a través de un fondo común de recuerdos, y también gracias a las interacciones sociales necesarias para fijarlos y para convocarlos, la memoria contribuye al sentido de pertenencia, a la cohesión y a la identidad."

\footnotetext{
${ }^{11}$ En esta misma línea Cazeneuve argumentó que los rituales conmemorativos "introducen en el tiempo histórico -la diacronía- los modelos mitológicos ubicados fuera del tiempo -la sincronía-, en esa especie de eternidad propia del mundo sagrado de los antepasados, o, si se prefiere, en el eterno retorno" (Cazeneuve, 1971: 30).

12 Para Durkheim los rituales conmemorativos consisten "exclusivamente en rememorar el pasado y, de alguna manera, en reactualizarlo por medio de una verdadera representación dramática” (Durkheim, 2007: 364).
} 
Ahora bien, y sin dejar de notar la importancia que para los actores pueda tener el hecho de mantener viva la memoria sobre ciertos hechos del pasado, entendemos la otorgación de sentidos que se hace sobre ellos como una práctica social orientada desde el presente. Así, coincidimos con autores como Portelli (2016a: 477, cursivas nuestras) quien afirma que "la memoria es un constante trabajo de búsqueda de sentido, que filtra los rastros de la experiencia entregando al olvido lo que no tiene más significado en la actualidad". O el mismo Traverso (2007:22, cursivas nuestras), quien sostiene que "la memoria individual o colectiva es una visión del pasado siempre matizada por el presente". Siguiendo esta perspectiva nos importará prioritariamente la conmemoración (como forma ritual de una relación social que utiliza el pasado como respuesta a los problemas del presente) frente a lo conmemorado (aquellos acontecimientos del pasado que la memoria busca restituir en el presente).

Nora Rabotnikof señala que los trabajos abocados al estudio de lo conmemorado en sintonía con los postulados durkheimianos anteriormente expuestos- enfatizaron la necesidad grupal de darse a sí mismos una continuidad identitaria a través del tiempo. Para que la unidad grupal y la continuidad identitaria no se vean erosionadas, las creencias sobre el pasado deben sobrevivir al cambio social: "la función de los ritos conmemorativos no sería tanto transformar el pasado poniéndolo al servicio del presente, sino la de revivirlo, reproducirlo, para reactualizar así el sentido de comunidad" (Rabotnikof, 2009: 185). Al contrario, los trabajos enfocados en la conmemoración pusieron el acento en las condiciones presentes y contextuales de la reconstrucción, recuperación o invención del pasado (Hobsbawn y Ranger, 2002 [1983]) subrayando el cambio en las formas de reconstruirlo. Consecuentemente estos trabajos trasladaron el foco de análisis a "las incidencias de las condiciones políticas y culturales de cada uno de esos presentes en los que se realiza la conmemoración" (Rabotnikof, 2009: 186). Esta segunda postura permite comprender cómo el contexto presente de la conmemoración orienta -no sin condicionamientos y disputas- el contenido, la forma y los sentidos otorgados a lo conmemorado ${ }^{13}$.

Siguiendo esta línea de análisis, Jaume (2000) y Jelin (2002a) afirman que la pregunta sobre el cómo y cuándo se conmemora/recuerda/olvida se vuelve prioritaria respecto a aquella enfocada en qué es lo conmemorado/recordado/olvidado. Como

\footnotetext{
${ }^{13}$ Sin adherir acríticamente a ninguna de estas posturas, nos parece importante hacer notar que la diferencia sustancial entre ambas proviene de los supuestos ontológicos y epistemológicos en los que descansan. Mientras para la segunda postura no hay nada en el acontecimiento del pasado que limite $u$ oriente sus posibilidades de apropiación o reinterpretación desde el presente; la primera descansa en un realismo ingenuo que supone que los hechos del pasado están ahí, disponibles para todos, e inmutables para su actualización en el presente.
} 
hemos dicho anteriormente, en nuestro caso privilegiaremos la reflexión sobre las formas rituales (canales o soportes materiales) en que el pasado es reconstruido desde el presente, frente aquella otra que se pregunta qué pasado se refleja en el presente. Sin embargo es necesario aclarar que no cualquier invención, producción o interpretación de la memoria colectiva es posible en el presente, sino que este proceso está condicionado históricamente y situado contextualmente dentro de marcos sociales (Halbwachs, 2004 [1925]) ${ }^{14}$.

La perspectiva teórica asumida -la cual nos permitió definir a la Fiesta Provincial del Inmigrante como un ritual conmemorativo- nos lleva a hacer el esfuerzo por ver cómo en dicho contexto los agentes disputan formas de representar, ordenar y constituir sentidos sobre el pasado (Jelin, 2002b:2). Formas que se encuentran orientadas por los proyectos que dichos actores poseen en el presente (Jaume, 2000: 67). Tal y como afirman Ansaldi (1996) y Montesperelli (2004) cualquier conmemoración repone una tensión entre el pasado y el presente donde el control por el pasado -es decir, qué se recuerda y qué se olvida- es un componente esencial en la construcción del poder y la legitimidad. Así, es importante tener en cuenta que los actores intervienen en las conmemoraciones porque "esas representaciones del pasado tienen el poder de tornar legítimas las posiciones presentes y de influir en las batallas del ahora" (Cattaruzza, 2007: 19).

De modo que incorporar los estudios de la memoria y la historia de las memorias enriquece las líneas de investigación de este trabajo. Un paradigma mundial memorilistico (Rousso, 2015), con nuevas herramientas interpretativas y metodológicas (Flier, 2014), logra detectar los sentidos de las memorias y sus contracaras de olvidos y silencios. Los usos del pasado, los usos del olvido (entre otras funciones) dan cuenta de la dimensión política de la memoria. En particular nos permite recuperar el sentido más perfecto de las memorias: su capacidad de incomodar, de molestar, de poner en duda las certezas y las creencias que tranquilizan y que generalmente se recuestan o anidan en las versiones oficiales, conformando memorias "monumentos" (Portelli, 2016b). Así, la historia de la memoria permite observar los ciclos de memoria y los ciclos de olvido, así como la emergencia de cambios de sentidos y la posibilidad de emergencias de memorias subterráneas, aquellas de larga duración que estaban destinadas a la invisibilidad son recuperadas -

\footnotetext{
${ }^{14}$ En Halbwachs los marcos sociales de la memoria no son simplemente la suma de los recuerdos individuales, sino que son "[...] los instrumentos que la memoria colectiva utiliza para reconstruir una imagen del pasado acorde con cada época y en sintonía con los pensamientos dominantes de la sociedad" (Halbwachs, 2004: 10, cursivas nuestras). En estos términos, la memoria debe ser vista y abordada como un ejercicio del presente que permite tomar acciones hacia el futuro.
} 
muchas veces como memorias incómodas- por una activación de las preguntas del presente.

De esta manera la Fiesta Provincial del Inmigrante no será un dispositivo cultural de mera reproducción estructural ni un contexto circunstancial para la pura agencia aestructural, sino un espacio donde el pasado forma parte de las disputas que se desarrollan en el presente ${ }^{15}$. Como brillantemente concluye Jaume al analizar dos ceremonias donde se conmemoraba la Masacre de Margarita Belén,

"Más que reafirmar el orden social [en sintonía con aquellas miradas que vieron en el ritual un modo de reproducción social, agregamos nosotros] o construir una transgresión [en sintonía con aquellas otras que analizaron sus funciones aestructurales, insistimos] ambos actos de homenaje a las víctimas de Margarita Belén habilitaron un espacio simbólico y ceremonial para que diferentes grupos y facciones políticas disputaran el sentido mismo de la historia nacional." (2000: 90, cursivas nuestras)"

Habiendo afirmado en la introducción de este Marco Teórico que la Fiesta Provincial del Inmigrante -en tanto ritual conmemorativo- permite que la comunidad berissense se imagine a sí misma, se vuelve necesaria una reflexión sobre estos dos últimos conceptos.

Según Nisbet (2009) entre las cinco ideas-elementos que dieron forma al pensamiento sociológico durante el siglo XIX, la fundamental y de más largo alcance ha sido la de comunidad ${ }^{16}$. Autores como Tönnies, Le Play, Marx, Durkheim, Simmel y Weber (entre otros) han hecho foco en este tema/concepto fundante de la teoría social. Entre nosotros De Marinis (2010a y 2012) señala que, en una de sus acepciones, comunidad aparece en la literatura sociológica como el antecedente de sociedad: comunidad permitiría comprender las configuraciones de la sociedad moderna señalándonos -en su contraste- el pasado, lo que hemos sido, un punto de inicio a partir del cual construir el relato histórico que muestre cómo hemos llegado a ser lo que somos. Pero a la vez, en una segunda acepción, comunidad se vuelve un concepto abstracto (típico-ideal) con el cual analizar algunas de las dimensiones que

\footnotetext{
15 Coincidimos plenamente con Díaz Arias cuando define a las ceremonias conmemorativas "como producciones culturales heterogéneas y que muestran no solo el carácter normativo sino también contra hegemónico que en ellas opera" (2007: 171, cursivas nuestras). Si en ellas encontramos formas de reproducción social ligadas a la construcción/invención de una memoria histórica desde el presente (o en otros términos, procesos de identificación que buscan su anclaje y legitimación local en el presente remitiendo a un pasado re-inventado periódicamente), también es cierto que -como señalan Williams y Thompson- la hegemonía no es un flujo unidireccional sino un proceso relacional donde los actores subalternos disputan recursos simbólicos y materiales.

${ }^{16}$ Las otras cuatro ideas-elementos fueron las de autoridad, status, lo sacro y alienación.
} 
asumen los lazos sociales actuales. Aquí, sin dejar de referir completamente al pasado, comunidad no se circunscribe a él ni buscaría analizar el presente funcionando como su contraste sino que permitiría describir y comprender una dimensión constitutiva de las sociedades modernas: comunidad no sería solo lo que la sociedad disolvió, sino un modo de agregación social actual.

En lo que respecta a nuestro trabajo será la concepción weberiana de comunidad la que utilizaremos a lo largo de la tesis. Según Weber (1998) este concepto denomina el desarrollo de una relación social ${ }^{17}$ donde el posicionamiento de sus participantes hacia la acción se sostiene en una percepción subjetiva de pertenencia conjunta. En ella, el sentimiento subjetivo hacia "lo afectivo" y su vínculo con "lo tradicional" jugarán un papel fundamental. En palabras del propio Weber

\begin{abstract}
"Llamamos comunización a una relación social cuando y en la medida en que la actitud en la acción social se inspira en el sentimiento subjetivo (afectivo o tradicional) de los participantes a construir un todo" (1998:33).
\end{abstract}

Partiendo de expectativas, sentidos, creencias y valores que se suponen compartidos -es decir, un marco de significación en común (Naishtat, 2002)- la comunidad se vuelve un "ser juntos" que posibilita la reposición de los fundamentos simbólicos del orden social. Un sentimiento de totalidad que recrea lazos interpersonales con capacidad de permanecer en el tiempo (Geicsnek, 2012). Al interior de esta perspectiva general, la concepción weberiana posee tres elementos particulares que nos parecen centrales para la comprensión de nuestro tema de estudio. El primero indica que la comunidad se constituye por "contraste consciente frente a terceros" (Weber, 1998:34). Ella se funda relacionalmente -en términos identitarios- por distinción. En segundo lugar la caracterización weberiana no supone ausencia de conflicto, sino que lo percibe como una condición inherente en la comunidad $Y$ por último señala que uno de los elementos comunalizadores más potentes es la creencia subjetiva -compartida por los actores de la relación social, reiteramos- de un origen común. Característica que adquiere especial relevancia entre los grupos étnicos y las naciones. Así, siguiendo a Weber, Monkevicius (2009: 32) señala que la creencia en una procedencia común resulta tan efectiva que determina la representación del colectivo social como portador de la misma sangre o sustancia, a

17 Tengamos en cuenta que el concepto weberiano de Vergemeinschaftung (comunización o comunalización) aparece traducido en las ediciones al español de Economía y Sociedad (traducción del Fondo de Cultura Económica que circula en la Argentina) como comunidad. Operación en la que, como bien marca De Marinis (2010b) suprimieron el prefijo "Ver", quitándole a "comunidad" la connotación procesual que poseía "comunalización". 
la manera de una comunidad de parentesco. Consecuentemente el origen -en tanto construcción social fundada en la creencia de un pasado compartido- se vuelve un poderoso aglutinador social.

En línea con esta caracterización, Anderson (2007) señaló que la comunidad es el producto de un trabajo imaginativo que sus miembros desarrollan desde el presente: la comunidad se (re)crea a sí misma, imaginándose. Perspectiva que si bien ya se encontraba delineada en Durkheim (2007: 392) -"una sociedad es, ante todo, la idea que se hace de ella misma- Anderson extenderá notablemente a partir de su análisis sobre los orígenes del nacionalismo. Cabe señalar que dicho trabajo de creación social de la realidad posee un paralelismo con la tradición etnometodológica, según la cual son las personas quienes crean las situaciones en las cuales -y las reglas a partir de las cuales- desarrollan sus prácticas. Procesos donde finalmente se crean a ellos mismos y sus realidades sociales (Mehan y Wood, 1975). En la teoría etnometodológica (cuyo origen podemos fijar en los estudios de Schutz y la lectura que de ellos hizo Garfinkel, 1967) el actor es considerado un constructor de la realidad en la cual vive.

Al interior de esta caracterización general sobre el proceso de creación de lo social, nos interesa rescatar que según Anderson la comunidad es imaginada (en primer lugar) porque, pese a que todos sus miembros no se conocen entre sí, "en la mente de cada uno vive la imagen de su comunión" (2007: 24). Esa imagen mental, lejos de carecer de sustento real, es el producto de un trabajo continuo de creación. En segundo lugar la comunidad se imagina como limitada a partir de poseer fronteras finitas más allá de las cuales se encuentran otras comunidades de las cuales se distingue. En tercer lugar, ella se imagina en tanto comunidad porque, independientemente de la desigualdad existente en su interior, se concibe a partir de la existencia de un compañerismo profundo y horizontal entre sus integrantes. Por último, en cuarto lugar, toda construcción imaginaria de la comunidad implica la existencia de un conjunto de supuestos con respecto al tiempo -supuestos respecto al carácter legendario o mítico del pasado- que ordenan la memoria colectiva mediante el recuerdo de ciertos hechos y el olvido de otros.

Este trabajo de Anderson (2007) encuentra una línea de continuidad con las investigaciones que indagaron la producción de imaginarios sociales (en general) e imaginarios urbanos (en particular). Si bien la postura teórica de Anderson -respecto al trabajo de recreación imaginaria que las comunidades llevan a cabo para instituirse y reconstruirse en tanto tales- posee prioridad conceptual en nuestra tesis, exponemos 
a continuación un acercamiento a la noción de imaginarios urbanos con la cual dialogaremos. Aquí la pregunta clave que hay que hacerse es, como bien señala lucci (2012:3), ¿qué entendemos por imaginarios urbanos? Ellos podrían ser definidos siguiendo a Ledrut (1987), Saffa (1998), García Canclini (1999), Lacarrieu (2006) y Lindón (2007)- como esquemas de representación simbólicos, socialmente construidos, a partir de las cuales los actores que habitan el espacio urbano lo reconocen y distinguen. Estos esquemas de representación que conforman al imaginario urbano, además, son incorporadas por los actores en esquemas prácticos de acción que les permiten desenvolverse, interactuar con otros actores e interpretar dichas prácticas. Como señaló Castoriadis (1985) en uno de los estudios seminales para estas temáticas, los imaginarios son la creación incesante de figuras, formas, imágenes y símbolos a partir de los cuales los actores se refieren a algo: en este caso, a la ciudad. Así, si la noción de imaginarios urbanos poseen algún valor conceptual, es justamente porque permite "reconstruir visiones del mundo desde las cuales los sujetos actúan con propósitos y efectos de 'realidad'" (Lindón, Aguilar y Hiernaux, 2006:14). En este marco cabe señalar que los imaginarios urbanos se reconstruyen a partir de prácticas y discursos que -entre otros espacios sociales- se expresan en fiestas, conmemoraciones, monumentos, grafitis, etc. Aquí nos interesarán específicamente aquellos imaginarios urbanos re-elaborados a partir de la apelación a un conjunto de hechos ocurridos en el pasado de una ciudad (Backzo, 1999).

Dos de las preguntas más interesantes que existen dentro de la producción sobre imaginarios urbanos, giran en torno a $1^{\circ}$ ) porqué algunos de ellos perduran y otros perecen y $2^{\circ}$ ) cómo se encuentran jerarquizados al interior de la estructura simbólica de una comunidad. Sin duda ambas preguntas están relacionadas: no todos los imaginarios poseen la misma jerarquía al interior del simbolismo de una ciudad, siendo aquellos que poseen un mayor status los que generalmente logran perdurar a lo largo del tiempo. En la medida en que expresan la simbología de los sectores dominantes, los imaginarios urbanos organizados desde el Estado y/o las instituciones de la sociedad civil que gozan de reconocimiento social, logran perdurar. Tal y como analizaremos en la Fiesta Provincial del Inmigrante. Así, finalmente, hay que ver en los imaginarios urbanos la búsqueda de legitimación de ciertas formas simbólicas de representar el orden social, con sus inclusiones y exclusiones.

Las herramientas conceptuales expuestas anteriormente nos permitirán analizar las formas en que los descendientes de inmigrantes ultramarinos (reunidos en las 
asociaciones étnicas locales) y los representantes de la intendencia municipal, construyeron un imaginario sobre la comunidad berissense -en la Fiesta Provincial del Inmigrante- a apelando a hechos de su propio pasado. Sin embargo, como veremos, este proceso no es lineal ni carece de conflictos y resistencias.

\subsection{Una toma de postura y su caracterización: nociones fuertes, débiles, seculares y religiosas del ritual}

Es necesario aclarar que nuestra caracterización de la Fiesta Provincial del Inmigrante apela a una noción fuerte y secular del ritual. Conociendo los cambios conceptuales sufridos por la categoría de rito -desde su uso como sustantivo de lo que para los enfoques tradicionales de Müller, Spencer, Tylor, Frazer y Otto era un adjetivo (ritual) hasta el empleo del término ritualización con el que los análisis goffmanianos e interaccionistas explicaron una gran variedad de prácticas cotidianas (Moore y Myerhoff, 1977; Ariño, 1996)- decidimos adoptar una acepción fuerte del término: mientras la acepción débil sostiene que toda práctica social está sujeta a convencionalismos repetitivos, ritualizados, la acepción fuerte describe, analiza y busca comprender una forma particular de práctica social (Segura, 2004).

Asimismo entendemos al ritual en su acepción secular, siguiendo la caracterización que Moore y Myerhoff (1977) hacen de ellos. Pese a que tanto los rituales seculares como los religiosos buscan "mostrar lo invisible" estos autores señalan que los rituales seculares aluden "a este mundo y solo a él", mientras que los rituales religiosos refieren a "otro mundo" para influir sobre aquel donde el ritual se realiza. Mientras los rituales religiosos mostrarían la existencia de otro mundo a través del intento de trascender aquel en el cual el ritual se realiza, el ritual secular muestra la existencia de relaciones, ideas, valores de su propio espacio social. De esta manera los rituales seculares objetivarían (o reificarían en términos de Berger y Luckman, 1993) dichas relaciones, ideas o valores afirmando su significancia para el espacio social en el cual se realizan. Teniendo en cuenta esta toma de postura, a continuación presentamos seis características de los rituales conmemorativos que nos posibilitarán describir empíricamente e interpretar analíticamente la Fiesta Provincial del Inmigrante. ${ }^{18}$

18 Estas seis características con las que delimitamos la descripción del ritual conmemorativo que estudiaremos no son las únicas con las que otros autores han caracterizado a los rituales. Para un tipo de análisis donde se enumera una mayor cantidad de características, ver Díaz Cruz (1998: 225-226). 


\section{a- Sujeto y objeto de la celebración:}

En su investigación sobre la fiesta Isambert (1982) menciona que, como toda práctica colectiva que celebra significaciones sociales, estos rituales poseen dos componentes básicos: un sujeto celebrante y un objeto celebrado. El autor entiende por el primero a la colectividad o grupo que lleva a cabo el ritual y lo dota de significado, mientras que con el segundo término hace referencia al ser 0 acontecimiento que -por poseer una importante significación para el sujeto celebrantees evocado en la acción ritual mediante todo tipo de símbolos. En sintonía con los estudios durkheimianos Isambert entiende a la fiesta como una instancia social que le permite al sujeto celebrante celebrarse a sí mismo vía el objeto celebrado: en otros términos, cuando el grupo celebra un objeto no hace otra cosa que auto-celebrarse.

\section{b- Secuencia de acciones ordenadas y recurrentes en el tiempo:}

Riviera (1988: 7) señala que los rituales se caracterizan por ser "una secuencia ordenada de acciones", con fases y subunidades que obedecen a una ordenación estricta de actividades pre-definidas ${ }^{19}$. Asimismo Moore y Myerhoff (1977) sostienen que la secuencia de acciones reiteradas (circunscripta por la limitación del acto ritual en un principio y un final) le agrega un orden que domina al acto en su conjunto ${ }^{20}$. Coincidiendo con Durkheim respecto a que "no puede haber sociedad que no sienta la necesidad de mantener y reafirmar a intervalos regulares, los sentimientos colectivos y las ideas colectivas que constituyen su unidad y su personalidad" (2007: 397 cursivas nuestras), Cazeneuve (1971) y Maisonneuve (2005) ligan la característica ordenadora del ritual con la recurrencia temporal que poseen sus prácticas. En tal sentido, y enfocándonos particularmente en los rituales conmemorativos, es importante mencionar que la repetición de ciertos significados sociales permite que los mismos queden depositados en la memoria colectiva (Montesperelli, 2004). Otorgándole un carácter político a dicha repetición ordenada Segura afirma que este proceso se lleva a cabo "para insistir sobre algo, para habituar o acostumbrar, para guiar las acciones.

\footnotetext{
${ }^{19}$ Riviera hace un señalamiento interesante sobre la etimología del término rito: “La palabra 'rito' y orden son de la misma raíz indoeuropea: rta, arta, que nos remonta al orden del cosmos, al orden de las relaciones entre los dioses y los hombres, y al orden de los hombres entre ellos. Según Benveniste, el rito, del latín ritus (es lo que está ordenado; lo que hace falta hacer) está asociado a las formas griegas artus (ordenanza), ararisko (armonizar, adaptar), arthmos (unir, ligar), las que derivan ellas mismas de la raíz indoeuropea $a r^{\prime \prime}$ (Riviera, 1997: 1).

${ }^{20}$ En esta línea Hobsbawn señala que los rituales seculares buscan 'inculcar ciertos valores y normas de comportamiento a través de la repetición (en Blázquez, 1997: 11).
} 
Se repite para olvidar que se repite y así volver naturales las mediaciones políticas" (Segura, 2004: 9).

\section{c- Dramatización de significaciones sociales:}

Esta secuencia de acciones ordenadas y repetidas en el tiempo asume una forma dramatizada a través de la cual los actores involucrados representan al objeto celebrado. Como señala Da Matta

"Por medio de la dramatización tomamos conciencia de las cosas y comenzamos a encontrarles sentido, esto es, a verlas como algo social (...) O más bien, por medio de las dramatizaciones el grupo individualiza algún fenómeno, y así puede transformarlo en instrumento capaz de individualizar a la colectividad como un todo, dándole identidad y singularidad. El modo básico de realizar tal cosa, la elevación de un dato infraestructural a cosa social es lo que llamamos ritual, ceremonial, festividad, etc." (Da Matta, 2002: 48).

Por su parte Moore y Myerhoff (1977) afirman que la dramatización ritual transforma la conducta de los actores, quienes experimentan un cambio de roles respecto a los que desempeñan por fuera del espacio-tiempo ritual. Siguiendo esta línea argumental otros autores han visto en la dramatización ritual una performance teatral (Balandier, 1994) en la cual el sujeto celebrante simula voluntariamente ser "otro distinto-de-él" (Arttoni, 1996: 130). En palabras de Duvignaud, es esencial que durante la fiesta

"se produzca ese 'efecto de alejamiento' que provoca, durante todo el tiempo de la ceremonia, una distancia entre los papeles que la sociedad actual impone a los hombres y mujeres, y esa capacidad momentánea de ser 'otra cosa'" (Duvignaud, 1997:19).

\section{d- Estructura de comunicación:}

Debido a su carácter simbólico y dramatizado el ritual se vuelve un sistema pedagógico a través del cual se trasmiten valores, imágenes y mensajes (Riviére, 1988) particularmente útil para actores que, como el Estado, necesitan construir legitimidad política, estabilidad soberana o instituir un linaje, un mito de origen, un panteón de figuras icónicas y monumentalizadas (Duvignaud, 1989). Como afirma Ortemberg, las fiestas son

"un dispositivo pedagógico esencial para comunicar individuos, grupos e instituciones entre sí y darle entidad a la comunidad política" (Ortemberg, 2013: 16). 


\section{e- Medios a través de los cuales se construyen identificaciones colectivas:}

Una de las características más recurrentemente señalada por los autores dedicados al estudio del ritual, es la capacidad que ellos poseen para crear contextos en los cuales se reproducen valores morales y significaciones sociales que identifican a los miembros de un grupo (y los distinguen de otros). En este sentido Velasco afirma que lo sorprendente

"es la capacidad de los rituales para transformar a las personas, para otorgarles nuevas identidades, para reafirmar identidades previamente adquiridas o para dirimir conflictos de identidad nunca del todo resueltos (Velasco, 1986: 66)"

Alejándose de cualquier lectura esencialista o reificante de lo social que haya utilizado inicialmente el concepto de identidad -donde cada grupo social poseería de manera diferenciada una raza, una cultura y un lenguaje propio homologables entre si $^{21}$ - el concepto de identificación permitió hacer foco en el carácter procesual, relacional y contextual en el que producen aquellos significados, prácticas, normas y valores sociales que ponen en común a una serie de actores sociales, distinguiéndolos de otros (Brubaker y Cooper, 2001). Así, el ritual se ha vuelto un contexto privilegiado para el estudio del proceso, siempre abierto y conflictivo, en el que se co-construyen las identificaciones sociales.

Jaume (2000) y Jelin (2002a) abordan con claridad la relación entre esta capacidad del ritual para re-afirmar identificaciones sociales y aquella otra de

\footnotetext{
21 Desde la antropología Narroll (1964) e Isajiw (1974) definieron a los grupos étnicos mediante la conjunción de aquellos tres elementos (raza-cultura-lenguaje) tendiendo a pensarlos como islas independientes, culturalmente homogéneas y sin contacto con otros grupos sociales. Dentro de la sociología esta mirada sobre los grupos étnicos se hizo a partir del uso del concepto identidad: ésta refirió inicialmente a procesos sociales supuestamente atrapados en una lógica de lo Semper ĺdem cuya manifestación discursiva señalaba lo idéntico, lo permanente, lo cerrado, lo duradero y homogéneo de la realidad social. Así, identidad referiría a aquellas totalidades sociales -muchas veces engañosas y casi siempre tranquilizadoras (Caggiano, 2005)- cuya lógica interna, colectivos sociales que la integran, modos en que marcan sus diferencias, propósitos que los reúnen y movilizan serían conocidas de antemano. Este concepto de identidad fue utilizado por la sociología clásica para describir agregados sociales que (supuestamente) poseían las características de pureza, orden, coherencia y homogeneidad interna (Albertsen y Diken, 2000). Haciendo notar que lo que obnubiló a la tradición clásica de la sociología fue lo aparentemente manejable y duradero de la experiencia humana en sociedad (Latour, 1993 y 2001), otros autores indican que lo que ella ha visto en torno a identidad fue todo lo que garantizaba relaciones sociales estables y aseguraba su continuidad (Augé, 1994). Las criticas contextualistas y relacionales de Barth (1976) a aquella concepción esencialista de Narroll e Isajiw sobre los grupos étnicos -sumadas a que la dinámica social de nuestra contemporaneidad incrementó el movimiento, la inestabilidad y el contacto permanente entre grupos sociales- hicieron que desde la sociología se privilegiara el concepto de identificación por sobre el de identidad: si esta podía referir a cierta esencia inmutable, coherencia, estabilidad, homogeneidad y ausencia de vínculos extra-grupo; identificación rompía procesualmente dichas limitaciones (Brubaker y Cooper, 2001).
} 
instituirse como espacios de memoria (ver punto f). Si perder la memoria es potencialmente un indicio de disolución identitaria, el ritual y su capacidad de escenificar de manera dramatizada un conjunto de hechos pasados permite mantener viva la identidad.

"el núcleo de cualquier identidad individual o grupal está ligado a un sentido de permanencia (de ser uno mismo, de mismidad) a lo largo del tiempo y del espacio. Poder recordar y rememorar algo del propio pasado es lo que sostiene la identidad" (Jelin, 2002a: 24-25).

\section{En este sentido}

"Los grandes rituales colectivos (...) son ocasiones ceremoniales muy propicias para articular el pasado con el presente, y por lo tanto son también propicias para analizar los mecanismos por los cuales esos rituales activan solidaridades y colaboran en la construcción de la identidad colectiva" (Jaume, 2000: 75-76).

\section{f- Significación de un tiempo social:}

Como mencionamos anteriormente los rituales conmemorativos buscan insertar en la diacronía del tiempo histórico a los referentes mitológicos que no encuentran un recipiente temporal sincrónico (Durkheim, 2007). El carácter representativo de su dramatización hará referencia a un episodio mitológico que actualiza e instituye un relato de origen o creación, con el fin de salvaguardar la fisonomía moral de la colectividad ante el poder destructor del olvido (Monkevicius, 2009). Asimismo esta producción ritual de memorias sobre ciertos hechos del pasado está orientada desde un presente contextualmente situado. Siguiendo esta línea argumental -agregamos ahora- el ritual conmemorativo permite representar una historia mítica, un acontecimiento que ha tenido lugar en un pasado que es resignificado desde el presente como primordial u originario (Eliade, 1968; Lacarrieu, 2009). Proceso que se lleva a cabo con el fin de avivar la memoria en torno a "un pasado apropiado" y eslabonar el presente con él (Mary Douglas, 1973). A través de la construcción de un puente retórico con ese pasado, los rituales conmemorativos se vuelven un espacio privilegiado para que los actores celebrantes busquen legitimarse en el presente instituyéndose en centro de aquel relato histórico (Kertzer, 1988; Moore y Myerhoff, 1997; Segura, 2000; Ortemberg, 2013).

Trasladando este análisis a las fiestas conmemorativas, Hernández Sandoica (2000) afirma que éstas no existen sin un uso político de la memoria cuyo origen y motivo se correspondería con la idea y práctica de poder de quienes la instauran e 
inauguran ${ }^{22}$. En la misma línea Homobono Martínez (1990: 9) concluyó que las fiestas conmemorativas constituyen "historiodramas o simbolizaciones rituales de un pasado histórico, cuya reactualización ceremonial sería utilizada como legitimación del orden social". Tal vez sea Vovelle (1985) quien mejor expresó el nexo entre fiesta, memoria y poder mediante una anécdota personal: interrogado por un gestor político interesado en encontrar los orígenes históricos que le permitan revivir los juegos de la fiesta del Corpus Aix, este académico que entendía que "cualquier fiesta solo puede ser de su tiempo" le aconsejó que si quería conseguir su propósito debía ofrecer trabajo a la mano de obra maghrebrina que vivía en la parte vieja de la ciudad. Sabiendo que esto difícilmente sucedería, Vovelle nos pidió

"Aceptemos pues, de una vez y para siempre, que en todas las épocas la fiesta se crea la herencia que le conviene...". (1985: 195)

Con el objetivo principal de definir a la Fiesta Provincial del Inmigrante como un ritual conmemorativo recorrimos algunas de las miradas socio-antropológicas del ritual que le dieron un marco teórico al estudio empírico del fenómeno festivo. Explicitamos nuestra adopción de una noción fuerte y secular del ritual describiendo las características centrales que nos permitirán describir empíricamente e interpretar analíticamente nuestro objeto de estudio. A fin de situar nuestra investigación en diálogo con otros trabajos temáticamente afines, repasamos a continuación una serie de trabajos del campo de los estudios migratorios y el campo historiográfico de nuestro país.

\footnotetext{
${ }^{22}$ Esta autora caracteriza a la fiesta conmemorativa como un lugar de memoria, "un espacio concreto (en tiempo y lugar) en que una sociedad (o un sector representativo de ella) vendría a recrear, participando de su actualización, las claves y premisas de una concreta atribución de significados puesta en circulación por el poder" (2000: 40)
} 


\section{Estado de la Cuestión: un recorrido por los antecedentes}

Si bien nuestra investigación dialoga a nivel teórico con los antecedentes citados anteriormente, lo hará de manera específica con un conjunto de trabajos empíricos insertos en el campo de los estudios migratorios y en el campo historiográfico de la Argentina $^{23}$. Trabajos que abordaron temáticas afines a la nuestra y fueron publicados, casi exclusivamente, durante los últimos veinticinco años. Con ellos elaboramos nuestro Estado de la Cuestión, "una síntesis crítica de las investigaciones previas en torno a un tema de interés, una síntesis que pone tales investigaciones en relación, a la vez que las evalúa" (Bengochea y Levín, 2012:79). Cabe aclarar que el Estado de la Cuestión realizado será de tipo histórico (Swales, 2004), organizado en función de un eje temporal, cronológico, en el cual se produjeron las investigaciones más relevantes sobre el tema ${ }^{24}$. En este tipo de estados de la cuestión, la dimensión histórica -como eje articulador- "permite arrojar luz sobre sobre la evolución del pensamiento acerca de un tema a lo largo del tiempo" (Bengochea y Levín, 2012: 81).

\subsection{El campo de los estudios migratorios de la Argentina: inmigración y memoria}

En este apartado brindamos un panorama general sobre la conformación y la producción académica del campo de los estudios migratorios en la Argentina. Recorrido sintético -buscando no caer en una repetición innecesaria luego de los exhaustivos trabajos de Armus (1986), Devoto (1992), Devoto y Otero (2003)- y en el cual haremos hincapié en los trabajos que indagaron específicamente la relación entre inmigración y memoria. Este panorama nos permitirá, en el apartado siguiente, introducirnos en las investigaciones que tomaron a las fiestas que organizan los inmigrantes y sus descendientes, como un objeto de estudio en el cual indagar dicha relación.

En nuestro país el interés académico por la inmigración provino, centralmente, desde la sociología, la historiografía y la antropología. A partir de los años 60 -cuando los flujos migratorios llegados desde Europa habían declinado notoriamente- el

\footnotetext{
23 Campos académicos con límites difusos y pertenencias disciplinares diversas. Ambos están compuestos por sociólogos, historiadores, antropólogos, cientistas políticos, comunicadores sociales, demógrafos, etc.

${ }^{24}$ Swales (2004) distingue cuatro tipos de Estados de la Cuestión: el histórico, el statu quo, el teórico y el temático. En tato tipos ideales, los mismos no se encuentran en estado puro en ninguna investigación, sino que lo más habitual es encontrar simultáneamente algunas dimensiones de ellos dentro de un mismo Estado de la Cuestión.
} 
sociólogo italiano Gino Germani llevó a cabo un análisis sobre el proceso de modernización de la sociedad argentina en el cual los inmigrantes tenían un rol central. Modelo de integración y movilidad social ascendente que postulaba una supuesta "fusión" entre los grupos migratorios y la sociedad receptora; dando lugar a la conformación de un "crisol de razas" nacional. Si bien esta lectura optimista sobre el proceso de integración de los inmigrantes a la sociedad argentina y su conformación acrisolada influyó notablemente en los estudios posteriores, ella convivió con un "difuso optimismo" (Devoto, 1992) que lentamente comenzaría a mostrar los límites del mito integrador.

Entre fines de los años 70 y principios de los 80, la historiografía (Bjerg, 2016) y la antropología (Maffia, 2010b) comenzaron a estudiar sostenidamente el fenómeno migratorio. Los investigadores provenientes de estas disciplinas introdujeron una serie de perspectivas analíticas novedosas, estrategias metodológicas poco utilizadas y temas escasamente indagados. El desplazamiento desde una historia económica hacia una historia social, la pregunta por la conformación de límites étnicos entre los grupos migratorios y la adopción de una estrategia metodológica que recuperara la voz de los actores -entre otros aspectos- provocaron la apertura de una nueva etapa en el campo de los estudios migratorios (Devoto, 1992).

Como parte de este proceso la preeminencia del marco interpretativo del crisol de razas se vio cuestionada por las lecturas que, desde la Argentina, se hicieron del modelo de análisis pluralista de origen norteamericano. Constituyendo una tensión entre quienes defendían al modelo acrisolado como aquel que mejor describía el proceso de integración de los inmigrantes en la sociedad argentina y quienes entendían que el modelo pluralista era el que lo explicaba cabalmente. Modelos expresados mediante las metáforas del crisol y el mosaico, y que portan lecturas opuestas sobre el proceso de integración anteriormente mencionado: mientras la metáfora del crisol supone una integración social exitosa y no conflictiva -en la cual las distintas "razas" se habrían fusionado en un nuevo y homogéneo "ser nacional"- la metáfora del mosaico supone la existencia de un heterogéneo pluralismo cultural conformado por la sumatoria -no siempre armónica- de distintos grupos étnicos (Devoto y Otero, 2003; Devoto, 2009). En tal sentido, De Cristóforis señala que

"La defensa de una y otra interpretación generó interesantes debates entre los estudiosos de la inmigración en la Argentina. Numerosas indagaciones se encaminaron a discernir cuál era el modelo más pertinente para comprender los procesos de integración de los extranjeros en distintos ámbitos de la Argentina. En este sentido, los resultados de las investigaciones no han sido unívocos: dependiendo del lugar, la época o del grupo inmigratorio en cuestión, los historiadores han puesto de relieve que el grado de asimilación de los recién llegados fue variable" (De Cristóforis, 2016: 74). 
Como resultado de este debate las investigaciones insertas en el campo de los estudios migratorios se direccionaron en dos sentidos: por un lado encontramos los trabajos que desde una escala macro buscaron dar respuesta a problemáticas y dinámicas globales (como el vínculo de los inmigrantes con las estructuras económicas, sociales y políticas de la Argentina) y por otro se ubicaron las investigaciones que desde una escala micro analizaron distintas dimensiones de la experiencia de un grupo migratorio en ámbitos acotados. Insertos en esta segunda línea, a partir de los años 90 proliferaron los estudios de caso (Archenti, 2010) sobre distintos grupos migratorios. En torno a la inmigración limítrofe y asiática encontramos los trabajos de Bialogorski (1993, 2001, 2004); Pacecca (1993, 1998); Courtis (1998, 2000, 2005); Gavazzo (2002, 2007), Canelo (2007, 2008); Pizarro (2006, 2007); Recalde (2002); Gómez (2006, 2009); Grimson (1999, 2000, 2003, 2006); Mera, (1998); Caggiano (2004, 2005); Halpern (2006, 2007); Laumonier, Rocca y Smolensky (1983); entre otros. Sobre la inmigración africana encontramos los trabajos de Maffia (2001, 2004, 2007, 2010a), Otero Correa (2000); Kobelinsky (2003); Traoré (2006); Cicogna (2007); Zubrzycki, Ottenheimer, Agnelli y Kleidermacher (2008), Agnelli y Zubrzycki (2008); Frigerio (2008); entre otros. Asimismo se renovaron las investigaciones sobre la inmigración europea, sobre todo la proveniente de Europa Oriental: aquí se encuentran los trabajos sobre la colectividad croata (Rosan, 2002, Misetich, 2006), polaca (Zubrzycki, 2002), ucraniana (Ballina, 2006), búlgara (Ballina, 2005), lituana (Maffia, 1995; Maffia, Morgante y Fora, 1998; Monkevicius, 2002, 2006b, 2009) e inmigrantes que arribaron a la Argentina durante el siglo XX bajo la categoría de refugiados (Pacecca, 2000; Asa, Courtis, Pacecca y Talpone, 2007) o de exiliados (De Cristóforis, 2015)

Si bien los temas indagados por estos trabajos exceden ampliamente la posibilidad de ser reseñados aquí -lo cual además nos alejaría de nuestro propósito-, nos interesa marcar que la relación entre inmigración y memoria no formó parte de las preocupaciones centrales del campo de los estudios migratorios de la Argentina. Sin embargo, como bien señala Monkevicius (2009: 27), la pregunta por la reconstrucción de las identificaciones étnicas y las identificaciones nacionales de los inmigrantes y de sus descendientes permitió problematizar "la diferencia entre la experiencia vivida y aquella que es recuperada simbólicamente". La preocupación por dicha diferenciación constituyó el camino central a través del cual la pregunta por la memoria sería incluida en el campo de los estudios migratorios: a través de ella no solo se buscó analizar los modos en que los inmigrantes recordaban hechos de su propia experiencia migratoria sino además -en línea directa con nuestras preocupaciones- comprender cómo lo 
hacían sus descendientes. Actores que acceden y se vinculan con ese pasado mediante una representación simbólica; un acto de memoria construido a partir de la apelación a un pasado que les fue trasmitido. Una memoria heredada.

En línea con la proliferación de estudios sobre el pasado reciente (mencionada en el punto 1.6 del Marco Teórico)-, desde principios del siglo XXI se produjo en Argentina un creciente interés por la relación entre inmigración y memoria. Situación que se evidencia en el número de ponencias temáticamente afines que se presentaron en jornadas académicas dedicadas a las migraciones ${ }^{25}$ y distintos talleres enfocados a problematizar específicamente aquella relación ${ }^{26}$. Y si bien las nociones de memoria, usos sociales del pasado y tradición constituyen categorías explicativas de segundo orden en la comprensión de los temas indagados, encontramos antecedentes relevantes en los trabajos de Bjerg (2001), Rosan (2002), Misetich (2003), Tossounian (2004), Masotta (2004), Doudtchitzky (2004), Masseroni (2005, 2006), Mera (2006), Bargman (2006), Barbieri (2006), Portela (2006), Castells (2006) y Palermo (2007). Frente a estos trabajos, las investigaciones de Baeza sobre la comunidad boliviana (2017), Castiglione sobre la comunidad coreana (2017) y Monkevicius sobre las comunidades lituana (2000, 2005a, 2005b, 2005c, 2006a, 2006c, 2007a, 2007b, 2009, 2011) y caboverdeana $(2012,2013,2015 a, 2015 b, 2017)$ hicieron de la memoria, los usos sociales del pasado y la reconstrucción de tradiciones culturales ejes centrales de sus análisis. Finalmente, el modo en que es recordado el pasado en las experiencias de distintos grupos migratorios constituye uno de los temas centrales que articulan los trabajos sobre la colonización judía en la provincia de Entre Ríos y Santa Fe (Flier, 2011; Freidenberg, 2013; Cherjovsky, 2017).

Luego de este repaso general sobre la formación del campo de los estudios migratorios de la Argentina y los trabajos que analizaron la relación entre inmigración y memoria, nos enfocaremos específicamente en las investigaciones que vieron en las fiestas un objeto de interrogación legítimo. Haciendo hincapié en los trabajos que analizaron cómo los descendientes de inmigrantes reconstruyen memorias colectivas, usan socialmente el pasado y ponen en práctica distintas tradiciones culturales en contextos festivos. Antecedentes específicos de nuestra investigación.

\footnotetext{
${ }^{25}$ En las “Jornadas un siglo de migraciones en la Argentina contemporánea: 1914-2014", realizada en el Instituto Gino Germani (UBA, octubre del 2016) tuvo lugar una mesa titulada "Migraciones, exilios y memoria". La misma fue coordinada por la Dra. Patricia Flier. Parte de los trabajos presentados en esas jornadas pueden ser consultados en De Cristóforis y Novick (2016).

${ }^{26}$ En abril del 2006 se realizó en Buenos Aires el taller de discusión titulado "Usos de la memoria y trasmisión oral en los estudios migratorios". El mismo formó parte del Congreso Argentino de Estudios sobre Migraciones internacionales, Políticas Migratorias y de Asilo.
} 


\subsection{La fiesta como objeto de investigación en el campo de los estudios migratorios de la Argentina}

A principios de los años 90 Da Orden (1991) señaló que el campo de los estudios migratorios de la Argentina contaba con muy pocos trabajos que vieran en las prácticas festivas un objeto de estudio legítimo ${ }^{27}$. Lejos de haber sido una propiedad exclusivamente local $^{28}$ la escasez de trabajos sobre el fenómeno festivo se debió -en buena medida- a la deslegitimación que le había impuesto su supuesto vínculo con prácticas sociales caracterizadas como irracionales, lúdicas, carentes de sentido, irreflexivas, improductivas, pintorescas, ociosas, irrelevantes o desproblematizadas. Tal y como que señalamos en el Marco Teórico.

Esta situación llevó a que algunas de las grandes preguntas del campo de los estudios migratorios (como la inserción/integración de los inmigrantes en la sociedad argentina, por ejemplo) se abordaran a partir de temas como el parentesco, las pautas matrimoniales, el asociacionismo, el vínculo con el mercado laboral, la distribución espacial, su participación política, etc. Así, "sorprendentemente" (Halpern, 2006:245) se "pasaron por alto" (Giorgis, 2004:115) un conjunto "de aspectos tal vez más difusos y difíciles de aprehender como las fiestas" (Da Orden, 1991:379). Extendiendo este diagnóstico hasta nuestros días, Bjerg y Cherjovsky (2014:5) afirman que "pocos historiadores y antropólogos se han interesado por las celebraciones étnicas y, aunque los estudiosos de la inmigración no las han eludido, no han hecho de ellas el objeto principal de sus investigaciones." Sin ánimo polemista nos permitimos señalar que desde aquel señalamiento realizado por Da Orden a inicios de los años '90, el campo de los estudios migratorios ha ido revirtiendo progresivamente la escasez de investigaciones que tomaron a la fiesta como objeto y/o contexto de sus trabajos.

Una característica de esta producción es que la enorme mayoría de las investigaciones desarrolladas durante los últimos veinticinco años han tomado como referente empírico a inmigrantes latinoamericanos (y sus descendientes), particularmente bolivianos y peruanos. Los trabajos de Laumonier (1990), Grimson (1999), Giorgis (2004), García Vázquez (2005), Bonaparte (2005), Vargas (2005),

\footnotetext{
${ }^{27}$ La autora cita como únicos antecedentes los trabajos de Gandolfo (1988), Pianetto y Galliari (1989) y Devoto (1990). A ellos nos permitimos sumar, como antecedentes anteriores a la década del 90, el trabajo de Laumonier, Rocca y Smolensky (1983) sobre la fiesta de Copacabana realizada por inmigrantes bolivianos en Buenos Aires.

${ }^{28}$ En los mismos años Freidenmberg y Kasinitz (1990: 109) señalaron que al interior del campo de los estudios migratorios de Estados Unidos, las investigaciones sobre "festivales y celebraciones públicas [era] un área de observación relativamente reciente". De dicho campo caben resaltar los antecedentes de Orsi (1985), Bodnar (1992) y Schultz (1994).
} 
Serafino (2010), Serafino y Demarchi (2015), Hernández, (2010), Gavazzo (2004, 2005, 2006, 2013), Sassone y Baby-Collin (2012), Passarelli y Giménez (2015), Mallimaci Barral (2016), Nava le Favi (2016), Passarelli, Rodrigo, Romero y Giménez (inédito), Escribal y Rivarola (2017) se centran en inmigrantes bolivianos. Asimismo el trabajo de Vega (2011) analiza conjuntamente las prácticas festivas realizadas por inmigrantes bolivianos y peruanos, mientras estos últimos se vuelven el referente empírico que monopoliza los trabajos de Benza $(2001,2005)$. Por su parte los trabajos de Halpern (2006), Barelli $(2011,2014)$ y Granero (2016) se centran en festividades realizadas por inmigrantes paraguayos.

Al interior de estos trabajos es notoria la centralidad que adquieren las festividades religiosas: la Fiesta de Nuestra Señora de Copacabana (Laumonier, 1990; Grimson, 1999; García Vázquez, 2005; Vega, 2011; Gavazzo, 2013; Passarelli y Giménez, 2015; Passarelli y otros, inédito; Vargas, 2005; Escribal y Rivarola, 2017), la Fiesta de la Virgen de Urkupiña (Giorgis, 2004; Bonaparte, 2005; García Vázquez, 2005; Hernández, 2010; Sassone y Baby-Collin, 2012; Passarelli y otros, 2015; Mallimaci Barral, 2016; Nava le Favi, 2016), la Fiesta de la Virgen de Chaguaya (Serafino, 2010; Serafino y Demarchi, 2015) y la Fiesta de Caacupé-í (Halpern, 2006, Barelli, 2011, 2014; Granero, 2016) monopolizaron los intereses de quienes analizaron las prácticas festivas realizadas por los inmigrantes latinoamericanos (y sus descendientes). Únicamente los trabajos de Benza $(2001,2005)$ están centrados en festejos patrios.

En sintonía con nuestra tesis estas investigaciones encontraron en el estudio de las prácticas festivas la posibilidad de analizar las relaciones que un grupo social activa (interna y externamente) con el fin de construir prestigio, legitimidad y visibilidad social. Dieron cuenta de los sentidos plurales, en conflicto y plenamente racionales que los actores otorgan a una misma práctica festiva. Asimismo vieron en las fiestas un espacio en el cual las dinámicas entre reproducción y subversión de las distinciones sociales (entre migrantes y nativos) es continuamente tensionada. Por otro lado se preguntaron cómo la dramatización ritual de un mito de origen permite que los actores se lean -en contexto migratorio- como parte de una historia compartida. $Y$ finalmente entendieron a las fiestas como un momento en el cual los actores reconstruyen un conjunto de tradiciones culturales que lejos de ser la conservación de una esencia ancestral o un pasado fundacional, son la puesta en escena de su vínculo con la sociedad de acogida. 
Respecto a la bibliografía que analizó las prácticas festivas en las cuales participan inmigrantes africanos (y sus descendientes) hemos encontrado pocos antecedentes. Este objeto de estudio aparece analizado en el trabajo ya citado de Martín (1997), en dos de Maffia (2001, 2010a), en uno de Funes y Quinteros (2013) y en tres de Geler $(2008,2010,2011)$.

Tanto el trabajo de Martín (1997) como los de Geler (2008, 2010, 2011) analizan con grados diversos de profundidad- la participación de los inmigrantes africanos y sus descendientes en el carnaval porteño. Al reconstruir la genealogía de este carnaval, el trabajo de Martín (1997) describe el rol constitutivo que los afroargentinos tuvieron en la conformación de distintas murgas locales. Mientras los dos primeros trabajos de Geler (2008 y 2010) estudian en profundidad la participación de los afrodescendientes en el carnaval porteño hacia fines del siglo XIX, el último (Geler, 2011) analiza las representaciones sociales del "negro carnavalesco" que aparecieron en la prensa gráfica porteña y en los periódicos de la comunidad afro entre finales del siglo XIX y principios del siglo XX.

Por su parte el trabajo de Maffia (2001) permite visualizar los sentidos que los migrantes caboverdeanos (y sus descendientes) otorgan a las festividades que ellos mismos organizan, el rol que estas fiestas tienen en el contexto migratorio y el modo en que las organizan/financian. Las fiestas -afirma la autora- cumplen la función de recuperar y reforzar valores sociales entendidos grupalmente como propios (solidaridad, humildad, conocimiento vinculados a la tierra, simpatía, etc.) así como obtener y reafirmar valores sociales producidos durante el proceso migratorio. En tal sentido los festejos permiten reforzar la condición de grupo y servir como un espacio donde los migrantes y sus descendientes reconstruyen un conjunto de identificaciones sociales.

El segundo trabajo de Maffia (2010a) y el de Funes y Quinteros (2013) analizan lateralmente el vínculo que los migrantes caboverdeanos (y sus descendientes) nucleados institucionalmente en la Asociación Cultural y Deportiva de Ensenada poseen con la Fiesta Provincial del Inmigrante (Berisso). Ambos trabajos -con grados totalmente disímiles en su profundidad analítica, descriptiva y teórica- afirman que a partir de los años 90 los eventos festivos se volvieron uno de los contextos en los cuales las segundas y terceras generaciones de descendientes buscaron revertir el proceso de invisibilización atravesado por sus ancestros ${ }^{29}$. Entrando muchas veces en

\footnotetext{
${ }^{29}$ Es el argumento de Maffia (2010a) quien nos da los elementos históricos y teóricos para entender la doble argumentación que existe detrás de este proceso: si por un lado el migrante caboverdeano se
} 
tensión con sus padres y abuelos, estos actores ven en las fiestas un espacio en el cual reivindicar su origen africano y una afiliación diaspórica, visibilizándose como afrodescendientes.

Si bien estos dos últimos trabajos poseen una enorme relevancia para nuestra investigación -no solo por haber abordado el nexo entre migrantes (o sus descendientes) y prácticas festivas, sino también por haber hecho trabajo de campo con los miembros de la colectividad caboverdeana de Ensenada en relación a su participación en la Fiesta Provincial del Inmigrante- entendemos que su foco está puesto en analizar temas distantes a los nuestros: la migración caboverdeana, el parentesco y la familia como estrategias de reproducción social (Maffia, 2010a) o las prácticas de comunicación llevadas a cabo por dicha colectividad (Funes y Quinteros, 2013). De esta manera la Fiesta Provincial del Inmigrante no aparece descripta ni problematizada en tanto contexto en el cual estudiar aquellos temas (volviéndose un espacio más entre otros ${ }^{30}$ ).

Finalmente, la bibliografía sobre las prácticas festivas en las cuales participan inmigrantes europeos (y sus descendientes) no solo es más extensa sino que posee suma importancia para nuestra investigación. Aparte de los tres trabajos que señaló Da Orden (1991) como únicos antecedentes publicados antes de 199031, durante los últimos veinticinco años se han publicado los trabajos de Da Orden (1991, 2003); Núñez Seixas (2001); Irazuzta (2001), Ballina y Ottenheimer (2006), Palermo (2007), Monkevicius (2009), Palleiro (2011), Freidenberg (2013) y el de Bjerg y Cherjovsky (2014).

En cuanto a los contextos festivos y los referentes empíricos de estos trabajos cabe mencionar que Da Orden indagó las romerías españolas realizadas en Mar del Plata durante el período 1897-1930, Núñez Seixas se enfocó en las fiestas realizadas por inmigrantes españoles en Buenos Aires durante el período 1890-1930, y el trabajo

volvía invisible para el Estado argentino debido a que mayoritariamente ingresaban al país con pasaporte portugués (debido a que hasta mediados de los años 70 Cabo Verde fue colonia portuguesa); por otro lado estos migrantes llevaron a cabo distintas estrategias de blanqueamiento como forma de volverse invisibles en un país conformado por una matriz cultural que niega la presencia de negros (alisarse el cabello mota, tapárselos con pañuelos, dejar de hablar criol, etc ). Volveremos sobre estos temas en el capítulo № 5 .

30 Los contextos donde estos trabajos han indagado aquellas temáticas fueron: programas de radio, jornadas culturales, muestras o exposiciones, recitales, conferencias, festejos por La Semana de la caboverdeanidad, la celebración de fechas patrias (Día de África, Día de la Independencia de Cabo Verde) o el Aniversario de la Institución; La Fiesta del Inmigrante (en Avellaneda, donde participa la Asociación Caboverdeana de Dock Sud) y la Fiesta Provincial del Inmigrante (en Berisso, donde participa la Asociación Cultural y Deportiva Caboverdeana de Ensenada).

${ }^{31}$ Ver nota al pie no 27. 
de Bjerg y Cherjovsky analiza un conjunto de fiestas donde participaron inmigrantes daneses (en Buenos Aires) y judíos (en Santa Fe) durante el período 1920-1940.

Por su parte la compilación de Palleiro refiere a distintos festejos realizados actualmente por descendientes de irlandeses en honor a San Patricio. El trabajo de Palermo también toma como referentes empíricos a los descendientes de irlandeses pero toma como contexto festivo a analizar las conmemoraciones realizadas a mediados de los años 2000 en homenaje al Padre Fahy y el Almirante Brown. La tesis doctoral de Monkevicius está centrada en las ceremonias conmemorativas realizadas actualmente por las instituciones lituanas de Capital Federal, Gran Buenos Aires y Berisso. El trabajo de Irazuzta está dedicado a analizar las ediciones de 1994 y 1995 del Encuentro de las Colectividades en la ciudad de Rosario donde participan varias colectividades étnicas. La investigación de Freidenberg aborda la conmemoración del Centenario de Villa Clara (Entre Ríos) durante el año 2001. Y, finalmente, el trabajo de Ballina y Ottenheimer analiza el proceso de selección de bellezas étnicas desarrollado por distintas colectividades de Berisso ${ }^{32}$ con el objetivo de elegir a las reinas que las representaron durante las ediciones 2003/2005 de La Fiesta Provincial del Inmigrante (Berisso).

Entre otros temas las investigaciones de Da Orden y Núñez Seixas vieron en el estudio de la práctica festiva una vía para comprender las estrategias que los agentes celebrantes llevaron a cabo con el objetivo de vincularse a las esferas de poder local, construir legitimidad (al interior y exterior del grupo étnico) y consolidar su posición social en contexto migratorio. Frente a ellos el trabajo de Bjerg y Cherjovsky analizó las tensiones entre identidades étnicas y nacionales que los inmigrantes daneses y judíos expresaron en contextos festivos. Así, dichas fiestas permiten comprender cómo -en un período de fuertes tensiones entre las identificaciones étnicas y la construcción estatal de una matriz identitaria nacional- cada colectividad gestionó el ajuste de sus diferencias al interior de la matriz cultural oficial. Por su parte Ballina y Ottenheimer analizan el proceso de selección de bellezas étnicas desarrollado por distintas colectividades de Berisso como una de las formas a través de las cuales se reproducen las fronteras étnicas a nivel local. Por su parte los textos compilados por Palleiro, el artículo de Palermo, la tesis doctoral de Monkevicius y el libro de Freidenberg analizaron la construcción de memorias étnicas en contextos conmemorativos como una forma a través de la cual los descendientes de inmigrantes europeos recrean identificaciones y límites étnicos. Finalmente, al estar centrados en

\footnotetext{
32 Específicamente, las colectividades española, alemana, búlgara, ucraniana y lituana.
} 
rituales conmemorativos donde los descendientes de inmigrantes europeos reponen un relato mito sobre los orígenes de la ciudad/nación, los trabajos de Freidenberg e Irazuzta poseen una enorme relevancia para nuestra tesis.

Como vemos, mientras una pequeña parte de esta producción está enfocada en las festividades realizadas en el pasado por inmigrantes, la mayor parte se dedicó a estudiar festividades donde actualmente participan sus descendientes. Situación importante para nuestro trabajo ya que -como dijimos anteriormente- la Fiesta Provincial del Inmigrante es organizada por descendientes de inmigrantes, actores que acceden, apelan y se vinculan con el pasado (un pasado trasmitido, no experimentado) mediante una representación simbólica, un acto de memoria. Por tal motivo a continuación nos detendremos en los aportes que estas investigaciones realizaron.

La compilación de Palleiro muestra cómo las fiestas organizadas por descendientes de migrantes irlandeses se constituyeron en lugares de memoria, logrando instaurar a dichos actores como legítimos herederos de una historia, un pasado y una tradición. En esta misma línea, el trabajo de Palermo analiza cómo a través de los festejos conmemorativos de dos personajes históricos, los descendientes de inmigrantes irlandeses recrean simbólicamente un pasado que les permite autolegitimarse en el presente. Al rescatar el rol que el Padre Fahy y el Almirante Brown jugaron en la constitución religiosa y estatal de la Argentina -ligándolos con un conjunto de cualidades morales positivas- sus descendientes se posicionan en el presente como legítimos herederos de un lugar destacado en la historia de nuestro país. Dichas figuras son traídas al presente como padres fundadores de la comunidad y así, -si el origen y la organización de nuestra sociedad se deben al papel que estas figuras jugaron en el pasado- sus descendientes adquieren reconocimiento social en el presente.

Por su parte Monkevicius entenderá a los rituales conmemorativos como uno de los principales soportes a través de los cuales la comunidad lituana vehiculiza el pasado (materializa y trasmite la memoria) para asegurarse la continuidad de una diversidad cultural que la distinga al interior del relato homogéneo del crisol de razas. En este sentido la autora describe cómo a través las ceremonias conmemorativas la comunidad lituana vehiculiza elementos del pasado -construyendo y transmitiendo una memoria colectiva- para (des)marcarse y visibilizarse al interior de aquella homogeneizadora construcción simbólica. Así, la evocación y reactualización del origen permitiría combatir la incertidumbre sobre la identidad lituana en el presente, 
volviendo al ritual un poderoso ordenador y unificador de las identificaciones étnicas mediante la reconstrucción social de memorias.

En la misma línea el trabajo de Freidenberg describe la participación de las colectividades judía, alemana y suizo-francesa en la conmemoración del Centenario de Villa Clara como parte de una estrategia de intervención en el presente, cuyo objetivo central estuvo ligado a la construcción de legitimidad en un contexto de crisis social, económica y política (nos referimos a los sucesos acontecidos en diciembre del año 2001). La autora afirma que la construcción de una memoria colectiva y su escenificación dramatizada en la fiesta estuvieron íntimamente ligadas a legitimar el lugar que dichos grupos étnicos tenían en la estructura social de la comunidad. Dicho de otra forma, la conmemoración del Centenario de Villa Clara habilitó un espacio en el cual estos grupos dramatizaron un relato sobre el origen de la comunidad que -al situarlos en el centro de su genealogía histórica- buscó estabilizar y legitimar su posición social en un contexto de crisis. Finalmente, la investigación de Irazuzta indaga la participación de varias asociaciones étnicas de origen europeo en una misma festividad, mostrando cómo -al reponer anualmente el mito del crisol de razas y ligar la historia de la ciudad con la historia de la nación- los rituales conmemorativos permiten que las sociedades contemporáneas actualicen un relato de origen y repongan los elementos simbólicos que vinculan a sus miembros.

Sabiendo que posiblemente hayan quedado por fuera de esta revisión algunos trabajos, celebramos poder cerrar este apartado señalando que el campo de los estudios migratorios de la Argentina ha revertido la escasa producción de investigaciones sobre el fenómeno festivo señalada por Dar Orden (1991) a inicios de los años 90. El estudio de las fiestas ayudó a encontrar otros caminos para analizar las formas de cohesión grupal entre migrantes, el modo en que éstos actores producen redes y lazos de ayuda mutua o compadrazgo -que en contextos extra festivos se desactivan-, las estrategias a través de las cuales los inmigrantes y sus descendientes adquieren prestigio, legitimidad o reconstruyen jerarquías sociales al interior de una misma colectividad. La fiesta se ha vuelto un canal a través del cual estudiar las relaciones que los migrantes y sus descendientes entablan con el contexto migratorio, un espacio donde se reconstruyen identificaciones étnico-nacionales, un momento donde se visibilizan actores que el resto del tiempo aparecen invisibilizados por la matriz cultural hegemónica de nuestro país. Estos trabajos nos han permitido ver en la práctica festiva el desarrollo de las formas simbólicas a través de las cuales se 
reproducen ritualmente las identificaciones locales y nacionales. A la vez nos aportaron un conjunto de elementos significativos a la hora de comprender cómo, en la Argentina, las fiestas étnicas se han vuelto un contexto donde la Nación se reproduce a sí misma dramatizando simbólicamente sus mitos de origen y sus formas de inclusión/exclusión social. Pero a la vez -pensado en clave conmemorativa- el contexto festivo ha demostrado tener una enorme potencialidad para abordar procesos ligados a la producción social de memorias. Aquí, la dimensión simbólica del acto ritual y su ligazón analítica con la fiesta ha permitido analizar los usos del pasado y la reactuación de tradiciones culturales. Haciendo del pasado un recurso privilegiado que orienta la acción y le otorga sentido a ciertas prácticas del presente.

\subsection{La fiesta como objeto de investigación en el campo historiográfico de la Argentina}

El rol de la Revolución Francesa en la producción de representaciones sociales destinadas a imprimir en la visión y el entendimiento de sus participantes el concepto de Nación, volvió a las fiestas un objeto de estudio privilegiado de la historiografía francesa, estadounidense, española (Vovelle, 1985; Ozouf, 1988, 1989; Heers, 1988; Chartier, 1995). Influidos por esta tradición, desde mediados del siglo XIX un conjunto de investigadores del campo historiográfico argentino comenzaron a preguntarse por el rol que tuvieron las fiestas patrias en la producción de representaciones sociales ligadas a la construcción de nuestra Nación.

Antes de ingresar en estos trabajos quisiéramos mencionar que a principios del siglo XXI Garavaglia (2000) hizo un señalamiento para el campo historiográfico argentino similar al que hacia Da Orden (1991) para el campo de los estudios migratorios: citando solo tres trabajos publicados antes del suyo afirmó que "Mucho se ha escrito sobre las fiestas (...) pero, éste no ha preocupado, salvo escasas excepciones, a nuestros historiadores" (Garavaglia, 2000: 76) ${ }^{33}$.

\footnotetext{
${ }^{33}$ Sin ánimo polemista entendemos que esa afirmación podría ser revisada ya que, como puede verse en el citado de autores que hacemos a lo largo del apartado, hemos encontrado más de tres trabajos publicados en este campo académico con anterioridad al año 2000. Más allá de esto, y en clara sintonía con lo sucedido en el campo de los estudios migratorios, vemos que el estudio del fenómeno festivo se incrementa en el campo historiográfico argentino a partir de los años 90.
} 
Tomando como corte el proceso independentista ${ }^{34}$ Clementi (1984), Vogel (1991), Salvatore (1997), Garavaglia (2000, 2002, 2007), Wilde (2011), Munilla Lacasa (2013a, $2013 b)$ y Ortemberg $(2010,2013)$ indagaron distintas formas festivas a través de las cuales las elites gobernantes buscaron inventar y representar un conjunto de tradiciones que identificaran la particularidad de una Nación (Argentina) que todavía no existía como tal. En este sentido sus trabajos se preguntaron cómo a través de las fiestas se buscó comunicar e imprimir en la visión de sus participantes un ideario de Nación que legitimara a ciertas instituciones y sectores sociales: si el pueblo era el nuevo sujeto de la soberanía (en reemplazo del Rey), a él debían trasmitírsele pedagógicamente los fundamentos de la Nación vía la representación escénica del nuevo orden social, sus héroes, tradiciones e hitos fundacionales. Para estos autores las fiestas fueron parte de los recursos simbólicos empleados institucionalmente para que el pueblo interpretara lo que estaba viviendo y legitimara los nuevos ensayos políticos. En tal sentido las fiestas desempeñaron un papel fundamental en la construcción y trasmisión de lo que se entendería por Nación, como así también en la producción de identificaciones nacionales y la representación de una determinada imagen del poder y la sociedad. Así, el estudio de distintas fiestas ayudó a describir cómo la Nación fue representada simbólicamente a lo largo del tiempo, al mismo tiempo que dicha representación confirmaba jerarquías, modos de exclusión y proyectos políticos de un grupo social en particular.

Entre fines del siglo XIX y principios del siglo XX las fiestas mayas y julianas sufrieron un proceso de estadificacion, escolarizacion y militarización. Como señala Sigal (2006: 119) se reemplazó "la fiesta" por "la Patria" a partir de una presencia más fuerte del Estado; el cual no solo elaboró una memorabilia basada en la inauguración de monumentos, museos y estatuas sino que le asignó al ejército y a la escuela la tarea de difundir el culto a los próceres nacionales. De esta manera la propia mitología patriótica consagró "al Estado como centro de su celebración" (Devoto, 2005: 184193). Según afirma Bertoni (1992: 81-82) las fiestas patrias de este período fueron parte de "espectáculo oficial" en el cual la sociedad dejó de ser un ejecutante activo del rito para pasar a ser considerada parte del público que asistía pasivamente a él. Así, existió un enorme esfuerzo del Estado por revitalizar las fiestas oficiales y construir una actitud pasiva de la ciudadanía, propugnando una identidad homogénea y uniforme. La asistencia de escolares y batallones militares caracterizaron las

\footnotetext{
${ }^{34} \mathrm{En}$ tal sentido quedan por fuera de los antecedentes con las que dialogaremos, los muy interesantes trabajos de Torre Revello (1943) y Busaniche (1959) sobre las formas festivas durante el periodo colonial.
} 
conmemoraciones de este periodo, en un contexto de preocupación por el sostenimiento de una homogénea identidad nacional.

En este marco el trabajo de Bertoni (2007) aporta un cruce relevante para nuestra tesis: indaga extensamente el rol que jugaron los festejos patrios en la (re)construcción de la nacionalidad, la tradición patria y una memoria oficial durante el período de la inmigración masiva (1880-1920). La autora estudia las fiestas que organizó una parte de elite porteña con el fin de salvaguardar los fundamentos de una homogénea identidad nacional -y su lugar en ella- que veía amenazados por la heterogeneidad social que el fenómeno inmigratorio le imprimió a la Argentina. Reponer un panteón de héroes y hechos fundantes de la patria y trasmitir una lengua ante el conjunto de los individuos que se buscó nacionalizar, fueron parte de los roles que asumieron las fiestas patrias durante este período. La apelación al recuerdo de ciertos hechos y personajes de la historia se volvió -según esta autora- un recurso de la memoria oficial para dar respuestas a un problema del presente: la dilución de una homogénea identidad nacional ante la presencia masiva, y heterogénea, de inmigrantes ultramarinos.

Siguiendo algunas de estas preocupaciones temáticas -trasladándolas a otros contextos geográficos y períodos históricos- el trabajo de Bisso (2013) se enfocó en el vínculo que algunos gobiernos totalitarios y fraudulentos entablaron con los sectores populares a partir las fiestas patrias y los carnavales. Objeto de estudio -nos referimos al carnaval- que concentro el interés de los académicos interesados en analizar la cultura popular (Puccia, 1974; Chamosa, 2003). Por su parte el trabajo de Blázquez (2012) se dedicó a analizar la reposición ritual de la simbología nacional y la construcción de identificaciones nacionales en contexto escolar mediante el estudio de las fiestas patrias.

Finalmente cabe mencionar que, en vísperas de conmemorarse los doscientos años desde sus independencias y luego de dichas conmemoraciones, en muchos países de América se renovaron las preguntas del campo historiográfico sobre las formas de representar la Nación a partir de las fiestas ${ }^{35}$. Sin poder extendernos en dicha producción académica rescatamos los trabajos locales de Grimson, Amati y Kodama (2007), Lacarrieu (2009 y 2013), Baeza (2010), la tesis doctoral de Amati

\footnotetext{
${ }^{35}$ Nos referimos a la compilación realizada por el Dr. en Historia González Pérez (2011) para el caso de Colombia, Venezuela, Bolivia, México y Brasil; la compilación realizada por las Dras. en Historia Moya López y Olvera Serrano (2012) para el caso de México y la publicación colectiva reunida en "Temas de Patrimonio Cultural" (2009) para el caso de la Argentina. Para el caso de México son de sumo valor los números especiales dedicados a la conmemoración del "doble bicentenario" (la Independencia y la Revolución), publicados por las revistas Desacatos (№ 34, 2010) y Política y Cultura (№ 33, 2010).
} 
(2011) y un libro colectivo editado por esta misma autora (Amati, et. al. en prensa). Mientras Lacarrieu $(2009,2013)$ se enfocó en los festejos del Bicentenario haciendo énfasis en la dimensión conmemorativa que asumió dicho evento y las preguntas del presente que despertaría el uso contextual de la memoria colectiva, el trabajo de Baeza (2010) no solo se pregunta cómo celebrar el 25 de mayo de 1810 desde Carmen de Patagones -siendo que la noticia de aquel hecho histórico llegó a la ciudad un año más tarde- sino que problematiza el lugar subalterno que tuvieron los afrodescendientes, los pueblos originarios y los inmigrantes limítrofes en la celebración del Bicentenario. Por su parte el trabajo de Grimson, Amati y Kodama (2007) está dedicado a comparar los sentidos sobre lo nacional que, a lo largo del tiempo, expresaron un conjunto de eventos patrios en la Argentina y Brasil. En esta misma línea la tesis doctoral de Amati (2011) se enfoca en los festejos patrios del 25 de Mayo (realizados en Buenos Aires entre los años 2006 y 2010) para dar cuenta de los cambios y continuidades en los sentidos otorgados a lo nacional. De esta manera la autora describe el modo en que los actores participantes repusieron una tradición patria y construyeron distintos imaginarios sobre la comunidad de pertenencia a lo largo del período estudiado. Siguiendo esta línea de interrogación, el libro colectivo editado por Amati (et al., en prensa) analiza los significados, las memorias y los sentimientos asociados a la Nación Argentina -durante el Bicentenario de la Declaración de la Independencia- a partir de una etnografía de los festejos oficiales que se realizaron en el municipio de Florencio Valera y los contra-festejos que se produjeron en la ciudad de San Miguel de Tucumán durante el año 2016.

Como vemos, los estudios del campo historiográfico argentino que indagaron las formas institucionales de representar los orígenes, fundamentos y legitimidad de la Nación a través de contextos festivos nos recuerdan que la dramaturgia del poder no es ajena a su funcionamiento. El estudio de las fiestas patrias o conmemorativas permitió comprender los modos institucionales en que la Nación se reconstruye a sí misma escenificando un relato mítico sobre sus orígenes, hitos fundacionales, héroes y leyendas que, a su vez, legitiman cierto ordenamiento social en el presente. Procesos que lógicamente no sucedieron sin que los actores excluidos por aquellas formas de representar el orden social elaboraren diversas prácticas de resistencia o sus propios contra-festejos. 


\section{Estrategia Metodológica: entre lo cualitativo y lo cuantitativo}

\subsection{Recorte espacio/temporal y ejes de investigación}

El primer recorte que realizamos para analizar el rol que juega el pasado en la producción de un imaginario sobre la comunidad berissense está dado, lógicamente, por el objeto de investigación: la Fiesta Provincial del Inmigrante. Ahora bien, a ese recorte espacial era imprescindible cruzarlo con un recorte temporal. El período de estudio (1978-2015) está marcado por la primera edición de la fiesta (1978) y la finalización de nuestro trabajo de campo (2015). La justificación acerca del porqué decidimos finalizar nuestro trabajo de campo ese año está dada, centralmente, por dos motivos. El primero refiere a una coyuntura histórica: en esa fecha se inició un nuevo ciclo histórico en Berisso que impactó notablemente sobre la organización de fiesta, los actores que participan de ella y los hechos del pasado a través de los cuales se reconstruye un imaginario sobre la comunidad: a partir de diciembre del año 2015 la intendencia municipal ya no estaría -como lo estuvo de manera ininterrumpida desde el regreso de la democracia- bajo el mando del peronismo. Desde esa fecha en adelante el radicalismo, dentro del conglomerado de partidos que conformaron la plataforma electoral de Cambiemos, gobierna la intendencia municipal. Este cambio en la gestión política del municipio trajo aparejados modificaciones en algunas de las instituciones de la ciudad. Entre ellas la Asociación de Entidades Extranjeras, institución que co-organiza la Fiesta Provincial del Inmigrante junto al municipio.

El otro motivo es puramente personal y se encuentra justificado en un absoluto pragmatismo académico: hasta marzo del año 2017 conté con una beca doctoral del CONICET, siendo necesario cerrar el trabajo de campo en una instancia que me permitiera contar con el tiempo necesario para escribir la tesis antes de que la beca finalizara. Pensé, equivocadamente, que un año iba a ser suficiente. No solo el trabajo de campo se mantuvo relativamente abierto -la búsqueda de nuevas fuentes escritas, el procesamiento de datos estadísticos y la necesidad rehacer puntualmente algunas entrevistas lo mantuvieron en ese estado- sino que la (re)escritura de cada uno de los capítulos constituyó un camino tan esclarecedor como sinuoso (Cardoso de Oliveira, 1996; Geertz, 1989; Becker, 2011)

Por último, aquel recorte espacio/temporal debió ser afinado para poder analizar empíricamente el rol que juega el pasado en la reproducción de un imaginario sobre la comunidad berissense. Así, decidimos acotar nuestra mirada sobre tres ejes: los soportes escritos en las cuales se materializa la memoria oficial de la fiesta, las prácticas y los testimonios orales a través de los cuales el pasado es traído al presente en la Fiesta Provincial del Inmigrante. 


\subsection{La metodología elegida, las técnicas utilizadas y las fuentes consultadas}

Mientras la elección del marco teórico a partir del cual definimos a la Fiesta Provincial del Inmigrante como un ritual conmemorativo implicó dialogar con otras disciplinas -nos referimos a la antropología y a la historia-, al momento de abordar empíricamente nuestro tema de estudio decidimos utilizar una estrategia metodológica que combinara aspectos cualitativos y cuantitativos. A continuación describimos la metodología elegida, las técnicas utilizadas y las fuentes consultadas en cada uno de los capítulos que componen la segunda parte de la tesis.

Debido a que el pasado inmigratorio es uno de los elementos constitutivos del imaginario dramatizado en la fiesta, los dos primeros capítulos están centrados en reconstruir los ejes centrales de la historia inmigratoria de la Argentina y de Berisso. Allí seguimos la sugerencia metodológica hecha por Devoto (2009: 13) respecto a la productividad analítica de estudiar temáticas migratorias en una doble escala -nacional y regional-, combinando "el uso del telescopio y del microscopio" según la necesidad de enfocar procesos temáticamente afines pero de magnitudes completamente disímiles.

Mientras en el primer capítulo utilizamos fuentes secundarias provenientes (en su mayoría) del campo historiográfico, en el segundo combinamos el uso de esas fuentes con los datos cuantitativos que proveen las fuentes censales. Así, trabajamos con los Censos Nacionales de Población y Vivienda (INDEC, 1991, 2001 y 2010) para completar la información sobre la población de origen extranjero que Lobato (2004) publicó para al período 1909-1980. Ambas fuentes nos permitieron reconstruir un conjunto de datos de sumo valor sobre la población de origen extranjero que vivió en Berisso a lo largo de todo un siglo (1909-2010).

Cabe aclarar que el censo de 1991 no había sido consolidado a nivel de partido (al menos para Berisso) antes de esta tesis. Tanto el procesamiento de ese censo (con la certificación de sus datos como inéditos) y el procesamiento del censo del año 2001, fueron realizados por la Dirección Provincial de Estadísticas y Censos a pedido nuestro ${ }^{36}$. Respecto al censo de 1991 es importante hacer otra aclaración metodológica. La pregunta sobre el país de nacimiento fue parte de un formulario ampliado que se aplicó sobre una muestra poblacional menor a la que incluyó el censo, y por lo tanto los datos sobre la población extranjera fueron expandidos a partir

\footnotetext{
${ }^{36}$ Agradecemos al personal de dicha Dirección y a la Prof. en Sociología (FaHCE-UNLP) María Paula Celestino, quién nos ayudó a representar gráficamente los datos de los censos mencionados. Dichos y su representación gráfica están incluidos en el Anexo № 3: “Población extranjera en Berisso (censos, 1991, $2001,2010)^{\prime \prime}$.
} 
de la muestra original: así, un valor de 4 representa a una sola persona expandida. En tal sentido el procesamiento realizado para este censo solo servirá como referencia ilustrativa, no pudiendo formar parte de una base comparativa con los censos posteriores sin tener en cuenta estos mínimos recaudos metodológicos. Pese a estas limitaciones hemos decidido presentar los datos del censo de 1991 porque no hemos encontrado datos del censo de 1980 y, en consecuencia, sin ambos censos la serie histórica sobre la inmigración en Berisso quedaba con un extenso período de desinformación (entre 1970 y 2001). Finalmente georreferenciamos los datos sobre la población de origen extranjero que según el censo del 2010 residía en Berisso. Al vincular el uso de fuentes estadísticas con herramientas metodológicas provenientes de la Geografía, ese trabajo nos permitirá analizar la distribución/segregación de los inmigrantes que viven en la ciudad. Para la elaboración de los mapas se utilizó la versión de prueba del software ArcGIS, la base de datos Redatam correspondiente al cuestionario básico del censo mencionado y la cartografía censal confeccionada por el INDEC ${ }^{37}$.

Para contextualizar el origen de la fiesta durante la última dictadura y comprender las reinterpretaciones que los distintos actores hacen de ese pasado, en el tercer capítulo analizamos un conjunto de documentos escritos y realizamos entrevistas en profundidad a algunas de las personas que participaron de aquel proceso fundacional. Entre los documentos escritos se encuentran un conjunto de notas publicadas en el semanario local ("El Mundo de Berisso) y una revista de circulación local ("Ciudad Inmigrante. La Revista de Berisso), las Gacetillas Oficiales de la fiesta que anualmente redacta la Asociación de Entidades Extranjeras (AEE), el Estatuto de la AEE, notas oficiales que el municipio de Berisso le envió a la Gobernación de la Provincia de Buenos Aires y un Decreto promulgado por dicha gobernación. Textos escritos y firmados por (o donde aparece el testimonio de) personas que participaron del origen de la fiesta.

Cabe señalar que los testimonios orales recabados a partir de la realización de entrevistas y los testimonios escritos que aparecen los documentos mencionados anteriormente, no fueron concebidos como relatos factuales, limitados a una supuesta función informativa que revele "la verdad de lo sucedido" (Pollak, 2006). Al desnaturalizarlos -alejándonos de cualquier postura metodológica que los incorpore

\footnotetext{
${ }^{37}$ Para esta tarea contamos con la asistencia técnica del Personal de Apoyo que trabaja en el Área de Apoyo Metodológico del IdHICS (UNLP-CONICET). Agradecemos especialmente a los Lic. en Sociología (FaHCE-UNLP) Lucas Alzugaray y María Laura Peiró. Los mapas resultantes de la georreferenciación están incluidos en el Anexo № 4, “Georreferenciación de la población de origen extranjero residente en Berisso (censo del 2010)"
} 
acríticamente como verdades dadas- los datos que estos testimonios orales y escritos brindan nos permitirán mostrar que las memorias sobre el origen de la fiesta son un objeto históricamente construido, librado a reinterpretaciones y disputas.

Dentro de las culturas gráficas en las cuales aún vivimos, los documentos escritos ocupan un lugar de suma importancia para el análisis sociológico. Al ser parte constitutiva de la sociedad en la cual nuestros sujetos de estudio desarrollan sus prácticas, los documentos que ellos producen constituyen un recurso analítico e interpretativo que los cientistas sociales no debemos ignorar (Hammersley y Atkinson, 1994). Así, y considerándolas el soporte material en el cual queda depositada la memoria escrita de la fiesta, en el cuarto capítulo analizamos las Gacetillas Oficiales de la fiesta publicadas entre 1980 y 2015. Dentro de ellas nos centramos en las editoriales que escribieron los representantes de las asociaciones étnicas y la intendencia municipal.

Esas editoriales fueron analizadas, centralmente, a partir del tipo de análisis del discurso que Alonso (1998) denomina sociológico. A su juicio el sociólogo no debe quedar encerrado en el texto, sino que debe entender al texto como un soporte de discursos situados en un determinado contexto social. Su foco no está en el nivel genético, interno, morfológico, lingüístico, psicoanalítico o semiótico del discurso, sino en la relación que el discurso escrito -por un determinado actor- entabla con su contexto histórico de producción. En sus propios términos, el análisis sociológico del discurso es "una hermenéutica ligada, fundamentalmente, a la situación y a la contextualización histórica de la enunciación, en tanto que interpretación ligada a la fuerza social y a los espacios comunicativos concretos que arman y enmarcan los discursos" (Alonso, 1998:188). Como señala Ricoeur (1995) el texto es el plano objetivo y material de un proceso que encuentra valor hermenéutico en cuanto nos sirve de soporte para llegar a hacer visibles e interpretables, las acciones significativas de los sujetos en sociedad. Así, el texto no contiene el sentido, ni es el sentido mismo, sino que es el mediador hacia él. Su vía de acceso.

El análisis sobre las fuentes cuantitativas (censos) y las fuentes documentales (estatuto y gacetillas de la $A E E$, diarios y revistas, notas municipales y decretos provinciales) que realizamos en el tercer y cuarto capítulo, fue complemento con la realización de un trabajo de campo etnográfico -en la Fiesta Provincial del Inmigranteque se prolongó durante seis años (2010-2015). Los resultados de ese trabajo de campo constituyen el material analizado en los capítulos cinco y seis. Claramente la estrategia metodológica adoptada para elaborar el material que analizamos en estos 
capítulos fue de tipo cualitativa (Alonso, 1998; Vasilachis, 2006; Archenti y Piovani, 2010). En ella realizamos observaciones participantes, escribimos registros en nuestro diario de campo, sacamos fotografías, elaboramos mapas, grabamos/desgrabamos los discursos de los representantes de las asociaciones étnicas locales y la intendencia municipal y entrevistamos a descendientes de inmigrantes que participaban de distintas asociaciones étnicas.

Sin embargo la estrategia metodológica cualitativa utilizada en ambos capítulos difiere en un punto central. Los registros que forman parte del capítulo cinco fueron elaborados, mayoritariamente, desde una perspectiva etic (la del investigador): las observaciones participantes que realizamos durante la primera parte del trabajo de campo tenían más de lo primero que de lo segundo. Más observación que participación. Postura que no solo terminaba derivando sobre el tipo de registros que escribía en mi diario de campo, sino además en los testimonios orales que obtenía: ninguno de ellos forma parte de una entrevista, sino que son la desgrabación de los discursos institucionales pronunciados públicamente en la fiesta. Lo mismo puede decirse de los mapas dibujados y las fotos tomadas: al ser elaborados por mí, estos registros portan "mi mirada" sobre la fiesta.

Las observaciones participantes (sea mayor o menor el grado de participación) implicaron la presencia en el contexto de interacción en el cual los actores desarrollaban sus prácticas. Técnica de investigación que permite acceder y describir dicho accionar en su propio contexto de producción. Como señala Piovani (2010a: 167) "la observación es el modo de establecer algún tipo de contacto empírico con los objetos/sujetos/situaciones de interés a los fines de su descripción, explicación o comprensión". A diferencia del tipo de observación que los actores hacemos en el desarrollo de nuestra vida cotidiana, la observación científica requiere disciplina, sistematicidad y constancia (Cardoso de Oliveira, 1996): en tal sentido hemos asistido durante seis años a los cinco actos que articularon cada edición de la fiesta, describiendo el contexto, los actores, sus prácticas y registrando sus discursos orales. La cantidad de observaciones participantes y registros obtenidos durante ese período estuvo guiada metodológicamente por la saturación de categorías emergentes, tal como se expone en la Grounded Theory desarrollada por Denzin y Lincoln (1994). Así, y teniendo en cuenta que muchas de las prácticas y discursos reiteraban sus formas, contenidos y sentidos, hemos tomado la decisión metodológica de describir y analizar únicamente aquellas prácticas y discursos que sintetizaban el contenido del resto.

Cabe señalar que la presencia sistemática del investigador en el contexto de interacción no constituye, necesariamente, una vía de acceso a los sentidos que los actores le otorgan a esas prácticas ni a las representaciones que ellos elaboran. Una 
de las técnicas utilizadas para reconstruir los sentidos y representaciones sobre el pasado, sus usos y la dramatización de la memoria oficial, implicó grabar/desgrabar los discursos que los representantes de las asociaciones étnicas y la intendencia municipal realizaron en aquel contexto de interacción. Discursos orales que -al igual que los discursos escritos publicados en las Gacetillas Oficiales de la fiesta- fueron analizados a partir del tipo de análisis del discurso que Alonso (1998) denomina sociológico.

Si hasta aquí utilicé en varias oportunidades la primera persona del singular para describir el trabajo de campo realizado, es necesario aclarar que durante algunos meses conté con el apoyo de otras tres personas: María Paula Celestino (Prof. en Sociología, FaHCE-UNLP), Andrés Stefoni (Lic. en Sociología, FaHCE-UNLP) y Martín Urtasun (Lic. en Sociología, FaHCE-UNLP). A estos colegas/amigos les solicité "cubrirme" en algunos de los actos a los cuales no podía asistir ${ }^{38}$. Inicialmente su presencia en el trabajo de campo fue pensada para aliviar el sentimiento de culpa que me generaba "no estar ahí", pero al leer sus registros noté que ellos cumplían un rol central en el desarrollo de la investigación: si mis observaciones y notas pueden ser calificadas -siguiendo a Piovani (2010a: 169)- como directas, las de ellos constituían un conjunto de registros indirectos. Esta forma de nombrarlos no refiere al supuesto carácter "secundario" o "lateral" que poseerían, sino que al haber sido diagramadas específicamente para esta investigación constituían un mecanismo de control metodológico indirecto. En términos de Piovani las observaciones y notas indirectas ayudan a responder un conjunto de preguntas que en ciencias sociales pocas veces solemos hacernos: ¿Cuándo otro colega va a "nuestro campo", qué ve y qué registra? ¿Qué datos construye a partir de lo que vio y registró? Todo lo que ellos describieron (tanto lo que iba en línea con lo que yo había registrado como lo que iba en otra dirección, y por eso cuestionaba y enriquecía mi mirada) constituyó un mecanismo de control metodológico fundamental durante esa etapa de la investigación.

Frente a los materiales analizados en el quinto capítulo, los registros de campo analizado en el último capítulo de la tesis fueron elaborados bajo la necesidad de reponer una perspectiva emic (la de los propios actores) sobre la fiesta. La etnografía, como método socio-antropológico de investigación, no era tal si no lograba comprender los sentidos que los actores le otorgaban a su participación festiva (Guber, 2001). Debía interpretar sus experiencias según sus propios términos. Así,

\footnotetext{
${ }^{38}$ El trabajo de estas tres personas se concentró en el período 09/2012-03/2013. Durante esos meses tuve la posibilidad de realizar una estancia de investigación y formación de posgrado en el Instituto de Migraciones de la Universidad de Granada (España), financiada por una BECA ERASMUS-ARTESS.
} 
tanto las entrevistas en profundidad y semiestructuradas como las notas de campo que realice durante la segunda parte de la investigación buscaron reconstruir la perspectiva nativa. En tanto técnica, este tipo de entrevistas permiten acceder a las significaciones que los actores le otorgan a sus propias prácticas y a las de otros actores. $Y$ si bien en antropología suelen tener un carácter complementario respecto a las observaciones participantes, en la sociología poseen un valor central y científico en sí mismas (Piovani, 2010b: 192). En definitiva, las entrevistas semiestructuradas realizadas en profundidad constituyen una forma especial de conversación entre dos o más personas; la cual es registrada y dirigida por el investigador con el propósito de favorecer la producción de un discurso conversacional continuo y con cierta línea argumental sobre un tema de interés definido en el marco de una investigación. Técnica sumamente útil cuando se busca reconstruir los sentidos que los actores le otorgan a distintos hechos del pasado (Alonso, 1998).

\subsection{Consideraciones sobre la ética en la investigación}

La primera consideración sobre la ética en la investigación que quisiéramos realizar refiere al rol que ocupamos durante el trabajo de campo. Todas las personas entrevistadas y aquellas que nos brindaron información por fuera de la instancia de entrevista sabían -porque así se lo hicimos saber- que esos datos formarían parte de esta investigación. En ninguna de las interacciones que generé durante el trabajo de campo asumí una práctica de investigación encubierta (Burgess, 1984) que me permitiera acceder a algún tipo de información -o construir algún dato- ocultando mi rol de investigador. En tal sentido, todas las personas con las cuales interactué de manera sistemática durante el desarrollo de esta investigación sabían quién era y qué hacía ahí.

La segunda consideración refiere a la identificación que en el cuerpo del texto haremos de los actores. Las personas que identificamos con nombres y apellidos son $1^{\circ}$ ) los entrevistados que nos dieron su pleno acuerdo para que así sea y $2^{\circ}$ ) los representantes de las asociaciones étnicas locales y la intendencia municipal que pronunciaron públicamente sus discursos o firmaron los textos que analizaremos.

Ahora bien, ya sea en el caso de la información relevante surgida de "relatos no solicitados" por el investigador (Hammsersley y Atkinson, 1994), en momentos de las entrevistas en los cuales existía un pedido por parte del entrevistado para que apagáramos el grabado, o cuando nos indicaron expresamente que preferían que su nombres no aparezcan en nuestra investigación, hemos tomado la decisión de identificarlos únicamente con nombres ficticios (y sin apellido). 


\section{Reflexiones finales}

En el Marco Teórico mostramos la enorme influencia que ha tenido el estudio antropológico del ritual como matriz teórica desde la cual se indagó el fenómeno festivo. A la vez vimos cómo el vínculo entre fiesta e irracionalidad (y su superación) y la polarización dicotómica entre reproducción/cambio del orden social (y su superación) dependieron en gran medida del uso que los investigadores del fenómeno festivo han hecho de diversas teorías del ritual. Luego de recorrer estos marcos conceptuales caracterizamos a los rituales conmemorativos, entendiendo que la apelación y los usos del pasado forman parte de las estrategias de legitimación social que los actores desarrollan en el presente. Finalmente presentamos la concepción weberiana de comunidad y vimos el modo en que, según Anderson, ellas se imaginan a sí mismas. Este recorrido teórico ha sido necesario para definir -y será imprescindible para comprender- la Fiesta Provincial del Inmigrante como un ritual conmemorativo a través del cual la comunidad berissense se imagina a sí misma.

En el Estado de la Cuestión presentamos un conjunto de trabajos temáticamente afines -provenientes del campo de los estudios migratorios y del campo historiográfico argentino- con los cuales dialogaremos durante el resto de la tesis. Esta presentación buscó además, dejar en evidencia la progresiva legitimidad académica que la fiesta adquirió como objeto de estudio durante los últimos veinticinco años. Finalmente cerramos esta primera parte de la tesis presentando la Estrategia Metodológica utilizada a lo largo de nuestra investigación. Allí no solo describimos las técnicas utilizadas y las fuentes consultadas, sino que además realizamos un conjunto de aclaraciones sobre las decisiones éticas tomadas en el proceso de investigación. A partir de estos elementos, en los seis capítulos que componen la segunda parte de la tesis nos abocamos a indagar específicamente distintas dimensiones del objeto y el tema de estudio. 


\section{Segunda Parte}

\section{Capítulo № 1: Inmigración y Estado en la Argentina}

En este capítulo nos proponemos, como objetivo específico, reconstruir los ejes centrales de la historia inmigratoria de la Argentina a partir de fuentes secundarias provenientes, mayoritariamente, del campo historiográfico. Esto nos permitirá (en el capítulo siguiente) contextualizar las dinámicas inmigratorias que caracterizaron a la ciudad de Berisso dentro de una escala nacional. Como señalamos en el apartado dedicado a explicitar la estrategia metodológica, en este capítulo hemos decidido seguir la sugerencia realizada por Devoto (2009: 13) respecto a la productividad analítica de trabajar temáticas migratorias en una doble escala -nacional y regional-, combinando "el uso del telescopio y del microscopio" según la necesidad de enfocar procesos temáticamente afines pero de magnitudes completamente disímiles.

Antes de ingresar en los ejes centrales de la historia inmigratoria de la Argentina es imprescindible señalar que esta generalización demográfica acarrea, de no ser aclarada, una serie de equívocos posibles. La inmigración llegada a la Argentina no se asentó en el territorio nacional de manera uniforme ni homogénea, siendo el litoral de nuestro país (Devoto, 2009: 20) -y en especial la Provincia de Buenos Aires (De Cristóforis, 2016: 57-58)- la zona que más inmigrantes recibió. Así, cuando hablemos de "la inmigración en la Argentina" nos estaremos refiriendo (en gran medida) a la inmigración asentada en dicha zona geográfica. En la cual, además, está ubicada la ciudad de Berisso.

\section{Inmigración y Estado en la Argentina}

Para presentar las líneas rectoras de la historia de la inmigración en nuestro país reproducimos a continuación una periodización que se ha vuelto canónica dentro del campo de los estudios migratorios (Devoto, 2009). Periodización que se encuentra dividida en cuatro grandes etapas: $1830-1880,1880-1914,1918-1960$ y 1960-2010. La fecha de inicio del primer período ha sido tomada por el campo de los estudios migratorios como el punto de partida de un largo y sostenido proceso de las migraciones europeas hacia la Argentina, vinculado con la consolidación del poder rosista y un nuevo equilibrio de fuerzas entre las provincias y la ciudad de Buenos Aires. La finalización de este período está dada, a su vez, por la apertura de una etapa que se caracterizó por la masividad de los flujos inmigratorios llegados a nuestro país 
desde 1880. Tiempos en que se desarrolló una activa política de Estado, inaugurada con la Ley Avellaneda. Etapa que se cierra con la Primera Guerra Mundial (1914), cuando no solo cambian las características del movimiento migratorio sino centralmente- las iniciativas estatales por regular, limitar y reorientar los movimientos poblacionales entre sus fronteras nacionales. Respecto a la Argentina, hasta la Primera Guerra Mundial su Estado y la sociedad han sido caracterizados como "débiles": "Estado débil en tanto carente de estructuras desde las que se pueda homogeneizar una sociedad (...) Sociedad débil, dada la limitada capacidad de sus grupos dirigentes de imponerse como grupos de referencia del conjunto de los habitantes" (Devoto, 2009:15). La Argentina posterior a la Primera Guerra Mundial (1918) tendrá en el Estado un actor con instrumentos políticos y culturales muchos más sólidos para intervenir sobre una población que, a partir de la década de 1930, comenzaría a recibir cada vez menos inmigrantes. El cierre de este período es comúnmente situado a comienzos de la década de 1960, cuando los flujos inmigratorios provenientes de ultramar decaen y comienza a ser visible en el área metropolitana de Buenos Aires la inmigración latinoamericana (Benencia, 2009). Finalmente, el último censo nacional (2010) nos permitirá dar por concluida esta periodización.

\subsection{0-1880: El inicio de un largo y sostenido proceso de inmigración europea hacia la Argentina}

Una de las consecuencias del proceso de conformación nacional abierto a partir de la Declaración de la Independencia Argentina, fue la recurrencia con que las elites intelectuales y gobernantes de la época debatieron el rol que debería tener la inmigración en nuestra sociedad. Sin embargo la preocupación por los países de procedencia o la influencia que los inmigrantes pudieran desarrollar sobre la cultura, el Estado o la política nacional quedarían coyunturalmente pospuestas ante la necesidad de atraer la mano de obra que necesitaba el desarrollo económico liberal en marcha.

Sintetizando el pensamiento de la elite letrada ${ }^{39}$ y gobernante de este período Alberdi (1974 [1852]) asoció el ejercicio del gobierno con la obligación de poblar un extenso y "desierto" territorio nacional que, por dichas características, limitaba cualquier programa de desarrollo económico. En este sentido la población se volvería -

\footnotetext{
${ }^{39}$ Con el concepto de elite letrada Halperin Donghi (1982) alude al grupo intelectual del '37 compuesto por Sarmiento, Alberdi, E. Echeverría, J. M. Gutiérrez, V. F. López, J. Mármol y F. Frías. El mismo Halperin Donghi señala que estos intelectuales justificaban su rol de constructores de la nación autopresentándose como la solución a los problemas de una sociedad esencialmente pasiva.
} 
al mismo tiempo- el fin y el medio del proyecto político y económico en curso. Pero a la vez la adaptación del territorio nacional a una economía moderna e internacionalmente competitiva excluía a la población originaria. Ella aparecía a los ojos de la elite letrada y gobernante como naturalmente reticente a las exigencias del desarrollo económico propuesto: "En América todo lo que no es europeo es bárbaro: no hay más división que esta 1) el indígena, es decir, el salvaje; 2) el europeo, es decir, nosotros" señalaba Alberdi (1974: 90). Frente a la "atrasada y bárbara" población originaria los individuos necesarios para poblar el territorio nacional debían poseer los hábitos de una socialización moderna, productiva y civilizada que permitiera "elevar la capacidad real de nuestros pueblos a la altura de sus constituciones escritas y de los principios proclamados". ¿Cómo hacerlo? se preguntaba y respondía el mismo Alberdi: "por la educación del pueblo, operada mediante la acción civilizante de la Europa, es decir, por el inmigrante" (1974: 86).

Como afirma Devoto, luego de la Batalla de Caseros la noción de inmigrante quedó ligada a la idea de civilización, y ésta a Europa. Hecho no solo evidente en las obras de la elite letrada sino también en la Constitución de 1853 y en la Ley de Inmigración y Colonización de 1876:

"En sus términos, inmigrante era el europeo, aunque ello (...) estaba dicho con un eufemismo. El artículo 12 de la ley señalaba: 'Repútase inmigrante, para los efectos de esta ley, a todo extranjero (que) llegase a la República para establecerse en ella, en buques de vapor o vela'. Por su parte, el artículo 18 especificaba que los buques de inmigrantes eran aquellos que llegaban 'de los puertos de Europa o de los situados cabos afuera" (Devoto, 2009: 31).

Para los sectores de la elite gobernante la inmigración de origen europeo debía cumplir dos objetivos. El primero era de tipo demográfico, ya que la misma era cuantitativamente necesaria para cubrir un espacio que se consideraba desierto. "¿Qué nombre daréis, qué nombre merece un país compuesto de doscientas mil leguas de territorio de una población de ochocientos mil habitantes? Un desierto", decía Alberdi (1974: 44) en sintonía con el diagnóstico que realizaba Sarmiento, para quien "El mal que aqueja a la República Argentina es la extensión: el desierto la rodea por todas partes y se le insinúa en las entrañas; la soledad, el despoblado sin una habitación humana, son, por lo general, los límites incuestionables entre unas y otras provincias (Sarmiento, 1974:1 [1845]).

Pero a la vez la inmigración era imprescindible cualitativamente, al erigirse la figura del inmigrante norteuropeo en fundamento de la productividad y la civilización necesaria. Estas pretensiones que unían inmigración europea, civilización y 
productivismo industrialista impulsaron el programa estatal de la Generación del '37 y se plasmaron finalmente en la letra de la Constitución Nacional de 1853 (art. 25):

"El Gobierno Federal fomentará la inmigración europea y no podrá limitar, restringir ni gravar con impuesto alguno la entrada en el territorio argentino de los extranjeros que traigan por objeto labrar la tierra, mejorar las industrias y enseñar las ciencias y las artes."

Mientras el impacto que significó la Independencia hizo que el porcentaje de extranjeros asentados en la ciudad de Buenos Aires disminuyera del 17\% (en 1810) al $4 \%$ (en 1822), el Censo Nacional de 1869 vuelve a recordarnos que el 49,6\% de la población de esta ciudad era extranjera ${ }^{40}$. Evidentemente los frutos políticos de aquellas pretensiones de la elite argentina no se plasmaron únicamente en la letra constitucional, sino que tuvieron un claro correlato sobre la sociedad.

\subsection{0-1914: El período de la inmigración masiva}

Manteniendo la fidelidad con el liberalismo económico que había propugnado la elite de la década del '30, la elite conocida como Generación del '80 buscó construir "La Argentina Moderna" bajo un conjunto de exigencias del mercado internacional que colocaban al país como productor y exportador de materias primas. En la búsqueda de lo que dichos actores entendieron por desarrollo y progreso nacional, la prioridad otorgada a la actividad económica por sobre la política supuso la formulación de objetivos que apuntaron, principalmente, a la atracción de mano de obra y capitales europeos. No solo dichas ideas de progreso y desarrollo suponían un orden político y social que lo habilitara, sino que el orden buscado implicaba la exclusión de cualquier escollo que limitara la consolidación del Estado nacional (Oszlak, 1985). En este sentido -y con leves diferencias respecto a la Generación del '37- la elite letrada y gobernante de la Generación del '80 volvió a encontrar en la población indígena y negra un impedimento "degenerativo e inadaptable" para el desarrollo del país (Joaquín V. González, en Terán, 2008).

\footnotetext{
${ }^{40}$ Como mencionamos al inicio de este capítulo no podemos generalizar esta situación a la totalidad del territorio nacional. Sin embargo, tomando nota de la ubicación demográfica que tuvo la gran mayoría de la inmigración, los censos de la ciudad de Buenos Aires son un parámetro imprescindible para ver cómo fluctuó la misma. A modo de ejemplo vemos que el Censo Nacional de población de 1869 señala un $49,6 \%$ de extranjeros en la ciudad de Buenos Aires, cuando el porcentaje nacional llegaba al $11,5 \%$ (Devoto, 2009: 236).
} 
Mientras Carlos Octavio Bunge festejaba la "desaparición" de esas poblaciones gracias a los efectos benéficos y europeizantes que tuvieron la viruela, la tuberculosis y el alcoholismo en Buenos Aires ${ }^{41}$, Ingenieros veía en las lejanas "islas de Cabo Verde negros que son 'una oprobiosa escoria de la especie humana' (...) para quienes la piedad solo puede desear la dulce extinción de las razas inferiores" (citado en Terán, 2008: 162). En "tierras templadas y habitables por razas blancas" como la Argentina, este representante del positivismo y el darwinismo social postuló que la protección estatal de los pueblos originarios solo era admisible para asegurarles una dulce extinción, a menos que su resguardo responda "a inclinaciones filantrópicas semejantes a las que inspiran a las sociedades protectoras de animales" (Ídem: 296). Frente a estas poblaciones, una vez más, la inmigración europea aparecía en el imaginario de la elite como la única posibilidad de introducir en la Argentina los elementos necesarios para alcanzar el civilizado progreso nacional.

Aunque la política inmigratoria argentina se remonta a los años $1810^{42}-1812^{43}$ podemos fijar la inauguración de sus aspectos fundamentales a partir de $1880^{44}$. En primer lugar los porcentajes de inmigrantes arribados al país permiten hablar de una época de inmigración masiva: entre 1881 y 1914 llegaron a la Argentina algo más de 4.200.000 personas (Devoto, 2009: 247) ${ }^{45}$. Si revisamos los datos censales vemos que en 1895 Argentina tenía un $25,5 \%$ de inmigrantes sobre su población total, porcentaje que en 1914 ascendería al 30\%, siendo ultramarinos un 27,3\% (Devoto, 2009: 49 y 294). Dato descomunal si tenemos en cuenta que en esos diecinueve años intercensales la población casi se duplicó.

En segundo lugar la procedencia de esta inmigración supuso un predominio de los inmigrantes procedentes del sur de Europa: de los 4.200.000 inmigrantes que llegaron entre 1881 y 1914 , alrededor de 2.000 .000 eran italianos y cerca de 1.400 .000 eran

\footnotetext{
${ }^{41}$ En sus palabras: "Además, el alcoholismo, la viruela y la tuberculosis -ibenditos sea!- habían diezmado a la población indígena y africana de la provincia-capital, depurando sus elementos étnicos, europeizándolos, españolizándolos" (Bunge, 1905: 156).

${ }^{42}$ La fecha señala un decreto de la Primera Junta "que indica que todos los extranjeros de países 'que no estén en guerra con nosotros' podían trasladarse al país, donde 'gozarán de todos los derechos de los ciudadanos'" (Devoto, 2009: 211).

${ }^{43}$ La fecha indica el dictado de un decreto mediante el cual el primer triunvirato de la administración post-colonial declaró la necesidad de la inmigración al ser "la población el principio de la industria y el fundamento de la felicidad de los Estados" (Panettieri, 1970:9).

${ }^{44}$ Para un repaso de las políticas inmigratorias en la Argentina, sus fundamentos y orientaciones ver Novick, 1997.

${ }^{45}$ Tanto Devoto (2009: 247) como Panettieri (1970:31) coinciden en afirmar que el alto porcentaje de emigrados (36\%) nos habla de una inmigración de tipo golondrina. En buena medida esta migración estuvo compuesta por jornaleros europeos que llegaban a la Argentina durante la época de la cosecha para retornar posteriormente a sus lugares de origen.
} 
españoles (Devoto, 2009: 247). El dato se vuelve significativo si tenemos en cuenta que la llegada de inmigrantes provenientes del norte de Europa suponía (al menos para la elite letrada y gobernante) el arribo de personas con alguna experiencia en el marco del industrialismo y poseedoras de los hábitos sociales, políticos y educativos deseados. Por el contrario los inmigrantes procedentes del sur eran asociados a países de considerable atraso cultural, con estructuras económicas predominantemente agrarias y una socialización política vinculada a formas absolutistas de gestión estatal ${ }^{46}$.

En tercer lugar, si bien la Argentina ocupa el tercer puesto -detrás de Estados Unidos y Canadá- entre los países que recibieron más inmigrantes europeos entre 1830 y 1950 , el nuestro fue el país con mayor cantidad de extranjeros respecto a su población nativa: en 1895 sobre un total de 3.954.911 habitantes, 1.004 .527 eran extranjeros, es decir el 25,4\% de la población (Panettieri, 1970: 25).

Por último, y en cuarto lugar, otra de las características sobresalientes de esta inmigración fue su localización demográfica ya que se asentó mayoritariamente en áreas urbanas del litoral argentino: el área metropolitana del Gran Buenos Aires reunió entre el $40 \%$ y el $60 \%$ de la población extranjera total (Germani, 1968).

Mientras este proceso inmigratorio se desarrollaba en el pasaje de entre-siglos, el Estado argentino surgió como resultado de un proceso institucional que incluyó el dominio del territorio nacional y la federalización de Buenos Aires. Sin embargo esta "situación triunfal" (Bertoni, 2007) en la que se encontraba la institucionalidad estatal incubaba la sensación de que la sociedad podía entrar en proceso de disolución debido a la masividad inmigratoria:

"ante los angustiados ojos de muchos contemporáneos, la sociedad nacional y la nacionalidad -entendida como la manifestación de la singularidad cultural de un puebloparecían entrar en disgregación" (Bertoni, 2007: 18).

Así, y luego de propiciar la llegada de inmigrantes, intelectuales como Sarmiento y Mansilla expresaron un sentimiento de amenaza por sofocación, la falta de aire y ausencia de espacio ante la muchedumbre inmigratoria que hacía de Buenos Aires

\footnotetext{
${ }^{46}$ Alarmado por el origen nacional de estas personas, el mismo Alberdi que había dado forma al vínculo entre gobierno y población; en 1873 afirmó que, así, finalmente "poblar es apestar, corromper, degenerar, envenenar un país cuando en vez de poblarlo con la flor de la población trabajadora de Europa, se la puebla con la basura de la Europa atrasada o menos culta". Opinión en concordancia con la de Mansilla, para quien era en la Argentina "donde el mal gusto que elimina la Europa encuentra, falto de crítica, amplio refugio" (citado en Terán, 2009: 118 y 119 respectivamente).
} 
una ciudad inhabitable ${ }^{47}$. A esta sensación de asfixia se sumaba una heterogeneidad social que amenazaba la gobernabilidad estatal. Mientras Alsina afirmaba que "la diversidad de razas coexistiendo en una nación crea problemas sociales gravísimos" y pedía que se conserve "en nuestra república la homogeneidad" social ${ }^{48}$, , Juan Agustín García concluía que mientras "las distintas razas en contacto no se fundan en una sola por el predominio de cualquiera de ellas, la nota característica de nuestro pueblo será la heterogeneidad, la división y subdivisión en grupos, con ideas y sentimientos radicalmente distintos" ${ }^{49}$.

A su vez, en el pasaje de entre-siglos los extranjeros aparecieron ante los ojos del Estado, distintas fuerzas políticas (centralmente el radicalismo) y el naciente movimiento obrero como un problema de difícil solución: el Estado vio en la autoidentificación étnica una limitación para su proyecto de construir una matriz cultural homogénea, el radicalismo entendió que al no estar nacionalizados no eran ciudadanos con derechos electorales que pudiesen engrosar su caudal electoral (Rock, 1977) y el movimiento obrero vio en la sociabilidad étnica un impedimento para la construcción de una conciencia de clase unificada (Falcón, 1992). De esta manera la identificación étnica y su sociabilidad institucional se volvieron objetos de una batalla en la cual el Estado, los partidos políticos y el movimiento obrero buscaron construir una identificación nacional, política o de clase.

En este contexto el proyecto simbólico del crisol de razas constituyó la base ideológica sobre la cual el Estado buscó homogeneizar la diversidad social y afirmar, así, su soberanía sobre una población extremadamente heterogénea. Y a la vez significó la construcción de un mito de origen que delimitó los marcos dentro de los cuales debían/podían integrarse ciertos colectivos étnicos (mientras otros quedaban completamente excluidos). Entre otros autores Segato (2007) ha señalado que "crisol de razas" significó la construcción de un origen mítico de la nación donde la mezcla de "razas" se cerró totalmente sobre la europeidad. La construcción de una nacionalidad homogénea dentro aquel imaginario simbólico -el cual afirma que los argentinos descendemos de los barcos y vivimos en una Nación sin indios ni negros, pero "razonablemente bien integrada" (Devoto, 2009: 219)- implicó inicialmente el marcaje de las diferencias étnicas para luego delimitarlas y designar la viabilidad de su ingreso

\footnotetext{
${ }^{47}$ Citado en Terán (2009: 118).

${ }^{48}$ Citado en Terán (2008: 235).

${ }^{49}$ Citado en Terán (2009: 126).
} 
a la nacionalidad ${ }^{50}$. El Estado argentino y sus agencias institucionales (la escuela, la salud y el servicio militar) funcionaron como una máquina de aplanar diferencias étnicas, haciendo que el acceso a la ciudadanía estuviera condicionado por un principio rector:

"todas las personas étnicamente marcadas, sea por la pertenencia a una etnia derrotada (los indios y los africanos) o a un pueblo inmigrante (italianos, judíos, españoles, polacos, rusos, sirios y libaneses, alemanes, ingleses o tantos mas) fueron convocadas o presionadas para desplazarse de sus categorías de origen para, solamente entonces, poder ejercer confortablemente la nacionalidad. La ecualización cultural, a través de un proceso de producción de neutralidad étnica, fue percibida como una condición para el acceso a la ciudadanía. La nación fue concebida y formulada como una gran etnia artificial, inventada en el laboratorio de la generación de 1880 y reproducida por la escuela mediante una depurada técnica de clonaje" (Segato, 2007: 57 y 58)

Este programa estatal buscó nacionalizar a la población de origen extranjero, y a la vez significo moldear la multiplicidad y heterogeneidad social en una especie de etnicidad ficticia (Balibar, 1991), férreamente uniformizada. Aunque careció de variantes y originalidad, la estrategia estatal ante el problema de la heterogeneidad social se centró en inventar y difundir pedagógicamente una tradición nacional. Cabe recordar que la construcción y la trasmisión pedagógica de esa tradición nacional contó -a lo largo de todo el siglo XX- con el inestimable apoyo de la historiografía oficial (Bjerg, 2016; Garguin, 2017). Pedagogía que, además, se construyó para enfrentarse a la pedagogía patriótica instaurada por las elites inmigrantes. Fue así que -como mencionamos en el Estado de la Cuestión- los festejos cívicos se volvieron un elemento privilegiado a la hora de trasmitir una visión de mundo que sirviera para legitimar el orden social, producir identificaciones nacionales y brindar pedagógicamente una determinada imagen del poder y la sociedad. Como afirmó Devoto, los contextos festivos trataron de

"crear una auténtica religión cívica que, según los moldes de las religiones tradicionales, se base en inculcar una fe a través de los ritos en los que la palabra ocupará un lugar secundario ante la dimensión ceremonial, que impone una secuencia de actos reiterada una y otra vez en el mismo orden" (Devoto, 2009: 279).

\footnotetext{
${ }^{50}$ Frente a este constructo simbólico del crisol de razas -constructo estatal y muchas veces asumido como tal por elites intelectuales (Germani fue uno de los autores que lo utilizó para analizar el rol de los inmigrantes en una sociedad nacional en vías de integración y modernización)- Devoto concluye: "Ciertamente la noción clásica de 'crisol de razas' no puede defenderse (...) solo un milagro, ajeno al ámbito del mundo de las relaciones sociales, podía permitir que una sociedad tan heterogénea fuese una sociedad integrada" (Devoto, 2009: 343).
} 
En un contexto signado por la inmigración masiva, la elite letrada y gobernante vio en las fiestas patrias la posibilidad de (re)construir los fundamentos de la identidad nacional, inventar una tradición y reponer públicamente una memoria oficial que salvaguarde su lugar en la estructura social (Bertoni, 2007). La apelación al recuerdo de ciertos hechos y personajes de la historia a través de las fiestas patrias se volvió un recurso de la memoria oficial para responder a un problema del presente: la posible disolución de la identidad nacional ante la presencia masiva y heterogénea de inmigrantes ultramarinos.

\subsection{8-1960: El descenso de los flujos migratorios hacia la Argentina}

Pese a que no se interrumpieron los flujos migratorios provenientes desde Europa -de hecho aumentaron entre fines de la década de 1940 y principios de siguiente ${ }^{51}$ - la nota característica de este período fue su progresiva disminución. La finalización de la Primera Guerra Mundial (1918), la crisis del mercado de trabajo argentino, la conflictividad social que derivó en la Semana Trágica (1919), los avances que desde la década de 1930 tuvieron los nacionalismos a escala internacional y la implantación de políticas migratorias restrictivas fueron algunos de los procesos que desalentaron los flujos migratorios hacia nuestro país (Bertoni, 2007; Devoto, 2009). Sin ir más lejos el censo de 1960 muestra que los europeos residentes en la Argentina eran dos millones, representando el $10 \%$ de la población total; apenas algo más de un tercio del porcentaje alcanzado en el censo de 1914 cuando la población del país era de casi ocho millones de personas (Devoto, 2009: 294 y 420).

A la par de esta caracterización cuantitativa se produjo una variación de tipo cualitativa en los flujos migratorios. Bajo el impacto de la política de cuotas aplicada por el gobierno de los Estados Unidos (a partir de los primeros años de la década de $1920^{52}$ ) la inmigración hacia nuestro país sufrió un cambio en la participación relativa de cada grupo nacional, haciendo que los países del centro, este y sudeste de Europa sean los que incrementaron su participación frente a los del sur y sudoeste europeo. Si bien el $72 \%$ de los inmigrantes ultramarinos que en 1923 vivían en la Argentina eran

\footnotetext{
${ }^{51}$ Dicho repunte de los flujos migratorios ultramarinos hacia la Argentina -compuestos principalmente por italianos y españoles- estuvo ligado centralmente a las condiciones político-económicas que se presentaban en las sociedades de origen: el fin de la Segunda Guerra Mundial (1945). Sin embargo las condiciones político-económicas de la sociedad de destino incentivarían la llegada de inmigrantes a nuestro país: el crecimiento económico y las políticas migratorias implementadas por el primer gobierno de Juan Domingo Perón (1946-1952) (De Cristóforis, 2016: 106; Devoto, 2009:408).

52 La Ley de Orígenes Nacionales fue dictada por el Congreso de los Estados Unidos en 1921, y reformulada hacia 1924.
} 
españoles e italianos, la migración del centro y el este de Europa había pasado del 3,4\% en 1921 al 9,3\% en 1923 (Devoto, 2009: 357).

Frente al descenso y los cambios en los flujos migratorios ultramarinos, la preocupación del Estado y de las elites (tanto nativa como las elites de extranjeros radicados en la Argentina) estuvo mayoritariamente referida a la integración de ciertos colectivos migratorios con la sociedad argentina. En buena medida, tanto para los inmigrantes como para las primeras generaciones de sus hijos nacidos en nuestro país, la integración tuvo un carácter compulsivo. Mientras a los inmigrantes el Estado los continuaba "convocando" para que se desplacen desde sus adscripciones étnicas de origen hacia la adquisición de la ciudadanía argentina (Segato, 2007) sus hijos irían "atravesando" una educación pública que en cada fiesta patria reponía la simbología nacional para, así, construir un vínculo identitario entre ambos (Blázquez, 2012). Pero a la vez la construcción de un imaginario de la nación integraría simbólicamente a los inmigrantes, sus hijos y la sociedad local en un relato acrisolado (blanco y europeo) que finalmente incluyó a algunas pertenencias étnicas y excluyó a otras (Joseph, 2000; Guano, 2003; Briones, 2005).

A diferencia de los festejos patrios del período anterior que buscaron legitimar el orden social vigente (sus instituciones y actores centrales, hitos y héroes nacionales), en este período se sumaron un conjunto de festejos que buscaron celebrar el mito del crisol de razas y la raíz hispana del mismo. Así, por ejemplo, ante el pedido de las asociaciones españolas el presidente Yrigoyen dispuso en 1917 que el 12 de Octubre se sumara al calendario de fiestas patrias para conmemorar el Día de la Raza (Devoto, 2009: 364).

Como vemos, durante esta etapa de la historia argentina la preocupación por los inmigrantes ultramarinos y sus hijos estuvo centrada en la integración social. Preocupación que en parte buscó ser respondida por estrategias que implicaron la renuncia a una adscripción étnica de origen, el tránsito por distintas instituciones públicas y la legitimación de ciertas adscripciones étnicas al interior de un imaginario acrisolado de la nación.

\subsection{0-2010: La visibilización de la inmigración latinoamericana}

Frente a la declinación de los flujos migratorios ultramarinos mencionada anteriormente, la nota característica de este período es la visibilización que progresivamente adquiere la inmigración limítrofe en la Argentina (Caggiano, 2005; 
Grimson, 2006; Ceva, 2006; Benencia, 2009). Inmigración que lejos de ser una novedad -y aquí se inscribe parte de la paradoja- posee una larga y constante tradición en nuestro país: entre el primer censo (1869) y el último (2010) su proporción respecto al total de la población osciló entre un 2 y un $3,1 \%{ }^{53}$. Debido a que el flujo de la inmigración limítrofe se mantuvo relativamente constante a lo largo del tiempo y los flujos ultramarinos habían declinado aceleradamente, la representación de los primeros sobre el total de inmigrantes en la Argentina creció notablemente: mientras en 1991 la inmigración limítrofe representaba al 50,2\% de los inmigrantes residentes en nuestro país, en 2001 representaba al 60,3\% y en 2010 llegaría a representar al $69 \%{ }^{54}$.

Hasta mediados de siglo XX la inmigración limítrofe estuvo mayoritariamente radicada fuera del litoral argentino, vinculada a la provisión de mano de obra rural en economías de frontera. Así, por ejemplo, los migrantes paraguayos se insertaron laboralmente en las cosechas de algodón y yerba mate de Formosa, Chaco, Corrientes y Misiones. Los bolivianos trabajaron en las cosechas de tabaco en Salta y Jujuy, caña de azúcar en Tucumán o la horticultura en Mendoza. Los chilenos se asentaron en la Patagonia realizando tareas de esquila y en el Valle de Río Negro recolectando las cosechas de pera y manzana, o trabajando en la explotación petrolera. Pero las crisis sufridas por estas economías durante la década del 60 y la reestructuración de los mercados de trabajo regionales (bajo el avance de la agroindustria, la incorporación de tecnología y la sustitución de cultivos) incentivaron su migración interna hacia áreas con mayor posibilidad de absorber empleo; centralmente Capital Federal y el Conurbano Bonaerense (Benencia y Gazzotti, 1995; Benencia, 2009).

La tasa de ingreso constante y su migración interna hacia Buenos Aires hicieron que a partir de los años 60 los inmigrantes latinoamericanos comenzaran a ser visibles en un litoral argentino acostumbrado a vincularse con inmigrantes ultramarinos. $Y$ decimos inmigrantes latinoamericanos -y ya no limítrofes- porque el volumen que adquirió la inmigración proveniente del Perú durante las últimas dos décadas ha llevado a que la misma sea considerada parte constitutiva de los análisis sobre la inmigración reciente hacia nuestro país (Cerruti, 2009)55. En 2010 la inmigración

\footnotetext{
${ }^{53}$ Fuente: INDEC, Censos Nacionales de Población, Hogares y Viviendas; series 1869 a 2010.

${ }^{54}$ Fuente: INDEC, Censos Nacionales de Población, Hogares y Viviendas; 1991, 2001 y 2010.

${ }^{55}$ Solo a modo de ejemplo mencionamos que durante el período 1980-2001 esta inmigración creció un 931\% (pasando de 8.561 a 88.260 personas) y en 2010 llegó a ser el 4to país de origen entre los inmigrantes americanos radicados en la Argentina. Fuente: Censos Nacionales de Población y Vivienda, INDEC, series 1980, 2001 y 2010.
} 
limítrofe más la proveniente del Perú llegó a representar el 94,2\% de los inmigrantes americanos radicados en la $\operatorname{Argentina}^{56}$, llevando a un 3,5\% la proporción de inmigrantes latinoamericanos sobre la población total de nuestro país. Es importante mencionar que en 2010 los inmigrantes latinoamericanos -léase limítrofes más los provenientes de Perú- se encontraba radicada en un $71,68 \%$ entre la Ciudad Autónoma de Buenos Aires (19,13\%) y la Provincia de Buenos Aires $(52,55 \%)$, siendo una población mayoritariamente joven, económicamente activa (el 79,4\% está incluido en el rango etario de la Población Económicamente Activa, 15 a 64 años) y con un creciente índice de feminización (el 53, $6 \%$ eran mujeres) ${ }^{57}$.

Por último es importante mencionar -respecto a su integración en la sociedad argentina- que desde inicios de la década del 90 la inmigración latinoamericana ha sido percibida por grandes sectores de la sociedad argentina como un problema. Esta inmigración no solo se hizo visible en el litoral de nuestro país por su migración interna, sino que además se la vinculó con el crecimiento de las tasas de pobreza, desempleo, delincuencia y cólera: una visibilidad signada por la negatividad (Oteiza, Novick y Aruj, 1997; Caggiano, 2005; Grimson, 2006; Halpern, 2007; Vázquez, 2008; Benencia, 2009). Paradójicamente, mientras a inicios de los años 90 el gobierno nacional y algunos medios de comunicación fundamentaban su argumento respecto a que Argentina había ingresado al primer mundo anunciando la llegada de una nueva oleada de inmigrantes ${ }^{58}$-"Alemania tenía sus inmigrantes turcos, Estados Unidos mexicanos y la Argentina, bolivianos" (Grimson, 2006: 69)- con el correr de los años estos mismos actores señalaron a la inmigración latinoamericana como parte de distintos problemas sociales.

Problemas a los cuales los inmigrantes intentaron dar respuestas con estrategias de integración social y reafirmación de su nacionalidad como las prácticas festivas. Como señalamos en el Estado de la Cuestión, distintos investigadores vieron en las fiestas realizadas por inmigrantes latinoamericanos una práctica que les permite reafirmar su nacionalidad, conformar un espacio de socialización (hacia dentro del grupo étnico), adquirir prestigio y visibilidad social desde la representación cultural (hacia afuera del grupo étnico). Enfrentando y buscando revertir los estigmas y

\footnotetext{
56 Constituido por un $36,4 \%$ de paraguayos, un $23,5 \%$ de bolivianos, un $13,0 \%$ de chilenos, un $10,6 \%$ de peruanos, un $7,9 \%$ de uruguayos y un $2,8 \%$ de brasileños (Censo Nacional de Población, Hogares y Viviendas, INDEC, 2010).

${ }^{57}$ Fuente: INDEC, Censo Nacional de Población, Hogares y Viviendas, 2010

${ }^{58}$ Comparable, en sus términos, a la inmigración ultramarina que arribó al país entre fines del siglo XIX y principios del XX. Situación totalmente falaz si tenemos en cuenta la progresión de los flujos migratorios europeos de aquellos años y la progresión de los flujos migratorios durante más de un siglo.
} 
prejuicios circulantes en el contexto migratorio (Grimson, 1999; Giorgis, 2004; Bonaparte, 2005; Gavazzo, 2013).

\section{Reflexiones finales}

Elaborado a partir de fuentes secundarias -sistematizando los aportes centrales que los investigadores más reconocidos en el campo de los estudios migratorios hicieron durante las últimas décadas- en este capítulo nos propusimos trazar las líneas rectoras de la historia de la inmigración en la Argentina.

Si bien toda periodización puede ser cuestionada, el recorrido realizado en las páginas anteriores buscó mostrar que la inmigración no es un fenómeno que pueda ser reducido a una supuesta "edad de oro" en la conformación de nuestra nacionalidad, su pasado mítico. Y mucho menos (pese a la preeminencia que en estas páginas le hemos dado a las migraciones provenientes desde Europa y América Latina) la inmigración puede ser un fenómeno que quede circunscripto a los contingentes inmigratorios provenientes desde un único origen continental. Teniendo presente estas líneas de escala macro, en el capítulo siguiente nos trasladamos hacia el plano local para analizar las dinámicas migratorias que atravesaron a una ciudad de origen portuario y fabril: Berisso 


\section{Capítulo $N^{\circ} 2$}

\section{Berisso: Inmigración, asociacionismo étnico, trabajo e identidad política}

Tomando en cuenta las líneas rectoras de la historia de la inmigración en la Argentina descriptas en el capítulo anterior, en este capítulo nos proponemos -como primer objetivo específico- describir las dinámicas migratorias que caracterizaron a la ciudad de Berisso a lo largo del último siglo (1909-2010) ${ }^{59}$. Teniendo en cuenta el origen portuario y fabril de esta ciudad, el segundo objetivo que nos proponemos es analizar la extensión/consolidación/decadencia del asociacionismo étnico y el sistema fabril berissense, haciendo énfasis en las tensiones que a lo largo del siglo XX se produjeron entre las identificaciones étnicas y las identificaciones políticas. Para alcanzar este objetivo extendemos la periodización señalada para el primero, desde 1871 (año en que se instala el primer saladero en Berisso) hasta 2015 (año en que finalizamos nuestro trabajo de campo).

Este análisis será fundamental para comprender (en los capítulos siguientes) la construcción de memorias colectivas y los usos sociales del pasado que los descendientes de inmigrantes ultramarinos reunidos en las asociaciones étnicas y los representantes de la intendencia municipal realizan en la Fiesta Provincial del Inmigrante. En otros términos, la historia inmigratoria y política de Berisso articulan los marcos sociales de la memoria (Halbwachs, 2004) a partir de los cuales es posible comprender la apelación que dichos actores hacen, en contexto festivo, a hechos del pasado local.

Respecto a la organización del capítulo hemos decidido dividirlo en cuatro subperiodos delimitados por los cambios que sufrieron las dinámicas migratorias, laborales y políticas a nivel local: 1871-1936, 1936-1955, 1955-1983 y 1983-2015. Finalmente, es importante recordar que si bien utilizaremos fuentes secundarias provenientes del campo historiográfico y datos estadísticos provenientes de distintas fuentes censales, brindaremos -a partir de estas últimas- un conjunto de datos inéditos construidos específicamente para esta investigación.

\footnotetext{
59 Las fechas de inicio de esta periodización corresponden al "Censo General de la Ciudad de La Plata, capital de la provincia. Población, Propiedad Raíz, Comercio e Industrias", realizado entre el 22 y el 30 de mayo de 1909 (Editado en La Plata, Talleres La Popular, 1910). Por su parte, la fecha de finalización se corresponde con el último Censo Nacional de Población, Hogares y Viviendas (INDEC, 2010).
} 


\section{Berisso: inmigración, trabajo y política}

\subsection{1-1936: La proliferación de identificaciones étnico-nacionales}

A diferencia de La Plata o Chascomús (quienes tuvieron un origen político y defensivo respectivamente) la ciudad de Berisso se desarrolló como resultado del cruce entre su localización portuaria ${ }^{60}$ y la instalación de un extendido sistema fabril (Lobato, 2004; Ballina, 2006). Desde 1784 integró el Partido de Magdalena hasta que en 1821 el gobierno del General Manuel Rodríguez decidió desglosar el territorio de dicho partido y constituir el Partido de Ensenada, al que Berisso pasaría a pertenecer. Más de un siglo después, el 3 de abril de 1957, Berisso y Ensenada lograron su autonomía plena al separarse administrativamente de La Plata, conformando dos partidos independientes (Sanucci, 1983) ${ }^{61}$.

La ciudad de Berisso no adoptó su nombre en honor a Luis Berisso -quien en 1881 fuera designado titular del partido al cual pertenecía ${ }^{62}$ - sino que lo hizo en honor a su hermano, el empresario italiano Juan Berisso ${ }^{63}$. Fue él quien el 24 de junio de 1871 puso en funcionamiento el primer saladero de la ciudad, inaugurando un desarrollo industrial que se vería profundizado a inicios del siglo XX con la instalación de tres frigoríficos, una destilería y una hilandería: en 1904 sobre las estructuras del antiguo saladero de Juan Berisso comenzó a funcionar el frigorífico La Plata Cold Storage, en 1907 el frigorífico Swift compró dichas instalaciones, en 1915 el frigorífico Armour radicó su planta a pocas cuadras del Swift, en 1925 Yacimientos Petrolíferos Fiscales instaló una destilería de crudo y al año siguiente comenzó a funcionar la hilandería Patent Knitting Company (Lobato, 2004; Muñiz Terra, 2012).

Su ubicación portuaria y la expansiva oferta de trabajo industrial fueron factores decisivos para que esta ciudad del litoral argentino se vuelva uno de los principales destinos del flujo inmigratorio que llegó a la Argentina entre fines del siglo XIX y principios del siglo XX (De Cristóforis, 2016: 97) ${ }^{64}$. Los datos censales muestran que en 1884 Berisso contaba con una población de 1.800 personas, en 1909 la cifra ascendió a 2.553 (de los cuales 1.499 eran nativos y 1.054 extranjeros, representando al $41 \%$ de su población) y en 1914 la población llegó a 8.847 personas (de las cuales 3.604 eran nativos y 5.243 extranjeros, representando al 59\%). El siguiente periodo censal en el cual se puede discriminar la población berissense por origen nacional es

\footnotetext{
${ }^{60}$ Berisso está localizada a 9 kilómetros de La Plata, lindando con el Rio de la Plata.

${ }^{61}$ Decreto-Ley № 4656 del Gobierno de la Provincia de Buenos Aires.

62 Decreto de la Provincia de Buenos Aires del 6 de Agosto de 1881, firmado por el Gobernador Provincial, Dardo Rocha.

63 Nacido en Lavagna el 15 de febrero de 1833, Juan Berisso llegó a la Argentina en 1848 (Sanucci, 1983).

${ }^{64}$ Siguiendo el patrón de localización territorial que, a nivel nacional, describimos en el capítulo anterior.
} 
el de 1947, donde alcanza las 33.970 personas (de los cuales 24.107 eran nativos y 9.857 extranjeros, representando al $29 \%)^{65}$. Como podemos inferir de estos datos, entre 1884 y 1909 la tasa de crecimiento poblacional aumentó 1,4 puntos porcentuales, entre 1909 y 1914 lo hizo en 28,2 puntos porcentuales, entre 1914 y 1924 aumentó 1,7 puntos porcentuales y entre 1924 y 1947 aumento 5,2 puntos porcentuales. Cruzando estos datos vemos (cuadro $N^{\circ} 1$ ) que el período censal en el cual la población de Berisso creció en mayor proporción es justamente aquel donde porcentualmente más inmigrantes recibió (1909-1914).

Cuadro № 1: Población extranjera y nativa de Berisso, por sexo (1884-1947)

\begin{tabular}{|l|c|c|c|c|c|c|c|c|}
\hline Años & $\begin{array}{c}\text { Arg. } \\
\text { Masc. }\end{array}$ & $\begin{array}{c}\text { Ext. } \\
\text { Masc. }\end{array}$ & $\begin{array}{c}\text { Arg. } \\
\text { Fem. }\end{array}$ & Ext. Fem. & $\begin{array}{c}\text { Arg. } \\
\text { Total }\end{array}$ & $\begin{array}{c}\text { Tasa de } \\
\text { Total }\end{array}$ & Total & $\begin{array}{c}\text { Tarecim. anual } \\
\text { (en puntos } \\
\text { porcentuales) }\end{array}$ \\
\hline $\mathbf{1 8 8 4}\left(^{*}\right)$ & & & & & & & 1800 & \\
\hline $\mathbf{1 9 0 9}$ & 764 & 686 & 735 & 368 & 1499 & 1054 & 2553 & 1,4 \\
\hline $\mathbf{1 9 1 4}$ & 1868 & 3984 & 1736 & 1259 & $\mathbf{3 6 0 4}$ & $\mathbf{5 2 4 3}$ & 8847 & $\mathbf{2 8 , 2}$ \\
\hline $\mathbf{1 9 2 4}\left(^{*}\right)$ & & & & & & & 10470 & 1,7 \\
\hline $\mathbf{1 9 4 7}$ & 12911 & 5950 & 11206 & 3903 & $\mathbf{2 4 1 1 7}$ & $\mathbf{9 8 5 3}$ & 33970 & $\mathbf{5 , 2}$ \\
\hline
\end{tabular}

Fuente: Propia en base a Lobato, 2004:45.

$\left.{ }^{*}\right)$ No están discriminados por nacionalidad ni sexo.

Pese a encontrarnos con la imposibilidad censal (hasta 1991) de discriminar los orígenes nacionales de la población extranjera que vivía en Berisso, los registros de personal del frigorífico Armour brindan datos significativos. Si tenemos en cuenta que entre 1915 y 1930 la población de Berisso rondaba las 10.000 personas y ese frigorífico empleaba normalmente a 2.500 -cifra que se duplicaba en los períodos en los cuales se faenaban ovinos, cerdos y aves, y durante los conflictos bélicos sucedidos en Europa- sus registros de personal se vuelven representativos de la población local. A partir de esta fuente Lobato (1992 y 2004) afirmó que entre 1915 y 1930 más del $60 \%$ del personal empleado en el Armour provenía de Europa y Asia, predominando las nacionalidades que mayormente integraron los flujos migratorios hacia la Argentina (italianos y españoles) pero notando una significativa presencia de árabes y rusos $^{66}$. Si bien estos eran los orígenes nacionales con mayor peso porcentual, no eran los únicos: Polonia, Checoslovaquia, Bulgaria, Grecia, Lituania y Serbia los siguen en un listado de 39 países (Lobato, 2004: 113).

\footnotetext{
65 Fuentes: Censos Nacionales de Población y Vivienda, INDEC y Lobato (2004).

${ }^{66}$ Con la denominación de "rusos" la autora se refiere a los inmigrantes provenientes de las aldeas de Minsk (actualmente Bielorrusia), Kiev y Odessa (actualmente pertenecen a Ucrania). Con con la denominación de "árabes" se refiere a inmigrantes provenientes de Siria, Palestina, Líbano y Jordania.
} 
Especificando la composición por sexo, la autora indica que en los años 1917 y 1918 solo el $36 \%$ y el $35,6 \%$ de los obreros que ingresaron al frigorífico eran argentinos. En 1917 los inmigrantes rusos conformaban el 19,1\% del personal total, los italianos el $15,4 \%$, los españoles el $8,1 \%$ y los árabes el 7,3\%. Un año después los rusos representaban el $18,7 \%$, los árabes el $17,8 \%$, los italianos el $11,1 \%$ y los españoles el $5,2 \%$. Por su parte las obreras de origen extranjero representaban en 1917 y 1918 solo el $32,5 \%$ y el 37,1\% del total de las mujeres empleadas. En 1917 las españolas representaban el $12,5 \%$ del personal, las italianas el $7,5 \%$ y las rusas el $7,5 \%$. Un año después las españolas alcanzarían el 16,1\%, las italianas el $13,6 \%$, las rusas el $5 \%$ y las ucranianas el 1,2\% (Lobato, 1992).

Como afirma Lobato (1992 y 2004) hasta mediados de los años '30 la heterogeneidad de lenguas y costumbres que caracterizaron al espacio fabril berissense fue una de las causas que dificultó la conformación de una conciencia de clase unificada y la vinculación de los trabajadores con las asociaciones políticas locales ${ }^{67}$. Sin embargo, fuera del espacio laboral en el cual los inmigrantes aparecían mayoritariamente fragmentados, estos actores conformaron un extenso tejido de asociaciones étnicas que los agrupó por nacionalidad, lengua y costumbres compartidas $^{68}$. Entre 1907 y 1918 se crearon la Sociedad Albanesa (1907), la Sociedad Mutual Vargdienis de la colectividad lituana (1909, luego llamada Némunas), la asociación griega Fraternidad de los Chios Adamandios Corais (1911, actualmente llamada Colectividad Helénica y Platón), el Centro Yugoslavo Argentino de Berisso (1911), la Unión Polaca (1913), la Sociedad Portuguesa (1915), la Sociedad Española (1915), la Sociedad San Patricio de la colectividad irlandesa (1915), la Juventud Israelita (1915), la Sociedad Islámica de Socorros Mutuos y Beneficencia (1917), la Juventud Islámica Amelita (1918) y la Sociedad Italiana (1918).

Durante la décadas del 20 y el 30 crearon el Centro Armenio "Hayguetron" (1924), la Colectividad Alemana (1924), la Sociedad Ucraniana Prosvita (1924), la Colectividad Inglesa (1925), el Hogar Checoslovaco Domov (1925), el Club Eslovaco Stefanic

67 Tal y como afirmamos en el capítulo anterior, el hecho de que lo extranjeros no estuvieran nacionalizados hacía que no fuesen ciudadanos con derechos electorales y, por lo tanto, sujetos con los que el radicalismo se vinculara asiduamente (Rock, 1977). A su vez el movimiento obrero veía a los inmigrantes como un problema, ya que sus adscripciones étnicas eran entendidas como un límite en la conformación de una conciencia de clase unificada (Falcón, 1992).

${ }^{68}$ Lobato afirma que en las primeras décadas del siglo XX, en Berisso existía una "conformación de grupos heterogéneos de trabajo, donde las diferencias de idiomas y de las costumbres se constituyeron -junto a otros factores- en barreras para la creación de un colectivo laboral (...) Mezclados en los espacios de trabajo pero divididos por sus idiomas y costumbres la separación de los trabajadores excedía, en el caso de Berisso, el marco de la fábrica. Los lazos solidarios se establecían entre 'paisanos', entre compatriotas y el vínculo nacional aparecía con más fuerza que el de clase" (Lobato, 1992: 216). 
(1931), una segunda asociación lituana de nombre Mindaugas (1931), una nueva asociación islámica bajo el nombre de Juventud Islámica Alauita (1932), otra asociación ucraniana de nombre Renacimiento (1933), la sociedad Yugoslavia Libre (1934), la Sociedad Cultural Búlgara Kiril y Metodio (1936) y en el contexto de la guerra civil Española reabre la Sociedad de ese país $(1937)^{69}$.

Siendo un fenómeno prácticamente universal, en la Argentina esta práctica asociativa se propuso originalmente crear hospitales donde asistir a sus connacionales, editar periódicos que los mantuvieran informados respecto a lo que sucedía en sus países de origen, cubrir gastos de sepelios e integrar a los recién llegados con la sociedad local mediante la búsqueda laboral. Con el correr de los años estas instituciones llegaron a brindar seguros de desempleo, pagar los gastos de repatriación para socios de escasos recursos y enviar ayuda humanitaria a sus países ante distintas catástrofes naturales. Pero centralmente estas asociaciones buscaron conformar un ámbito de sociabilidad que permitiera "mantener viva y difundir su cultura" a través de la proyección de películas, la realización de espectáculos teatrales, fiestas, reuniones, etc. (Núñez Seixas, 2001; Devoto, 2009). Y si bien el foco estuvo puesto en estos objetivos, no hay que olvidar el papel que las asociaciones étnicas tuvieron en la construcción de un nuevo orden simbólico que vinculara a los inmigrantes -entre sí mismos- mediante la transmisión y resignificación de distintos elementos culturales (Bjerg, 2001; Monkevicius, 2009). Elementos seleccionados por las elites dirigentes que permitían recrear -en contexto migratorio- una comunidad originaria entre sus asociados, una "parentela imaginaria" (Devoto, 2009). En este sentido la selección, reinvención y dramatización del pasado asumió una posición central en la articulación de los inmigrantes y la conformación de una comunidad imaginada (Anderson, 2007).

\subsection{6-1955: La proliferación de identificaciones político-clasistas}

Si hasta mediados de la década de 1930 las identificaciones étnicas articularon a los inmigrantes que vivían en Berisso con mayor capacidad que las identificaciones políticas y de clase, la sucesión de conflictos laborales desatados a partir de esa fecha

\footnotetext{
${ }^{69}$ El cruce de distintas fuentes (Gacetillas de la Asociación de Entidades Extranjeras de Berisso editadas entre 1980 y 2015; Guruciaga, 1995; Zubrzycki, 2001; Lobato, 2004; Ballina y Ottenheimer, 2006; Ballina, 2006) nos ha mostrado que en algunos casos las fechas de fundación de las asociaciones, el cese de actividades o sus separaciones son contradictorios o confusos. En tal sentido hemos decidido reproducir, únicamente, los datos que hemos podido confirmar o coinciden plenamente en dichas fuentes.
} 
(despidos, reducción de la jornada laboral, baja en los salarios, huelgas o boicots en la línea de producción) hicieron que las diferencias idiomáticas, culturales y nacionales comenzaran a quedar relegadas frente a la identificación de una condición compartida: ser trabajadores.

Esta situación se dio en un contexto donde la población de Berisso aumentó exponencialmente, siendo la población nativa la que creció de manera considerable frente a la población de origen extranjero. Si bien el número de extranjeros radicados en la ciudad continuó aumentando entre 1914 (5.243 personas) y 1947 (9.853 personas), entre esta fecha y 1960 el número de extranjeros descendió (7.508 personas). Frente a ellos la población local de origen argentino pasó de estar compuesta por 3.604 personas en 1914 a la sorprendente cifra de 24.117 personas en 1947 y 33.475 en 1960; haciendo que la participación de los inmigrantes sobre la población total disminuyera progresivamente desde un 59\% (en 1914), al 29\% (en 1947) y al 18\% (en 1960). Sin embargo, y frente a este dato cuantitativo, fue el carácter cualitativo del aumento de la población nativa la que se volvería sumamente importante: el mismo no solo se debió al nacimiento de las primeras generaciones de argentinos con padres inmigrantes sino, centralmente, a la migración interna de argentinos provenientes de Santiago del Estero, Corrientes, Tucumán y Catamarca que llegaban a Berisso en búsqueda de trabajo (James, 2004:31; Lobato, 2004: 47).

Ambas situaciones -conflictividad laboral y un marcado descenso en la proporción de inmigrantes ultramarinos sobre la población nativa- confluyeron para que a mediados del siglo XX los empleados insertos en la extensa trama fabril de Berisso encontraran en la articulación política un camino para identificar aquellos problemas que atravesaban y suspendían (coyunturalmente) las diferencias étnico-nacionales. Dicho de otra manera, en este nuevo contexto las fronteras de pertenencia no solo se volvieron más restringidas -pasando de la fragmentación y la heterogeneidad étnica a la articulación y la homogeneidad laboral (Lobato, 2004: 198)- sino que comenzaron a estar nucleadas a partir de la adscripción política: al anarquismo, socialismo y comunismo se sumaron la Unión Cívica Radical y el sindicalismo fabril en tanto formas de identificación política que nuclearon a los trabajadores de la ciudad. Así, y como contrapartida a la proliferación de asociaciones político/laborales a nivel local (Lobato, 2004) encontramos en este período una notable disminución en la creación de asociaciones étnicas: si entre 1907 y 1937 registramos la creación de veintitrés asociaciones étnico-nacionales, entre 1937 y 1955 solo constatamos el origen de la 
Sociedad Bielorrusa (1941), el cambio de nombres ${ }^{70}$ o la unión ${ }^{71}$ de algunas asociaciones creadas antes de 1937.

En el marco de estas dinámicas, entre mediados de 1944 y fines de 1945 Berisso atravesará un período que con el correr de los años se volverá crucial en la reconstrucción de los imaginarios locales y sus prácticas conmemorativas: su vínculo con los orígenes del peronismo. Durante los primeros días de agosto de 1944 -meses después de que se inaugurara en Berisso una dependencia de la Secretaría de Trabajo y Previsión ${ }^{72}$ - Juan Domingo Perón llegó a la ciudad para visitar el Sindicato Autónomo de la Carne y anunciar la construcción de viviendas para los trabajadores del sector ${ }^{73}$. Allí se le manifestó con preocupación la situación de 150 empleados recientemente despedidos, ante quienes Perón se comprometió a lograr su reincorporación. Días después (10 de agosto) Perón regresó a Berisso para ser homenajeado en una jornada donde los obreros colmaron el acto y los frigoríficos quedaron completamente vacíos (Lobato, 2004: 239). Entre agosto de 1944 y el año que le siguió los trabajadores de la ciudad no solo vieron disminuir sus salarios y fuentes laborales sino que las huelgas y boicots en la línea de fábrica les ofrecían tan pocas satisfacciones como los enfrentamientos con las fuerzas de seguridad. Finalmente, a comienzos de septiembre de 1945 Perón volvió a Berisso para asistir a los funerales de Doralio Reyes (hermano del dirigente sindical Cipriano Reyes), asesinado en un enfrentamiento con militantes comunistas (James y Wolfson, 1987: 448). Si entre los meses de septiembre y octubre la situación laboral era crítica, la destitución de Perón de sus cargos institucionales y el posterior encarcelamiento en la Isla Martín García hicieron que los trabajadores de Berisso perdieran al único interlocutor estatal que había intervenido en sus reclamos.

\footnotetext{
${ }^{70}$ En 1948 la Sociedad Bielorrusa adopta el nombre de Sociedad de Socorros Mutuos Hogar Bielorruso y durante la década del 60 tomará el nombre de Centro Cultural y Deportivo Vostok que conserva en la actualidad. La asociación griega Fraternidad de los Chios Adamandios Corais pasará a llamarse Sociedad Helénica Platón (no conocemos la fecha exacta) y la Sociedad Cultural Búlgara Kiril y Metodio pasará a llamarse Iván Vasov (en 1955).

${ }^{71}$ Nos referimos a la Sociedad Islámica de Socorros Mutuos y Beneficencia, la Juventud Islámica Amelita y la Juventud Islámica Alauita. En 1949 estas instituciones se nuclearon en el Círculo Cultural y Recreativo Árabe, quienes fusionándose con la Biblioteca Bernardino Rivadavia dieron origen al Hogar Árabe Argentino de Berisso.

72 James y Wolfson (1987: 448) señalan que "Gracias a la favorable intervención de la Secretaría de Trabajo y Previsión, se dieron los primeros e importantes pasos para consolidar una organización sindical en las plantas del Swift y el Armour."

73 En ese momento Perón ocupaba los cargos de Secretario de Trabajo, Ministro de Guerra y Vicepresidente de la Nación en el gobierno de facto que tuvo como presidente a Farrell entre 1944y 1946.
} 
Así,

"Durante los días 13 y 14 de octubre circularon rumores sobre la realización de una huelga nacional para apoyar al coronel preso. En los frigoríficos se hablaba permanentemente de la huelga. El día 15 los trabajadores salieron en manifestación por la calle Montevideo y, al día siguiente, muchas mujeres se concentraron en la calle Nueva York dando vivas a Perón. De algunos barrios alejados llegaron otros trabajadores que recorrían las calles y que fueron dispersados por la policía. Hubo pedradas contra la casa del dirigente radical local, Carlos Bassani. La expectativa por el paro rodeaba a la muchedumbre y el sindicato trabajaba febrilmente. El 17 de octubre, apenas comenzó el día, los piquetes de huelga se apostaron en las cercanías de los frigoríficos, frente a la fábrica textil, en las vías de acceso a la localidad. El transporte se paralizó y los comercios fueron empujados al cierre por los grupos de obreros." (Lobato, 2004: 241-242)

El resto del trayecto y su historia son bastante conocidos: las columnas obreras que partieron desde Berisso -articuladas por el sindicalismo fabril que comandaba Cipriano Reyes- se dirigieron hacia la Plaza San Martín (La Plata) pidiendo la liberación de quien consideraban el único garante de sus derechos. Además del ataque producido en Berisso contra la casa del dirigente radical Carlos Bassani, en La Plata los obreros descargaron toda su violencia, burla y ridiculización contra numerosos comercios y confiterías de moda, la prensa (diario El Día, El Argentino, las corresponsalías de los diarios La Prensa y Crítica), el Banco Comercial, las sedes de los clubes deportivos de Gimnasia y Estudiantes, el edificio del Jockey Club, la Universidad Nacional de La Plata y la residencia de su rector. Esta violencia, burla y ridiculización hizo foco sobre algunas instituciones ubicadas en el centro de la ciudad capital -no tanto sobre sus ciudadanos- mostrando que la autoridad, el prestigio y el aura de inviolabilidad que las rodeaba podían ser cuestionados (James y Wolfson, 1987). Finalmente algunos de estos obreros terminarían el 17 de Octubre de 1945 en la Plaza de Mayo (ciudad de Buenos Aires) dando por concluida una jornada que se volvería mítica y fundacional del peronismo ${ }^{74}$.

El enorme apoyo popular con que Perón fue electo presidente de la República en febrero de 1946 empoderó a los trabajadores frigoríficos como un actor protagonista de esa parte de la historia nacional. En este escenario, y pese al marcado descenso en la demanda de alimentos que trajo aparejado el final de la Segunda Guerra Mundial, los obreros de Berisso vieron en el nuevo gobierno un actor que intervenía en el conflicto defendiendo sus puestos de trabajo. Si anteriormente la voluntad patronal

\footnotetext{
${ }^{74}$ Como señala Lobato (2004: 117) la interpretación de Gino Germani (1968) sobre el papel de los migrantes internos en los orígenes de peronismo han dado lugar a una abundante literatura donde los trabajadores de Berisso están siempre presentes. Por ejemplo los textos de Mora y Araujo y Llorente (1980), Torre (1988, 1990 y 1995) y Del Campo (1983).
} 
era cuestionada únicamente por las organizaciones políticas y sindicales (con resultados dispares), ahora el Estado articulaba el conflicto. $\mathrm{Y}$ ante los ojos de los obreros lo hacía a favor a favor de ellos: todo podía ser discutido; los despidos, la duración del trabajo, las condiciones laborales, el poder patronal, el salario, las vacaciones, etc. $Y$ si bien esta experiencia no era nueva, el contexto había cambiado. Ahora los obreros "no sentían la amenaza del despido y confiaban en que la arbitrariedad empresaria podía ser controlada, sobre todo porque ahora no estaban solos" (Lobato, 2004: 253).

Con el correr de los años la identificación obrera con el peronismo y los sindicatos afines crecieron en la misma proporción con la que irían disminuyendo el resto de las identificaciones políticas $\mathrm{y}$, centralmente, las identificaciones étnicas. El peronismo logró integrar a un conjunto de personas -bajo la identificación social de trabajadoresque se encontraban fragmentadas por origen regional, nacional y diversas adscripciones políticas. $\mathrm{Y}$ aunque dicho proceso no se diera sin tensiones y conflictos, el mismo quedo grabado a fuego en la memoria local y los imaginarios que ella reproduce a través de sus prácticas conmemorativas:

"La relación de los trabajadores con Perón se convirtió desde entonces en un punto importante de las nuevas narrativas locales. El pasado asociado a la lucha y a la organización obrera fue un eje constituyente de un campo de confrontación político e ideológico. No era batallas violentas, como las del tiroteo entre partidarios de Peter y de Reyes, sino una lenta y constante reproducción de un sentido asociado a la experiencia peronista, a la armonía y el bienestar que la acompañaron (...). En todos esos relatos el peronismo, y el 17 de octubre, marcó la historia de los trabajadores de la carne y de Berisso en un antes y un después, claramente divididos y enfrentados (...). El peso de esas construcciones discursivas fue de tal magnitud que en el momento en que los trabajadores recordaban su experiencia de vida, la representación del pasado de Berisso había adquirido las formas amalgamadas de Perón, Evita y los trabajadores en armónica conjunción. La forma de este imaginario fue el producto de una lenta y constante reproducción de un sentido asociado a la experiencia peronista, a la armonía y el bienestar que la acompañaron. El pasado de conflictos y tensiones fue sepultado, en particular cuando la visión nostálgica de un mundo perdido se extendió luego de destitución de Perón" (Lobato, 2004: 242-243, cursivas nuestras).

Marcado por una fuerte migración interna y el descenso de la inmigración de ultramar, este período estuvo caracterizado por el declive del asociacionismo étnico y la proliferación de un conjunto de asociaciones políticas (primero), sindicatos y unidades básicas peronistas (finalmente). Es importante recordar que en el período de entreguerras, la presión estatal sobre algunas asociaciones étnicas impactó enormemente en el declive de estas instituciones (Romero, 2002). Proceso que continuó a partir del golpe de estado de 1943 y el primer gobierno peronista. Como 
señaló Devoto (2009: 411-412, 431), en su momento fundacional el peronismo apeló discursivamente a una identificación de "lo nacional" con "lo criollo" en la cual no solo éste era encarnado por aquel migrante interno sino que "lo extranjero" aparecía impidiendo el autónomo desarrollo nacional. En ese marco, orientado por sus disputas con lo que consideraba parte de la "penetración ideológica del comunismo" en nuestro país, el Poder Ejecutivo Nacional dictó en 1949 un decreto a través del cual se disolvió la Unión Eslava: esta institución con sede en Berisso ${ }^{75}$ reunía a inmigrantes ucranianos, bielorrusos, checoslovacos, húngaros y judíos que -siendo activistas políticos ligados al comunismo- habían organizado una campaña denominada "Ayuda a la Patria" para colaborar con la URSS (mediante el envío de calzado y ropa) frente a la invasión alemana (Ballina, 2006).

El impacto de estas dinámicas llevó a que durante el período analizado Berisso fuese caracterizada como una comunidad constitutivamente peronista. Proceso que se daría en detrimento de su identificación con un origen inmigratorio. Finalmente, la masiva irrupción del migrante interno en el espacio fabril y su posterior vinculación con el peronismo hicieron entrar en crisis el relato homogéneo de una ciudad que se autorepresentaba -desde el litoral ribereño- como esencialmente descendida de los barcos.

\subsection{5-1983: El declive de identificaciones político-clasistas y el renacer de identificaciones étnico-nacionales}

Si la llegada de Perón al poder fue un parteaguas en la historia de Berisso su derrocamiento en 1955 abrió una nueva etapa caracterizada por la conflictividad política y una profunda crisis laboral. El declive en la actividad fabril encontraría su piso -entre fines de los años 70 e inicios de los 80 - con el cierre definitivo de los frigoríficos y la hilandería local ${ }^{76}$. Cuando en 1969 el frigorífico Armour cerró sus puertas, el Swift compró las instalaciones haciéndose cargo parcialmente del personal despedido. Poco tiempo duraría esta situación ya que al año siguiente el Swift declaró

\footnotetext{
75 Funcionó en la sede del actual Club Social y Deportivo "Vostock" de la Colectividad Bielorrusa.

${ }^{76}$ Respecto a la situación laboral en el frigorífico Armour, Lobato (2004) señala que entre julio de 1958 y enero de 1959 el personal despedido alcanzó al 30\% de su planta. Respecto a la conflictividad laboral reinante en la ciudad desde inicios de los años 60, esta autora señala el alcance masivo que tuvo la huelga del año 1962. Pese a que los obreros de la industria cárnica lograron un nuevo convenio colectivo de trabajo luego de la huelga, las empresas de este sector no cumplieron el acuerdo firmado. Así, mientras entre 1964 y 1965 los obreros del Swift y el Armour de Berisso volvieron a realizar numerosas huelgas, las empresas tomaron la decisión de despedir a 800 trabajadores y suspender por 90 días a más de 5.500 trabajadores.
} 
la quiebra y su gestión pasó a manos del Estado. Diez años después, finalmente, el Swift cerraría su planta.

A nivel local la experiencia obrera de este período estuvo signada por el cruce entre la inestabilidad laboral, la restauración del poder patronal y la persecución política de los gobiernos de turno (Gresores, 2001; Lobato, 2004). El pasaje de "la sociedad del trabajo a la crisis del trabajo" implicó la desarticulación progresiva de las identificaciones sociales ligadas al mundo obrero: aquel mundo que había logrado articular a dispersas y heterogéneas identificaciones étnicas había entrado en crisis, y con él el sistema de identificaciones obreras. En la misma línea, si el peronismo había logrado articular en torno suyo a diversas adscripciones políticas -llevando al anarquismo, el socialismo y el comunismo a su mínima expresión- el contexto que se abrió entre el derrocamiento de Perón y principios de los años 80 buscó "erosionar" todo vestigio de identificación peronista (James, 2004). Así, en un período en el cual las identificaciones laborales habían entrado en crisis y las identificaciones políticas aparecían limitadas (particularmente durante la última dictadura militar), las identificaciones étnicas encontraron un nuevo espacio de proliferación.

Es importante tener en cuenta que al interior de las asociaciones étnicas este proceso se vio atravesado por la progresiva participación de argentinos con ascendencia inmigratoria y un cambio en los objetivos fundacionales de dichas instituciones. Con el paso del tiempo los propósitos originales con los cuales las asociaciones étnicas habían sido creadas -ligados centralmente a la asistencia socialfueron direccionados en dos sentidos: hacia su interior los objetivos estuvieron centrados en formar un ámbito de sociabilidad que permitiera reconstruir identificaciones sociales y sentidos de pertenencia ligados a un origen nacional compartido (Maffia, 2003). Por otra parte los objetivos externos comenzaron a estar centrados en la posibilidad de construir prestigio, legitimidad o visibilidad social desde las asociaciones (Devoto, 2009). En ambas direcciones la recordación de ciertos hechos del pasado y la reactuación de tradiciones culturales formaron parte de las estrategias más utilizadas para alcanzar estos objetivos (Palermo, 2007; Monkevicius, 2009; Irurzun, 2014).

Ahora bien, a diferencia de lo sucedido en las primeras décadas del siglo XX, el renacer del asociacionismo étnico estuvo acompañado por el descenso progresivo en el número de inmigrantes que vivían en la ciudad. Como hemos mencionado anteriormente el censo de 1947 muestra que la población total de Berisso había alcanzado las 33.970 personas (de los cuales 24.107 eran nativos y 9.857 extranjeros, 
representando al 29\%) y el de 1960 indica que su población había ascendido a 40.983 personas (de las cuales 33.475 eran argentinos y 7.508 eran extranjeros, representando un 18,31\%). Por su parte el de 1970 muestra que la población estaba compuesta por 58.833 personas (de las cuales 51.977 eran argentinos y 6.856 eran extranjeros, representando un 11,65\%) y el censo de 1980 mantiene la progresión alcista llevando la población total hasta las 66.152 personas ${ }^{77}$. Frente a una tasa de crecimiento poblacional que entre 1947 y 1960 aumentó 1,4 puntos porcentuales, entre 1960 y 1970 otros 3,7 puntos porcentuales y entre 1970 y 1980 lo haría en otros 1,2 puntos porcentuales, la población de origen extranjero disminuye año a año.

Cuadro N²: Población extranjera y nativa de Berisso, por sexo (1947-1980)

\begin{tabular}{|l|c|c|c|c|c|c|c|c|}
\hline Años & $\begin{array}{c}\text { Arg. } \\
\text { Masc. }\end{array}$ & $\begin{array}{c}\text { Ext. } \\
\text { Masc. }\end{array}$ & $\begin{array}{c}\text { Arg. } \\
\text { Fem. }\end{array}$ & Ext. Fem. & $\begin{array}{c}\text { Arg. } \\
\text { Total }\end{array}$ & $\begin{array}{c}\text { Ext. } \\
\text { Total } \\
\text { crecim. } \\
\text { anual. (en } \\
\text { puntos } \\
\text { porcentuales) }\end{array}$ & Total \\
\hline $\mathbf{1 9 4 7}$ & 12911 & 5950 & 11206 & 3903 & 24117 & $\mathbf{9 8 5 3}$ & $\mathbf{3 3 9 7 0}$ & \\
\hline $\mathbf{1 9 6 0}$ & 16814 & 4104 & 16661 & 3404 & 33475 & $\mathbf{7 5 0 8}$ & $\mathbf{4 0 9 8 3}$ & 1,4 \\
\hline $\mathbf{1 9 7 0}$ & $\left(^{* * *}\right)$ & & $\left(^{* *}\right)$ & & 51977 & $\mathbf{6 8 5 6}\left(^{* *}\right)$ & $\mathbf{5 8 8 3 3}$ & 3,7 \\
\hline $\mathbf{1 9 8 0}\left(^{*}\right)$ & & & & & & & $\mathbf{6 6 1 5 2}$ & 1,2 \\
\hline
\end{tabular}

Fuente: Propia en base a Lobato, 2004:45.

$\left.{ }^{*}\right)$ No están discriminados por nacionalidad ni sexo.

$\left({ }^{* *}\right)$ Corresponde al total de extranjeros sin discriminar por sexo.

$\left.{ }^{* * *}\right)$ Modificamos el cuadro de Lobato en estos ítems ya que contiene errores. La autora indica un total de 29.749 argentinos masculinos y un total de 29.084 argentinas femeninas. Esos son los totales correspondientes a hombres y mujeres, sin discriminar por nacionalidad.

En el marco de dichas dinámicas (crisis laboral, gobierno dictatorial, descenso en la cantidad de inmigrantes que vivían en la ciudad y cambios en los objetivos del asociacionismo) a fines de 1978 un conjunto de asociaciones étnicas berissenses comenzaron a organizar La Fiesta Provincial del Inmigrante con apoyo del municipio local y la gobernación provincial. Si bien los capítulos siguientes estarán dedicados íntegramente a ella no quisiéramos dejar de mencionar que, según Lobato (2004), este ritual conmemorativo habría buscado crear un imaginario armónico de la comunidad que -al recordar un origen mítico de la Nación Argentina ligado a la llegada y el esfuerzo de los inmigrantes ultramarinos- permitiera silenciar y olvidar los recuerdos que unían a Berisso con los orígenes del peronismo. Así, en una coyuntura marcada por la desarticulación del tejido fabril y el ascenso de la violencia política ${ }^{78}$, un conjunto de actores institucionales habrían encontrado en esta fiesta la posibilidad de recrear

\footnotetext{
77 Fuentes: Censos Nacionales de Población y Vivienda, INDEC y Lobato (2004).

78 La violencia política desatada por la última dictadura cívico-militar tuvo un saldo particularmente trágico en la ciudad Berisso. Según el registro de detenidos-desaparecidos y asesinados elaborado por la “Comisión de Memoria, Recuerdo y Compromiso de la Ciudad de Berisso" existieron, al menos, 126 desapariciones forzadas y 17 asesinatos (Bretal, 2014:18).
} 
un imaginario armónico de la comunidad: así, al recordar su origen ultramarino, la fiesta habría permitido acallar los conflictos políticos del presente.

\subsection{3-2015: Continuidad en las identificaciones políticas y cambios en las dinámicas migratorias}

Lejos de haber sido completamente silenciada, olvidada o desarticulada por la dictadura, la identificación local con el peronismo (en sus diferentes versiones) mostrará plena vigencia durante este período: de manera ininterrumpida, entre el regreso de la democracia y la finalización de nuestro trabajo de campo (2015), el peronismo ganó todas las elecciones municipales por amplia mayoría. Si miramos únicamente el porcentaje de votos con el cual los candidatos del peronismo ganaron las elecciones municipales, vemos que en 1983 Carlos Nazar obtuvo el 54\%, en 1987 Juan Nadef obtuvo el 58\%, en 1991 Eugenio Juzwa obtuvo el 38\%, en 1995 Néstor Juzwa obtuvo el 55\% y fue re-electo en 1999 con el 57\%; y finalmente Enrique Slezack gano consecutivamente las elecciones de 2003, 2007 y 2011 con el $45 \%$, el $29 \%$ y el $46 \%$ de los votos $^{79}$. Evidentemente buena parte de la capacidad que el peronismo tenía para interpelar a la sociedad local continuó vigente entre 1983 y 2015, dejando en claro que el peronismo no solo formaba parte de la identidad política berissense sino que la población local contaba con una enorme cantidad de personas que se auto-identificaban como peronistas: de las 75 mil personas (aproximadamente) que vivían en Berisso a mediados de los años 90, 15 mil estaban afiliadas al partido peronista (James 2004: 33). Si del total poblacional descontamos las personas que por cuestiones de edad no podían afiliarse a ningún partido político, el porcentaje de afiliados al peronismo es abrumador.

La capacidad que el peronismo tuvo para interpelar a buena parte de la sociedad berissense (aunque no de manera homogénea ni libre de conflictos) fue tan potente que dicha vinculación sobrevivió a las crisis y recomposiciones del mercado laboral. $A$ principios de los años '80 el tejido fabril que había posibilitado el desarrollo económico de la ciudad y propiciado la llegada de miles de inmigrantes se encontraba completamente desarticulado: los saladeros, los frigoríficos y la hilandería ya no existían. Una década después, bajo la gestión estatal de Carlos Menem -peronista que

\footnotetext{
79 Estos números se amplían notoriamente si sumamos los porcentajes de los otros candidatos del peronismo que participaron de las elecciones pero no las ganaron. Por ejemplo, en 2003 Slezack sacó el $45 \%$ de los votos y el ex intendente berissense Carlos Nazar sacó el $15 \%$. Así, y solo sumando a ellos dos, el peronismo obtenía el $60 \%$ de los votos.
} 
años antes había lanzado su campaña presidencial en Berisso- la desocupación a nivel local alcanzaría el 35\% (James: 2004: 33 y 274). La dinámica privatizadora y el proceso de desindustrialización que llevó a cabo el gobierno de Menem impactó de lleno en Berisso: en comparación con 1990, para 1995 Petroquímica La Plata había reducido su personal en un $50 \%$, la Refinería de petróleo YPF lo había hecho en un $85 \%$, Astilleros Rio Santiago en un $60 \%$ y Propulsora Siderúrgica en un 52\% (Adriani y Suarez, 2003: 284).

Frente a una trama laboral en crisis, la llegada de planes y programas sociales a la ciudad comenzaron a ocupar (precaria pero masivamente) su lugar. En ese contexto de sobrevivencia material la "red de resolución de problemas" articulada por el peronismo (Auyero, 2012) solidificó su intervención en el territorio municipal mediante la implementación de planes y programas sociales; haciendo que las redes construidas para la implementación de una política pública se solaparan con las redes políticas del peronismo (lucci, 2015). Finalmente, a partir de 2003 se abrió una etapa de crecimiento en la economía nacional que impactó localmente con la apertura de distintas microempresas -centralmente orientadas a la elaboración de productos alimenticios o asociadas a la industria química- y algunas obras de infraestructura como la ampliación del Puerto La Plata y la realización del Terraplén Costero (lucci, 2015:83).

Ahora bien, mientras el signo político bajo el cual se llevó a cabo la gestión municipal de Berisso no cambió entre 1983 y 2015, las dinámicas inmigratorias de este período sufrieron cambios significativos. Como no encontramos estudios sobre la población de origen extranjero radicada en Berisso con posterioridad al censo de 1980, desagregaremos a continuación los datos censales correspondientes a los años 1991, 2001 y 2010. Al trabajar sobre algunos datos inéditos ${ }^{80}$ esperamos aportar un conjunto de conocimientos sobre dicha población y completar, así, el análisis sobre las dinámicas migratorias que caracterizaron a esta ciudad a lo largo de todo un siglo (1909-2010). Finalmente, georreferenciamos los datos del censo 2010 para analizar la distribución/segregación espacial de los inmigrantes que viven en la ciudad. Este trabajo -que vincula el uso de fuentes estadísticas con herramientas metodológicas provenientes de la Geografía- nos permitirá describir un conjunto de dimensiones sociales fundamentales para comprender (en el capítulo $n^{\circ} 6$ ) el lugar que ocupan la

\footnotetext{
${ }^{80}$ Los datos que aportamos de los censos de 1991 y 2001 fueron procesados, a nivel de partido, por la Dirección Provincial de Estadística y Censos para esta investigación. Específicamente, los datos del censo del año 1991 fueron certificados como inéditos. Para un mayor detalle del trabajo realizado sobre estas fuentes ver el apartado dedicado a la Estrategia Metodológica.
} 
inmigración europea y la inmigración americana en la Fiesta Provincial del Inmigrante. ${ }^{81}$

Cuando miramos conjuntamente los últimos tres censos (cuadro $\mathrm{N}^{\circ} 3$ ), el primer dato relevante es que la cantidad de extranjeros radicados en la ciudad revierte la tendencia decreciente que indicamos para el período 1947-1970, pasando de 3.321 personas en 1991, a 3.841 en 2001 y 4.827 en 2010. Por su diferencia con los períodos anteriores el segundo dato relevante es la creciente feminización de la inmigración radicada en la ciudad: mientras en los períodos 1884-1947 y 1947-1980 los extranjeros superaban a las extranjeras, en el período 1991-2010 la tendencia se revierte.

Cuadro N 3: Población extranjera y nativa de Berisso, por sexo $(1980-2010)$

\begin{tabular}{|l|c|c|c|c|c|c|c|c|c|}
\hline \multicolumn{1}{|c|}{ Años } & $\begin{array}{c}\text { Arg. } \\
\text { Masc. }\end{array}$ & $\begin{array}{c}\text { Arg. } \\
\text { Fem. }\end{array}$ & $\begin{array}{c}\text { Arg. } \mathbf{\text { esp. }} \\
\text { sexo }\end{array}$ & $\begin{array}{c}\text { Ext. } \\
\text { Masc. }\end{array}$ & $\begin{array}{c}\text { Ext. } \\
\text { Fem. }\end{array}$ & $\begin{array}{c}\text { Arg. } \\
\text { Total }\end{array}$ & $\begin{array}{c}\text { Ext. } \\
\text { Total }\end{array}$ & Total & $\begin{array}{c}\text { Tasa de } \\
\text { crecim. anual. } \\
\text { (en puntos } \\
\text { porcentuales) }\end{array}$ \\
\hline $\mathbf{1 9 8 0}$ & & & & & & & & 66152 & \\
\hline $\mathbf{1 9 9 1}\left(^{*}\right)$ & 34986 & 36423 & 31 & $\mathbf{1 4 9 5}$ & $\mathbf{1 8 3 6}$ & 71440 & $\mathbf{3 3 2 1}$ & 74761 & 1,3 \\
\hline $\mathbf{2 0 0 1}$ & 37171 & 39080 & - & $\mathbf{1 7 7 9}$ & $\mathbf{2 0 6 2}$ & 76251 & $\mathbf{3 8 4 1}$ & 80092 & 0,7 \\
\hline $\mathbf{2 0 1 0}$ & 40779 & 42864 & - & $\mathbf{2 2 3 3}$ & $\mathbf{2 5 9 4}$ & 83643 & $\mathbf{4 8 2 7}$ & 88470 & 1,05 \\
\hline
\end{tabular}

Fuente: Elaboración propia a partir de los Censos Nacionales de Población y Vivienda, INDEC (1991, 2001, 2010).

(*) En la publicación en formato papel, Tomo I-serie B №2, Buenos Aires 1994, del Censo Nacional de Población y Vivienda 1991, ISBN 950-988-50-8, el total de población aparece desagregado de manera distinta a la que aquí referimos: de las 74.761 personas que vivían en Berisso los argentinos varones que señala son 34.986 , los extranjeros varones 1.483 , las argentinas mujeres 36.423 , las extranjeras mujeres 1.783; llevando a que los argentinos totales sean 71.409 y los extranjeros totales sean 3.266 ; indicando la existencia de 86 personas de las cuales se ignora nacionalidad y sexo. El cruce de información que aquí publicamos para el año 1991 es aquel procesado por la Dirección Provincial de Estadística y Censos a pedido nuestro, dónde sí se logra especificar el total de extranjeros y su sexo. Desde allí inferimos el resto de la información, quedándonos sin especificar los totales por sexo de los argentinos: hay que tener en cuenta que si de las 86 personas que el dato publicado en dicho Tomo, no conoce nacionalidad ni sexo, nosotros pudimos especificar a 55 de ellos quedándonos 31 argentinos de quienes no podemos afirmar su sexo.

Más allá de estos datos generales, cada censo permite analizar un conjunto de dimensiones relevante sobre la población extranjera que vive en Berisso. A continuación desagregamos esta información a partir de cuatro variables: continente y país de origen, sexo y edad. ${ }^{82}$

Si agrupamos la información del censo de 1991 a partir del continente de origen vemos que el $61 \%$ de los inmigrantes que vivían en Berisso provenía de Europa y el

\footnotetext{
${ }^{81}$ El Censo Nacional de Población y Viviendas elaborado por el INDEC en el año 2010 es el único que puede georreferenciarse. Para un mayor detalle sobre la georreferenciación realizada sobre esta fuente, ver el apartado a la Estrategia Metodológica.

82 Para ver la información completa, en términos absolutos y su representación gráfica en términos relativos, ir al Anexo № 3: “Censos 1991-2001-2010”
} 
$35 \%$ de América. Cuando realizamos un análisis por país de origen vemos que el $42 \%$ de los inmigrantes europeos eran italianos, cerca del $15 \%$ eran polacos y un $13 \%$ españoles. Por su parte el $38 \%$ de los inmigrantes americanos eran peruanos, un $17 \%$ paraguayos y el $16 \%$ uruguayos. Pasando a una desagregación por sexo vemos que entre los inmigrantes europeos casi el $60 \%$ eran mujeres y el $40 \%$ varones, mientras que entre los inmigrantes americanos las mujeres representaban al $47 \%$ y los hombres al $52 \%$. Al mirar la información por grandes grupos de edad vemos que menos del $1 \%$ de los inmigrantes europeos tenía entre 0 y 14 años, el 34\% tenía entre 15 y 64 años y casi el $64 \%$ tenía 65 años o más. Por su parte el $5 \%$ de los inmigrantes americanos tenían entre 0 y 14 años, el $85 \%$ tenía entre 15 y 64 años, y el $8 \%$ tenía 65 años o más (ver gráficos $n^{\circ} 1,2,3,4$ y 5 del anexo $n^{\circ} 3$ ).

Si agrupamos la información del censo del 2001 a partir de las mismas variables encontramos, respecto al continente de origen, que el $69 \%$ de los extranjeros que vivían en Berisso provenían de América y el $27 \%$ de Europa. Cuando realizamos un análisis por país de origen vemos que más del $50 \%$ de los inmigrantes europeos eran italianos, el $12 \%$ españoles y el $7 \%$ polacos. Por su parte más del $60 \%$ de los inmigrantes americanos eran peruanos, $20 \%$ paraguayos y el $8 \%$ uruguayos. Pasando a una desagregación por sexo vemos que entre los inmigrantes europeos casi el $60 \%$ eran mujeres y el $40 \%$ varones; y entre los inmigrantes americanos casi el $52 \%$ eran mujeres y el $48 \%$ varones. Al desagregar la información por grandes grupos de edad vemos que el $1 \%$ de los inmigrantes europeos tenía entre 0 y 14 años, el 30\% tenía entre 15 y 64 años y casi el $70 \%$ tenía 65 años o más. Por su parte el $9 \%$ de los inmigrantes americanos tenía entre 0 y 14 años, el $85 \%$ tenía entre 15 y 64 años, y casi el $5 \%$ tenía 65 años o más (ver gráficos $n^{\circ} 6,7,8,9$ y 10 del anexo $n^{\circ} 3$ )

Por último en el censo del 2010 encontramos, respecto al continente de origen, que el $87 \%$ de los extranjeros que vivían en Berisso provenían de América y el $12 \%$ de Europa. Cuando los agrupamos por país de origen vemos que el $57 \%$ de los inmigrantes europeos eran italianos, el $13 \%$ españoles y el $6 \%$ polacos. Por su parte el $60 \%$ de los inmigrantes americanos eran peruanos, el $24 \%$ paraguayos y el $6 \%$ bolivianos. Pasando a una desagregación por sexo vemos que entre los inmigrantes europeos casi el $60 \%$ eran mujeres y el $40 \%$ varones, mientras que entre los inmigrantes americanos el porcentaje de mujeres superaba en 5 puntos al de los hombres (52\% a $47 \%$, respectivamente). Al desagregar la información por grandes grupos de edad vemos que el 1,49\% de los inmigrantes europeos tenía entre 0 y 14 años, el $24 \%$ tenía entre 15 y 64 años y casi el $75 \%$ tenía 65 años o más. Por su parte, casi el $9 \%$ de los inmigrantes americanos tenía entre 0 y 14 años, casi el $85 \%$ tenía 
entre 15 y 64 años, y más del $6 \%$ tenía 65 años o más (ver gráficos $n^{\circ} 11,12,13,14$ y 15 del anexo $\left.n^{\circ} 3\right)$

En síntesis, mirados conjuntamente a partir de las variables elegidas, los censos de 1991, 2001 y 2010 muestran:

- Un significativo aumento porcentual de los inmigrantes americanos respecto a los europeos. En 1991 el 35\% de los inmigrantes eran americanos y el 61\% europeos. Por su parte, en 2001 los inmigrantes americanos representaban el $69 \%$ de los extranjeros y en 2010 alcanzaban el 87\%. En progresión inversa, mientras en 2001 los inmigrantes europeos representaban al 27\% en 2010 llegaban al $12 \%$.

- Una significativa estabilidad porcentual respecto a los países de origen de los inmigrantes europeos y americanos. Siendo a la vez Italia, España, Perú y Paraguay los países con mayor representatividad de ambos continentes.

- Una significativa estabilidad porcentual respecto a la composición por sexo de los inmigrantes europeos y una creciente feminización de los inmigrantes americanos. En 1991, 2001 y 2010 la composición de los europeos se mantiene estable en torno al $60 \%$ para las mujeres y el $40 \%$ para los hombres. Por su parte entre los migrantes americanos las mujeres pasan de ser el $47 \%$ en 1991 , al $51,7 \%$ en 2001 y $52,8 \%$ en 2010 .

- Un progresivo envejecimiento de la población europea y una mayoritaria y estable inserción de los inmigrantes americanos dentro de los rangos etarios de la Población Económicamente Activa. En 1991 casi el 65\% de la población extranjera de origen europeo tenía más de 65 años de edad, mientras casi el $86 \%$ de la población extranjera de origen americano tenía entre 15 y 64 años. Por su parte el período intercensal 2001-2010 muestra que los europeos llevan del 70 al $75 \%$ la proporción de personas que pasan los 65 años de edad, mientras que los inmigrantes americanos mantienen en torno al $85 \%$ el porcentaje de población que tiene entre 15 y 64 años.

Ahora bien, dónde están ubicados estos inmigrantes dentro del espacio social berissense. Para analizar la distribución/segregación espacial de los inmigrantes que actualmente viven en Berisso presentamos a continuación los datos centrales de la georreferenciación realizada a partir del último Censo Nacional de Población y 
Viviendas (INDEC, 2010) ${ }^{83}$. Partiendo de un diagnóstico general sobre la creciente urbanización de las migraciones (UN-HABITAT, 2005), nuestro análisis se inserta en una de las corrientes que dominaron los estudios socio-antropológicos sobre la ciudad (Magnani, 2002). Centrados en la utilización de variables cuantitativas e indicadores demográficos, los trabajos inscriptos en esta corriente indagaron la desagregación social, el colapso del sistema de transporte, las deficiencias del saneamiento, los problemas de vivienda, la distribución desigual del equipamiento y el incremento de la violencia urbana (Caldeira, 1984). Como señala Segura (2015), dentro de esta línea se encuentran las investigaciones que describieron las características físicas de las periferias urbanas en Latinoamérica, relevaron las condiciones materiales de vida de sus residentes e indagaron los procesos históricos que las generaron (Katzman, 2001; Sabatini, Cáceres y Cerdá, 2001; Rodríguez y Arriaga, 2004; Saraví, 2008). En diálogo con los trabajos que analizaron la inserción residencial de los inmigrantes europeos en la Argentina de principios del siglo $\mathrm{XX}^{84}$ y la segregación espacial de los inmigrantes latinoamericanos en la Argentina contemporánea (Canelo, 2006; Grimson 2009; Caggiano y Segura, 2014; entre otros) presentamos a continuación un análisis sobre la distribución/segregación espacial de los inmigrantes en la ciudad de Berisso.

Uno de los primeros datos que surgen de la georreferenciación realizada es que si bien en todos los radios censales de Berisso existe una mayor representación de la población nativa sobre la extranjera, el porcentaje de extranjeros crece considerablemente en la periferia de ciudad, particularmente en el sur. En otros términos, mientras la población nativa está mayormente representada en los radios censales del centro de la ciudad, los inmigrantes están mayormente representados en la periferia sur (ver mapa $n^{0} 1$ del anexo $n^{\circ} 4$ ). Lógicamente, si excluimos del análisis a la población nativa y nos concentramos en la población extranjera (sin discriminar orígenes continentales) vemos que ella se encuentra mayormente representada en los radios censales de la periferia sur de la ciudad (ver mapa $n^{\circ} 2$ del anexo $n^{\circ} 4$ ).

Si pasamos a un análisis por orígenes continentales, notamos que los inmigrantes europeos no solo se encuentran mayoritariamente representados en el centro de la ciudad (ver mapa $n^{\circ} 3$ del anexo $n^{\circ} 4$ ), sino que si casi el $50 \%$ de ellos están distribuidos en 18 de los 99 radios censales que posee la ciudad. Por su parte, los inmigrantes americanos no solo se encuentran mayormente representados en la

\footnotetext{
${ }^{83}$ Para ver la representación gráfica de la información que presentamos a continuación, ir al Anexo № 4 "Georreferenciación de la población de origen extranjero residente en Berisso (censo del 2010)".

${ }^{84}$ Para un repaso general por esta bibliografía ver Devoto, 2009: 336-341. Un estudio clásico sobre el tema, fuertemente influenciado por los postulados del modelo del crisol de razas, se encuentra en Korn (1989).
} 
periferia sur, sino que además el $60 \%$ de ellos está distribuido en tan solo 10 radios censales (ver mapa $n^{\circ} 4$ del anexo $n^{\circ} 4$ ). Datos que parcialmente se desprendían de los análisis presentados en los mapas $n^{\circ} 2$ y $n^{\circ} 3$, y que comparten el diagnóstico realizado por aquellos autores que describieron la segregación socio-espacial de los inmigrantes latinoamericanos en la ciudad de Buenos Aires (Canelo, 2006; Grimson 2009; Caggiano y Segura, 2014; entre otros).

Si miramos específicamente cómo se distribuyen los tres grupos migratorios con mayor peso porcentual del continente europeo y el continente americano, el análisis adquiere mayores grados de profundidad y riqueza. Entre los inmigrante europeos vemos que el $64 \%$ de los italianos se encuentra distribuido en 22 radios censales, el $67 \%$ de los españoles se encuentra distribuido en 20 radios censales y el $56 \%$ de los polacos se encuentra distribuido en 22 radios censales (ver mapas $n^{\circ} 5,6$ y 7 del anexo $n^{\circ} 4$ ). Por su parte entre inmigrantes americanos vemos que el $64 \%$ de los peruanos está distribuido en 6 radios censales, el 39\% de los paraguayos está distribuido en 4 radios censales y el $46 \%$ de los bolivianos está distribuido en solo 3 radios censales (ver mapas $n^{\circ} 8,9$ y 10 del anexo $n^{\circ} 4$ ).

Leyendo de manera conjunta estos datos queda claro que la mayor parte de los inmigrantes europeos viven distribuidos entre varios radios censales del centro de la ciudad; un espacio socialmente legitimado no solo por contar con instituciones políticas, religiosas, económicas, educativas y culturales sino además por estar provisto de todos los servicios públicos (transporte, asfalto, alumbrado, agua corriente, cloaca, recolección de residuos, etc.). Mientras tanto la mayor parte de los inmigrantes americanos viven concentrados en muy pocos radios censales de la periferia sur de la ciudad; un espacio social que no solo se caracteriza por carecer de los elementos con los que es legitimado el centro sino además por estar plagado de estigmas sociales ligados a la inseguridad, la pobreza, etc. ${ }^{85}$. Como ejemplo de esta situación nos parece importante mostrar que ambas poblaciones viven de manera diferenciada uno de los problemas más graves que tiene la ciudad: debido a su condición geográfica -lindera con el Rio de La Plata- la inundación afecta recurrentemente a buena parte de su población. Al estar construido sobre un suelo denominado Cordón Litoral, el riesgo de

\footnotetext{
${ }^{85}$ Cabe aclarar que las periferias urbanas son espacios sociales (además de caracterizados a partir de un conjunto de carencias) donde sus habitantes desarrollan diversas agencias (Caldeira, 1984). Es decir, lugares donde no solo hay ausencias y limitaciones sino presencias con plena capacidad de acción. Si bien somos conscientes de esto, nuestro tema de investigación y el contexto urbano en el cual lo indagamos no buscó describir, analizar y comprender las experiencias urbanas en las periferias de una ciudad (Segura, 2015). Tal vez en futuras investigaciones -a los fines de realizar un trabajo comparativonos acerquemos a las prácticas festivas que desarrollan los inmigrantes americanos que habitan la periferia sur de Berisso
} 
inundación que posee el centro de Berisso es de nivel medio. Por su parte, al estar construido sobre suelos denominados Fango y Bañado, la periferia sur de la ciudad posee un riesgo de inundación de nivel máximo (ver mapas $n^{0} 11$ y 12 del anexo $n^{\circ} 4$ ).

Así, la primera conclusión a la que nos permite llegar este análisis es que los inmigrantes europeos y los inmigrantes americanos no solo viven en espacios socialmente diferenciados por sus grados de legitimidad e infraestructura, sino que habitan lugares que sufren de manera distinta uno de los problemas más graves que posee Berisso. En tal sentido, la representación social del espacio que hemos construido a partir de la georreferenciación nos ayuda a comprender cómo se expresan en él las desigualdades sociales.

La segunda conclusión implica afinar la mirada. Si bien existen radios censales donde la población inmigrante de una misma nacionalidad es claramente mayoritaria, no podríamos afirmar la existencia de "guetos étnicos" dentro de los cuales vivirían solamente personas de un mismo origen nacional (Wirth, 1928; Sennett, 1997). Si bien la mayor parte de los inmigrantes europeos están distribuidos en varios radios censales del centro de la ciudad y la mayor parte de los inmigrantes americanos están distribuidos en pocos radios censales de su periferia sur, al interior de esta división general encontramos que todos los grupos migratorios comparten el espacio urbano con nativos e inmigrantes de otros orígenes nacionales. Dicho claramente, dentro de aquella tendencia general respecto a la segregación urbana no podemos afirmar que existan barrios con claros límites étnico-nacionales. Sino dos grandes zonas, con límites porosos, dentro de las cuales conviven varios grupos migratorios de un mismo origen continental (Portes, Roberts y Grimson 2005; Caggiano y Segura, 2014).

\section{Reflexiones finales}

A partir de fuentes secundarias provenientes de campo historiográfico y datos censales, en este capítulo analizamos las dinámicas migratorias que caracterizaron a la ciudad de Berisso. En esa línea ampliamos el conocimiento brindado por Lobato hasta el año 1980 con un análisis detallado de la población de origen extranjero residente en la ciudad con posterioridad a dicha fecha. Debido a que en cada apartado nos enfocamos en distintos períodos históricos, creemos necesario brindar ahora una mirada de conjunto sobre cómo se desarrolló este fenómeno a lo largo de todo un siglo (1909-2010). Hasta el año 1947 la población de origen extranjero radicada en la ciudad crece sostenidamente. Entre 1947 y 1991 decrece considerablemente. Y a 
partir de 1991 vuelve a crecer, tanto en términos absolutos como en términos relativos respecto a la cantidad total de población (ver cuadro $\mathrm{N}^{\circ} 4$ y gráficos $\mathrm{N}^{\circ} 16$ y $\mathrm{N}^{\circ} 17$ )

\section{Cuadro № 4:}

\begin{tabular}{|c|c|c|c|c|c|}
\hline \multicolumn{6}{|c|}{ Porcentaje de extranjeros sobre la población total, } \\
Berisso (1909-2010) \\
\hline Años & $\begin{array}{c}\text { Arg. } \\
\text { Total }\end{array}$ & $\begin{array}{c}\text { Ext. } \\
\text { Total }\end{array}$ & Total & $\begin{array}{c}\text { \% de } \\
\text { extranjeros } \\
\text { sobre el } \\
\text { total }\end{array}$ & $\begin{array}{c}\text { \% de } \\
\text { extranjeros } \\
\text { sobre total } \\
\text { redondeado }\end{array}$ \\
\hline 1909 & 1499 & $\mathbf{1 0 5 4}$ & 2553 & $\mathbf{4 1 , 2 8}$ & 41 \\
\hline 1914 & 3604 & $\mathbf{5 2 4 3}$ & 8847 & $\mathbf{5 9 , 2 6}$ & 59 \\
\hline 1947 & 24117 & $\mathbf{9 8 5 3}$ & 33970 & $\mathbf{2 9 , 0 1}$ & 29 \\
\hline 1960 & 33475 & 7508 & 40983 & 18,32 & 18 \\
\hline 1970 & 51977 & 6856 & 58833 & 11,65 & 12 \\
\hline 1991 & 71409 & $\mathbf{3 3 2 1}$ & 74761 & $\mathbf{4 , 4 4}$ & 4 \\
\hline 2001 & 76334 & $\mathbf{3 8 4 1}$ & 80092 & $\mathbf{4 , 8 0}$ & 5 \\
\hline 2010 & 83643 & $\mathbf{4 8 2 7}$ & 88470 & $\mathbf{5 , 4 6}$ & 5 \\
\hline
\end{tabular}

Fuente: Elaboración propia

Gráfico No 16:

Porcentaje de extranjeros sobre la población total en Berisso (1909-

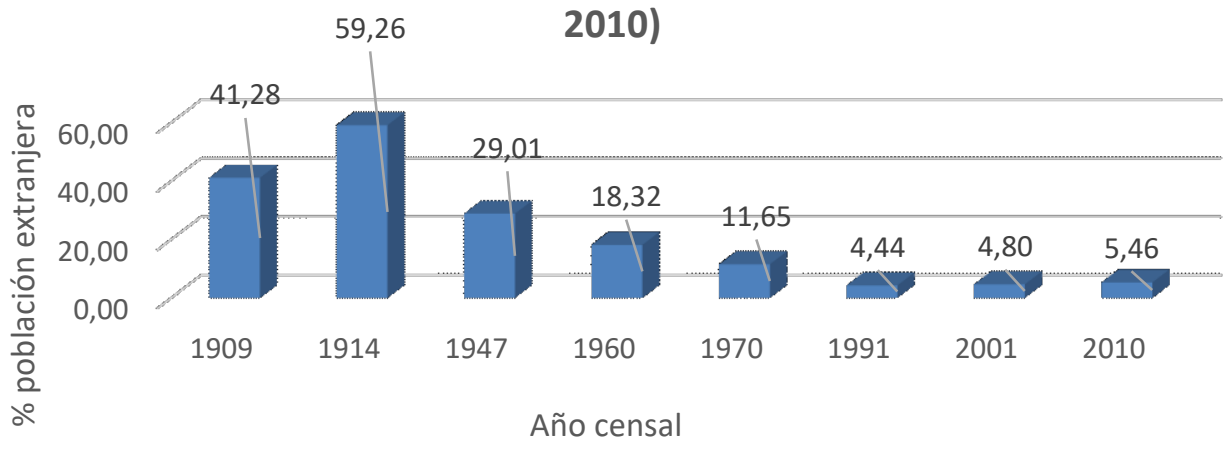

Fuente: Elaboración propia

\section{Gráfico No 17:}

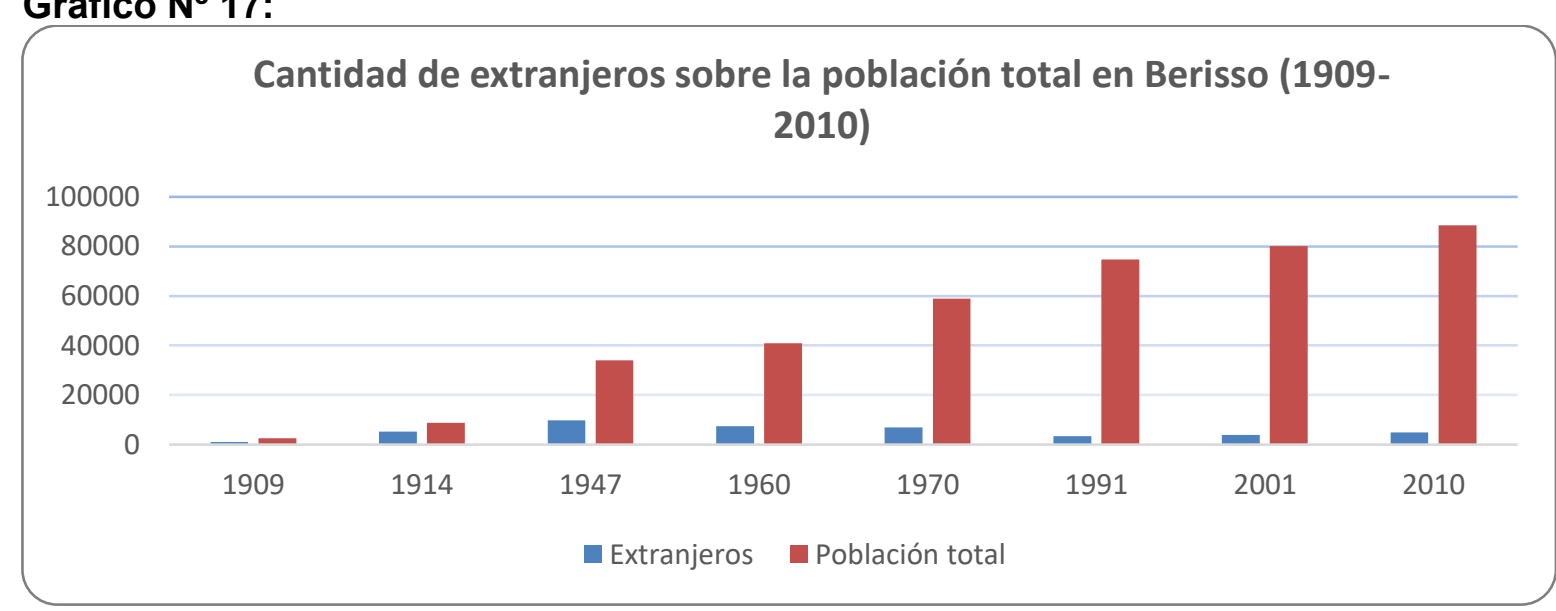

Fuente: Elaboración propia 
Por otra parte describimos el surgimiento del asociacionismo étnico, sus objetivos fundacionales y los cambios que sufrieron a lo largo del tiempo, analizando las tensiones que a lo largo del siglo $X X$ se desarrollaron entre las identificaciones étnicas y las identificaciones políticas. Así, mostramos cómo entre 1880-1935 la multiplicidad de adscripciones étnicas prevaleció sobre la constitución de adscripciones obreras, de clase y políticas. Durante el período 1935-1955 indicamos la reversión de ese proceso, mostrando el vínculo que la comunidad berissense tuvo con los orígenes del peronismo. Respecto al período 1955-1983 señalamos el declive de identificaciones políticas y el renacer de identificaciones étnicas a nivel local, situando nacimiento de la Fiesta Provincial del Inmigrante durante la última dictadura militar. Finalmente, para el período 1983-2015 mostramos la continuidad de las identificaciones políticas ligadas al peronismo y el cambio en las dinámicas migratorias. En este marco profundizamos el análisis de la población de origen extranjero -a partir de censos de 1991, 2001 y 2010- tomando en cuenta cuatro variables: continente y país de origen, sexo y edad. Por último georreferenciamos los datos del censo 2010 para describir y analizar la distribución/segregación espacial de los extranjeros que viven en la ciudad.

Por último, respecto al fenómeno del asociacionismo étnico, quisiéramos mencionar que si en los 64 años que van entre 1936 y 1990 constatamos únicamente la creación de dos asociaciones (la Asociación Bielorrusa en 1941 y la creación de la Sociedad Eslovaca en 1977, cuyo origen implicó la fusión del Club Eslovaco fundado en 1931 y el Hogar Checoslovaco fundado en 1925) y la reapertura de una sola asociación (la tercer reapertura de la Sociedad Española, en 1978), en los 14 años que van entre 1990 y 2004 constatamos la reapertura de la Colectividad Irlandesa San Patricio (1991), la creación de la Colectividad Croata (1998), la reapertura de la Colectividad Alemana de Berisso, La Plata y Ensenada (2004) y la reapertura de la Asociación Portuguesa de Berisso (2004) que fuera fundada en 1915 con pocos años de actividad. Como vemos, este proceso de creación y reapertura de asociaciones étnico-nacionales de origen europeo se acelera a inicios de la década de 1990, en un contexto en el cual ya no llegaban nuevos inmigrantes europeos y ascendía notablemente la cantidad de inmigrantes americanos radicados en la ciudad.

Teniendo en cuenta lo trabajado hasta aquí, a partir del capítulo siguiente nos centraremos en distintas dimensiones del objeto y el tema de estudio. En el próximo capítulo contextualizamos el origen de la Fiesta Provincial del Inmigrante durante la última dictadura militar y analizamos las distintas reinterpretaciones que realizan, desde el presente, los actores involucrados en aquel proceso fundacional. 


\title{
Capítulo $\mathbf{N}^{\circ} 3$
}

\section{El origen de la Fiesta Provincial del Inmigrante. Recuerdos, olvidos y silencios de un pasado en disputa}

\begin{abstract}
"Podría decirse que desde el cierre de los establecimientos [frigoríficos] había cierta práctica social de conmemoración entre sus habitantes, definida como una práctica intencional que otorgaba cierto significado a los acontecimientos. La gente recordaba, celebraba y hasta se apenaba frente a aquellos hechos que formaban parte de una identidad y una concepción cultural y generacional comunes reconocidas por todos. La localidad evocaba su pasado del mismo modo que los grupos nacionales crearon su propia historia al recordar juntos un pasado reconstruido. La comunidad se creaba a sí misma con un estilo peculiar" Lobato (2004)
\end{abstract}

El período de la última dictadura cívico-militar argentina (1976-1983) ha sido caracterizado por algunos estudiosos de la fiesta como un período anti-festivo. La prohibición del carnaval -eliminándolo del calendario oficial de fiestas y sancionando la utilización de su instrumento central, el bombo, por estar asociado a la liturgia peronista- constituye uno de los elementos centrales a partir de los cuales Lacarrieu (2006) y Martín (2009) caracterizaron de esa manera al período dictatorial. Discutiendo dicha caracterización y profundizando el análisis sobre la política cultural de la dictadura, Longoni (2013) y González $(2013,2014)$ han mostrado que durante esa etapa de la historia argentina distintos actores del aparato estatal y la sociedad civil crearon y organizaron conjuntamente otras festividades. En el marco de esa discusión, este capítulo tiene como objetivo específico contextualizar el origen de la Fiesta Provincial del Inmigrante durante la última dictadura, analizando el rol que en ese proceso tuvieron el intendente de Berisso y algunos miembros de las asociaciones étnicas locales. Actores, estos últimos, que con la llegada del gobierno de facto pasaron a ocupar las primeras líneas en la gestión municipal. Paralelamente analizaremos las reinterpretaciones que -desde el presente- los actores que participaron de aquel proceso fundacional hacen de un mismo pasado. Volviéndolo un objeto en disputa.

En buena medida este análisis será realizado a partir de los testimonios orales y textos escritos por un conjunto de actores que participaron de manera directa en el origen de la fiesta. Testigos que no solo vivieron el pasado que hemos tomamos como objeto de estudio sino que además estaban vivos durante la elaboración de nuestra tesis. Característica (la de compartir con el investigador un mismo tiempo histórico) que si bien no ha implicado grandes discusiones teóricas, metodológicas ni epistemológicas para la sociología, ha sido constitutiva de un campo académico con el 
cual dialogaremos asiduamente: la historia reciente o historia del presente (Mudrovcic, 2000; Aróstegui, 2004; Franco y Levín, 2007).

Antes de contextualizar el origen de la fiesta y analizar el proceso institucional que lo permitió, es necesario recordar tres elementos históricos. En primer lugar, mencionar que el último golpe de Estado fue recibido con indiferencia o beneplácito por buena parte de la sociedad argentina (O' Donnell, 1997; Novaro y Palermo, 2003). Si bien la escases de voces discordantes ha sido atribuida a la dinámica represiva desarrollada por actores estatales y para-estatales, el voto de confianza que distintos sectores de la sociedad civil le otorgaron al nuevo gobierno se tradujo en un vínculo con diversos grados de colaboración (Vezzetti, 2002; Águila, 2008).

En segundo lugar, desde la asunción del general (retirado) Ibérico M. Saint Jean como gobernador de la Provincia de Buenos Aires ${ }^{86}$ se inició un proceso de descentralización de las funciones del Estado provincial hacia los municipios, otorgándoles mayor poder y autonomía a los intendentes (Rodríguez, 2009). Siguiendo esta línea argumental, el análisis que haremos sobre el origen de la fiesta dialoga con una serie de trabajos que abordaron a escala local los vínculos entre la gestión municipal y la sociedad civil durante la última dictadura (García Delgado y Silva, 1985; González Bombal, 1985; Oszlak, 1991; Lvovich, 2010).

Por último, cabe recordar que durante el gobierno de facto solo el $10 \%$ de los municipios de nuestro país estuvieron gobernados por personal del aparato militar o de las fuerzas de seguridad, siendo el Gran Buenos Aires el lugar donde más intendentes con dichas trayectorias hubo: la cantidad de industrias radicadas en la zona y la necesidad estatal de controlar a los trabajadores que se opusieran al proyecto políticoeconómico de la dictadura, hizo que el Gobernador designe como intendentes municipales del Gran Buenos Aires a personas que provenían del aparato militar o pertenecían a las fuerzas de seguridad (Rodríguez, 2009). Entre ellos al ex comisario de Quilmes, Ricardo Cersósimo, quien en 1976 fue designado Intendente Municipal de Berisso. Dos años después Cersósimo se volvió uno de los actores centrales en el origen de la Fiesta Provincial del Inmigrante.

\footnotetext{
86 Ibérico Saint Jean fue nombrado gobernador el 8 de abril de 1976, sucediendo al general Adolfo Sigwal quien estuvo en el cargo menos de un mes (entre el 24 de marzo y el 8 de abril). Saint Jean ormaba parte del mismo grupo del ejército en el que se encontraban el Presidente de facto, teniente general Jorge Rafael Videla (1976-1981) y el Ministro de Interior Albano Harguindeguy (1976-1981). Estos actores no solo se mostraban públicamente a favor de la represión, sino que además apoyaron al Ministro de Economía (José Alfredo Martínez de Hoz), propiciaron una apertura democrática en el muy largo plazo y sostuvieron una idea elitista de la participación política (Novaro y Palermo, 2003; Rodríguez, 2009)
} 


\section{Disputas por el origen: ¿Cuándo, quiénes y por qué participaron en el origen de la fiesta?}

Como señala Jelin (2017), mientras el pasado ya pasó -es algo determinado, no puede cambiarse- los sentidos otorgados a él constituyen un objeto de reinterpretación y disputas. El origen de la fiesta, contextualizado entre mediados y fines de los años 70 por los actores que participaron de él, es un ejemplo característico de esta situación. Cada uno de ellos narran el origen de la fiesta de manera distinta, buscando que su versión del pasado logre constituirse en la narrativa oficial: no solo las fechas y los contextos enunciados por estos emprendedores de la memoria (Jelin, 2002a) difieren notablemente, sino que además cada uno nombrará a diferentes personas e instituciones como los "actores centrales" de aquel proceso fundacional. Sin embargo dos hechos aparecen recurrentemente señalados como fundamentales en el origen de la fiesta: la declaración de Berisso como Capital Provincial del Inmigrante y la creación de la Asociación de Entidades Extranjeras (AEE). Veamos.

La Gacetilla Oficial de la fiesta que anualmente reparte la AEE, indicó en el año 2002 que "en 1976, con un gran esfuerzo de todas las entidades se organiza la Primera Fiesta del Inmigrante". Dos años antes (2000) el historiador Luis Alfredo Guruciaga -fundador del "Museo 1871" y "Ciudadano llustre" de Berisso- había publicado un texto en la Gacetilla Oficial donde mencionaba que la proliferación del asociacionismo étnico dio lugar a la formación de una institución -en referencia a la AEE- "que desde 1977 organiza la Fiesta del Inmigrante". Al respecto el intendente de Berisso, Enrique Slezack, escribió en la Gacetilla Oficial del año 2010 que "Una vez más, ininterrumpidamente desde 1978, Berisso se viste de Fiesta." Algunos años después (2015) la editorial que la AEE publicó en la Gacetilla Oficial volvió a mover la fecha de origen de la fiesta; afirmando que ese origen mismo estuvo ligado a "la enorme atención y entusiasmo que generaron" las presentaciones musicales realizadas durante 1975 por los grupos de danzas que conformaban el Círculo Internacional de Folklore. Dichas presentaciones -hechas en la Escuela de Enseñanza Media $\mathrm{N}^{0} 1^{87}$ y la Conmemoración del Centenario de Chascomús- habrían llevado a que "las autoridades de algunas asociaciones étnicas de Berisso se reunieran durante 1975 para proyectar la realización de la primera Fiesta de las Colectividades" a nivel local ${ }^{88}$.

\footnotetext{
87 Llamada “Raúl Scalabrini Ortiz" (calle 10 y 169).

${ }^{88}$ Gacetilla Oficial, 2015. Resaltado nuestro.
} 
Por fuera de la Gacetilla Oficial, Alfredo Dulke (hijo de lituanos, miembro de la colectividad lituana, integrante de la primera comisión directiva de la $A E E$, presidente de ella durante el año 2014 y ex Coordinador de Colectividades Extranjeras durante las intendencias municipales de Enrique Slezack) brindó un relato similar sobre el origen de la fiesta. Sin embargo volvió a trasladar aquella fecha de origen hacia 1976/77:

"la fiesta arrancó un poco por casualidad y un poco por necesidad. En el 76, con un amigo de la colectividad ucraniana, Emilio Piesciorovsky, se nos ocurrió hacer un festival, un festival de danzas donde participaban los ucranianos y los lituanos de Berisso y tres colectividades que no eran de acá (...) Eso no hizo que se creara la asociación [en referencia a la AEE] pero fue el motivador para que al año siguiente se organizara una fiesta, un festival de danzas o fiesta de las colectividades. Eso fue lo que hizo que en este momento la fiesta esté cumpliendo 36 años." 89

Por su parte Dr. Juan Minoian (hijo de armenios, miembro de la colectividad armenia y primer presidente de la AEE, cargo que ocuparía de manera ininterrumpida entre 1980 y 1998) describió de manera distinta aquel proceso fundacional; trasladando el origen de la fiesta hacia 1978. En un texto publicado en el semanario local, "El Mundo de Berisso", Minoian mencionaba:

"Varios vecinos nos reunimos desde el año 1976 para madurar esta moción [crear la fiesta] hasta que, junto con Sofía Rapi, miembro de la Colectividad Albanesa, Stella Loholaberry de la Colectividad Española y Néstor Ruiz de la Colectividad Eslovaca, creamos en 1978 la 'Asociación de Entidades Extranjeras de Berisso' y nacieron formalmente las 'Fiestas del Inmigrante'."90

Lejos de relacionar el origen de la fiesta con aquel festival de danzas mencionado por Dulke o vincularlo con una iniciativa vecinalista como hacía Minoian, Stella Loholaberry (hija de españoles, miembro de la colectividad española y primera secretaria de actas de la $A E E)$ señala que la fiesta tuvo su origen en una propuesta que el intendente municipal le hizo llegar a las colectividades étnicas de la ciudad:

"La convocatoria [para organizar la fiesta] fue del municipio. Fue la intendencia la que tuvo la idea, no fueron las colectividades. Porque si bien hubo una especie de festival de colectividades en Berisso unos años antes de que empezara la fiesta, eso no se puede tomar como una fundación; aunque hoy muchos digan que sí. Hay personas que participaron de ese festival que ahora dicen que ellos fueron los iniciadores de la fiesta [en referencia a lo afirmado por

89 En "Voces de patria", Dirección de Comunicaciones Institucionales de la Municipalidad de Berisso. Publicado 24 de septiembre de 2013. Disponible en: https://www.youtube.com/watch?v=rqthDWSqTis.

90 Dr. Juan I. Minoian, en "El Mundo de Berisso" semana del 30 de septiembre al 6 de octubre, 2011, pág. 5. Resaltado nuestro. 
Alfredo Dulke], incluso colectividades que no quisieron participar cuando las colectividades se reunieron originalmente para organizarla.

Bueno... El intendente de ese momento, Cersósimo, que era intendente de facto, se enteró de casualidad que querían declarar Capital del Inmigrante a la ciudad de... creo que Campana. A mediados de 1977 él se entera de eso y dice 'no puede ser, Berisso tiene muchísimo más'. Entonces con su secretaria o directora de cultura, Alicia Gellert, juntaron toda la documentación y la presentaron... por eso declararon a Berisso Capital del Inmigrante. Cuando ve que eso ya está por salir, cita a las colectividades (a las que tenían representación) para organizar la fiesta. Fue así como te lo cuento, la fiesta fue una idea de Cersósimo, no de las colectividades." ${ }^{1}$

A fines de 1977 los representantes de algunas asociaciones étnicas le entregaron al intendente municipal (Ricardo Cersósimo) la documentación necesaria para respaldar un proyecto cuyo objetivo principal era declarar a Berisso "Capital Provincial del Inmigrante". Seguidamente, el 20 de febrero de 1978 el secretario de Obras y Servicios Públicos de la ciudad (Dr. Ignacio García) envió una carta al secretario de Asuntos Municipales de la Provincia de Buenos Aires (Cnel. Arturo E. Pellejero) pidiendo que se analicen los fundamentos de aquel proyecto. La nota señala:

"Cúmpleme dirigirme a Ud. Solicitando quiera prestar apoyo al adjunto proyecto, elevando a la consideración del Poder Ejecutivo Provincial este expediente mediante el cual se gestiona que la Ciudad de Berisso sea declarada por decreto "CAPITAL PROVINCIAL DEL INMIGRANTE” (...) Es imposible ignorar la significación del extranjero dentro de la vida institucional de este Partido (...) En consecuencia señor Secretario, estimamos que resaltar tan amplia como importante contribución de los extranjeros, a lograr con su esfuerzo y lealtad el engrandecimiento de este Partido, significará un reconocimiento del pueblo argentino hacia todos los individuos de buena voluntad que vinieron a habitar este suelo patrio. Teniendo en cuenta que el próximo tres de abril se cumple el vigésimo primer Aniversario de la autonomía comunal, fecha de especial importancia dentro de este Partido, sería sumamente propicio lograr la aprobación de lo requerido antes de la fecha." ${ }^{92}$

Finalmente, el 28 de marzo de 1978, el Gobernador de la Provincia de Buenos Aires (Ibérico Saint Jean-Smart) sancionó el decreto militar № 438/78 declarando a Berisso "Capital Provincial del Inmigrante". Su texto afirma:

\footnotetext{
"Declárese, en el territorio de la Provincia "Capital del Inmigrante" a la ciudad de Berisso, partido del mismo nombre en homenaje a los inmigrantes que contribuyeron con su esfuerzo y lealtad al engrandecimiento de dicha ciudad (...) Los antecedentes históricos, estadísticos y sociales demuestran la existencia de un notable proceso que convirtió a esa localidad -puede decirse que desde sus orígenes- en un verdadero crisol de nacionalidades, con caracteres que le asignan una fisonomía propia y sin dudas única en la Provincia." (Resaltado nuestro)
}

\footnotetext{
${ }^{91}$ Entrevista realizada en Diciembre del 2016.

92 Citado en Filgueira, 2002: 86. Resaltado nuestro.
} 
La presencia de inmigrantes, "su esfuerzo, lealtad, buena voluntad y contribución al engrandecimiento institucional de la ciudad", es algo que -según expresa aquel proyecto municipal- no solo "debe" ser reconocido sino que "es imposible" de ignorar. Por su parte el decreto provincial no solo fijará un "origen" berissense ligado a la llegada de inmigrantes ultramarinos sino que además repondrá un imaginario de la comunidad completamente "acrisolado". Origen mítico e imaginario que, como analizaremos en los capítulos siguientes, es actualizado anualmente en la Fiesta Provincial del Inmigrante. Volviéndola un espacio en el cual la apelación a ciertos hechos del pasado permite que los descendientes de inmigrantes ultramarinos reunidos en las asociaciones étnicas locales construyan prestigio y legitimidad social.

Después de haber logrado la promulgación de aquel decreto el intendente municipal volvió a citar a los representantes de algunas asociaciones étnicas para organizar la primera edición de la fiesta. Indicando cuáles fueron las asociaciones que estuvieron presentes en dicha reunión -y por lo tanto podrían reclamar para sí el reconocimiento de haber creado la fiesta- Walleria Worblewski (descendiente de polcados y miembro de la asociación polaca) señala:

"Italianos, polacos, albaneses, ucranianos, lituanos, bielorrusos y búlgaros. Éramos siete las colectividades que comenzamos con esto de la fiesta. Mandaron a todos eh... a todas las colectividades... [en referencia a la convocatoria realizada desde municipio] pero nosotros fuimos los primeros que estuvimos en el despacho del intendente. ${ }^{.93}$

Así, entre noviembre y diciembre de 1978 -en un contexto que no solo se encontraba marcado por la gestión dictatorial del aparato estatal sino también por la crisis del tejido fabril de la ciudad, el descenso en la cantidad de inmigrantes radicados en ella y la reorientación en los objetivos fundacionales del asociacionismo étnico (ver capítulo $N^{\circ} 2$ )- las siete asociaciones étnicas anteriormente mencionadas organizaron la primera edición de la Fiesta Provincial del Inmigrante con apoyo de la intendencia municipal y la gobernación provincial. Un año después (noviembre de 1979) se produjo la creación del otro actor institucional que anualmente organiza la fiesta junto a la intendencia municipal: la AEE. Según leemos en su Gacetilla Oficial:

"Al llevarse a cabo la segunda edición [de la fiesta] y más específicamente en la cena de Elección de la Reina organizada en las instalaciones del 'Cedro Azul', Néstor Ruiz que participaba activamente en el 'Club Checoslovaco Argentino de Berisso' (...) tiene la visión de nuclear de otra manera a las Colectividades. Es así que una vez consensuado con su Comisión Directiva, hacen efectiva la primera reunión en la Sede

\footnotetext{
93 En "Voces de patria", Dirección de Comunicaciones Institucionales de la Municipalidad de Berisso. Publicado 24 de septiembre de 2013. Disponible en: https://www.youtube.com/watch?v=rqthDWSqTis.
} 
del Club Checoslovaco, un 28 de noviembre de 1979, y a la que asisten casi todas las entidades. De esta manera se acordó que la mayoría de las Colectividades se agruparan en una entidad que pasó a llamarse Asociación de Entidades Extranjeras de Berisso." ${ }^{14}$

Las once asociaciones que crearon esta entidad en 1979 (esa "mayoría, aquel "casi todas") fueron la Asociación Patriótica Albanesa de Berisso, el Hogar Árabe Argentino, la Sociedad Armenia de Berisso (hoy llamada Colectividad Armenia de Berisso), el Club Social y Deportivo "Vostock" de la Colectividad Bielorrusa, la Sociedad Búlgara "Iván Vazov", la Sociedad Checoslovaca (hoy llamado Club Eslovaco Argentino), la Sociedad Cultural Lituana de Socorros Mutuos "Nemunas", la Sociedad Española de Berisso, la Sociedad Italiana, la Unión Polaca en Berisso y la Colectividad Yugoslava (hoy llamada Centro Yugoslavo Argentino) (ver anexo $n^{0} 5$, "Asociación de Entidades Extranjeras", Reforma del Estatuto, 2006).

Aquel encuentro entre los representantes de las asociaciones étnicas y el intendente municipal no solo motorizó la declaración de Berisso como "Capital Provincial del Inmigrante" sino que además fue central en la creación de la AEE y el origen de la fiesta. Para describir este proceso utilizamos distintas fuentes documentales (una nota enviada desde la municipalidad berissense hacia la gobernación provincial, un decreto provincial, las Gacetillas y el Estatuto de la AEE, etc.). A la par bastaría hacer un simple cálculo matemático para para fijar el origen "duro, fáctico, real"- de la fiesta en el año 1978: en el año 2017 se llevó a cabo la edición número cuarenta de una fiesta que se realizó ininterrumpidamente desde su primera edición. Sin embargo, como bien señala Jelin (2002a:78, cursivas nuestras) "la historia 'dura', fáctica, de los eventos y acontecimientos que 'realmente' existieron se convierte en un material imprescindible pero no suficiente para comprender las maneras en que los sujetos sociales construyen sus memorias, sus narrativas y sus interpelaciones a esos mismos hechos."

Siguiendo esta postura reunimos y contrastamos los testimonios orales y escritos de un conjunto de actores, mostrando que no existe una interpretación unívoca sobre el origen de la fiesta: las fechas, los contextos y los actores señalados como fundamentales se constituyen, en el presente, en objetos de reinterpretación y disputa. De esta manera el análisis realizado sobre el origen de la fiesta no buscó evidenciar "supuestas falacias" en las narrativas de los actores sino examinar críticamente la producción social de memorias sobre aquel proceso histórico. Tal y como señalamos

\footnotetext{
${ }^{94}$ Gacetilla Oficial de la fiesta, AEE, 2012. Resaltado nuestro.
} 
en el apartado dedicado a exponer la Estrategia Metodológica, los testimonios orales y escritos no fueron concebidos como relatos factuales; limitados a una supuesta función informativa que revele "la verdad de lo sucedido" (Pollak, 2006). Al desnaturalizarlos -alejándonos de cualquier postura que los incorpore acríticamente como verdades dadas- mostramos que las memorias sobre el origen de la fiesta son un objeto históricamente construido, librado a reinterpretaciones. Con este juego de fuentes (entre relatos orales y documentos escritos) analizamos el proceso a través del cual un conjunto de actores institucionales construyeron -en tensión- una memoria sobre el origen de la fiesta. Análisis que nos permitió comprender que ese pasado es "un objeto en disputa, donde actores diversos expresan y silencian, resaltan y ocultan, distintos elementos para la construcción de su propio relato. Lo que encontramos es una lucha por las memorias, una lucha social y política en la que se dirimen cuestiones de poder institucional, simbólico y social" (Jelin, 2017: 285).

\section{2. ¿Qué debía ser conmemorado (recordado/olvidado)? imaginar la comunidad a partir de sus recuerdos y olvidos}

Si bien los datos expuestos en el apartado anterior nos permiten afirmar que en menos de dos años la ciudad fue declarada "Capital Provincial del Inmigrante" (marzo de 1978), se realizó la primera edición de la fiesta (noviembre/diciembre 1978) y se creó la AEE (en noviembre de 1979), poco nos dicen sobre los motivos conmemorativos que guiaron dicho proceso. Consecuentemente no nos permiten responder la pregunta sobre qué hechos del pasado habría buscado traer al presente este ritual conmemorativo en su propio contexto de surgimiento. Para responder este interrogante analizaremos dos soportes de la memoria escrita local. Análisis a partir del cual mostraremos que no solo la fecha, los contextos y los actores que participaron del origen de la fiesta constituyen objetos de reinterpretación y disputa, sino que los motivos por los cuales ese proceso se habría llevado a cabo también lo son. Veamos.

En 2011, como presidente de la AEE, Pascual Arena publicó una nota en "Ciudad Inmigrante. La Revista de Berisso" donde señaló que la fiesta fue creada "para mantener vivas las raíces de los inmigrantes que llegaron a los frigoríficos a buscar trabajo, escapando de las malas condiciones en las que vivían en Europa'95. Por su parte, el Dr. Juan Minoian señaló ese mismo año -en aquel texto publicado en el semanario "El mundo de Berisso" que citamos anteriormente- que el origen de la

\footnotetext{
${ }^{95}$ Pascual Arena, Colectividad Italiana. Publicado en "Ciudad Inmigrante. La Revista de Berisso", Año 2, № 13, septiembre 2011. Resaltados nuestros.
} 
fiesta estuvo ligado a otros dos objetivos. Objetivos que no solo eran completamente distintos a los manifestados por Pascual Arena sino que además corrían el riesgo, según Minoian, de ser olvidados en el presente:

"Los pioneros [en la organización de la fiesta] fueron inmigrantes directos y argentinos de primera generación. Hoy casi todos los mayores se han ido y son los hijos y nietos los que han tomado la posta (...) Pero en la vorágine de los acontecimientos tal vez se pueden ir perdiendo los objetivos y motivaciones que originaron estas fiestas si no lo fijamos con el testimonio escrito, así como se perdieron las Actas [de la $A E E$ ] que fueron entregadas al Presidente que me sucedió en el año 1999."

Buscando dejar registrados estos objetivos fundacionales en un testimonio escrito -limitando la posibilidad de su olvido e instituyéndose a sí mismo en testigo central de los acontecimientos narrados- Minoian señaló que la fiesta se creó principalmente para "recordar el dolor que subyacía a cada grupo (...) arribado a estas tierras de promisión en los comienzos de la centuria pasada". Aquel dolor que había movilizado a millones de inmigrantes hasta la costa berissense -y que debía ser recordado en cada edición de la fiesta- estaba ligado en su caso a "las horrorosas vivencias que mis padres, de origen armenio, padecieron en manos del yatagán ${ }^{96}$ turco durante el genocidio perpetrado a principios del siglo XX". Descriptos a lo largo de cuatro páginas, publicadas semanalmente durante el período que dura la fiesta, los recuerdos de los padecimientos vividos por sus padres se cierran con una invitación a que "cada una de las colectividades narre los acontecimientos que motivaron la llegada de sus ancestros (algunos dramáticos, otros trágicos, ninguno turístico) a fines del siglo XIX y principios del XX".

Lo que actualmente se recuerda en contexto festivo no es todo lo que, según Minoian, debería ser recordado. El paso del tiempo y la distancia intergeneracional entre los creadores de la fiesta y sus actuales realizadores complotan contra la posibilidad de recordar uno de los objetivos que la originaron: las experiencias traumáticas que atravesaron los inmigrantes que llegaron a Berisso a inicios del siglo XX. En ese marco, el testimonio de Minoian no solo vendría a contener la posibilidad de su olvido, sino que además buscaría vincular aquel objetivo fundacional con un deber de memoria (Jelin, 2013): recordar para no repetir. Deber que no solo se encuentra relacionado con las persecuciones étnicas, religiosas y políticas que sufrieron aquellos inmigrantes, sino que está asentado en la convicción de que solo el

\footnotetext{
${ }^{96}$ El yatagán es un sable de origen oriental.
} 
"recuerdo permanente de lo ocurrido puede construir una barrera contra la repetición de atrocidades similares" (Jelin, 2017: 90).

Finalmente, antes de terminar el texto, Minoian señala el otro objetivo por el cual a fines de los años 70 se habría creado la fiesta. Objetivo que no buscaba recordar hechos traumáticos del pasado, sino intervenir sobre el ánimo de la población berissense en un contexto donde el tejido fabril de la ciudad había entrado en crisis:

"Comprendí que era el momento oportuno cuando, en la década del '70 comenzó la crisis de los frigoríficos, principal fuente de trabajo de la ciudad de Berisso. Debía aparecer un objetivo estimulante para que no decayera el ánimo de la población. Varios vecinos nos reunimos desde el año 1976 para madurar esta moción, hasta que (...) creamos en 1978 la 'Asociación de Entidades Extranjeras de Berisso' y nacieron formalmente las 'Fiestas del Inmigrante'". ${ }^{97}$

Uniendo ambos objetivos fundacionales en una misma narración, Minoian no solo construye una memoria de los acontecimientos que dieron origen a la fiesta (¿quiénes participaron, dónde, cuándo, qué objetivos los movían?), sino que al recordar los acontecimientos traumáticos vividos por sus padres logra elaborar una memoria de memorias (Passerini, 1992), una post-memoria (Hirsch, 1996)" "memorias de lo que no se vivió" en carne propia (Vezzetti, 2002: 17). Así, construye una narración sobre el pasado donde las capas y las temporalidades de las memorias se superponen continuamente (Jelin, 2017), haciendo que sus recuerdos se trasladen desde el genocidio turco perpetrado contra el pueblo armenio (Imperio Otomano, 1915-1923) hasta la desindustrialización iniciada en la Argentina a fines de los años 70. Dicho de otra manera, una memoria construida entre la experiencia trasmitida y la experiencia vivida.

Mirados conjuntamente, los relatos de Pascual Arena y Juan Minoian ligan el origen de la fiesta con $1^{\circ}$ ) la posibilidad de mantener vivas un conjunto de tradiciones culturales europeas trasplantadas a suelo argentino, $2^{\circ}$ ) la necesidad de recordar las experiencias traumáticas que motivaron el proceso inmigratorio y $3^{\circ}$ ) la capacidad de estimular el ánimo de una población que enfrentaba la crisis de su tejido fabril. Más allá de las significativas diferencias que estos testimonios exponen nos interesa resaltar la centralidad que adquieren la reactuación de tradiciones culturales y la

\footnotetext{
${ }^{97}$ El Mundo de Berisso, ediciones correspondientes a la semanas del 23 al 29 de septiembre, y del 30 de septiembre al 6 de octubre de 2011. Resaltado nuestro.

${ }^{98}$ Cabe señalar que la conceptualización de Hirsch (1996) fue pensada en relación a los hijos de quienes sobrevivieron al Holocausto, y en tal sentido fue desarrollada para dar cuenta de las memorias que elaboran las segundas generaciones sobre las experiencias traumáticas vividas por sus padres. Situación similar a la del Dr. Juan Minoian.
} 
recordación de ciertos hechos del pasado entre los motivos por los cuales se habría creado la fiesta (volveremos sobre este punto).

Frente a estas motivaciones -evidentemente significativas para sus propios actores- Lobato (2004) presenta una explicación radicalmente distinta sobre el origen de la Fiesta Provincial del Inmigrante. Si los testimonios de Arena y Minoian permiten acercarnos a los hechos del pasado que el ritual conmemorativo buscó traer al presente -mediante su recuerdo- y señalar las tradiciones que pretendía mantener con vida -mediante su reactuación-, el argumento de Lobato se enfoca en los aspectos que la práctica conmemorativa buscó olvidar y/o silenciar. La autora afirma que a fines de los años 70 el contexto laboral de la ciudad y la coyuntura política del país crearon un marco propicio para que la declaración de Berisso como "Capital Provincial del Inmigrante" se concrete en menos de cuarenta días ${ }^{99}$. En un contexto donde el aparato estatal fue ocupado por las Fuerzas Armadas, algunas asociaciones étnicas y la intendencia municipal sentaron las bases para conmemorar una historia de la comunidad que -al revitalizar un tópico de la historia nacional ligado a la llegada y el esfuerzo de los inmigrantes ultramarinos- permitiera olvidar y/o silenciar los recuerdos que unían a Berisso con los orígenes del peronismo (ver capítulo $\mathrm{N}^{\circ} 2$ ). Al articular las adscripciones étnicas, conmemorar un origen inmigratorio y representar un vínculo social tan armónico como acrisolado, la fiesta logró desarticular las adscripciones políticas, silenciar los recuerdos que unían a la ciudad con los orígenes del peronismo y despojar al presente de sus aristas conflictivas. Así, según Lobato, la creación de un imaginario armónico y acrisolado de la comunidad implicó olvidar y/o silenciar los conflictos políticos del pasado mediante una práctica conmemorativa que puso a los inmigrantes ultramarinos en el centro de la historia local:

"Durante la última dictadura militar, se reavivó la reconstrucción del pasado de la localidad retomando el 'espíritu del inmigrante' y se legitimó esta reconstrucción, cuando en el año 1978 se estableció, por decreto del gobernador militar de la provincia, que Berisso fuera la Capital Provincial del Inmigrante (...) La tríada inmigrante, trabajo, armonía se reavivaba despojada de algunas aristas conflictivas; se omitía al nativo porque estaba estrechamente relacionado con el peronismo y se rescataba la armonía porque ella había contribuido a construir el progreso de la ciudad. La identidad local se construía dotando de nuevos significados al pasado de la comunidad y los agentes formadores se superponían. Los gobernantes locales de la última dictadura militar retomaron las viejas visiones de la comunidad referidas al esfuerzo inmigrante, pero acentuaron las facetas de armonía que suponían existentes en su seno. Al mismo tiempo [ante la crisis del tejido fabril local] los habitantes de Berisso generaron una práctica social de conmemoración en la que participaban todo los miembros de la comunidad para buscar una solución a las incertidumbres del presente (...) Los miembros de las instituciones asociativas se vestían con los trajes típicos regionales o nacionales, bailaban, cantaban canciones de sus tierras, preparaban las comidas que los identificaban. Todas estas experiencias se

\footnotetext{
${ }^{99}$ Periodicidad que hemos narrado en el apartado anterior.
} 
superponían en un contexto fuertemente represivo que afectó la vida cotidiana (...) de la localidad. La Fiesta del Inmigrante ayudó a crear una imagen de la realidad armónica y a olvidar los conflictos del pasado" (Lobato, 2004: 67-68, cursivas de la autora).

En oposición a lo sucedido en el período 1935-1955, donde las identificaciones políticas habían hecho declinar las adscripciones étnicas, serán éstas las que a fines de los años '70 resurjan bajo el intento estatal de desarticular las adscripciones políticas. Proceso en el cual, según Lobato (2004), la creación de la fiesta jugó un rol central al permitir olvidar y/o silenciar los recuerdos que unían a Berisso con los orígenes del peronismo. En línea con lo anteriormente expuesto varios autores afirmaron que las asociaciones étnicas funcionaron en nuestro país como uno de los espacios privilegiados donde las elites dirigentes construyeron una identidad de clase media (Míguez, 1992) que -al reponer el mito de una nación homogéneamente blanca, acrisolada y de origen europeo- se opuso al imaginario político peronista (Garguin, 2009). Trasladando este argumento a la escala local podríamos pensar que la declaración de Berisso como "Capital Provincial del Inmigrante" y la conmemoración festiva de un origen inmigratorio -recordando y reactuando el mito fundacional de una ciudad blanca, acrisolada y europea- habría buscado desarticular las identificaciones políticas ligadas al peronismo mediante su olvido y/o silenciamiento.

Por nuestra parte creemos que la hipótesis de Lobato (2004) sobre el origen de la fiesta se vuelve más potente si la leemos a la luz de los cambios que sufrieron los objetivos fundacionales del asociacionismo étnico. Como describimos en el capítulo anterior, desde mediados del siglo XX dichos objetivos pasaron a estar centrados (internamente) en la reafirmación de una sociabilidad que permitiera reconstruir identificaciones y sentidos de pertenencia, y (externamente) en la posibilidad de construir prestigio, legitimidad y visibilidad social en la esfera pública. En ambas direcciones la recordación de ciertos hechos del pasado y la reactuación de tradiciones culturales formaron parte de las estrategias más utilizadas para alcanzar estos objetivos. Así, en el contexto represivo de los años 70 las identificaciones étnicas podrían haberse vuelto una herramienta válida para reafirmar una sociabilidad en común y adquirir prestigio, legitimidad y visibilidad social mediante la reactuación de tradiciones culturales y la recordación de ciertos hechos del pasado. A las identificaciones políticas le habría pasado todo lo contrario.

En tal sentido no quisiéramos dejar de comentar que, como bien señala Ballina (2006) en un trabajo dedicado a las estrategias identitarias de aquellos inmigrantes eslavos que participaban de la Colectividad Bielorrusa de Berisso (Club Social y 
Deportivo "Vostock"), la llegada del autodenominado Proceso de Reorganización Nacional abrió un nuevo contexto para las identificaciones étnicas y las identificaciones políticas. Según este autor, a partir de 1976 las asociaciones étnicas de la ciudad comenzaron a imponerse no hablar de política. En algunos casos, de hecho, hablar de política al interior de las instituciones étnicas era "una actividad totalmente prohibida con el fin de 'evitar los choques'” (Ballina, 2006: 78). Prohibición que comenzó a formar parte de los estatutos de estas instituciones. Por nuestra parte quisiéramos señalar que al interior del primer Estatuto de la AEE (redactado en el año 1980) lo prohibición de "lo político" aparece expresamente señalado en su artículo n5: "Esta Asociación carece de filiación política, tanto en su local como en sus reuniones, no será permitido mantener discusiones de carácter político (...) El incumplimiento podrá ser penado por la Comisión Directiva de la Asociación, con la expulsión del o de los delegados y hasta de la colectividad o colectividades que incurran en la falta, ya sea por un tiempo determinado o definitivamente, siendo comunicada esta pena a la entidad representada" (cursivas nuestras) ${ }^{100}$.

Sería ilusorio pensar que, en un determinado momento histórico, "lo político" se constituyó en una prácticas "naturalmente" conflictiva, una exclusión deliberada y legitimada por los propios actores. Frente a ello entendemos que lo "naturalmente" conflictivo de "lo político" tiene sus raíces en las limitaciones que le impuso la llegada de la última dictadura militar a las identificaciones políticas. Frente a ellas, las identificaciones étnicas resurgieron a partir de la recordación de ciertos hechos del pasado inmigratorio y la reactuación de ciertas tradiciones culturales

Mientras los actores involucrados en el origen de la fiesta señalan que ella permitió "mantener vivas" -reactuándolas- un conjunto de tradiciones culturales europeas y recordar las experiencias traumáticas atravesadas por los inmigrantes que llegaron a Berisso "entre fines del siglo XIX y principios del XX", Lobato afirma que

\footnotetext{
${ }^{100}$ En su reforma del año 2006, dicho artículo pasó al 4to lugar y amplió las formas de la prohibición: "Esta Asociación carece de filiación política. No será permitido a sus asociados, cualquier tipo de manifestación, verbal, escrita, gráfica o de cualquier otro tipo de exteriorización, ni mantener discusiones, todas ellas de naturaleza política, racial y/o religiosa; tanto en su local, como en sus reuniones, dentro del ámbito de actividad propia y/o participada de la Asociación de Entidades Extranjeras de Berisso. El incumplimiento de lo establecido en este artículo será sancionado, de acuerdo a la gravedad del caso, de conformidad al procedimiento y demás medidas previstas en los artículos 19 a 21 inclusive del Título Segundo, Capítulo de los Derechos y Obligaciones de los Socios". Pero a la vez agregó nuevos artículos referidos a esta prohibición. Así, leemos en el artículo no 12: “(...) En cualquiera de las actividades organizadas por la Asociación de Entidades Extranjeras de Berisso las instituciones, únicamente podrán exhibir los elementos representativos (banderas, escudos insignias, etc.) de la nación o regiones que la integran, estando prohibido el uso de carteles, banderas, escudos, emblemas, leyendas identificatorias de partidos, movimientos u organizaciones políticas" (cursivas nuestras). Ver Anexo № 5 "Asociación de Entidades Extranjeras (AEE)".
} 
dicho origen estuvo ligado a un proyecto estatal tendiente a olvidar y/o silenciar los recuerdos que unían a la ciudad con los orígenes del peronismo. Al iluminar "una cara" de los procesos a través de los cuales se construyen las memorias colectivas, ambas lecturas sobre el origen de la fiesta permiten comprender la tensión existente entre recuerdos y olvidos. Pero a la vez, si trasladamos ambas lecturas a los términos de Rabotnikof (2009) -expuestos en el Marco Teórico- podemos presentar con mayor densidad analítica la distinción conceptual entre lo conmemorado y la conmemoración.

Lo conmemorado -los acontecimientos del pasado que la memoria busca restituir en el presente- habría estado ligado a la posibilidad de mantener vivas las raíces culturales europeas trasplantadas a suelo argentino y la necesidad de recordar las experiencias traumáticas que motivaron la llegada de inmigrantes a Berisso en el período de entre siglos. Focalizar nuestra mirada en lo conmemorado nos podría llevar a señalar que la fiesta no habría buscado transformar el pasado para ponerlo al servicio del presente, sino que su sentido habría estado ligado a revivir y reproducir ese pasado para actualizar el sentido de comunidad. Llevada al extremo esta mirada termina sustancializando el pasado, descansando en un realismo ingenuo que supone que los hechos del pasado están ahí, inmutables para su actualización en el presente, disponibles para todos los actores.

Por su parte la conmemoración -esa forma ritual de una relación social que utiliza el pasado como respuesta a los problemas del presente- se habría propuesto fortalecer el ánimo de la población local (en contexto de crisis laboral) y escenificar un imaginario armónico de la comunidad que limitara los recuerdos que unían a la ciudad con los orígenes del peronismo (en contexto dictatorial). Así, focalizar nuestra mirada sobre la conmemoración permite poner el acento en las condiciones presentes de la reconstrucción, recuperación o invención del pasado que la fiesta habría habilitado. Y consecuentemente analizar cómo el contenido, la forma y los sentidos otorgados a lo conmemorado estuvieron condicionados por el contexto en el que se realizó la conmemoración.

\section{Sobre los silencios}

"La fiesta fue una idea de Cersósimo, no de las colectividades" nos dijo Stella Loholaberry cuando la entrevistamos. Asimismo, al comentar cuáles fueron las colectividades que estaban presentes en el despacho de Cersósimo en aquella reunión fundacional, Walleria Worblewski señaló el rol protagónico que tuvo el 
intendente. Ahora bien, ¿por qué en los relatos de Alfredo Dulke y Juan Minoian actores que participaron activamente del origen de la fiesta- Cersósimo no aparece nombrado y en cambio si lo es, por ejemplo, Emilio Piesciorovsky?

En la introducción de este capítulo señalamos que Cersósimo fue uno de los intendentes del Gran Buenos Aires que llegaron a dicho puesto viniendo de las fuerzas de seguridad. La enorme cantidad de industrias radicadas en la zona y la necesidad estatal de controlar a los trabajadores que se opusieran al proyecto político-económico de la dictadura, hizo que el Gobernador de la Provincia de Buenos Aires designe como intendentes a un conjunto de actores que provenían del aparato militar o pertenecían a las fuerzas de seguridad. Antes de ser nombrado Intendente de Berisso (03/06/1976) $)^{101}$ Cersósimo fue Director de Seguridad de la Provincia de Buenos Aires (6/12/75-6/5/76) y Comisario de la Ciudad de Quilmes. Su nombre aparece en los archivos de la DIPBA (Dirección de Inteligencia de la Provincia de Bs As, Comisión Provincial de la Memoria) y en varios juicios por Delitos de Lesa Humanidad: Cersósimo fue acusado, por responsabilidad en la línea de mandos, de torturas, desapariciones y apropiación de menores ${ }^{102}$. Es importante recordar que durante su intendencia la violencia desatada por el aparato estatal tuvo un saldo particularmente trágico en Berisso. Según el registro de detenidos-desaparecidos y asesinados elaborado por la "Comisión de Memoria, Recuerdo y Compromiso de la Ciudad de Berisso" existieron, al menos, 126 desapariciones forzadas y 17 asesinatos (Bretal, 2014:18).

Tal vez por conocer algunos de estos datos Alfredo Dulke y Juan Minoian no nombran a Cersósimo como uno de los actores centrales en el origen de la fiesta, y si nombran a Emilio Piesciorovsky. Ahora bien ¿qué otros datos tenemos sobre Minoian, Piesciorovsky y Dulke? Viniendo desde las asociaciones étnicas locales, los dos primeros pasaron a ser funcionarios del municipio berissense durante el último gobierno de facto. Mientras Emilio Piesciorovsky ocupó los cargos de Secretario de Gobierno y Director de Asuntos Jurídicos ${ }^{103}$, Juan Minoian fue el Secretario de Bienestar Social ${ }^{104}$. Respecto a Dulke no tenemos datos sobre su participación

\footnotetext{
${ }^{101}$ Ricardo Cersósimo fue precedido en el cargo de Intendente de Berisso por el Capitán de Corbeta Alfredo Fariña, quien lo ocupó solo por tres meses (de 03/76 a 06/76). Cersósimo fue intendente de Berisso entre 03/06/76 y 08/09/80, sucediéndolo en el cargo el Arq. Roberto Arún hasta la llegada de la democracia.

102 Causas no 16.419, caratulada "Dr. Félix Pablo Crous, s/denuncia (La Cacha-Lisandro Olmos)" (Centro Clandestino de Detención La Cacha), causa nro. 3393/2007 caratulada "Subzona 1/11 y otros sobre privación ilegal de la libertad, y causa №1 "Causa incoada en virtud del decreto 280/84 del Poder Ejecutivo Nacional".

${ }^{103}$ Con el regreso de la democracia pasaría a ocupar el cargo de Director de Asesoría Letrada durante la gestión del Ing. Carlos Nazar

${ }^{104}$ Durante la gestión municipal del Arq. Roberto Arún (9/80-12/83).
} 
institucional durante la última dictadura cívico-militar. Sin embargo, y como veremos en el último capítulo, uno de los entrevistados lo caracteriza como "un tipo jodido, fascista, rodeado de leyendas urbanas con la dictadura."

En septiembre del año 2017, como parte de la 40 ${ }^{\circ}$ Fiesta Provincial del Inmigrante, se llevó a cabo un homenaje a los miembros de la primera Comisión Directiva de la AEE. Allí se les entregó un diploma que recordaba el cargo que cada uno había ocupado en dicha comisión. Algunos de ellos ya habían fallecido, siendo sus familiares quienes recibieron el diploma. El resto se hicieron presente para ser homenajeados, tomando el micrófono unos instantes para recordar a quienes habían fallecido o narrar alguna anécdota sobre el proceso de conformación de la AEE y el origen de la fiesta.

Una vez finalizado el acto me acerqué a saludar a Silvia (una de las integrantes de la primera Comisión Directiva de la AEE) quién me dijo sentirse tan emocionada por el reconocimiento como enojada por "lo que acababa de pasar". ¿Qué era lo que le había molestado? Recorriendo juntos el trayecto hasta su casa comprendería el motivo de su enojo:

\footnotetext{
" ¿Te diste cuenta que ni lo nombraron a Cersósimo? Estos tipos [en referencia a quienes acababan de ser homenajeados] se ponen ahí, en primera fila, para recibir su diploma y se olvidan de Cersósimo. Son unos figurones... ¡Como si ellos hubieran creado la fiesta! La idea de hacer la fiesta no fue de ellos, fue de Cersósimo. Igual los entiendo; ahora ni lo nombran porque fue intendente de facto. Pero son unos hipócritas, fueron colaboracionistas y ahora ni lo nombran."
}

Valentina Salvi (2017:13) señala que en las sociedades post-dictatoriales los pasados violentos pueden ser recordados en sus aspectos más dolorosos y ser asumidos -es decir, reconocidos como propios- o ser deliberadamente olvidados, ocultados, disimilados y silenciados para no afrontar ni aclarar las responsabilidades que se derivan de ellos. A lo cual agrega que, para los actores involucrados con esos pasados, recordar implica (de un modo u otro) lidiar con las responsabilidades por lo sucedido. Si bien el problema de la responsabilidad (Jaspers, 1998; Arendt, 2003) no es una dimensión a trabajar en esta tesis, los hechos narrados en este apartado buscaron dar cuenta del lugar que ocupan algunos silencios en torno al origen de la fiesta. 


\section{Reflexiones finales}

A primera vista la contextualización que realizamos sobre el origen de la Fiesta Provincial del Inmigrante parecería contradecir los argumentos de quienes, de una manera u otra, caracterizaron a la última dictadura cívico-militar como un período antifestivo (Lacarrieu, 2006; Martín, 2009). Sin embargo, como señalamos al inicio de este capítulo, otras autoras (Longoni, 2013 y González, 2014) discutieron dicha caracterización mostrando que durante ese período de la historia argentina algunos actores del aparato estatal y la sociedad civil crearon y organizaron conjuntamente distintas festividades. Por nuestra parte entendemos que ambas lecturas, pese a parecer opuestas, son parcialmente ciertas. Certezas que provienen del objeto de estudio abordado y la postura teórica asumida por cada una de esas investigaciones.

Tal y como analizamos en el Marco Teórico, los investigadores del fenómeno festivo se dividieron entre quienes vieron en las fiestas un contexto que reproduce el orden social y los que vieron en ellas un contexto que busca cuestionar los fundamentos de aquel ordenamiento. Planteado en términos dicotómicos: las posturas se dividieron entre quienes vieron en las fiestas un mecanismo de reproducción social y quienes vieron en ellas una coyuntura que habilita el cambio social. Marcos interpretativos dentro de los cuales puede ser incorporada la discusión sobre el vínculo entre fiesta y dictadura.

Si tenemos en cuenta que el carnaval es una de las fiestas populares a través de las cuales sus actores cuestionan/subvierten las jerarquías del orden social, es entendible que las instituciones estatales del período dictatorial lo hayan eliminado del calendario oficial de fiestas (Lacarrieu, 2006; Martín, 2009). Frente a estas fiestas, Longoni (2013) y González $(2013,2014)$ vieron en las fiestas del poder una pretensión del aparato estatal por "reafirmar las jerarquías sociales" (González, 2013:2) y "(re)fundar un orden social tradicional cimentado en la trilogía de 'Dios, patria y familia"' (González, 2014:145). En la misma línea, cabe recordar que durante el mes de mayo de 1979 el ejército argentino propuso conmemorar el centenario de una de sus "gestas más gloriosas": la conquista del desierto. Como señalan Bisso y Kahan esta fiesta "se inscribió en una narrativa singular que justificaba el accionar de los hombres de armas en la 'guerra interna' para asegurar la organización nacional. Así como durante la 'Campaña del desierto' se había eliminado a un enemigo interno que se negaba a integrarse al Estado nacional, en 1979 el Ejercito volvía a usar las armas contra otro enemigo también situado al interior del propio territorio: la "subversión" (Bisso y Kahan, 2014:22). Evidentemente el período dictatorial no puede ser 
caracterizado de manera homogénea como anti-festivo, sino como un período durante el cual se prohibieron aquellas fiestas que cuestionaban los fundamentos de la estructuración social y se promovieron otras que pudieran reponerlos. Entre estas últimas, la Fiesta Provincial del Inmigrante.

El análisis realizado sobre el origen de la fiesta muestra que la tensión entre recuerdos, olvidos y silencios -inherente a los procesos de construcción social de memorias- emergió de los proyectos de intervención que cada uno de los actores tenían sobre su propio contexto (Jaume, 2000; Jelin, 2002b). Si la construcción de memorias colectivas permite que los actores disputen un conjunto de recursos simbólicos ligados a la estructuración social del presente (Ansaldi, 1996; Montesperelli, 2004; Cattaruzza, 2007), el hecho de instituir un origen mítico de la comunidad en el cual los inmigrantes europeos se volverían sus actores centrales, habilitó un recurso fundamental para que sus descendientes construyan legitimidad y prestigio social apelando al pasado. Por la vía inversa, silenciar los recuerdos que unían a la comunidad con los orígenes del peronismo redujo las posibilidades para que los actores auto-identificados como peronistas disputen, en el contexto represivo de los años 70 , algún grado de legitimidad o prestigio social apelando a dichos recuerdos. Proceso de construcción de memorias oficiales que implicó, en aquellos años, un conjunto de olvidos y silencios voluntarios sobre la historia de la ciudad.

Por otra parte contextualizar el surgimiento de esta fiesta no solo nos permitió describir la dinámica institucional de dicho proceso histórico -mostrando el rol que jugaron los representantes de algunas asociaciones étnicas y la intendencia municipalsino analizar además los sentidos conmemorativos que lo guiaron. Como señaló Halpern (2006) en su investigación sobre el ritual de Caacupé-í realizado por inmigrantes paraguayos, contextualizar el surgimiento de una fiesta no es un gesto trivial de erudición historicista sino el modo de analizar cómo una práctica fue significada en sus propias condiciones de producción y los modos en que es resignificada en el presente. Bajo esta propuesta mostramos cómo la reactuación de tradiciones culturales europeas y el recuerdo de las experiencias traumáticas que atravesaron los inmigrantes se encontraban -en línea con los cambios en los objetivos del asociacionismo étnico- entre los motivos que los sujetos de la celebración indican como fundacionales de la fiesta. Paralelamente analizamos cómo la reactuación de tradiciones culturales europeas y el recuerdo de aquellas experiencias traumáticas se encontraban relacionados con la necesidad institucional de intervenir sobre el presente. Así, el origen de la fiesta no solo se habría correspondido con la posibilidad de estimular el ánimo de una comunidad que atravesaba la crisis terminal de su tejido 
fabril, sino además con la preocupación estatal por olvidar y/o silenciar los recuerdos que unían a Berisso con los orígenes del peronismo. Finalmente, este análisis nos permitió comprender la tensión inherente a los procesos de construcción de memorias: la búsqueda de las asociaciones étnicas por recordar un pasado ligado a la llegada de inmigrantes europeos fue la contracara de la necesidad estatal por silenciar/olvidar un pasado vinculado con los orígenes del peronismo. 


\section{Capítulo $N^{\circ} 4$}

\section{Memoria escrita, sentidos conmemorativos e imaginarios sobre la comunidad. Un análisis de las Gacetillas Oficiales de la Fiesta Provincial del}

Inmigrante

Tomando como corpus de análisis las editoriales publicadas anualmente en la Gacetilla Oficial de la fiesta $(1980-2015)^{105}$, en este capítulo analizamos diacrónicamente los sentidos que los sujetos de la celebración le otorgaron al ritual conmemorativo y los imaginarios (Anderson, 2007) que construyeron sobre la comunidad local (Weber, 1998). Dicho soporte de la memoria escrita (Monkevicius, 2009) no solo conforma un archivo (Nora, 1993) en el cual los sujetos de la celebración dejan depositadas un conjunto de representaciones y sentidos sobre el pasado de la comunidad (Ricoeur, 2007), sino que además constituye un canal (Yerushalmi, 2006) a través del cual trasmitir hacia la esfera pública aquellas representaciones y sentidos durante el período festivo.

En diálogo con lo trabajado en el capítulo anterior, el análisis sobre dichas editoriales pretende mostrar cómo la recordación de un pasado inmigratorio y fabril permite que las asociaciones étnicas locales y la intendencia municipal reconstruyan un imaginario sobre Berisso. En tal sentido, nos interesa preguntarnos qué hechos del pasado son seleccionados y traídos al presente en cada edición de la fiesta y cómo operan esos recuerdos en la construcción de un imaginario sobre la comunidad. Respecto a la organización del capítulo dividimos la exposición en cuatro sub-períodos marcados, fuertemente, por los ciclos políticos de gobierno: $1^{\circ}$ ) dictadura (entre 09/1980 y 09/1983), $2^{\circ}$ ) restablecimiento democrático (entre 09/1984 y 09/1989), $3^{\circ}$ ) los años noventa (entre 09/1990 y 09/2002) y $4^{\circ}$ ) post crisis del año 2001 (09/2003 y 09/2015).

Vale la pena señalar que los representantes de la Asociación de Entidades Extranjeras (AEE) y el intendente municipal son los encargados de producir, fijar y trasmitir anualmente una memoria oficial a través de las editoriales publicadas en la Gacetilla Oficial de la fiesta (Pollak, 1989; Connerton, [1989] 1993; Olick, 2003). Un

\footnotetext{
${ }^{105}$ El período se corresponde con la primera edición de la Gacetilla Oficial de la fiesta (1980) y la que se publicó cuando finalizamos nuestro trabajo de campo (2015). Así, el corpus está compuesto por todas las ediciones de dicha publicación. Agradecemos a Aníbal Guaraglia (Biblioteca del CEYE) y Stella Loholaberry (colectividad española y ex secretaria de la AEE) habernos facilitado algunas de las ediciones más antiguas.
} 
trabajo de la memoria (Jelin, 2002a) que refleja la capacidad de estos actores -las elites dirigentes de ambas instituciones- para monopolizar la producción de textos (Cardona, 1999); fijando y trasmitiendo un conjunto de sentidos sobre el pasado de Berisso. Así, veremos cómo estos emprendedores de la memoria (Jelin, 2002a) reproducen un mito de origen -a ser recordado en contexto festivo- ligado a la llegada de inmigrantes europeos durante el período de entre-siglos (XIX y XX) y la existencia de un extendido sistema fabril. Rememorando este origen mítico la comunidad será imaginada mediante un conjunto de características legadas, a su vez, por los inmigrantes ultramarinos que la habrían forjado. De esta manera el inmigrante será instituido en figura emblemática de la memoria local: héroe, pionero y fundador de la comunidad. Proceso donde se resaltarán algunos rasgos de su accionar histórico y se silenciarán aquellos que puedan ser vistos como negativos. Así, debido a su carácter excepcional, lo realizado por los inmigrantes ultramarinos quedará vinculado al terreno de lo ejemplar y lo memorable, contribuyendo a la elaboración de un pasado mítico que exige adhesión global y acrítica a estas figuras.

Antes de ingresar en el análisis de las editoriales publicadas en la Gacetilla Oficial de la fiesta se vuelve necesario hacer dos breves reflexiones. La primera refiere al lugar que ocupan las fuentes escritas en la producción y el análisis de las memorias. La segunda gira en torno al diálogo que nuestro trabajo plantea respecto a los estudios enfocados en analizar la producción escrita de las asociaciones étnicas en la Argentina.

La construcción de un par oposicional entre historia y memoria -del cual autores como Halbwachs [1925 (2004)] y Nora [1984 (1992)] fueron centrales- produjo el distanciamiento de "sus" fuentes: mientras las fuentes escritas (el archivo) fueron pensadas como constitutivas del análisis historiográfico, las fuentes orales (el testimonio) han sido vinculadas con la producción social de memorias. Para ser más precisos habría que decir que Halbwachs (1990) separaba la memoria histórica de la memoria colectiva. La distancia entre la primera (escrita, aprendida, larga, unificada, objetiva) y la segunda (vivida, oral, corta, plural, subjetiva) no difiere de la oposición que el propio Nora trazó entre historia y memoria:

"lejos de ser sinónimos, tenemos conciencia de lo que les opone. La memoria es la vida, arraigada siempre en grupos vivientes y, por ello, está en evolución permanente, abierta a la dialéctica del recuerdo y de la amnesia, inconsciente de sus deformaciones sucesivas, vulnerable a todas las utilizaciones y manipulaciones, susceptible de prolongadas latencias y de frecuentes revitalizaciones. La historia es 
la reconstrucción siempre problemática e incompleta de lo que ya no existe. La memoria es siempre un fenómeno actual, un vínculo vivido con el presente eterno. La historia es una representación del pasado. La memoria no se acomoda más que a los datos que la confortan, puesto que es afectiva y mágica; se alimenta de recuerdos vagos, telescópicos, globales y flotantes, particulares o simbólicos, y es sensible a todas las transferencias, censuras, pantallas o proyecciones. La historia recurre al análisis y al discurso crítico, puesto que es una operación intelectual y desmitificadora" (Nora, 1992: 20).

Refiriéndose al uso de las fuentes, en la década de 1920 Halbwachs señaló que la necesidad de fijar por escrito "lo que pasó" constituía un prueba evidente de la decadencia de la memoria "verdadera"; signo de un quiebre en la "corriente continua de pensamiento" que le sirve de soporte al grupo que recuerda. Lo cual terminará marcando un comportamiento distintivo al momento de seleccionar los acontecimientos que articulan el caótico acontecer histórico. Este paso de la memoria viva -la que no necesita ser fijada- a la historia escrita es retomado por Nora en la década de 1980, quien concluye que el auge de los lugares de recordación muestra la transformación de la memoria en historia. Así, coincidiendo con Halbwachs, Nora señala que la necesidad de escribir y fijar "lo que pasó" demuestra la imposibilidad de recordarlo de manera directa: ni más ni menos, el debilitamiento del lazo que une los hechos del pasado con el grupo que recuerda. Elementos que tendremos particularmente en cuenta para el análisis de las Gacetillas Oficiales de la fiesta, ya que las mismas fueron elaboradas por sujetos que no vivieron "lo que pasó". Actores que -como mencionamos en la introducción y la primera parte de la tesis- fijan por escrito una memoria heredada, transmitida por sus propios ancestros.

Actualmente aquella oposición entre historia y memoria es criticada por buena parte del campo académico, y la tensión entre ambas pasó a ser la clave analítica a partir de la cual abordar sus relaciones. Logrando, así, que la herencia positivista que fetichizó el documento escrito e identificó el oficio del historiador con el archivo sea mayoritariamente abandonada. Ahora bien, tanto para los historiadores del pasado reciente como para quienes provenimos de otras disciplinas (en particular la sociología) una de las preguntas centrales sobre estos temas sigue siendo qué pasa en la producción social de memorias cuando los actores "se apropian" de una de las fuentes con las que se identificó al trabajo científico. En nuestro caso, qué ocurre cuando el canal escrito se convierte en un medio fundamental para la construcción y trasmisión de la memoria oficial de una comunidad ¿Qué acontecimientos y actores son evocados? ¿Cómo se los recuerda? ¿Con qué características? 
Por otra parte, sobre la producción escrita de las asociaciones étnicas en Argentina, nos interesa señalar que si bien el campo de los estudios migratorios de nuestro país cuenta con numerosas alusiones a los periódicos editados por distintas colectividades, existen pocos trabajos dedicados a la prensa étnica o la cultura impresa (Cibotti, 1994; García Sebastiani, 2004; Misetich, 2006; Dujovne, 2008, 2014), a los libros conmemorativos, registros de celebraciones públicas (Cherjovsky, 2017), las actas (Martino y Martínez, 2013) o los boletines institucionales (Monkevicius, 2005a, 2006c, 2007a) de una determinada colectividad étnica. Respecto a estos antecedentes nuestro trabajo no solo difiere en algunas de las preguntas de investigación que nos hemos realizado, sino además en las fuentes analizadas. Mientras en dichos trabajos el corpus indagado está compuesto por los periódicos, libros conmemorativos, registros de celebraciones, actas y boletines de una colectividad en particular, las Gacetillas Oficiales de la Fiesta Provincial del Inmigrante incluyen un heterogéneo conjunto de textos escritos por las veinte colectividades étnicas que conforman la AEE, las autoridades de esta institución y el intendente de Berisso. Así, salvo en un caso particular, no hemos encontrado antecedentes dentro del campo de los estudios migratorios de la Argentina que analicen un soporte de la memoria que haya sido escrito de manera colectiva entre varias colectividades y el Estado. La excepción a esta regla lo constituye el trabajo que Ballina (2007) hizo sobre el mismo soporte escrito que analizaremos aquí. Sin embargo, a diferencia de nuestro trabajo, no solo la finalización del período de estudio es otro (2003) sino que además su análisis está orientado a comprender “cómo y cuándo (...) lo 'étnico' se ha convertido en el objeto de un discurso estético" (Ballina, 2007:10). Así, el autor no se centra -como haremos nosotros- en las editoriales escritas por los representantes de las asociaciones étnicas y la intendencia municipal, sino en poemas, cuentos breves y relatos autobiográficos que algunos miembros de las distintas asociaciones étnicas publicaron en dichas gacetillas durante el período mencionado.

A continuación analizamos las editoriales publicadas por los representantes de las asociaciones étnicas locales y la intendencia municipal en las Gacetillas Oficiales de la Fiesta Provincial del Inmigrante (Berisso, 1980-2015). Como mencionamos en el apartado dedicado a exponer la Estrategia Metodológica, dicho análisis será realizado siguiendo el tipo de análisis del discurso que Alonso (1998) caracteriza como sociológico: un análisis que lejos de centrarse en las características genéticas, internas, morfológicas, lingüísticas, psicoanalíticas o semióticas del discurso sitúa al texto en relación a su contexto histórico e indica al actor que lo escribe. 


\section{Las editoriales publicadas en las Gacetillas Oficiales de la fiesta}

\subsection{La última dictadura cívico-militar: entre septiembre de 1980 y septiembre de 1983}

Entre finales de los años 70 y principios de los 80 los sujetos de la celebración mencionaban en sus editoriales que la fiesta tenía un doble sentido: "homenajear" a los "inmigrantes ultramarinos" que "forjaron" Berisso en el "periodo de entre-siglos (XIX y XX)" y a la vez, hacer que la comunidad "recuerde" sus "orígenes, costumbres y tradiciones". Al interior de estos motivos conmemorativos los inmigrantes ultramarinos no solo eran indicados como los "héroes que forjaron la comunidad", sino que además eran ligados a un conjunto de valores morales socialmente legitimados: "esfuerzo, sacrificio, trabajo". Por su parte Berisso aparece caracterizada como una comunidad donde la "unión, el progreso y la integración" no solo permitieron que los inmigrantes encontraran "paz y trabajo", sino también que pudieran formar un "hogar", una "familia". Veámoslo en sus propias palabras.

El Intendente municipal manifestaba que

"Esta celebración, detrás de sus características alegres y festivas, esconde un profundo sentido de homenaje a los hombres y mujeres que más allá del parentesco que liga a los ciudadanos de Berisso con algún inmigrante, representa el agradecimiento a quienes con su esfuerzo y trabajo cotidiano forjaron esta ciudad, constituyéndose en los pequeños héroes de una pequeña historia que, sumada a otras, es la historia del país." 106

Por su parte el presidente de la AEE señalaba

"Berisso, firme en su accionar, se ha puesto de pie (...) y abre sus brazos para rendir un brillante, justo y sincero homenaje a aquellos inmigrantes que hace más de 100 años llegaron a orillas de este majestuoso río buscando hogar, paz y trabajo, y con su tesón forjaron la pujante ciudad de Berisso. La Asociación de Entidades Extranjeras y toda la familia berissense (...) se brinda totalmente a cantarles a aquellos pioneros.

Gracias a esa laboriosidad de la comunidad unida, y a las distintas autoridades municipales que bregaron por su engrandecimiento, Berisso se transformó en el paradigma del progreso comunitario y con justicia se la declaró Capital Provincial del Inmigrante en el año 1978 (...) La Asociación de Entidades Extranjeras en esta IV Fiesta del Inmigrante insta a hombres y mujeres que continúen asumiendo con trabajo y con fe, el compromiso de forjar la Gran Nación Argentina, defender su soberanía y con denodado esfuerzo cristalizar la integración y el progreso de la comunidad (...) Berisso 'puerto del mundo', anualmente hace que con esta fiesta se recuerden orígenes, costumbres y tradiciones para celebrar así, todos juntos, un destino común."107

\footnotetext{
${ }^{106}$ Arq. Roberto José Arún, Gacetilla Oficial, 1981. Resaltado nuestro.

107 Dr. Juan Minoian (colectividad armenia), Gacetilla Oficial, 1981. Resaltado nuestro.
} 
La Gacetilla Oficial de la fiesta no solo se vuelve un soporte escrito donde rastrear los sentidos que los sujetos de la celebración le otorgaban al ritual conmemorativo y encontrar los diacríticos identitarios mediante los cuales construían un imaginario sobre Berisso, sino que además refleja la mirada que estos actores tenían sobre su propia coyuntura. A principios de los años 80 , frente al conflicto bélico desatado entre la Argentina y Gran Bretaña, los sujetos de la celebración interpelaban a la comunidad local en términos de una impostergable defensa de la soberanía nacional. Así, y luego de incluir a los inmigrantes llegados a Berisso entre "fines del siglo XIX y principios del actual" como parte de las "corrientes colonizadoras que dieron una imagen característica y especial al grupo étnico berissense", el presidente de la AEE mencionaba:

"El día 2 de Abril, se logra la recuperación de las Islas Malvinas, este acontecimiento retumbó por los cuatro costados cardinales del globo, como el deseo de un pueblo, ansioso de recuperar su soberanía territorial, proyectándose aún con más tesón hacia su verdadera identidad y dimensiones, donde sus Malvinas son parte de su territorio continental. Esto despertó un sentimiento patriótico que estalló en todas las latitudes de la República, mostrando al mundo su posición anticolonial y su firme determinación de no ser avasallada su soberanía nacional. Es así como el 2 de Abril, marca el hito más importante de los últimos tiempos, donde se sella con fuego y sangre la mejor etapa de la identidad de un pueblo, el argentino, frente al colonialismo imperialista. Esta historia palpitante, de los días que nos toca vivir, a pesar de las circunstancias que supuso la guerra como tal, ha sido una enseñanza positiva que nos ha ayudado a proyectarnos como Nación." 108

Lejos de analizar estos textos desde una óptica moralizante (haciendo una lectura desde el presente que juzgue la ética de los actores) o realizar un anacronismo que proyecte en el pasado un conjunto de categorías de interpretación elaboradas en nuestra contemporaneidad (Rousso, 2007), nos parece necesario señalar la valoración que el presidente de la AEE hacía sobre el conflicto bélico: según sus propias palabras la Guerra de Malvinas había dejado una "enseñanza positiva" y permitido "sellar la mejor etapa de la identidad del pueblo argentino". Es importante recordar el poder comunalizador que según Weber (1998) poseen los conflictos bélicos: este proceso no solo se produce al interior del grupo que está en combate, sino que es activado por el líder carismático para crear comunidad entre quienes no se encuentran en el campo de batalla ${ }^{109}$.

\footnotetext{
108 Dr. Juan Minoian (colectividad armenia), Gacetilla Oficial, 1982. Resaltado nuestro.

109 Para un análisis del modo en que Weber analiza el vínculo entre comunidad y guerra, ver de Marinis (2010b)
} 
Cerrado el conflicto bélico la fiesta permitió que el presidente de la AEE vuelva a mirar -desde ella- la coyuntura nacional y hacer un llamamiento a la comunidad local:

"quizás estemos en las circunstancias más difíciles de la historia del País por su situación política y económica. En estos momentos difíciles, Berisso no se amedrenta y celebra la $6^{a}$ Fiesta del Inmigrante, rindiendo homenaje a aquellos hombres y mujeres que ofrendaron su sacrificio y desvelo a esta Patria, rica y generosa que los cobijó y les brindó paz y trabajo". ${ }^{110}$

El sacrificio -en tanto categoría moral- forma parte de los elementos simbólicos con los cuales se construye un imaginario sobre la comunidad (local y nacional). Aquel sacrificio "ofrendado por los inmigrantes que forjaron Berisso" es homologado al sacrificio que hizo el pueblo argentino, "a fuerza de fuego y sangre", para defender su soberanía nacional. Una comunidad berissense que a su vez era presentada en términos parentales: a través de la producción de un parentesco ficticio (Barfield, 2000) Berisso es imaginada como una "familia" cuyo vínculo consanguíneo o afinal "liga a todos los ciudadanos con algún inmigrante" (veremos la utilización reiterada de este recurso en el capítulo $N^{\circ} 5$, donde profundizaremos el análisis sobre la construcción de parentescos ficticios en contexto festivo).

Asimismo la historia de la comunidad berissense es presentada como ejemplo y síntesis de la historia nacional. En esta línea notamos una doble adscripción nacional: si inicialmente la adscripción se referencia con el país de origen de los inmigrantes, progresivamente pierde fuerza frente a la adscripción con el país receptor. La Patria, ahora, es la Argentina. Así, la comunalización (Weber, 1998) en torno al origen extranjero cede su lugar frente a una comunalización como "argentinos". Finalmente cabría pensar que el recuerdo del "hito más importante de los últimos años" (la guerra) y las "dificultades políticas y económicas" del momento podrían estar indicando -en su reverso- un conjunto de silencios sobre un período de la historia nacional durante el cual el Dr. Juan Minoian -presidente de la AEE- fue funcionario público (ver capítulo № $3)$.

${ }^{110}$ Dr. Juan Minoian (colectividad armenia), Gacetilla Oficial, 1983. Resaltado nuestro. 


\title{
1.2. El restablecimiento democrático: entre septiembre de 1984 y septiembre de 1989
}

Respecto al por qué se realizaba la fiesta, los sujetos de la celebración reiteraban durante los años 80 los motivos expuestos durante el período anterior. En sus editoriales señalaban que ella se hacía, en primer lugar, para "homenajear" y "recordar" a los inmigrantes que "llegaron a Berisso entre fines del siglo XIX y principios del XX" y, en segundo lugar, para que la "comunidad rememore" sus tradiciones y costumbres "trayendo a la memoria su propio origen". Dentro de estos motivos conmemorativos los inmigrantes seguían siendo presentados como los "pioneros" que, con el "silencio" y "esfuerzo" de su "sangre" "engrandecieron" a Berisso. Ciudad caracterizada como una comunidad "unida", portadora de una "herencia milenaria", que "respeta a sus ancestros", "cuna de amor, trabajo y paz", un lugar donde la "convivencia fraterna" entre todas las "razas" es posible.

Según el intendente municipal la fiesta se realizaba para "homenajear y recordar a todos aquellos que engrandecieron este suelo y sembraron los caminos de nuestra ciudad con el silencio y el esfuerzo de su sangre, aportando a la materialización del SER ARGENTINO”. En sus editoriales señaló además que Berisso no solo poseía "la grandeza de los pueblos que respetan a sus ancestros" sino que esta comunidad "ha sido capaz de demostrar que la convivencia fraterna entre las razas es posible." 111

Por su parte el presidente de la AEE manifestó que

\begin{abstract}
"Berisso fue adquiriendo una imagen característica y especial aportada por las corrientes colonizadoras de fines del siglo XIX y principios del presente; el grupo étnico se fue forjando y conformando el ser berissense, del que podemos decir con orgullo que es digno ejemplo dentro de la comunidad de nuestra patria. (...) Esta fiesta rememora tradiciones y costumbres y se rinde, así, un homenaje a los pioneros que poblaron esta tierra, a la que ofrendaron sus sacrificios y desvelos, forjando una comunidad que lucha permanentemente por su grandeza y embellecimiento. ${ }^{112}$

"Con esta fiesta magna traemos nuevamente a la memoria los orígenes, costumbres y tradiciones de aquellos antepasados nuestros que se asentaron en Berisso; y celebramos juntos un destino común." ${ }^{113}$
\end{abstract}

Pero además, y al igual que en el período anterior, la Gacetilla Oficial se vuelve el lugar donde los sujetos de la celebración vinculaban los motivos conmemorativos y los

\footnotetext{
111 Ing Carlos Nazar, Gacetilla Oficial de la fiesta, 1984, 1985 y 1986 respectivamente. Resaltado nuestro.

112 Dr. Juan Minoian (colectividad armenia), Gacetilla Oficial, 1984. Resaltado nuestro.

113 Dr. Juan Minoian (colectividad armenia), Gacetilla Oficial, 1986. Resaltado nuestro.
} 
imaginarios sobre Berisso con una lectura del presente. Posiblemente en referencia a los alzamientos carapintadas del año 1987 y los juicios que se les hicieron al año siguiente, el intendente municipal manifestó su seguridad respecto a que "ante las horas adversas que le toca vivir a nuestra patria" los berissenses iban a demostrar -durante la fiesta- ser "una comunidad con herencia milenaria." ${ }^{114}$ En esta misma línea, donde los motivos conmemorativos y los imaginarios locales se cruzan con una mirada sobre el presente, el presidente de la AEE señaló:

\begin{abstract}
"El país está atravesando por una difícil situación económica; difícil para gobernante u gobernado, y Berisso dentro de ese parámetro de dificultades, transita una situación dramática agravada por la desaparición de tradicionales fuentes de trabajo (...) A pesar de ello, sostenemos que esta situación abre un paréntesis y estimula al ser berissense a movilizarse, con la esperanza en el gobierno constitucional que dará, con seguridad, prioridad, aportando el grano de arena para que nuevamente se alcen las cortinas de los comercios e industrias. Berisso necesita nuevas fuentes de trabajo y su excepcional comunidad lucha por no morir (...) A pesar de la crisis nuestra comunidad jamás bajó ni bajará la guardia; el pueblo se mantiene estoicamente con la esperanza, fe y el temple de sus antecesores para poder sobrellevar este temporal que destruyó las fuentes de trabajo. ${ }^{115}$
\end{abstract}

Hoy, que contamos con un gobierno constitucional, la AEE exhorta -como siempre, y más que nunca- a todos los hombres y mujeres a continuar con fe, uniéndose en el trabajo y la paz, para que esta nación siga siendo la tierra de promisión que iluminó la senda de nuestros mayores y se constituya así en el núcleo de ideas que nos encamine a la integración total y definitiva del ser argentino. Berisso es cuna de amor, trabajo y paz; unidos haremos que crezca, engrandeciendo al mismo tiempo la nación argentina." 116

El contexto festivo habilitaba un espacio donde el recuerdo de las cualidades morales de los inmigrantes se imbricaba con una lectura de las dificultades económicas del presente y las esperanzas políticas abiertas por la democracia. A fines de los años 80 Berisso era presentada como una comunidad que luchaba por no morir a causa del desempleo, donde el recuerdo del "sacrificio" legado por quienes "forjaron" la ciudad permitía enfrentar el cierre de sus comercios e industrias. El trabajo (o mejor dicho, su ausencia, su pérdida, su destrucción) aparece en estos textos como categoría capaz de nuclear un diagnóstico sobre el presente. Esta lectura sobre el contexto laboral local era, nuevamente, presentada en clave nacional: así como en el período anterior la historia inmigratoria de Berisso era ejemplo de la historia nacional, ahora las esperanzas sobre la realidad laboral de la ciudad eran enmarcadas dentro de la escala nacional. Finalmente cabe señalar que ante las dificultades laborales del

\footnotetext{
${ }^{114}$ Dr. Juan Enrique Nadeff, Gacetilla Oficial, 1988.

115 Dr. Juan Minoian (colectividad armenia), Gacetilla Oficial, 1984. Resaltado nuestro.

${ }^{116}$ Dr. Juan Minoian (colectividad armenia), Gacetilla Oficial, 1986. Resaltado nuestro.
} 
presente, la adscripción étnica pareciera debilitarse frente a la adscripción de clase: una adscripción local en tanto pueblo obrero y trabajador.

\subsection{Los años 90: entre septiembre de 1990 y septiembre del 2002}

Dos décadas después de haber tenido su primera edición, la fiesta continuaba siendo caracterizada por los sujetos de la celebración como un momento en el cual la comunidad berissense rinde "homenaje" y "recuerda" a los inmigrantes que la "forjaron", un espacio donde sus descendientes trabajaban en "pos de la memoria" local, para que la comunidad no "olvide sus orígenes" y se "reúna" para "mantener vivas sus raíces". Dentro de estos motivos conmemorativos los inmigrantes seguían siendo caracterizados como aquellos "pioneros" que construyeron "las bases" de la sociedad berissense; portadores de un conjunto de cualidades morales ("luchadores, tolerantes, solidarios", etc.). Finalmente Berisso comenzaría a ser caracterizada como un "colorido crisol de razas", un "símbolo de paz, trabajo y esperanza".

Uno de los intendentes municipales de este período señaló que, con la fiesta

"Rendimos homenaje a los pioneros de esta tierra. Con una nueva esperanza de futuro mejor para nuestros hijos y el deseo de que aquel colorido y laborioso Berisso que vieron los ojos de nuestros abuelos, sea otra vez realidad." ${ }^{117}$

Otro de ellos indicó que los inmigrantes,

"pese a las diferencias culturales lograron entrelazarse, armonizando un rico crisol de razas: en cada mes de septiembre, los hijos, nietos y ahora también bisnietos de aquellos inmigrantes, los recuerdan (...) Esos verdaderos luchadores fueron los forjadores y pujantes pioneros de este querido Berisso, que se constituyó en un símbolo de paz, trabajo y esperanza."118

Y finalmente, quien lo sucedió en el cargo, manifestó que

"Sin aquellos esfuerzos compartidos, esta historia no podríamos escribirla. Sé que consolidaron las bases de este querido Berisso, lo hicieron con mucho esfuerzo y con verdadero compromiso, por eso continuar con esta Fiesta es contribuir y mantener vivas nuestras raíces." 119

\footnotetext{
117 Dr. Juan E. Nadef, Gacetilla Oficial, 1991. Resaltado nuestro.

${ }^{118}$ Eugenio Juzwa, Gacetilla Oficial, 1995. Resaltado nuestro.

${ }^{119}$ Néstor Daniel Juzwa, Gacetilla Oficial, 2001. Resaltado nuestro.
} 
Así, según estos actores, cada edición de la fiesta permitía que la comunidad berissense se "reúna" ${ }^{20}$ para reafirmar el

"el espíritu y los valores que le dieron origen: la tolerancia frente a lo diferente, el tesón frente a las adversidades, el sentido de la cooperación como la única vía posible para crecer y, por sobre todas las cosas, el valor de la solidaridad que permitió darle fisonomía a esta hermosa ciudad de Berisso." 121

Por su parte, tres de los presidente que tuvo la AEE durante este período señalaron que con la fiesta

"no sólo se recuerdan costumbres e imágenes, sino que se rinde tributo a aquellos inmigrantes que forjaron nuestra ciudad." ${ }^{22}$

"se homenajea a los inmigrantes que atravesaron los mares hacia la desconocida América." ${ }^{\prime 23}$

Siendo sus descendientes quienes no hacen otra cosa que

"trabajar en pos de la memoria de sus padres, sus abuelos, y por el futuro de nuestros hijos, para que no olviden nunca sus orígenes, sus verdaderas raíces." 24

Al igual que en los períodos anteriores encontramos publicados en la Gacetilla Oficial un conjunto de testimonios donde los sujetos de la celebración vinculan los motivos conmemorativos y los imaginarios sobre Berisso con una lectura sobre el presente. Siendo tal vez uno de los más significativos que pudimos encontrar, la Gacetilla del año 2002 incluyó un extenso texto de Luis Alfredo Guruciaga (historiador y escritor nacido en Berisso, fundador del "Museo 1871" y "Ciudadano llustre" de la ciudad). Pese a que él mismo no sea parte de los sujetos de la celebración aquí analizados, entendemos que al ser publicado en la Gacetilla Oficial su texto contó con el apoyo (tal vez no unánime) de ellos. Luego de hacer un breve recorrido por la historia inmigratoria de Berisso, Guruciaga presentó una mirada crítica y desesperanzada sobre el contexto que atravesaba el país:

"Hoy Argentina se parece a cualquiera de aquellos países que nuestros abuelos inmigrantes debieron dejar. La falta de trabajo, la inseguridad y hasta el peligro de una guerra peor a la que aquellos debieron sufrir (porque sería entre nosotros mismos) nos lleva a recorrer embajadas y buscar nuestras raíces europeas que nos acredite una nacionalidad que casi habíamos despreciado

\footnotetext{
120 Néstor Daniel Juzwa, Gacetilla Oficial, 2001. Resaltado nuestro.

${ }^{121}$ Néstor Daniel Juzwa, Gacetilla Oficial, 1997. Resaltado nuestro.

122 Dr. Juan Minoian (colectividad armenia) Gacetilla Oficial, 1995. Resaltado nuestro.

123 Jorge Santiago Mc Govern (colectividad irlandesa), Gacetilla Oficial, 2000. Resaltado nuestro.

124 Héctor Kavaliunas (colectividad lituana), Gacetilla Oficial, 2002. Resaltado nuestro.
} 
(...) Hoy seguramente estaremos en mejores condiciones para entender el enorme valor de aquellos inmigrantes y lo triste de nuestra situación. La involución política argentina nos llevó a esto." 125

La apelación al pasado inmigratorio de la Argentina y el recuerdo de las causas que motorizaron dicho proceso (desempleo, inseguridad, guerras) constituye un elemento central a partir del cual Guruciaga construyó su lectura sobre el presente. En ella resalta la indicación del continente europeo como única referencia originaria a la que los argentinos habrían ido a buscar (entre otras cosas) sus raíces. Finalmente evidenciamos un cambio en la significación de aquel origen aglutinador: de motivo de vergüenza y desprecio, Europa pasa a ser recuperado como lugar deseado por motivos económicos.

\subsection{Post crisis del año 2001: entre septiembre del 2003 y septiembre del 2015}

Luego de la crisis social, política y económica que atravesó el país entre 2001 y 2002 encontramos que los sujetos de la celebración continuaban reiterando los motivos conmemorativos indicados en los períodos anteriores, como así también los elementos centrales con los que construían un imaginario sobre Berisso. En sus editoriales mencionaban que la fiesta se realizaba para "recordar" a los inmigrantes, "rememorar" sus sueños y "homenajearlos". Fiesta caracterizada como un espacio en el cual sus descendientes lograban demostrar que "siguen vivas las raíces" y "representan la identidad local". De esta manera la fiesta era vista como una instancia que no solo permitía "celebrar la historia de la comunidad y el país" sino que además lograba "unir" a los berissenses y mostrar su "esencia".

Al interior de estos motivos conmemorativos -como hemos señalado anteriormente- los inmigrantes continuaban siendo caracterizados como los "pioneros" que "forjaron" la ciudad de Berisso, actores que al "privilegiar el bien común por sobre cualquier diferencia e interés individual" crearon "las bases de la sociedad". Ligado al aporte que aquellos inmigrantes (llegados a las "costas" berissenses "entre principios del siglo XX y mediados de los años 50") la ciudad era caracterizada como una comunidad "generosa, solidaria, tolerante"; con capacidad de "lucha, trabajo y desarrollo"; un "armónico crisol de razas, una babel de paz, un mosaico multicultural"; una "síntesis de la Argentina".

${ }^{125}$ Guruciaga, L., Gacetilla Oficial, 2002. Resaltado nuestro. 
A lo largo de todo este período el intendente de Berisso señaló que en la fiesta

"la comunidad berissense celebra su historia, rinde tributo, homenajea y rememora el sueño de aquellos inmigrantes que sin olvidar jamás sus raíces encontraron en nuestra ciudad un espacio propicio para formar sus familias, para criar a sus hijos, verlos crecer y desarrollarse en un suelo que los cobijó (...) En ese contexto, la solidaridad y la convivencia se alzaron como una de las banderas primordiales de esos inmigrantes que siempre pusieron el bien común por sobre el individual, inclusive por sobre las diferencias idiomáticas, políticas o culturales (...) El empedrado de la calle Nueva York, las ruinas del Swift, el Puerto hecho a pala por manos inmigrantes y hasta el nombre de nuestras calles, son vívidos testimonios de una ciudad que supo levantarse como una babel de paz, tolerancia y esperanza. (...)

Fueron los sueños de aquellos pioneros los que motivaron a esos hijos y nietos a mantener vivas las raíces y la identidad cultural de cada uno de los pueblos que constituyeron a Berisso en un rico y armonioso crisol de razas (...) En muy pocos lugares se ha dado este fenómeno que tanto nos caracteriza y distingue: hemos sido capaces de mantener, generación tras generación, ese legado original de costumbres y tradiciones llegadas desde rincones tan lejanos, que al entremezclarse conformaron un particular mosaico en el cual se refleja nuestra esencia e identidad (...) Sin dudas la tolerancia y convivencia armónica de la vida cotidiana berissense, son parte de esa herencia que nos dejaron aquellos pioneros que venían desde distintos puntos del mundo y cada colectividad ha resguardado ente el paso del tiempo (...) Y es esa identidad, nuestra memoria, nuestra historia, la que desde esta gestión de gobierno pretendemos preservar y consolidar". ${ }^{126}$

Por su parte los presidentes de la AEE señalaron que

"el esfuerzo mancomunado de toda la comunidad hace posible que podamos renovar el homenaje permanente a aquellos pioneros que, sin olvidar jamás sus países de origen, adoptaron a Berisso, tierra de trabajo y esperanza, como su lugar en el mundo (...) En esta fiesta reinará la auténtica síntesis de lo que somos los berissenses, un auténtico crisol de razas, construido por nuestros mayores en paz y armonía." 127

\section{En este marco la fiesta era presentada como una instancia que}

"une a los berissenses y nos permite representar durante el mes de septiembre nuestra identidad local (...). A través de la fiesta se demuestra que sigue viva la llama de nuestras raíces. (...) Berisso conjuga la síntesis de la Argentina, con oleadas migratorias que llegaron desde principios del siglo XX hasta mediados del '50 (...) Todos ellos llegaron a nuestras costas en busca de esperanza y contención. Se integraron a través de una férrea cultura del trabajo en una comunidad que los recibió con generosidad. Fueron aquellos que circularon con sus guardapolvos blancos por los pasillos del Swift y del Armour, los que ocuparon las viejas casonas de la calle Nueva York con sus bares, comercios y restaurantes. Son los que encendieron esa

\footnotetext{
${ }^{126}$ Enrique Slezack, Gacetilla Oficial, extractos correspondientes a los años 2004, 2006, 2007, 2010, 2011 y 2013 y 2015 . Resaltado nuestro.

127 Jorge Pagano (colectividad italiana), Gacetilla Oficial, 2004. Resaltado nuestro.
} 
llama de amor a nuestras raíces y el amor a este Berisso que les abrió su alma brindándoles un lugar donde vivir, trabajar, progresar y formar una familia." 128

Así, la fiesta permitía

"recordar y apreciar las enseñanzas que nos trajeron nuestros inmigrantes, de todas las colectividades, donde con el amor puesto en la familia, crearon las bases de nuestra sociedad (...) Una Fiesta esperada por nuestro pueblo berissense y por todos los que deseamos honrar con trabajo a los que nos dieron la vida y nos pusieron en este maravilloso país. Quiera Dios, que entre todos podamos demostrar a través de la música, las danzas tradicionales y las comidas típicas, la alegría y el orgullo que sentimos de ser hijos o nietos de inmigrantes. $Y$ a todos los que están en el cielo, nos miren con orgullo de ser un grupo de argentinos que festejamos con ellos, llevando sus trajes típicos, saludando a nuestra gente, y compartiendo con todos los miles de visitantes las tradiciones que nos enseñaron." 129

\section{A su vez indicaron que en la fiesta se}

"celebra y revive la inmigración de nuestros ancestros, quienes desde distintos lugares arribaron a esta hermosa ciudad, en búsqueda de cobijo y progreso. A partir de allí, las familias comenzaron una nueva vida en la que luego de insertarse laboralmente, principalmente en los recordados frigoríficos Swift y Armour, criaron y educaron a sus hijos y sembraron el espíritu que, aún hoy, mantiene viva la Fiesta. (...) Como escenario multicultural es la demostración, sin importar el paso del tiempo, que sigue intacta la capacidad de lucha, desarrollo y crecimiento y la llama de la historia que renace todos los años. La Fiesta es la demostración de que el pueblo de Berisso conserva y transfiere la esencia que nos define y que representa, y honra el esfuerzo de quienes nos vieron nacer y nos indicaron un camino de prosperidad y esperanza." ${ }^{30}$

Por último, volvemos a encontrar en la Gacetilla Oficial un conjunto de testimonios en los cuales los sujetos de la celebración vinculaban los motivos conmemorativos y los imaginarios sobre Berisso con una lectura sobre el presente. Siendo tal vez quién expuso de manera más clara y condensada esta relación, el intendente municipal señaló en 2013 que a lo largo de su historia Berisso se había visto atravesada

"por momentos de pujanza y por otros que nos golpearon duramente. Pero nunca bajamos los brazos y hoy podemos decir con convicción, que estamos recuperando ese brillo de antaño. Despertamos y crecimos al calor de una década [en alusión a los años del kirchnerismo] que nos devolvió la capacidad de soñar y los motivos por los cuales ser visitados, conocidos y reconocidos. Hoy visualizamos un próspero presente y un futuro prometedor, en el que después de casi un siglo y medio de

\footnotetext{
128 Gerardo Apcarian (colectividad armenia), Gacetilla Oficial, 2012. Resaltado nuestro.

129 Rosana Bajcic (colectividad croata), Gacetilla Oficial, 2013. Resaltado nuestro.

130 Luis Molina, (colectividad irlandesa), Gacetilla Oficial, 2014. Resaltado nuestro.
} 
existencia, volvemos nuestra mirada hacia el rio [en referencia a las obras que se realizaban en la Terminal de Contenedores del Puerto]."131

El recuerdo del rio y el puerto (lugares sumamente significativos para narrar un origen ligado a la inmigración ultramarina) le permitieron al intendente construir una lectura sobre la reactivación económica del presente. Dichos espacios sociales fueron señalados durante este período como la fuente de la cual renacía el trabajo perdido por el cierre de los frigoríficos: luego de varias décadas donde la comunidad fuera narrada desde la ausencia de trabajo, en el presente volvía a ser imaginada como un lugar de prosperidad y desarrollo.

\section{Reflexiones finales}

Dentro de las culturas gráficas en las cuales aún vivimos, los documentos escritos ocupan un lugar de suma importancia para el análisis sociológico. Al ser parte constitutiva de la sociedad en la cual nuestros sujetos de estudio desarrollan sus prácticas, los documentos que ellos producen constituyen un recurso analítico e interpretativo que los cientistas sociales no debemos ignorar (Hammersley y Atkinson, 1994). El análisis de las editoriales publicadas en las Gacetillas Oficiales de la fiesta nos permitió indagar cómo los sujetos de la celebración seleccionan, fijan y trasmiten mediante la escritura aquello que debe ser recordado en cada edición de la fiesta. Ante la dificultad creciente de recordar de manera directa -ya que las personas que participan de ella no transitaron por la experiencia migratoria ni trabajaron en la industria frigorífica- los sujetos de la celebración construyen una memoria sobre "lo que debe ser rememorado" en el ritual conmemorativo. Proceso que refleja la capacidad de dichos actores institucionales -sus elites dirigentes- para monopolizar la producción de textos (Cardona, 1999) y reafirmar los límites del grupo que recuerda en torno a la versión oficial de su propio pasado (Monkevicius, 2009).

Por otra parte el análisis realizado nos permitió mostrar los sentidos que los sujetos de la celebración le otorgaron al ritual conmemorativo a lo largo del tiempo, señalar los diacríticos identitarios a través de los cuales reconstruyeron un imaginario sobre la comunidad local y exponer el modo en que ambos aparecían interviniendo en una mirada sobre el presente. Respecto a los sentidos otorgados a la fiesta, ellos giraron -de manera recurrente- en torno al recuerdo de un origen ligado con la llegada

${ }^{131}$ Enrique Slezack, en Gacetilla Oficial, 2013. Resaltado nuestro. 
de inmigrantes europeos durante el período de entre-siglos. A su vez la posibilidad de "rememorar los sueños" de aquellos inmigrantes y "mantener vivas" sus "raíces culturales" a lo largo del tiempo, estuvo vinculada a la necesidad de "recordar el pasado" de una comunidad de origen inmigratorio y fabril. Como vimos en las editoriales escritas por estos actores, la fiesta es significada como una instancia donde la sociedad berissense -en su conjunto, de manera homogénea y sin fisuras- "recuerda y rememora su origen inmigratorio, repone su historia y muestra una herencia que marca su esencia e identidad". Según los sujetos de la celebración, la fiesta permite que "la comunidad se (re)una, conserve y trasmita un bagaje cultural milenario, reviva sus raíces y rinda homenaje a los inmigrantes ultramarinos que -olvidando sus diferencias- forjaron Berisso".

Respecto al imaginario construido sobre la comunidad local es importante mencionar que ella es caracterizada a partir de la "convivencia pacífica, la aceptación de las diferencias, la tolerancia, la contención, la esperanza, el amor, el respeto, la solidaridad, el trabajo, el sacrificio, etc.". Idénticos elementos con los que se caracteriza a los inmigrantes ultramarinos que la forjaron. En ese marco la comunidad es muchas veces presentada -de manera contradictoria- mediante las metáforas del crisol y el mosaico. Dos imágenes que portan (en términos tipológicos) concepciones opuestas respecto al proceso de integración de los inmigrantes a la sociedad argentina. Como expusimos en el primer capítulo, mientras la primera concepción supone un proceso de integración exitoso y no conflictivo en el cual la fusión de distintas "razas" habría conformado un nuevo y homogéneo "ser nacional"; la segunda concepción supone la existencia de un heterogéneo pluralismo cultural conformado por la sumatoria (no siempre armónica) de distintos grupos étnicos (Devoto y Otero, 2003; Devoto, 2009; De Cristóforis, 2016).

A su vez, al instituir un origen donde los inmigrantes ultramarinos aparecen como "pioneros" y "forjadores" de la comunidad, la conmemoración de aquel origen permite que sus descendientes -verdaderos "herederos de una tradición que se lleva en la sangre"- construyan legitimidad, reconocimiento y prestigio social en el presente (Palermo, 2007; Palleiro, 2011; Freidenberg, 2013). El uso reiterado del posesivo "nuestros padres/ancestros" y el señalamiento respecto de que ellos habrían "creado las bases de nuestra sociedad" no solo ponen a estos actores en el centro del relato fundacional sino que reconstruye un límite (de pertenencia) frente a quienes no poseerían algún vínculo genealógico con ellos. De esta manera, la apelación al lazo sanguíneo que une a los inmigrantes y sus descendientes se vuelve un elemento sintomático del límite entre quienes serían (y quienes no) los verdaderos herederos de 
la memoria y la cultura que define "la esencia" de los berissenses. Volviendo a la memoria una "arena para la confrontación de estrategias de legitimación" social en el presente (Montesperelli, 2004: 7). En tal sentido, cabe mencionar que las Gacetillas Oficiales exhiben una clara superposición de temporalidades en la construcción social de memorias (Jelin, 2017). Dicho en términos metodológicos, evidencian la superposición de una memoria larga y una memoria corta (Da Silva Catela, 2007). Situación que termina reconstruyendo supuestas continuidades históricas allí donde priman las rupturas impuestas por cada coyuntura: una memoria larga (sobre la inmigración de entre siglos que creó las bases de la sociedad local) y una memoria corta (sobre los hechos del pasado reciente que la fueron afectando).

Por otra parte cabe mencionar que los sujetos de la celebración reproducen el relato mítico del crisol de razas apelando a elementos que esencializan y biologizan relaciones históricamente cambiantes. En sus textos la metáfora botánica sobre las "raíces europeas sembradas en suelo argentino" se vuelve una herramienta retórica utilizada recurrentemente para reconstruir una identificación colectiva que distingue a la sociedad berissense. Como señaló Alonso (1994) la afirmación de una cultura originaria vía la utilización de metáforas biológicas es uno de los recursos más utilizado por las ideologías nacionalistas con el objetivo de crear identidad entre el pueblo, la herencia, el territorio y el Estado. De esta manera los sujetos de la celebración ponen en escena un conjunto de significaciones ligadas a aquel ideario nacional -creado por las élites intelectuales y gobernantes del siglo XIX (ver capítulo №1)- que concibieron a la nación como una entidad homogénea y armónica conformada por flujos migratorios provenientes desde Europa. Dicho ideario excluye otras diversidades o especificidades étnicas que, aunque presentes a nivel local (ver capítulo $\mathrm{N}^{\circ} 2$ ), quedan completamente invisibilizadas por la utopía del crisol de razas.

Finalmente, una breve reflexión merece el modo en que estos actores miran el presente (y lógicamente, se representan el futuro) a través del pasado. En un texto de enorme riqueza, Geertz señalaba que con "su mito explicativo los balineses no buscan en el pasado las causas del presente, sino que buscan más bien la norma para juzgar el presente, buscan el modelo inmutable por el cual el presente debería modelarse pero que por accidente, ignorancia, indisciplina o descuido dejó de seguirse con tanta frecuencia" (Geertz, 2006d: 279). A lo largo del capítulo vimos cómo, en cada etapa histórica, las Gacetillas Oficiales de la fiesta se vuelven un lugar en el cual los sujetos de la celebración usan el pasado para leer el presente. En algunas ocasiones la lectura del pasado permitía mirar el presente de manera esperanzadora. Sin embargo, 
en muchas otras, ese pasado aparecía como una edad de oro a partir de la cual el presente es evaluado de manera desesperanzadora.

Así, este soporte de la memoria escrita fue fundamental para comprender cómo el recuerdo de un pasado inmigratorio e industrial -significando un tiempo social fundacional- forma parte de los elementos del pasado a través de los cuales los sujetos de la celebración reconstruyen un imaginario (Anderson, 2007) sobre la comunidad (Weber, 1998). Proceso que no se da en el vacío sino justamente en contexto festivo: es la conmemoración (en tanto forma ritual de una relación social que utiliza el pasado como respuesta a los problemas del presente) donde 10 conmemorado (los acontecimientos del pasado que la memoria busca restituir en el presente) permite que dichos actores institucionales reconstruyan anualmente dicho imaginario social.

Si en este capítulo hicimos foco sobre uno de los soportes escritos de la memoria local, en el capítulo siguiente describimos y analizamos etnográficamente los cinco actos que articularon la Fiesta Provincial del Inmigrante entre los años 2010 y 2015. Allí nos focalizaremos en las prácticas y discursos orales a través de los cuales los descendientes de inmigrantes ultramarinos reunidos en las asociaciones étnicas locales y los representantes de la intendencia municipal, traen el pasado al presente. Reconstruyendo, así, un imaginario tan armónico como acrisolado y peronista. 


\section{Capítulo $\mathbf{N}^{\circ} 5$ \\ La Fiesta Provincial del Inmigrante (2010-2015): la reconstrucción de un imaginario armónico, acrisolado y peronista}

"Cuando decimos que un pueblo 'recuerda', en realidad decimos primero que un pasado fue activamente
trasmitido a las generaciones contemporáneas (...) y que después ese pasado trasmitido se recibió como
cargado de un sentido propio" cargado de un sentido propio"
Yerushalmi (2006)

En este capítulo describimos las prácticas y discursos orales a través de los cuales los descendientes de inmigrantes ultramarinos reunidos en las asociaciones étnicas locales que conforman la Asociación de Entidades Extrajeras (AEE) y los representantes de la intendencia municipal reconstruyeron un imaginario sobre Berisso en la Fiesta Provincial del Inmigrante (2010-2015). En diálogo con las características del ritual conmemorativo mencionadas en el Marco Teórico, mostramos el modo en que estos actores apelan a un conjunto de hechos del pasado para representar los orígenes étnicos/políticos de la comunidad berissense y construir un imaginario que los sitúa en el centro de su historia. Así, nos interesará resaltar la existencia de prácticas tendientes a la reproducción de los elementos simbólicos de la estructuración social, poniendo en primer plano la capacidad ordenadora que posee el uso de la memoria oficial en contexto festivo (Pollak, 1989; Connerton, [1989] 1993; Olick, 2003).

Para alcanzar este objetivo, durante el período 2010-2015 llevamos a cabo nuestro trabajo de campo en la Fiesta Provincial del Inmigrante. Allí analizamos etnográficamente los cinco actos de la fiesta (secuencia de acciones ordenadas y recurrentes en el tiempo) en los cuales los descendientes de inmigrantes ultramarinos reunidos en las asociaciones étnicas locales y los representantes de la intendencia municipal (sujetos de la celebración) repusieron un imaginario tan armónico como acrisolado y peronista. Utilizando esta fuente primaria de información, mostraremos cómo la selección y apelación a un conjunto de hechos del pasado les permite dramatizar el pretendido origen ultramarino de una comunidad que, a su vez, habría dado origen al peronismo (significando un tiempo social originario y dramatizando dichas significaciones). La trasmisión pública de estos recuerdos (volviendo al contexto festivo una estructura de comunicación) nos permitirá comprender cómo dichos actores reconstruyen una identificación colectiva que no solo vincula a los miembros de la comunidad sino que además se volverá central en la construcción de 
su propia legitimidad. Así, el ritual conmemorativo se constituye en un soporte fundamental en el cual los sujetos de la celebración reponen anualmente la versión oficial de la memoria local ${ }^{132}$.

Para comprender la actualidad de la fiesta -luego de haber narrado en el capítulo № 3 el proceso que llevó a su creación en el año 1978- es importante tener en cuenta que a aquellas asociaciones que organizaron las primeras ediciones y fundaron la $A E E$, se les han ido sumando progresivamente otras nueve: el Club Germano Argentino, la Asociación Ucraniana de Cultura "Prosvita", la Colectividad Croata (bajo el nombre de Asociación Raíces Istrianas La Plata, Berisso y Ensenada), la Colectividad Griega (bajo el nombre de Colectividad Helénica y Platón de Socorros Mutuos de La Plata, Berisso y Ensenada), la Colectividad Eslovena de Berisso, La Plata y Ensenada, la Colectividad Portuguesa Virgen de Fátima, la Colectividad Irlandesa San Patricio de La Plata, Berisso y Ensenada, la Asociación Caboverdeana de Ensenada y la Colectividad Israelita de La Plata, Berisso y Ensenada. ${ }^{133}$

De esta manera las veinte asociaciones étnico-nacionales que actualmente conforman la AEE y participan de la fiesta representan a las colectividades armenia, árabe, albanesa, búlgara, lituana, griega, ucraniana, italiana, yugoslava, portuguesa, eslovaca, irlandesa, polaca, alemana, eslovena, croata, bielorrusa, española, caboverdeana e israelita. Como vemos, salvo las asociaciones árabe, armenia, caboverdeana e israelí, el resto representan un origen nacional europeo. Y si la participación de las dos primeras podría ser explicada en términos estadísticos por la enorme proporción de inmigrantes que llegaron a Berisso proveniente de dichos países durante el período de entre-siglos (superando incluso a los italianos y españoles, Lobato, 2004) es importante recordar que la colectividad armenia ha sido parte del grupo que fundó y dirigió de manera ininterrumpida la AEE durante 18 años (ver capítulo $n^{\circ} 3$ ). Por su parte la colectividad caboverdeana comenzó a participar de la fiesta en el año 2001 y la colectividad israelí en el año 2011.

132 Como señalamos en el apartado dedicado a exponer la Estrategia Metodológica, la cantidad de observaciones participantes y registros obtenidos durante el trabajo de campo estuvo guiada metodológicamente por la saturación de categorías emergentes, tal como se expone en la Grounded Theory desarrollada por Denzin y Lincoln (1994). Entre los años 2010-2015 relevamos un conjunto de discursos y prácticas que reiteraban sus formas, contenidos y sentidos. A los fines de no saturar la lectura -y pese a que unas de las características de ritual conmemorativo refiere a dicha reiteraciónhemos decidido incluir únicamente los discursos y prácticas que sintetizan el contenido del resto. Por su parte, los discursos orales de los actores que exponemos a lo largo del capítulo son recortes textuales (desgrabados) y la descripción de sus prácticas corresponden a los registros de nuestras notas de campo.

${ }^{133}$ En el año 2006, cuando se reformó su estatuto, la AEE contaba con 19 miembros (ver anexo no 5, "Asociación de Entidades Extranjeras"). Finalmente, en el año 2011 se incorporaría la Colectividad Israelita. 


\section{Celebración Litúrgica Ecuménica: la misa}

Pese a ser un ritual secular -donde se expresan relaciones, ideas y valores de especial significación para su propio contexto (Moore y Myerhoff, 1977)- la Fiesta Provincial del Inmigrante inicia sus actividades en un lugar sagrado. Cada 4 de septiembre (Día Nacional del Inmigrante ${ }^{134}$ ) en la Iglesia María Auxiliadora ${ }^{135}$ se lleva a cabo una misa católica denominada Celebración Litúrgica Ecuménica ${ }^{136}$. Allí, apelando a hechos del pasado local, sus organizadores construirán una representación sobre la comunidad berissense en el cual la heterogeneidad religiosa y étnica se vuelve la base originaria de un Berisso armónico, pacífico y unido.

A este acto asisten las autoridades de las veinte asociaciones étnicas, sus abanderados y reinas (vestidos/as con trajes tradicionales), el presidente de la AEE, el intendente municipal, integrantes del Poder Ejecutivo berissense, el Director Provincial de Colectividades Extranjeras, la Reina Provincial del Inmigrante, la primera y segunda princesas, mejor compañera, miss simpatía (en adelante sus acompañantes), las reinas infantiles de cada colectividad y un público compuesto por familiares y amigos de las personas anteriormente mencionadas.

Simétricamente ubicados a un lado y otro de la puerta de ingreso -bajo un vitral en el cual se ve a Jesús con los brazos abiertos- los abanderados y reinas de cada una de las asociaciones étnicas invitan a los asistentes a ingresar en ella (foto $\mathrm{n}^{0} 1$, pág.: 149). Una vez en el interior de la Iglesia estas personas se ubican en lugares previamente designados: la parte delantera de las dos columnas de asientos quedan reservadas para el presidente de la $\mathrm{AEE}$, el intendente, el director de colectividades extranjeras, los integrantes del ejecutivo municipal, la Reina Provincial del Inmigrante, sus acompañantes (columna izquierda) y las reinas infantiles de cada una de las colectividades (columna derecha). Detrás de ellos, en ambas columnas, se ubica el público (fotos $n^{\circ} 2$ y n³, pág.: 149).

\footnotetext{
${ }^{134}$ El 4 de septiembre de 1812 el primer Triunvirato firmó un decreto cuya letra señalaba que "el gobierno ofrece su inmediata protección a los individuos de todas las naciones y a sus familias que deseen fijar su domicilio en el territorio argentino". Sobre estas bases, en 1949, el Poder Ejecutivo Nacional firmó el decreto № 21.430 estableciendo que el 4 de septiembre sea proclamado Día Nacional del Inmigrante.

135 Ubicada en calle 10, entre Avenida Montevideo y 166.

${ }^{136}$ La misa es uno de los actos que se realiza desde la primera edición de la fiesta (1978).
} 


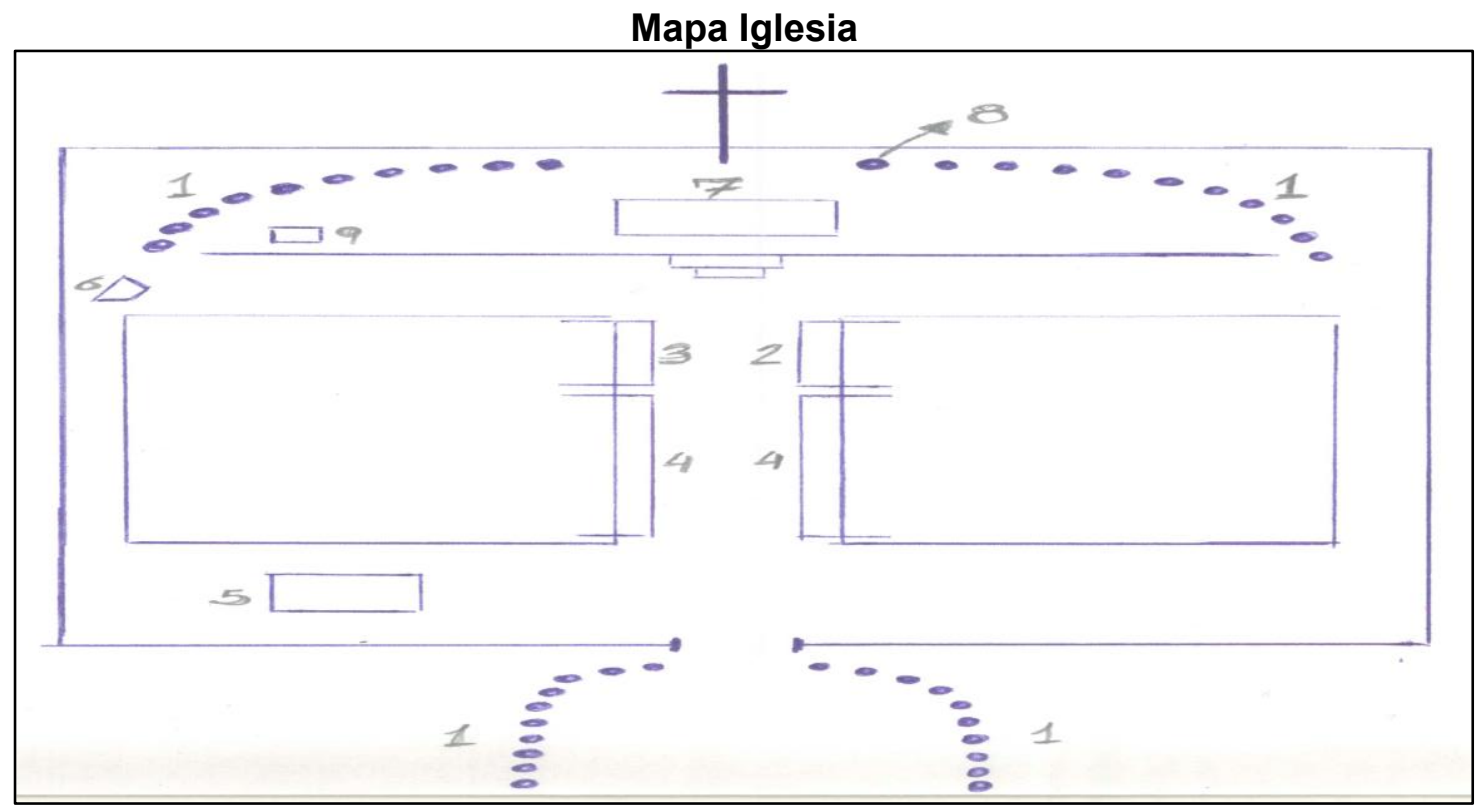

Referencias:

1- Abanderados de las colectividades

5- Mesa con ofrendas

2- Reinas infantiles de las colectividades

3- Autoridades municipales, autoridades de las colectividades, Reina Provincial del Inmigrante y sus acompañantes
6- Oradora
7- Altar
8- Bandera Argentina
9- Púlpito

4- Público

Después de que los asistentes se ubican en dichos lugares, el párroco desciende del altar (acompañado de un abanderado que porta la insignia argentina) y se traslada hasta la puerta de ingreso para solicitarle a los abanderados y reinas de cada colectividad que lo acompañen nuevamente hasta el altar. Una vez en él, las reinas y abanderados se distribuyen simétricamente en torno a la bandera argentina y la virgen María (foto $n^{\circ} 5$ pág.: 150). En este marco el cura inicia la misa caracterizando a la convivencia social berissense como completamente armónica, donde la unidad prevalece por sobre las diferencias étnicas o religiosas. En su discurso la religión y la fiesta serán señaladas por sus capacidades para identificar a los berissenses como hermanos, re-ligándolos en torno a un pasado compartido que debe ser recordado anualmente.

Así, y señalando el motivo por el cual se realiza la misa, el cura afirmó:

"Hoy vamos a recordar a todos aquellos antepasados nuestros que llegaron a esta tierra de brazos abiertos (...) Recordemos con esta misa que inaugura la fiesta a nuestros antepasados, que con tantas esperanzas y sueños pero también con tanto dolor, vinieron a Berisso, eligieron la Argentina, y tuvieron que poner sus raíces en una tierra extraña. $Y$ que aquí, siendo de distintas nacionalidades, de distintas religiones compartieron el ser inmigrantes. Y por eso la convivencia fue pacífica, la convivencia ha sido y es armoniosa. Recordémoslos a ellos, que nos han dado la sangre y nos han dado otra nacionalidad además de esta. Recordémoslos con mucho cariño." (2015) 
Sin embargo la necesidad de recordar -traer el pasado al presente- no será el único motivo por el cual se realice la misa. En la edición del 2013 el párroco señaló:

"Estoy presidiendo esta celebración donde todos estamos pidiéndole al Señor que no perdamos el norte. ¿Qué significa eso? Significa que nosotros debemos tener en cuenta, y potenciar, todo aquello que hicieron nuestros antepasados, aquellos que nos precedieron, aquellos que forjaron este lugar, aquellos que vinieron hace mucho $\mathbf{y}$ nos dieron esto que somos. Cada uno de nosotros representamos a distintas colectividades, pero hoy, nosotros debemos sumar, no restar. Debemos potenciar todas aquellas cosas buenas que nos han legado nuestros antepasados (...) Tenemos la responsabilidad de seguir actuando, seguir trabajando por la unidad, la unidad de los cristianos. La unidad de todos aquellos hombres de buena voluntad (...).

Pidámosle al Señor y a la Santísima Virgen María Auxiliadora que nos cubra con su manto, más allá de una cultura, más allá de los credos, más allá de alguna idiosincrasia, para que sepamos entonces potenciar todo aquello que nos ayuda a cuidarnos, nos ayuda a seguir construyendo esta ciudad de Berisso (...) Hoy comenzamos el mes de la fiesta de las colectividades, este mes que nos acaricia el alma, este mes que nos identifica como hermanos." (2013)

Si generalmente las misas constituyen un acto conmemorativo donde se reactua la última cena de Jesús, en este caso sus sentidos aparecen asociados a necesidad de actualizar en el presente un recuerdo ligado al origen inmigratorio de la ciudad. Pero a la vez el cura construye una imagen sobre la Argentina (en general) y Berisso (en particular) caracterizada por la apertura, la unidad, la armonía y la convivencia pacífica. Apelando a un metáfora botánica (que veremos reiterarse en los siguientes actos) Berisso aparece en su discurso como una "tierra" a partir de la cual los inmigrantes "forjaron" la sociedad local, plantando sus "raíces". Tanto la metáfora botánica como la indicación de los inmigrantes como padres fundadores de la comunidad permiten que sus descendientes se posicionen en el presente como legítimos herederos de un "legado" que se lleva en la "sangre". Como han mostrado Palermo (2007), Palleiro (2011) y Freidenberg (2013), señalar a los inmigrantes como héroes fundadores de la comunidad -vinculándolos con un conjunto de cualidades morales positivas- permite que sus descendientes se sitúen en el presente como legítimos herederos del pasado local y únicos garantes del sostenimiento de dichos valores.

Es importante señalar que, además, en el discurso del cura aparecen elementos que biologizan y sustancializan relaciones sociales históricamente cambiantes (Alonso, 1994). La metáfora botánica acerca de las raíces inmigratorias trasplantadas a suelo argentino comenzará a ser cruzada con una concepción esencialista de la identidad berissense, donde la sangre adquiere un lugar preponderante. De esta manera no solo 
las relaciones sociales se convertirán en algo "dado y primordial" sino que además se construirán lazos de pertenencia comunitaria mediante elementos biológicos que presentan como inexorable el vínculo entre lo social y lo natural (Geertz, 2006c). Como vimos, el lazo de consanguinidad que menciona el cura ("aquellos antepasados nuestros que nos han dado la sangre") es relacionado con la capacidad que posee el periodo festivo para hermanar a los berissenses ("este mes que nos identifica como hermanos"). Al otorgarle reconocimiento y significación cultural a hechos biológicos este actor construye un parentesco ficticio que amplía la definición de familia e incluye en ella a individuos que no poseen ninguna relación de sangre (consanguínea) ni de matrimonio (afinal). Debido a su capacidad para vincular a personas que no tienen dichos lazos, el parentesco ficticio ha sido caracterizado como una forma de mantener integrados y unidos a los miembros de un sistema social -y por lo tanto, a él mismo- en torno a un conjunto de valores y obligaciones morales (Barfield, 2000): la solidaridad, la ayuda, la confianza, la cooperación, la unión y el amor se mezclarán en el discurso del párroco con la obligación de recordar a los padres fundadores de la comunidad.

Luego de aquellas palabras iniciales una oradora y el cura se reparten la lectura de algunos textos bíblicos que hacen referencia al carácter migrante de Jesús, la partida de Abraham de su tierra natal y la unión del pueblo cristiano por sobre las diferencias nacionales. Seguidamente el párroco lleva a cabo una homilía donde expone los elementos centrales que articulan el acto. Así, por ejemplo, en 2011 afirmó:

"[este oficio religioso] es ofrecido a Dios por todos nosotros, todos y cada uno de los que forman parte aquí del pueblo de la ciudad de Berisso. Y cuando digo todos, cabemos todos, cristianos, no cristianos, los grandes pueblos, las grandes religiones, judíos, musulmanes, católicos; todos cabemos en el gran abrazo de Dios (...) sin ninguna distinción de ningún tipo. Quisiera hablar muy brevemente de la palabra de Dios en relación a este festejo que nos convoca (...). Si ustedes escuchan las tres lecturas que hemos hecho (...) ellas nos recuerdan cuál es la mayor virtud del hombre: amar a Dios en el amor, en el cariño, en la misericordia, en el servicio para con el prójimo, para con el hermano (...) Y el amor a Dios se da a todos los hombres. Para Dios no hay distinciones, ni de razas, ni de pueblos, ni de culturas, ni religiosas.

(...) Hoy estamos todos aquí reunidos en el inicio de esta fiesta del inmigrante. Me conmueve profundamente, porque todos nosotros o la mayoría tenemos varias mezclas de sangre, la mayoría somos hijos, nietos o bisnietos de gente que vino con un sueño bajo el brazo, desde lejos. Y que vino a forjar un futuro mejor, que vino a cumplir con mucho sacrificio un sueño. Nosotros somos fruto de ese amor, de ese cariño, de esa pasión; también de esos malos momentos, de ese tener que dejar la tierra, la cultura, de tener que dejarlo todo. Somos fruto de todo eso. Y creo, además, que tenemos una obligación de amor para con nuestros ancestros y para con Dios: hacer que esto no se pierda.

Vieron que las fiestas y las conmemoraciones son antiquísimas, y nos invitan a celebrar quienes somos, lo que somos. Pero también nos invitan a no olvidar, a ir 
haciendo memoria. Y a pasar la posta de esta memoria. Con este ritual, con este clima de fiesta que hoy nos reúne, tenemos la obligación de que no se olvide el sacrificio de todos y cada uno de aquellos que vinieron desde lejos y forjaron el pueblo de Berisso; y en particular también forjaron nuestra Argentina (...) Pidámosle a Dios que nos de la fuerza para continuar con esto con alegría y mucha responsabilidad, porque no es cualquier cosa lo que nos han trasmitido, no es cualquier cosa pertenecer a tal o cual nación, ser descendiente de tal o cual inmigrante. Que Dios los bendiga y bendiga esta fiesta." (2011)

En orden alfabético un/a representante de cada una de las colectividades étnicas sube al púlpito y lleva a cabo una breve plegaria -en el idioma de la nacionalidad que representan- en el cual piden "al Señor por la paz en el mundo, que reine entre todas las naciones la verdadera paz que viene de ti". Seguidamente vuelve a hablar el cura:

"Queridos hermanos, en distintos idiomas hemos entendido, y así lo han entendido aquellos que nos precedieron, porque había algo importante en sus corazones, que era el amor. El amor por esa tierra deseada, el amor por aquellos que se encontraban, el amor que sembraba el camino que los unía. El amor debe entonces prevalecer en cada uno de nosotros (...) Seamos nosotros generadores de paz a pesar de la diversidad, busquemos siempre la unidad; no se puede construir con ideologías, se construye con amor, se construye con respeto al otro, se construye buscando siempre lo que nos une, no lo que nos divide." (2014)

Finalmente los representantes de cada una de las colectividades recogen las ofrendas que han depositado en una mesa situada junto a la puerta de la Iglesia, se las lleva al cura hasta el altar y éste dirige las últimas palabras del acto:

"Que las dificultades no nos hagan bajar los brazos sino todo lo contrario, seamos un pueblo que camina hacia adelante, que mira hacia atrás pero quedándose con lo mejor del pasado para poder proyectar un mundo nuevo. Un mundo mejor. Para poder dejarles a aquellos que vienen algo mejor de lo que hemos encontrado (...) Querida familia, hemos comenzado entonces esta fiesta poniendo a Jesús en el medio, a aquel que nos da la vida." (2014)

Escoltado por un abanderado que porta la insignia argentina, el cura y los representantes de las colectividades se retiran hacia la puerta dando por finalizada la misa (foto $n^{\circ} 4$ pág.: 149). La Fiesta Provincial del Inmigrante se inicia con una misa que repite, anualmente, la misma secuencia de acciones ordenadas y una inamovible disposición de los actores en el espacio ${ }^{137}$. Evidentemente el ordenamiento de este

137 Retomamos la concepción de Harvey (1998) y Bourdieu (2007) sobre el espacio, para quienes el mismo no solo está socialmente producido sino que a la vez es el marco que ordena la experiencia. Si el espacio no es una realidad externa a las prácticas sociales y éstas no pueden ser pensadas fuera del 
ritual conmemorativo impone una secuencia de acciones ordenadas en el tiempo y una disposición de los actores en el espacio donde todo parece estar pre-definido. Debido a estas características la misa se vuelve un contexto privilegiado en el cual reproducir un imaginario armónico sobre Berisso y la Argentina, indicando a la heterogeneidad étnico-religiosa como su base originaria: de la misma manera que la bandera argentina articula y unifica al resto de las insignias patrias de cada colectividad -poniéndose en el centro o delante de ellas- Jesús y la Virgen María "abrazan y cubren con su manto" a los presentes sin distinción alguna. Así, la fiesta y la religión aparecen en el discurso del cura con la capacidad de unir lo que podría aparecer disperso. Como mencionó en la misa del año 2010: "Si Jesús es el símbolo de unión entre los migrantes y a éstos los unió principalmente su fe, es justamente porque Jesús fue el primer migrante".

Analíticamente es importante señalar que en este acto encontramos varias formas de identificación y homogeneización (la humano-religiosa, la nacional, la que debe reconstruirse a través de la memoria) que al aparecer mezcladas generan un conglomerado armónico, unido y pacífico. Pero no solo la fiesta y la religión tienen según el párroco- la capacidad de unir a los presentes sino que junto a la sangre permiten crear un potente parentesco ficticio entre ellos. La fiesta, la religión y la sangre terminan siendo elementos centrales en la construcción discursiva de una parentela imaginaria en la cual los asistentes a la misa fueron interpelados como hermanos de una misma familia. En este sentido recordemos que para Weber "la creencia en el parentesco de origen -siendo indiferente que sea o no fundada- puede tener consecuencias importantes, especialmente para la formación de la comunidad" (Weber, 1998: 318, cursivas nuestras).

La misa, siendo un lugar de memoria (Nora, 1992) en el cual se recuerda la última cena de Jesús, constituye durante la fiesta un espacio en el cual recordar a los inmigrantes que vinieron "hace mucho tiempo y desde lejos" para "forjar" a Berisso y la Argentina. Al construir un mito de origen y señalar a los héroes fundadores de la comunidad, este acto permite que sus descendientes se instituyan en el presente como los legítimos herederos de un lugar socialmente reconocido. Acto que lama a "no olvidar" un "legado" que funciona en el presente como herencia comunitaria: el esfuerzo, el trabajo, la paz, la armonía, la convivencia, el amor. Así, la misa se vuelve

espacio (Segura, 2010), ello se debe a que el espacio físico expresa el espacio social. Hay que recordar que el espacio social es "uno de los lugares donde se afirma y ejerce el poder, y sin duda en la forma más sutil, el de la violencia simbólica como violencia inadvertida" (Bourdieu, 2002: 122). En adelante, cada vez que hagamos mención al espacio nos estaremos refiriendo a esta noción de espacio social. 
un momento propicio para actualizar obligaciones morales y lograr que los recuerdos sobre la experiencia migratoria continúen siendo socialmente trasmitidos. Un contexto en el cual, fundamentalmente, la posibilidad del olvido aparece ligada al temor de perder elementos constitutivos de la "identidad local": si se perdieran los recuerdos de dicha experiencia se estaría olvidando lo que el pueblo berissense es, "lo que somos" (en palabras del mismo cura que en 2010 alentó a los asistentes para que "sigan haciendo la fiesta, porque ella asegura el porvenir de nuestra identidad").

De esta manera la celebración litúrgica permite recordar hechos del pasado. Un pasado a través del cual definir a Berisso como una tierra que unió armónicamente todas las diferencias. La misa trae al presente una época dorada (Halbwachs, 1990) para la comunidad local, un pasado tan idílico como armónico y acrisolado que decide olvidar o negar cualquier esbozo de conflictividad en el presente ("mirar para atrás solo para quedarnos con lo mejor del pasado", dijo el cura). Una versión de la memoria tan selectiva como legitimadora.

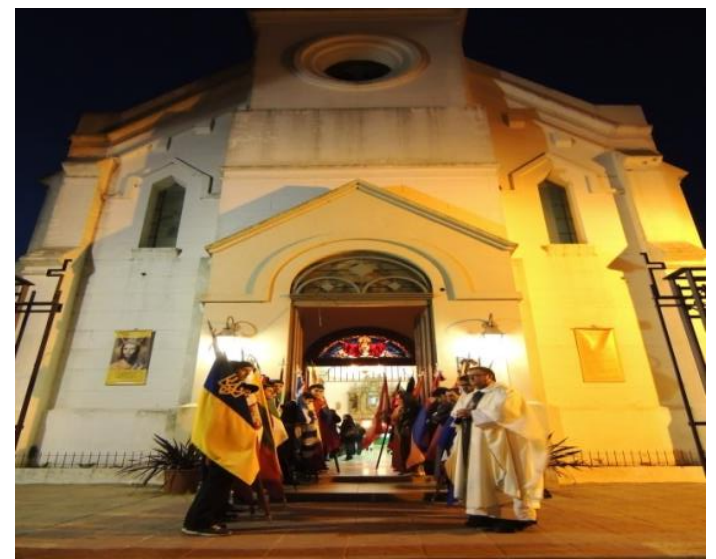

Foto $N^{01}$ (2013): Puerta de ingreso a la Iglesia María Auxiliadora

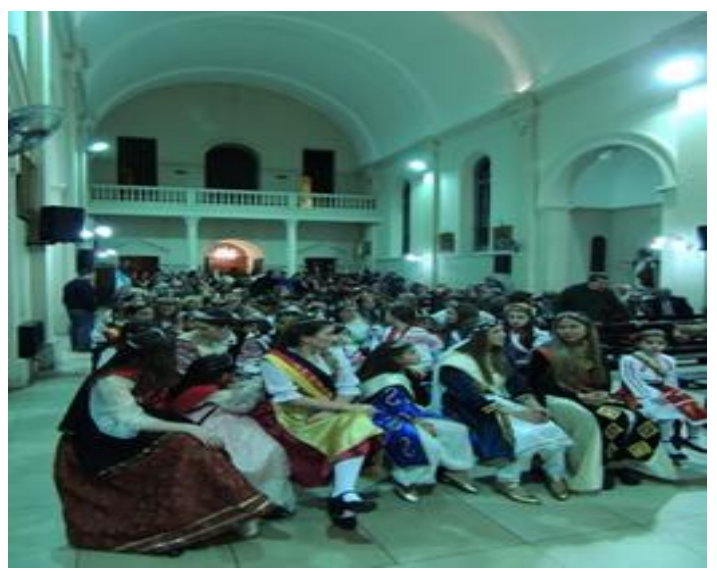

Foto N³ (2014): Reinas infantiles y juveniles.

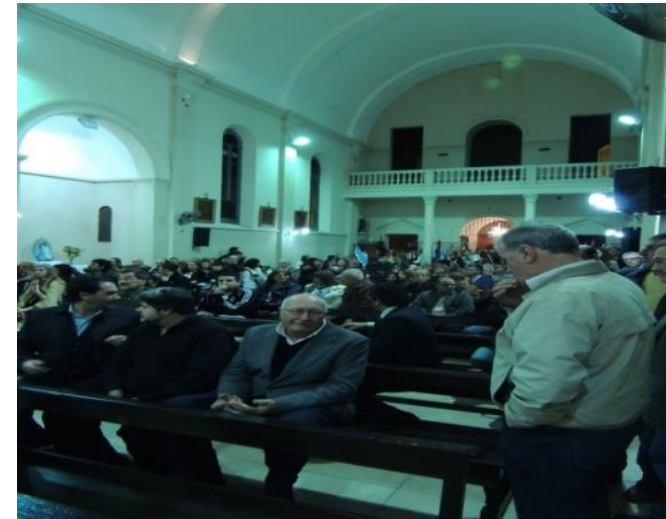

Foto $\mathrm{N}^{0} 2$ (2014): Autoridades municipales y de la AEE. De derecha a izquierda en primera final, Luis Molina (colectividad irlandesa) y Alfredo Dulke (colectividad lituana).

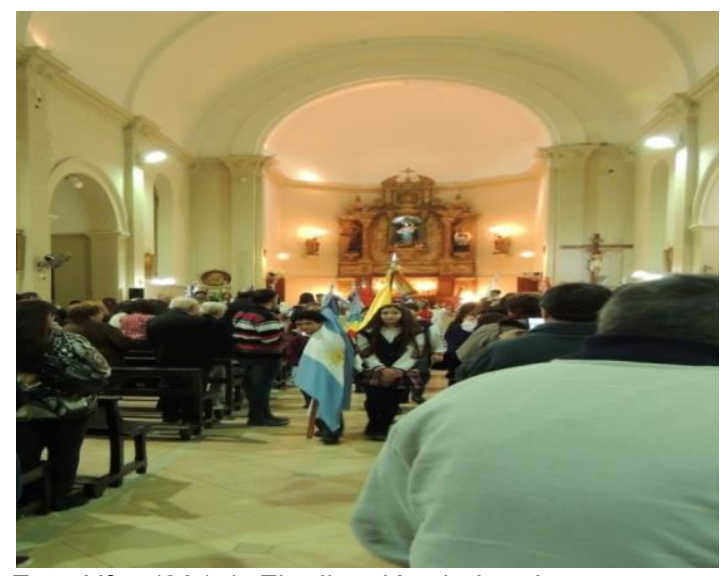

Foto $N^{\circ} 4$ (2015): Finalización de la misa 


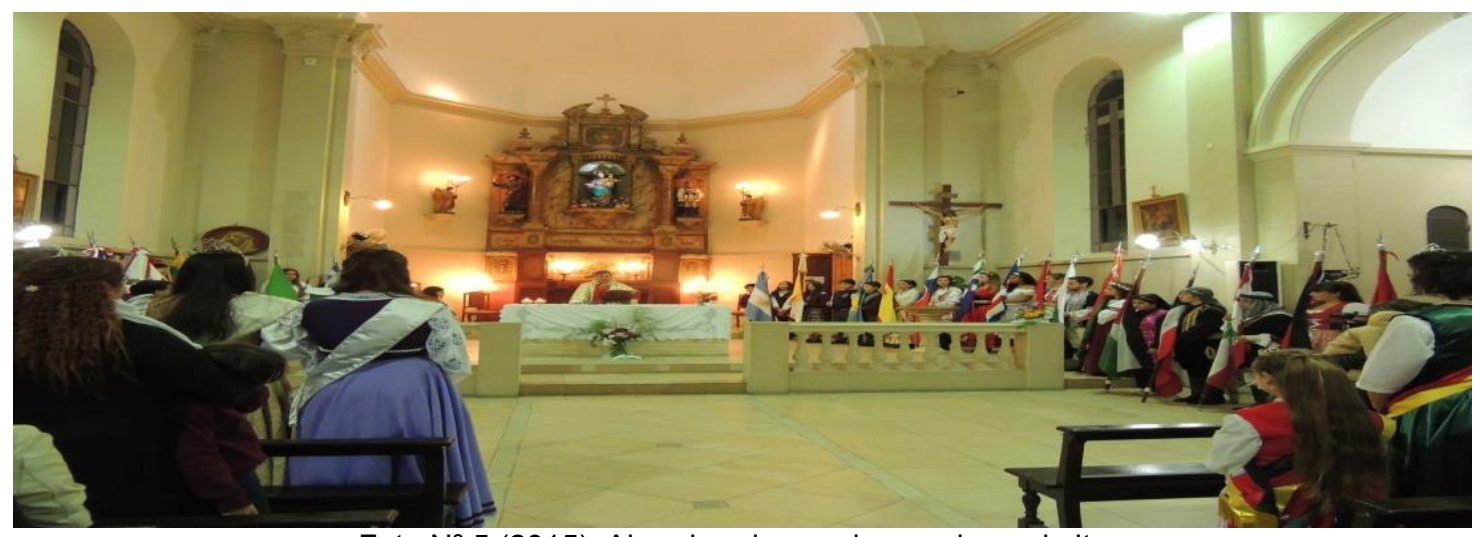

Foto $\mathrm{N}^{\circ} 5$ (2015): Abanderados y reinas rodean el altar

\section{Encendido de la Lámpara Votiva y Posta del Inmigrante}

El día posterior a la misa, en la sede de la Colectividad Helénica y Platón (griega) ${ }^{138}$ se realiza el encendido de una antorcha que -luego de recorrer la sede de algunas colectividades étnicas en un acto denominado Posta del Inmigrante- concluye su camino en el Centro Cívico de Berisso encendiendo la Lámpara Votiva que se encuentra situada sobre el Monumento a los Inmigrantes ${ }^{139}$. A ambos actos asisten las autoridades de las veinte colectividades, sus reinas y abanderados, la Reina Provincial del Inmigrante (y sus acompañantes), el presidente de la AEE, el Director de Colectividades Extranjeras, el intendente municipal, el secretario de gobierno, la directora de la Secretaría de Deportes, la directora de Cultura, el presidente del Consejo Deliberante, deportistas autoconvocados (quienes realizan la Posta del Inmigrante) y un público compuesto por familiares y allegados de las personas antes mencionadas.

Al interior de la colectividad griega la disposición espacial de los actores se asemeja a la descripta para la misa: al ingresar encontramos dos columnas de sillas en las cuales la parte delantera está reservada para las autoridades de las colectividades y la gestión municipal, mientras la parte trasera se reserva para el público. En el pasillo formado entre ambas columnas se ubican los deportistas autoconvocados. Delante de ellos, de pie y dispuestos/as en forma circular, están los/as abanderados y reinas de cada una de las colectividades. En el centro de dicho círculo se ubican el presidente de la colectividad griega, el presidente de la AEE, el intendente municipal y un abanderado que porta la insignia argentina y la antorcha a encender. Finalmente por delante de todos ellos hay un escenario en el cual se desarrolla una breve coreografía/representación teatral (fotos $n^{\circ} 6$ y 7 pág.: 155).

\footnotetext{
138 Ubicada en el cruce de las calles 8 y 164.

${ }^{139}$ Estos actos se incorporaron en la segunda edición de la fiesta (1979).
} 


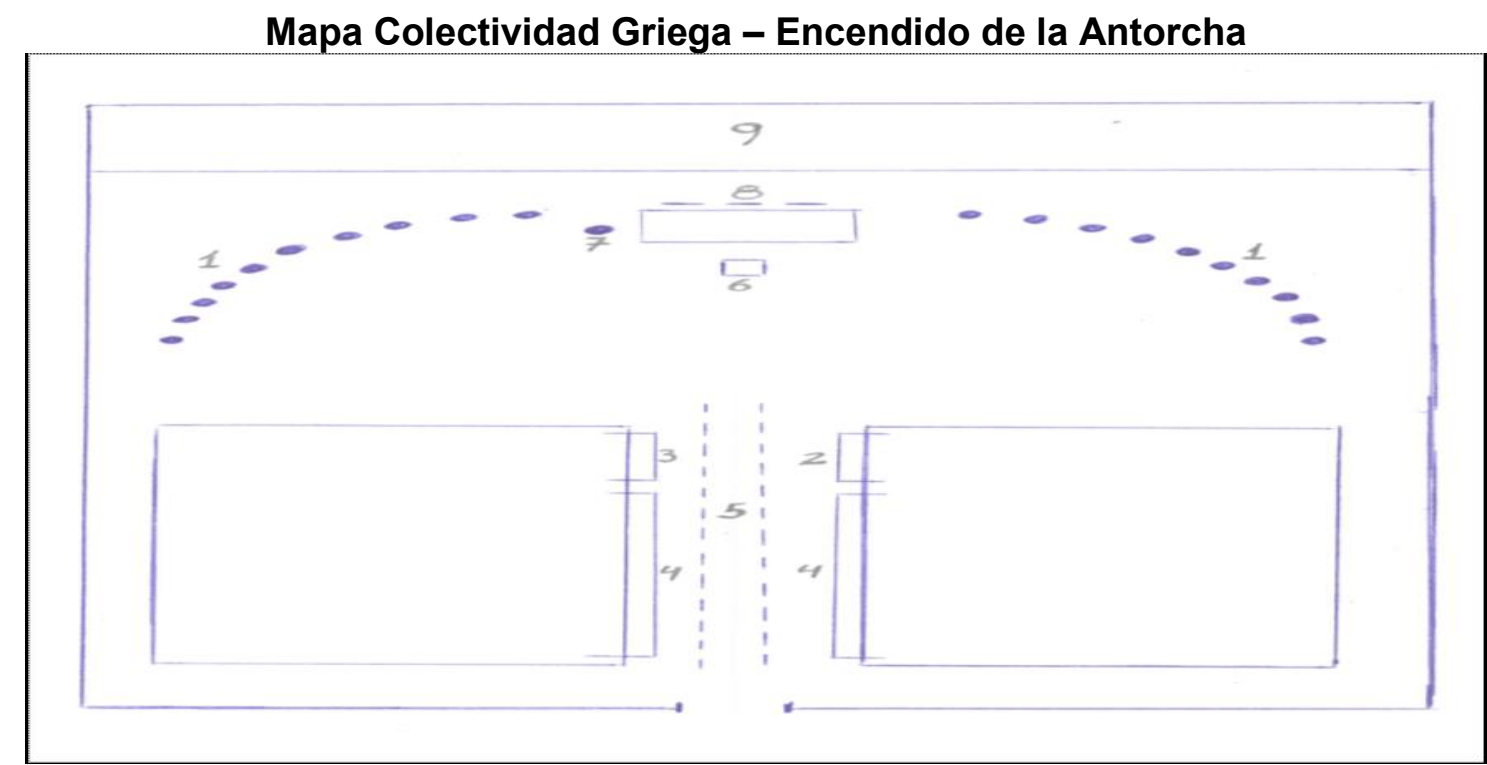

Referencias:

1- Abanderados de las colectividades

6- Antorcha

2- Autoridades de las colectividades

7- Bandera Argentina

3- Autoridades municipales

8- Oradores

4- Público

5- Deportistas autoconvocados

9- Escenario

Al iniciar el acto el locutor da la bienvenida afirmando que el mismo se realiza para rendir "homenaje a todos y cada uno de nuestros queridos inmigrantes" e invita a entonar las estrofas del Himno Nacional argentino. Luego el presidente de la colectividad griega, el presidente de la AEE y el intendente municipal harán uso de la palabra manifestando los motivos del acto (en particular) y la fiesta (en general). Así, el primero de ellos afirmó que

"El encendido de la antorcha recrea el inicio de los Juegos Olímpicos y se apaga con el cierre de la fiesta. Es un símbolo de unión entre todas las etnias y marca la perpetuidad en el tiempo de las raíces, costumbres y cultura de cada colectividad (...) Para todos los inmigrantes, para todas las colectividades esta fiesta es muy importante porque representa la posibilidad de mantener vivas nuestra cultura, nuestras costumbres." (2015)

Por su parte el presidente de la AEE mencionó que

"Este acto de inicio de la fiesta, con la antorcha, recorriendo cada una de las colectividades y finalmente encendiendo la Lámpara Votiva en el Centro Cívico lo realizamos en muestra de amor y paz entre cada una de las colectividades. Acá no existe ningún tipo de rencor; en Berisso seguimos viviendo mancomunadamente todas las colectividades." (2015) 
Por último el intendente municipal pronunció un discurso en el cual afirmó que esta fiesta

"trasciende un producto -el trigo, la soja o el maíz- o cualquier fiesta que sea producto del accidente geográfico de una ciudad. Esta es la fiesta que marca, que muestra, la esencia de los berissenses y de los extranjeros en esta tierra; que llegaron, se bancaron, se ayudaron mutuamente. Sobra ver nada más lo que pasa en el mundo para darnos cuenta de que somos privilegiados de vivir en una tierra de tolerancia. Donde el judío y el árabe se pelean por ser de Gimnasia o de Estudiantes, donde los que son católicos y los que no son católicos se respetan (...) Los berissenses nos bancamos, somos una gran familia.

(...) Tuvimos épocas difíciles, 2001, 2000, cuando los chicos no tenían ni para comprar la ropa de los ballets, donde era muy difícil hermosear los salones, donde hacíamos una fiesta que no era tan fiesta porque no había alegría. Y creo que hoy están pasando otras cosas en la ciudad (...) Honrando la memoria de nuestros viejos y nuestros abuelos hemos empezado nuevamente el emprendimiento en el Puerto, que es el que nos dio la vida de ser una ciudad portuaria, anfitriona de sueños de tanta gente corrida por el hambre y la guerra. Hoy nuestra fiesta está nuevamente unida al Puerto, volviendo a tener esa historia que hizo que vengan nuestros abuelos y nuestros viejos, esa historia de ciudad portuaria que dio lugar a esa remanida palabra: crisol de razas (...). Esta fiesta debe seguir sirviendo al pueblo de Berisso y a cada una de las colectividades para seguir manteniendo nuestra historia." (2015)

Luego de estos discursos cuatro mujeres de la colectividad griega llevan a cabo una coreografía en la cual bailan una danza tradicional (foto $n^{\circ} 8$, pág.: 156) y coronan a un joven que se encargará de encender la antorcha y pasársela a uno de los deportistas autoconvocados (foto $n^{\circ} 9$, pág.: 156). Finalmente el locutor cierra el acto afirmando:

"Y así la antorcha (...) dejará en cada colectividad la llama que las une. La llama que une a todas las culturas, a todas las naciones, dando comienzo a esta nueva edición de la Fiesta Provincial del Inmigrante. Fiesta que homenajea a todos nuestros queridos inmigrantes, manteniendo viva la historia de nuestros queridos padres, abuelos y bisabuelos." (2013)

Mientras los deportistas recorren las sedes de casi todas las colectividades de la ciudad -elaborando un trayecto, un itinerario, que traza una geografía de la memoria no anclada a un lugar físico específico (Jelin, 2017: 174) ${ }^{140}$ - el resto de quienes estaban presentes en la colectividad griega se trasladan hacia el Monumento a los

\footnotetext{
${ }^{140}$ Para una representación gráfica del recorrido ver Anexo № 2 “Asociaciones Étnicas, calles y lugares históricos de Berisso".
} 


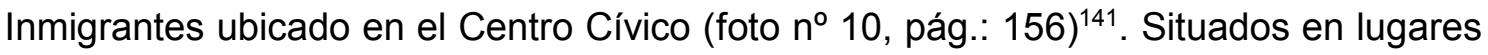
previamente definidos esperarán la llegada de los deportistas que portan la antorcha para, así, encender la Lámpara Votiva emplazada sobre dicho monumento: los/as abanderados/as de cada una de las colectividades formarán un pasillo (entre la Av. Montevideo y el Monumento) por donde pasarán los deportistas con la antorcha, sobre la escalinata del Monumento se ubicarán la Reina Provincial del Inmigrante (y sus acompañantes) y las reinas juveniles e infantiles de cada colectividad (fotos $n^{\circ} 11$ y 12 , pág.: 156).

\section{Mapa Monumento a los Inmigrantes}

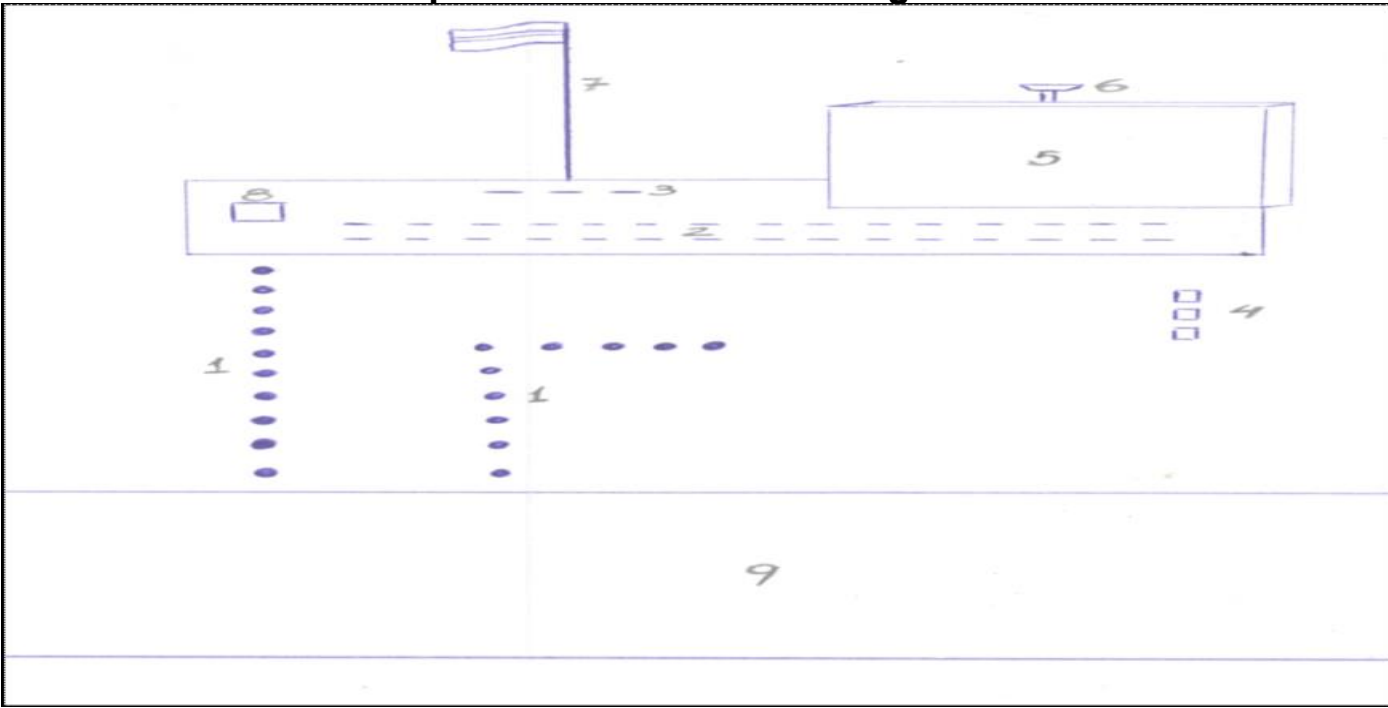

Referencias:

1- Abanderados/as de las colectividades

2- Reinas Infantiles de las colectividades

3- Reina Provincial del Inmigrante y sus acompañantes

4- Oradores

5- $\quad$ Pared con las 20 banderas de los países representados

6- Lámpara Votiva

7- Bandera Argentina

8- Busto a "Los pioneros que gestaron la ciudad"

9- Av. Montevideo

Una vez que estos actores están ubicados en los lugares establecidos y los deportistas se acercan con la antorcha, el locutor inicia el acto con las siguientes palabras:

141 Sentado en la vereda frente al Centro Cívico -mientras espero la llegada de los deportistas autoconvocados- escucho una conversación entre la vendedora de un local de ropa que se encontraba en la puerta mirando hacia el Monumento y dos conocidas suyas. Al pasar por delante del local estas personas le preguntaron qué hacía en la vereda, bajo la lluvia. “¿Cómo qué hago? Espero a que prendan la llama”. ¿Qué llama?, le preguntaron. “¿Cómo 'qué llama’? Por lo de la fiesta... los chicos están corriendo con la antorcha bajo la lluvia hace rato y ¿ustedes no saben nada?", contestó. ¿De qué chicos hablas, qué antorcha? quisieron saber. Entre risas la vendedora les reprochó: "¡Cómo se nota que ustedes no son berissenses! iUstedes son platenses que viven acá!". Al parecer nadie que sea de Berisso debería desconocer lo que sucede durante el tiempo de fiesta. Ser berissense y desconocer lo que pasa en la fiesta aparece como una contradicción en sus propios términos (Notas de campo, 2012). 
"Ahora sí, recibimos a los atletas ¡Bien arriba las banderas de todas las colectividades y todos los países! La hermandad de todos los pueblos (...) Cuántos recuerdos estamos viviendo una vez más aquí en Berisso, nuestra querida Capital Provincial del Inmigrante." (2015).

Luego de que el deportista que lleva la antorcha enciende la Lámpara Votiva (foto $n^{0} 13$, pág.: 156), el cura de la iglesia María Auxiliadora tomó el micrófono y bendijo el acto, cargándolo aún más de simbolismo:

"Así como un cuerpo tiene diferentes partes (los brazos, las piernas, la cabeza, etc.) todas hacen un cuerpo, una sola cosa donde cada uno funciona como corresponde; de la misma manera en esta hermosa ciudad cada colectividad es una cosa diferentes pero entre todas hacen una ciudad. (...) Así que en base a esta idea, de que cada uno con sus costumbres y tradiciones hacemos un cuerpo, una misma cosa, deseo que Dios los bendiga a todos y a esta fiesta de hermandad." (2012)

Finalmente el intendente municipal tomó el micrófono e hizo mención, una vez más, a que "esta fiesta tiene que ver con la historia de la ciudad, atravesada por la llegada de los inmigrantes. Ellos nos enseñaron los valores humanos de armar una familia y construir una vida digna y laboriosa" (2012). Dos años después, debido a la ausencia del intendente, el Secretario de Gobierno agregó algunos elementos interesantes en el discurso que cerraría el acto:

"Todos nosotros tenemos que ver con la inmigración. El que no es hijo de inmigrantes es nieto de inmigrantes. Así que la inmigración de ultramar nos nutrió de esos polacos, de esos italianos, de esos españoles... todos esos extranjeros tienen que ver con este Berisso. En el caso mío vengo de italianos y españoles, así que sabemos de esta comunión de razas que se hizo aquí, tanta gente abrazada por nuestros antepasados cuando llegaron a esta ciudad tan pequeña, que lo que tenía fundamentalmente era trabajo. Ellos vinieron y aquí nacimos nosotros. Una ciudad que es ejemplo de unidad, de hermandad y de paz." (2014)

Tal y como vimos en la misa, los actores participantes de estos actos manifiestan que los mismos se llevan a cabo para homenajear -recordándolos- a los inmigrantes que fundaron Berisso y conformaron en él un rico y armónico crisol de razas. Para estos actores -según sus propias palabras- el encendido de la Lámpara Votiva y la Posta del Inmigrante permiten mantener viva la historia y honrar la memoria de aquellos inmigrantes que llegaron a Berisso desde ultramar y dieron lugar a una tierra de unión, tolerancia, respeto, paz y hermandad entre todas las etnias. Ambos actos (en particular) y la fiesta (en general) no solo poseerían la propiedad de perpetuar en el tiempo las raíces y la cultura de aquellos inmigrantes sino que además permitirían mantener vivos 
los recuerdos de cada una de las colectividades, resguardando nada más ni nada menos que la esencia que define a los berissenses.

Analíticamente cabe señalar que la secuencia de acciones ordenadas y recurrentes en el tiempo que vemos desplegarse en estos actos permite que los sujetos de la celebración repongan, anualmente, el mito del crisol de razas e instituyan un imaginario donde el inmigrante ultramarino se vuelve el centro de una armónica convivencia. Inmigrantes que además, son ligados a un conjunto de valores socialmente reconocidos: dignidad, trabajo, familia, etc. Así, el inmigrante no solo es instituido en sujeto fundador de la comunidad sino que además es asociado a un conjunto de valores morales que parecieran ser transmitidos a sus descendientes por la vía sanguínea. Al igual que en la misa, durante estos actos la sociedad berissense es imaginada como una gran familia cuyos miembros -hermanados por la fiesta- presentan un mismo origen sanguíneo: inmigratorio y europeo.

A su vez los actos habilitan un espacio en el cual los sujetos de la celebración reconstruyen un imaginario que esencializa las identidades e inmoviliza la dinámica cultural. Si bien aquella metáfora botánica utilizada durante la misa (acerca de las raíces ultramarinas trasplantadas a suelo argentino) aparece reiterada en estos actos, ahora ella es vinculada con una metáfora biológica que sustancializan las relaciones sociales (Alonso, 1994): la sociedad berissense es homologada a un cuerpo que -como dijo el cura- funciona armónicamente gracias a la articulación de sus diferentes órganos. Así, el uso de la memoria oficial permite reconstruir en el presente un imaginario sobre la identidad (su esencia) y la cultura (inmutable) berissense. Finalmente, y fuera de los discursos, hemos intentado mostrar cómo la disposición espacial de las banderas de cada colectividad y el recorrido de la antorcha se cierran simbólicamente sobre la bandera argentina y el himno nacional, reproduciendo un imaginario donde la conformación étnica de la ciudad/nación y su armónica convivencia estarían articuladas por el aporte inmigratorio. Esta preeminencia y centralidad de la bandera argentina nos estaría señalando la relevancia del país de destino por sobre los países de origen, un elemento constitutivo de la idea de crisol.

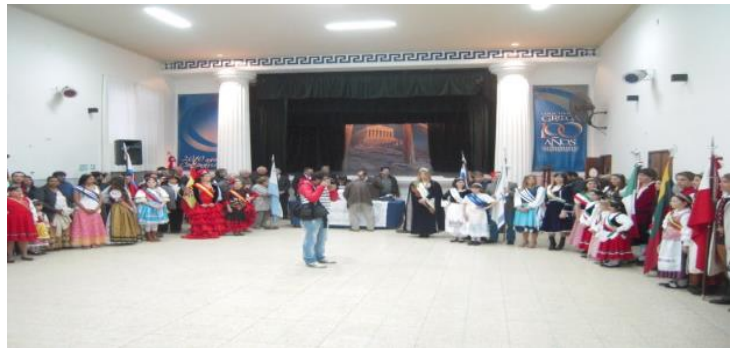

Foto N6 (2012): Interior de la colectividad griega

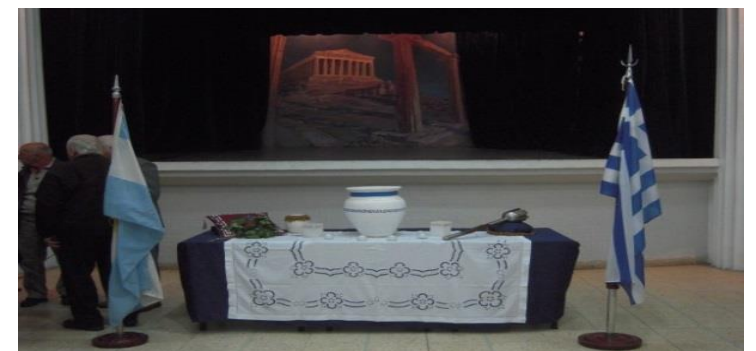

Foto $N^{0} 7$ (2012): Insignias nacionales y antorcha 


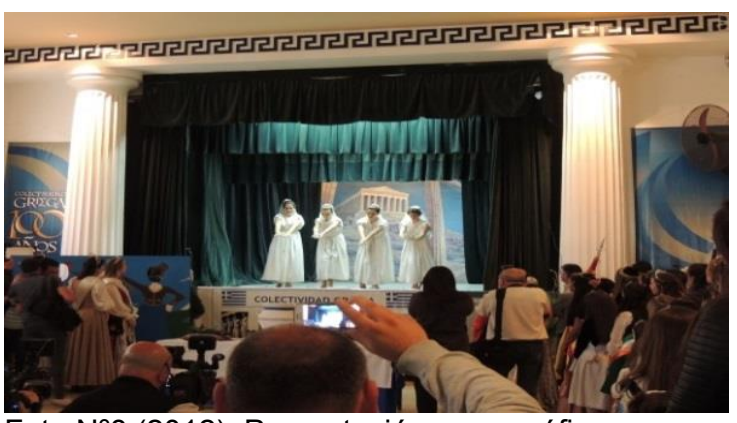

Foto N8 (2012): Presentación coreográfica

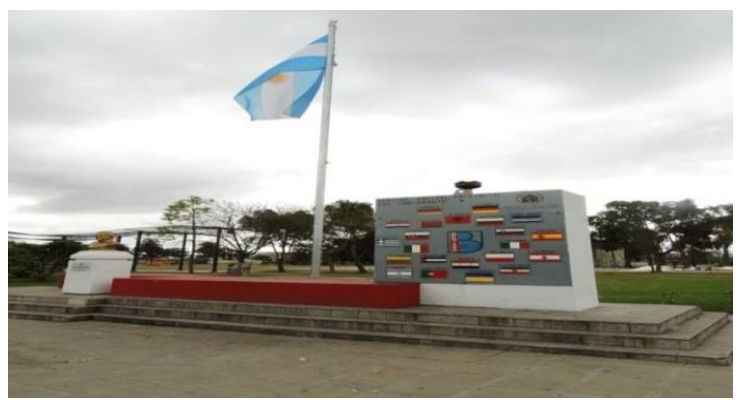

Foto $N^{0} 10$ (2013): Monumento a los Inmigrantes

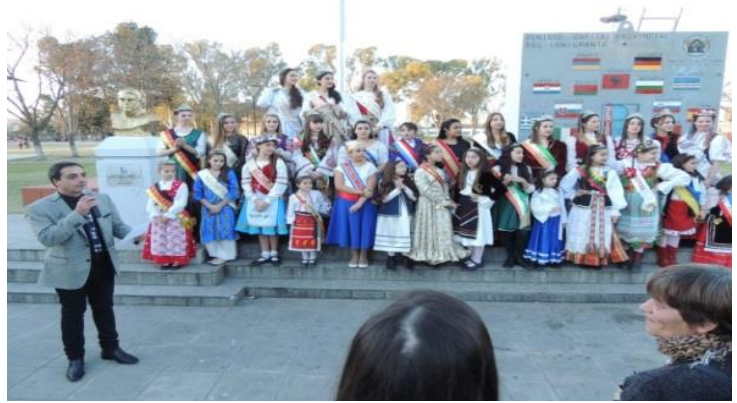

Foto No12 (2015): Reinas sobre el Monumento a los Inmigrantes

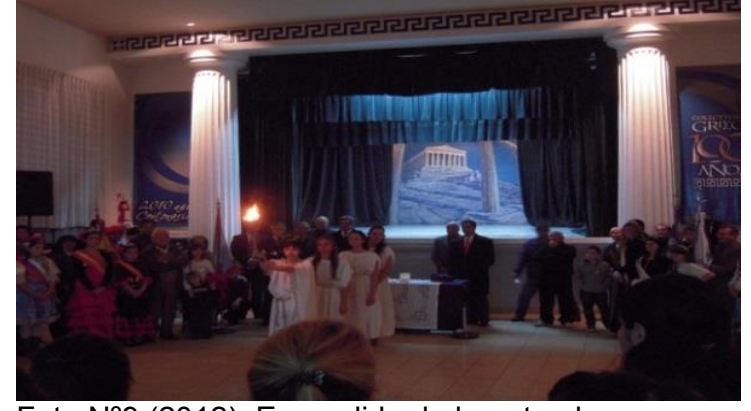

Foto N9 (2012): Encendido de la antorcha

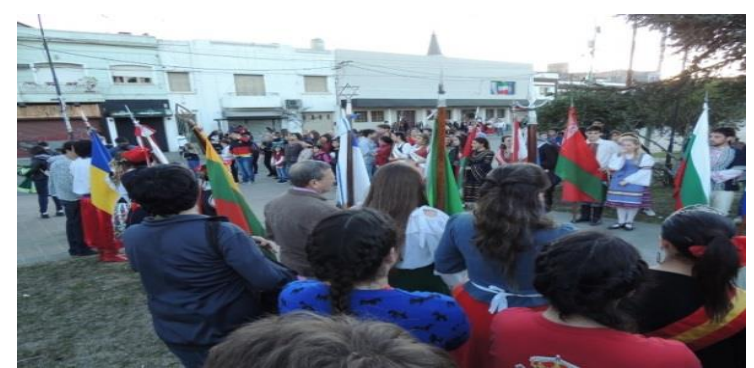

Foto No11 (2013): Pasillo entre Av. Montevideo y el Monumento a los inmigrantes

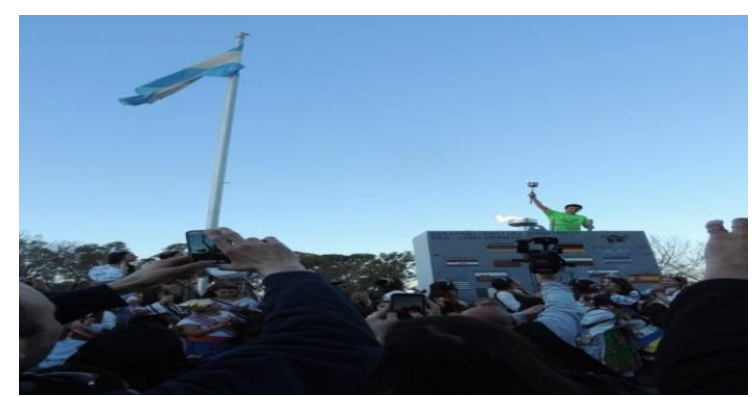

Foto $\mathrm{N}^{0} 13$ (2014): Encendido de la Lámpara Votiva ubicada sobre el Monumento a los Inmigrantes.

\section{Desembarco Simbólico: el puerto}

Según Evans Pritchard (1992) hay lugares del espacio social a los cuales se los define en función de su carácter ecológico: a ellos se los nomina en función de su relación con los recursos naturales de una sociedad. Sin embargo, al ser vinculados con algún acontecimiento que el conjunto de la sociedad considera relevante en su génesis o "esencia" estos espacios adquieren una carga simbólica que los separa momentáneamente de su carácter ecológico. Una de las ocasiones donde este proceso se desarrolla de manera más evidente son, según Pritchard, los rituales: al dotar de carácter simbólico a los espacios funcionales de la estructura económica, los rituales logran resignificarlos de manera absoluta. Siguiendo esta línea de análisis, y señalando desde posiciones teóricas disímiles la capacidad que poseen los rituales para dramatizar significaciones sociales, Balandier (1994) y Da Matta (2002) han 
indicado que dichos espacios se vuelven teatros en los que la sociedad se reproduce a sí misma.

Esto es lo que le sucede al Puerto de Berisso ${ }^{142}$ cuando el fin de semana siguiente a la misa, la posta del inmigrante y el encendido de la lámpara votiva se desarrolle en él uno de los actos más importantes de la fiesta: el Desembarco Simbólico ${ }^{143}$. Al representar la llegada de inmigrantes a las costas locales -señalando la procedencia ultramarina de uno de los objetos celebrados- este acto hace que el Puerto adquiera una enorme carga simbólica. Acto que, en palabras de uno de los sujetos de la celebración, "recrea el desembarco de los inmigrantes que llegaron a la ciudad huyendo de la guerra, del hambre y de la persecución política" (presidente de la AEE, 2015).

Al acto asisten el intendente municipal, el secretario de gobierno, el presidente del Consejo Deliberante, el coordinador municipal de Entidades Extranjeras, el director de Colectividades Extranjeras de la Provincia de Bs. As., el presidente de la AEE, directivos y miembros de las colectividades locales, la Reina Provincial del Inmigrante (y sus acompañantes), el jefe de la División Operaciones de Prefectura La Plata, representantes del Consorcio de Gestión del Puerto La Plata y Prefectura Naval Argentina, funcionarios comunales, autoridades educativas, concejales y un numeroso público.

A metros de la puerta de ingreso al Puerto -flanqueada por la bandera argentina y bustos de Eva Durarte y Juan Domingo Perón, cuyas placas definen a Berisso como la "Capital del Peronismo" y recuerdan que desde allí partieron las "primeras" columnas obreras que "liberaron" a Perón el 17 de octubre de 1945 (foto n¹4, pág.: 163) ) $^{144}$ - se monta un escenario en el cual se ubican la Reina Provincial del Inmigrante (y sus

\footnotetext{
${ }^{142}$ Ubicado en el cruce de las calles Montevideo y Nueva York, frente a la ex edificio del frigorífico Swift.

${ }^{143}$ Este acto comenzó a desarrollarse en el año 1995.

${ }^{144}$ La placa firmada por la Agrupación Peronista Desafío dice "Desde este histórico lugar partieron las primeras columnas de trabajadores argentinos que librearon al Coronel Juan Domingo Perón en su glorioso 17 de Octubre de 1945. Berisso, Capital del Peronismo". A una cuadra hay otras tres placas y un enorme mural referidos al vínculo entre ese espacio social, los trabajadores de Berisso y los orígenes del peronismo. La primera define a Berisso como el "Km. 0 del Peronismo", fue colocada el 17 de octubre del año 2014 y lleva las firmas del Presidente del Partido Justicialista de Berisso (Oscar Colombo) y la firma del Intendente Municipal (Enrique Slezack). Al año siguiente, para conmemorar los 70 años del 17 de octubre de 1945 se colocó en el mismo lugar otra placa, firmada por los mismos actores, en "homenaje a los militantes que desde esta emblemática esquina protagonizaron hace 70 años la histórica gesta que marcó a fuego la historia argentina que dio origen a nuestro Movimiento Nacional. La tercera placa, colocada el 17 de octubre del 2005, dice "Los vecinos del barrio Nueva York, a 60 años del 17 de octubre de 1945, mantenemos viva la lucha por los principios sociales de aquella histórica gesta obrera". Finalmente, en el mural las figuras de Perón y Eva se mezclan con la bandera argentina, imágenes del 17 de octubre sucedidas en Plaza de Mayo y las fábricas de Berisso. Ver fotos incluidas en la introducción de la tesis y en el Anexo №7.
} 
acompañantes), el intendente municipal, el presidente de la AEE y otras autoridades de la gestión local. Debajo del escenario se colocan los abanderados y reinas de cada colectividad rodeando a la bandera argentina (foto $n^{0} 15$ pág.: 163).

Mapa Puerto - Desembarco Simbólico

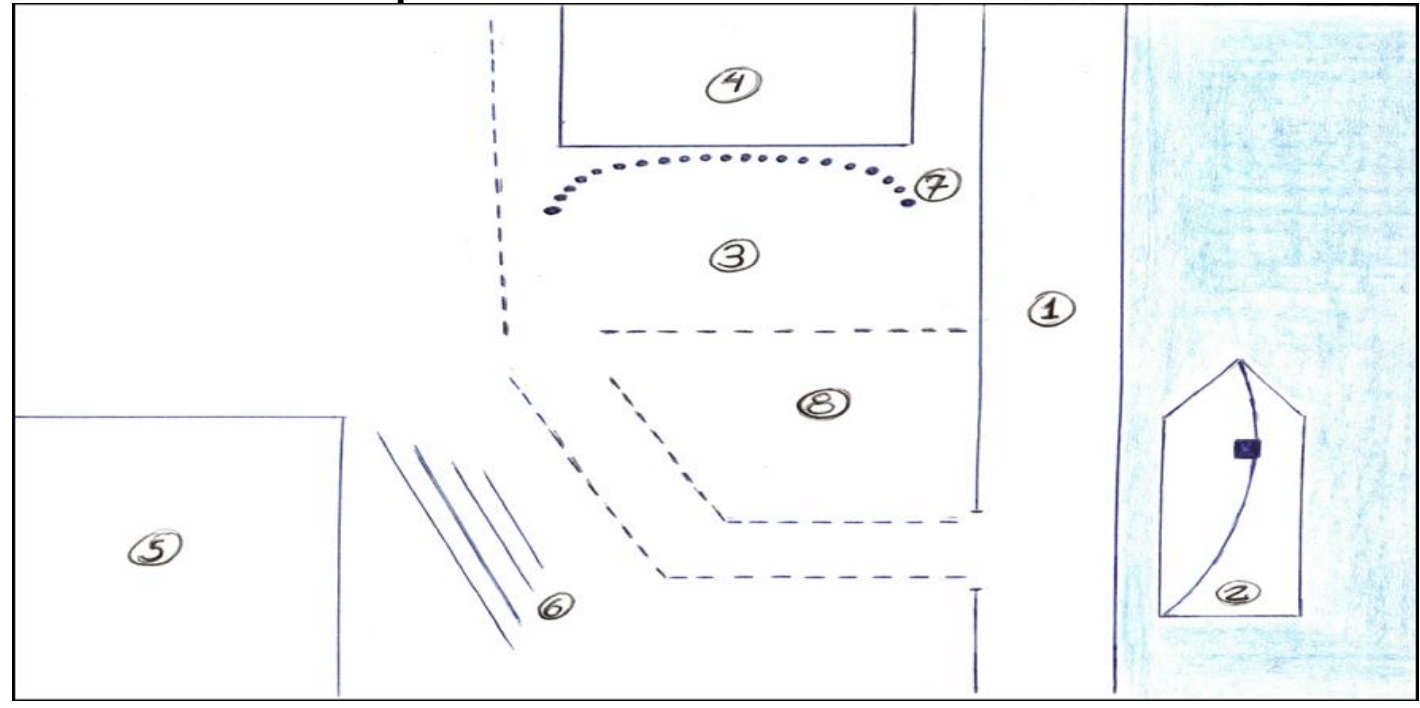

\footnotetext{
Referencias:

1- Dársena

2- Barco con "inmigrantes"

3- Espacio donde se realiza el baile intercolectividades

4- Escenario

5- Oficinas del Puerto (Ex Frigorífico Swift)

6- Gradas para el público

7- Abanderados/as de las colectividades y abanderada argentina

8- Público

- . - . - Vallas de seguridad
}

Desde el escenario, dando la bienvenida a los presentes, el locutor inicia el acto mencionando los sentidos del mismo:

"A continuación vamos a revivir uno de los momentos más fuertes e intensos de esta nueva edición de la fiesta: vamos a recrear el tradicional desembarco donde integrantes de distintas colectividades, con su ropa típica, ropa de época, nos van a recordar aquellos momentos en los cuales nuestros padres, nuestros abuelos y nuestros bisabuelos llegaban desde distintos puntos del mundo a esta tierra, a nuestra bendita patria." (2010)

Luego de estas palabras iniciales se invita a los presentes a entonar el Himno Nacional Argentino y el Himno de Berisso, acompañados por la Banda Musical de la Escuela Naval Militar y un/a soprano/a local (foto $n^{\circ} 16$ pág.: 163). La entonación de ambos himnos (tanto en este acto como en los anteriores y posteriores) crea una unisonancia en la cual la imagen de pertenencia a la comunidad se vuelve extremadamente potente: ahí, cada persona pierde su voz individual en un relato 
colectivo que lo identifica e incluye. Mostrando la capacidad que poseen los himnos para que una comunidad se imagine a sí misma en términos nacionales, Anderson señala que

"Por triviales que sean las palabras y mediocres las tonadas, hay en esta canción una experiencia de simultaneidad. Precisamente en tales momentos, personas del todo desconocidas entre sí pronuncian los mismos versos con la misma melodía. La imagen: unisonancia (...) La realización física de la comunidad imaginada en forma de eco" (Anderson, 2007: 204).

No solo por ser menos conocido sino también por resultar sumamente significativo el modo en que construye un imaginario sobre la ciudad, reproducimos las estrofas del Himno de Berisso ${ }^{145}$ :

Hija del río, adolescente y bella, te enviaron amores, el hambre y la guerra. Te dio su apellido Juan, aquel pionero, que trajo la industria de los saladeros.

En todos los idiomas te pidieron pan. En todos los idiomas te pidieron paz. Distintos colores de piel y banderas, iguales deseos de una vida nueva.

Berisso, barro, monte y esperanza... fábrica y obreros, puerto, barco y añoranza.

Cautivaste a todos, tú, dulce muchacha, sembraron tu vientre con pequeñas patrias.

Maduró en tu seno ese fruto nuevo y diste a luz niños de todos los pueblos. Tu amor es ejemplo para los humanos, no importa el origen ison todos hermanos! (resaltados nuestros)

Tanto la identificación de Berisso con una mujer como la metáfora biológica respecto a que de su vientre provienen todos los miembros de la comunidad -y por lo tanto, serían hermanos consanguíneos entre sí- vuelven a construir aquel parentesco ficticio que analizamos en actos previos. Sin embargo el hecho de que esos elementos simbólicos sean entonados por la totalidad de los presentes crea, aquí, una imagen de unidad y familiaridad mucho más potente. Es interesante notar -como ha hecho Mostov (2000) a escala nacional- los vínculos entre género y orígenes de la comunidad que aparecen en el himno a Berisso: en estas construcciones míticas, señala Mostov, las mujeres son las encargadas de reproducir físicamente a la comunidad.

145 En agosto de 1990 el Concejo Deliberante de Berisso llamó a concurso público para seleccionar la letra del himno de la ciudad, inexistente hasta esa fecha. El trabajo elegido fue el presentado por el escritor local Aníbal Guaraglia. 
A continuación las autoridades municipales y provinciales hacen uso de la palabra exponiendo los sentidos que le otorgan al acto. Fue ahí que el Secretario de Gobierno manifestó lo

"importante [que es] seguir realizando este acto que rememora la llegada en barco de los inmigrantes a nuestra querida ciudad. Un acto que nos recuerda, nos hace repensar, cómo llegaron nuestros padres y abuelos" (2010)

Al año siguiente, luego de que el Director Provincial de Colectividades afirmara que "este evento rememora la vida de nuestros antepasados que tanto lucharon por sus sueños y por nuestro país", el Secretario Municipal de Gobierno dijo que el desembarco demuestra que "Berisso es una ciudad que no olvida su historia, y los pueblos que no olvidan su pasado tienen un futuro venturoso" (2011). Por su parte, en 2012 el intendente municipal sumó a su discurso algunos elementos importantes a ser considerados:

"el Desembarco es uno de los hechos más trascendentes y significativos de la fiesta, ya que representa la historia de todos los inmigrantes que vinieron a estas tierras y lo hicieron para nunca más volver (...) El berissense no es mejor ni peor que otro, somos distintos, somos especiales. Aquella situación que hizo que muchos de nuestros abuelos vengan desde Europa corridos por el hambre o la persecución, buscando un lugar donde crear su familia, tener un pedazo de tierra, un techo. Son los sueños de mi abuela, de mis viejos; en este lugar de paz, de tolerancia se encontraron las colectividades que no podían convivir en la Europa arrasada por la guerra (...) Basta ver solo las ruinas de este frigorífico Swift, que fue el lugar convocante para muchísima gente: en una ciudad de 30 mil habitantes, 15 mil trabajan ahí y en el Armour. O este Puerto, hecho a pala por los propios inmigrantes (...) Acá estos inmigrantes convivían y trabajaban, y lo hacían de tal manera que lograron quedar en la historia de la Argentina con aquel 17 de octubre del 45 (...). Sin duda se trató de una historia de desarraigos y sacrificios, que hoy nosotros recordamos con nostalgia, pero también con alegría." (2012)

Un año más tarde (2013) tanto la presidenta de la AEE como el intendente municipal volvieron a manifestar cuáles eran los motivos por los cuales se realizaba el Desembarco. Según la primera, todos los presentes se encontraban ahí

"homenajeando a aquellos inmigrantes que vinieron a hacer patria a la ciudad de Berisso. Que hicieron que hoy estemos acá, nosotros, hijos, nietos y bisnietos de inmigrantes, honrándolos en un día como hoy; donde simulamos la llegada de ellos...algunos reviven, porque arriba del barco hay algunos inmigrantes que están redesembarcando." (2013) 
Seguidamente, luego de reiterar que el desembarco representa la historia de la ciudad, el intendente municipal afirmó que

"Este acto rememora a quienes bajaron de un barco (...) Nos merecemos honrar la memoria de los inmigrantes con esfuerzo y con objetivos que permitan que esta ciudad vuelva a surgir como un lugar industrial, una ciudad portuaria." (2013)

Una vez finalizados estos discursos un barco trae hasta la dársena del Puerto a los miembros de las colectividades que quisieron representar el arribo de sus antepasados (o de ellos mismos). Vestidos humildemente con ropa de época, portando valijas, fotos, instrumentos musicales y banderas de distintos países bajan del barco y entregan sus documentos ante dos personas que representan a un oficial de aduana y un empleado de migraciones (fotos n¹7-20, págs.: 163-164). Luego de ser anotados en un registro, los miembros de cada colectividad desfilan hasta el escenario mientras el locutor brinda datos históricos sobre el país representado y menciona los motivos por los cuales estas personas migraron hacia Berisso (dificultades políticas, económicas y persecuciones religiosas suelen ser los más reiterados). Al llegar hasta el escenario se colocan debajo de él, formando un semicírculo cuyo centro es ocupado por una abanderada que porta la insignia argentina.

Finalmente -situados al interior del semicírculo- el Desembarco concluye con una presentación teatral del Teatro Comunitario de Berisso ${ }^{146}$ y una presentación musical del Conjunto de Danzas Inter-Colectividades de la $A E E^{147}$. La primera presentación consta de dos escenas de la obra titulada "Primeros Relatos. La historia de Berisso contada por sus propios vecinos" donde se narra la partida (en barco) de los inmigrantes desde sus países de origen y la llegada a Berisso (foto $\mathrm{n}^{\circ} 21$ pág.:164). Por su parte el Grupo de Danzas realiza una presentación que luego de incluir algunos

\footnotetext{
${ }^{146}$ El Teatro Comunitario de Berisso está conformado (desde 2004) por vecinos de la ciudad que sin formación teatral decidieron "imaginar un Berisso de otra época" y "contar la historia de sus raíces" con una obra titulada Primeros Relatos. La misma "cuenta la llegada de los inmigrantes y la vida en los frigoríficos o 'las fábricas', como aún las llaman nuestros vecinos. Esplendor y ocaso de 'Swiftlandia', la catedral del 'cornerd beef', perfecta maquinaria industrial de la carne, donde lo único que no se envasaba era el mugido de la vaca. Berisso, con su diversidad de etnias que brindaron una gran riqueza cultural, se convirtió en un pueblo obrero que creció a orillas del sacrificio y el progreso. Quimeras de nuestros abuelos que vinieron buscando paz, pan y trabajo (...) Con un trabajo de creación colectiva basado en los recuerdos, anécdotas y experiencias de los propios vecinos, 'Primeros Relatos' busca fortalecer la identidad local a través del ejercicio de la memoria y la construcción de un relato conjunto" (Gacetilla de difusión entregada durante el Desembarco, cursivas nuestras).

${ }^{147}$ Grupo de danzas que incluye a miembros de todas las asociaciones étnicas de la AEE
} 
bailes tradicionales de las naciones representadas, termina con un pericón y una chacarera (fotos $\mathrm{n}^{\circ} 22-23$ pág.: 164).

Como puede verse, el Desembarco es un acto cargado de simbolismo y con una fuerte impronta conmemorativa que, a la vez, jerarquiza al Puerto como uno de los "espacios físicos donde ocurrieron los acontecimientos" narrados (Jelin, 2017:164). Un sitio de memoria completamente "auténtico". Los actores que participan de él manifiestan que ahí, a través de él, se re-vive, se re-crea, se re-memora, se representa y se recuerda la historia de la ciudad (y el país). Estos usos de la memoria oficial logran narrar la constitución de la ciudad -significando un tiempo social fundacional- mediante la reposición de un mito de origen según el cual los argentinos descenderíamos de los barcos. Bajo la reposición ritual del mito fundacional, la ciudad y la Nación no solamente son hijas del rio sino que Europa se instituye en el origen foráneo de su población. Pero a la vez el acto logra conformar una imagen de la sociedad berissense tan acrisolada como armónica, en la cual las diferencias de origen parecen haberse saldado en una tierra de paz, tolerancia, convivencia y trabajo: las banderas y bailes tradicionales de cada país representado terminan articuladas por la bandera Argentina, el pericón, la chacarera y el Himno Nacional Argentino. Así, como afirmó el semanario local, este acto intenta mostrar anualmente "la unión entre distintas nacionalidades, incluyendo a la Argentina, país que los recibió con los brazos abiertos" ${ }^{\prime 48}$.

Analíticamente es importante volver a señalar la capacidad que posee el Desembarco para dramatizar significaciones sociales a partir de su carácter teatral: el Puerto se vuelve el escenario en el cual los miembros de las distintas colectividades personifican a sus padres, abuelos o bisabuelos -cuando no a sí mismos- en un conjunto de escenas que representan la llegada de inmigrantes ultramarinos a Berisso/Argentina. Representación para la cual (como aludió el semanario local) "algunos de ellos dejaron crecer sus barbas por varios meses esperando el día de la ceremonia, e intentando que su actuación se aproximara a lo que había sido el arribo de sus ancestros"149. En esta dramatización no solo actúan los integrantes de las colectividades étnicas sino que además se convoca a un grupo de teatro para representar la partida de los inmigrantes ultramarinos y su arribo a las costas locales.

148 El Mundo de Berisso, edición semanal del 28 de septiembre/4 de Octubre del 2012. Resaltados nuestros.

${ }^{149}$ El Mundo de Berisso, edición correspondiente al 31de agosto/6 de septiembre del 2012. Una semana antes, en el mismo semanario el presidente de la AEE escribió una solicitada donde afirmaba: "Está abierta la inscripción a quienes quieran participar como actores de la experiencia única en la representación del desembarco". Cursivas nuestras. 
El carácter teatral de esta dramatización logra transformar la conducta de actores mediante una perfomance (Balandier, 1994) en la cual el cambio de roles sociales (Moore y Myerhoff, 1977) permite simular ser otro distinto a sí mismos (Arttoni, 1996; Duvignaud, 1997).

Pero si la inmigración ultramarina/europea se constituye en el eje central que articula el mito originario a ser conmemorado, el recuerdo de los vínculos locales con el peronismo comienza a aparecer como un segundo eje de enorme relevancia (un segundo objeto de conmemoración). El trabajo en el Swift, el Armour y los saladeros de Juan Berisso brindan el marco para recordar un 17 de octubre de 1945 que ya se encontraba presente en los bustos de Eva Duarte, Juan Domingo Perón y las placas recordatorias situadas en el ingreso al Puerto.

En síntesis, vemos en el Desembarco la reconstrucción de un imaginario (Anderson, 2007) sobre la comunidad (Weber, 1998) berissense que se encuentra articulado por el recuerdo de un origen foráneo (ultramarino, europeo) y el recuerdo de su vínculo histórico con el peronismo. "Somos distintos" manifestó el intendente, haciendo referencia a una doble característica con la que se construye el imaginario de la comunidad: tenemos un origen inmigratorio (europeo) como fundamento étnico y hemos dado origen a un hecho fundante de la política nacional (el peronismo). En tanto dinámica de distinción, estos elementos adquieren un lugar sumamente importante; siendo el pasado -en tanto marcador social- el que permita llevarla a cabo.

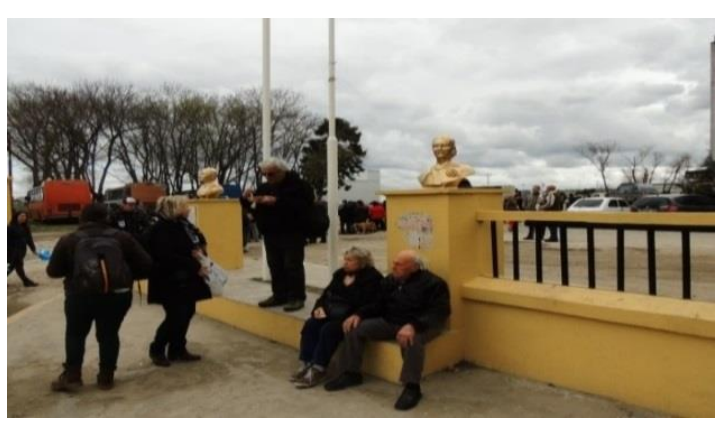

Foto $n^{0} 14$ (2013): Ingreso al Puerto, mástiles con la bandera Argentina y bustos de Juan Domingo Perón y Eva Durarte

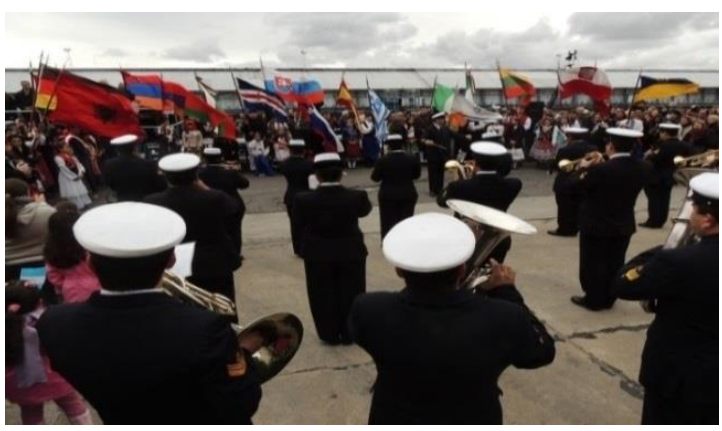

Foto n¹6 (2013): Entonación de los Himnos

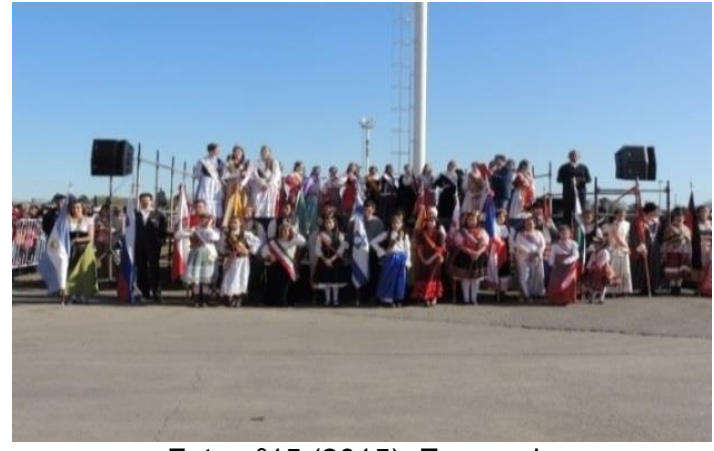

Foto $\mathrm{n}^{0} 15$ (2015): Escenario

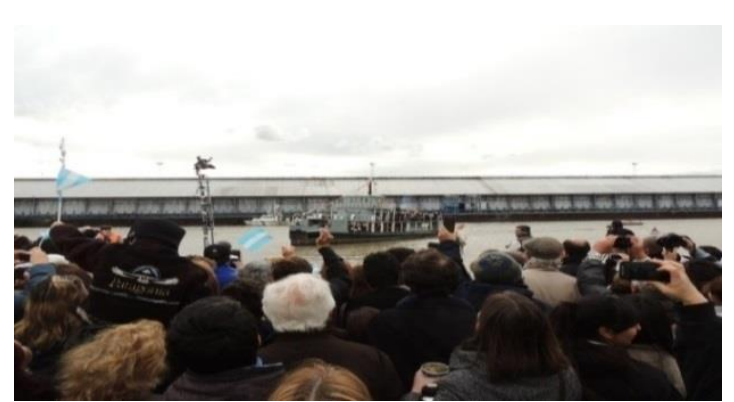

Foto $\mathrm{n}^{017}$ (2013): Arribo del barco 


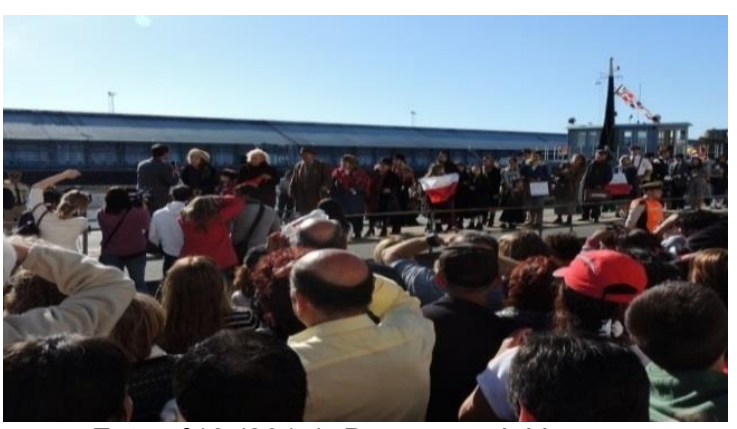

Foto $\mathrm{n}^{0} 18$ (2014): Descenso del barco

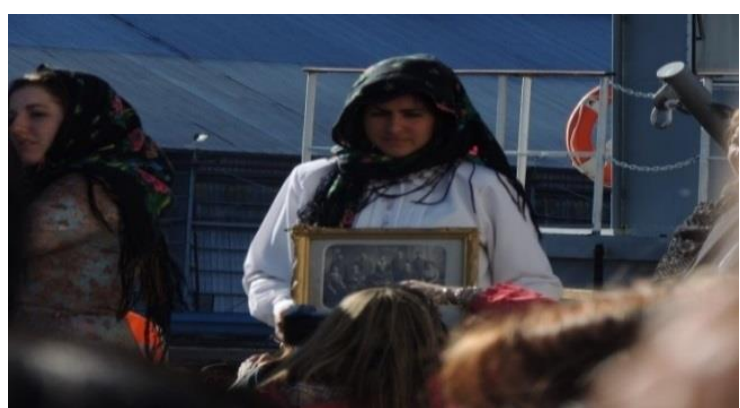

Foto n²0 (2014): Descenso desde el barco.

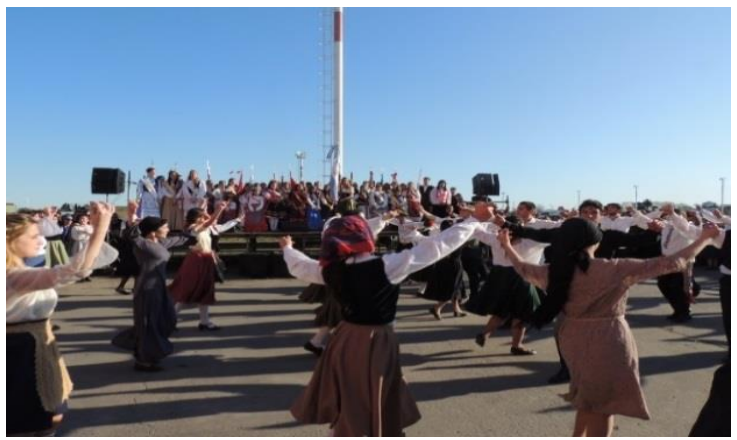

Foto $n^{0} 22$ (2015): Bailes tradicionales argentinos

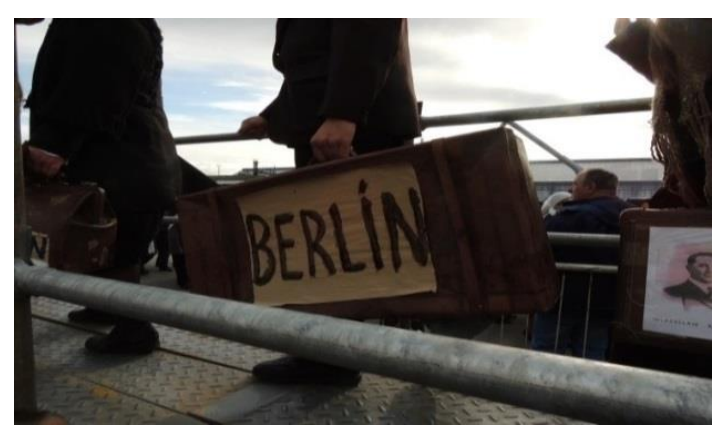

Foto $\mathrm{n}^{019}$ (2013): Descenso del barco

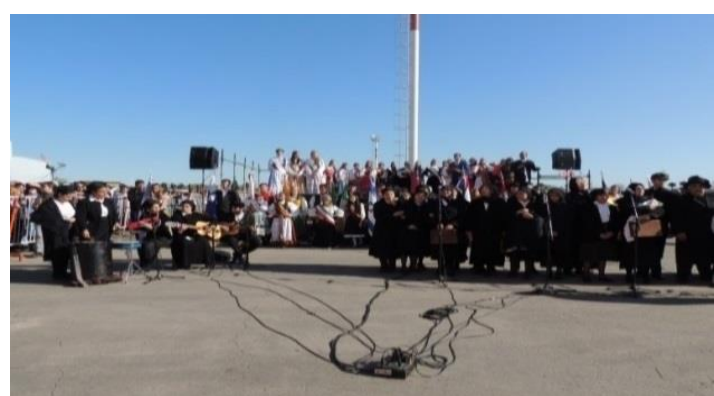

Foto n²1 (2015): Representación teatral (2015)

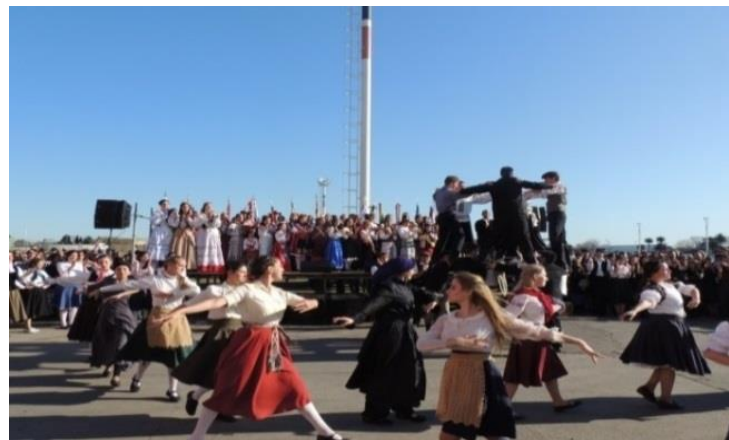

Foto n²3 (2015): Bailes étnicos

\section{Sobre el Centro Cívico: monumentos, bustos, murales y la Carpa de las Colectividades}

El fin de semana siguiente al Desembarco la fiesta traslada sus actividades hacia uno de los espacios sociales con mayor carga simbólica de la ciudad: el Centro Cívico ${ }^{150}$. Antiguamente se alojaron en él los saladeros San Juan y San Luis (de los hermanos Berisso) hasta que el frigorífico Swift compró sus estructuras edilicias para instalar un depósito y un crematorio de desperdicios animales. Décadas después durante el primer gobierno de Juan Domingo Perón- el Gobernador de la Provincia de

\footnotetext{
150 Ubicado en la Avenida Montevideo y calle 10. Desde el año 2009 la fiesta se trasladó a este espacio y el ingreso pasó a ser gratuito. Los primeros ediciones de la fiesta se hicieron en la Escuela de Enseñanza Media № 1 (10 y 169), luego se trasladó al salón del ex Sindicato de Trabajadores de la Carne (tanto en su sede de la calle Lisboa, 166, entre Domingo Leveratto, como en la de Napoles, 8 y 9), posteriormente al Hogar Social (Nueva York entre Av. Montevideo y Valparaiso) y entre 1999 y 2008 se hizo en el Gimnasio Municipal (9 y 169). Estas ediciones fueron abiertas al público pero no gratuitas.
} 
Buenos Aires decretó que este espacio (y todo lo que había en él) debía ser expropiado para formar un parque público denominado La Lealtad. ${ }^{151}$

Si bien estos datos refieren al pasado industrial y el vínculo histórico que el Centro Cívico tuvo con el peronismo, los monumentos, bustos y murales que hay en él continúan haciéndolo desde el presente. Como bien ha señalado Lefevbre (1971: 130) los monumentos, bustos y murales no solo poseen la capacidad de recordar y evocar el pasado de una ciudad sino que al unirlo con su presente dan forman a esa memoria colectiva a partir de la cual la comunidad se recrea a sí misma. Mientras uno de los monumentos del Centro Cívico indica que sobre él funcionó el antiguo saladero de Juan Berisso, a pocos metros se encuentran los bustos de Eva Duarte, Juan Domingo Perón y un enorme mural que incluye sus rostros y tres frases de la iconografía peronista: "Tu espíritu de unidad nacional no se destruye", "Pongo junto al alma de mi pueblo, mi propia alma. Evita" y "Seguiré vivo en los que luchan. J.W. Cooke"152. A solo unos pasos se erigen dos monumentos encargados de reponer el otro elemento identitario sobre el cual se construye la narrativa de la ciudad, su origen inmigratorio: junto al Monumento a los Inmigrantes que porta la Lámpara Votiva (descripto en el punto $\mathrm{N}^{0} 2$ de este capítulo) existe otro que rememora el desembarco de inmigrantes a la costa locales (fotos n²4-27, pág.: 171). Así, el Centro Cívico constituye un lugar de memoria no solamente "auténtico" -en la medida que señala, como el Puerto, un espacio en el cual sucedieron algunos de los hechos conmemorados durante la fiesta: en este caso la localización de los saladeros de Juan Berisso- sino que además "centraliza" en sí mismo un conjunto de marcas territoriales (Jelin y Langland, 2003; Messina, 2011) sobre hechos que no sucedieron exactamente allí.

Tal y como afirmó Ansaldi (1996) para el caso de la ciudad de Córdoba, los monumentos, bustos y murales existentes en el Centro Cívico de Berisso enuncian a los héroes y mitos fundacionales de la comunidad; instituyéndolos en modelos, ideas o símbolos en los que la sociedad se debería ver reflejada. Dicha forma de espacializar y materializar la memoria no es neutral ni azarosa, sino que forma parte de los intentos plenamente conscientes de algunas instituciones por reproducir los elementos

\footnotetext{
${ }^{151}$ Finalmente el proyecto (decreto № 25.916 de 1947) no se llevó a cabo en toda su dimensión, y al año siguiente este espacio recibiría la designación oficial de Centro Cívico. Fuente: Archivo de Geodesia de la Provincia de Buenos Aires, Carpeta 191, Ciudad de La Plata, Plano general y antecedentes de las instalaciones frigoríficas de La Plata.

152 Entre el año 2010 y el 2015 he ido reiteradamente al Centro Cívico, llamándome la atención que la periodicidad eleccionaria hiciera que un solo punto del mural se modificara: la firma del intendente peronista de turno. El resto quedaba casi igual. Solo los últimos años de mi trabajo de campo he visto en el mural un cambio: se incluyó el rostro de Néstor Kirchner.
} 
simbólicos del orden social e instituir un imaginario que legitime sus posiciones en la estructuración social del presente. ${ }^{153}$

Al analizar la iconografía del Centro Cívico, Daniel James (2004: 16-17) señaló que a diferencia de la mayoría de las ciudades argentinas Berisso no posee una plaza central. Ese espacio que en el resto de las ciudades de nuestro país suele enfrentar un edificio legislativo con otro religioso, en Berisso no existe. Sin embargo su Centro Cívico cumple una de las funciones centrales de aquellas plazas: al brindar testimonio de la historia de la comunidad funciona como un sitio dedicado a la rememoración y la conmemoración. En tal sentido coincidimos con James (2004) cuando afirma que los murales, estatuas y monumentos mencionados anteriormente muestran el intento plenamente racional de algunas instituciones locales por constituir, expresar y recordar los elementos centrales sobre los que se construyen (y disputan) las memorias locales ${ }^{154}$.

Estas marcas territoriales escenifican la memoria oficial de una comunidad de origen inmigratorio (ultramarino), articulada por la dinámica fabril y participe central en el nacimiento del peronismo. Así, el Centro Cívico se vuelve un espacio en el cual un conjunto de actores institucionales ligan el pasado con el presente, construyendo un imaginario multiétnico, obrero y peronista sobre Berisso ${ }^{155}$. Imaginario que reproduce ciertos hechos del pasado, olvidando y negando otros hechos del pasado. En este espacio social cargado de simbología y dedicado a la recordación, los organizadores de la fiesta montan durante tres fines de semana la Carpa de las Colectividades. En ella se alojan los veinte stands de las colectividades étnicas y un enorme escenario para sus presentaciones musicales.

\footnotetext{
${ }^{153} \mathrm{El}$ contrapunto que nos presenta el trabajo de Ansaldi (1996) es relevante, ya que en él se analiza la institucionalización de los héroes patrios locales -José María Paz y Dalmacio Vélez Sársfield- ante la llegada masiva de inmigrantes. El autor muestra cómo las instituciones locales solidificaron su lugar de dominación política ante la sociedad local (en oposición a los nuevos habitantes de la ciudad) inaugurando estatuas, monumentos y panteones de dichos héroes patrios.

${ }^{154} \mathrm{El}$ autor describe y analiza -además de los monumentos, bustos y grafitis que hemos mencionado- un mural que narra la historia fabril de la ciudad, el monumento a "El Gaucho", la estatua de una mujer con un niño en brazos denominada "Maternidad" y el "Monumento a los Desaparecidos".

${ }^{155}$ Estos elementos permiten, además, pensar la constitución del nexo local entre etnicidad y clase: la inserción del peronismo en una ciudad de origen inmigratorio (ver capítulo 2) habilitó que su población pudiera "imaginarse como parte de una armoniosa comunidad obrera argentina compuesta de trabajadores inmigrantes" (James, 2004:30).
} 


\section{Mapa Centro Cívico: Carpa de las Colectividades, Murales, Bustos y}

Monumentos

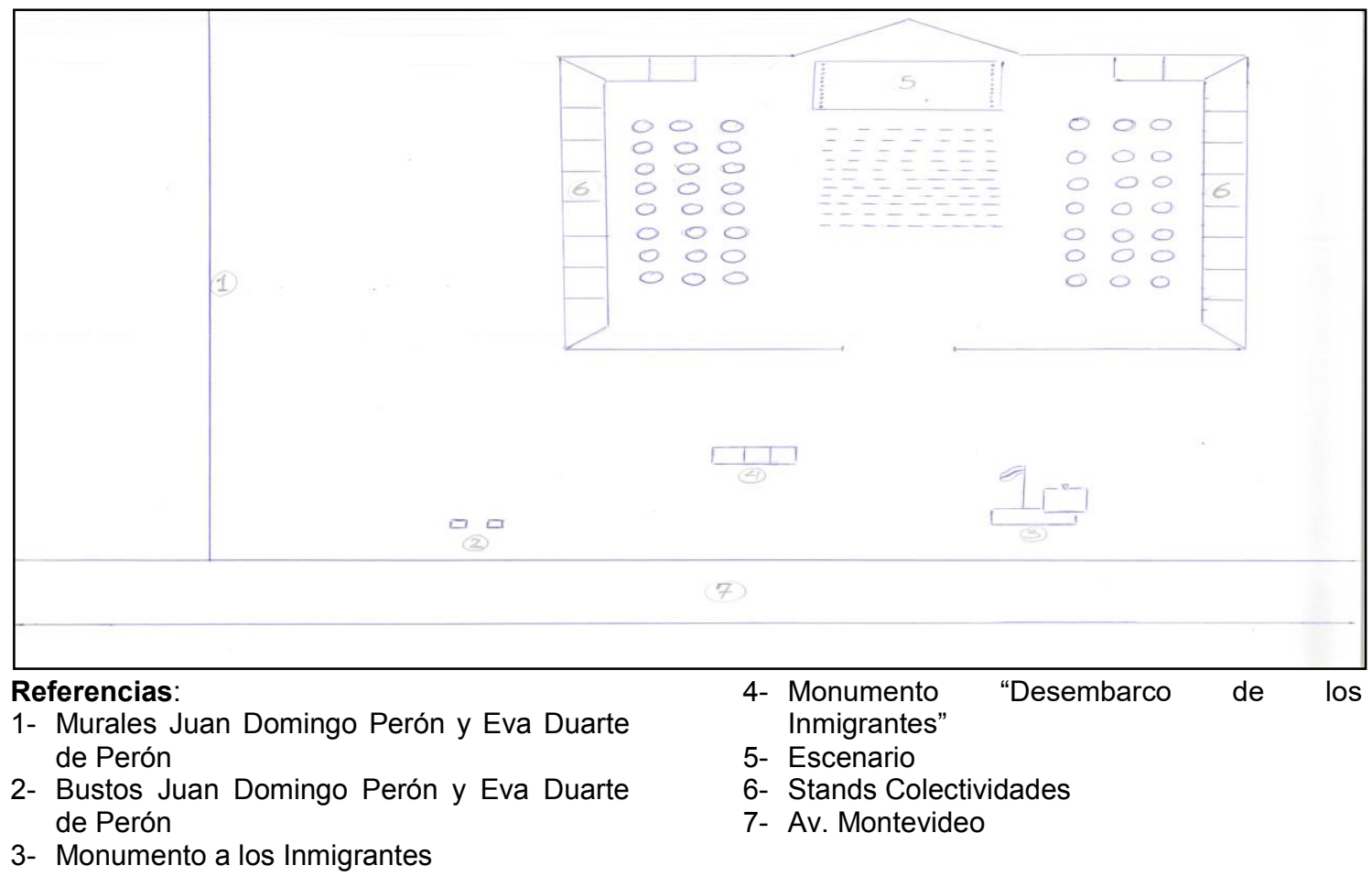

Al igual que lo señalado por Irazuzta (2001) en su estudio sobre el Encuentro de las Colectividades de la ciudad de Rosario encontramos que tanto la disposición espacial al interior de la Carpa, como las prácticas que los sujetos de la celebración desarrollan en ella y la simbología circulante, habilitan el cruce entre dinámicas de distinción y re-unificación étnica. Respecto a la dinámica de distinción los stands y el escenario son espacios donde cada colectividad distingue el origen nacional que representa y particulariza su "cultura típica". Mientras la fachada de los stands simula la arquitectura del país representado, en su interior las banderas, artesanías y fotos (con paisajes, personajes o edificios famosos) conforman un conjunto de elementos a partir de los cuales cada colectividad identifica su origen nacional distintivo. Finalmente, la representación de la "cultura típica" de cada una de las colectividades se cierra sobre cuatro diacríticos (gastronomía, música, bailes y vestimenta) expuestos en los stands y el escenario de la Carpa ante miles de personas ${ }^{156}$ (fotos $n^{0} 28-30$, 167ágs.. 171-172). Diacríticos que no solo reponen su "cultura típica" en términos folklóricos, sino que además se encuentra completamente despolitizada. Como parte de su trabajo de campo con miembros de la Colectividad Búlgara, Ballina (2006) cuenta una anécdota sumamente potente sobre este tema que merece la pena ser citada:

${ }^{156}$ La AEE informó que a la edición 2015 asistieron cerca de 140 mil personas. 
"En Berisso hemos visto fotos que conservan algunos informantes, donde se puede observar a grupos de mujeres tejiendo ropa y mantas que tenían el destino mencionado [colaborar con la campaña Ayudar a la Patria que sus connacionales, vinculados al comunismo, llevaban a cabo desde la Unión Eslava para colaborar con la URSS frente a la invasión alemana]. Estas fotos (...) se podían observar por ejemplo en el stand de la colectividad búlgara en el cierre de la XXVI Fiesta Provincial del Inmigrante. Una de esas fotos señalaba 'Conferencia eslava, Berisso, 1946'” (Ballina, 2006: 76 cursivas nuestras).

Esa foto que en otros contextos históricos habría sido conflictiva para los miembros de la colectividad -recordemos, en 1949 el Poder Ejecutivo Nacional decreta la disolución de la Unión Eslava por considerarla parte de la penetración ideológica del comunismo en nuestro país- era resignificado décadas después en el contexto festivo "como patrimonio histórico y memoria" de la colectividad.

Aquella dinámica de distinción y conformación de fronteras étnicas llegará a su punto máximo con la elección de La Reina Provincial del Inmigrante; acto que no solo es televisado por el canal local ${ }^{157}$ y reúne a un jurado compuesto por "notables de la zona"158 sino que además es fiscalizado por un escribano y animado por presentadores reconocidos a escala nacional ${ }^{159}$ (foto $n^{0} 31$, pág. 172). Como han mostrado Ballina y Ottenheimer (2006) las reinas de cada colectividad son sometidas a un proceso de selección interno donde deberán probar su filiación genealógica con el país representado y, a la vez, adscribir únicamente a dicha identificación nacional más allá de poseer (o no) ascendencia migratoria de varios países. Asimismo, en el acto en el cual se elegirá a La Reina ellas deberán demostrar que poseen conocimiento del país representado, brindar datos sobre su "cultura", desfilar con los trajes tradicionales y bailar alguna danza folklórica. En este proceso la exigencia por demostrar la "autenticidad étnica" de las participantes habilita una nueva construcción de fronteras entre las colectividades participantes.

Así, la reproducción de una concepción folklórica y despolitizada de la cultura -vía el proceso de selección de cuatro diacríticos identitarios-, la caracterización distintiva de los stands mediante la iconografía de cada país y la elección de las reinas vía la "autentificación étnica", permiten que cada colectividad se introduzca en el relato homogéneo de la nación como "alteridad" habilitada. Es importante mencionar que a dichos elementos culturales se les asigna una autenticidad que deriva más de un

\footnotetext{
157 Canal "Somos La Plata, Berisso y Ensenada".

${ }^{158}$ Entre ellos se suele invitar a historiadores y antropólogos de la UNLP.

159 Entre otros, han concurrido Ante Garmaz (durante las primeras ediciones), Tete Coustarot y Marina Calabró (durante las últimas ediciones).
} 
"proceso de interpretación que atribuye significado en el presente haciendo referencia al pasado", que de una cualidad objetiva de ese pasado (Briones, 1994:103). Y mientras la construcción de fronteras que se pone en marcha con la selección de "autenticidades étnicas" (Ballina y Ottenheimer, 2006) se encuentra basada en el cuerpo del sujeto étnico y su ligación sanguínea, la reproducción de una concepción folklórica y despolitizada de la cultura puede ser representada por sujetos "no étnicos" sin perder su supuesta autenticidad (Monkevicius, 2009: 281).

Sin embargo cada uno de los sub-espacios en los que se lleva a cabo la división/separación étnica quedan superados en un espacio donde se dramatiza la unión/fusión de todas las colectividades: mientras en el escenario las banderas de los veinte países representados se encuentran simétricamente dispuestas en torno a la bandera argentina y la pantalla que lo ilumina proyecta la frase "Berisso, puerto del mundo", en cada uno de los laterales de la Carpa se ubican diez estands formando una herradura cuyo centro aloja extensas mesas y sillas para el público (foto $\mathrm{n}^{\circ} 32 \mathrm{y}$ 33, pág.: 172). De esta manera los espacios comunitarios ante los cuales la segmentación étnica se disuelve logran construir la trama de una nueva pertenencia grupal: berissenses/argentinos. Desde aquel escenario el intendente municipal puso en palabras algunas de estas ideas:

"Esta fiesta muestra un solo tema, la historia de los berissenses; que es también la historia de nuestra argentina, la del trabajo, del esfuerzo y la tolerancia. Como vemos en este escenario, donde confluyen todas las colectividades, hermanadas, compartiendo con el público sus danzas, sus tradiciones. $Y$ ahí abajo, todas las colectividades, una al lado de la otra. Judíos y árabes; acá no importan las diferencias que en otros países los dividen. Acá lo vemos, en Berisso nos respetamos, convivimos, uno al lado del otro. Como además lo muestran ustedes [el público] ahí abajo, compartiendo la mesa con gente que minutos antes tal vez ni conocían. Esto es lo que nos dejaron nuestros antepasados y nosotros mantenemos vivo: sus tradiciones, sus culturas, sus comidas, sus bailes; pero por sobre todas las cosas la tolerancia y la convivencia en paz. Lo vemos hoy en esta fiesta. Aquellos inmigrantes se encontraron en Berisso y dieron forma a lo que somos. Somos esto. La mezcla de todo eso que cada inmigrante aportó y cada colectividad sigue manteniendo vivo. Somos esto. Los berissenses, los argentinos, somos todo esto, mezclado, pero unido." (2012).

Si afuera de la Carpa los recuerdos sobre un pasado inmigratorio y peronista dan forma a la memoria oficial de Berisso, dentro de ella el imaginario sobre la historia de la ciudad se completa en torno a la simbología del crisol de razas. Sin embargo, como marcó James (2004), aquellos recuerdos y este imaginario solo interpelan a la comunidad local si el contexto presente lo habilita. A mediados de 1995 el largo 
proceso de desindustrialización iniciado con el cierre de los frigoríficos (ver capítulo $\mathrm{N}^{\circ}$ 2) había corrido una de las bases fundamentales sobre las que se asentaban las identidades locales. La desocupación del 35\% (James, 2004: 33) había hecho que la auto-identificación berissense como pueblo trabajador entrara en crisis, y con ella el rol articulador del peronismo. Presenciando cómo algunos representantes del órgano legislativo municipal realizaban la conmemoración del 17 de octubre de 1945, James afirmaba:

"Mientras contemplaba la ceremonia desde la otra vereda de la avenida Montevideo [frente al Centro Cívico] y escuchaba los discursos de los representantes 'históricos' y la generación más joven de dirigentes como Néstor, vi al hijo mayor de éste, Emiliano, que se acercaba. Tras saludarnos señalé con un gesto la vereda de enfrente y le pregunté por qué no participaba del acto. Luego de un momento de silencio, sonrió irónicamente y encogiendo sus anchos hombros dijo: 'Esto no me dice nada'. (...) Pero el movimiento de la cabeza y los hombros con que señaló el acto al otro lado de la avenida Montevideo no sólo aludía al grupo reunido en conmemoración al 17 de octubre de 1945 frente a los bustos de Perón y Evita. Abarcaba mucho más, sospecho: virtualmente todos los símbolos y recuerdos encarnados en la plaza, incluido el pasado inmigrante de sus bisabuelos ucranianos, que llegaron en la década de 1920 para trabajar en los frigorificos.

Observaciones a partir de las cuales concluye:

"Para Emiliano y su generación de berissenses los significados del pasado aún al alcance de sus padres son cada vez más opacos por obra del cambio histórico y cultural (...) En la era de la desindustrialización y la marginación social y económica concomitante, que ha puesto fin a la trayectoria laboral de muchos viejos berissenses y condenado a numerosos integrantes de la generación de Emiliano a un futuro de trabajos temporarios en la periferia de mercados laborales muy empequeñecidos, la memoria de 17 de octubre de 1945 puede ser simplemente insostenible a largo plazo, ya que está privada de toda relevancia en el contexto social contemporáneo. Dejará de ser la memoria viva de la comunidad para quedar reducida al status formal de un hecho histórico" (James, 2004: 281-283, cursivas nuestras).

A mediados de los años '90 el paisaje de la memoria (James, 2004:18) en que algunas instituciones locales habían convertido al Centro Cívico ya no poseía la misma capacidad para interpelar a la población local. Al parecer "cada imagen del pasado que no es reconocida por el presente como una de sus propias preocupaciones amenaza con desaparecer irreversiblemente" (Benjamin, 1968). $Y$ en tal sentido, como ha señalado Achugar (2003), los mismos monumentos que han estado cargados de sentidos para una generación pueden ser completamente indiferentes para la siguiente. 
Quince años después del brillante trabajo de James nos permitimos señalar la existencia de algunos cambios en el modo en que ciertos recuerdos eran utilizados por los sujetos de la celebración para interpelar a la población local. No solo la participación de los jóvenes era abrumadoramente mayoritaria en las presentaciones de los conjuntos de danzas o la atención de los stands sino que el contexto festivo habilitaba la apelación constante, convergente y articulada entre el origen ultramarino, el pasado fabril y el vínculo constitutivo de la sociedad local con el peronismo. En tal sentido entendemos que -durante el período 2010/2015- los sujetos de la celebración reconstruyeron en contexto festivo un imaginario armónico de la comunidad local apelando a un pasado tan europeo como peronista.

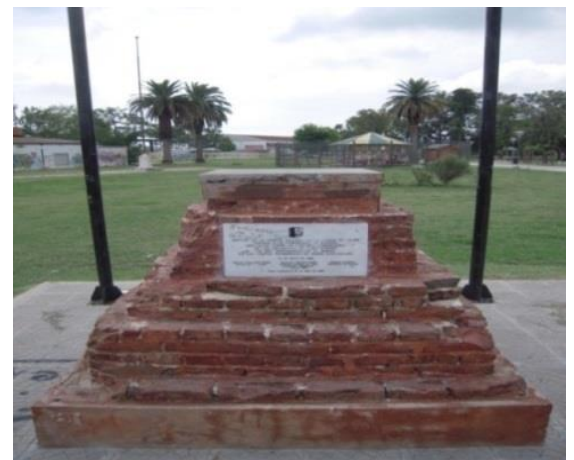

Foto No24 (2010): Cimientos de los Saladeros de Juan Berisso

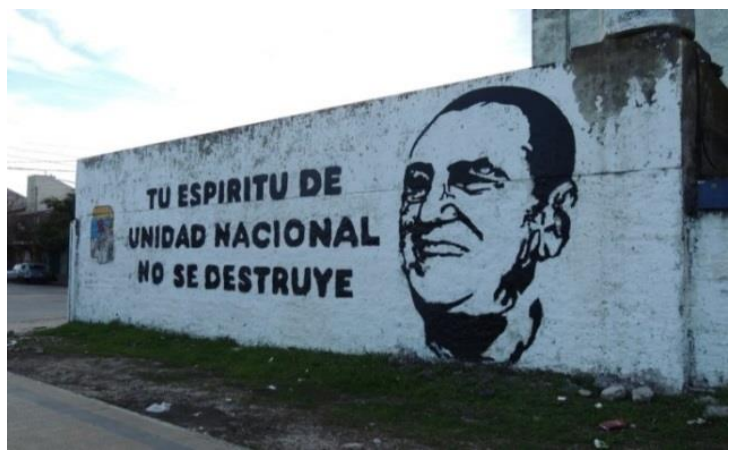

Foto N²6 (2015): Grafiti

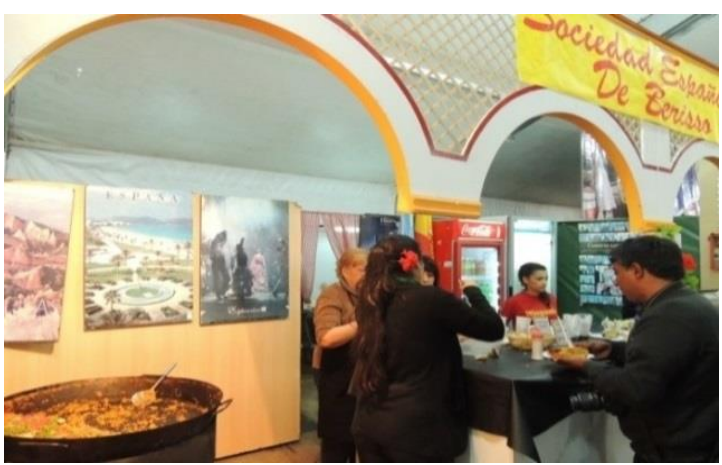

Foto N²8 (2015): Stand de la Colectividad Española

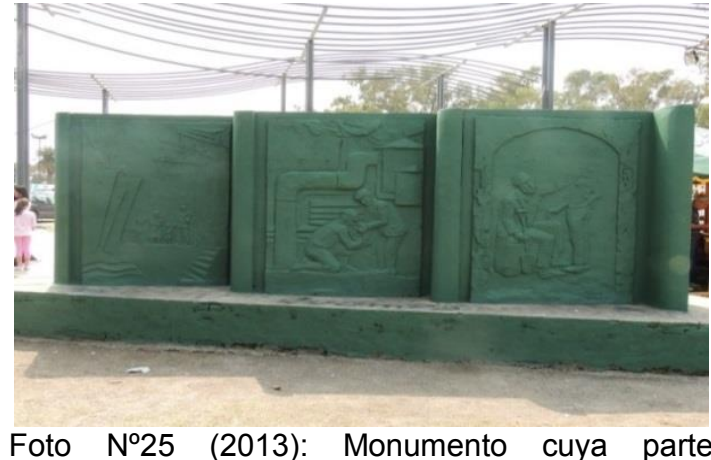
izquierda rememora la llegada de inmigrnates (en barco) a Berisso

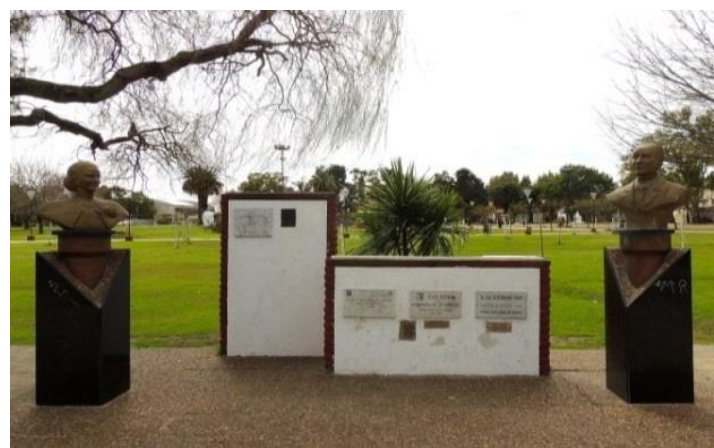

Foto $\mathrm{N}^{\circ} 27(2015)$ : bustos y placas recordatorias a Eva Durarte y Juan Domingo Perón

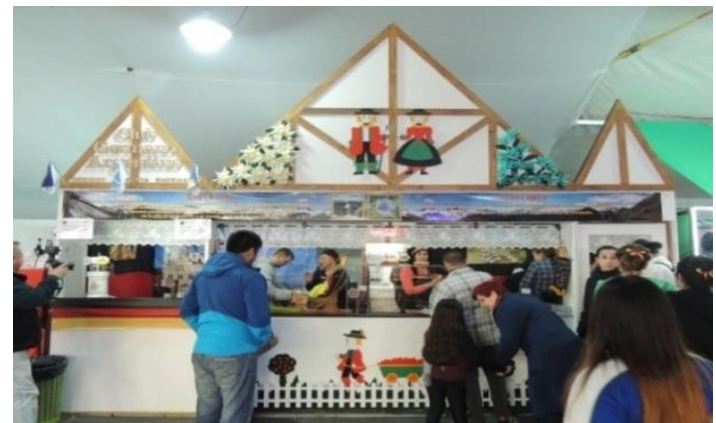

Foto N²9 (2015): Stand de la Colectividad Alemana 


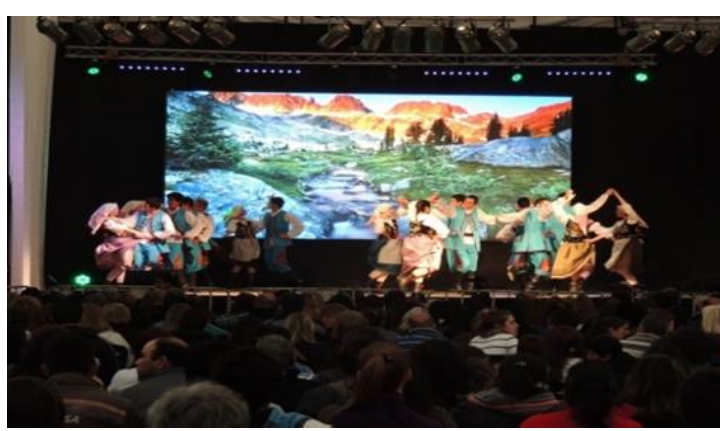

Foto N³0 (2014): Bailes tradicionales

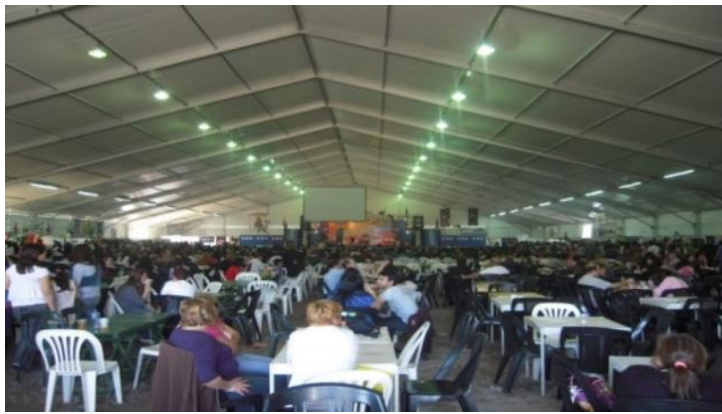

Foto N³2 (2010): Espacio común de la Carpa de las Colectividades

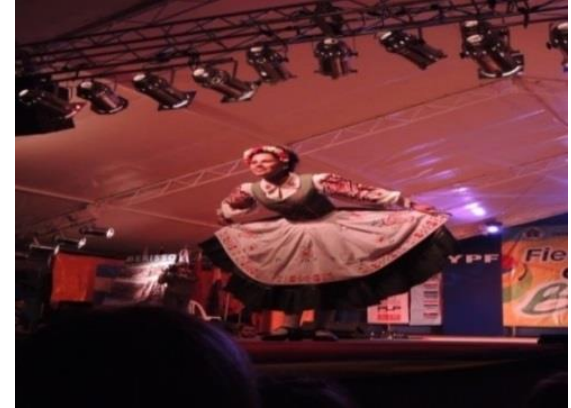

Foto N³1 (2013): Desfile durante la elección de la Reina Provincial del Inmigrante

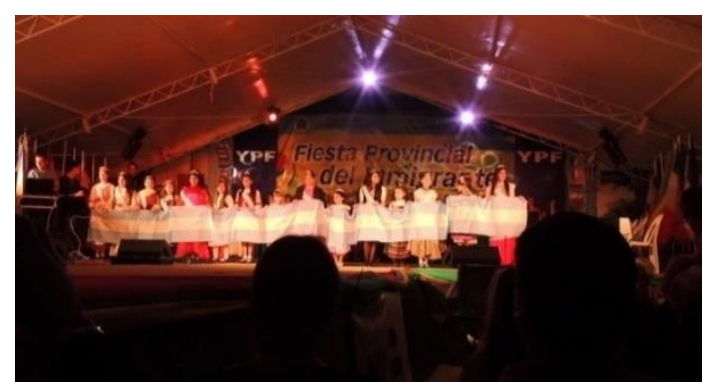

Foto $N^{\circ} 33$ (2013): Reianas de las distintas colectividades portando la bandera Argentina sobre el escenario de la Carpa

\section{Desfile de Clausura}

Luego de cinco fines de semana con actividades continuas, la Fiesta Provincial del Inmigrante llega a su fin con un Desfile de Clausura realizado sobre la Avenida Montevideo ${ }^{160}$. Vestidos con sus "trajes típicos" y al ritmo de sus bailes tradicionales los miembros de las distintas colectividades recorren la avenida central mostrando sus banderas y reinas ante un numeroso público ${ }^{161}$.

A la altura del Centro Cívico ${ }^{162}$ se monta una grada en la cual se ubican las autoridades locales y provinciales (foto $n^{\circ} 34$ pág.: 176): el intendente municipal, el presidente de la AEE, el director Provincial de Colectividades, el presidente del Consejo Deliberante, el Juez de Paz, representantes de algunas embajadas y consulados extranjeros, las autoridades de las colectividades étnicas, distintas autoridades del ejecutivo municipal y establecimientos educativos, directivos de empresas nacionales y algunos invitados especiales (los intendentes de La Plata y Ensenada, el gobernador de la Provincia de Buenos Aires, la viceministra de

\footnotetext{
160 Desde calle 16 a calle 8 .

${ }^{161}$ Este acto se realiza desde la segunda edición de la fiesta (1979).

162 Montevideo entre calles 10 y 11.
} 
Economía Bonaerense, las ministras provinciales de Desarrollo Humano y Cultura, y distintos candidatos a ocupar cargos públicos han estado presentes) ${ }^{163}$.

Al iniciar el acto el locutor manifiesta algunos de los motivos por los cuales se lo realiza y anuncia las actividades que se llevarán a cabo:

"Bienvenidos al cierre de esta nueva Fiesta Provincial del Inmigrante con el tradicional desfile sobre la avenida Montevideo; donde recordamos, una vez más, la historia que nos dejaron nuestros antepasados mediante el recorrido que cada colectividad hará aquí luciendo sus trajes típicos, sus banderas y reinas, mientras bailan sus danzas típicas." (2015).

Antes de escuchar los discursos de algunas autoridades locales y provinciales se entonan nuevamente el Himno Nacional Argentino y el Himno a Berisso. Posteriormente el presidente de la AEE, alguno de los invitados especiales y el intendente municipal llevan a cabo pequeños discursos. En la edición 2010 el presidente de la $A E E$ recordó el motivo que había dado origen a la fiesta con las siguientes palabras:

"Hace poco más de 33 años atrás, un grupo de colectividades se reunieron para conformar la Asociación de Entidades Extranjeras. Se unió...un poco la idea fue... Berisso estaba mal, Berisso estaba triste. Habían cerrado los frigoríficos. Berisso se había quedado sin trabajo (...) Esos representantes de las colectividades llevaron adelante la fiesta para enfrentar lo que nos estaba pasando".

Y mencionó que las colectividades debían estar

"orgullosas por mantener nuestras raíces, nuestro... de dónde venimos, de los países europeos, de muy lejos. Mucha gente que vino acá a forjar Berisso, mucha gente que vino a forjar nuestra nación."

Quien lo sucedió en el cargo mencionó al año siguiente que cada edición de la fiesta no solo permitía "mantener vivas nuestras raíces culturales" sino que además es

"una manera de recordar a nuestros abuelos, a aquellos que formaron ese Berisso que tanto quisieron. Con esta fiesta (...) recordamos a cada uno de ellos por ser quienes crearon las bases de nuestra sociedad." (2011).

163 La fecha en la que se realiza la fiesta (septiembre-octubre) coincide con el cierre de distintas campañas electorales. En tal sentido el cierre de la fiesta se vuelve un momento propicio para los cierres de estas campañas. 
Por su parte los invitados especiales suelen hacer mención a la historia fabril de la ciudad, su vínculo con el surgimiento del peronismo y reproducir el relato mítico sobre el (supuesto) origen foráneo, ultramarino, de nuestra nacionalidad. Así el Director Provincial de Colectividades de la Provincia de Bs. As. dijo:

"yo hablo siempre de aquello que hablaba el General Perón, del trasvasamiento generacional. Como hoy vemos en las colectividades, donde la colectividad puede unir a un bisabuelo, al abuelo, a los padres y a los nietos. Todos en un mismo trabajo conjunto, defendiendo las raíces, defendiendo la cultura (...) Yo solamente quiero manifestarles mi orgullo de estar acá en Berisso, tierra histórica, tierra emblemática: la tierra del 17 de octubre desde donde partieron aquellas columnas de obreros en 1945". (2010).

De la misma manera el Intendente de La Plata recordó al año siguiente que

"Berisso ha sido la capital del trabajo, ha sido la capital de la industria, ha sido la capital de los hechos políticos más importantes de la historia de la República Argentina [en referencia al 17 de octubre de 1945] (...) Miles de argentinos en estas calles tributan honor a la historia inmigratoria de la Argentina, que es ni más ni menos, la historia del pueblo argentino. Nos han traído desde los barcos la cultura del trabajo, del amor, de la solidaridad, la cultura de la unidad familiar y fundamentalmente la del amor a la patria." (2011).

Por último, y antes de dar inicio al desfile de las colectividades, el intendente de Berisso brindó su discurso reiterando que este acto

"tiene que ver con nuestra historia. Con acordarnos de ese pasado. Honrar la memoria de gente como mi abuela que vino escondida en un barco por la guerra, a esta ciudad que era la ciudad que permitía encontrarse, prestarse una taza de azúcar por el alambrado, cuidarle los pibes a alguien cuando se iba al hospital o hacer un trámite. Este acto tiene que ver con esos sueños traídos de Europa corridos por la guerra y el hambre, como dice nuestro himno (...). La Argentina era ese lugar, y Berisso precisamente en el esplendor e inicios del siglo $X X$ con los frigoríficos daba esas oportunidades (...). La historia de los inmigrantes es una historia de lucha, una historia de trabajo, historias que marcaron definitivamente nuestra ciudad (...). Esta es la fiesta del espíritu, de la esencia de aquel sacrificio de los inmigrantes llegados a la Argentina para hacerla grande. Pero que también es una historia de alegría, como vemos en los nombres de nuestras calles, Unión, Perseverancia, Porvenir, Progreso, Industria (...). Y así hoy festejamos en esta avenida Montevideo la libertad de haber logrado los sueños de nuestros abuelos." (2014).

Una vez finalizados estos discursos se da lugar al desfile de las veinte colectividades (fotos $n^{\circ} 35-37$, pág.: 176). Encabezados por la nueva Reina Provincial 
del inmigrante ${ }^{164}$ y una abanderada que porta la insignia argentina, los miembros de cada colectividad avanzan ordenadamente por la avenida Montevideo. De fondo se escucha al locutor mencionar algunos datos históricos sobre el país representado, los motivos o períodos en que se produjo su migración hacia la Argentina y una breve descripción sobre "su cultura" que se cierra con un "Gracias inmigrantes, gracias a todos ustedes por pasear hoy la historia y la cultura de sus antepasados. La historia de Berisso. La historia y la cultura de este hermoso crisol de razas que es la Argentina" (2015).

La Fiesta Provincial del Inmigrante -tal como empezó- se cierra con un acto donde sus actores hacen mención a que allí se recuerda la historia de la inmigración que llegó desde Europa para forjar a Berisso (en particular) y a la Argentina (en general). En este acto, como en los anteriores, sus actores manifiestan estar honrando la memoria de quienes al sentar las bases de nuestra sociedad construyeron un armónico crisol de razas en el cual conviven todas las diferencias. Estos actores no solo hacen mención a dichos motivos mediante sus discursos sino que sus prácticas remiten a dichas ideas: luego de entonar el Himno Nacional y el Himno de Berisso las colectividades desfilan unificadamente detrás de la bandera Argentina mostrando algunos de los elementos a partir de los cuales construyen la representación de su "cultura típica". A la vez los tópicos con los que elaboran el imaginario berissense (inmigración europea, trabajo, solidad, amor por la patria, etc.) aparecen relacionados a un vínculo parental donde la referencia a los antepasados, abuelos y padres se vuelve recurrente. Así, la sociedad berissense es presentada como una gran familia que -en contexto festivo- actualiza un deber moral: recordar a quienes forjaron sus bases.

Finalmente, un lugar destacado vuelve a adquirir el peronismo en los recuerdos de algunos actores institucionales. Para ellos Berisso no solo es la capital del inmigrante sino la capital de la industria y los hechos políticos más importantes de la historia Argentina: el 17 de octubre de 1945 y su movilización obrera aparecieron en las ediciones 2010-2015 de la fiesta ligados a la inmigración europea. La presencia simultánea de ambas matrices identitarias puede sonar extraña si recordamos: $1^{\circ}$ ) las tensiones entre adscripciones étnicas y adscripciones políticas existentes a nivel local hasta mediados del siglo XX (ver cap. $\mathrm{N}^{\circ} 2$ ), $2^{\circ}$ ) la hipótesis de Lobato (2004) respecto a la capacidad que tuvo la fiesta en contexto dictatorial para silenciar los elementos de la historia local que la unían con el peronismo (ver cap. №3), y $3^{\circ}$ ) la afirmación de

\footnotetext{
${ }^{164}$ Elegida durante el último evento que se desarrolla en la Carpa de las Colectividades, la noche previa al Desfile
} 
James (2004) en torno a que en 1995 la identificación étnica y la identificación política habían entrado en una crisis. A la luz de lo descripto es importante afirmar el carácter coyuntural con el que se redefinen y activan ambas matrices identitarias a nivel local: en un contexto signado por cierta reactivación económica y la revitalización del peronismo como fuerza política, durante los años en que realizamos nuestro trabajo de campo la fiesta habilitó un espacio donde convergieron -sin dejar de estar tensionadas- aquellas matrices que en el pasado se habían presentado bajo la forma de una mutua exclusión.

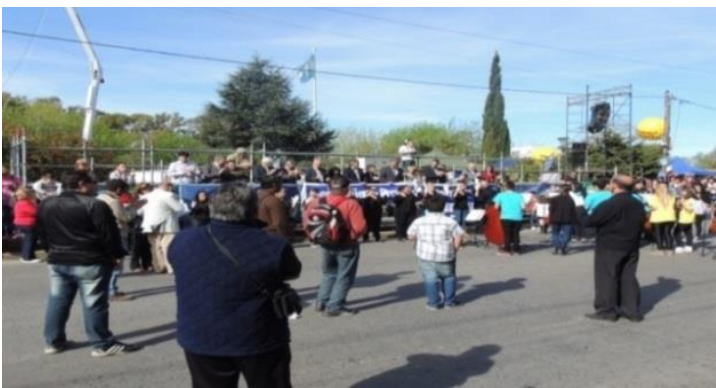

Foto N³4 (2015): Autoridades locales

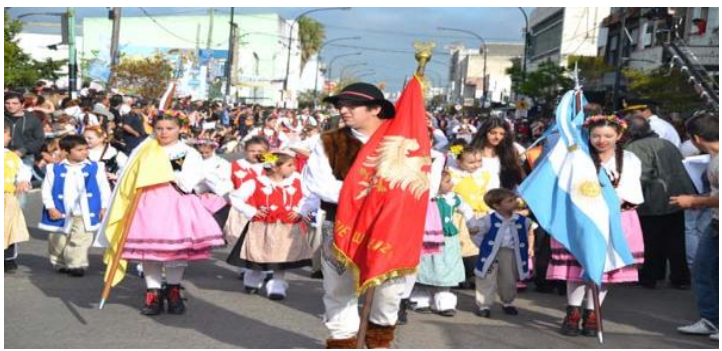

Foto N³6 (2013): Desfile de las Colectividades

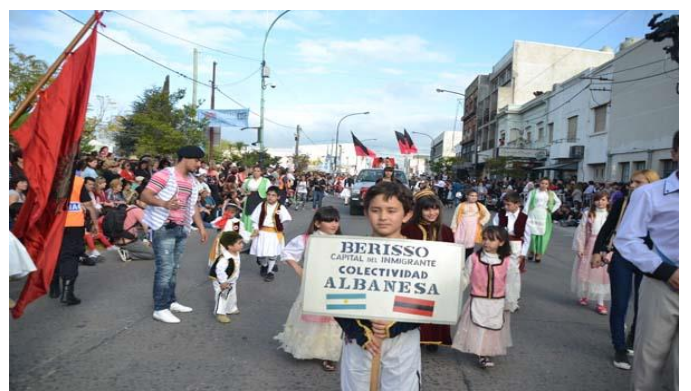

Foto N³5 (2013): Desfile de las Colectividades

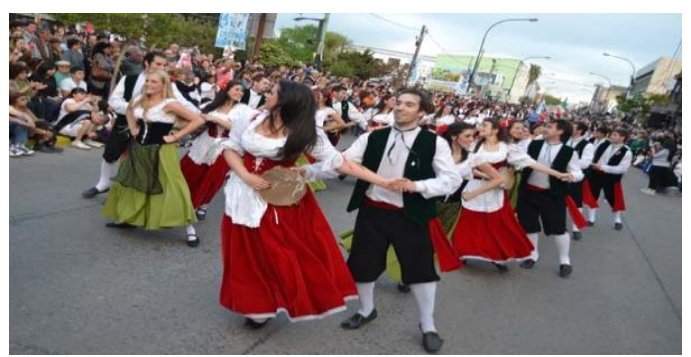

Foto N³7 (2014): Desfile de las Colectividades

\section{Reflexiones finales}

A lo largo de este capítulo describimos y analizamos las prácticas y discursos orales que desarrollaron los sujetos de la celebración en la Fiesta Provincial del Inmigrante (2010-2015). Esto nos permitió comprender el modo en que estos actores (autorizados y con poder) construyen un imaginario sobre la comunidad berissense seleccionando, fijando y representando una memoria oficial vinculada (centralmente) al supuesto origen europeo de su población y (subsidiariamente) al papel que ella habría jugado en los orígenes del peronismo.

Prácticas y discursos que no se desarrollan en el vacío sino, justamente, en contexto festivo: debido a su carácter simbólico y su capacidad para dramatizar significaciones sociales (Da Matta, 2002) este ritual conmemorativo se vuelve una estructura de comunicación a partir de la cual los sujetos de la celebración trasmiten un conjunto de valores, imágenes y narrativas fundamentales para la construcción de 
su propia legitimidad (Riviére, 1988; Kertzer, 1988; Balandier, 1994; Moore y Myerhoff, 1997; Segura, 2000). Como vimos en la primera parte de la tesis, este dispositivo pedagógico (Ortemberg, 2013) se vuelve central para que los sujetos de la celebración reproduzcan un mito de origen, un linaje, un panteón de figuras icónicas o monumentalizadas (Duvignaud, 1989) que los coloca en el centro de la historia local. Formas de ordenar y construir sentidos sobre el pasado que están orientadas por los proyectos que cada actor posee en el presente (Ansaldi, 1996; Jaume, 2000; Jelin, 2002b; Cattaruzza, 2007).

En este marco la representación y transmisión intergeneracional del pasado nos permitió acercarnos a la dimensión intersubjetiva de las memorias colectivas y describir cómo los miembros de las asociaciones étnicas dramatizan un conjunto de significaciones sociales ligadas al mito del crisol de razas -creado por la elite intelectual del siglo XIX (ver capítulo №1)- a través de las cuales representan a la comunidad como una entidad unida, solidaria, homogénea y armónica, conformada por flujos migratorios provenientes desde Europa. Como señalaron Irazuzta (2001) y Freidenberg (2013) para el caso de Rosario y Villa Clara, la reposición del mito del crisol de razas y la vinculación de la historia de Berisso con la historia Argentina no solo habilita un contexto donde actualizar un relato de origen, sino que además permite que los miembros de las asociaciones étnicas construyan reconocimiento y legitimidad social. Al instaurarse como únicos herederos de aquellos "héroes que fundaron la comunidad" -poseedores y garantes de sus virtudes morales- los descendientes de inmigrantes ultramarinos se sitúan en un lugar de enorme relevancia en el contexto local. El vínculo familiar -en especial el lazo sanguíneo, genético- que uniría a estos actores con una de las figuras míticas de la memoria local (los héroes, fundadores, pioneros, creadores de la sociedad berissense) les permite posicionarse en un lugar de prestigio y legitimidad. Vínculo que no solo une a quienes poseen el lazo sanguíneo sino que además construye un límite de exclusión con quienes no lo poseerían. Y en tal sentido, como ha señalado Jelin (2017: 195), el familismo designa y empodera a aquellas voces que serán autorizadas para narrar su versión del pasado en la esfera pública.

Por otra parte, respecto a la centralidad que adquieren los sujetos de la celebración durante la fiesta, es importante subrayar que su ubicación en el espacio y la monopolización de los discursos (indicada en todos los actos y graficada en los mapas) muestran posiciones diferenciadas que se corresponderían con situaciones de privilegio y segmentación social. La delimitación/ocupación del espacio (Monkevicius, 
2009) y la monopolización discursiva (Bourdieu, 2001b) son elementos que permiten distinguir, jerarquiza y legitimar a dichos actores.

Asimismo analizamos la dinámica a partir de la cual ciertas alteridades son contenidas y legitimadas estatalmente dentro de aquel mito acrisolado: la selección de diacríticos culturales folklorizados y no politizados que realizan las asociaciones étnicas locales permite que el Estado las interpele y legitime en clave nacional-culturalfolklorizante (Caggiano, 2004; Monkevicius, 2009). Si históricamente el Estado ha buscado generar unidad y homogeneidad en su población, la construcción identitaria que continúan llevando a cabo los descendientes de inmigrantes dispone que la referencia a la patria de origen de sus ancestros -como estructura política- quede relegada ante la selección de diacríticos culturales no politizados (gastronomía, vestidos y danzas "tradicionales") (Bodnar, 1992). De esta manera, y leído desde el presente, el aporte de los inmigrantes queda reducido a un nivel cultural que clausura cualquier debate sobre su rol en la construcción política de la Nación (Maffia, Ballina y Monkevicius, 2005).

Paralelamente vimos cómo la apelación a un conjunto de recuerdos sobre la historia fabril de Berisso habilita un marco de identificación con los orígenes locales del peronismo. El Desembarco se lleva a cabo en un espacio cuya puerta de ingreso se encuentra rodeada por bustos de Juan Domingo Perón, Eva Duarte y placas que definen a la ciudad como "Capital del Peronismo", recordando que desde allí partieron las columnas obreras que liberaron a Perón "en su glorioso 17 de Octubre". Asimismo la Carpa de las Colectividades se monta sobre un espacio cargado de simbología peronista: bustos de Eva Duarte y Juan Domingo Perón se mezclan en el Centro Cívico con murales que poseen imágenes y frases de la iconografía peronista. Estos recuerdos no quedan solamente fijados en dichas marcas territoriales sino que además circulan a través de distintos discursos orales: mientras el intendente recordaba que los "inmigrantes europeos" llegados en el período de entre-siglo "lograron quedar en la historia de la Argentina con aquel 17 de octubre del 45", los invitados especiales señalaban su orgullo de estar en "la tierra del 17 de octubre desde donde partieron aquellas columnas de obreros en 1945".

Cabe mencionar que estos recuerdos sobre el 17 de octubre y los orígenes del peronismo se encuentran rodeados por un aura de armonía que, en su reverso, silencia la existencia de cualquier hecho de violencia ocurrido durante esa jornada. Esta situación es algo que James y Wolfson (1987) ya habían señalado en un trabajo elaborado a partir de los testimonios de ex trabajadores y militantes berissenses que 
participaron del 17 de Octubre. Los "silencios, supresiones, amnesias y tabúes"165 sobre los hechos de violencia realizados por los obreros contra algunas de las instituciones ubicadas en el centro de La Plata son notorios (ver capítulo №2). Silencios que se producen, justamente, porque toda lectura del pasado se realiza desde el presente: en una ciudad donde la armonía y el peronismo se vuelven ejes centrales a través de los cuales reconstruir un imaginario sobre la comunidad local, los recuerdos sobre aquella jornada mítica deben olvidar cualquier hecho de violencia. Así, coincidimos plenamente con James y Wolfson cuando señalan (siguiendo a Bosi, 1979) que

"la memoria no es nunca, pues, una evocación pura y espontanea de los hechos o experiencias del pasado, tal como realmente sucedieron o como originalmente se los vivenció: implica un proceso permanente de elaboración y reelaboración de esos sucesos. Y esto es válido, sobre todo, con respecto a la rememoración de acontecimientos que tuvieron importancia pública y política" (James y Wolfson, 1987: 452).

Es importante mencionar que, de manera recurrente en el tiempo ${ }^{166}$ y en base a un conjunto de acciones ordenadas (Moore y Myerhoff, 1977; Riviera, 1988) los sujetos de la celebración repitieron en la fiesta una idea rectora: "Berisso es un pueblo que no olvida su pasado, su historia, sus raíces". Es ella la que permite "ir haciendo memoria, recordar quiénes somos, hacer que esto no se pierda; mantener vivas nuestras raíces (recordándolas, reviviéndolas, recreándolas); honrar y rememorar nuestra historia mostrando la esencia que nos caracteriza". En tal sentido entendemos que la selección y usos del pasado realizadas por estos actores no solo busca salvaguardar la fisonomía moral de la comunidad sino además reconstruir una identificación colectiva que la articula y dota de unidad ante la amenaza del olvido (Schwartz, 1992; Connerton, 1993; Zerubavel, 2007; Monkevicius, 2009). Pero a la vez, si el ritual produce y trasmite un conjunto de significaciones sociales (Geertz, $2006^{a}$ ), es porque se encuentra inserto dentro de una trama cultural que habilita esa dinámica: dicho de otra forma, la interpretación de aquellos símbolos rituales solo es posible si se los sitúa en el contexto donde adquieren plena significación (Turner, 2008). Así, entendemos que tanto la historia inmigratoria y fabril de Berisso como los procesos de identificación étnica y política que se dieron en ella a lo largo del siglo XX (ver capítulo $\mathrm{N}^{\circ} 2$ ) forman parte de la trama cultural a partir del cual la apelación a la

\footnotetext{
165 Popular Memory Group (1982: 217, citado en James y Wolfson, 1987:452).

166 Esta característica no solo se vuelve evidente en la estructura interna de los actos analizados, sino que la organización del calendario festivo entre 2010 y 2015 muestra la misma estructura.
} 
simbología del crisol de razas y el peronismo adquieren sentido (y son resignificados) en contexto festivo.

En esta misma línea quisiéramos, finalmente, hacer una breve reflexión metodológica. A lo largo del capítulo utilizado un conjunto de notas de campo, mapas, fotos y testimonios que pertenecen a distintos años, construyendo una narración unificada que podría ser criticada por "carecer de historicidad". Sin embargo sabemos que la dramatización ritualizada de cualquier mito de origen no es estática y que toda reproducción de la cultura implica, en sí misma, una alteración (Sahlins, 1988). En tal sentido entendemos que no hubo ausencia de historicidad durante el desarrollo del ritual conmemorativo, sino que los acontecimientos "nuevos" quedaban completamente insertos en estructuras de sentido preexistentes; ancladas en una simbología que entre los años 2010 y 2015 remitió a los mismos mitos de origen. Algo idéntico podría decirse respecto a los actores: ¿Importa señalar el nombre de tal o cual actor, cuando en líneas generales todos ellos apelaban a los mismos recuerdos y bajo formas argumentales similares? Así, y si bien a lo largo del capítulo indicamos las fechas de cada registro y los nombres de quienes emitían públicamente sus discursos, nos parece fundamental señalar que esos datos son secundarios respecto al análisis del rol que ocupa el pasado en la reproducción de un imaginario sobre la comunidad berissense en la Fiesta Provincial del Inmigrante.

Si en este capítulo analizamos las prácticas a través de las cuales se reproducen los elementos simbólicos de la estructuración social (sus ordenamientos jerárquicos y dinámicas de legitimación mediante el uso de la memoria oficial), en el capítulo siguiente nos dedicaremos a mostrar que dicha reproducción se da a la par de un conjunto de conflictos, silencios y disputas. Así, en el capítulo siguiente completamos la lectura de la Fiesta Provincial del Inmigrante poniendo en primer plano la dimensión opuesta a la que privilegiamos analíticamente en este. Dándole un lugar central a los actores y su capacidad de agencia. 


\section{Excurso No 1: El Aniversario de Berisso}

"En la disputa por la definición de fechas, símbolos y ceremonias conmemorativas es donde comienza a figurarse el carácter culturalmente arbitrario, histórico, social y políticamente construido de la nación" (da

Silva Catela, 2001)

Como expusimos en el segundo capítulo, la ciudad de Berisso logró su autonomía plena el 3 de abril de 1957, cuando se separó administrativamente de La Plata. Asimismo mencionamos que ella no adoptó su nombre en honor al apellido de quien fuera el primer representante institucional del partido al cual perteneció hasta lograr su autonomía, sino al de su hermano, el empresario italiano Juan Berisso. Esto se debió a que fue él quien inauguró la historia fabril de la ciudad -un 24 de junio de 1871- al poner en funcionamiento el primer saladero local.

A fines del siglo $X X$ estos hechos, fechas y personajes fueron parte de un cambio fundamental en las prácticas conmemorativas de la ciudad. Hasta el año 1998 la Municipalidad de Berisso disponía que su Aniversario se festeje el 3 de abril, conmemorando la fecha en la cual había logrado su autonomía. Sin embargo el 11 de diciembre de 1998 (luego de un breve debate en el Concejo Deliberante) se promulgó la Ordenanza № 2247 que declara "padre fundador de la ciudad" a Juan Berisso y traslada el festejo de su aniversario al 24 de junio, conmemorando la fecha en la que comenzó a operar su saladero. Si durante el Centenario de la Argentina la decisión sobre qué fecha debía ser conmemorada implicó una definición sobre el pasado y el presente de la nacionalidad (Cattaruzza, 2007: 31), el traslado del "origen" de Berisso hacia un pasado más remoto no solo implicó un cambio fundamental en los sentidos de la conmemoración sino también en los actores que ella empodera: se pasó de conmemorar un origen administrativo a conmemorar un origen industrial, donde el centro de la escena lo ocupa un inmigrante europeo (italiano).

En 2012, al festejarse el $141^{\circ}$ aniversario del (nuevo) origen de Berisso, uno de los concejales que redactaron aquella ordenanza afirmó:

"Recién hace unos años se acordó poner una fecha para conmemorar la fundación de la ciudad (...). Se eligió el día en que comienza a operar el saladero San Juan. Obviamente es una designación simbólica, pero que ya fue aceptada por la gente de la ciudad y forma parte de su calendario de celebraciones, representándola e 
identificándola tanto como un documento de identidad. Esta fecha es parte de su fisonomía tanto como la Fiesta del Inmigrante." 167

El vínculo entre la fecha en que se conmemora el aniversario de la ciudad y su historia inmigratoria no solo se evidencia a partir del origen nacional de su "padre fundador" -o en menciones a la fiesta como la anteriormente expuesta-, sino que se plasma en la elección del espacio social donde se realiza la conmemoración y en las prácticas que se desarrollan en él. Así, por ejemplo, la conmemoración del $143^{\circ}$ aniversario de la ciudad (2014) se realizó en "La Curva de las Naciones"168 inaugurando un monumento denominado "Banderoteca". Un sitio que a diferencia de los lugares de memoria denominados "auténticos", por el hecho de haber sido aquellos donde ocurrieron los hechos narrados (como el Puerto durante el acto del Desembarco Simbólico), puede ser calificado de "artificial": un sitio de memoria expresamente construido con fines conmemorativos. Allí el subsecretario municipal de Planificación y Gestión de Obra Pública -acompañado por los representantes de las colectividades étnicas, el presidente de la AEE, el Director Provincial de Colectividades, el Director de Colectividades Extranjeras de Berisso, la Reina Provincial del Inmigrante (y sus acompañantes), el intendente municipal y otras autoridades locales ${ }^{169}$; dio inicio al acto describiendo el monumento con los siguientes términos:

"La obra presenta dos líneas de mástiles separados por una fuente que simboliza el océano. Es una obra que simboliza el espíritu inmigrante de la ciudad, que tiene que ver con la historia de cada uno de los berissenses".

Luego de que los abanderados de cada colectividad izaran las insignias de los países representados -y lo mismo sucediera con las banderas de Berisso ${ }^{170}$, Buenos Aires y la Argentina- se procedió a entonar las estrofas del Himno Nacional Argentino y

167 Dr. Oscar Alcoba, en "El Mundo de Berisso", edición del 22 al 28 de junio del 2012, resaltados nuestros.

${ }^{168}$ Camino de ingreso a la ciudad, ubicado en Avenida Génova y calle 151.

169 Nos referimos a los representantes de la Prefectura y la Escuela Naval Militar, los representantes religiosos de la comunidad musulmana, un rabino por la comunidad judía, el pastor de la Iglesia Bautista y el párroco de la Iglesia María Auxiliadora.

170 Tanto la Bandera de Berisso como su Escudo portan una enorme carga iconográfica que muestra los símbolos a través de los cuales la ciudad se representa a sí misma. La Bandera tiene en su centro un barco y una chimenea, "símbolos de la afluencia de los inmigrantes" y aquellos frigoríficos que se volvieron una de las principales "fuentes laborales para la mano de obra extranjera". Por su parte el Escudo posee una chimenea "que hace referencia a la actividad fabril que se desarrolló durante años en la ciudad" y cinco líneas onduladas en blanco que "hacen referencia de una ciudad ribereña"; siendo su forma rectangular y su partición "atípicas a todos los escudos de distintas nacionalidades debido a que Berisso es un verdadero crisol de razas". Fuente: http://www.berisso.gov.ar/historia.php Para una descripción detallada de estas insignias, ver Anexo № 6"Bandera y Escudo de Berisso". 
el Himno de Berisso (fotos $n^{\circ} 38$ y 39, pág.: 183). Finalmente, luego de que los representantes de distintas religiones dejaran un mensaje de paz, el intendente de Berisso cerró el acto manifestando:

"En cada una de estas banderas que hoy enarbolamos hay un sueño. El sueño de los abuelos que vinieron en búsqueda de un lugar que no conocían y en el que establecieron sus familias y criaron a sus hijos; en el que buscaron lugares para reunirse y mantener viva su cultura. Hoy recordamos el desarraigo y esos sacrificios para entender a nuestra ciudad, que es distinta a otras, con nuestro Puerto que nos marca definitivamente como una sociedad de integración y tolerancia".

Tal y como señala Jelin (2017: 157), en "la medida en que existen diferentes interpretaciones sociales del pasado, las fechas de conmemoración pública están sujetas a conflictos y debates. ¿Qué fecha conmemorar? O mejor dicho, ¿quién quiere conmemorar qué?" Como dijimos anteriormente, este pasaje -desde la conmemoración de un origen administrativo a la conmemoración de un origen fabril e inmigratorioilumina un cambio fundamental en las dinámicas conmemorativas de la ciudad en el cual la etnicidad adquiere progresivamente mayor importancia. De hecho mientras en el año 2009 aún se conmemoraba el aniversario de Berisso con un acto realizado sobre el Centro Cívico -junto al monumento que recuerda que allí estuvo emplazado el saladero de Juan Berisso, rodeado de simbología que vincula el origen de la ciudad con el trabajo y la solidaridad (lucci, 2012)-, en 2014 dicha conmemoración comenzó a festejarse sobre "La Curva de las Naciones" y la "Banderoteca" con un acto que vincula el origen de la ciudad con la inmigración ultramarina. Si todo calendario oficial es un espacio en disputa que permite traer el pasado al presente, el cambio de fechas aquí narrado nos recuerda que las preguntas por el origen -dónde está, cuál es, qué sentidos porta, cómo conmemorarlo- se responden y disputan únicamente desde el presente.

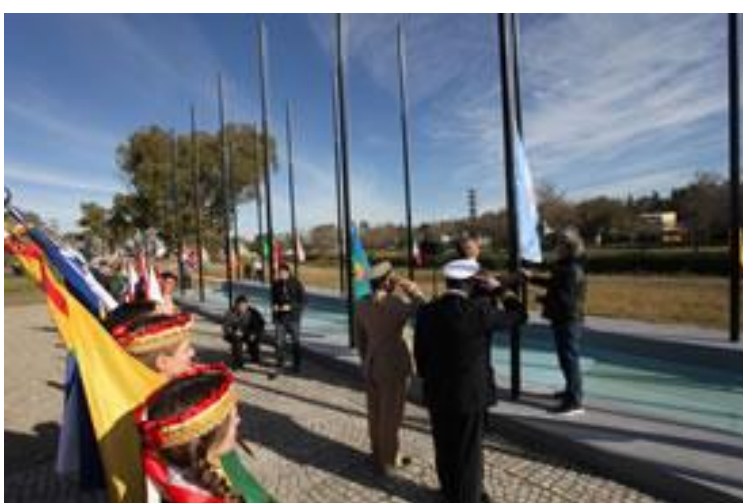

Foto $\mathrm{N}^{\circ} 38$ (2014): Izamiento

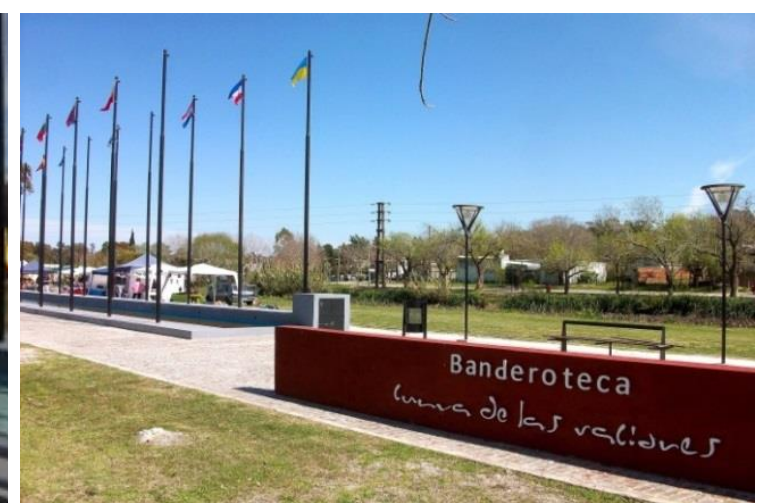

Foto N 39 (2015): Banderoteca 


\section{Capítulo $\mathbf{N}^{\circ} 6$}

\section{La Fiesta Provincial del Inmigrante (2010-2015): disputas, exclusiones y conflictos}

"Las actividades que se llevan a cabo ¿son conmemoraciones de acontecimientos pasados o vehículos de una lucha política coyuntural?" Jelin (2002b)

Luego de haber analizado las prácticas y discursos orales a través de los cuales los descendientes de inmigrantes ultramarinos reunidos en las asociaciones étnicas locales y los representantes de la intendencia municipal reconstruyeron anualmente un imaginario armónico, acrisolado y peronista sobre la comunidad berissense reproduciendo los elementos simbólicos de su estructuración social mediante el uso de la memoria oficial- en este capítulo llevamos a cabo un análisis de las disputas, silencios y conflictos que se expresaron en la Fiesta Provincial del Inmigrante (20102015). A partir del material empírico elaborado durante nuestro trabajo de campo, buscamos completar una descripción de la fiesta que dé cuenta de las dimensiones analíticas inherentes a la perspectiva teórica asumida: aquella que alejándose de posturas dicotómicas pretende comprender, en un mismo contexto festivo, el modo en que actores plenamente reflexivos conjugan de manera simultánea un conjunto de prácticas tendientes a la reproducción y al cambio social. Así, mostraremos cómo esta fiesta no constituye un mero dispositivo a través del cual se reproducen las diferencias culturales ni un momento donde las mismas quedan completamente subvertidas, sino un contexto de permanentes disputas.

Para realizar esta tarea nos centramos en las disputas por la visibilidad étnica que desarrollan los descendientes de inmigrantes africanos nucleados en la asociación caboverdeana de Ensenada y los conflictos desatados a partir de la negativa de los organizadores de la fiesta para permitirles el ingreso a las asociaciones que reúnen a los inmigrantes latinoamericanos. Ambos actores, a través de distintas prácticas y discursos, cuestionan los fundamentos (blancos/europeístas) del mito del crisol de razas a través del cual la comunidad era representada en la fiesta. Subsidiariamente presentamos algunos materiales de campo sobre los conflictos que generó la irrupción en el contexto festivo de distintos partidos políticos y movimientos sociales que 
cuestionaron la legitimidad de una gestión municipal que estaba a cargo del peronismo ${ }^{171}$.

\section{Disputas: caboverdeanos}

Los contextos festivos en los cuales participan los descendientes de inmigrantes africanos se han constituido (a lo largo de toda Latinoamérica) en un objeto de estudio privilegiado a la hora de analizar los procesos de identificación afro, las disputas por la visibilidad étnica que desarrollan dichos actores y la emergencia de sus memorias (Ardito, 2014). En la Argentina estos procesos comenzaron a volverse notorios a mediados de los años '90 cuando diversas corrientes multiculturalistas pusieron en crisis el imaginario acrisolado (blanco y europeo) a través del cual nuestra sociedad se autorepresentaba. Así, la crisis de aquel imaginario habilitó una estructura de oportunidades (Frigerio y Lamborghini, 2011) para que los inmigrantes africanos y sus descendientes disputen visibilidad étnica y reconocimiento social en la esfera pública, haciendo emerger sus memorias subalternas. En diálogo con estos trabajos, a continuación analizamos las disputas por la visibilidad étnica y los usos sociales del pasado que desarrollaron los miembros de la colectividad caboverdeana en la Fiesta Provincial del Inmigrante, poniendo en primer plano la conflictividad existente en ella.

\section{1. "Es un quilombo, pero no pueden irse"}

Mientras transcurría la última edición de la fiesta en la cual realizamos nuestro trabajo de campo (2015) -más precisamente el día en que se realizaba el Encendido de la Lámpara Votiva- le pregunté a Sergio cómo se estaba desarrollando la fiesta. "Es un quilombo. Otra vez el mismo problema de siempre entre Entidades (en referencia a la $A E E)$ y el Municipio. Parece que la intendencia quiere municipalizar la fiesta". Cuál sería el problema, le pregunté. "Y... que entidades perdería autonomía en las decisiones y la fiesta pasaría a ser del municipio" me respondió este nieto de

\footnotetext{
${ }^{171} \mathrm{El}$ análisis sobre las prácticas que desarrollan los miembros de la colectividad caboverdeana tiene un lugar preponderante frente al que haremos sobre las que desarrollaron los inmigrantes latinoamericanos, los partidos políticos y distintos movimientos sociales. Esto se debe a dos motivos: en primer lugar, mi participación en proyectos de investigación dirigidos por la Dra. Marta Maffia -en los cuales se trabajaban problemáticas afro- me llevó a generar un mayor caudal de información sobre las prácticas festivas que desarrollan los miembros de la colectividad caboverdeana. Y, en segundo lugar, las prácticas que desarrollan los inmigrantes latinoamericanos, los partidos políticos y distintos movimientos sociales forman parte de un material que pretendemos ampliar y profundizar durante $\mathrm{mi}$ formación pos-doctoral.
} 
inmigrantes caboverdeanos, miembro de la Comisión Directiva de la asociación que los reúne en la ciudad de Ensenada ${ }^{172}$.

La tensión entre la AEE y el Municipio es vista por distintos actores como un problema recurrente. Luis Sosa (otro de los miembros de dicha Comisión Directiva) nos señaló que "antes la AEE era autónoma, en 2003 el municipio se metió completamente en Entidades Extranjeras. Ahora es como que Entidades está adentro de la Municipalidad, pasó a ser una dependencia del municipio. Ahí se politizó todo. Igual esto no es nuevo, el municipio siempre tuvo la intención de adueñarse de la fiesta. $Y$ eso hace que la fiesta sea cada vez peor para las colectividades $y$ mejor para el municipio"173. Al preguntarle a Stella Loholaberry (hija de españoles, miembro de la Colectividad Española de Berisso y primera secretaria de actas de la AEE) por este mismo tema, ella nos comentó que "sí, es así... pero eso sucede porque cada uno atiende sus intereses y no se dan cuenta que la Municipalidad no puede organizar la fiesta sin las colectividades y las colectividades sin el municipio tampoco" (2016). Ahora bien, y como nos señaló Sergio aquel día sobre el Centro Cívico, "algunas colectividades están convencidas de que el municipio se quiere quedar con la fiesta pero no pueden irse.” ¿Por qué estos actores se quedarían pese a que reiteradamente la fiesta sea "un quilombo", un espacio completamente "politizado" en el que cada uno "atiende sus intereses"? ¿Cuáles serían los capitales en disputa por los cuales, pese a su disconformidad, participan de ella? Y así, ¿qué sentidos le otorgan a su participación?

Cuando la fiesta había finalizado (edición 2015), fui a una de las reuniones de Comisión Directiva que se hacía en la sede de la colectividad caboverdeana. Ese día se hizo el balance económico sobre cómo les había ido en la fiesta: neto, ocho mil pesos. "Bueno, no está mal. El año pasado salimos hechos, no perdimos plata pero tampoco ganamos nada y laburamos muchísimo. Con esto podemos terminar el desagote de los baños o revocar la pared del salón que se está llenando de humedad", manifestó uno de los presentes. Semanas antes, en pleno desarrollo de la fiesta, una de las personas que integraba dicha Comisión Directiva me pediría disculpas por

\footnotetext{
172 Esta asociación fue fundada el 13 de septiembre de 1927 bajo el nombre de Sociedad de Socorros Mutuos de Ensenada. En 1944 cambio su nombre por el de Asociación Caboverdeana de Ayuda Mutua y a principios de la década del '60 volvió a cambiarlo por el que mantiene actualmente. Las funciones de ayuda mutua ya no eran necesarias o (como sostienen algunos informantes entrevistados para esta tesis) ya no podían ser costeadas. En su lugar, la preservación y difusión de "la cultura caboverdeana" ocupó centralidad.

173 Luis Sosa, argentino nativo, casado con una descendiente de caboverdeanos, miembro de varias comisiones directivas de dicha colectividad, representante de la misma ante la AEE y secretario de actas de esta asociación. Entrevista, 2016.
} 
interrumpir la charla que mantenía con quien era el presidente de la colectividad, pero necesitaba avisarle de manera urgente que la intendencia de Ensenada les había confirmado que el subsidio solicitado sería finalmente aceptado, aunque por un monto considerablemente menor: "No importa. Agarremos lo que nos den. Con eso y lo que estamos haciendo acá [en la fiesta] terminamos la obra en el club", le respondió el presidente.

En esta misma línea, haciendo referencia al sentido comercial otorgado a la fiesta, Javier Botana ${ }^{174}$ y Luis Sosa nos dirían:

"hoy la fiesta está centrada en ver quién junta más plata, quién gana la reina y ver quién puso el stand más lindo. Hoy no veo mucho más que eso (...) Qué se yo, actualmente la fiesta termina siendo un Picurba ${ }^{175}$ temático de colectividades, no más que eso." (Javier Botana, 2016)

"Antes la fiesta no era tan comercial. Si bien era privada y se cobraba entrada, iban solo las personas allegadas a cada colectividad. La gente no iba a pasar por ahí, consumir algo y listo. Hoy en día, se abre a todo el público con tal de sumar dinero a las arcas de las entidades. Se ha vuelto muy materialista. Antes era más cultural, la gente iba específicamente a ver los conjuntos de baile y prestaba atención a eso, porque el patio de comidas estaba en otro lado. Ahora está todo junto y no se le da pelota a lo cultural. De hecho fijate que la fiesta antes duraba un mes [septiembre] y ahora la estiran hasta las primeras semanas del mes siguiente porque la gente acaba de cobrar... Es materialismo puro, están pensando en lo económico." (Luis Sosa, 2015)

El carácter comercial de la fiesta (la posibilidad de recaudar fondos en ella) no solo se vuelve significativo para los miembros de la colectividad caboverdeana. Otras colectividades alquilan sus stands -en la Carpa de las Colectividades- a distintos emprendimientos privados.

"La gente que vos ves ahí -me diría Sergio señalando a las personas que atendían el stand árabe- no son de la colectividad. Algunas colectividades chicas, con pocas personas, no pueden sostener el ritmo de venir todo el día, todos los días. Traer las cosas desde la colectividad, cocinar, vender. $Y$ como algunos años les fue mal [perdieron plata] ahora directamente los alquilan ${ }^{176}$ (...) Diez mil pesos por fin de semana le pagan a la colectividad; imaginate lo que deben ganar esos tipos. Nosotros preferimos hacer todo y estar en el stand contándole a la gente quiénes somos, qué es Cabo Verde. A veces perdemos plata y todos los años terminamos peleados porque hacer esto es muy desgastante. Los fines de semana la gente quiere descansar, en la semana vienen al club a trabajar y encima, ahora, tiene que venir para acá. Además los que atendemos y cocinamos somos los mismos que bailamos,

\footnotetext{
${ }^{174}$ Bisnieto de caboverdeanos, ex presidente de la colectividad caboverdeana, miembro de varias de sus comisiones directivas, entrevista 2016

175 Picurba es la denominación con la que se conoce a los Picnic Urbanos realizados en distintas ciudades del País. Los mismos son organizados por un emprendimiento privado de la ciudad de La Plata y están centrados en la oferta de productos gastronómicos.

${ }^{176}$ El stand de la colectividad árabe es alquilado a un emprendimiento privado dedicado a producir y vender gastronomía árabe en distintos tipos de eventos públicos.
} 
desfilamos; hacemos todo, mucho sacrificio. Nosotros también somos pocos, pero hacemos el esfuerzo de venir."177

Un año antes, recorriendo la Carpa de las Colectividades junto a Daniel Saino (miembro de la colectividad polaca) me comentó que esa edición de la fiesta no estaba "saliendo bien, pero así y todo, entre lo que hacemos acá y en la del vino ${ }^{178}$ pagamos los impuestos de todo el año y hasta podemos llegar a hacer algún arreglo en la colectividad". En línea con lo manifestado anteriormente por Sergio (respecto a que algunas de las colectividades chicas alquilaban sus stands) Daniel Saino me señaló aquel día que "los irlandeses tercerizaron todo; bebidas, comidas, todo. Los que están en el stand son de Buenos Aires... ¿Te das cuenta? Ni de Berisso son. La colectividad va a porcentaje de lo que estos venden. Y chau."

Evidentemente la posibilidad de recaudar fondos durante la fiesta era importante para muchas colectividades. Sin embargo entender que estos actores participan (o no pueden salir de) ella únicamente por dinero, sería un error. Así como en las aldeas de Bali la posibilidad de obtener recursos económicos no era lo que movilizaba el complejo sistema de apuestas activado durante las riñas de gallos (Geertz, 2006b), en la fiesta sucedía algo similar: tanto allá como acá, centrar el análisis sobre la circulación de recursos económicos imposibilita comprender que, centralmente, en ambos contextos está en disputa uno de los recursos simbólicos centrales en la trama cultural de la ciudad: el status. O en todo caso, las formas de reconocimiento social de ese status: la legitimidad, el prestigio, el reconocimiento, la visibilidad social, etc. "En los juegos profundos, en los que se apuestan grandes cantidades de dinero -diría Geertz (2006b: 356)-, lo que está en juego es algo más que las ganancias naturales: la consideración pública, el honor, la dignidad, el respeto, en una palabra (...) el status".

Luego de recorrer la Carpa de las Colectividades junto a Sergio, regresé al stand de la colectividad caboverdeana. Junto a Lucrecia (tía de Sergio y miembro de la Comisión Directiva de la colectividad caboverdeana) intenté seguir la charla que había mantenido con su sobrino mencionando el sacrificio que implicaba estar todo el día ahí, varios fines de semana, haciendo todo lo que ellos hacían. Su respuesta me descolocó: "Si, es un sacrificio enorme. Pero si no viniéramos sería un suicidio.

\footnotetext{
177 Notas de campo, 2015

${ }^{178}$ Se refiere a la Fiesta del Vino de la Costa, la cual se realiza desde hace trece años durante el segundo fin de semana de Julio. La misma es co-organizada por la Municipalidad de Berisso (a través de la Subsecretaría de Hacienda y Producción), la Cooperativa de la Costa y la Facultad de Ciencias Agrarias y Forestales de la Universidad Nacional de La Plata. En ella los productores vitivinícolas de la zona ofrecen sus productos.
} 
Con lo que costó entrar [a la AEE y su fiesta] y las que nos aguantamos acá, si no venimos nos tenemos que ir del club. ¡Ni te imaginas la que se armaría en la Asamblea!". Para Lucrecia -y seguramente para muchos de los miembros de la Comisión Directiva que ella integraba- participar de la fiesta formaba parte de una estrategia de supervivencia institucional (no solo económica): en dos meses la comisión directiva tenía que rendir cuentas ante la Asamblea de Socios y hacer un balance de su gestión. Luego de eso, en el mismo acto, se elegirían las nuevas autoridades. Al momento de hablar con Lucrecia no estaba claro si la Comisión Directiva que ella integraba presentaría la única lista de candidatos, o por el contrario otros socios armarían una lista de oposición. Más allá de esta situación Lucrecia entendía que no estar en la fiesta implicaba un suicidio para cualquier Comisión Directiva. "La oposición" podría esgrimir durante la Asamblea "esa falta" como argumento que horade la legitimidad de la actual comisión:

"Estar o no estar acá -me reiteró Lucrecia- es una decisión que no puede tomar la comisión actual, ni ninguna otra. Por lo que costó entrar y las que sufrimos acá, salir es algo que debería votarse en Asamblea. Si un año una comisión decide no venir, al otro tiene que renunciar e irse del club. Así de simple."179

No estar en la fiesta es poner en riesgo la posibilidad de dirigir la colectividad. Lo cual, en el fondo, es lo que aparece como importante en el testimonio de Lucrecia. Elemento que se vuelve constitutivo del sentido por el cual participar de la fiesta y porqué realizar tanto sacrificio: se podía ganar o perder plata, pero no se podía dejar de estar. Fue ahí que comencé a comprender con más elementos el comentario que me hiciera su sobrino cuando me señaló, sobre el Centro Cívico de Berisso, que pese a la incomodidad que les provocaba la intromisión del municipio algunas colectividades no podían irse de la fiesta. Ahora bien ¿a qué refieren estos actores cuando manifiestan que el ingreso a la AEE y su fiesta habían sido dificultosos? ¿Por qué veían a estos espacios como lugares de sufrimiento?

\section{2. "Lo que costo entrar, las que sufrimos acá"}

La Colectividad Caboverdeana empezó a participar de la AEE como asociación invitada en el año 1998 y en 2001 pasó a ser miembro pleno, con derecho a participar de todos los actos de la fiesta. Dividiendo este proceso en un antes y un después en el año 2001, Emiliana (nieta de caboverdeanos, colaboró con la colectividad durante los

\footnotetext{
${ }^{179}$ Notas de campo, 2015
} 
años 2000) nos diría que "todo el período de la presidencia de Javier Botana (19971999) fue el del ingreso a la AEE. Después, durante la presidencia de Selma Simó (a partir de 2001) ya tuvimos reina y participábamos activamente de la fiesta" (2014).

Al preguntarle a Javier Botana (bisnieto de caboverdeanos) cómo fue el ingreso de la colectividad a la AEE durante su presidencia, nos respondería:

"En 1998, junio, julio, agosto... no sé, apareció por debajo de esa puerta [señala la puerta de ingreso a la colectividad] una notita donde la AEE nos invitaba a la presentación del cronograma de la fiesta. Uno de los días se hacía un acto en la colectividad árabe, fuimos con la idea de ver qué pasaba... cumplir con la invitación y ver. Al llegar nos recibió el presidente de la AEE y nos dice: 'Que bueno que vinieron. Ustedes no se van más de acá.' Dicho y hecho. Ese año solo participamos del Desfile de Clausura. Al año siguiente empezamos a ir a algunas reuniones de Entidades, como invitados, y nos explicaron que como no aún éramos miembros podíamos hacer tal y cual cosa, pero no podíamos participar de todas las actividades. Ese año no tuvimos stand en la fiesta por ejemplo (...) En los años siguientes nos dimos cuenta que no podíamos seguir participando a medias, con un pie adentro y otro afuera. Y la postura de la comisión directiva fue 'si ya estamos en el baile, bailemos en serio. No estemos como decorado'. Y empezamos a participar activamente. Hasta ahí, al menos en este primer período, la sensación era que Entidades era un espacio de brazos abiertos."(2016)

Finalizado el periodo en el cual Javier Botana fue presidente de la colectividad,

Luis Sosa sería el representante de la colectividad en la AEE hasta el año 2003.

-¿Luis, cómo era Entidades en esa época?

"En esa época Entidades estaba dividida. Siempre estuvo dividida y ahora sigue igual. Hay colectividades grandes (o que se jactan de ser grandes porque tiene muchos socios o muchos descendientes) y están las colectividades chicas, como nosotros. Las grandes son la italiana, la árabe, la polaca, la alemana. Esas son las que organizan la fiesta desde su punto de vista, y las chicas tenían que someterse a las decisiones de esas colectividades grandes. Las chicas tenemos voz y voto, te tienen que escuchar. Ahora, de ahí a que finalmente se termine haciendo algo de lo que proponemos...es difícil.

- ¿Y cómo organizan la fiesta? ¿Cómo se toman las decisiones si la AEE está dividida entre colectividades grandes y chicas?

"Todo lo que pasa ahí es un fraude. Por ejemplo, ese grupo de las grandes ya no quiere que las presidencias sean rotativas, quieren volver al sistema anterior donde se votaba. Para apretar gente y ser siempre ellos los que presidan la entidad. Son así." (2016).

Al preguntarle si su salida de la AEE se debió a la división existente -al menos en sus términos- entre colectividades "grandes" y "chicas" o el modo "fraudulento" a través del cual se tomaban las decisiones, su respuesta nos brinda elementos centrales para analizar los vínculos políticos entre la AEE y el Municipio:

"Cuando a mí me sacaron de Entidades fue claramente por una cuestión política entre las colectividades y el municipio. Fue en 2003, cuando el municipio 
se metió completamente en Entidades. Yo era secretario de actas en Entidades y las colectividades grandes no habían postulado a nadie como candidato a presidente. Era raro. $\mathrm{Y}$ las colectividades chicas nunca habían propuesto uno. $\mathrm{Y}$ aparecen de un momento para otro, el último día, los italianos postulando a Pagano ${ }^{180}$. ¡Que ni era miembro de la colectividad italiana! Bueno, se vota y terminamos empatados ocho a ocho. Éramos dieciséis colectividades con voz y voto. Y ahí las otras siete colectividades chicas me propusieron ser presidente, contra Pagano. Imaginate... no acepté. Yo en eso no me quería meter. Menos sabiendo que todo venía del lado de la política. Entonces dije que no, y quedó él como único candidato. Los ocho grandes votaron por él, los seis chicos no lo votaron y quedaban sin definir los votos de los búlgaros y el nuestro. Yo directamente dije que no lo iba a votar y los búlgaros tampoco lo iban a votar. Pero qué pasa, en 2003 asume Slezack como intendente de Berisso, que es de origen búlgaro ${ }^{181}$, y presionó a la colectividad para que voten a Pagano mientras negociaban con algunos miembros de la Comisión Directiva de nuestra colectividad para sacarme de Entidades. Finalmente me sacaron, pusieron a otro y lo votaron a Pagano. A la semana siguiente llegó a nuestra colectividad un horno pizzero como 'regalo' de Pagano. ¡Me cambiaron por un horno pizzero, ¿entendes?! [risas] Ponelo así sí queres: para esa comisión directiva tuve el valor de un horno pizzero [risas]."

Esta no sería la única situación en la cual los miembros de la colectividad caboverdeana se sintieron parte de un fraude -o directamente discriminados- al interior de la AEE y su fiesta. En el año 2001, cuando ya eran miembros plenos de la AEE, comenzaron a participar de todos los actos, entre ellos la elección de la Reina Provincial del Inmigrante. Situación que finalmente no sucedería porque la representante de Cabo Verde fue excluida por ser madre soltera:

"Más allá de que sea mi hija, olvídate de eso -nos diría Luis Sosa- Analía entraba en los actos de la fiesta, desde la Misa en adelante, y la gente la miraba. A los diecisiete años era muy llamativa, daba la sensación de que la gente la miraba diciendo 'acá está la reina'. Y los de Entidades se enteraron que era madre soltera... Aunque no había

${ }^{180}$ En referencia a Jorge Pagano, sindicalista local, titular de la asociación mutual de Servidores Públicos de la Provincia de Buenos Aires (SEPUBA). Luego de 18 años consecutivos durante los cuales el Dr. Juan Minoian presidió la AEE, Jorge Pagano asumiría dicho cargo por primera vez en 1999, representando a la misma colectividad a la que pertenecía Minoian (Árabe). Ese año uno de los principales auspiciantes de la Fiesta sería SEPUBA. Cuatro años después (2003) se realizó la elección del nuevo presidente de la AEE, quien comenzaría su mandato al año siguiente. Tal y como nos relató Luis Sosa, Pagano volvería a ganar las elecciones, aunque ahora lo haría representando a otra colectividad (Italiana). Situación completamente anómala en la historia de la AEE, y a la que muchos de nuestros entrevistados refieren como parte de una misma lógica política: en ninguna de sus presidencias Pagano podía demostrar según nuestros entrevistados- trayectoria al interior de dichas colectividades. Era un "infiltrado" en la AEE, un actor "puesto desde afuera" [la política] con acuerdo de "algunas colectividades grandes". La trayectoria político/institucional de Pagano (siempre ligada a diversas fracciones del partido peronista) es tan extensa como el listado de denuncias por corrupción/amenazas que la componen. Ante la imposibilidad de nombrar en esta cita al pie de página todos los cargos institucionales que ha ocupado durante los últimos 25 años, y hacer mención a las denuncias por corrupción/amenazas en las que se ha visto envuelto, solo nombramos dos: en el año 2000 fue detenido (orden del juez Carlos Bruni hijo) por una estafa que SUPEBA habría cometido contra una jubilada. Actualmente es el presidente del Bloque Peronista en el Cuerpo Legislativo del Honorable Consejo Deliberante de Berisso.

${ }^{181}$ Luis Sosa confunde la ascendencia de Slezack (la cual es ucraniana). Sin embargo, al momento en que se desarrollaba los hechos que Luis Sosa nos narraba, la mujer de Slezack era quién participaba activamente de la Colectividad Búlgara. 
reglamento de reinas en el estatuto de Entidades algunos opinaron que no podía participar y otros que sí, porque justamente no había reglamento. Los primeros decían que había un reglamento pero no lo presentaban. Recién en el 2002 presentaron el reglamento de reinas y estaba escrito en computadora...papel blanquito, recién hecho... En aquel momento no se hizo la denuncia ante el INADI 182 simplemente porque Analía no quiso. Pero el problema en Entidades fue grande... De hecho, Minoian, que es ciudadano ilustre de Berisso y para mí es una persona discriminadora, racista, despreciable, dijo delante mío: 'Bueno, si se metió en otra cosa... si le gustó otra cosa... que ahora se la banque. No puede ser reina."'

Para Emiliana este episodio marcaría un antes y un después respecto a la participación de la colectividad caboverdeana en la fiesta:

"Hubo un período en Entidades, entre 1998 y 2001, que estuvo todo bastante bien. En 2001 hubo un problema serio. Que yo hubiera votado por irme a la mierda. Ya éramos invitados desde 1998, en 2001 pasamos a ser miembros y presentamos reina. La descalifican porque era mamá. El reglamento de reinas decía que tenía que ser soltera y sin hijos. Ahí, o nos íbamos a la mierda (que era mi postura) o nos quedábamos asumiendo que el reglamento es el reglamento. Reglamento discriminatorio. $\mathrm{Si}$, sin dudas. Pero si vos entraste a Entidades, avalaste. Muy desagradable fue esa situación porque además provocó una pelea interna en la colectividad, cuando en realidad éramos todos víctimas de lo que había pasado" (2014).

En ambos testimonios el conflicto aparece leído como un acto de discriminación que convierte en víctimas a todos los miembros de la colectividad. Años después otra elección de la Reina Provincial del Inmigrante desataría un nuevo conflicto entre la colectividad caboverdeana y la AEE.

"Fiesta de Inmigrante, 2008 -continuaría Emiliana- La reina de la colectividad caboverdeana era la favorita del público. No va que ni figura. De nueve jurados, siete tenían apellidos italianos... y la italiana terminó saliendo entre las tres elegidas. El jurado además estaba mayoritariamente compuesto por maestras, las mismas maestras que en la escuela enseñan que en la Argentina no hay negros. La muuuy informada te dice que los negros se extinguieron con la fiebre amarilla. Entonces la misma maestra que te dice que en Argentina no hay negros después es jurado donde había una negra (...) Pese a ser la favorita de público, nuestra reina ni figuró. Entonces al otro día, en el Desfile de Clausura nos pusimos unas remeras negras con letras blancas que decía "Oscuro como la elección". Usamos tus términos [se refiere al "cosa de negros" que usaría de manera peyorativa un Otro blanco] para denunciar tus propias acciones. Sos vos el que está haciendo 'cosas de negros', en el sentido negativo que le das a ese 'cosa de negros'.

182 INADI (Instituto Nacional contra la Discriminación, la Xenofobia y el Racismo). 


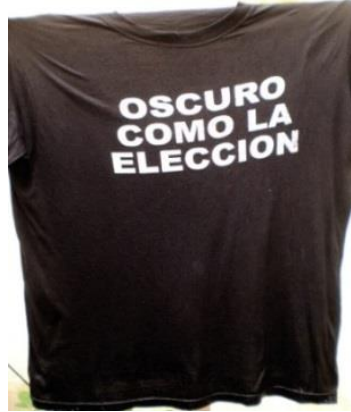

Remera usada por Miembros de la Colectividad Caboverdeana durante el Desfile de Clausura, año 2008.

Fuente: Gentileza Emiliana

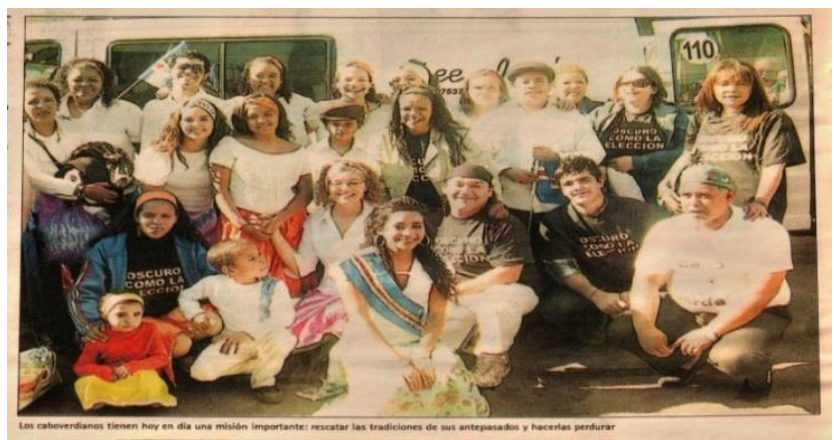

Miembros de la Colectividad Caboverdeana con remera de fondo negro y la inscripción en blanco: "Oscuros como la elección”. Desfile de Clausura, año 2008

Fuente: Diario El Día, 2 de Marzo del 2010.

Por un lado el relato de Emiliana nos recuerda el rol que desarrollaron algunas instituciones del Estado Argentino -particularmente la escuela- en tanto máquinas de aplanar diferencias (Segato, 2007) y anular sentidos sobre el pasado para poder, así, construir una memoria oficial ligada al imaginario del crisol de razas. Memoria a partir de la cual el olvido del negro se tradujo en corolario de su desaparición (Geler, 2005). Si el imaginario del crisol no solo fundió diferencias raciales o étnicas sino también diferencias mnemónicas (Monkevicius, 2015b:116), tener a una maestra como jurado conllevaba -al menos para Emiliana- una ceguera cromática (Frigerio, 2008) que impedía reconocer la presencia de negros en la Argentina. Pero a la vez su relato nos permite ver cómo aquel señalamiento -"sos vos el que está haciendo cosas de negros"- logra marcar al "Otro desmarcado", asignándole un atributo estereotipado de negritud cargado de sentidos negativos. De esta manera lo impuro, lo ilegal, lo ignominioso que las representaciones hegemónicas asignan a los negros en la Argentina son retomadas por estos actores para marcar a un Otro, blanco, desmarcado.

"Después de eso la relación con Entidades se fue a la mierda -continuaría Emiliana-. A nuestra reina la invitaban a programas de radio, y un día la acompañó una señora mayor de la colectividad a un programa y se les apareció Dulke, de la colectividad lituana, amenazándolas. Les empezó a gritar que 'cómo van a ensuciar así a la fiesta' y cosas por el estilo. El clima era re espeso, en serio. El viejo Dulke es un tipo jodido, fascista, rodeado de leyendas urbanas con la dictadura. $Y$ en ese momento, él era nada más ni nada menos que el presidente de la AEE.

Empezaron los aprietes por todos lados, llamadas anónimas a la casa de esa señora que acompaño a la reina al programa de radio. Entonces en la colectividad empezamos a hablar de que ya no había solo discriminación, ahí había directamente aprietes y amenazas. En el fondo, el problema no era solo que 'nos habían robaron la corona', sino todo lo que se produjo alrededor con el tema de las amenazas, los aprietes. Y mi opinión era que eso había que denunciarlo. Algunos no quisieron, no les pareció para tanto... ok pero como institución la comisión tenía que salir al menos con un comunicado de respaldo, de solidaridad con la reina. Entonces ahí la cosa se tensó internamente entre aquellos que pensaban que sí, que claramente éramos víctimas de discriminación y los que no lo vieron así. Obviamente yo entendí que sí, 
porque la negación es una de las formas más sutiles y perversas de discriminación: no te registré, no existís, no estas, no sos (...).

Evidentemente hasta el día de la elección de la reina, en 2008, nos falló la estrategia de visibilización. Es decir, no somos plenamente víctimas. También tenemos nuestra cuota de responsabilidad. Algo fallo en la parte de comunicación y presentación. ¿Y por qué te digo hasta ese día? Porque al día siguiente de la elección de la reina, al salir con esa remera, si algo no fallo fue la estrategia de visibilización. Después de eso salimos en todos los medios, nos llamaron de varias radios, salieron notas, etc."

Como si esto fuera poco, en el año 2010 la presentadora invitada a la elección de la Reina Provincial del Inmigrante (Teté Coustarot) cometió un error en el momento menos indicado. Luego de horas en las que cada participante desfiló (con vestidos de gala), bailó alguna danza folclórica (con sus trajes "típicos") y respondió preguntas sobre "la cultura" del país representado, el jurado eligió a la Reina y sus acompañantes. Al momento de anunciar a la elegida como miss simpatía, la conductora anunció a la representante de Portugal cuando en realidad los votos del jurado le asignaban el galardón a la representante de Cabo Verde. Durante la premiación nadie notó el error y la representante de Portugal recibió el galardón, pero en la primera reunión que tuvo la AEE con posterioridad a la fiesta se fiscalizaron los votos, desatándose la polémica. Quien era presidente de la AEE (Gustavo Zimny, colectividad polaca) afirmó que "hubo un error involuntario de la conductora Teté Coustarot al escribir ella en su papel, de manera equivocada, el veredicto del jurado. Intentamos revertir la situación pero la señora no quiso volver atrás y se produjo este episodio"183. Por su parte la conductora adujo, "yo repetí la información que me proporcionaron como proveniente del jurado. Por lo demás, es lo único que tenía que hacer con respecto a la elección de las reinas y princesas"184. Finalmente, quien era presidenta de la colectividad caboverdeana (Carolina Kalipolittis) señaló,

"No lo entendemos como una discriminación -tal como se planteó en casos anteriores- ni un boicot, como se habló en algunos ámbitos. Fue un error y queremos que nuestra representante tenga lo que logró. Además de ser elegida como mejor compañera por sus pares, había sido seleccionada como Miss Simpatía [por el jurado]. Es una situación compleja." 185

La discusión entre las colectividades de la AEE salió rápidamente a la luz, extendiéndose por más de un mes. El periódico platense El Día se hizo eco y cubrió la

\footnotetext{
${ }^{183}$ Diario el Día, 06-09-2010. Nota "Dos Miss Simpatía y una dura polémica en Berisso".

184 Diario El Día, 06-09-2010. Op. Cit.

185 Diario El Día, 06-09-2010. Op. Cit.
} 
polémica durante todo el período, publicando a fines de Octubre la última nota sobre lo sucedido:

"Otra vez los vientos de la sospecha agitaron la elección de la reina provincial de los inmigrantes, en Berisso (...) Nunca fue fácil elegir mujeres en Berisso. Y lo sabe la gente de Cabo Verde, que otra vez se sintió ninguneada en esa fiesta que cada año consagra a las mejores exponentes.

(...) Antes de estas peleas, las candidatas formaban un ramillete encantador que buscaba más las lágrimas evocadoras del abuelo que el aplauso del soberano. Pero eso se acabó. Ya ni la nostalgia es desinteresada. Es que en las pasarelas ha prosperado la idea de que los jurados no son confiables y que cualquier medición puede ser dibujada. Por eso, hace dos años, cuando los caboverdeanos, que se jugaban una fija con su candidata, Maira Martínez, se encontraron al final con las manos vacías, se armó un pequeño escándalo. Se habló de fraude y complot. 'No es la primera vez que nos pasan cosas como estas', aseguraron. Dos años después, la misma colectividad aparece en el centro de escena denunciando lo que al parecer fue otro despojo." 186

Por nuestra parte entendemos que los tres conflictos desatados durante las elecciones de la Reina nos hablan de procesos sociales distintos. Si en 2001 algunos de los miembros de la colectividad caboverdeana manifestaron estar siendo discriminados -"no hicimos la denuncia ante el INADI simplemente porque Analía no quiso", diría Luis Sosa-, y en 2008 señalaron que se había cometido fraude -"nos robaron la corona", diría Emiliana- en 2010 el conflicto podría estar remitiendo a la distinción que los descendientes de esta colectividad realizan respecto al país del cual Cabo Verde se independizó a fines del siglo XIX: Portugal. Hay aquí un proceso consciente de distinción donde el error de la conductora despertó la reacción inmediata de dichos actores. Indignados, tanto Sergio como Emiliana harían alusión a aquel episodio con frases casi idénticas que podrían ser resumidas en un ¿¿Podes creer? Con Portugal se equivocó. ¡Con Portugal! ¿Entendes? ¡No nos podes confundir con Portugal!"

Algunos datos históricos nos ayudarán a comprender esta dinámica de distinción. Cabo Verde es un archipiélago situado en el África noroccidental que estuvo bajo dominio portugués hasta 1975, año en que declaró su independencia y se estableció como República. Las repetidas sequías, hambrunas y las imposiciones del régimen colonial portugués hicieron que desde mediados del siglo XIX buena parte de la población de este archipiélago migrara hacia distintos destinos (Maffia, 2010a), siendo la Argentina uno de los países a los que -en términos proporcionales- menos caboverdeanos llegaron ${ }^{187}$. En nuestro país se registra la presencia de inmigrantes

\footnotetext{
186 Diario El Día 31-10-2010. Nota "Ni la más linda ni la más simpática"

187 Contarino Sparta (2007) señala unos 2000 inmigrantes caboverdeanos.
} 
provenientes de Cabo Verde desde aproximadamente el año 1906, pero fue entre 1927 y 1933 cuando se produjo el mayor número de ingresos (Mateo, 2003). Por las características insulares del territorio caboverdeano los migrantes lograron insertarse en el mercado de trabajo local cubriendo tareas relacionadas con el trabajo marítimo: así, la Marina Mercante, la Armada y la industria pesquera fueron los sectores en los cuales existió mayor representación caboverdeana. Por esta misma razón los inmigrantes de este país se radicaron en ciudades portuarias como Mar del Plata, Bahía Blanca, Rosario, Dock Sud y Ensenada (Martino, 2015), creando en estas dos últimas ciudades las instituciones que continúan agrupándolos en torno a un origen nacional compartido.

La dificultad de señalar con precisión el número de caboverdeanos que llegaron a la Argentina está dada por dos motivos: $1^{\circ}$ ) al haber sido parte de una colonia portuguesa la mayor parte de los caboverdeanos que migraron hacia nuestro país lo hicieron con pasaporte portugués y $2^{\circ}$ ) otros tantos ingresaron clandestinamente, regularizando su situación migratoria una vez establecidos en la Argentina. Motivos por los cuales existen pocos registros oficiales sobre el ingreso de esta población y, en esos casos, fueron mayoritariamente clasificados como portugueses (Martino y Martínez, 2013). A estos datos que nos marcan las limitaciones de los registros oficiales -volviendo escasamente visible la presencia de estos inmigrantes- debemos sumarle el hecho de que los propios caboverdeanos desarrollaron un conjunto de prácticas de invisibilización y blanqueamiento para integrarse a una sociedad que ha negado, sostenidamente, la presencia de negros en la Argentina (Contarino Sparta 2007; Maffia, 2010a). Blanquearse para ser invisible fue una estrategia de adaptación a una comunidad nacional que desde su simbología oficial se representa a sí misma apelando a un origen europeo, blanco. Alisarse el cabello mota, cortarlo al ras en el caso de los hombres o taparlo con pañuelos (lenços) en el caso de las mujeres, fueron prácticas habituales en una población que además de dejar de hablar en crio/188 se identificó mayoritariamente como portuguesa. Si Cabo Verde era África y este continente era sinónimo de negro, Portugal era Europa y sinónimo de blanco. Así, teniendo pasaporte portugués y estando recientemente arribados a un país de hegemónica matriz cultural europeísta, los inmigrantes caboverdeanos se identificaron con Portugal para insertarse en la sociedad Argentina con el menor grado de conflictividad posible (Maffia, 2010a).

\footnotetext{
188 Lengua nativa de Cabo Verde, aunque no es la lengua oficial ni aquella impuesta por el colonizador, es la lengua nacional.
} 
Estas estrategias de invisibilización y blanqueamiento no se circunscribieron a los inmigrantes africanos sino que, como indica Geler (2011), entre fines del siglo XIX y principios del siglo $\mathrm{XX}$ las primeras generaciones de sus descendientes continuaban reproduciéndolas. Para nuestro caso es particularmente relevante el análisis que la autora realiza respecto al lugar que ocupaban los afrodescendientes en el carnaval porteño de esas décadas. Según Geler (2011:207), al asumir "el personaje del negro estereotipado", los afrodescendientes ayudaban a que ese estereotipo se consolidara socialmente. De esta manera reforzaban su lugar en la blanquitud "que se generaba en el carnaval y que incluía e igualaba a todos los participantes en una 'argentinidad' (que como sabemos era blanco-europea)".

Sin embargo entre mediados de los años 70 y los años 90 del siglo XX, la independencia de Cabo Verde, la militancia de las segundas y terceras generaciones de argentinos con ascendencia caboverdeana y la llegada a nuestro país de corrientes multiculturalistas (Frigerio y Lamborgini, 2011) comenzaron a poner en crisis el imaginario homogéneo con el cual muchas naciones se habían representado a sí mismas (Comaroff y Comaroff, 2011). La confluencia de estos procesos abrieron un nuevo contexto para las prácticas identitarias de los afrodescendientes: mientras una parte de los inmigrantes caboverdeanos continuaron identificándose con Portugal ("europeos y blancos") muchos de sus hijos, nietos y bisnietos comenzaron a identificarse con África, haciendo de la negritud un recurso cultural y político a través del cual visibilizarse (Mateo, 2003; Frigerio, 2008; Maffia, 2010a, Martino, 2015). En tan sentido Emiliana nos diría:

"Mi abuelo, caboverdeano, se llamaba a sí mismo portugués. Para él, él era portugués. Y hasta hoy escucho a los más viejos que le dicen a sus nietos '¿Para qué queres ir a Cabo Verde?, anda a Portugal que es más lindo'. No los entiendo (...) Los caboverdeanos de esa generación, muchos, no quisieron emparentarse con África continental. A lo sumo se reivindicaban como parte de una cultura nacida en el medio del atlántico y no como parte del continente africano (...) Para mí, ser afrodescendiente, además de una cuestión genotípica, es una posición política."(2014)

Este proceso se volverá notorio recién durante los años 90 , no solo por cuestiones de edad en dichas generaciones de descendientes y la llegada a nuestro país de distintas corrientes multircultralistas, sino también porque durante los años 70 el apoyo local al proceso independentista de Cabo Verde ${ }^{189}$ se dio en un contexto local altamente represivo. En este sentido uno de los miembros de la asociación caboverdeana recordaba

\footnotetext{
${ }^{189}$ Minoritario dentro de la colectividad caboverdeana, pero efectivamente existente.
} 
"Durante la lucha por la independencia no se puede hablar [de relaciones con Cabo Verde] por el control que había; aquí estaba el gobierno militar que tenía muy buena convivencia con la dictadura de Salazar y todo aquel que levantaba la voz contra Salazar, contra Portugal, era un poco buscado acá. A la sociedad [caboverdeana] vinieron muchas veces a investigar, a buscar, a ver si estábamos involucrados"190

En esta misma línea, respondiendo por qué la asociación caboverdeana no se vinculó con la AEE y su festividad hasta fines los años 90- Emiliana señaló que los años transcurridos entre mediados de los ' 70 y principios de los ' 80 fueron

"muy para adentro. Esa época fue una época como de status quo, donde se decía ¿para qué tal cosa? Si así estamos bien. Lo que nos mató a nosotros política y socialmente, fue la dictadura. Cabo Verde se independiza en el '75, Augusto tuvo que tirar muchas cosas y Chuch que era el cónsul también estaba jugadísimo, fueron personas que la pasaron muy mal." ${ }^{\prime 191}$

Teniendo en cuenta que la primera edición de fiesta se realizó hacia fines de los años 70 , en un contexto claramente represivo (ver capítulo №3), será recién a fines de los años '90 cuando algunos inmigrantes caboverdeanos y sus descendientes encontraron en ella un espacio donde revertir aquel proceso de invisibilización y blanqueamiento desarrollado por sus ancestros. Como ya mencionamos, este proceso se vio favorecido por la llegada a nuestro país de corrientes multiculturalistas que pusieron en crisis el imaginario acrisolado -homogéneo, blanco y europeo- de nuestra nacionalidad, abriendo una nueva estructura de oportunidades (Frigerio y Lamborgini, 2011) para la visibilización de personas auto-identificadas como afrodescendientes.

Al preguntarle a Javier Botana acerca de los motivos por los cuales la Comisión Directiva que él presidía (con 22 años) decidió ingresar a la AEE y la fiesta, nos diría:

"¿Sabes lo que pasa? A mí me encanta hablar de Cabo Verde y de dónde venimos. Pero en un punto te cansa tener que explicar quién sos y de donde venís. A mí siempre me molestó eso de tener que repetir y dar explicaciones sobre eso. Cosa que acá en Ensenada no nos pasa, porque nos conocen todos. Pero a la institución siempre le costó salir a la calle. Entonces llegó la invitación para ir a la fiesta y pensé que era una forma de hacer algo con eso que siempre me había molestado. Si la gente de Berisso, o de cualquier lado, nos ve, pregunta, se entera... después cada uno de nosotros, de manera individual, tal vez no tenemos que salir a dar explicaciones continuamente de quienes somos. En la fiesta nos sentamos a hablar por placer de dónde venimos y quiénes somos (...) Si vos no te haces visible, nadie tiene porqué saber quién sos. Por eso, ponernos en una vidriera, mostrar quienes somos, qué hacemos estuvo genial. Y la fiesta sirvió para eso.

(...) Siempre convivimos con la frase de que en Argentina no hay negros; y yo miraba y decía ¿qué onda, no me ven? Hasta alguno más progre te decía que en Argentina hubo negros...y de nuevo ¿no me ves? ¡Acá estoy, sigue habiendo negros!

\footnotetext{
190 Citado en Maffia, 2010a: 295. Resaltado nuestro.
}

191 En Funes y Quinteros, 2013:177. Resaltado mio 
Yo estoy orgulloso de lo que soy y de mis orígenes, no lo tengo que ocultar, lo tengo que mostrar. $Y$ en eso la fiesta de Berisso fue una vidriera espectacular para mostrarnos (...)

Antes los caboverdeanos buscaban pasar desapercibidos para evitar problemas de integración, conflicto, discriminación. Nosotros [se refiere a los descendientes más jóvenes] nos tenemos que hacer ver. No pasar desapercibidos. Y en eso la fiesta nos sirvió mucho. Es un momento donde contas con alegría quién sos y qué es Cabo Verde. No es una situación donde te piden explicación, nosotros decidimos ir ahí a mostrarnos. Yo tengo ganas de contarte, ahí no es el visitante el que viene a interrogarte... No sé, esa es mi sensación: fuimos con una decisión consciente de mostrar con alegría quienes somos, que nos conozcan. Dispuestos a eso."

- ¿Y hoy, actualmente, cómo lo ves? ¿Los motivos por los cuales seguir yendo a la fiesta siguen siendo los mismos o cambiaron?

"No sé. Para mí la fiesta es una conquista. Pero ojo, cuando nos incorporamos ese era el único... bueno, no sé si el único, pero sí el principal lugar de visibilización que teníamos. Yo veía que la colectividad estaba cada vez más chica, más diluida... y el hecho de ir a la fiesta hizo que alguna gente nos reconozca y otra que es descendiente se acerque, o vuelva, a la colectividad. Hoy, para mí, nuestra participación en la fiesta cumplió un ciclo. Pero de vuelta, es una conquista. No sé si dejaría de ir. Lo hicimos, fue un puntapié, nos sirvió. No hay que abandonarla, es un lugar donde seguir estando. Pero ¿sabes qué? La fiesta es para determinadas cuestiones. Las reinvindicaciones del colectivo afro no las tenemos que hacer ahí. $\mathrm{O}$ al menos, ese no es el lugar central, ni el único. Hay otros. Tal vez ese no sea el ámbito. Ese es el ámbito de una fiesta de comidas típicas, muestro un poco de la cultura, participo con los bailes, desfilo y listo. Si la fiesta no cambia de formato, no veo posibilidad de hacer otro tipo de actividades ahí." (2016)

En el mismo sentido, quien era presidenta de la colectividad en el año 2012 recordaba el proceso por el cual a fines de los años 90 ingresaron a la fiesta en los siguientes términos:

"Ahí empezó un destape cultural importante donde empezábamos a participar en varios lugares que antes ni registraban la cultura caboverdeana, ni dónde era el país, nada. Entonces ahí como que empezamos a surgir de manera cultural. Hasta ese momento el club se manejaba casi exclusivamente con la gente de la colectividad, en Ensenada ya somos tan parte del lugar que pasamos desapercibidos. Pero ahí nos empezamos a hacer conocidos en otras partes y pudimos abrir puertas y recuperar un poco. Porque hasta tanto, al trabajar siempre con el mismo grupo de la colectividad, pareciera que se va a preservar más, pero es al revés, se va perdiendo un montón (...) Todo lo que perdimos en esos años, lo fuimos recuperando a partir de estos años donde nos empezamos a replantear qué es nuestra cultura." 192

Como vemos, al ser consultados sobre los motivos por los cuales participaban de la fiesta, el hecho de "salir de la sede" y "mostrarse en lugares donde no somos (re)conocidos" no solo aparecen asociados sino que se vuelven centrales. Es por eso que el ingreso a la fiesta constituye "una conquista" en el proceso de visibilización. En este mismo sentido, al recorrer la Carpa de las Colectividades durante la edición de

${ }^{192}$ Citado en Funes y Quinteros, 2013: 181-182. Resaltado nuestro 
año 2015, Mónica (descendiente de caboverdeanos, miembro de la comisión directiva)

me diría:

"Fue un logro enorme haber entrado a la AEE en los años 2000. Porque a Cabo Verde había que sacarlo afuera del club. Sí o sí. Había que salir de ahí, mostrarnos, que nos vean, que nos conozcan. Que vean lo que hacemos, lo que somos, porque si no salimos no nos ven, y si no nos ven... nos morimos. A diferencia de Ensenada acá en Berisso, antes de la fiesta ni sabían que existíamos. Viste como es todo esto, siguen pensando que los inmigrantes eran todos europeos... que de otros lados no vino nadie. Y no es así, acá hay de todo, pero no los dejan entrar. Y así la gente no los conoce. Igual, ya sabes cómo es... tampoco es que entramos y está todo bien. Olvídate que alguna vez tengamos una reina o que nos den bola en algo: somos negros... y de Ensenada [risas]."193

Como hemos señalado anteriormente la búsqueda de visibilización realizada por estos actores -al menos en el contexto de la fiesta- ha estado signada por un conjunto de conflictos y disputas. Con esto no solo nos referimos a los acontecimientos desarrollados durante las elecciones de la Reina o aquella disputa por la presidencia de la AEE que le costó el cargo a Luis Sosa. Tanto Javier Botana como Selma Simó ${ }^{194}$ (quienes fueron presidentes de la colectividad en los períodos donde ingresó y pasó a ser miembro pleno de la AEE) harían mención a algunos de estos conflictos:

-Javier, anteriormente me comentabas que "al menos en este primer período, la sensación era que Entidades era un espacio de brazos abiertos". ¿Qué pasó después?

"Mira... yo ya no estaba ahí. Pero sé que en Entidades hasta se dieron reuniones donde en nuestra cara se preguntaban ' $¿ P o r$ qué los tenemos que aguantar a estos acá? ¿Quién carajo son? ¿Quién los trajo? ¿Por qué se quieren hacer miembro? Que vengan, que desfilen y que no rompan las bolas.' Porque tenes el problema de que no solo somos negros sino que además somos de Ensenada. Acá el 'bienvenidos todos los hermanos de mundo', no... 'La Argentina es el país más abierto del mundo'...bueno... hasta que recorres un poco la calle. Qué se yo, no sé si en Entidades las cosas están dadas para hacernos cargo de ciertos prejuicios" (2016)

-Selma, ¿cómo ves que la colectividad siga participando de la fiesta? ¿Qué te parece?

"Yo, personalmente, no estoy de acuerdo con estar en la AEE y en la fiesta, pero eso es algo que se decidió en Asamblea.

-¿Y por qué no estás de acuerdo?

"Porque los negros ya sufrimos mucho como para seguir poniendo la cara y que nos maltraten. Sacar al club de la sede tiene sus costos. Es mucho esfuerzo. Y ser maltratado, duele". ${ }^{195}$

\footnotetext{
193 Notas de campo, 2015.

194 Descendiente de caboverdeanos por vía materna.

195 Notas de campo, 2015.
} 
Estos relatos no solo exponen la conflictividad existente en la AEE y su festividad, sino que muchos de esos conflictos son leídos y denunciados por los miembros de la colectividad caboverdeana en clave de discriminación. Situación que otros estudios vienen evidenciando como característica distintiva de los afrodescendientes (respecto a los propios inmigrantes africanos). Por ejemplo, Martino (2015:120) afirma que progresivamente los afrodescendientes "incorporan problemáticas asociadas a la discriminación racial que constituyen un cambio importante dado la omisión de estos temas entre los inmigrantes." En nuestro caso Emiliana haría referencia a esta misma situación, señalándonos que "los viejos te van a decir que jamás fueron discriminados, cuando en realidad no fue completamente asi". Conflictos que a su vez son leídos en clave de discriminación racial ("somos negros"), de género ("no hicimos la denuncia solamente porque Analía no quiso") y espacial ("somos de Ensenada").

Esta última dimensión, la espacial, posee un carácter singular dentro de las dinámicas de inclusión/exclusión que se producen en contexto festivo. En el año 2000, cuando la colectividad caboverdeana se encontraba disputando su ingreso a la fiesta como miembro pleno de la AEE, el presidente de esta institución dejó en claro dónde se encontraba el límite geográfico que indicaba a quiénes les pertenecía (y a quienes no) esta festividad: "Los berissenses somos los dueños de esta Fiesta." 196

Nos parece fundamental volver a marcar la vinculación entre la participación de la colectividad caboverdeana en la fiesta y un proceso de "sacarla de la sede". De diversas formas la mayoría de los relatos refieren a este proceso: antes de la fiesta la colectividad era "muy para adentro", le costaba "salir a la calle", "hacerse visible" y que "nos conozcan". Después, una vez en ella, encontraron un lugar de "visibilización”, una "vidriera donde mostrarnos". "Si no salimos no nos ven, y si no nos ven... nos morimos", concluía Mónica, evidenciando la potencia que existe en la mirada del Otro. Hay algo inherente al ser vistos -asociado al mostrarse y difundir lo que hacen- que implica la búsqueda de reconocimiento social. Un reconocimiento que, como mencionamos anteriormente, no se produce exento de conflictos, contradicciones, esfuerzo y dolor. Y que ni siquiera tiene para todos los actores la misma significación:

- ¿Luis, te parece que fue importante ingresar a la fiesta?

\footnotetext{
196 Jorge Santiago Mc Govern (colectividad irlandesa), Gacetilla Oficial, 2000. Resaltado nuestro. Dejando en claro quienes tendrían prioridad en las distintas tareas de la fiesta, Mc Govern señaló: “El objetivo fundamental de este año, era realizar la Fiesta Provincial del Inmigrante, ofreciendo la mayor participación posible a los bailarines, cantores, trabajadores del espectáculo, etc. que sean berissenses; por ello en este libro, invitamos a participar a los escritores, periodistas, poetas, que sean berissenses"
} 
"No sé si fue importante. Sinceramente. Creo que la colectividad tiene lo suficiente como para mostrarse sola, y no depender de nadie. Además, estando ahí, he visto cosas que nos hicieron... que digo, no, esto no va más, tenemos que salir de acá. Pero no es decisión mía. Si fuera decisión mía ya hubiéramos salido hace rato. Más allá de Entidades, a la colectividad la gente la reconoce. Nos llaman a participar de distintos eventos, con lo cual no necesitamos de Entidades. Asumo que gracias a Entidades el conocimiento de la colectividad fue mucho más rápido, pero eso no quiere decir que no la conocían. O que no tenemos otras formas de que nos conozcan. Lo podemos hacer nosotros, independientemente. La colectividad tiene cosas llamativas para hacerse ver sin Entidades (...)

Antes de ir a Entidades, para la colectividad, para los caboverdeanos, Cabo Verde era esto [la asociación] y con eso estaba bien, se conformaban con esto. Este era su mundo, y estaba bien. No les interesaba salir a otro lado. Ahora, Entidades sirvió para que los conocieran afuera. Pero lo pudo haber hecho sin Entidades Extranjeras. Lo podríamos haber hecho solos, sin meternos ahí. No reniego de eso, pero tengo claro que lo podríamos haber hecho solos si hubiera habido más gente con la visión de salir de la institución a mostrar qué es Cabo Verde (...) Antes había una conformidad de que 'nosotros somos esto, y nos divertimos acá [en la sede de la asociación]. Esto es Cabo Verde para nosotros. Y listo, no importa más nada.' No digo que era poco eh...porque estaba muy bueno. Muy bueno. Pero era acá, adentro." (2016)

Lacarrieu, Maronese y Mazetelle (2005) han señalado que a fines del siglo XIX existió en la Argentina una política de la semejanza -siguiendo a García Canclini (1999) las autoras refieren con este término a la estrategia institucional que desarrolló el Estado para licuar diferencias entre los colectivos inmigratorios y crear una etnicidad homogénea- que promovió el ocultamiento de las fiestas en el espacio público. Únicamente se autorizaban las celebraciones de las colectividades étnicas que, reuniendo a inmigrantes europeos, podían ser uniformizadas detrás de la simbología del crisol de razas. En ese proceso las autoras afirman que los inmigrantes africanos fueron "obligados" a replegarse en sus propios salones para realizar distintas fiestas. Señalamiento que coindice con lo manifestado por algunos miembros de la colectividad caboverdeana de Ensenada cuando nos decían que "antes" -para los inmigrantes provenientes de aquel país- la colectividad era "muy para adentro", "le costaba salir" o "se divertían acá."

Si el proceso de entrar en la AEE y su fiesta formó parte de un salir de la institución, esa dinámica de egreso/ingreso -con toda su conflictividad, reiteramospermitió que dichos actores disputaran visibilidad y reconocimiento social en la esfera pública. Proceso donde los descendientes se volvieron un actor central, tal y como lo ilustra uno de nuestros registros de campo: "Al interior de La Carpa de las Colectividades le comenté a quién atendía el stand de la colectividad caboverdeana 'lo bueno' que estaban los chocolates que vendían: 'Si, ¿viste?... cosas de negros' fue la respuesta directa, con mueca socarrona, que me dio una de las chicas que lo 
atendían. Me sorprendió la habilidad de esa joven (25 años o menos) para dar vuelta el sentido comúnmente otorgado al 'cosa de negros' y su capacidad para vincularse desde la negritud con algo positivo (lindo, rico, bueno, etc.). No dudó un segundo en aprovechar mi comentario de cortesía para construir una forma de identificarse que, alejándose del sentido peyorativo que socialmente porta el 'cosa de negros', unifica negritud y positividad." (Nota de campo, 2011). Evidentemente, como señaló Adamovsky (2012:347) al analizar el proceso de reetnización de los afrodescendientes en nuestro país, entre fines del siglo $X X$ y principios del $X X I$ "aparecieron por primera vez síntomas de que lo negro -tradicionalmente un insulto o motivo de vergüenza- se transformaba en emblema de desafiante orgullo."

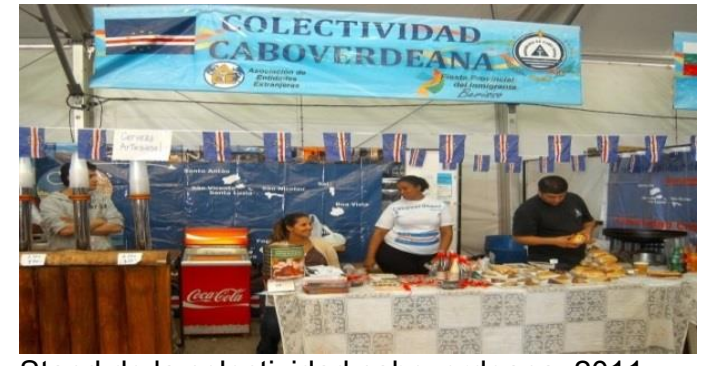

Stand de la colectividad caboverdeana, 2011.

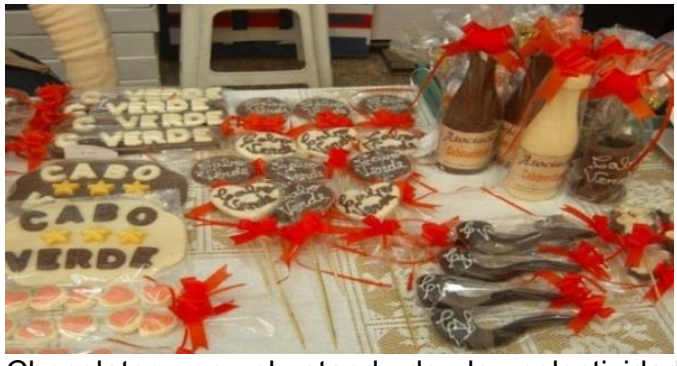

Chocolates en el stand de la colectividad caboverdeana, 2011.

Hasta aquí lo presentado nos permitió mostrar, inicialmente, que la motivación económica no reguló exclusivamente la participación de la colectividad caboverdeana en la Fiesta Provincial del Inmigrante. No negamos que ella estuviera presente o fuera importante, pero haber centrado nuestra explicación en el sentido económico de la misma no nos habría posibilitado comprender otras dimensiones. Al recorrer las actas de la colectividad caboverdeana de Dock Sud, Martino y Martínez (2013) Ilegaron a una conclusión similar. Estas autoras mostraron que durante las primeras décadas del siglo XX las fiestas realizadas al interior de la colectividad no solo permitieron obtener los fondos necesarios para solventar el funcionamiento de la institución sino que además eran un espacio de socialización entre los inmigrantes y -centralmente- una instancia donde se ponía en juego la legitimidad de la Comisión Directiva. Una fiesta "bien hecha" (con buena y abundante comida, bebida y música) donde "todo saliera bien" (no ocurriera ningún hecho indecoroso) otorgaba prestigio y legitimidad a sus organizadores. Al menos, frente al resto de los socios.

Por nuestra parte entendemos que ligar la participación de los miembros de la colectividad caboverdeana en la fiesta con un sentido puramente económico no nos habría permitió comprender otros dos procesos de suma importancia. En primer lugar 
no habríamos podido dar cuenta que allí (también) se juega la legitimidad de una Comisión Directiva que pretende seguir dirigiendo la institución. La Comisión que decida unilateralmente no ir a la fiesta -sin que la decisión esté abalada por la Asamblea de Socios- estaría cometiendo, como dijo Lucrecia, un suicidio. Leído en esta clave, aquel "no se pueden ir" manifestado por Sergio al inicio del capítulo adquiere pleno sentido: hay colectividades que más allá de la conflictividad del espacio no podrían abandonar la AEE y su fiesta sin un enorme costo institucional que excede lo económico. Lo cual sucede, justamente, porque en dichos espacios se disputan un conjunto de capitales simbólicos ligados a la estructuración social del presente: legitimidad, prestigio, reconocimiento, visibilidad, etc.

En esta clave de análisis lo expuesto nos ayudó -en segundo lugar- a comprender la búsqueda de visibilidad que realizan algunos de los inmigrantes caboverdeanos y, centralmente, sus descendientes. El ingreso de esta colectividad a la fiesta forma parte de una dinámica en la cual, hacia fines de los años 90, los miembros de la Comisión Directiva decidieron salir de su sede. "Había que sacar a Cabo Verde afuera del club. Sí o sí. Había que salir de ahí, mostrarnos, que nos vean”, nos dijeron. Mientras la mayoría de los inmigrantes caboverdeanos y las primeras generaciones buscaron invisibilizarse y blanquearse como estrategia de incorporación a la sociedad Argentina, los actores anteriormente mencionados desplegaron la estrategia inversa como forma de auto-reproducción social: visibilizarse, identificándose como afrodescendiente. Así, a diferencia de lo marcado por Geler (2011) para el caso de los afrodescendientes en el carnaval porteño de entre-siglo (XIX y XX), notamos que actualmente las nuevas generaciones de afrodescendientes encuentran en las prácticas festivas un contexto en el cual revertir aquel proceso de invisibilización y blanqueamiento atravesado por sus ancestros.

\subsection{Ser parte de, sin ser lo mismo que: usos del pasado y tradiciones culturales}

En este apartado nos interesa analizar el modo en que los miembros de la asociación caboverdeana construyen -en contexto festivo- una identificación nacional y cultural apelando al pasado y reactuando tradiciones culturales. En tal sentido nos preguntamos por los hechos del pasado y los diacríticos culturales que, al ser recordados y reactuados, les permiten construir una identificación nacional y cultural que no solo los incluya como parte de la historia inmigratoria de la Argentina sino además los distinga de otros grupos étnicos. Así, veremos cómo la apelación a ciertos 
hechos del pasado inmigratorio y la reactuación de tradiciones culturales forman parte de los recursos a través de los cuales estos actores se integran a un colectivo sin perder especificidad.

Respecto a la apelación al pasado, la asociación caboverdeana relata en la Gacetilla Oficial de la fiesta el proceso migratorio que atravesaron sus "padres fundadores", señalando los motivos que los llevaron a radicarse en la Argentina:

"La inmigración caboverdeana llegó [a la Argentina] a principios del siglo XX, en consonancia con el resto de los inmigrantes. A diferencia de los 12 millones de africanos que llegaron a América entre los siglos XV y XVI, los caboverdeanos fueron los únicos que no llegaron como esclavos, sino en busca de trabajo y mejores horizontes para desarrollarse. A diferencia de los europeos, no llegaron empujados por guerra alguna." 197

Luego de incluirse como parte de la historia inmigratoria que caracterizó a la Argentina desde principios de siglo ("en consonancia con") la demarcación de límites con otros grupos migratorios ("a diferencia de") permite que estos actores se distingan al interior de aquel relato histórico. Si bien los inmigrantes caboverdeanos -según el texto citado- habrían formado parte de la inmigración de ultramar que llegó a la Argentina a principios del siglo XX, los motivos por los cuales habrían migrado difieren completamente de los que motivaron la llegada de doce millones de africanos (esclavitud) y el resto de los inmigrantes europeos (guerras). Así, estos actores seleccionan y "usan" ciertos hecho del pasado (apelando al recuerdo de una presencia africana en la Argentina que se encuentra tan distante de la guerra como de la esclavitud) para proveerse de una historia legitimadora (Hoffman, 2000) y darse una continuidad temporal a partir de la cual visibilizar la presencia de afrodescendientes en nuestro país (Monkevicius, 2012). Si la apelación al pasado inmigratorio de sus ancestros hace que estos actores puedan incluirse como parte de una larga historia de la inmigración en la Argentina, el uso selectivo de ciertos elementos del pasado (léase los motivos por los cuales no habrían migrado) les permite distinguirse dentro de aquel relato homogeneizante.

Cabe resaltar que el recuerdo de un pasado inmigratorio desligado de cualquier filiación con la esclavitud podría estar funcionando, además, como elemento central de distinción al interior del colectivo que reúne a los afrodescendientes en Argentina. Si bien no es el eje central de este capítulo, encontramos aquí una diferencia con el análisis realizado por otros autores que valdría la pena desarrollar en futuros trabajos. Por ejemplo, al describir el accionar de líderes y dirigentes afro -en tanto

${ }^{197}$ Gacetilla Oficial de la fiesta, 2012, resaltado nuestro. 
emprendedores de la memoria- Monkevicius (2012:87) señala que estos actores construyen, fijan y estandarizan la "memoria a partir de un origen esclavo, el cual utilizan como homogeneizador hacia adentro y como herramienta de lucha política hacia afuera". La autora afirma que la esclavitud se presenta como un núcleo simbólico, un punto de referencia, a partir del cual se abroquelan los emprendedores de la memoria para definir las coordenadas desde las que se establecen identificaciones, pertenencias y alteridades. Estrategia que diluye la variabilidad y heterogeneidad de esta población, convirtiendo a diferentes sectores "en descendientes de africanos esclavizados aunque provengan de movimientos migratorios, como los caboverdeanos o los africanos llegados recientemente" (Ídem: 101).

En nuestro caso vemos que este proceso se daría de manera inversa: construir un pasado vinculado con la esclavitud no solo imposibilitaría contar con una herramienta de lucha "hacia afuera" sino que además dejaría de formar parte de los elementos comunalizadores (Brown, 1990) "hacía adentro". Ahondar en estas diferencias habilitaría la posibilidad de comprender los usos contextuales y estratégicos de "un mismo pasado" por parte de los actores que componen el heterogéneo colectivo afrodescendiente en nuestro país: mientras en determinados contextos, y para algunos actores, la recordación de la trata esclavista legitima demandas de reparación histórica y luchas contra el racismo, en otros -como los analizados aquí- ese pasado está lejos de funcionar en el mismo sentido. Si hay un pasado del cual los miembros de la asociación caboverdeana se despegan durante la Fiesta Provincial del Inmigrante es, justamente, aquel que podría vincularlos con la esclavitud. Ese pasado, en este contexto y para estos actores, estaría limitando la posibilidad de construir y disputar legitimidad. Más allá de esta diferencia vemos en ambos casos un trabajo de la memoria a partir del cual se selecciona los "acontecimientos que merecen/deben ser recordados, frente a otros que caerán en el olvido, el silencio o la negación" (Monkevicius, 2015b:114).

Aquella estrategia de inclusión por distinción (ser parte de una historia de la inmigración en Argentina tomando distancia de Europa y otros países africanos a partir de los motivos por los cuales migraron sus antepasados) permite que la participación de la colectividad caboverdeana en la fiesta adquiera un carácter distintivo. En esta estrategia, la memoria de ciertos hechos del pasado se convierte en una memoria para actuar en el presente de acuerdo a determinadas demandas y necesidades (Woortmann 2000; Monkevicius, 2012). Estrategia sumamente compleja pero 
evidentemente efectiva a partir de la cual incluirse distinguiéndose: ser parte de, sin ser lo mismo que.

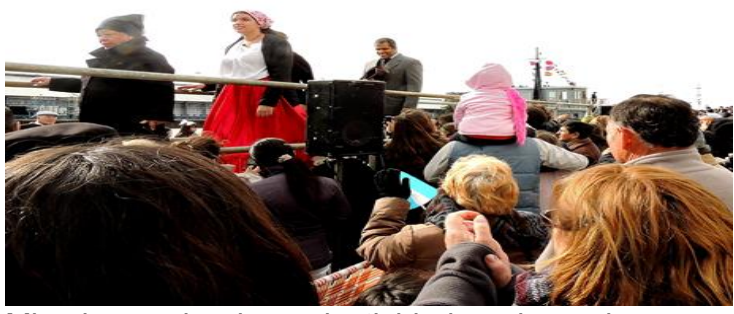

Miembros de la colectividad caboverdeana durante el Desembarco Simbólico, 2013.

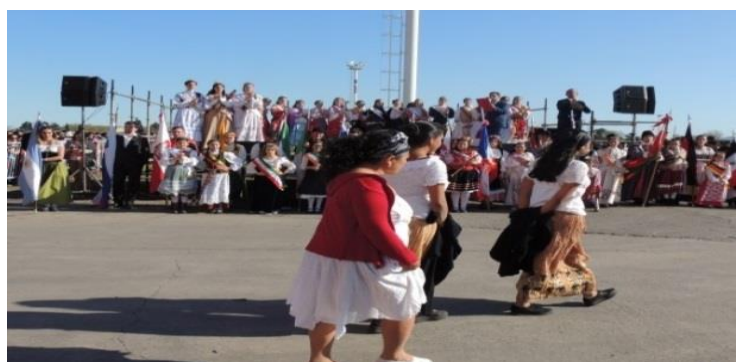

Miembros de la colectividad caboverdeana durante el Desembarco Simbólico, 2015.

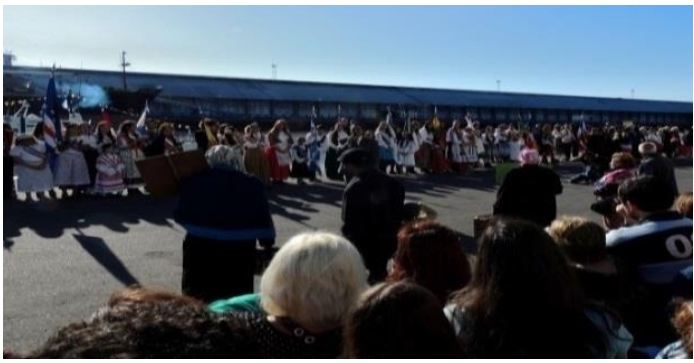

Miembros de la colectividad caboverdeana durante el Desembarco Simbólico, 2014.

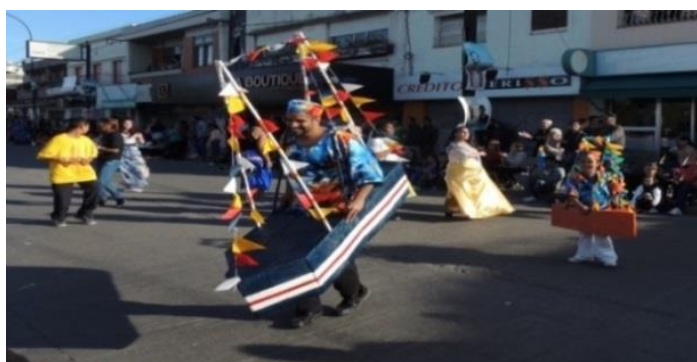

Miembros de la colectividad caboverdeana apelando a la imagen del barco durante el Desfile de Clausura, 2015.

Este proceso de inclusión por distinción -vía la apelación al pasado inmigratorio de la asociación- continúa con una descripción de su "cultura típica". Ella es construida mediante la selección de diacríticos culturales folklorizados y no politizados: centralmente gastronomía "típica" y danzas "tradicionales". Año tras año la colectividad caboverdeana cocina en su stand de la Carpa de las Colectividades algunos de los platos que conforman su gastronomía "típica". Asimismo -sobre el escenario de dicha Carpa y durante el Desfile de Clausura- el grupo de danzas presenta distintos bailes "tradicionales" de Cabo Verde.

Respecto a la gastronomía el plato seleccionado para representar su comida "típica" es la cachupa ${ }^{198}$. Este plato puede ser elaborado de diversas maneras dependiendo del contexto donde -y para el cual- se prepara. El mismo puede tener una composición muy simple (con pocos insumos y bajos costos) o requerir una elaboración compleja (con muchos, variados y costosos insumos) ${ }^{199}$. Durante la fiesta

\footnotetext{
198 Un estofado cocido lentamente a base de maíz (hominy), judías, pescado o carne (salchichas, carne vacuna, cabra o pollo).

199 La cachupa puede asumir tres formas/denominaciones: “a) Cachúpa agua-e-sal, que está basada en el maíz cocido o semiaplastado en el pilão, desmigajado en el balaio de 'sacudir' y puesto a cocinar solo con agua y sal. Es la alimentación de los 'pobrecitos'; b) Cachupa-dos-remediados, a la cual se adiciona un poco de poroto seco, berro, una tajada de tocino o feta de atún e incluso algunas batatas o trozos de mandioca, inhame, platano verde o calabaza; c) Cachupa-de-gente-branca, que puede servir para una
} 
la asociación caboverdeana procura elaborar la cachupa denominada rica. Denominación que no refiere a su sabor sino a que su preparación es costosa en términos económicos. En Cabo Verde los sectores sociales con menos recursos pocas veces (justamente festivas) preparan la cachupa rica, mientras que ella forma parte de la dieta habitual de los sectores sociales con más recursos. A este plato también se lo denomina (ver nota al pie n¹99) "cachupa de gente branca" y es considerado "un plato de clase" (Romano, 1970). Así, la cachupa rica no solo -ni principalmentesatisface una necesidad alimenticia sino que cumple un rol social: la manera y las ocasiones en que se la prepara, el dónde, el con quiénes y el modo en que se la ingiere, denotan su rol social (Lahitte y Maffia, 1983; Maffia, 2010a).

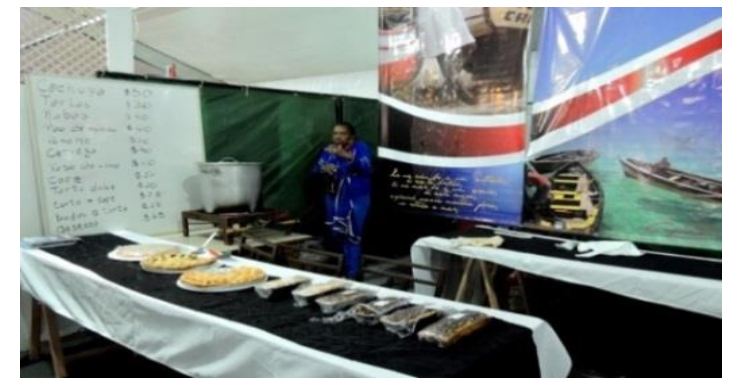

Miembros de la asociación caboverdeana cocinando en su stand, 2015.

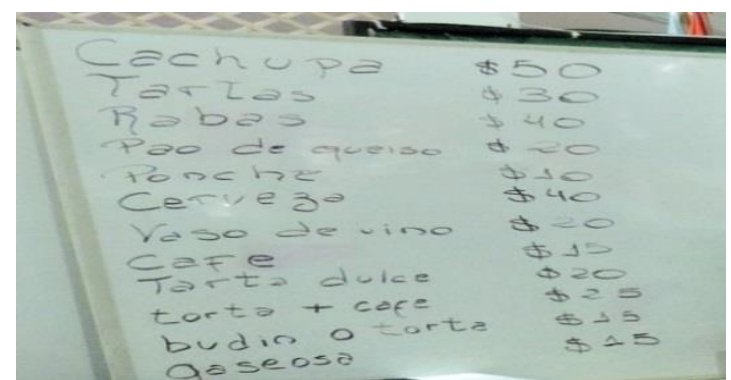

Ampliación pizarra comidas/precios, 2015.

Respecto a las danzas "tradicionales" de Cabo Verde el grupo de bailes de esta colectividad presenta un conjunto de mornas y coladeiras. Estilos musicales presentados de la siguiente manera:

"La morna es el género musical por excelencia de Cabo Verde. Nace a finales del siglo XIX en Boa Vista como la forma musical más culta de las islas. (...) En los años '50 apareció la coladeira, como una forma más acelerada de la morna, que permite bailar con un compás más rápido."200

receta especial y tiene la siguiente preparación: maíz cocido y pelado mezclado con poroto, haba o arveja, seco, en una olla con agua, donde se juntan condimentos verdes, hortaliza, tocino o chorizo, adobado incluso con costeletas de cerdo o carne bovina, unas rodajas de salchichón, cebolla o ajo, hojas de laurel, mandioca nueva o papa inglesa. Esos ingredientes, en manos especializadas, hacen de la cachupa un plato de clase, con semejanzas al grão-de-bico (garbanzo) en Portugal" (Romano, 1970: 146147).

${ }^{200}$ Gacetilla Oficial, 2012. Resaltado mío. 
Al consultarle por qué la colectividad decidía presentar la morna y la coladeira como sus bailes "tradicionales", Emiliana nos comentó que esos estilos son presentados en público porque fueron los que el colonizador (Portugal) aceptó e impuso como bailes "oficiales" de Cabo Verde. Situación que iría en detrimento del funaná y el colá san jon (bailes con una carga de sensualidad a partir de la cual el público podría inferir connotaciones sexuales que no necesariamente poseen). En ese sentido Emiliana señaló que al interior de la colectividad caboverdeana los inmigrantes (sobre todo aquellos que se identificaban como portugueses o no atendían las manifestaciones africanistas descolonizadoras) nombraban a la morna y a la coladeira como los géneros musicales "tradicionales" del archipiélago. Proceso que -en este punto en particular- encuentra un paralelismo con lo que Geler señaló en torno a las canciones y las danzas que los afrodescendientes cantaban y bailaban en el carnaval porteño de entre siglos (XIX-XX).

Según esta autora:

"Como resultado de siglos de dominación, discriminación y desigualdad, pero también debido a la gran imbricación social e ideológica de los afrodescendientes en la construcción del Estado nacional argentino, muchos negros y mulatos habían asumido que su cuerpo y modales eran portadores de la barbarie/no-europeidad que había que desterrar para integrarse a la nación moderna y civilizada, pudiendo aislar elementos concretos de burla y parodia." (Geler, 2011: 205)

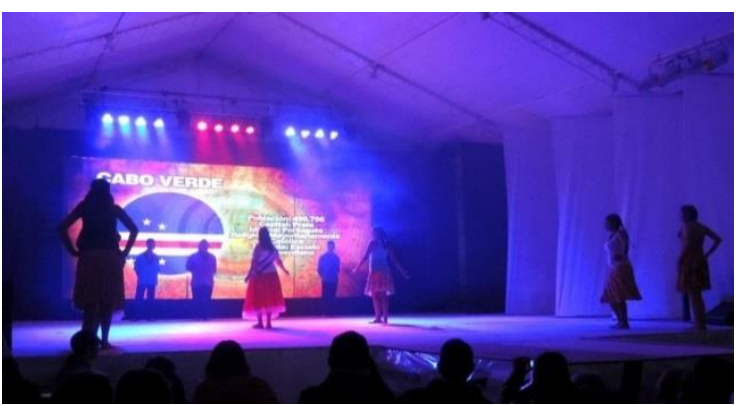

Grupo de danzas de la colectividad caboverdeana, escenario de la Carpa de las Colectividades, 2015.

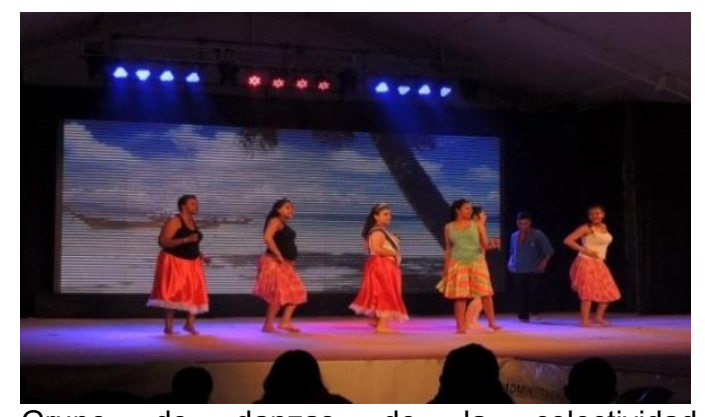

Grupo de danzas de la colectividad caboverdeana, escenario de la Carpa de las Colectividades, 2015.

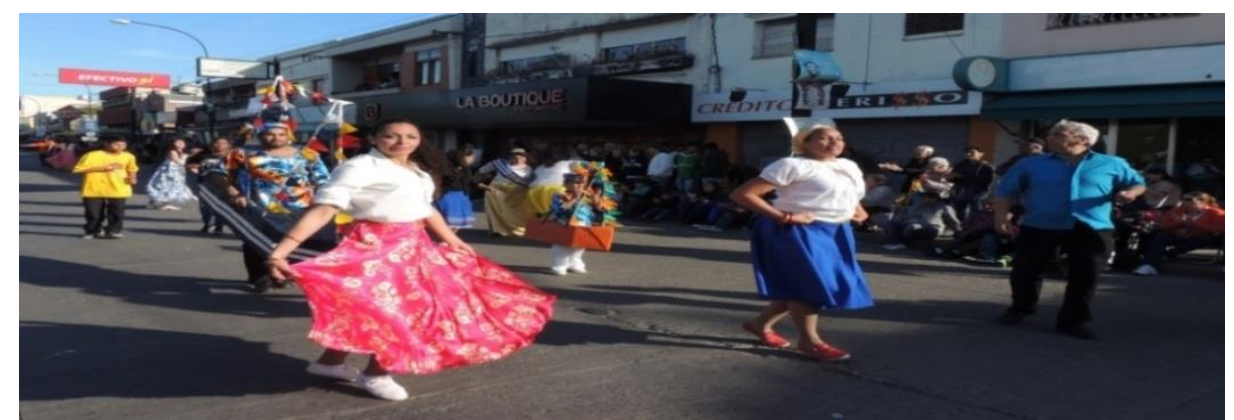

Miembros de la colectividad caboverdeana durante el Desfile de Clausura, Avenida Montevideo, 2015. 
Al estar construida a partir de diacríticos socialmente legitimados, la representación de la "cultura típica" caboverdeana en contexto festivo resulta sumamente significativa. La cachupa rica es tanto un plato "de status" como de "gente blanca" y la morna o la coladeira son "la forma musical más culta de las islas". De esta manera la "cultura típica" caboverdeana -elaborada a partir de un conjunto de diacríticos de la cultura legítima- legitimaría su presencia en la fiesta. Dicho en otros términos, la reactuación de esta tradición cultural habilita una participación festiva de manera distinguida, autorizada. Así, la apelación al pasado inmigratorio y la reactuación de tradiciones culturales permite que los miembros de la colectividad caboverdeana formen parte en la historia de la inmigración en la Argentina sin perder especificidad: distinguirse aseguraría la continuidad de una diversidad cultural al interior de dicho constructo homogeneizante (Monkevicius, 2009). La apelación al pasado inmigratorio y la reactuación de tradiciones culturales no solo les permite formar parte de la larga historia inmigratoria de nuestro país, sino además (des)marcase, visibilizarse y legitimarse. (Des)marcarse respecto a Europa y otros países africanos vehiculizando elementos de pasado, visibilizarse para autoreproducirse y legitimarse como afrodescendientes reactuando tradiciones culturales autorizadas.

Si bien, como dijimos al inicio de este capítulo, las prácticas festivas en las cuales participan descendientes de inmigrantes africanos han permitido analizar procesos de identificación afro, disputas por la visibilidad étnica y la emergencia de memorias subalternas, entendemos que estos procesos adquieren características distintivas según los contextos festivos en el cuales se desarrollan. En nuestro caso esos procesos se desarrollan, justamente, en un ritual conmemorativo a partir del cual la comunidad es imaginada apelando a la simbología del crisol de razas (blancas y europeas). Como han mostrado otros trabajos, desde hace algunos años el Estado argentino reintrodujo relatos del pasado negro dentro de una narrativa nacional habilitando un contexto para la incorporación y visibilización de esta minoría cultural. Entre otras formas de reconocimiento institucional ${ }^{201}$ cabe mencionar la inclusión de una memoria afro en los festejos realizados por el Bicentenario de la Revolución de Mayo (2010). Con lo cual, si los rituales conmemorativos han sido parte de los instrumentos a través de cuales los Estados nacionales construyeron y estandarizaron una historia nacional -indicando a ciertos hechos como fundantes de un mito de origen y ocultando/silenciando a otros que, así, se volvieron parte de las memorias subterráneas (Pollak, 1989; Hanchard, 2008)- no por ello debemos olvidar que los

201 Para un detalle de las mismas ver Monkevicius, 2013: 233 
sentidos otorgados a esa historia varían a lo largo del tiempo (Jelin, 2002b). Recordemos: algunos miembros de la elite intelectual y gobernante de la Argentina conocida como la Generación del '80, afirmaban que la población negra era un elemento "degenerativo e inadaptable" para el desarrollo del país, festejaron su "desaparición" gracias a los efectos "benéficos y europeizantes de la viruela, la tuberculosis y el alcoholismo", y vieron en los negros de Cabo Verde a "una oprobiosa escoria de la especie humana, para quienes la piedad solo puede desear la dulce extinción de las razas inferiores" (ver capítulo № 1).

Es muy factible que el imaginario acrisolado con el cual la sociedad berissense/argentina era representada en contexto festivo haya entrado en crisis. Y es en estas coyunturas de crisis (Pollak, 1992) donde otras versiones del pasado, otras memorias, encuentran espacios para irrumpir en la esfera pública. Espacios que si bien continúan siendo subalternos, permiten que algunos actores disputen visibilidad, prestigio y legitimidad. Procesos que nos permiten mostrar algunos de los conflictos silenciados por el imaginario armónico que analizamos en el capítulo anterior: la unión, solidaridad, paz y convivencia con las que se articulaba el imaginario de la comunidad berissense en contexto festivo -aunque aún prevalecientes- comenzaron a ser cuestionados.

\section{Exclusiones: inmigrantes latinoamericanos}

\section{1. "Queremos que esto se revierta"}

Pese a que el imaginario acrisolado a través del cual la comunidad era representada en contexto festivo pueda haber entrado en crisis -y esas coyunturas habiliten un espacio para la irrupción de otros actores (y sus memorias)- no todos los colectivos inmigratorios presentes en la ciudad han logrado ingresar a la AEE y su fiesta: hasta la finalización de nuestro trabajo de campo los inmigrantes latinoamericanos seguían siendo "lo que no entra en el crisol" (Caggiano, 2005).

Como expusimos en el capítulo $\mathrm{N}^{\circ}$ 2, desde los años '90 la inmigración latinoamericana que vive en Berisso ha ido creciendo significativamente, tanto en términos porcentuales como absolutos. Si en 1991 el porcentaje de inmigrantes latinoamericanos alcanzaba al 35\% de la población extranjera, en 2001 representó al $69 \%$ y en 2010 al $87 \%$. Proceso que no se debe únicamente al fallecimiento de los inmigrantes europeos (recordemos que en 2010 el 75\% de esta población superaba los 65 años de edad) sino fundamentalmente a la llegada continua de inmigrantes 
latinoamericanos (pasando de 1.178 personas en 1991, a 2.687 en 2001 y 4.200 en 2010). En el año 2010, los 4.200 inmigrantes latinoamericanos que vivían en Berisso representaban al $4,79 \%$ de la población total de la ciudad (compuesta por 88.470 personas), porcentaje que superaba el promedio nacional $(3,5 \%)$.

Si bien estos actores tienen una presencia notoria en la ciudad, hasta la finalización de nuestro trabajo de campo la misma no se reflejó en la Fiesta Provincial del Inmigrante: la apelación al supuesto origen europeo de la comunidad dramatizando el mito del crisol de razas y escenificando la llegada en barco de distintos grupos migratorios- logró invisibilizar a la enorme mayoría de los inmigrantes que viven en Berisso. Además, y pese a que desde hace varias décadas los inmigrantes latinoamericanos tienen representación institucional en la ciudad, hasta fines del año 2015 las asociaciones que reúnen a los peruanos, paraguayos, bolivianos, uruguayos, chilenos, brasileños y colombianos no habían logrado ingresar a la AEE. Es importante aclarar que no todas ellas lo solicitaron formalmente, pero la negativa de esta institución para aceptar a quienes sí lo han hecho puede haber desalentado al resto.

Las negativas de la AEE para incorporarlas y permitirles participar de la fiesta llevaron a que un grupo de ellas -nos referimos a las asociaciones que representan a los inmigrantes peruanos, bolivianos, brasileños, uruguayos y colombianos- le solicitaran a las autoridades municipales su apoyo para realizar un festival de colectividades latinoamericanas. Luego de algunas reuniones entre los funcionarios de la Dirección de Cultura y los representantes de las cinco asociaciones mencionadas, en 2013 se resolvió que a partir del año siguiente se realizaría un festival denominado "Patio Latinoamericano". El mismo tendría lugar los días 15 y 16 de abril en el Playón Municipal "Padre Carlos Cajade"202, donde esas asociaciones expondrían su gastronomía, música y danzas tradicionales bajo el mismo formato que posee la Carpa de las Colectividades de la Fiesta Provincial del Inmigrante. Finalmente, por problemas en la estructura edilicia del Playón Municipal la edición 2014 del "Patio Latinoamericano" fue cancelada por la intendencia municipal.

Para evitar nuevos inconvenientes y darle mayor visibilidad al evento se acordó que al año siguiente el "Patio Latinoamericano" se realizaría sobre el Centro Cívico durante el fin de semana del 16 y 17 de abril. Nuevamente, pero ahora por cuestiones climáticas, la Dirección de Cultura del municipio decidió unilateralmente cancelar el evento.

${ }^{202}$ Calle Av. Montevideo y 11. 


\section{"Por razones climáticas, se suspendió el Festival 'Patio Latinoamericano"}

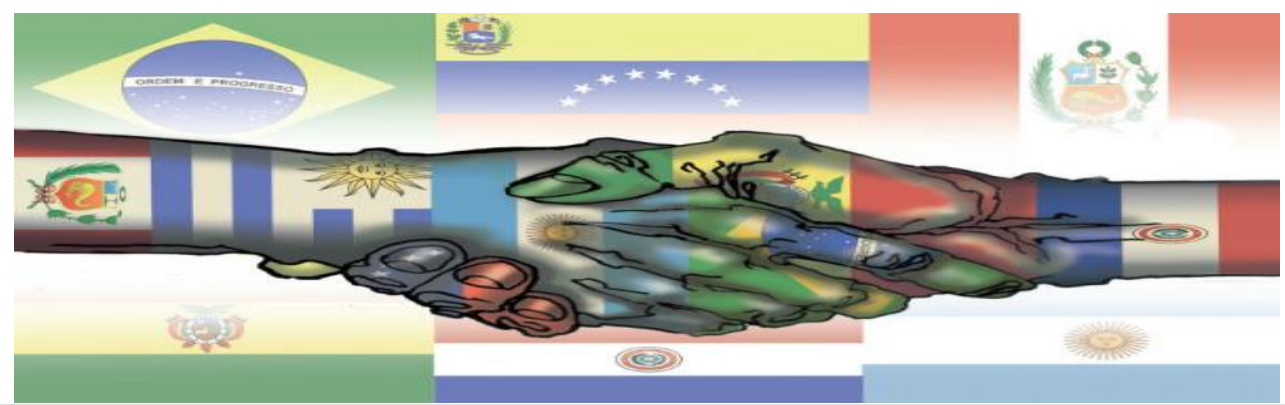

Una propuesta cultural que convoca a las expresiones latinoamericanas.

La Dirección de Cultura, informa que debido a las condiciones climáticas registradas en los últimos días y al pronóstico de lluvias para el próximo fin de semana, se suspendió la propuesta 'Patio Latinoamericano' que iba a realizarse en el Parque Cívico los días sábado 16 y domingo 17 de abril."203

Al encontrarse con las negativas de la AEE (para participar de la Fiesta Provincial del Inmigrante) y las limitaciones de la intendencia municipal (para realizar el Patio Latinoamericano), a mediados del año 2014 algunas de las colectividades que reúnen a los inmigrantes latinoamericanos se inscribieron en un registro municipal para participar de la "Feria de Artesanos y Productos Típicos Berissenses". Dicha feria se monta sobre el Centro Cívico durante el desarrollo de la Fiesta Provincial del Inmigrante. Por fuera del espacio de la "Carpa de las Colectividades" y mezclados con puestos donde se vendían difusores de calor, juguetes para bebes, chocolates artesanales, ropa usada, CDs y DVDs, portarretratos, talabartería, ponchos, mates, boinas, panqueques y alfajores de maicena, lámparas y artículos para el hogar; dulces caseros, sándwiches de matambre, pastelitos de membrillo, radios antiguas, quesos y fiambres, cestos de mimbre y un sinfín de productos, se ubicaron los stands de algunas de las colectividades latinoamericanas. Entre ellos se encontraba el de la colectividad colombiana. Manifestando su malestar porque los organizadores de la fiesta los hayan dejado fuera de la Carpa de las Colectividades, su presidenta (Sandra Milena Hernández) señaló:

"Estoy un poco inconforme con la organización del evento. Nosotros hicimos un censo donde encontramos 150 colombianos viviendo en la ciudad de Berisso y también tenemos una personería jurídica [en alusión a algunos de los motivos por los cuales la AEE les denegaba el ingreso]. Decidimos unirnos a la actividad para mostrar nuestra gastronomía, nuestra cultura, nuestros trajes y bailes típicos. Por eso nos acercamos a la Asociación de Entidades Extranjeras para apoyarlos, participar y sentirnos un poco más unidos pero nos pusieron fuera de la carpa, diciendo que son colectividades europeas que vienen con muchísimos años de trayectoria.

203 Fuente: http://www.berisso.gov.ar/noticia/por-razones-climaticas-se-suspendio-el-festival-patiolatinoamericano 
El límite impuesto por la AEE habría sido argumentado a partir de la personería jurídica que algunas colectividades supuestamente tendrían (y otras no), el tiempo que unos llevan en la ciudad ( $\mathrm{y}$ otros no) y el origen nacional europeo al cual algunas representan (y otras no). Límites "legales", "temporales" y "nacionales".

"Nos dejaron en la parte de afuera -continuaría diciendo Sandra Milena Hernández- haciéndonos pagar un canon de 7.500 pesos [para estar en la Feria de Artesanos]. El sábado 27 nos acercamos a hacer el armado del stand y no teníamos luz, sólo un conector sin ni siquiera el tomacorriente y sólo tres paredes, la cuarta no estaba. Tampoco hubo seguridad, hoy a la mañana nos encontramos con que nos habían robado algunos utensilios con los que trabajamos. Queremos trabajar en conjunto y mostrar nuestra cultura, pero acá nos dieron el stand $\mathrm{N}^{\circ} 60$, el último, y no estamos al lado de Perú ni ninguna otra colectividad sino al lado de microemprendimientos que venden distintos productos".

La diferencia entre el "adentro" y el "afuera" era absoluta. El límite entre la Carpa de las Colectividades y la Feria de Artesanos no era solamente físico, sino también simbólico. Si la Carpa constituye un espacio de legitimación -con buenas condiciones edilicias y técnicas, donde los stands muestran la "cultura típica" de cada colectividadla Feria aparece como un lugar donde las condiciones materiales y simbólicas están completamente degradadas para la representación cultural. Teniendo en claro que las decisiones sobre la posibilidad de participar de la fiesta no eran solo de la AEE sino también de la intendencia, Sandra Milena Hernández señaló:

"Quizás el intendente o quien organiza el evento no se dieron cuenta de la magnitud, la fuerza y el potencial que tenemos como colectividad, ya que estamos migrando mucho a la Argentina y aportando muchos estudiantes y trabajadores. El 30 y 31 de agosto realizamos una fiesta por la que pasaron más de 60 mil personas en Plaza Moreno [plaza central de la ciudad de La Plata], demostrando que sí llenamos un escenario desde las 12 a las 22 horas. En el momento de las elecciones sí buscan al colombiano empadronado, somos en total 2.500. Así que queremos participar y estar unidos dentro de la carpa como todas las colectividades, y no hacer diferencia por ser latinoamericanos.

Así, dejó en claro hacia dónde se orientaban sus demandas y perspectivas de acción:

"Queremos que esto se revierta. Nos gustaría mucho que en las carpas no sólo estuviera Colombia, sino también nuestros hermanos peruanos, ecuatorianos, uruguayos, chilenos, que somos la patria grande y no tenemos por qué ver las diferencias entre latinoamericanos y europeos, porque todos somos extranjeros." 204

\footnotetext{
204 Fuente: Periódico digital "Berisso Ciudad", 1 de Octubre del 2014. http://www.berissociudad.com.ar/nota.asp?id=22072\&id tiponota=8
} 
Si bien ninguna de las ediciones del Patio Latinoamericano se llevó a cabo ni las colectividades que reúnen a los inmigrantes latinoamericanos pudieron participar de la Fiesta Provincial del Inmigrante, entendemos que los intentos por organizar aquel Patio e instalar sus stands en la Feria de Artesanos ilumina un proceso donde estos actores articularon una demanda colectiva ante la Intendencia Municipal tendiente a disputar visibilidad en la esfera pública. Como han mostrado otros autores los contextos festivos adquieren especial relevancia para los inmigrantes latinoamericanos, ya que habilitan un espacio donde revertir la visibilización negativa de la que habían sido objeto durante los años 90 (Giorgis, 2004; Halpern, 2006; Granero, 2006; Gavazzo, 2004, 2005, 2006 y 2013; Sassone y Baby-Collin, 2012; Mallimaci Barral, 2016; Nava le Favi, 2016). Esos trabajos entendieron a las fiestas como una instancia de interacción social en la cual los inmigrantes latinoamericanos reconstruyen un conjunto de tradiciones culturales que, lejos de ser la conservación de una esencia ancestral o un pasado fundacional, son la puesta en escena de su vínculo con el contexto local (Grimson, 1999; Benza, 2001; García Vázquez, 2005; Bonaparte, 2005; Serafino 2010; Barelli, 2011; Passarelli y Giménez, 2015; Serafino y Demarchi, 2015).

Finalmente nos parece importante señalar que los inmigrantes latinoamericanos radicados en Berisso se habrían vuelto parte de los actores frente a los cuales -al menos hasta 2015- se reconstituyó el imaginario con el cual la comunidad era representada en contexto festivo. Si este imaginario se fundó en la creencia compartida de un origen común ("europeo, descendidos de los barcos, blancos") los inmigrantes latinoamericanos funcionaron como el contraste necesario (Weber, 1998:34) a partir del cual los descendientes de inmigrantes europeos conformaron un nosotros que, claramente, los excluye. Como vimos, no solo la AEE les ha vedado el ingreso sino que además la intendencia municipal reafirmó dicha exclusión "habilitándoles" espacios "por fuera" de la Fiesta Provincial del Inmigrante. Sin duda, aquella distribución/segregación espacial que describimos en el capítulo №2, mostrando que los inmigrantes latinoamericanos viven en la periferia sur de la ciudad, pareciera tener su correlato en el espacio físico y simbólico que tuvieron durante la Fiesta Provincial de Inmigrante (2010-2015). 


\section{Conflictos: partidos políticos y ambientalistas}

\section{1. "A donde está, a dónde está, la democracia de Slezack"}

Mientras la asociación caboverdeana y las asociaciones que reúnen a los inmigrantes latinoamericanos llevaron a cabo un conjunto de prácticas y discursos orales que cuestionan el imaginario acrisolado (blanco/europeo) con el cual la comunidad era representada en la fiesta, otros actores irrumpieron en ella canalizando demandas hacia (y disputándole lugares políticos a) una gestión de gobierno municipal que se encontraba a cargo del peronismo.

Uno de los actores que anualmente irrumpió en el Centro Cívico durante los Desfiles de Clausura estuvo conformado por un conjunto heterogéneo de partidos políticos. Todos los años, debido a que el acto se realiza pocas semanas antes de las elecciones (septiembre), estos actores desplegaron sus banderas y mesas partidarias mientras sus militantes repartían volantes y cantaban consignas políticas cuyo destinatario central era el peronismo.

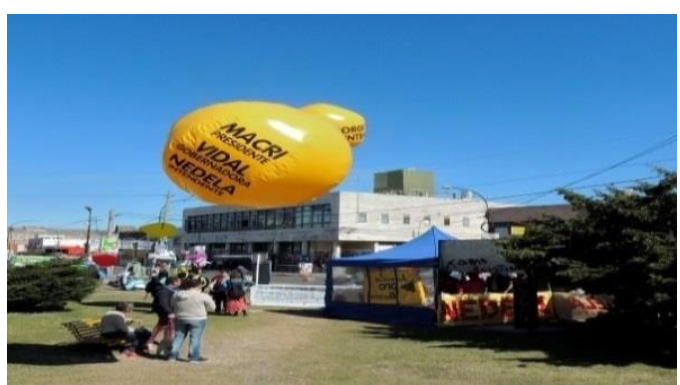

2013

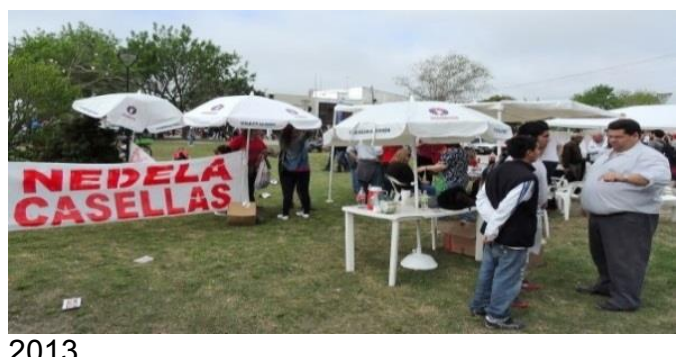

2013

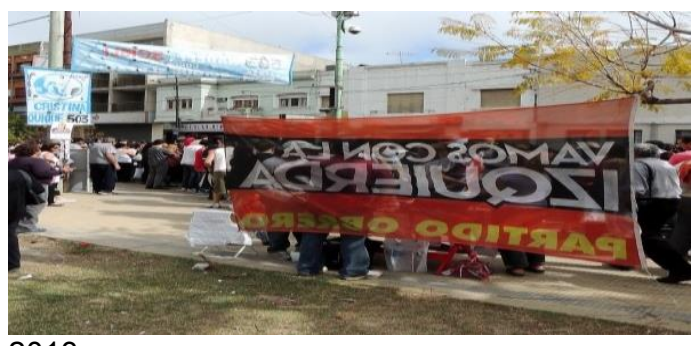

2013

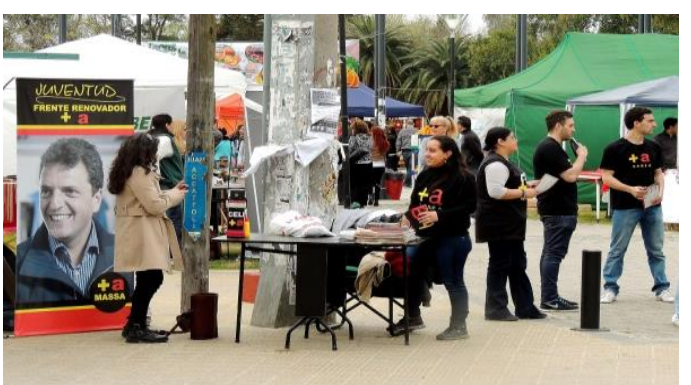

2013

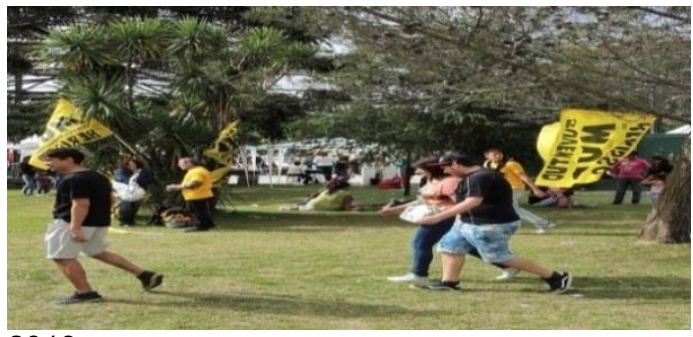

2013

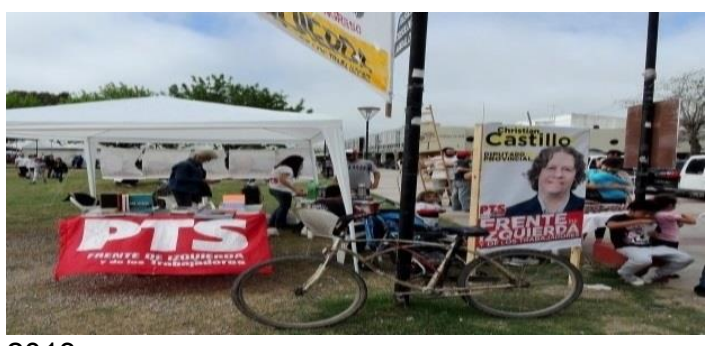

2013

Otro de los actores de la sociedad que en diversas ediciones irrumpió en la fiesta visibilizando sus demandas y cuestionando la legitimidad de algunas decisiones 
políticas adoptadas por el intendente municipal, estuvo conformado por un heterogéneo grupo de ambientalistas (asambleístas afectados por las inundaciones ocurridas durante abril del 2013, militantes contra el desmonte que provocaron la construcción del Terraplén Costero y el Puerto local, etc.). Luego del paso de la colectividad Italiana, dichos actores interrumpieron el Desfile de Clausura de los años 2013 y 2014 detrás de un enorme pasacalles que decía "Colectividad de Contaminados".

Vestidos en su mayoría con mamelucos blancos y tapando sus bocas con barbijos, recorrieron la Avenida Montevideo con banderas donde podía leerse: "No al desmonte", "Berisso defiende su monte", "Asamblea de vecinos y productores familiares autoconvocados en defensa del monte", "Contaminados", etc. Una vez que se encontraron situados frente al Palco Oficial le solicitaron al Intendente Municipal (Enrique Slezack) hacer uso del micrófono para leer públicamente un comunicado. Al no obtener respuesta se sentaron sobre la calle, tomaron un megáfono y comenzaron a corear algunas consignas. "El monte es vida, el Puerto contamina. El monte es vida, el Puerto contamina" se escuchó después de que el intendente afirmara -rodeado por una gigantografía que narraba las obras realizadas en el Puerto- que el desarrollo portuario incentivado desde su gestión haría renacer el trabajo que los berissenses habían perdido. Luego de esto, haciendo alusión al desarrollo urbanístico que el intendente acababa de prometer -cuando afirmó que el Terraplén Costero iba a permitir habitar zonas anteriormente inundables- los ambientalistas corearon: "No se vende, la tierra se defiende. No se vende, la tierra se defiende". Con el paso del tiempo y ante la negativa oficial de darles el micrófono, la tensión aumentó hasta que la policía comenzó a "pedirles" que se retiraran y permitieran que el Desfile finalizara. Luego de transcurrida media hora los ambientalistas se fueron cantando una consigna cuyo único destinatario era el intendente municipal: "A dónde está, a dónde está, la democracia de Slezack. A dónde está, a dónde está, la democracia de Slezack."205

Tal y como expusimos en el Marco Teórico, las fiestas no son únicamente un espacio en el cual los sectores dominantes reproducen el orden social, sino además un contexto donde otros actores visibilizan sus demandas y disputan la legitimidad de los sectores dominantes (Homobono, 1990; Ortemberg, 2013). A lo largo de este apartado hemos presentado algunos datos de campo que van en esa dirección y que serán profundizados en futuros trabajos para ahondar en los cuestionamientos que -en

\footnotetext{
${ }^{205}$ Se puede ver parte de esta situación en https://www.youtube.com/watch?v=WUsnbpUn1JU
} 
contexto festivo- recibió el peronismo: uno de los ejes identitarios a través de los cuales se construyó, hasta el año 2015, el imaginario sobre la comunidad local.

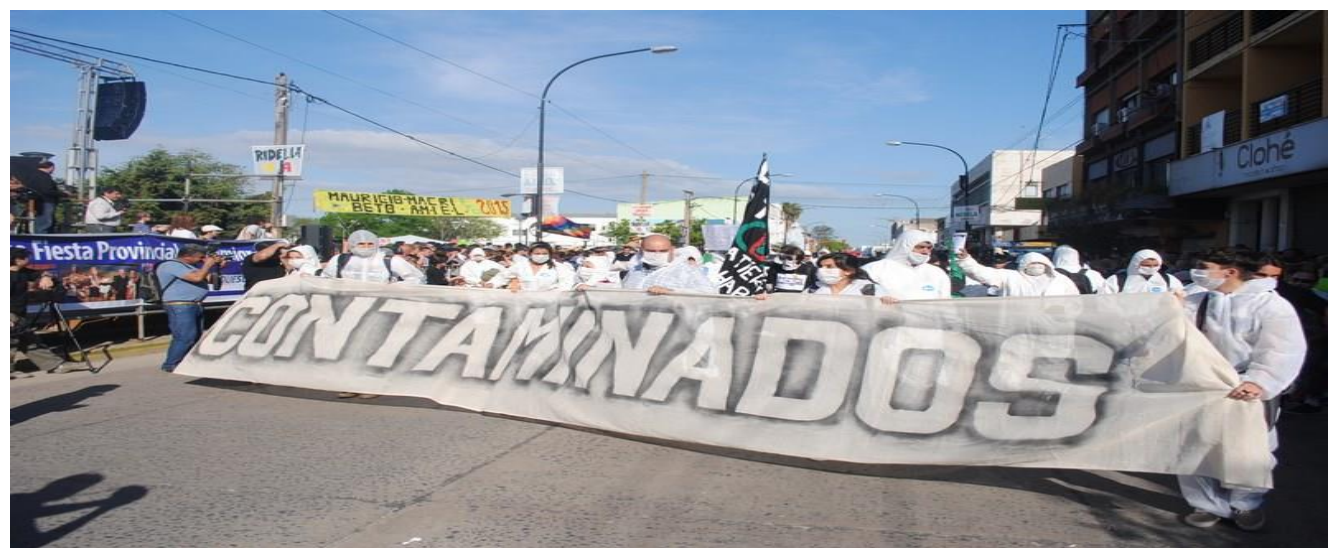

Fuente, Berisso Ciudad "El Portal de Noticias de Berisso y su región", 13 de Octubre 2014 http://www.berissociudad.com.ar/nota.asp?n=\&id=22178

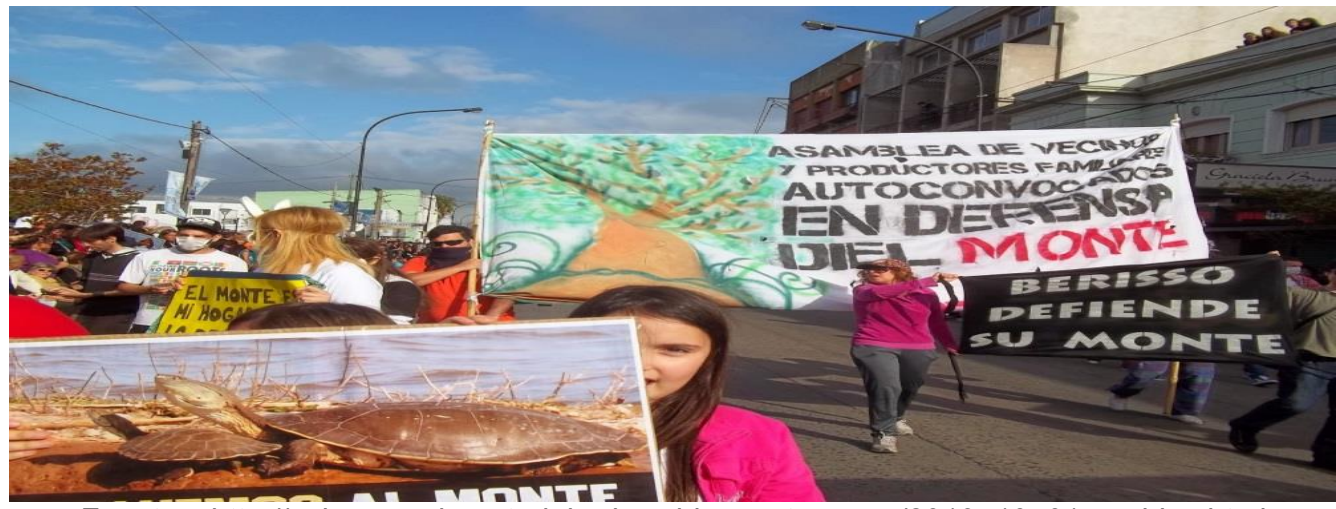

Fuentes: http://salvemoselmontedeberisso.blogspot.com.ar/2013 1001 archive.html

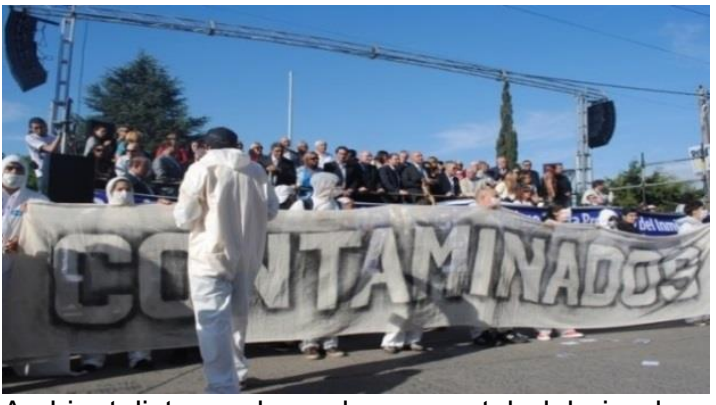

Ambientalistas colocando un cartel debajo de las autoridades municipales, palco oficial del Desfile de Clausura.

Fuente, Berisso Ciudad "El Portal de Noticias de Berisso y su región", 13 de Octubre 2014 http://www.berissociudad.com.ar/nota.asp?n=\&i $\underline{d=22178}$

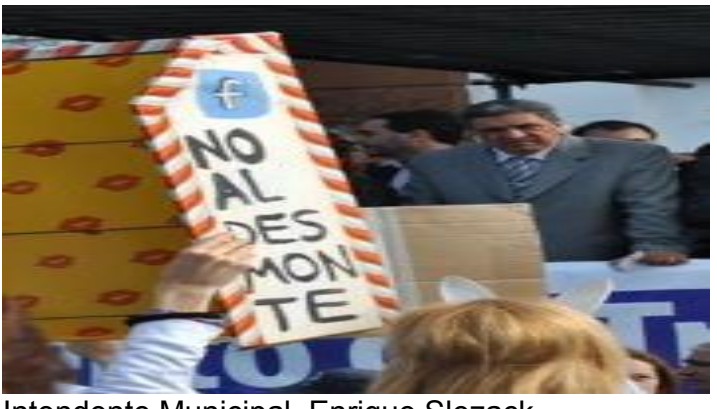

Intendente Municipal, Enrique Slezack

Fuente: Nuevo Ambiente, 14 de octubre 2013. http://www.nuevoambiente.org/2013/10/14/ladefensa-del-monte-ribereno-en-la-fiesta-delinmigrante/ 


\section{Reflexiones finales}

Lejos de aparecer como una instancia de ocio improductivo, lúdica y desproblematizada en la cual la irracionalidad de los actores se colocaría en un primer plano de análisis -como fue caracterizada por los estudios que trasladaron hacia ella el vínculo entre ritual e irracionalidad- las fiestas se vuelven un contexto en el cual actores plenamente reflexivos conjugan simultáneamente prácticas tendientes a la reproducción y al cambio social. Siguiendo esta última línea -ya que en el capítulo anterior nos habíamos enfocado en la primera- analizamos un conjunto de prácticas y discursos orales a través de las cuales distintos actores cuestionan el imaginario acrisolado y peronista con el cual la comunidad era representada en contexto festivo. La fiesta se vuelve un contexto de disputas, exclusiones y conflictos, que hacen entrar en crisis ese imaginario armónico con el cual la comunidad era representada. Tal y como definimos siguiendo a Weber (1998), la comunidad no supone la ausencia de conflictos, sino que los mismos se vuelven una condición inherente a ella. Sin embargo, para imaginarse en tanto tal, la comunidad debía resaltar la existencia de un compañerismo profundo y horizontal entre sus integrantes que oculte las desigualdades que la atraviesan (Anderson, 2007). Así, lo largo del capítulo mostramos cómo la Fiesta Provincial del Inmigrante se vuelve un contexto en el cual mientras algunos actores disputan visibilidad y reconocimiento social otros cuestionan la legitimidad y representatividad de una gestión municipal a cargo del peronismo. Allí, fundamentalmente, el origen blanco y europeo de la comunidad fue cuestionado por descendientes de inmigrantes caboverdeanos e inmigrantes latinoamericanos. 


\section{Excurso № 2: El equívoco de María}

Durante la primera parte de mi trabajo de campo ocupé, en el contexto festivo, el lugar/rol de observador distante, neutral, ascético. Sabía que debía ir a la fiesta porque, como señalé en la introducción de la tesis, para los propios actores ahí se jugaba algo a ser indagado. Sin embargo, iba a la fiesta con un block de notas, lapiceras, cámara, grabador y muy poca capacidad para entablar algún diálogo con las personas que me rodeaban. $Y$ si bien la presencia de alguien que saca un cuaderno, un grabador o una cámara para registrar "todo" lo que está a su alrededor condiciona el hacer de los actores, mis observaciones participantes tenían más de lo primer que de lo segundo. Hasta ese momento del trabajo de campo contaba con muy pocos elementos que me permitieran reconstruir la tan mentada "perspectiva del actor". Así, y como señalamos en la Estrategia Metodológica, la tarea del método etnográfico quedaba incompleta (Guber, 2001).

Promediando el trabajo de campo se hizo imprescindible romper con un conjunto de temores; los cuales se encontraban (in)fundados en la posibilidad de cometer algún tipo de "error" que eliminara por completo la posibilidad de "seguir estando ahí". Así, en una de las misas que inauguraron la fiesta me acerqué a los miembros de la colectividad caboverdeana con el objetivo (de mínima) de que mis observaciones tuvieran un carácter más participativo y (de máxima) comenzar a elaborar una vía de acceso hacia el sentido práctico de estos actores. Luego de presentarme -diciendo mi nombre, mi profesión y comentándoles que estaba haciendo un trabajo sobre la Fiesta Provincial del Inmigrante- les consulté si en algún momento podíamos hablar sobre la participación de su colectividad. Mucho nos les interesó mi nombre, ni mi profesión, pero algo de la presentación que hice sobre mi tema de investigación causó el efecto buscado: me invitaron a su asociación, diciéndome que podía asistir a la próxima reunión de Comisión Directiva que tuvieran. Allí me presentarían al resto de sus miembros y podíamos hablar tranquilo.

Días después, finalizada dicha reunión de Comisión Directiva, se me acercó la única persona ante quien no había podido presentarme previamente. Luego de saludarla, María me preguntó amablemente quién era y qué hacía ahí. Le respondí diciendo mi nombre y contándole que estaba haciendo un trabajo sobre la participación de la colectividad caboverdeana en la Fiesta Provincial del Inmigrante. "Ah, sos periodista... iqué bueno! A esta hora nos estamos yendo pero volvé cuando quieras. Contá conmigo para lo que necesites, en serio. Todo lo que sirva para 
difundir lo que hacemos es bienvenido", me dijo. No quise corregirla, pero a decir verdad no soy periodista ni estaba realizando un trabajo para difundir lo que ellos hacían. Tome el comentario de María como un error involuntario, sin ninguna importancia y me retiré del salón. Mucho tiempo después entendí que el hecho de no haber prestado atención al equívoco de María había sido un error completamente mío. Tendría que haberme preguntado, al menos, ¿cuál era el rol que, para ella, yo cumplía ahí? ¿Mi lugar era el de sociólogo devenido etnógrafo durante el trabajo de campo o un canal a través del cual dar a conocer lo que ellos hacen? ¿Qué rol/lugar ocupaba yo, ahí, para ella?

Como señala Guber (2009) los primeros roles que nuestros informantes nos asignan no recorren un círculo arbitrario sino que siguen la experiencia de los sujetos, sus marcos interpretativos y sus sentidos comunes. Reconstruir ese proceso de asignación y negociación de roles ayuda a comprender un conjunto de dimensiones centrales del marco de sentidos desde el cual los actores nos hablan y en el cual inscriben sus prácticas (Frederic, 1998). De esa manera, preguntarnos ¿qué ven cuando nos ven? no implica solamente hacer un ejercicio de reflexividad metodológica (Bourdieu, 2003; Bourdieu y Wacquant, 2008) sino, fundamentalmente, acceder a la reflexividad nativa siguiendo la trama de expectativas que el investigador ha generado durante su trabajo de campo. En ese marco, Auyero y Grimson (1997) vieron en el equívoco etnógrafo/periodista el índice de una relación instrumental que los sectores populares buscan construir con los medios de comunicación para visibilizarse y visibilizar sus demandas en la esfera pública. Frente al "periodista" estos actores reconocen "un canal directo hacia el ámbito público" (ídem, 1997: 8). Así, cabe pensar que la equivocación del rol del "sociólogo" con el del "periodista" evidenciaba sentidos prácticos de mis informantes -en relación a ciertos "usos del periodista"- que solo podían ser interpretados si me preguntaba "qué era yo para ellos". ¿De qué aspectos del universo social indagado me informaba el equívoco de María? ¿Qué tipo de "dato" construía, ese equívoco, en esa situación de campo?

Casi al final de esta investigación logré comprender que para María yo ocupaba, en alguna dimensión, el mismo lugar/rol que para otros miembros de la colectividad caboverdeana tenía la Fiesta Provincial del Inmigrante: un canal a través del cual dar a conocer lo que hacen. La búsqueda de visibilidad que estos actores desarrollan en la fiesta -y que me costó mucho tiempo poder describir e interpretar- es la misma que ella puso delante de mis ojos cuando me confundió con un "periodista". Aquel "difundir lo que hacemos" a través de un "periodista" que manifestó María, estaba íntimamente ligado a un conjunto de expresiones que otros miembros de esa colectividad me 
dijeron cuando les pregunté sobre su participación en la fiesta: había que "sacar a Cabo Verde fuera de la sede"; "mostrarnos, que la gente nos conozcan y vea lo que hacemos"; "si no salimos de la sede, no nos ven; y si no nos ven, nos morimos"; "si vos no te haces visible, nadie tiene porqué saber quién sos. Por eso, ponernos en una vidriera, mostrar quienes somos, qué hacemos estuvo genial. Y la fiesta sirvió para eso."

\section{Auyero y Grimson señalan}

"En la medida en que los actores identifican al etnógrafo con el periodista es probable que tiendan a desarrollar los discursos que desean que alcancen el ámbito público, buscando desarrollar argumentaciones que demuestren la particularidad de su situación y la necesidad de ayuda, su situación de desprotección, etcétera." (Auyero y Grimson, 1997: 8).

Si por un lado el análisis sobre el lugar/rol que María me atribuyó contribuye a dar cuenta del sentido práctico que mis informantes le otorgaban a su participación festiva, por otro lado muestra la tendencia "epistemocéntrica" con la que hice la primera parte de mi trabajo de campo. Tendencia intelectualista que construye el mundo social desde una mirada teórica, un "ojo contemplativo" (Bourdieu y Wacquant, 2008) que tiende a elaborar una representación sobre lo social como si fuera un espectáculo, y no desde la lógica práctica de los actores. En suma, salir de ese lugar/rol fue central para construir un análisis de la Fiesta Provincial del Inmigrante que recupere la perspectiva del actor. 


\title{
Conclusiones
}

\begin{abstract}
"La inmigración es uno de los mitos fundacionales de la Argentina y constituye un rasgo cultural del imaginario y de la identidad de una sociedad que la vincula de manera indisoluble con su edad de oro."

(Bjerg, 2016)
\end{abstract}

El tiempo transcurrido desde que finalizamos nuestro trabajo de campo en la Fiesta Provincial del Inmigrante (diciembre del 2015$)^{206}$ ha sido central para distanciarnos del objeto de estudio y, a la vez, terminar de encontrarnos con él durante el proceso de escritura (Geertz, 1989; Cardoso de Oliveira, 1996; Guber, 2001). Esa relación entre proximidad y distancia nos permite mirar de manera global un material que en las primeras etapas de la investigación parecía fragmentario, caótico y disperso. En tal sentido presentamos a continuación las conclusiones más significativas que se desprenden del contenido de la tesis, las cuales no pretenden resumir lo expuesto en cada uno de los capítulos sino mostrar los procesos sociales que el caso analizado nos ayudó a comprender. Finalmente, cerramos la tesis exponiendo algunos de los aportes que la investigación realiza al cruce entre inmigración y memoria. Temas de indagación alrededor de los cuales se han constituidos sólidos campos académicos que no siempre dialogan entre sí.

Si la reposición ritual de mitos ha sido una entrada privilegiada para la interpretación académica de distintas formaciones culturales, la Fiesta Provincial del Inmigrante fue la llave (Grimson, 2011:222) que nos permitió conocer un conjunto de dimensiones centrales de la sociedad berissense. La importancia científica de estos rituales radica, justamente, en que ellos son constitutivos de la interpretación que los propios actores hacen de sí mismos y sus sociedades. Una narración que se cuentan sobre su propio pasado, la cual no solo les permite interpretarse como parte de un colectivo sino además darle forma, constituirlo, durante el acto narrativo. En ese proceso de comunalización (o creación de comunidad) el pasado juega un rol fundamental, instituyendo límites sociales hacia fuera y hacia adentro de la comunidad. Si por un lado el pasado logra identificar a sus miembros en torno al recuerdo de un origen compartido (distinguiéndolo de otros colectivos), al interior de

\footnotetext{
206 Si bien durante el año 2016 realizamos algunas entrevistas, revisamos nuevas fuentes documentales y procesamos algunos datos estadísticos, estos recursos estuvieron orientados a completar el material que construimos entre los años 2010 y 2015.
} 
este agregado social constituye un recurso a través del cual distintos actores disputan legitimidad, prestigio y reconocimiento social. Elementos simbólicos constitutivos de la estructuración social del presente. Así, la reposición ritual de mitos de origen expresa en el plano de lo simbólico las desigualdades sociales y el ejercicio del poder.

Insertos en ese marco de preocupaciones definimos a la Fiesta Provincial del Inmigrante como un ritual conmemorativo en el cual los descendientes de inmigrantes ultramarinos reunidos en las asociaciones étnicas locales y los representantes de la intendencia municipal (sujetos de la celebración) reconstruyeron a lo largo del tiempo (1978-2015) un imaginario sobre la comunidad berissense apelando a hechos de su propio pasado. Para decirlo de manera taxativa, el pasado juega un rol constitutivo en el imaginario sobre la comunidad berissense que la fiesta actualiza año tras año. Pero además, vertebra los procesos de identificación étnica y política de los actores que participan de ella. Al llegar a Berisso no solo me sorprendió la enorme cantidad de marcas territoriales de la memoria que recordaban al peronismo y a la inmigración ultramarina, sino el hecho de que para identificarse como berissenses mis vecinos realizaban un trabajo de memoria en el cual la ciudad aparecía, simultáneamente, como la capital provincial del inmigrante y la cuna del peronismo. Estos actores no podían narrase a sí mismos en tanto berissenses y yo no podía comprender cómo la comunidad era imaginada en contexto festivo, si ambos dejábamos de referíamos a hechos de su propio pasado. Esos mismos hechos del pasado utilizados para identificarse como berissenses eran aquellos que articulaba el imaginario armónico dramatizado en la fiesta.

Luego de recorrer distintas teorías antropológicas del ritual que dieron marco al estudio empírico del fenómeno festivo, la definición adoptada no solo nos permitió analizar el rol que juega el pasado en la escenificación de un imaginario sobre la comunidad berissense sino, fundamentalmente, comprender cómo la apelación a dicho pasado forma parte de las disputas del presente. Disputas que, como dijimos anteriormente, refieren a un conjunto de elementos simbólicos de la estructuración social: legitimidad, prestigio, reconocimiento, visibilidad, status, etc. Alejándonos de un conjunto de perspectivas teóricas que señalaron la ausencia de rituales en las sociedades modernas -vinculándolos con la existencia de supuestas prácticas irracionales, ociosas e improductivas en las sociedades tradicionales- la perspectiva teórica asumida buscó comprender la relación que la fiesta posee con la estructuración de la sociedad berissense, analizando en ella la existencia simultánea de prácticas tendientes a la reproducción y al cambio del orden social. 
En ese marco analizamos empíricamente los elementos a través de los cuales los sujetos de la celebración repusieron, en la esfera pública, la memoria oficial de Berisso. Aquí, el lugar central lo ocuparon dos mitos de origen: un origen de la comunidad ligado a la llegada de inmigrantes ultramarinos (durante el período de entre siglos, XIX-XX) y el vínculo que ella tuvo con los orígenes del peronismo (durante el 17 de Octubre de 1945). Ahora bien, si las prácticas desarrolladas por dichos actores encontraron un marco de sentidos dentro del cual ser interpretadas es porque, en buena medida, dichos mitos de origen están sostenidos en hechos del pasado local. En otros términos, la historia inmigratoria y la historia política de Berisso estructuran los marcos sociales de la memoria dentro de los cuales las prácticas y discursos orales desarrollados en contexto festivo adquieren pleno sentido. $Y$ por lo tanto, fue a partir de la reconstrucción de esas historias que pudimos describir, analizar y comprender las prácticas y discursos orales desarrollados durante la fiesta.

Buscando dar cuenta de esta situación reconstruimos los ejes centrales de la historia inmigratoria y fabril de Berisso, centrándonos en las tensiones que existieron a lo largo del siglo XX entre las identificaciones étnicas y las identificaciones políticas. Sistemas de adscripción identitarios que -de manera alternativa- prevalecieron una sobre la otra a partir de los contextos sociales en las cuales eran activadas: mientras en el período 1871-1936 proliferaron las identificaciones étnicas (por la heterogeneidad social que el arribo de inmigrantes le imprimió a la sociedad berissense) y en el período 1936 y 1955 proliferaron las identificaciones políticas (como respuesta a la crisis del tejido fabril), durante el período 1955-1983 se produjo un declive de las últimas y un renacer de las primeras (ante las limitaciones que las distintas gestiones del Estado le impusieron a las identificaciones políticas). Situados en este último período -dando cuenta de los cambios que sufrieron los objetivos fundacionales del asociacionismo étnico y el rol que jugaron los descendientes de inmigrantes en dicho proceso- contextualizamos el origen de la Fiesta Provincial del Inmigrante a fines de los años 70. En un contexto dictatorial marcado por la crisis del tejido fabril de la ciudad y la violencia política, la creación de la fiesta estuvo ligada a la necesidad de reponer un imaginario armónico sobre Berisso: al recordar un origen inmigratorio (europeo) de la comunidad, aquel imaginario acrisolado buscó silenciar/olvidar los recuerdos que la unía con los orígenes de peronismo.

Luego de describir el proceso institucional a través del cual los sujetos de la celebración lograron crear la fiesta en 1978, aquella contextualización nos permitió analizar las reinterpretaciones que actualmente existen sobre ese pasado. Las fechas, los contextos, los actores señalados como centrales en el proceso fundacional y los 
motivos por los cuales la fiesta habría sido creada constituyen, en el presente, un objeto de reinterpretación, disputas y silencios. Respecto a esta dimensión constitutiva de la producción social de memorias -junto al recuerdo (de un origen inmigratorio) y el olvido (de los vínculos de la comunidad con los orígenes del peronismo)- analizamos los silencios en torno al rol que jugó el intendente municipal en el origen de la fiesta. Un actor fundamental en todo ese proceso, quién años después sería sometido a juicios por Crímenes de Lesa Humanidad. Así, dar cuenta de las reinterpretaciones, conflictos y silencios sobre aquel origen festivo nos permitió analizar la producción social de memorias sobre un mismo pasado. Un pasado claramente en disputa. Resta saber en qué medida nos afectará (o no) haber escrito sobre algunas de las "historias sagradas" de la comunidad (Portelli, 2004; Visacovsky, 2005; Kahan, 2014).

Entrando en uno de los ejes centrales de nuestra indagación (los soportes escritos de la memoria), las Gacetillas Oficiales de la fiesta nos permitieron mostrar cómo las elites dirigentes de las asociaciones étnicas locales y la intendencia municipal fijan por escrito y trasmiten hacia la esfera pública lo que debe ser recordado durante el período festivo: la llegada de inmigrantes europeos y el papel que ellos jugaron en la conformación de la comunidad berissense. En tanto soporte y canal de la memoria escrita, dichos actores dejan depositados en esta gacetilla los sentidos y representaciones sobre el pasado de la comunidad. Narrando, así, su memoria oficial. En ese maco mostramos los elementos a partir de los cuales es reconstruido un imaginario armónico sobre la comunidad berissense: paz, convivencia, solidaridad, respeto a la diferencia, trabajo, contención, tolerancia, amor, sacrificio, etc. Cualidades morales legadas, a su vez, por aquellos inmigrantes que la habrían forjado.

De esta manera analizamos el rol que cumple el pasado para los descendientes de inmigrantes: si sus antepasados "crearon las bases de la sociedad berissense", legándole un conjunto de cualidades morales que la distinguen, estos actores se sitúan en un lugar de enorme prestigio y reconocimiento social. Lugar que solo podrían ocupar quienes portan, por la vía sanguínea, un vínculo directo con los "padres fundadores" de la sociedad berissense. Al instituir al inmigrante ultramarino en figura mítica de la memoria local -"conquistadores, héroes, pioneros, padres fundadores que forjaron las bases de nuestra sociedad"- sus descendientes encuentran en el pasado un recurso de legitimación. Al fijarlo por escrito y trasmitirlo hacia la vía pública durante el contexto festivo, ese pasado los instituye en verdaderos herederos de una tradición "que se lleva en la sangre". Únicos garantes de que no se pierda "la memoria y las tradiciones que definen la esencia de los berissenses". 
Finalmente nos centramos en los dos últimos ejes de nuestra indagación: las prácticas y los testimonios orales a través de los cuales el pasado es traído al presente durante la Fiesta Provincial del Inmigrante. A casi cuarenta años de su primera edición, el trabajo de campo que realizamos durante el período 2010-2015 nos permitió analizar cómo los descendientes de inmigrantes ultramarinos y los representantes de la intendencia municipal continuaban dramatizando en la fiesta un imaginario sobre la comunidad berissense apelando a hechos de su propio pasado.

Respecto a los descendientes de inmigrantes ultramarinos, una de las primeras conclusiones de ese trabajo gira en torno al rol del pasado en las estrategias de identificación étnica. ¿Cómo se reproduce la identificación étnica en aquellos grupos migratorios que no recibieron nuevos flujos de inmigrantes? Para estos colectivos sociales -los cuales viven en una comunidad atravesada por la simbología del crisol de razas- la apelación al pasado, la construcción social de memorias, la posibilidad de recordar un mismo origen y mantener vivas sus tradiciones culturales, es una de las estrategias centrales a través de las cuales reproducir la identificación étnica entre sus descendientes. Actores que, como hemos mencionado reiteradamente, se apropian de una memoria heredada. Una memoria construida en base a una experiencia que les fue trasmitida. Así, y para estos actores, el pasado constituye un recurso fundamental al momento de identificarse étnicamente.

Volviendo al contexto festivo, cabe señalar que mientras la llegada de inmigrantes europeos seguía siendo el objeto central a ser conmemorado, el recuerdo del rol jugado por la comunidad en los orígenes del peronismo constituyó un segundo objeto a celebrar: ambos recuerdos articulaban, de manera llamativa, un imaginario armónico sobre Berisso. $Y$ decimos que esto se daba de manera llamativa porque, en primer lugar, hasta mediados del siglo XX las identificaciones étnicas y las identificaciones políticas habían sido activadas/desactivadas de manera alternativa por distintas coyunturas sociales. En segundo lugar porque desde mediados de siglo XX las asociaciones étnicas que reunían a inmigrantes europeos (y sus descendientes) funcionaron en nuestro país como lugares a partir de los cuales se construyó una identificación de clase media que se opuso a la identificación política peronista. En tercer lugar, porque en sus orígenes el peronismo apeló a una identificación con el migrante interno que se opuso discursivamente a todo aquello que tuviera vínculos con "lo extranjero". Y en cuarto lugar, porque la creación de la fiesta estuvo ligado a la posibilidad de crear un imaginario armónico de la comunidad berissense que, al recordar un origen inmigratorio, permitiera silenciar/olvidar los recuerdos que la unían con los orígenes del peronismo. 
En este marco se vuelve sumamente significativo el uso político del pasado que realizó el intendente municipal cuando -hablando de los inmigrantes europeos- cerró el Desembarco Simbólico del año 2012 con las siguientes palabras: "Acá estos inmigrantes convivían y trabajaban, y lo hacían de tal manera que lograron quedar en la historia de la Argentina con aquel 17 de octubre del 45." En un mismo gesto discursivo, los inmigrantes europeos se vuelven el actor central en las gestas fundacionales del peronismo. Evidentemente todo hecho (hasta el que nos podría parecer irreductible a cualquier interpretación) por lejano o por banal que sea, puede funcionar a los intereses y fines del presente que los interroga (Bisso y Kahan, 2014: 18-19). En este marco cabría preguntarnos cuáles son los intereses y fines del intendente municipal para vincular, tan claramente, a los inmigrantes europeos con los orígenes del peronismo. Sin tener elementos que nos permitan afirmarlo taxativamente, entendemos que el intendente no elaboraba un discurso en el cual su interlocutor imaginario estaría situado en el pasado: se está dirigiendo a los descendientes de los inmigrantes ultramarinos que se encontraban delante de él; argentinos que construyen sus identificaciones apelando al pasado y "manteniendo vivas" las tradiciones de sus ancestros. Así, tal vez, el intendente haya buscado construir un vínculo entre aquellos inmigrantes europeos y el peronismo que logre, finalmente, señalarles a sus descendientes que deben recordar ese vínculo y mantener vivas las tradiciones de sus ancestros. Ser tan peronistas como sus padres, abuelos, o bisabuelos.

A través de la descripción y en análisis etnográfico de los cinco actos de la fiesta, pudimos comprender cómo los descendientes de inmigrantes ultramarinos y el intendente municipal apelaban a hechos del pasado berissense para dramatizar el pretendido origen ultramarino de una comunidad que, a su vez, habría dado origen al peronismo. Prácticas y discursos que no se producían en el vacío sino, justamente, en un espacio social plagado de marcas territoriales de la memoria: bustos, grafitis, placas y monumentos rememoraban la llegada de inmigrantes ultramarinos durante el período de entre-siglos y el rol jugado por los obreros berissenses durante el 17 de octubre de 1945. Paralelamente vimos cómo la comunidad berissense era homologada a un cuerpo social en el cual cada uno de sus integrantes cumplía, como un órgano, una función vital. Pero no solo la metáfora biológica operaba sobre el imaginario construido en contexto festivo, sino que la comunidad berissense era homologada a una gran familia -elaborando un parentesco ficticio entre sus miembrosdonde la sangre convertía relaciones sociales en algo dado y primordial. Metáforas biológicas que, finalmente, eran vinculadas con una metáfora botánica donde los 
inmigrantes (al plantar sus raíces en tierra berissense) habrían conformado un rico y armónico crisol de razas. Así, mostramos cómo las identificaciones étnicas eran contenidas y legitimadas estatalmente en relación al mito acrisolado: la selección de diacríticos culturales folklorizados, asépticos y no politizados que desarrollan los descendientes de inmigrantes permite que el Estado los interpele y legitime en clave nacional-cultural-folklorizante.

Luego de haber analizado las prácticas y discursos orales a través de los cuales los descendientes de inmigrantes ultramarinos y el intendente municipal reconstruyeron un imaginario armónico, acrisolado y peronista sobre la comunidad berissense -reproduciendo elementos simbólicos de su estructuración social mediante el uso de la memoria oficial-, describimos las disputas, exclusiones y conflictos que se expresaron durante el período 2010-2015. Centrados en la capacidad de agencia de distintos actores, analizamos un conjunto de prácticas y discursos orales tendientes al cambio de la estructuración social.

En primer lugar esto nos permitió completar nuestra descripción de la fiesta, dando cuenta de las dos dimensiones analíticas inherentes a la perspectiva teórica asumida: alejándonos de posturas dicotómicas buscamos comprender, en un mismo contexto festivo, el modo en que actores plenamente reflexivos desarrollaban simultáneamente prácticas tendientes a la reproducción y al cambio de la estructuración social. Lo cual, además, terminó de poner en diálogo nuestra investigación con trabajos académicos que no vieron en las fiestas un mero dispositivo a través del cual se reproducen las diferencias sociales ni un momento donde las mismas quedan completamente subvertidas, sino un contexto de negociaciones, disputas, tensiones, conflictos. Un contexto el cual analizar empíricamente las relaciones entre reproducción y cambio social, entre estructura y agencia, entre historia y biografía, entre sociedad e individuo. Mientras los trabajos centrados en las fiestas del poder ubicaron su referente empírico en distintos actores del Estado y los trabajos enfocados en las fiestas populares lo hicieron en distintos sectores de la sociedad civil, entendimos que para comprender lo que sucedía en la Fiesta Provincial de Inmigrante teníamos que ubicarnos en un punto intermedio. Un lugar que nos permitiera mirar las prácticas desarrolladas tanto por actores estatales y actores de la sociedad civil. Claramente no fuimos los primeros en hacerlo; Hobsbawn (1998:18) había señalado que las fiestas y rituales conmemorativos deben ser entendidos como "fenómenos duales", ya que si bien están construidos "desde arriba" (el Estado) no pueden ser interpretados académicamente si el análisis no incluye una descripción "desde abajo" (la sociedad civil). 
En ese marco nos centramos en las disputas por la visibilidad étnica que desarrollaban los descendientes de inmigrantes africanos y la exclusión de los inmigrantes latinoamericanos. Actores que, de una manera u otra, cuestionaban los fundamentos míticos del crisol de razas (blancas y europeas) con el cual la comunidad era representada en contexto festivo. Así, describimos la conflictividad existente en una fiesta que anualmente repuso un imaginario armónico sobre Berisso. Recordemos: la paz, la tolerancia, el respeto a la diferencia y la solidaridad se erigían como parte de sus elementos constitutivos.

El trabajo etnográfico realizado junto a los miembros de la colectividad caboverdeana nos permitió, fundamentalmente, interpretar los sentidos que estos actores le otorgaban a sus prácticas festivas. Siendo la búsqueda de visibilidad social uno de los sentidos que orienta la acción de estos actores. En una fiesta donde se reponían los fundamentos míticos del crisol de razas, estos actores vieron un contexto en el cual revertir el proceso de invisibilización atravesado por sus ancestros. En ese marco la apelación al pasado inmigratorio de sus ancestros (desligado de la esclavitud y las guerras) constituyó una herramienta a través de la cual estos actores se insertaban dentro de la historia de la inmigración en la Argentina sin perder especificidad. Usos del pasado que les permitían incluirse dentro de un relato fundacional de la nación y, a la vez, distinguirse dentro de él.

Por su parte, pese a los intentos por ingresar a la fiesta, los inmigrantes latinoamericanos quedaban completamente excluidos de ella. Su búsqueda de reconocimiento social choca, literalmente, contra el pretendido origen ultramarino de una comunidad descendida de los barcos. La caracterización cuantitativa de la población extranjera que actualmente vive en Berisso y el análisis de su distribución/segregación espacial nos permitió comprender que la desigualdades sociales expresadas en términos simbólicos poseen su correlato en términos materiales: los inmigrantes latinoamericanos no solo quedaban fuera de la Fiesta Provincial del Inmigrante (y por lo tanto del imaginario con el cual la comunidad berissense es representada), sino que además vivían en las afueras de la ciudad; su periferia sur. Un espacio inundable, con escasos servicios públicos y plagados de estigmas sociales. Por si cabe reiterarlo: las fiestas no son un contexto lúdico donde se desarrollen prácticas improductivas, son un espacio de conflictos donde se dirime la reproducción de las desigualdades sociales. 
Por último, presentamos subsidiariamente algunos materiales de campo sobre los conflictos que generó la irrupción de distintos partidos políticos y movimientos sociales en contexto festivo. Estos materiales (que deben ser ampliados y profundizados en futuros trabajos) buscaron brindar una primera aproximación a los cuestionamientos que sufrió una gestión municipal comandada por peronismo. Si en una dimensión las prácticas de estos actores -al igual que las desarrolladas por los descendientes de inmigrantes caboverdeanos y los inmigrantes latinoamericanos- lograban evidenciar la conflictividad inherente al contexto festivo, por otra parte nos permitió dar cuenta que la legitimidad que gozaban dicha gestión municipal ligada al peronismo podía ser cuestionada. $Y$ no en cualquier contexto, sino en una fiesta donde el peronismo pone en escena toda su liturgia política. Allí, y ante la vista de todos, distintos actores desarrollaron un conjunto de prácticas que cuestionaban su legitimidad.

Luego de estas conclusiones parciales, quisiéramos reconstruir una conclusión general que ponga en perspectiva histórica los procesos centrales que hemos analizado a lo largo de la tesis. Una conclusión que vincule los orígenes de la fiesta con su presente, preguntándonos por los procesos sociales del presente a los cuales la apelación al pasado habría buscado responder. En otros términos, ¿cuáles son los procesos sociales del presente que orientan los usos sociales de pasado y la reposición de la memoria oficial en contexto festivo?

Si la reconstrucción de un imaginario armónico sobre la comunidad berissense moldea las formas de significar el orden social -apelando a un pasado seleccionadoentendemos que esta dinámica se profundiza en circunstancias de incertidumbre política y profundos cambios sociales (Moore y Myerhoff, 1977). En el contexto dictatorial de los años 70 la creación de la fiesta buscó construir una imagen armónica de la comunidad que, al recordar su origen ultramarino, permitiera silenciar/olvidar los recuerdos que la unían con los orígenes del peronismo. En una coyuntura de enormes incertidumbres políticas y profundos cambios sociales, la Fiesta Provincial del Inmigrante repuso en la esfera pública un imaginario acrisolado de la comunidad. Bajo esta misma forma argumentativa entendemos que entre los años 2010 y 2015 la dramatización de un imaginario tan armónico como acrisolado y peronista buscó $1^{\circ}$ ) invisibilizar un cambio fundamental en la composición de la población extranjera que vive en la ciudad y $2^{\circ}$ ) enfrentar la incertidumbre respecto a la permanencia de una mayoritaria identificación local con el peronismo. Un imaginario a través del cual 
moldear las formas de significar el orden social en un contexto atravesado, nuevamente, por enormes incertidumbres políticas y profundos cambios sociales.

Por un lado, la reposición del mito del crisol de razas y la dramatización del supuesto origen europeo de la población local permitió ocultar la existencia de inmigrantes latinoamericanos radicados en Berisso desde hace más de tres décadas. La caracterización de los inmigrantes ultramarinos como "padres fundadores" de la comunidad -y de sus descendientes como verdaderos "herederos de una tradición"constituyeron un límite legitimador frente a "los recién llegados" (Elias y Scotson, 2000). Pese a ser parte de la enorme mayoría de la población extranjera que vive en la ciudad, hasta la finalización de nuestro trabajo de campo los inmigrantes latinoamericanos quedaban excluidos de la fiesta. Si en el período de entre-siglos las elites criollas repusieron en el espacio público -a través de las fiestas patrias- una memoria oficial que limitó el ingreso de los inmigrantes ultramarinos a sus círculos sociales (Bertoni, 2007), el caso analizado en esta tesis muestra un dinámica similar entre los descendientes de inmigrantes ultramarinos ("establecidos") y los inmigrantes americanos ("recién llegados"). Tanto en aquel período como en éste, las formas de significar el orden social a través de los rituales conmemorativos repusieron un límite simbólico entre argentinos y extranjeros. Si bien en la Fiesta Provincial de Inmigrante el objeto a ser celebrado gira en torno al inmigrante ultramarino, la apelación a un origen inmigratorio de la comunidad es llevada a cabo por actores que no pasaron por esa experiencia. Argentinos, descendientes de inmigrantes, que usan el pasado como recurso de legitimación social en el presente. Así, esta fiesta no es de los inmigrantes que viven en Berisso, sino de los argentinos que poseen ascendencia inmigratoria. Como hemos dicho anteriormente, la memoria de (un pasado local vinculado con la inmigración ultramarina) se transforma en una memoria para (actuar en el presente). Un presente en el cual la categoría legitimadora de "inmigrante" podría ser disputada por "los recién llegados".

Por otra parte la apelación a los recuerdos que identifican a la comunidad con los orígenes del peronismo habrían intentado contener una vinculación política entre sus miembros que (si bien nunca fue homogénea ni estuvo ausente de conflictos) tal vez haya entrado nuevamente en crisis: en diciembre del 2015, mientras finalizábamos nuestro trabajo de campo, el radicalismo ganó las elecciones municipales por primera vez en la historia de Berisso. Fue entonces que recordamos la sentencia con la que James concluye su libro sobre las memorias locales de una militante peronista: "La memoria puede ser un poderoso instrumento movilizador capaz de dinamizar las identidades políticas, pero no puede garantizar resultados políticos” (2004: 279-280). 
"Si hay un rasgo que identifica a las ciencias sociales en Argentina es el análisis e interpretación del peronismo", escribió Elizabeth Jelin hace treinta años (1997:302). Si bien coincidimos con ella, creemos que la inmigración ha sido el otro fenómeno constitutivo de nuestra sociedad y, por lo tanto, de las ciencias sociales ocupadas de su estudio. El peronismo y la inmigración han sido fenómenos que dieron forma a nuestros modos de mirar, narrar, comprender e imaginar a la sociedad argentina.

Cuando empezamos la investigación que derivó en esta tesis doctoral habíamos tomado la decisión de centrarnos únicamente en la inmigración, entendiéndola no solo como uno de los fenómenos constitutivos de la sociedad berissense sino además como un recurso de apelación mnemónico a través del cual los descendientes de inmigrantes ultramarinos construyen un imaginario sobre la comunidad berissense que legitima sus posiciones en la estructuración social del presente. El peronismo, de a poco, se fue metiendo por la ventana de nuestro trabajo. Interrumpiéndolo, cuestionándolo, enriqueciéndolo. $Y$ no solo por el hecho de que en su origen la fiesta pretendió borrar los recuerdos que unían a la ciudad con sus momentos fundacionales, sino porque en el propio contexto en el cual hacíamos trabajo de campo los recuerdos sobre dicho vínculo constituyeron otro de los recursos mnemónico del imaginario dramatizado. Evidentemente la fuerza con que la inmigración y el peronismo dieron forma a la sociedad berissense seguían vivas, o al menos algo de su vivacidad se expresaba en la fiesta. Y si Berisso continúa siendo un riquísimo espacio social en el cual estudiar el vínculo entre ambos fenómenos, la Fiesta Provincial del Inmigrante constituyó una pequeña fracción de él. Una aldea en la cual indagar los grandes temas de una cultura (Geertz, 2006c). Un recorte de la realidad a partir del cual comprender algunas dimensiones centrales de aquellos procesos que dieron forma a la sociedad argentina y a las ciencias sociales ocupadas de su estudio. Así, en términos de escalas, es importante concluir que los mitos dramatizados en la fiesta no remitían únicamente al pasado de la comunidad berissense, sino que ellos se encontraban insertos dentro de una escala nacional. "Berisso conjuga la síntesis de la historia nacional", señalaron algunos actores durante el desarrollo de la Fiesta Provincial del Inmigrante.

Finalmente, nos resta presentar algunos de los aportes que -a nuestro entender- la tesis realiza a ese espacio de conocimientos que se encuentra ubicado, justamente, en el cruce entre el campo de los estudios migratorios y el campo de los estudios de la memoria. El campo de los estudios migratorios de la Argentina posee algunos vicios 
de auto-reproducción; donde los temas, objetos y fuentes de indagación parecen reiterarse. Es claro que hay que seguir estudiando esos temas (sean cuales fueran), pero habría que incentivar la búsqueda de nuevos objetos o nuevas fuentes. $O$ al menos renovar las preguntas que le hacemos a esos temas, objetos y fuentes. No es tarea sencilla; la extensión, calidad y densidad de la producción que lo componen hacen extremadamente difícil generar alguna novedad. En este marco una de los primeros aportes que la tesis genera está dado por el contexto de investigación: Berisso. Ciudad atravesada históricamente por diversas corrientes migratorias y donde la proliferación del asociacionismo étnico fue notable. Contexto de investigación que no ha sido indagado con la profundidad que, a nuestro entender, merece. Al interior de este primer aporte, un lugar destacado ocupa la desagregación pormenorizada de los censos de 1991, 2001 y 2010 y la georreferenciación realizada de este último. Datos que, en muchos casos, estaba inéditos o fueron producidos específicamente para esta investigación. Dicho análisis no solo nos permitió caracterizar a la población extranjera que vive en la ciudad sino además comprender su distribución/segregación espacial. Datos de sumo valor para comprender quiénes son los actores que se quedan fuera de la fiesta y el imaginario sobre la comunidad berissense dramatizado en ella: inmigrantes latinoamericanos, jóvenes, mayoritariamente mujeres, que viven en la periferia sur de la ciudad.

En diálogo con un conjunto de trabajos que analizaron las prácticas festivas desarrolladas por los descendientes de inmigrantes ultramarinos, uno de los interrogantes que la tesis buscó profundizar fue cómo indagar temáticas migratorias desde sujetos que no atravesaron por esa experiencia ¿Cómo hablar de la inmigración desde actores que no migraron? Justamente, indagando los modos en que ellos hablan de la inmigración y analizando las prácticas a través de los cuales apelan a ella. Si la inmigración no es para estos actores una experiencia propia, una experiencia vivida, la apelación mnemónica a ella puede constituir un mecanismo de identificación personal, un recurso de legitimación cultural, un eje de agregación social, etc. Posibilidades no excluyentes y que solo se responden a partir de la investigación empírica. Así, entendemos que la tesis genera un segundo aporte al campo de los estudios migratorios a partir de un objeto (las fiestas conmemorativas) y una pregunta (la relación entre inmigración y memoria) con pocos antecedentes.

Por su parte el campo de las memorias ha estado atravesado -no solo en nuestro país- por aquellas preguntas que despertaron las salidas de distintos regímenes políticos violentos. $\mathrm{Y}$ si bien en muchas de las investigaciones insertas en ese campo el cruce entre memoria y etnicidad es central, la memoria y los usos sociales del 
pasado que desarrollan los descendientes de inmigrantes no constituyen aún un objeto de estudio en sí mismo. No todos los pasados que estos actores traen al presente están ligados a hechos traumáticos o violentos. Objeto de estudio que -reiteramosvertebró las preguntas del campo de los estudios sobre memoria. Tal vez aquí radique uno de los motivos por los cuales los pasados a los cuales apelan los descendientes de inmigrantes no hayan constituido un objeto de estudio privilegiado en él. Pero a la vez la pregunta por la construcción social de memorias que realizan los descendientes (los hijos de militantes políticos desaparecidos durante las dictaduras del Cono Sur Latinoamericano, por ejemplo) ha constituido un claro objeto de estudio al interior de este campo. Campo que, sin dudas, puede aportarle al estudio de las memorias elaboradas por los descendientes de inmigrantes un conjunto de perspectivas analíticas, epistemológicas, teóricas y metodológicas de sumo valor.

Hacia el final de uno de sus breves y provocadores textos, Becker (2016: 243-248) se pregunta acerca de cuándo llega, exactamente, ese momento a partir del cual dejamos de trabajar en un proyecto de investigación. "Cómo científicos en ejercicio, nos preguntamos constantemente si nuestra investigación está completa. ¿Puedo detenerme ya?" A lo cual responde que "uno puede dejar de buscar más casos, más pruebas, cuando todos aquellos que tiene voz en el asunto coinciden en aceptar que hemos hecho lo suficiente." Claro, el problema es que aquellos que tiene voz son justamente quienes van a evaluar si efectivamente podías dejar de trabajar en tu investigación o debías seguir haciéndolo por algún tiempo más. Así, como buen dador de trucos del oficio (Becker, 2009), nos señala que el punto en el cual podemos dejar de trabajar en una investigación es cuando logramos controlar "las amenazas más probables a la validez" de nuestros argumentos. En el fondo, según Becker lo que hay que hacer es "protegerse contra los defectos más probables y esperar algunos fracasos y algo de crítica. Es la única opción real." 


\section{Bibliografía}

Archenti N. y Piovani J. I. (2010) "Los debates metodológicos contemporáneos", Cap. II, en Metodología de las Ciencias Sociales, Marradi, A., Archenti N. y Piovani J. I, Cengage Learning Argentina, Buenos Aires.

Achugar, H. (2003) "El lugar de la memoria, a propósito de monumentos", en Jelin, E. y Langland V. (comps) Monumentos, memoriales y marcas territoriales, Madrid y Buenos Aires, Siglo XXI

Adriani, L. y Suárez, M.J. (2003) "Transformaciones en el mercado de trabajo del Gran La Plata en el contexto de convertibilidad", en Pintos, P. (comp.), Pensar La Plata. Políticas públicas, sociedad y territorio en la década de los noventa, La Plata, Al Margen.

Agnelli, S. y Zubrzycki, B., (2008) "Trayectorias migratorias y actividades económicas de los inmigrantes senegaleses en la ciudad de La Plata", en Actas del III Congreso Nacional de la Asociación Latinoamericana de Asia y África (ALADAA), Villa La Angostura, Neuquén.

Águila, G. (2008) Dictadura, represión y sociedad en Rosario, 1076/1983. Un estudio sobre la represión y los comportamientos y actitudes sociales en dictadura. Buenos Aires, Prometeo.

Alberdi, J. B. [1852] (1974) Bases y puntos de partida para la organización política de la República Argentina, Buenos Aires, Plus Ultra.

Albertsen, N., y Diken, B., (2000) ¿What is the social?, Department of Sociology, Lancaster University

Alonso, A. M. (1994) "The Politics of Space, Time and Substance: State Formation, Nationalism and Ethnicity", en Annual Review of Anthropology 23: 379-405.

Alonso, L. E. (1998) La mirada cualitativa en sociología. Editorial Fundamentos, Madrid

Amati, M. A. (2011) Rito y nación. Continuidades y cambios del 25 de mayo en Argentina. Tesis Doctoral, Facultad de Ciencias Sociales, UBA.

-------, Alatsis, G.; Britez, A.; Fernández Ameghino, M.; Galizio, A.; Herrera, N.; Tejero Yosovitch, Y. (En prensa) Disputas por el Bicentenario en Argentina: memorias colectivas, festejos oficiales y alternativos. Universidad Nacional Arturo Jauretche.

Anderson, B. (2007) Comunidades imaginadas. Reflexiones sobre el origen y la difusión del nacionalismo. México, Fondo de Cultura Económica.

Ansaldi, W. (1996) "Las prácticas sociales de la conmemoración en la Córdoba de la modernización, 1880-1914", en http://www.catedras.fosc.uba.ar/udishal; 
publicado originalmente en Sociedad $N^{\circ} 8$, Facultad de Ciencias Sociales (UBA), pp. 95-127.

Archenti, N. (2010) "Estudio de caso/s", Cap. XIV, en Metodología de las Ciencias Sociales, Marradi, A., Archenti N. y Piovani J. I, Cengage Learning Argentina, Buenos Aires.

Ardito A. L., (2014) "Cuando Don Carnal se viste de negro: la negritud nuestroamericana entre lo 'negro' y lo 'afrodescendiente'”, en Latinoamérica, Revista de Estudios Latinoamericanos N59, pp. 223-249, México.

Arendt, H., (2003) "Responsabilidad personal bajo una dictadura", en Responsabilidad y Juicio, Paidós, Barcelona.

Armus, D., (1986) "Diez años de historiografía sobre la inmigración masiva a la Argentina", en Estudios Migratorios Latinoamericanos, $n^{\circ} 4$, diciembre.

Ariño, A., (1992a) La ciudad ritual: La Fiesta de las Fallas. Barcelona, Anthropos.

-------(1992b) "La Fiesta de las Fallas. Una liturgia civil del valencianismo temperamental", en Revista de antropología social, núm. 1. Editorial Complutense, Madrid.

-------(1996) "La utopía de Dionisio. Las transformaciones de la fiesta en la modernidad avanzada", en Antropología, n 11, marzo, pp. 5-19.

Aróstegui, J. (2004) La historia vivida. Sobre la historia del presente. Madrid, Alianza.

Arttoni, A., (1996) "El juego de la tradición o la refuncionalización de la fiesta campesina de tradición oral en la modernidad tardía", en Antropología, n 11 , marzo, pp. 121-133.

Asa, P., Courtis, C., Pacecca M. I., y Talpone, G., (2007) "La población refugiada en la Argentina", en Torrado S., (Comp.) Población y bienestar en la Argentina del primero al segundo centenario. Una historia social del siglo XX. Tomo I. Buenos Aires, Edhasa.

Augé, M., (1994) Los "no lugares". Espacios del anonimato. Una antropología de la sobremodernidad, Barcelona, Gedisa.

Auyero, J. (2012) La política de los pobres. Las prácticas clientelistas del peronismo. Manantial, Buenos Aires.

- y Grimson, A. (1997). Se dice de mí. Notas sobre convivencias y confusiones entre etnógrafos y periodistas. Apuntes de Investigación del Cecyp, 1, 81-93.

Baczko, B. (1999) Los imaginarios sociales. Memorias y esperanzas colectivas. Buenos Aires: Nueva Visión.

Baeza, B., (2010) "Nación y subalternidad en el caso argentino", en Las ciencias sociales frente al Bicentenario: bordes e intersticios de la nación imaginada. 
Baeza B y Carrizo G, 1a ed. - Comodoro Rivadavia: Universidad Nacional de la Patagonia San Juan Bosco.

(2017) "Migrantes quechuas provenientes de Bolivia. La celebración del día de los muertos en Caleta Olivia, Santa Cruz, Argentina", en Clepsidra. Revista Interdisciplinaria de Estudios sobre Memoria, Volumen 4, Número 8, octubre, pp. 86-107.

Balandier, G., [1988] (1990) El desorden. La teoría del caos y las ciencias sociales. Gedisa, Barcelona.

-------(1994) El poder en escenas. De la representación del poder al poder de la representación, Barcelona, Paidós.

Balibar, E. (1991). The Nation Form: History and Ideology. En E. Balibar e I. Wallerstein, Race, Nation, Class: Ambiguous Identities (pp. 86-106), LondonNew York: Verso.

Ballina, S., (2005) "Umbrales y prácticas de etnicización: la comunidad búlgara de Berisso", en Cohen N. y Mera C. (Comps) Relaciones interculturales: experiencias y representación social de los migrantes. Buenos Aires, Antropofagia.

-------(2006) "Etnicidad y estrategias identitarias: modalidades de estructuración en un grupo eslavo de Berisso, Argentina", en Revista del CESLA, núm. 8, pp. 63-86.

-------(2007) "Arqueología de la alteridad en una comunidad de inmigrantes", en Papeles de Trabajo No15, pp.9-32.

-------y Ottenheimer, A. (2006) “Lógicas de lo auténtico: la belleza como frontera étnica en asociaciones de inmigrantes y sus descendientes", en Travessia, revista do inmigrante, año XIX, $\mathrm{n}^{\circ} 56$, setembro-dezembro.

Bajtin, M., [1987] (1994) La cultura popular en la Edad Media y en el Renacimiento. El contexto de Francois Rabelais. Alianza Editorial, Madrid.

Barbieri, M., (2006) "Experiencia migratoria y narrativa personal”. Ponencia presentada en el Congreso Argentino de Estudios sobre Migraciones Internacionales $y$ Políticas Migratorias y de Asilo. Buenos Aires, 25-27 de Abril.

Barelli A. I., (2011) "La Virgen de Caacupé-í símbolo de la inmigración paraguaya en San Carlos de Bariloche", Ponencia, IV Jornadas de Historia Social de la Patagonia. Santa Rosa, Argentina.

https://sociohistoricos.files.wordpress.com/2011/11/ponencia-barelli.pdf [Consultado 10-08-2016]

-(2014) "La Virgen de Caacupé como símbolo de paraguayidad en Bariloche, Argentina (1970-2012)", en Latinoamérica. Revista de Estudios Latinoamericanos, núm. 58, 2014, pp. 205-236 Centro de Investigaciones sobre 
América Latina y el Caribe Distrito Federal, México. http://www.redalyc.org/articulo.oa?id=64030718009

Barfield, T. (2000) Diccionario de Antropología. Siglo XXI Editores, México.

Bargman, D., (2006) "Construcciones identitarias y experiencias migratorias: Memorias de la inmigración familiar en la autodefinición identitaria de jóvenes argentinos"

Barth, F. (1976) Los grupos étnicos y sus fronteras, México, Fondo de Cultura Económica.

Becker, H. (2009) Trucos del oficio: cómo concluir su investigación en ciencias sociales, Buenos Aires, Siglo XXI.

--------(2011) Manual de escritura para científico sociales. Cómo empezar y terminar una tesis, un libro o un artículo, Buenos Aires, Siglo XXI

(2016) Mozart, el asesinato y los límites del sentido común: Cómo construir teoría a partir de casos, Buenos Aires, Siglo XXI.

Benencia, R., (2009) “Apéndice. La inmigración limítrofe”, en Historia de la inmigración en Argentina, Devoto, F., Buenos Aires, Sudamericana.

--------y Gazzotti, A., (1995) “Migración limítrofe y empleo: precisiones e interrogantes”, en Revista de Estudios Migratorios, CEMLA, n 31, Buenos Aires, diciembre.

Bengochea, N y Levín F. (2012) "El estado de la cuestión”, en En carrera: escritura y lectura de textos académicos y profesionales, Natale Lucía (coord.) Universidad Nacional de General Sarmiento, Los Polvorines, pp. 79-97.

Benjamin W., (1968) "Theses on the Philosophy of History", en Benjamin W., (comp.) Illuminations, Nueva York, Schocken Books, págs. 253-264

Benza, S. (2001) "El festejo patrio peruano en Buenos Aires: ritualización del mundo migrante y multiplicidad de la peruanidad", en Revista de Estudios Migratorios, CEMLA, año 16, Diciembre 2001, nº 49.

-------(2005) "Procesos de enseñanza no formal de la danza peruana entre migrantes peruanos en Buenos Aires", en Temas de Patrimonio Cultural N 7, 2005

Berger P., y Luckman, T., (1993) La construcción social de la realidad. Amorrortu, Buenos Aires.

Bertoni, L. A., (1992). "Construir la nacionalidad: héroes, estatuas y fiestas patrias 1887-1891", en Boletín del Instituto Dr. Emilio Ravignani, № 5.

--------(2007) Patriotas, cosmopolitas y nacionalistas. La construcción de la nacionalidad argentina a fines de siglo XIX, Buenos Aires, Fondo de Cultura Económica.

Bialogorski, M., (1993) "La Argentina y la nueva inmigración coreana. Inserción y síntoma de un conflicto", en VI Jornadas de colectividades: Identidad, integración 
e inserción en el país. Relaciones con los países de origen. Museo Roca, Buenos Aires, 28-30 de octubre.

(2001) "Coreanos, judíos y árabes en la Argentina: tres modalidades diferenciales de inserción social y simbólica. Una mirada contemporánea”, en Revista Chilena de Antropología, $\mathrm{n}^{\circ}$ 15, pp. 119-130. Facultad de Ciencias Sociales, Universidad de Chile. Santiago, Chile.

-(2004) La presencia coreana en la Argentina. Construcción de una experiencia migratoria. Tesis de Doctorado de la Universidad de Buenos Aires. Facultad de Filosofía y Letras.

Bisso, A., (2013) “¿Cómo organizar lo espontáneo?” en Cuadernos del Sur, Instituto de Humanidades, Universidad del Sur, Bahía Blanca, Argentina.

------- y Kahan, N. (2014) "Introducción", en Formas políticas de celebrar y conmemorar el pasado (1930-1943), Editorial Ceraunia, La Plata.

Bjerg, M. (2001) Entre Sofie y Tovelille. Una historia de inmigrantes daneses en la Argentina (1848-1930). Buenos Aires, Biblos. -(2016) "La inmigración en la Argentina: un mito fundacional y un problema historiográfico", en Revista Electrónica de Fuentes y Archivos, Centro de Estudios Históricos "Prof. Carlos S. A. Segreti”, Córdoba (Argentina), año 7, número 7 , pp. 322-329.

-------y Cherjovsky I. (2014) "Memoria publica e identidad étnica en el mundo rural de la Argentina. Conmemoraciones locales y fiestas de inmigrantes europeos, 19201940", en Estudios Migratorios Latinoamericanos, CEMLA, № 77, julio-diciembre. Buenos Aires, Argentina.

Blázquez G., (1997) El Sol de 25 viene asomando. Rituales escolares y construcción de la nación. Un análisis de casos: Córdoba 1995, en Ciencias Sociales. Centro de Investigaciones de la Facultad de Filosofía y Humanidades, Universidad Nacional de Córdoba, Córdoba, Vol. 1, n 1, pp. 11-19.

Bodnar, J. (1992) Remaking America: Public Memory, Conmemoration and Patriotism in the Twentieh Century, Princeton NJ: Princeton University Press

Bonaparte, J. M., (2005) "La fiesta como espacio de discurso y de prácticas sociales: El caso de la Virgen de Urkupiña en Córdoba", en Migraciones Contemporáneas y Diversidad Cultural en la Argentina, Domenech E. (comp), Centro de Estudios Avanzados, Universidad Nacional de Córdoba.

Bosi, E. (1979) Memoria e sociedade: lembranças de velhos, San Pablo.

Bourdieu P., (2000) "Algunas propiedades de los campos", en Cuestiones de Sociología. Madrid: Istmo, pp.112-119. 
-----(2001a) “Los ritos de institución”, en ¿Qué significa hablar?, Madrid: Akal Ediciones, pp. 78-87.

-------(2001b) "El lenguaje autorizado: las condiciones sociales de la eficacia del discurso ritual", en Qué significa hablar? Madrid: Akal Ediciones

-------(2002) “Efecto de lugar”, en La miseria del mundo. México, FCE.

-------(2003) El oficio del científico, Barcelona: Anagrama.

-------(2007) “La casa o el mundo dado vuelta”, en El sentido práctico. Buenos Aires, Siglo XXI.

--------y Wacquant, L. (2008) Una invitación a la sociología reflexiva. Buenos Aires: Siglo XXI.

Bretal, E. (2014) La épocas de los ingleses, la época de los militares, la época del cierre. Representaciones y clasificaciones sociales de los ex-obreros de frigorífico Swift de Berisso. Tesis de Maestría en Ciencias Sociales. Universidad Nacional de General Sarmiento, IDES.

Briones, C. (2005). "Formaciones de alteridad: contextos globales, procesos nacionales y provinciales", en C. Briones (Ed.), Cartografías argentinas: Políticas indigenistas y formaciones provinciales de alteridad (pp. 11-43). Buenos Aires: Antropofagia.

Brow, J. (1990) Notes on Community, Hegemony, and the Uses of the Past. Anthropological Quaterly 63 (1): 1-6.

Brubaker R., y Cooper F., (2001) "Más allá de 'identidad”, en Apuntes de Investigación del CECYP, vol.7, pp. 30-67, Buenos Aires.

Bunge, C.O., (1905) Nuestra América (Ensayo de Psicología Social), Buenos Aires, Valerio Abeledo Editor.

Burgess, R. G. (1984) In the Field. An introduction to Field Reserch. Routledge, London.

Busaniche, J. L. (1959) Estampas del pasado. Buenos Aires, Hachette.

Caggiano, S., (2004) “'Lo nacional' y 'lo cultural'. Centro de estudiantes y residentes bolivianos: representaciones, identidad y hegemonía", Ponencia, VII Congreso de Antropología Social, Villa Giardino, Córdoba, 25-28 de mayo.

------ (2005) Lo que no entra en el crisol. Inmigración boliviana, comunicación intercultural y procesos identitarios, Buenos Aires, Prometeo Libros.

-------y Segura, R. (2014) "Migración, fronteras y desplazamientos en la ciudad. Dinámicas de la alteridad urbana en Buenos Aires", en Revista de Estudios Sociales No. 48, Bogotá, enero- abril, pp. 29-42.

Caillois, R., (1963) L'homme et le sacré, París: Leroux 
Caldeira, T., (1984) A política dos outros. O cotidiano dos moradores da periferia e o que pensan do poder e dos poderosos. San Pablo, Editora Brasiliense.

Candau, J. (2001) Memoria e identidad. Buenos Aires, Del Sol.

Canelo B., (2006) Migrantes del área andina central y Estado porteño ante usos y representaciones étnicamente marcados de espacios públicos. Ciudad de Buenos Aires, Argentina. Informe final del concurso: migraciones y modelos de desarrollo en América Latina y el Caribe. Programa Regional de Becas Clacso. Disponible en:

http://biblioteca. clacso.edu.ar/gsdl/collect/clacso/index/assoc/D3355/canelo.pdf

-------(2007) “'Migrantes del área andina': Reflexiones acerca de la elección de una categoría problemática", en Actas de la VII Reunión de Antropólogos del Mercosur. Porto Alegre, 24-26 de julio.

-(2008) "Dirigentes de migrantes andinos, empleados y funcionarios públicos ante 'el estado'. Una mirada desde abajo para comprender procesos políticos locales", en Cuadernos de Antropología Social, $n^{\circ} 27$, Julio.

Cardini F. (1984) Días Sagrados. Tradición popular en las culturas Euromediterráneas. Editorial Argos Vergara, Barcelona, España.

Cardona, G. (1999) Antropología de la escritura. Barcelona, Gedisa.

Cardoso de Oliveira, R. (1996) "O trabalho do antropólogo: olhar, ouvir, escrever", en Revista de Antropología XXXIX, №1, pp. 13-37.

Castells, J., (2006) "Memorias e identidades: Relatos autobiográficos de sobreviventes del Holocausto arribados a la Argentina". Ponencia presentada em el VII Congreso Argentino de Antropología Social, Salta19-22 de septiembre.

Castiglione, M. C., (2017) "Memoria y ritos funerarios: una aproximación a la comunidad coreana en la ciudad de Buenos Aires", en Etnografías Contemporáneas, Año 3, № 5, pp.152-181. Disponible en:

http://www.unsam.edu.ar/revistasacademicas/index.php/etnocontemp/article/view $\underline{1230}$

Castoriadis, C. (1985) La institución imaginada de la sociedad, Barcelona, Tusquets.

Cattaruzza, M. A. (2007) Los usos del pasado. La historia y la política argentinas en discusión, 1910-1945. Editorial Sudamericana, Buenos Aires.

Cazeneuve J., (1971) Sociología del rito. Amorrortu, Buenos Aires.

César, R. (2005) El carnaval de Buenos Aires (1770-1850), Buenos Aires, Editorial de las Ciencias.

Cerruti, M., (2009) Diagnóstico de las poblaciones de inmigrantes en la Argentina. Serie de documentos de la Dirección Nacional de Población, №2, marzo, Buenos Aires. 
Ceva, M., (2006) "La migración limítrofe hacia la Argentina en la larga duración", en Migraciones regionales hacia la Argentina. Diferencia, desigualdad y derechos, Grimson, A., y Jelin E. (comps), Buenos Aires, Prometeo Libros.

Chamosa, O. (2003) "Lubolos, Tenorios y Moreiras: reforma liberal y cultura popular en el carnaval de Buenos Aires de la segunda mitad del siglo xix", en Sábato $\mathrm{H}$. y Lettieri A. (comps.). La vida política en la Argentina del siglo xix. Armas, votos y voces, Buenos Aires, Fondo de Cultura Económica, pp. 115-135.

Chartier, R. (1995) Disciplina e invención: la fiesta. En Sociedad y escritura en la Edad Moderna (pp. 19-36), Instituto Mora, Ciudad de México.

Cherjovsky, I. (2017) Recuerdos de Moises Ville. Buenos Aires, Teseo.

Cibotti, E. (1994) "Periodismo político y política periodística; la construcción pública de una opinión italiana en el Buenos Aires finisecular", en Entrepasados, №7.

Cicogna, M. P. (2007) "La comunidad de refugiados peruanos y senegaleses en la Ciudad Autónoma de Buenos Aires. Su caracterización sociocultural", en VII Jornadas de Sociología de la UBA, Buenos Aires, 5-9 de noviembre.

Clementi H. (1984) Las fiestas patrias. Leviatán, Buenos Aires.

Cohn, B. S. [1983] (2002) "Representaciones de la autoridad en la India victoriana”, en Hobsbawn E. y Ranger T. (Eds.) La invención de la tradición. Editorial Crítica, Barcelona, España.

and Dirks, N. (1988) "Beyond the Fringe: The Nation State, Colonialism, and the Technologies of Power", en The Journal of Historical Sociology, 1 (2): 224-229.

Collins, R. (2009) La sociología de Dios, en Perspectiva Sociológica: una introducción a la sociología no obvia. Universidad Nacional de Quilmes, Bernal, pp 45-79.

Comaroff, J. y Comaroff, J. (2011) Etnicidad S. A. Madrid: Katz Editores.

Connerton, P. [1989] (1993) Como as sociedades recordam, Oerias, Lisboa, Portugal

Contarino Sparta, L. L (2007) "La persistencia de las tensiones identitarias afroeuropeas: el caso de la comunicadad de Cabo Verde en la Argentina", en Revista Afroeuropa, JAS Vol 1, No 1.

Costa, R. (1976) Para una definición social de los actores sociales. La teoría del campo, Mímeo, Córdoba.

Courtis (1998) Coreano tu vida es una plancha: prácticas sociales de la alteridad. Tesis de licenciatura. Facultad de Filosofía y Letras, UBA.

-------(2000) Construcción de alteridad. Discursos cotidianos sobre la inmigración coreana en Buenos Aires. Buenos Aires, Eudeba.

-(2005) Variaciones conceptuales en torno a la discriminación étnico-nacional: discurso público y experiencia cotidiana. Tesis de Doctorado. Facultad de Filosofía y Letras, UBA. 
Cox, H. (1983) Las fiestas de locos. Taurus, Madrid.

Crespo C., (2004) La memoria festiva. Ponencia presentada en VII Congreso Argentino de Antropología Social, Villa Giardino, Córdoba. Universidad Nacional de Córdoba.

Cruells, A. P. (2006) "Ciudad, fiesta y poder en el mundo contemporáneo", en Revista Liminar. Estudios Sociales y Humanísticos, diciembre, año/vol. IV, n ${ }^{\circ} 002$, Universidad de Ciencias y Artes de Chiapas, San Cristóbal de las Casas, México, pp. 36-49.

Da Matta R. (2002) Carnavales, malandros y héroes. Hacia una sociología del dilema brasileño, FCE, México.

Da Orden M. L. (1991) "Una fiesta popular y la consolidación de una dirigencia étnica: las romerías españolas de Mar del Plata, 1897-1930", en Estudios Migratorios Latinoamericanos, Año 6, Nº 19.

-(2003) "Romerías Españolas e inserción social en tiempos de inmigración masiva a la Argentina", en Revista de Musicología y Archivo Histórico, Fundación Xeito Novo de Cultura Gallega, № 5.

Da Silva Catela, L. (2001) No habrá flores en la tumba del pasado. La experiencia de reconstrucción del mundo de los familiares de desaparecidos, Ediciones Al Margen, La Plata.

-------(2007) "Poder local y violencia: memorias de la represión en el Noroeste Argentino", en Isla A. (ed.) En los márgenes de la Ley: inseguridad y violencia en el Cono Sur, Buenos Aires, Paidos.

De Cristóforis N. A. (2015) "El exilio gallego en Buenos Aires: Luis Seoane entre el combate y el desencanto (1936-1955)", en Revista electrônica de ANPHLAC. Associação Nacional de Pesquisadores e Professores de História das Américas, pp. 43

-(2016) Inmigrantes y colonos en la provincia de Buenos Aires: una mirada de largo plazo (siglos XIX-XXI), Editorial de la Facultad de Filosofía y Letras, Universidad de Buenos Aires, Argentina.

------y Novick, S. (Comp., 2016) Jornadas un siglo de migraciones en la Argentina contemporánea: 1914-2014, 1a ed.- Ciudad Autónoma de Buenos Aires: Universidad de Buenos Aires. Instituto de Investigaciones Gino Germani-UBA, CLACSO. Disponible en

http://biblioteca.clacso.edu.ar/Argentina/iigguba/20170530080906/LibroMigraciones compr.pdf

De Giorgi, A. (2014) "Política y ritual. Una revisión de la tradición teórica antropológica”, en TRAMA, Año 5, №5, pp 23-31. 
De Marinis P. (2010a) "Comunidad: derivas de un concepto a través dela historia de la teoría sociológica", en Papeles del CEIC, Vol. 1, n 58 , marzo http://www.identidadcolectiva.es/pdf/intro.pdf -(2010b) "La comunidad según Max Weber: desde el tipo ideal de la Vergemeinschaftung hasta la comunidad de los combatientes", en Papeles del CEIC, Vol. $1, \mathrm{n}^{\circ} 58$, marzo.

http://www.identidadcolectiva.es/pdf/58.pdf -(2012) "Introducción: la comunidad en la teoría sociológica", en De Marinis P (coord.) Comunidad: estudios de teoría sociológica, Prometeo Libros, Buenos Aires.

Del Campo H., (1983) Sindicalismo y peronismo. Los comienzos de un vínculo perdurable, Buenos Aires, CLACSO.

Delgado Ruiz M., (2000) "La ciudad y la fiesta: afirmación y disolución de la identidad", en Fiesta, Tradición y Cambio, García Castaño F. J. (comp.) Proyecto Sur Ediciones, Granada, España pp. 73-97.

Denzin N.K., e Lincoln Y. S., (comps., 1994), Handbook of Qualitative Research, Londres, Sage Publications.

Devoto F. (1990) "Catolicismo y anticlericalismo en un barrio italiano de Buenos Aires (La Boca) en la segunda mitad del siglo XIX", en Estudios Migratorios Latinoamericanos, $n^{\circ}$ 8, p. 193.

Devoto F., (1992) Movimientos migratorios: historiografía y problemas. Buenos Aires, CEAL.

-------(2005). "Imágenes del Centenario de 1910: nacionalismo y república", en Nun, J. (comp.). Debates de Mayo. Nación, cultura y política. Buenos Aires, Gedisa, 169193.

-(2009) Historia de la inmigración en Argentina, Buenos Aires, Sudamericana.

--------y Otero H. (2003) "Veinte años después. Una lectura sobre el crisol de razas, el pluralismo cultural y la historia nacional en la historiografía argentina", en Estudios Migratorios Latinoamericanos, № 50, CEMLA, Buenos Aires.

Díaz Arias D. (2007) "Memoria colectiva y ceremonias conmemorativas. Una aproximación teórica", en Revista Diálogos Electrónicos de Historia, Vol. 7 n² sept 2006 - febrero 2007: pp 171-191.

Díaz Cruz R. (1998) Archipiélago de rituales. Teorías antropológicas del ritual, Anthropos. España.

Doudtchitzky, S., (2004) "El pasado como experiencia presente. Narraciones sobre la colonización agraria judía". En Actas del VII Congreso Argentino de Antropología Social. Villa Giardino, 25-28 de Mayo. 
Dujovne, A. (2008) "Cartografía de las publicaciones periódicas judías de izquierda en Argentina", en Revista del Museo de Antropología 1(1), pp. 121-138, Facultad de Filosofía y Humanidades, Universidad Nacional de Córdoba, Argentina (2014) Una historia del libro judío. La cultura judía argentina a través de sus editores, libreros, traductores, imprentas y bibliotecas, Buenos Aires, Siglo XXI

Durkheim E. [1912] (2007) Las formas elementales de la vida religiosa. El sistema totémico en Australia, Akal, Madrid.

Duvignaud, J., (1989) “El tiempo de la fiesta”, en El Correo de la Unesco, Año XLII, N 12.

-------(1997) El sacrificio inútil, Fondo de Cultura Económica, México.

Eiss, P. (2005) "Redemption Archives. Rememberiing the Future in a Revolutionary Past", enn Blovin, Frances X. y Rosemberg, W., Archives Documentation and Institutions of Social Memory, pp. 301-317.

Eliade, M. (1968) Mito y realidad, Barcelona, Labor.

Elias N. [1939] (2011) El proceso de la civilización, México, FCE.

-------y Scotson J., (2000) Os Estabelecidos e os Outsiders, Río de Janeiro. Jorge Zahar Editor.

Escribal F. y Rivarola L., (2017) "La fiesta popular como ejercicio de diversidad cultural: Los festejos de la Virgen de Copacabana en la Ciudad de Buenos Aires desde la perspectiva de las políticas culturales", ponencia presentada en el VI Encuentro Internacional sobre Estudios de Fiesta, Nación y Cultura, FaHCEUNLP, La Plata, septiembre.

Falcón R., (1992) “Inmigración, cuestión étnica y movimiento obrero (1870-1914)”, en Devoto F. J. y Miguez E. J. (comps) Asociacionismo, Trabajo e Identidad Étnica. Los italianos en América Latina en una perspectiva comparada, Buenos Aires, CEMLA-CSER-IEHS.

Fernández, I. (2007) Granada, espejo de la memoria y del olvido. La conmemoración de la "conquista" de Granada en relación con las otras conmemoraciones de 1492 en 1992.

https://identidadandalusi.wordpress.com/2007/01/02/granada-espejo-de-lamemoria-y-del-olvido-la-conmemoracion-de-la-conquista-de-granada-enrelacion-con-las-otras-conmemoraciones-de-1492-en-1992/ (consultado junio 2016)

Filgueira, R. (2002) Berisso, datos históricos y otros, III Edición Ampliada, ICLA, Centro Cultural de Difusión, Buenos Aires, Argentina. 
Flier, P. (2011). Historia y memoria de la colonización judía agraria en Argentina. La experiencia de Colonia Clara 1890-1950. (Tesis Doctoral). Universidad Nacional de La Plata, La Plata. Argentina.

(2014). Dilemas, apuestas y reflexiones teórico-metodológicas para los abordajes en historia reciente. La Plata: Universidad Nacional de La Plata. Recuperado de:

http://www.libros.fahce.unlp.edu.ar/index.php/libros/catalog/book/30

-------y Kahan E. (en prensa) Historia reciente en Argentina, Águila, G., Luciani, L., Seminara, L., Viano C. (coordinadoras), Universidad Nacional de Rosario.

Fourment-Kalvelis, J. I. (2015) "Historia de la Fiesta Provincial del Inmigrante", en Klimaitis, J. F. (comp) El espíritu de Berisso, Buenos Aires, Lemu Montún Ediciones.

Franco, M. y Levín, F. (2007) Historia Reciente. Perspectivas y desafíos para un campo en construcción. Buenos Aires, Paidós.

Freidenberg J. (2013) La invención del gaucho judío. Villa Clara y la construcción de la identidad argentina, Prometeo, Buenos Aires.

Freidenmberg J. y Kasinitz P (1990) "Los rituales públicos y la politización de la etnicidad en Nueva York", en Desarrollo Económico, v. 30, $\mathrm{n}^{\circ} 117$, abril-junio 1990.

Frederic, S. (1998). Rehaciendo el campo. El lugar del etnógrafo entre el naturalismo y la reflexividad. Publicar, 4(7), 85-103.

Freud, S. (1972) Tótem y Tabú, Alianza Editorial, Madrid.

Fribourg J. (1984) "Fetes à Saragosse. Paris. 'La Fete Patronale en Espagne: Substitut du Carnaval?'”, en Recontres Internationales sur le Carnaval. La Fete et la Communication. Niza, 6-10 marzo.

Frigerio, A. (2008) "De la desaparición de los negros a la reaparición de los afrodescendientes: comprendiendo las políticas de las identidades negras, las clasificaciones raciales y de su estudio en Argentina", en Los estudios afroamericanos y africanos en América Latina: herencia, presencia y visiones del otro. Córdoba; Buenos Aires Lugar. CLACSO, Consejo Latinoamericano de Ciencias Sociales. CEA-UNC, Centro de Estudios Avanzados-Universidad Nacional de Córdoba.

-------y Lamborghini, E. (2011) "Los afroargentinos: formas de comunalización, creación de identidades colectivas y resistencia cultural y política", en M. Enghel (ed.). Aportes para el desarrollo humano en Argentina, pp. 1-51. Buenos Aires: PNUD. 
Funes y Quinteros (2013) "Queremos contar que Cabo Verde existe". Estrategias de visibilización de la colectividad caboverdeana de Ensenada, desde el 2000 al 2010, Tesina de Licenciatura en Comunicación Social, Facultad de Periodismo y Comunicación Social, UNLP.

Gandolfo R. (1988) "Notas sobre la elite de un comunidad emigrada en cadena: el caso de los agnoneses", en Estudios Migratorios Latinoamericanos, n 8, p. 144.

Garavaglia, J. C. (2000) "A la nación por la fiesta: las fiestas mayas en el origen de la nación en el Plata", en Boletín del Instituto Ravignani № 22, 3ra serie, 2do semestre.

-------(2002) Buenos Aires y Salta en rito cívico: la revolución y las fiestas mayas. Andes, $N^{\circ} 13$, pp. 173-212.

(2007) Construir el pasado e inventar la nación: El Rio de la Plata, siglos XVIIIXIX. Buenos Aires, Prometeo.

García Canclini, N. (1999). Imaginarios Urbanos. Buenos Aires: Eudeba.

García Delgado, D. y Silva, J. (1985) "El movimiento vecinal y la democracia: participación y control en el Gran Buenos Aires", en Jelin E. (comp.) Los nuevos movimientos sociales/2. Buenos Aires, CEAL.

García Sebastiani, M. (2004) "Crear identidades y proyectar políticas de España en la Argentina en tiempos de transformación del liberalismo", El Diario Español de Buenos Aires (1905-1912)", en Estudios Migratorios Latinoamericanos, n 55 , diciembre.

García Vázquez, C. (2005) Los migrantes. Otros entre nosotros. Etnografía de la población boliviana en la provincia de Mendoza, Argentina. Mendoza, EDIUNC.

Garfinkel, H. (1967) Studies in Ethnomethodology, Englewood Cliffs, New Jersey, Prentice Hall.

Garguin, E., (2009) “'Los argentinos descendemos de los barcos'. Articulación racial de la identidad de clase media en Argentina (1920-1960)", en Visacovsky S. E., y Garguin E., (comps) Moralidades, economías e identidades de clase media: estudios históricos y etnográficos, Buenos Aires, Antropofagia.

-(2017) "La invención de una nación blanca en los comienzos de la historiografía argentina", en Formas del pasado. Conciencia histórica, historiografías, memorias. Pérez, A., Garguin, E., y Sorgentini E., (coord.) La Plata: Universidad Nacional de La Plata. Facultad de Humanidades y Ciencias de la Educación. (Estudios/Investigaciones; 61), pp. 25-52.

Recuperado de http://libros.fahce.unlp.edu.ar/index.php/libros/catalog/book/91 
Gavazzo, N., (2002) La diablada de Oruro en Buenos Aires: cultura, identidad e integración en la inmigración boliviana. Tesis de Licenciatura. Facultad de Filosofía y Letras, UBA.

(2004) “Identidad boliviana en Buenos Aires: las políticas de integración cultural", en Revista THEOMAI/THEOMAI Journal Estudios sobre Sociedad, Naturaleza y Desarrollo/Society, Nature and Development Studies, № 9, primer semestre.

-(2005) "La Diablada como patrimonio de la colectividad boliviana. Lo global, lo local y las políticas de identidad", en Temas de Patrimonio Cultural № 7, pp., 98118.

(2006) "Las danzas de Oruro en Buenos Aires: tradición einvención en el campo cultural boliviano", en CUADERNOS FHyCS-UNJu, n 31, pp., 79-105

-(2007) "La inclusión/exclusión de los inmigrantes en la imaginación de la nación. Una visión desde las organizaciones de Latinoamericanos del siglo XXI". Ponencia presentada en la VII RAM, Porto Alegre, Brasil.

--------(2008) "Inmigrantes en el imaginario de la nación. Una visión desde las organizaciones de tres comunidades latinoamericanas en la Argentina del siglo XIX", en Colección, Pontificia Universidad Católica Argentina, vol. 18/19, pp 4977."

(2013) “Sentirse boliviano en Buenos Aires", en Revista Anfibia, IDAES-UNSAM, pp., $\quad 1-5 . \quad$ http://www.revistaanfibia.com/ensayo/sentirse-boliviano-en-buenosaires/

Geertz, C., [1957] (2006a) "Ritual y cambio social: un ejemplo javanés", en La interpretación de las culturas, Gedisa, Barcelona.

-------[1972] (2006b) "Juego profundo: notas sobre la riña de gallos en Bali”, en La interpretación de las culturas, Gedisa, Barcelona.

------[1973] (2006c) "Descripción densa: hacia una teoría interpretativa de la cultura”, en La interpretación de las culturas, Gedisa, Barcelona.

-------[1973] (2006d) "Política del pasado, política actual: algunas notas sobre la utilidad de la antropología para comprender los nuevos estados", en La interpretación de las culturas, Gedisa, Barcelona

-------(1989) El antropólogo como autor. Paidós, Barcelona.

-(1994) "Centros, reyes y carisma: una reflexión sobre el simbolismo del poder", en Conocimiento local: ensayos sobre la interpretación de las culturas. Barcelona, Paidos, pp. 147-171. 
Geicsnek, E. (2012) "Comunidad, autoridad y orden social en Max Weber y Émilie Durkheim", en De Marinis P (coord.) Comunidad: estudios de teoría sociológica, Prometeo Libros, Buenos Aires.

Geler, L. (2005) "Afroargentinos de Buenos Aires: Recreación de una comunidad “invisible”, en J. Valverde del Río y S. Molleda (coords.), Las políticas de la memoria en los sistemas democráticos. 35-50. Sevilla: Asociación Andaluza de Antropología.

-(2008) ¿"Otros" argentinos? Afrodescendientes porteños y la construcción de la nación argentina entre 1873 y 1882. Tesis de doctorado. Barcelona, Universitat de Barcelona, España.

------(2010) Andares negros, caminos blancos. Afrodescendientes porteños, Estado y Nación a fines del siglo xix. Rosario, Prohistoria.

-------(2011) “¿Quién no ha sido negro en su vida? Performances de negritud en el carnaval porteño de fin de siglo (xix-xx)", en El Estado en América Latina. Recursos e imaginarios, siglos XIX-XXI. Pilar García Jordán (Ed.), Ediciones de la Universitat de Barcelona/TEIAA, España.

Germani, G. (1968) Política y sociedad en una época de transición, Buenos Aires, Paidos.

Giorgis M. (2004) La virgen prestamista. La fiesta de la Virgen de Urkupiña en el boliviano Gran Córdoba, Antropofagia, Buenos Aires.

Gómez, S. (2006) "Una aproximación a partir del análisis de dos asociaciones de inmigrantes japoneses del partido de La Plata", en Actas del $8^{\circ}$ Congreso Argentino de Antropología Social. Salta, 19-22 de Septiembre.

-------(2009) "Prácticas trasnacionales en la colectividad japonesa de Argentina", ponencia presentada en las Jornadas de Trabajo Comunidades Locales, Relaciones Trasnacionales. Buenos Aires, IDES, 12 de mayo.

González Bombal, I. M. (1985) "Protestan los barrios (El murmullo suburbano de la política)", en Jelin, E. (comp.) Los nuevos movimientos sociales/2. Buenos Aires, CEAL.

González A. S. (2013) "Política cultural en la última dictadura: fiestas oficiales e insterticios de resistencia en Córdoba”, en Revista Afuera: estudios de crítica cultural, $\mathrm{n}^{\circ} 13$, Buenos Aires, septiembre.

-------(2014) "Políticas culturales en la última dictadura argentina (1976-1983): fiestas oficiales, reinvención de tradiciones hispánicas e intersticios de resistencia artística", en ArtCultura, Uberlândia, v. 16, n. 28, p. 143-160, jan-jun. 
González Pérez, M. (2011, Coord.) Fiesta y Nación en América Latina. Las complejidades en algunos ceremoniales de Brasil, Bolivia, Colombia, México y Venezuela, Intercultura, Panamericana, Bogotá, Colombia.

Granero M., G., (2016) "Fiestas marianas entre migrantes paraguayos e internos en el Gran Rosario (Argentina): un análisis del marco ritual", en Revista Estudios en Antropología Social - Nueva Serie - 1(1): 86-104, enero-julio.

Gresores, G. (2001) "Conflictos obreros en la industria frigorífica bajo la dictadura militar", en Ciclos, Vol. 11, № 22, 2do Semestre, pp 87-107, Buenos Aires.

Grimson, A., (1999) "La Nueva Bolivia y las disputas por la integración. La Fiesta de Nuestra Señora de Copacabana", en Relatos de la diferencia y la igualdad. Los Bolivianos en Buenos Aires, Cap III. Eudeba, Buenos Aires.

-(2000) Fronteras, naciones e identidades. La periferia como centro. Buenos Aires, Ciccus.

(2003) “La vida política de la etnicidad migrante: hipótesis en transformación”, en Estudios Migratorios Latinoamericanos, CEMLA, № 50 , pp 143-158. (2006) "Nuevas xenofobias, nuevas políticas étnicas en la Argentina", en Migraciones regionales hacia la Argentina. Diferencia, desigualdad y derechos (Grimson, A., y Jelin E., comps), Buenos Aires, Prometeo Libros.

-------(2009) "Introducción" a La vida política en los barrios populares de Buenos Aires de Alejandro Grimson, Cecilia Ferraudi Curto y Ramiro Segura (comps.). Buenos Aires: Prometeo, 11-38.

(2011) Los límites de la cultura, Buenos Aires, Siglo XXI Editores.

--------, Amati, M y Kodama, K. (2007). "La nación escenificada por el Estado. Una comparación de rituales patrios", en Grimson, A. (comp.) Pasiones nacionales. Política y cultura en Brasil y Argentina, (pp. 413-501). Buenos Aires: Edhasa.

Guano, E. (2003) A Color for the Modern Nation: The Discourse on Class, Race, and Education in the Porteño Middle Class. Journal of Latin American Anthropology, 8 (1), 148-171.

Guber, R. (2001). La etnografía, método, campo y reflexividad. Bogotá: Grupo Editorial Norma.

-------(2009) El salvaje metropolitano. Reconstrucción del conocimiento social en el trabajo de campo, Buenos Aires: Paidós.

Guruciaga, L. A., (1995) Berisso, fotomemoria. Signo Publicidad, La Plata, Argentina.

Gutiérrez, A. (1997) Pierre Bourdieu. Las prácticas sociales, Co-edición: Editorial Universitaria, Universidad Nacional de Misiones, Posadas y Dirección Nacional de Publicaciones, Universidad Nacional de Córdoba.

Halbwachs M. (1990) A Memória Coletiva, Sao Pablo, Vértice. 
------- [1925] (2004) Los marcos sociales de la memoria, Barcelona, Anthropos.

Halperin Donghi T. (1982) Una nación para el desierto argentino, Buenos Aires, Centro Editor de América Latina.

Halpern, G., (2006) Etnicidad, inmigración y política. Representaciones y cultura política de exiliados paraguayos en Argentina, Tesis Doctoral, UBA, Facultad de Filosofía y Letras.

--------(2007) "Medios de comunicación y discriminación. Apuntes sobre la década del '90 y algo más", en Boletín de la Biblioteca del Congreso de la Nación № 123. Buenos Aires, Biblioteca del Congreso de la Nación.

Hammersley, M. y Atkinson, P., (1994) Etnografía. Métodos de investigación. Barcelona, Paidós.

Hanchard, M. (2008) "Black Memory versus State Memory: Notes toward a Method. Small Axe", A Caribbean Journal of Criticism 26: 45-62.

Harvey, D., (1998) La condición de la posmodernidad. Buenos Aires, Amorrortu editores.

Heers, J (1988) Carnavales y fiestas de locos. Península, Barcelona

Hernández Sandoica E. (2000) “Fiesta y 'memoria': entre historia política e historia cultural", en Fiesta, Tradición y Cambio, García Castaño F. J. (comp.) Proyecto Sur Ediciones, Granada, España pp. 129-155.

Hernández G., (2010) "Relatos de vida y religiosidad popular. Origen y sentidos de la fiesta de la Virgen de Urkupiña en Bahía Blanca", en Revista Cultura y Religión, Vol. IV, No 2: 147 - 165. [Consultado 11-08-2016]

http://www.revistaculturayreligion.cl/index.php/culturayreligion/article/view/121/12 $\underline{0}$

Hirsch, M. (1996). "Past Lves: Postmemories in Exile”, en Susan Rubin-Suleiman: Exile and Creativity, Tel Aviv, Tel Aviv University.

Hobsbawn E. (1998) Naciones y nacionalismos desde 1780. Barcelona, Crítica.

------y Ranger T. [1983] (Eds. 2002) La invención de la tradición, Editorial Crítica, Barcelona, España.

Hoffmann, O. (2000) "La movilización identitaria y el recurso a la memoria (Nariño, Pacífico colombiano)", en Memorias hegemónicas, memorias disidentes, editado por Gnecco C. y Zambrano, M., 97-120. Cauca: ICAN, Universidad del Cauca.

Homobono Martínez J. I., (1990) "Fiesta, tradición e identidad local", en Cuadernos de etnología y etnografía de Navarra, № 55, pp. 43-58, Editor, Pamplona, Gobierno de Navarra. Institución Príncipe de Viana.

-------(2004) "Fiesta, ritual y símbolo: epifanías de las identidades", en Revista Zainak, $\mathrm{N}^{\circ} 26$, pp. 33-76 
Irazuzta, I (2001) Argentina, una construcción ritual: nación, identidad y clasificación simbólica en las sociedades contemporáneas, Bilbao, Servicio Editorial, Universidad del País Vasco.

Irurzun, J., (2014) La identidad bonaerense. Colectividades y asociaciones. Espacios de encuentro. Tandil, CESAL.

Isambert F. A., (1982) Le sens du sacré. Fête etreligiónpopulaire, Paris, Les Editions de Minuit.

Isajiw, W., (1974) "Definitions of ethnicity", en Ethnicity N 1, 111-124.

lucci, M. J. (2012) "La producción y reproducción de imaginarios urbanos por parte de las autoridades municipales", en Revista Pilquen, Año XIV, № 15.

-------(2015) Redes políticas para la política social. La implementación de los programas "Banco Popular de la Buena Fe" y "Argentina Trabaja". Tesis Doctoral, Universidad Nacional de Quilmes.

James, D. (2004) Doña María. Historia de vida, memoria e identidad política, Buenos Aires, Manantial.

--------y Wolfson L. (1987) "17 y 18 de octubre de 1945: el peronismo, la protesta de masas y la clase obrera Argentina", en Desarrollo Económico. Vol. 27, No. 107 (Oct.- Dec.), pp. 445-461. http://www.jstor.org/stable/3467059

Jaume, F. (2000) "Estrategias políticas y usos del pasado en las ceremonias conmemorativas de la 'Masacre de Margarita Belén'. 1996-1998”, en Avá. Revista de Antropología. 2, 65-94.

Jaspers, K. (1998) El problema de la culpa. Sobre la responsabilidad política de Alemania, Barcelona, Alianza.

Jelin E. (1997) “Don't Cry for Me, Argentina, or The Globalization of Peronism”, en Contemporary Sociology 26, N³, pp. 302-4.

------(2002a) Los trabajos de la memoria, Siglo XXI Editores, España.

------(2002b) "Los sentidos de la conmemoración", en Las conmemoraciones. Las disputas en las fechas "in-felices", Siglo XXI, España

-------y Langland, V. (2003) (comps.) Monumentos, memoriales y marcas territoriales, Madrid y Buenos Aires, Siglo XXI.

-------(2013) "Memoria y democracia. Una relación incierta", en Política. Revista de Ciencia Política, Santiago de Chile, vol. 51, №2, pp. 129-144.

-------(2017) La lucha por el pasado: Cómo construimos la memoria social. Buenos Aires, Siglo XXI.

Joseph, G. (2000) Taking Race Seriously: Whiteness in Argentina's National and Transnational Imaginary. Identities, 7(3), 333-371.

Kahan, E. (2014) Recuerdos que mienten un poco. Prometeo, Buenos Aires. 
Katzman, R. (2001) "Seducidos y abandonados: el aislamiento social de los pobres urbanos", en: Revista de la CEPAL № 75, pp. 171-185.

Kertzer, D. (1988) Ritual, Politics, and Power, New Haven and London, Yale University Press.

Klimaitis, J. F. (comp) (2015) El espíritu de Berisso. Piezas literarias y documentales, Lemu Montún Ediciones, Berisso.

Kobelinsky, C. (2003) Ciudadanía Liminal. La objetividad quimérica del refugiado. Las trayectorias de refugiados malienses y senegaleses en Buenos Aires. Tesis de Licenciatura. Facultad de Filosofía y Letras, UBA.

Korn, F. (1989) Buenos Aires: los huéspedes del 20. Buenos Aires, GEL.

Lacarrieu M., (2006) "Las Fiestas, Celebraciones y Rituales de la ciudad de Buenos Aires: Imágenes e Imaginarios Urbanos", en Revista Electrónica Imaginarios Urbanos, pp. 1-10

(2009) "De cara al Bicentenario: revisitando el Centenario con la mirada puesta en las fiestas, conmemoraciones, celebraciones y rituales de la Ciudad de Buenos Aires", en Temas de patrimonio cultural N² 27, Lo celebratorio y lo festivo 1810/1910/2010. La construcción de la Nación a través de lo ritual. - $1^{\text {a }}$ ed. Buenos Aires: Comisión para la Preservación del Patrimonio Histórico Cultural de la Ciudad de Buenos Aires, 2009.

-------(2013) "Bicentenarios. Fiestas y Conmemoraciones para repensar las identidades", en Revista Todavía, Fundación Osde, Buenos Aires.

-------y Maronese, L., Mazetelle, L. (2005) "Fiestas e Interculturalidad. El patrimonio cultural inmaterial en la ciudad de Buenos Aires", en Voces Recobradas, Revista de Historia Oral; Instituto Histórico de la Ciudad de Buenos Aires, Secretaría de Cultura, Gobierno de la Ciudad de Buenos Aires Buenos Aires, año 7, n 20, pag 56-68.

Lahitte, H. y Maffia M. M. (1983) "En torno a la cachupa; una comida típica cabovediana", en Trabalhos de Antropología e Etnología, Sociedad Portuguesa de Antropología e Etnología, pp. 327-345.

Latour, B., (1993) Nunca hemos sido modernos. Ensayo de antropología asimétrica, Barcelona, Debate.

--------(2001) La esperanza de Pandora. Ensayos sobre la realidad de los estudios de la ciencia, Buenos Aires, Gedisa.

Laumonier, I., (1990) Festividad de Nuestra Señora de Copacabana. Un foco de cohesión de los migrantes bolivianos en la Argentina, CEMLA, Buenos Aires.

-------, Rocca M., y Smolensky, E., (1983) Presencia de la tradición andina en Buenos Aires, Buenos Aires, Belgrano. 
Ledrut, R. (1987) "Société réelle et société imaginaire", en Cahiers Internationaux de Sociologie, № 82, pp.41-56.

Lefebvre H. (1971) De lo rural a lo urbano, Ediciones Península, Barcelona.

Lindón, A. (2007) "La ciudad y la ida urbana a través de los imaginarios urbanos" en revista Eure., Vol.32, № 9. 2007. Santiago de Chile.

-------Aguilar M. A., y Hiernaux, D. (2006, coordinadores) Lugares e imaginarios en la metrópolis, Rubí (Barcelona): Anthropos Editorial; México: UAM-Iztapalapa, Div. Ciencias Sociales y Humanidades.

Lobato, M. Z., (1992) "Una visión del mundo del trabajo. Obreros inmigrantes en la industria frigorífica 1900-1930", en Devoto F. J. y Miguez E. J. (comps) Asociacionismo, Trabajo e Identidad Étnica. Los italianos en América Latina en una perspectiva comparada, Buenos Aires, CEMLA-CSER-IEHS.

(2004) La vida en las fábricas. Trabajo, protesta y política en una comunicad obrera, Berisso (1904-1970), Buenos Aires, Prometeo Libros.

Longoni, A. (2013) "Incitar al debate, a una red de colaboraciones, a otro modo de hacer", en Revista Afuera: estudios de crítica cultural, $n^{\circ} 13$, introducción al Dossier Entre el terror y la fiesta, Buenos Aires, septiembre.

Lvovich, D. (2010) "Burócratas, amigos, ideólogos y vecinalistas: el reclutamiento de funcionarios de municipales de Morón durante la dictadura militar (1976-1983)", en Un estado con rostro humano. Funcionarios e instituciones estatales en Argentina (desde 1880 hasta la actualidad), Bohoslavsky, E. y Soprano G. (comp.) Buenos Aires, Prometeo.

Maffia M., (1995) Prauriné: Construcción de la historia de vida de una inmigrante lituana. La Plata, Universidad Nacional de La Plata. (2001) "Acerca de Reuniones y Fiestas de Caboverdeanos en Argentina”, en Picotti, D. (comp.) El negro en la Argentina. Presencia y negación, Editores de América Latina, Buenos Aires, pp 429-462.

(2003) "Vida institucional, relación con el estado y patrimonio cultural en diversas colectividades de la Provincia de Buenos Aires", en Primeras Jornadas de Patrimonio Cultural Judío-Argentino, 12 y 13 de mayo de 2003, Instituto Nacional de Antropología y del Pensamiento Latinoamericano, Buenos Aires.

--------(2004) "La emergencia de una identidad diaspórica entre los descendientes de caboverdeanos en la Argentina", ponencia presentada en VII Congreso Argentino de Antropología Social, Villa Giardino, Córdoba, 25-28 de Mayo.

-------(2007) "Los nuevos inmigrantes africanos", en XI Jornadas Interescuelas/Departamento de Historia, 19-22 de Septiembre. 
-------(2010a) Desde Cabo Verde a la Argentina: migración, parentesco y familia, Biblos, Buenos Aires.

-------(2010b) "La antropología sociocultural en los estudios migratorios. Una mirada preliminar: Argentina 1970 - 2000", en Revista Temas de Antropología y Migración, Nº pp-69-77.

-------, Morgante, G. y Fora, M., (1998) "Lithuanian inmigration to Argentina”, en Two Homelands: Migration Studies (9). Ljubljana, Scientific Research Centre of Slovenian Academy of Sciences and Arts. The Institute for Slovenian Emigration Studies.

-------, Ballina, S. y Monkevicius, P., (2005) "Las asociaciones de inmigrantes extranjeros y sus descendientes en la provincia de Buenos Aires (Argentina)", en Studi Emigrazione, vol. XLII, nº 159, septiembre.

Magnani, G. C. J., (2002) "De perto e de dentro: notas para uma etnografía urbana", em Revista brasileira de ciencias sociales. Volumen $17 \mathrm{~N}^{\circ} 49$ pp. 11-29.

Maier, C. S. (1993) "A Surfeit of Memory", en History and Memory: Studies in the Representation of the Past, $\mathrm{n}^{\circ} 2$.

Maisonneuve J., (2005) Las conductas rituales, Buenos Aires, Nueva Visión.

Malinowski, B., [1922] (1986) Los Argonautas del Pacífico Occidental, Barcelona, Planeta-Agostini, 2 Vols.

Mallimaci Barral, A. I., (2016) "Prácticas religiosas en contextos de migración. Algunas articulaciones entre transnacionalidad, localidad e identidades", en Papeles del CEIC, vol. 2016/1, no 154, CEIC (Centro de Estudios sobre la Identidad Colectiva), Universidad del País Vasco. [Consultado 11-08-2016] http://dx.doi.org/10.1387/pceic.14189

Martín, A. (1997) Fiesta en la calle. Carnaval, murgas e identidad en el folklore de Buenos Aires, Ediciones Colihue, Buenos Aires, Argentina.

-------(2009) "Procesos de tradicionalización en el carnaval de Buenos Aires", en Cuadernos de la FHyCS-UNJu, No 36: 23-41.

Martino M. C. (2015) "Hacia una contextualización de las migraciones de caboverdeanos en el Gran Buenos Aires a partir de sus diferentes generaciones", en Revista Universitas Humanística, $\mathrm{n}^{\circ} 80$, julio-diciembre, pp. 107-131

http://revistas.javeriana.edu.co/index.php/univhumanistica/article/view/7495

-------y Martínez, G. C. (2013) “Un recorrido por las actas de la Sociedade de Socorros Mutuos 'Unión Caboverdeana de Dock Sud”, en Claroscuro, Revista del Centro de Estudios sobre Diversidad Cultural, n²12, pp. 96-117. 
Masotta, C. (2004) "Localidad, migración y traslado de la memoria en Ushuaia (Tierra del Fuego)". En Actas del VII Congreso Argentino de Antropología Social. Villa Giardino, 25-28 de Mayo.

Masseroni S. (2005) "Europeos del Este en Argentina. Experiencia migratoria, nostalgia y memoria", en Cohen N., y Mera C., (Comps.) Relaciones interculturales: experiencias y representación social de los migrantes. Buenos Aires, Antropofagia.

-(2006) "Migraciones y memoria: acerca de la búsqueda e interpretación de información". Ponencia presentada en el Congreso Argentino de Estudios sobre Migraciones Internacionales y Políticas Migratorias y de Asilo. Buenos Aires, 2527 de Abril.

Mateo L. M. (2003) "Os caçadores de heranças. Uma aproximação às descendências cabo-verdianas na Argentina", Certamen del Ministério dos Negócios Estrangeiros de la República de Cabo Verde para trabajos en Ciencias Sociales de investigadores miembros de la diáspora caboverdiana I Coloquio Internacional "Olhares de Descendencias". Biblioteca Nacional, Praia.

Mehan H. y Wood, H. (1975) The Reality of Ethnomethodology, New York, Wiley.

Messina, L. (2011) “El ex centro clandestino de detención 'Olimpo' como dispositivo de memoria: reflexiones sobre las marcas territoriales y sus usos", en Aletheia, Vol. 2, N $\mathrm{N}^{\circ} 3$.

Mera, C. (1998) La inmigración coreana en Buenos Aires. Multiculturalismo en el espacio urbano. Buenos Aires, Eudeba.

-------(2006) "Generación 1.5, buscando un lugar en el mundo". Ponencia presentada en el Congreso Argentino de Estudios sobre Migraciones Internacionales y Políticas Migratorias y de Asilo. Buenos Aires, 25-27 de abril.

Míguez, E. (1992) "Tensiones de identidad: Reflexiones sobre la experiencia italiana en la Argentina", en Devoto F., y Míguez E., (comps) Asociacionismo, trabajo e identidad étnica. Los italianos en América Latina en una perspectiva comparada, Buenos Aires, CEMLA, ISER, IEHS.

Mills, C. W. [1959] (1994) "Apéndice. Sobre artesanía intelectual”, en La imaginación sociológica, Fondo de Cultura Económica, Buenos Aires

Misetich, L., (2003) "Entre Zagreb y Jerusalem. Prácticas y memorias de la diáspora", en Misetich, L., y Dujovne, A., Entre Zagreb y Jerusalem. Prácticas y memorias de la diáspora, CEA, Centro de Estudios Avanzados, Universidad Nacional de Córdoba, Argentina.

(2006) La construcción de una Estado Nación a fines del siglo XIX. Cultura y política entre los croatas de posguerra en Argentina. Tesis de Maestría en 
Antropología. Facultad de Filosofía y Humanidades. Universidad Nacional de Córdoba.

Monkevicius P., (2000) "La comunidad lituana y los 'usos del pasado'. Algunas consideraciones sobre las ceremonias conmemorativas", en Revista de Historia Bonaerense. Instituto Histórico de Morón. Noviembre, año VII, n²2. Pp.40-45.

--------(2002) "La comunidad lituana bonaerense: características de la migración y estrategias culturales”, en Maffia, M., (Ed.) ¿Dónde están los inmigrantes? Mapeo sociocultural de grupos de inmigrantes y sus descendientes en la provincia de Buenos Aires. La Plata, Editorial Al margen.

------(2005a) “'Recordar es vivir': Tiempo y memoria a través de los boletines institucionales lituanos", en Actas de las III Jornadas de Investigación en Antropología Social, Facultad de Filosofía y Letras, 3,4,5 de agosto.

------(2005b) "Conmemoración sin recordación: las ceremonias conmemorativas lituanas en la construcción de identidad étnica", en IV Jornadas de Sociología de la UNLP, La Plata, 23, 24, 25 de noviembre.

------(2005c) "Migración, memoria y narración. El caso de la historia de vida con inicio polaco y presente lituano", en Estudios Migratorios Latinoamericanos, año 19, n 56.

-------(2006a) "La memoria en la construcción de la etnicidad: una aproximación antropológica". Ponencia presentada en el Congreso argentino de estudios sobre migraciones internacionales, políticas migratorias y de asilo. Buenos Aires, 25-27 de abril.

-------(2006b) "Entre la alteridad y el crisol. La inmigración lituana en argentina", en Travessia, revista do inmigrante. Año XIX, nº 56, setembro-dezembro.

-(2006c) "La etnicidad como trabajo de memoria: Prácticas rituales y textos escritos en la conmemoración del asociacionismo lituano", en Actas del VIII Congreso Argentino de Antropología Social, Salta, 19-22 de septiembre.

------(2007a) "Escribir, narrar y conmemorar el pasado. La memoria y la construcción de la lituanidad en Argentina", en $4^{\circ}$ Foro Latinoamericano de Memoria e Identidad, Montevideo, Uruguay, 25-28 de octubre.

------(2007b) "La memoria social en los estudios sobre etnicidad migrante: la comunidad lituana, instituciones y trasmisión", en Actas de las /I Jornadas Nacionales de Representaciones sociales, Buenos Aires, 25 y 26 de octubre.

-------(2009), Memoria y etnicidad en la comunidad lituana de la Argentina. Tesis Doctoral, Facultad de Ciencias Naturales y Museo, Universidad Nacional de La Plata. 
--------(2011) "Memoria social y reproducción de relatos orales en las asociaciones étnicas lituanas", en Avá no 18, enero-junio. pp. 61-74.

-(2012) “'No tenía que haber negros': Memorias subalternas y visibilización entre afrodescendientes e inmigrantes africanos en Argentina", en Revista Publicar en Antropología, año X, $\mathrm{n}^{\circ} \mathrm{XII}$, junio, pp. 87-105.

(2013) “'Que lo afro sea parte de la Nación Argentina': Resignificaciones estatales de las memorias negras", en Tabula Rasa. Revista de Humanidades, $\mathrm{N}^{\circ} 19$, pp. 227-243, julio-diciembre.

-------(2015a) "Pasados (in)discutidos: Conmemoraciones de la presencia afrodescendiente y africana en Argentina”, en Question, vol. 1, $\mathrm{n}^{\circ}$ 46. Facultad de Periodismo y Comunicación Social (UNLP). La Plata, pp. 376-385. Abril-julio. http://perio.unlp.edu.ar/ojs/index.php/question/article/view/2474

(2015b) "Reparar algo de esta maldita historia": Memorias del pasado negro desde la narrativa estatal en Argentina", en Revista Estudios Sociales, n 53. Pp. 112-123. Julio-septiembre. Universidad de los Andes, Bogotá, Colombia. http://res.uniandes.edu.co/indexar.php?c=Revista+No+53

(2017) "Visibilización y procesos de construcción de memorias entre afrodescendientes. El caso de El Afroargentino", en Íconos, Revista de Ciencias Sociales, $n^{\circ}$ 57. FLACSO, Ecuador. pp. 161-174.

http://dx.doi.org/10.17141/iconos.57.2017.2143

Montesperelli, P. (2004) Sociología de la memoria, Buenos Aires, Nueva Visión.

Moore, S. y Myerhoff, B. (1977) "Introduction: Secular Ritual: Forms and Meanings", en S. Moore y B. Myerhoff (Eds.), Secular Ritual.Assen, Amsterdam: Van Gorcum.

Mora y Araujo, M., y Llorente I., (comps, 1980) El voto peronista. Ensayos de sociología electoral argentina, Buenos Aires, Sudamericana.

Moreno Navarro I., (1982) "Cofradías andaluzas y fiesta: aspectos socioantropológicos", en Tiempo de fiesta. Ensayos antropológicos sobre las fiestas en España. Tres-Catorce-Diecisiete, Madrid.

Mostov, J. (2000) "Sexing the Nation / Desexing the Body. Politics of National Identity in the Former Yogoslavia", en Mayer T. (comp) Gender Ironies of Nationalism. Sexing the Nation. Londres - Nueva York, Routledge, pp.89-110.

Moya López, L. A., y Olvera Serrano, M. (coord. 2012) Conmemoraciones. Ritualizaciones, lugares mnemónico y representaciones sociales, Universidad Autónoma Metropolitana, Unidad Azcapotzalco, México.

Mudrovcic M., I., (2000) "Algunas consideraciones epistemológicas para una 'historia del presente"', Hispani Nova, Número 1, 1998-2000. 
Muir E., (2001) Fiesta y Rito en la Europa Moderna, España, Editorial Complutense de Madrid.

Munilla Lacasa, M. L. (2013a) "Mayo en Buenos Aires: fiestas cívicas y discurso simbólico en el período revolucionario (1810-1816)", en El origen de las fiestas patrias. Hispanoamérica en el área de las independencias, Ortemberg, P., (com. 2013), Protohistoria Ediciones, Rosario, Argentina, pp 43-64.

------(2013b) Celebrar y gobernar. Un estudio de las fiestas cívicas en Buenos Aires, 1810-1835. Buenos Aires, Miño y Dávila.

Muñiz Terra, L. (2012) Los (ex) Trabajadores de YPF. Trayectorias laborales a veinte años de la privatización, Espacio Editorial. Buenos Aires.

Naishtat, F. (2002) "La teoría weberiana de la acción en clave pragmática: del Weber 'oficial' al Weber 'no oficial'”, en Naishtat F. (comp.) La acción y la política: perspectivas filosóficas, Barcelona, Gedisa, pp. 143-170.

Nava le Favi, D. (2016) "Queremos que la fiesta sea como en Bolivia”: Prácticas, territorialidad(es) e identificación(es) en el culto de Urkupiña en la ciudad de Salta. Ponencia presentada en las IX Jornadas de Sociología, FaHCE-UNLP. La Plata.

Nisbet R. (2009) La formación del pensamiento sociológico, Amorrortu, Bs. As.

Nora, P. [1984 (1992)] "L'ère de la conmémoration", en Les lieux de mémoire, vol 3, Paris, Gaallimard.

(1993) “Entre Memória e História: A problemática dos lugares", en Journal of American Ethnic History, 12 (1):3-41.

Novaro, M. y Palermo, V. (2003) La Dictadura Militar 1976/1983: Del golpe de Estado a la restauración democrática. Editorial Paidós. Buenos Aires.

Novick, S., (1997) "Políticas migratorias en la Argentina", en Oteiza, E., Novick, S., y Aruj R., (comps), Inmigración y discriminación. Políticas y recursos, Buenos Aires, GEDAL.

Núñez Seixas Xosé M (2001) "Gaitas y tangos: las fiestas de los inmigrantes gallegos en Buenos Aires (1890-1930)" en Ayer, No. 43, La represión bajo el franquismo, pp. 191-223.

O' Donnell, G. (1997) "Las fuerzas armadas y el Estado autoritario del Cono Sur de América Latina", en Contrapuntos. Ensayos escogidos sobre autoritarismo y democratización. Buenos Aires, Paidós.

Olábarri, I. (1996) "La resurrección de Mnemósine: historia, memoria, identidad”, en Olábarri, I. y Capistegui, F. La "nueva" historia cultural, la influencia del posestructuralismo y el auge de la interdisciplinariedad, España, Universidad Complutense. 
Olick, J. (2003) "Whats Does It Mean to Normalize the Past? Official Memory in German Politics since 1989", en Olick J. (comp) States of Memory. Continuities, Conflicts, and Transformations in National Retrospection, Durham - Londres, Duke University Press, pp. 259-288.

Orsi, R. A. (1995) The Madonna of 11 TH Street: Faith and Community in Italian Harlem, 1880-1950, New Haven, CT:Yale University Press.

Ortember P. (2010) "El tedeum en el ritual político: usos y sentidos de un dispositivo de pactos en la América española y en la revolución de Mayo" en Anuario del Instituto de Historia Argentina № 10.

-------(comp., 2013) "Sentidos e historia de las fiestas patrias: una introducción", en El origen de las fiestas patrias: Hispanoamérica en la era de las independencias, Protohistoria Ediciones, Rosario, Argentina.

Oszlak, O. (1985) La formación del estado argentino, Buenos Aires, Editorial de Belgrano. (1991) Merecer la ciudad. Los pobres y el derecho al espacio urbano. Buenos Aires, Humanitas/ CEDES.

Oteiza, E, Novick S. y Aruj, R. (1997, comps) Inmigración y discriminación. Políticas y discursos, Grupo Editor Universitario, Buenos Aires.

Otero Correa, N., (2000) Afroargentinos y caboverdeanos. Las luchas identitarias contra la invisibilidad de la negritud en la Argentina. Tesis de Maestría del Programa de Pos Graduación en Antropología Social de la Universidad Nacional de Misiones.

Ozouf, M. (1988) Festivals and the French Revolution, Harvard University Press, Cambridge.

-----(1989) La fête révolutionnaire. 1789-1799, Folio, Paris

Pacecca M. I., (1993) "Identidades y estructuración de la diferencia: apuntes para un encuadre teórico", en Jornadas de colectividades: Identidad, integración e inserción social en el país. Relaciones con el país de origen. Museo Roca, Buenos Aires, 28-30 de octubre.

-------(1998) “Legislación, migración limítrofe y vulnerabilidad social”, en Actas de las IV Jornadas sobre Colectividades. IDES, 22-23 de octubre.

(2000) "Buenos Aires: un destino (sud)americano para emigrantes de Europa del este", en Revista de Historia Bonaerense. Instituto Histórico de Morón. Año VII, $\mathrm{n}^{\circ} 22$, noviembre, pp. 51-56.

Palermo, E. (2007) "Usos del pasado, memoria e identidad entre un grupo de descendientes de inmigrantes irlandeses de Buenos Aires. Una lectura a partir de dos héroes culturales", en Revista Avá N 11, pp. 87-114. 
Palleiro M. I. (2011) San Patricio en Buenos Aires: narrativa, celebraciones y migración, Palleiro M. I. (comp), Editorial de la Facultad de Filosofía y Letras, Universidad de Buenos Aires.

Panettieri, J. (1970) Inmigración en la Argentina, Buenos Aires, Ediciones Macchi

Passarelli A., y Giménez, J. (2015) "Rupturas y continuidades entre Copacabana y Urkupiña. Aproximaciones a los sentidos de dos festividades bolivianas en La Plata", en Question, VOL 1, n 45 , enero-marzo.

-------, Rodrigo F., Romero G., y Giménez J., (inédito) "Bajo un manto sagrado. Poder, espacio público y organización comunitaria en torno a la fiesta de la Virgen de Copacabana en la ciudad de La Plata."

Passerini, L. (1992) Memory and totalitarianism, Oxford, Oxford University Press.

Pianetto O., y Galliari M., (1989) "La inserción social de los inmigrantes españoles en la ciudad de Córdoba, 1870-1914", en Estudios Migratorios Latinoamericanos, CEMLA, № 13, p. 599.

Pieper J. (2006) Una teoría de la fiesta, RIALP, Madrid, España.

Piovani, J. I. (2010a) "La observación”, Cap. X, en Metodología de las Ciencias Sociales, Marradi, A., Archenti N. y Piovani J. I, Cengage Learning Argentina, Buenos Aires.

---------, (2010b) “La entrevista en profundidad”, Cap XII, en Metodología de las Ciencias Sociales, Marradi, A., Archenti N. y Piovani J. I, Cengage Learning Argentina, Buenos Aires.

Pizarro, C. (2006) "Tras las huellas de la identidad en los relatos locales sobre el pasado", en Cuadernos de Antropología Social, n² 24, diciembre, pp. 113-130.

-------(2007) "Asociaciones de inmigrantes e identidades extranjeras: el caso de la comunidad boliviana de Escobar", en Actas de la VII RAM. Porto Alegre, Brasil.

Pollak, M. (1989) “Memória, esqueçimento, silencio", en Estudos Históricos 2 (3): 3-15.

-------(1992) “Memória e identidade social”, en Estudos Históricos 5 (10): 200-212.

-------(2006) Memoria, olvido, silencio. La producción social de identidades frente a situaciones límite, La Plata, Ediciones Al Margen.

Popular Memory Group, (1982) "Popular Me-mory: Theory, Politics, Method", en Johnson $\mathrm{R}$ et al.: Making Histories: Studies in History Writing and Politics, Londres.

Portela, G., (2006) "Apuntes teóricos y metodológicos en torno a los conceptos de memoria colectiva e identidad en los estudios de comunidades inmigrantes a partir de un estudio de caso: la colonia pesquera inmigrante de Mar del Plata entre 1930 y 1950". Ponencia presentada en el Congreso Argentino de Estudios 
sobre Migraciones Internacionales y Políticas Migratorias y de Asilo. Buenos Aires, 25-27 de Abril.

Portelli, A. (2004) La orden ya fue ejecutada. Fondo de Cultura Económica, Buenos Aires.

(2016a) "Los usos de la memoria. Memoria-monumento, memoria involuntaria, memoria perturbadora", en Historias orales. Narración, imaginación y diálogo, Protohistoria Ediciones, Facultad de Humanidades y Ciencias de la Educación de la Universidad Nacional de La Plata, Argentina, pp.475-483.

------ (2016b). Historias orales: Narración, imaginación y diálogo. La Plata: Universidad Nacional de La Plata. Facultad de Humanidades y Ciencias de la Educación; Rosario: Prohistoria Ediciones. (Coediciones; 2)

Portes, A., Roberts, B. y Grimson A., (2005) Ciudades latinoamericanas. Buenos Aires: Prometeo.

Pritchard E.E. [1940] (1992) Los nuer, Barcelona, Anagrama.

------[1962] (2006) Ensayos de Antropología Social, Siglo XXI, Madrid, España.

Puccia, E. (1974) Breve historia del carnaval porteño. Cuadernos de Buenos Aires XLVI. Buenos Aires, Municipalidad de la Ciudad de Buenos Aires.

Rabotnikof N. (2009) "Política y tiempo: pensar la conmemoración”, en Sociohistórica, Cuadernos del CISH, Facultad de Humanidades y Ciencias de la Educación, Universidad Nacional de La Plata, Edulp, $n^{\circ} 26$ segundo semestre.

Recalde, A. (2002) "Los inmigrantes de origen latinoamericano en la ciudad de La Plata", en Maffia (Ed.) ¿Dónde están los inmigrantes? Mapeo sociocultural de grupos de inmigrantes y sus descendientes en la provincia de Buenos Aires. La Plata, Editorial Al Margen.

Ricoeur, P. (1995) Teoría de la interpretación. Discurso y excedente de sentido. Siglo XXI/Universidad Iberoamericana, México

--------(2007) "Historia y memoria. La escritura de la historia y la representación del pasado", en A. Pérotin-Dumon (dir.), Historizar el pasado vivo en América Latina. http://etica.uahurtado.cl/historizarelpasadovivo/es contenido.php

Rivers J. P. (1984) "La identidad local a través de la fiesta", en Revista de Occidente, № 38-39, pp. 17-34

Riviére C. (1988) Les liturges polítiques, Paris, P.U.F.

-------(1997) Une théorie des rites profanes. Trente propositions, Seminarios del CEIC, Leioa, Universidad del País Vasco.

Rock, D. (1977) El radicalismo argentino, 1890-1930, Buenos Aires, Amorrortu.

Rodríguez, L. G. (2009) 'Descentralización municipal, intendentes y 'fuerzas vivas' durante el Proceso (1976-1983)", en Cuestiones de Sociología (5-6), pp. 369- 
387, Facultad de Humanidades y Ciencias de la Educación, Universidad Nacional de La Plata.

Rodríguez, R., y Arriaga, C. (2004) "La segregación residencial en la ciudad latinoamericana", en Revista EURE, Vol. 29, № 89.

Romano, L. (1970) Cabo Verde. Renascenca de na civilização no Atlântico Médio. Ocidente, Lisboa.

Romero, L. A. (2002) "1920-1976: El Estado y las corporaciones", en Di Stefano R., Sabato, H., Romero L. A., y Moreno J. L. (autores), De las cofradías a la organización civil. Historia de la iniciativa asociativa en Argentina 1776-1990, Buenos Aires, Edilab editora.

Rosan, V. A., (2002) Prácticas diaspóricas: La comunidad croata en Buenos Aires. Tesis de Licenciatura. Facultad de Filosofía y Letras, Universidad de Buenos Aires.

Rousseau J. J. (1967) Lettre a M. D’Lambertsur son article, GENÉVE, Paris, Flammarion.

Rousso, H. (2007) "La trayectoria de un historiador del tiempo presente, 1975-2000", en Anne Pérotin-Dumon (dir.). Historizar el pasado vivo en América Latina. http://etica.uahurtado.cl/historizarelpasadovivo/es contenido.php -(2015) Hacia una globalización de la memoria, en Nuevo Mundo Mundos Nuevos [En ligne], Débats, mis en ligne le 18 septembre 2015, consulté le 29 janvier 2018. http://journals.openedition.org/nuevomundo/68429; Traduction de Miriam Hernández Reyna

Sabatini, F., Cáceres, G., Cerdá, J. (2001) "La segregación residencial en las principales ciudades chilenas", en Revista EURE, Vol. 27, № 82.

Saffa, P. (1998), Vecinos y vecindarios en la ciudad de México. Un estudio sobre la construcción de las identidades vecinales en Coyoacán, D. F. México: Ciesas, Porrúa - UAM, Iztapalapa.

Salvatore, R. (1997) "Fiestas federales: Representaciones de la República en el Buenos Aires rosista", en Entrepasados, VI, 11, Buenos Aires.

Salvi, V. (2017) "Actores de la memoria y luchas políticas por el pasado", Módulo 3 del Curso Introducción a los Estudios sobre Memoria: Problemas, Perspectivas, Debates. Núcleo de Estudios sobre Memoria (CIS-CONICET/IDES).

Sanucci L. E. M., (1983) Berisso, un reflejo de la evolución Argentina, Municipalidad de Berisso, 1983.

Sassone S., y Baby-Collin V., (2012) "La expansión de la devoción a la virgen de Urkupiña: Religiosidad popular y territorios urbanos de los migrantes bolivianos", en Territorios culturales y prácticas religiosas: nuevos escenarios en América 
Latina, Santarelli, S., y Campos M., (coord.) Editorial de la Universidad Nacional del Sur EDIUNS, Bahía Blanca; p. 303 - 335.

Saraví, G. A., (2008) "Mundos aislados: segregación urbana y desigualdad en la ciudad de México", en Revista Eure, XXXIV, N¹03, pp. 93-110, diciembre.

Sarmiento, D. F. [1845] (1974) Facundo, Buenos Aires, El Ateneo

-------[1887] (1994) “Condición del extranjero en América”, en Obras Completas, tomo XXXVI, Buenos Aires, Luz del Día, pp. 206 y 2007.

Schultz, U. (1993) La fiesta, Madrid, Alianza Editorial.

Schultz, A. R. (1994) Ethnicity on Parade: Inventingthe Norwegian American Trough Celebration, Amherst, Massachusetts: University of Massachusetts Press.

Schwartz, B. (1992) "La reconstrucción de Abraham Lincoln", en Middleton, T. Edwards (comp.), Memoria compartida, Paidós.

Scribano, A., Magallanes G., y Boito M. E. (comps., 2012) La Fiesta y la Vida: estudio desde una sociología de las prácticas intersticiales, CICCUS, Buenos Aires.

Segalen, M. (2011) Ritos y rituales contemporáneos, Alianza Editorial, Madrid.

Segato, R.L. (2007) La nación y sus otros: raza, etnicidad y diversidad religiosa en tiempos de políticas de la identidad, Buenos Aires, Prometeo Libros.

Segura, R., (2000) "Política patrimonial y construcción de una tradición en la ciudad de La Plata", en Actas del VI Congreso Argentino de Antropología Social. Mar del Plata.

(2004) "Análisis de un ritual urbano: conmemoración de la fundación de la ciudad de La Plata", en VII Congreso Argentino de Antropología Social, Villa Giardino, Córdoba, Universidad Nacional de Córdoba.

------(2010) Representar. Habitar. Transitar. Una antropología de la experiencia urbana en la ciudad de La Plata. Tesis Doctoral. IDES, Universidad Nacional de General Sarmiento.

-------(2015) Vivir afuera. Antropología de la experiencia urbana. Universidad Nacional de General San Martín, UNSAM EDITA, Buenos Aires, Argentina.

Sennett, R., (1997) Carne y piedra. El cuerpo y la ciudad en la civilización occidental. Madrid: Alianza Editorial.

Serafino, M. A. (2010) "La celebración de una virgen migrante, construcciones identitarias entre bolivianos y santafesinos en un sector de Quintas al norte de la ciudad de Santa Fe", en Sociedad y Economía, n 19, pp 117-134

--------y Demarchi, M., (2015) "Entre migrantes y nativos: La festividad de la virgen de Chaguaya en el cinturón hortícola al norte de la ciudad de Santa Fe, Argentina", en Odisea. Revista de Estudios Migratorios № 2, pp. 296-322 [Consultado 11-08- 
2016]

http://publicaciones.sociales.uba.ar/index.php/odisea/article/view/1698/1470

Sevilla A. y Portal M. A. (2005) "Las fiestas en el ámbito urbano", en La antropología urbana en México, García Canclini N. (coord.), México, Consejo Nacional para la Cultura y las Artes-Universidad Autónoma Metropolitana, Fondo de Cultura Económica, pp 341-376.

Sahlins, M. (1988) Islas de historia. La muerte del Capitán Cook. Metáfora, antropología e historia. Barcelona, Gedisa.

Sigal, S. (2006). La Plaza de Mayo. Una crónica. Buenos Aires, Siglo XXI.

Silla, R., (2011) Colonizar argentinizando: identidad, fiesta y nación en el Alto Neuquén. Buenos Aires, Antropofagia.

Swales, J. (2004) Research Genres: Explorations and Applications. Cambridge: Cambridge University Press.

Temas de patrimonio cultural № 27 (2009) Lo celebratorio y lo festivo 1810/1910/2010. La construcción de la Nación a través de lo ritual, $1^{\mathrm{a}}$ ed. - Buenos Aires: Comisión para la Preservación del Patrimonio Histórico Cultural de la Ciudad de Buenos Aires.

Terán O., (2008) Vida intelectual en el Buenos Aires fin-de-siglo: 1810-1910: Derivas de la cultura científica, Buenos Aires, Fondo de Cultura Económica.

-(2009) Historia de las ideas en la Argentina: diez lecciones iniciales, 1810-1980. Siglo Veintiuno, Buenos Aires.

Thompson, E. P. (1995) Costumbres en común, Barcelona: Crítica.

Todorov, T. (2000) Los abusos de la memoria, España Paidós.

Tossounian, L. (2004) “La conmemoración del '24 de abril de 1995': usos del pasado y comunalización", en Actas del VII Congreso Argentino de Antropología Social. Villa Giardino, Córdoba, 25 al 28 de Mayo.

Torre J. C., (comp. 1988) La formación del sindicalismo peronista. Buenos Aires, Legasa.

(1990) La vieja guardia sindical y Perón. Sobre los orígenes del peronismo. Buenos Aires, Sudamericana.

-------(1995) El 17 de octubre de 1945. Buenos Aires, Ariel.

Torre Revello, J. (1943) Crónicas del Buenos Aires colonial. Buenos Aires, Bajel.

Traoré, B. (2006) "Los inmigrantes senegaleses en la Argentina: ¿integración, supervivencia o participación?", en Actas de las Primeras Jornadas Afroargentinos hoy: invisibilización, identidad y movilización social. La Plata, 5-6 de Octubre. 
Traverso, E. (2007) El pasado. Instrucciones de uso. Historia, memoria, política. Marcial Pons, Madrid.

Turner, V. [1969] (1988) El proceso ritual. Taurus, Madrid.

-------[1967] (2008) La selva de los símbolos. Siglo XXI, Madrid.

Tylor, E. B. [1865] (1965) Researches into the Early History of Mankind, The Chicago University Press, Chicago/Londres.

UN-HABITAT (2005). International migrants and the city. Balbo, M. (ed.) Venezia, United Nations Human Settlement Program and Universitat IUAV di Venezia. Italia.

Van Gennep, A. [1908] (2008) Los ritos de paso. Alianza Editorial, Madrid.

Vargas J., (2005) "Festividad de la Virgen de Copacabana: De los Andes al Río de la Plata", en Temas de Patrimonio Cultural № 7.

Vasilachis, I. (2006) Estrategias de investigación cualitativa. Gedisa, España.

Vázquez, M. (2008) "Las formas de la visibilidad. Cultura, política e identidad en la comunidad boliviana en Buenos Aires", en Revista Sociedad, № 27, UBA, Facultad de Ciencias Sociales.

Vega A. (2011) "Expresiones musicales, religión e identidad entre migrantes del área andina en la ciudad de Buenos Aires", en MITOLOGICAS, Vol. XXVI, Bs. As. pp. $43-57$.

Vernes P. M. (1978) La ville, la fete, la démocratie, Paris: Traces-Payot.

Velasco H. (1986) "Rituales e identidad: dos teorías y algunas paradojas", en Revista de Occidente, $\mathrm{n}^{\circ}$ 56, enero, pp. 65-75.

Vezzetti, H. (2002) Pasado y presente. Guerra, dictadura y sociedad en la Argentina. Buenos Aires, Siglo Veintiuno.

Visacovsky, S. (2005) "El temor a escribir sobre historias sagradas", en Fréderic S. y Soprano G (comps) Cultura y Política en Etnografías sobre la Argentina. Universidad Nacional de Quilmes, Buenos Aires, pp. 271-313.

Vogel, H. (1991) "Fiestas patrias y nuevas lealtades", en Todo es Historia, año 25, № 287.

Vovelle M., (1985) "El desvío por la historia en el redescubrimiento de la fiesta", en Ideologías y mentalidades. Ariel, Barcelona, pp. 187-203.

Weber, M. [1922] (1998) Economía y Sociedad. Esbozo de Sociología Comprensiva, Fondo de Cultura Económica, México DF

Wieviorka, A. (1998) L'Ére du témoin. Plon, Paris.

Wilde, A. (2011) "Representaciones de la política posrevolucionaria. Un acercamiento a la liturgia republicana (1810-1853)", en Tio Vallejo G. (coord.), La república 
extraordinaria. Tucumán en la primera mitad del siglo XIX, Rosario, Prehistoria, pp. 79-147.

Williams, R. (1988) Marxismo y Literatura. Barcelona: Península.

-------(2003) Palabras Clave. Buenos Aires: Nueva Visión.

Wirth, L., (1928) The Ghetto. Chicago: Chicago University Press.

Woortmann, E. (2000), I"dentidades e Memória entre Teuto-brasileiros: Os dois lados do Atlantico", en Horizontes Antropológicos. Relaciones Interétnicas, 6, n 14, pp. 205-238.

Yerushalmi, Y. (2006) "Reflexiones sobre el olvido", en Usos del olvido. Comunicaciones del Coloquio de Royaumont, Nueva Visión, Buenos Aires.

Zerubavel, E. (2007) "Calendario e historia. Un estudio comparativo sobre la organización social de la memoria nacional”, en Aguiluz Ibarüen, M. y Waldman, G. (coord.) Memorias (in)cognitas. Contiendas en la historia. México, UNAM.

Zubrzycki, B. (2001) "Inmigrantes polacos y sus descendientes en la provincia de Buenos Aires, Argentina. Un estudio preliminar", en Revista del CESLA, N², pp 248-266.

--(2002) "Una aproximación al estudio de los polacos de La Plata, Berisso y Ensenada", en Maffia M., (Ed.) ¿Dónde están los inmigrantes? Mapeo sociocultural de grupos de inmigrantes y sus descendientes en la provincia de Buenos Aires. La Plata, Editorial Al Margen.

, Ottenheimer, A., Agnelli S., y Kleidermacher G., (2008) "Nuevas presencias africanas en la provincia de Buenos Aires", en Actas del IX Congreso Argentino de Antropología Social. Posadas, Misiones. 


\section{Anexos}

\section{Anexo № 1: Berisso, ubicación geográfica y barrios de la ciudad}
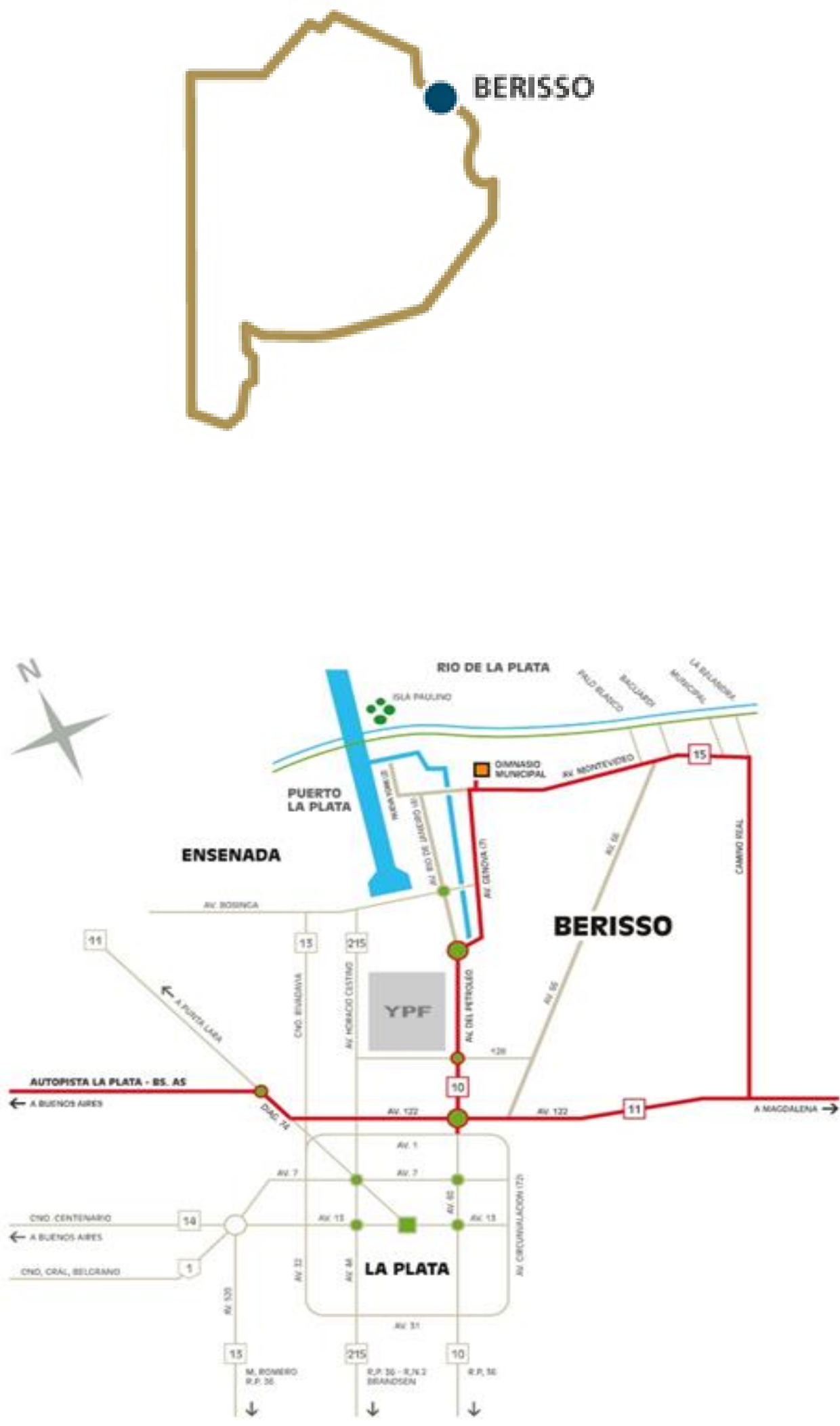

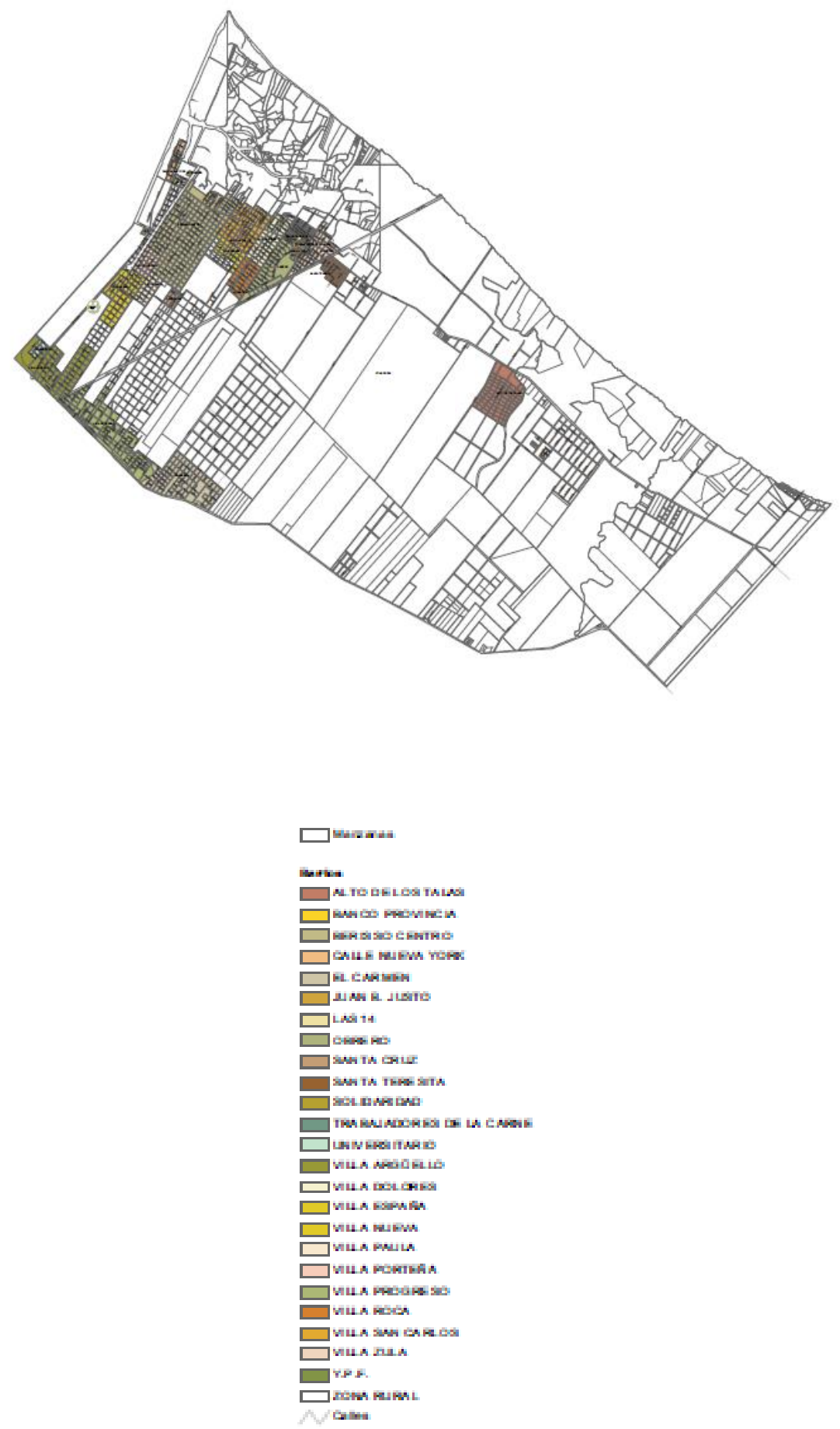


\section{Anexo $N^{\circ}$ 2: Asociaciones Étnicas, calles y lugares históricos de Berisso}

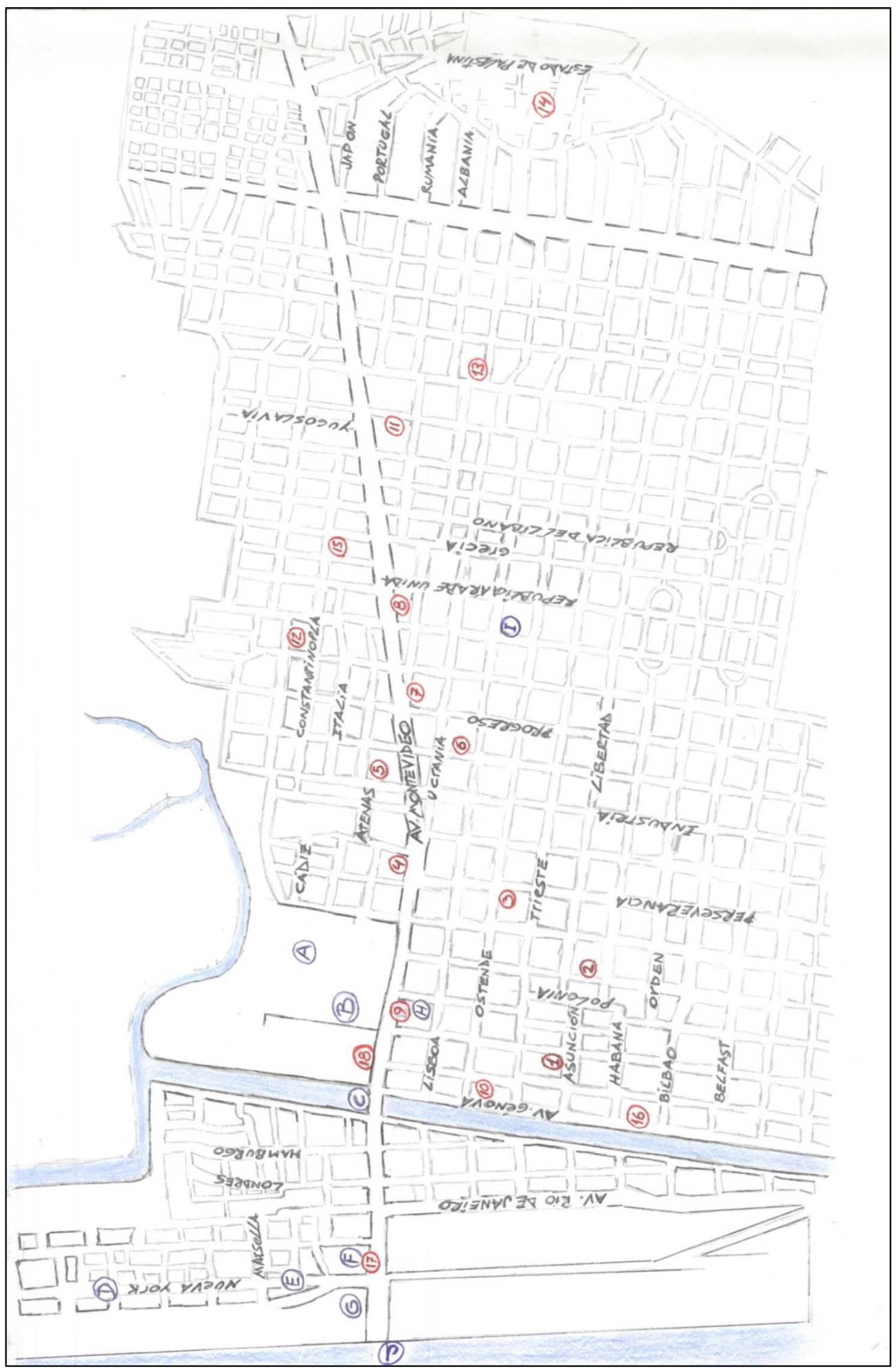




\title{
Referencias:
}
A- Gimnasio Municipal
B- Centro Cívico
C- Embarcadero
D- Mansión de Obreros
E- Conventillos
F- Hogar Social
G- Ex Frigorífico Swift
H- Iglesia María Auxiliadora
I- Municipalidad de Berisso
J- Puerto

1- Colectividad Polaca (calle $9 \mathrm{~N}^{\circ} 4222$ )

2- Colectividad Árabe (calle $11 \mathrm{~N}^{\circ} 4077$ )

3- Colectividad Bielorrusa (calle $165 \mathrm{~N}^{\circ}$ 1091)

4- Colectividad Ucraniana (Av. Montevideo $N^{\circ} 1088$ )

5- Colectividad Eslovaca (15 № 4599)

6- Colectividad Española (calle $16 \mathrm{~N}^{\circ} 4483$ )

7- Colectividad Lituana (Av. Montevideo № 1569)

8- Colectividad Búlgara (Av. Montevideo $\mathrm{N}^{\circ} 1789$ )

9- Colectividad Italiana (Av. Montevideo $N^{\circ} 841$ )

10- Colectividad Griega (calle $8 \mathrm{~N}^{\circ} 4202$ )

11- Colectividad Albanesa (calle $25 \mathrm{~N}^{\circ} 4616$ )

12- Colectividad Armenia (calle $18 \mathrm{~N}^{\circ} 4839$ )

13- Colectividad Eslovena (calle $168 \mathrm{~N}^{\circ} 1631$ )

14- Colectividad Yugoslava (Manzana 2 Casa 13 - Barrio Obrero)

15- Colectividad Portuguesa (calle $171 \mathrm{~N}^{\circ} 1881$ )

16- Colectividad Israelita (Calle $7 \mathrm{~N}^{\circ} 3911$, entre 161 y 162)

17- Colectividad Irlandesa (Av. Montevideo y 2)

18- Asociación de Entidades Extranjeras (Av. Montevideo № 604 esquina 8)

\author{
Hay tres asociaciones que tiene sus sedes fuera de Berisso: \\ -Club Germano Argentino, calle 22 № 1565 entre 64 y 65 - La Plata \\ -Asociación Caboverdeana de Ensenada, calle Moreno № 118 - Ensenada \\ -Asociación Raíces Istrianas La Plata, Berisso y Ensenada (Croatas), calle 59 № 516 \\ - La Plata
}




\section{Anexo No 3: Población extranjera en Berisso (censos, 1991, 2001, 2010)}

1991

Población total nacida en el extranjero por lugar de nacimiento según sexo y grupo de edad, Berisso, 1991

\begin{tabular}{|c|c|c|c|c|c|c|}
\hline \multirow{2}{*}{ Lugar de nacimiento } & \multirow{2}{*}{$\begin{array}{c}\text { Población total } \\
\text { nacida en el } \\
\text { extranjero }\end{array}$} & \multicolumn{2}{|c|}{ Sexo } & \multicolumn{3}{|c|}{$\begin{array}{c}\text { Grandes grupos de } \\
\text { edad }\end{array}$} \\
\hline & & Varones & Mujeres & $0-14$ & $15-64$ & $\begin{array}{l}65 \text { y } \\
\text { más }\end{array}$ \\
\hline Total & 3321 & 1495 & 1826 & 89 & 1759 & 1473 \\
\hline AMÉRICA & 1178 & 617 & 561 & 67 & 1013 & 98 \\
\hline Países limítrofes & 628 & 286 & 342 & 34 & 509 & 85 \\
\hline Bolivia & 111 & 70 & 41 & 18 & 93 & 0 \\
\hline Brasil & 51 & 15 & 36 & 0 & 32 & 19 \\
\hline Chile & 57 & 30 & 27 & 0 & 56 & 1 \\
\hline Paraguay & 211 & 77 & 134 & 4 & 166 & 41 \\
\hline Uruguay & 198 & 94 & 104 & 12 & 162 & 24 \\
\hline Países NO limítrofes (América) & 550 & 331 & 219 & 33 & 504 & 13 \\
\hline Perú & 456 & 271 & 185 & 27 & 425 & 4 \\
\hline Resto de América & 94 & 60 & 34 & 6 & 79 & 9 \\
\hline EUROPA & 2043 & 852 & 1191 & 16 & 711 & 1316 \\
\hline Alemania & 1 & 1 & 0 & 0 & 0 & 1 \\
\hline España & 276 & 116 & 160 & 8 & 105 & 163 \\
\hline Francia & 16 & 0 & 16 & 0 & 4 & 12 \\
\hline Italia & 867 & 396 & 471 & 0 & 386 & 481 \\
\hline Resto de Europa & 883 & 339 & 544 & 8 & 216 & 659 \\
\hline ASIA & 8 & 8 & 0 & 0 & 0 & 8 \\
\hline China & 0 & 0 & 0 & 0 & 0 & 0 \\
\hline Corea & 0 & 0 & 0 & 0 & 0 & 0 \\
\hline Japón & 0 & 0 & 0 & 0 & 0 & 0 \\
\hline Siria & 4 & 4 & 0 & 0 & 0 & 4 \\
\hline Taiwán & 0 & 0 & 0 & 0 & 0 & 0 \\
\hline Resto de Asia & 4 & 4 & 0 & 0 & 0 & 4 \\
\hline ÁFRICA & 0 & 0 & 0 & 0 & 0 & 0 \\
\hline OCEANÍA & 0 & 0 & 0 & 0 & 0 & 0 \\
\hline Otros (desconocidos) & 92 & 18 & 74 & 6 & 35 & 51 \\
\hline
\end{tabular}

Fuente: Elaboración propia en base a Censo Nacional de Población y Vivienda, 1991. Procesado por la Dirección Provincial de Estadística base de microdatos (datos inéditos)

De los 3.321 extranjeros que vivían en Berisso, 2.043 eran europeos, 1.178 americanos y 8 asiáticos. Las 92 personas restantes (cercano al 3\%) aparecen en la 
categoría "Otros (Desconocido)" y tanto África como Oceanía aparecen sin representación.

\section{Gráfico No 1:}

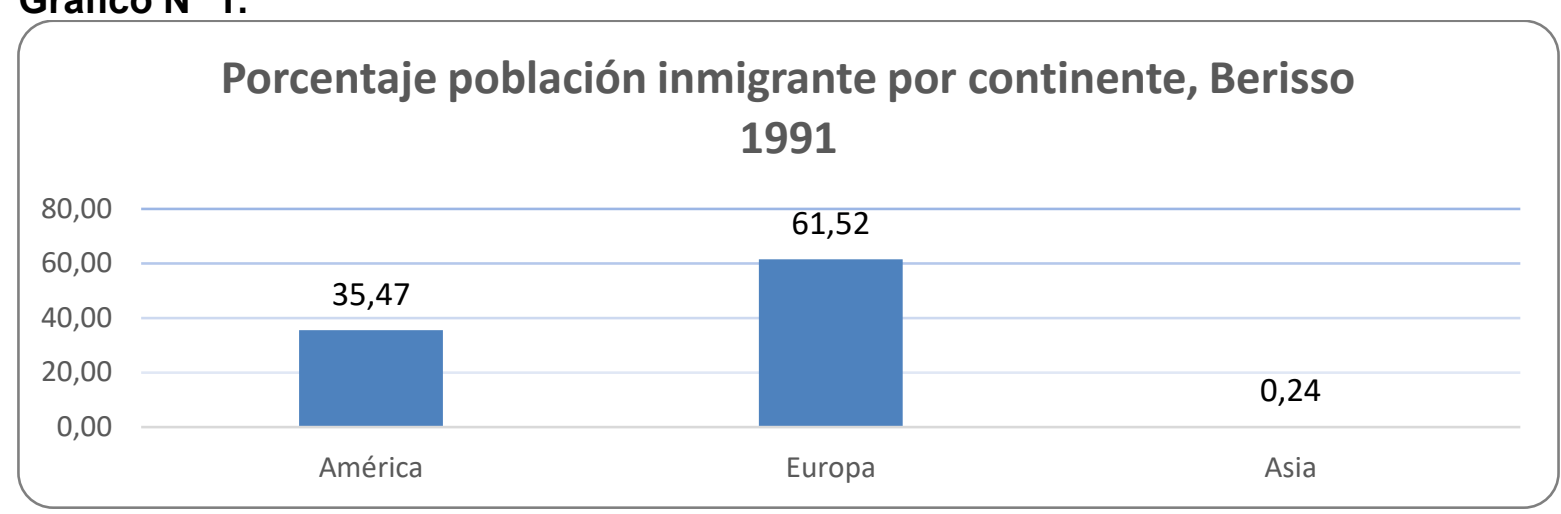

Fuente: Propia, en base al Censo Nacional de Población y Vivienda, 1991. Procesado por la Dirección Provincial de Estadística base de microdatos (datos inéditos).

De los 2.043 inmigrantes europeos, 867 eran italianos, 276 españoles, 305 polacos, 121 yugoslavos, 83 lituanos y 80 ucranianos. De los 311 inmigrantes agrupados en la categoría Resto de Europa, los países con mayor representación eran Checoslovaquia (62), Grecia (59), Portugal (51) y Rusia (44).

\section{Gráfico No 2:}

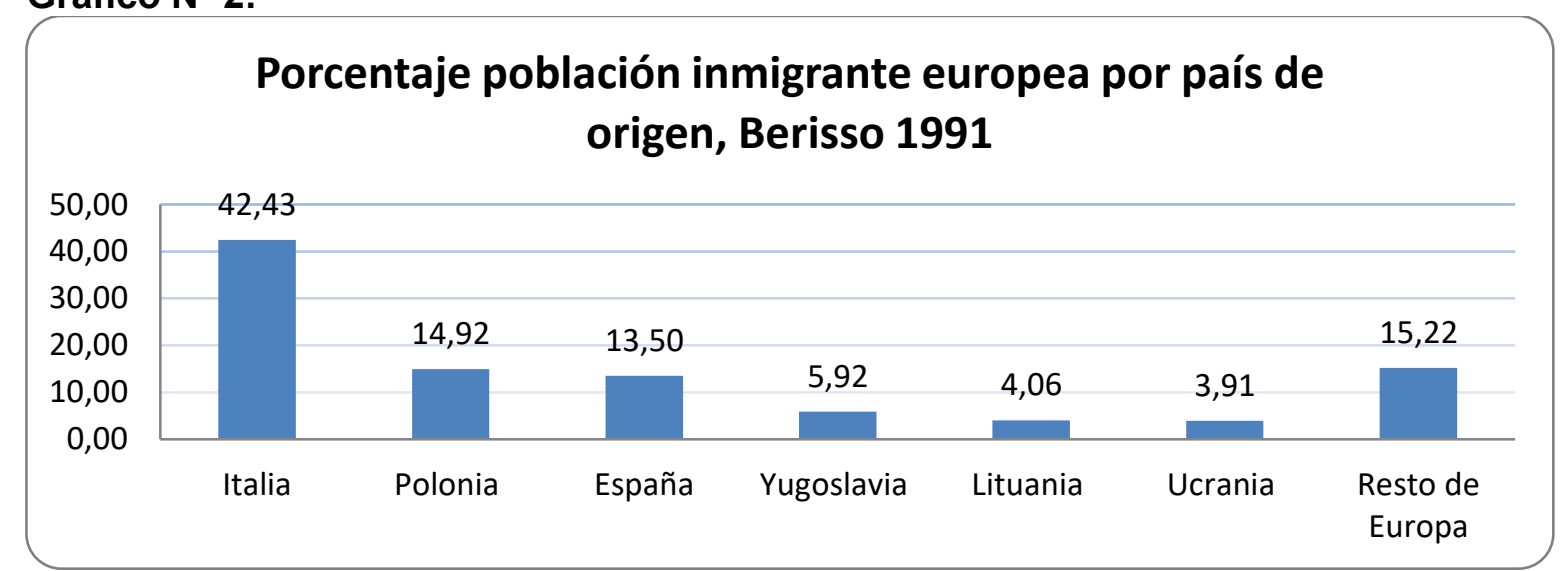

Fuente: Propia, en base al Censo Nacional de Población y Vivienda, 1991. Procesado por la Dirección Provincial de Estadística base de microdatos (datos inéditos)

De los 1.178 inmigrantes americanos, 456 eran peruanos, 211 paraguayos, 198 uruguayos, 111 bolivianos, 57 chilenos, 51 brasileros y de las restantes 94 personas $(7,98 \%)$ se encuentran agrupados en la categoría "Resto de América". 
Gráfico No 3:

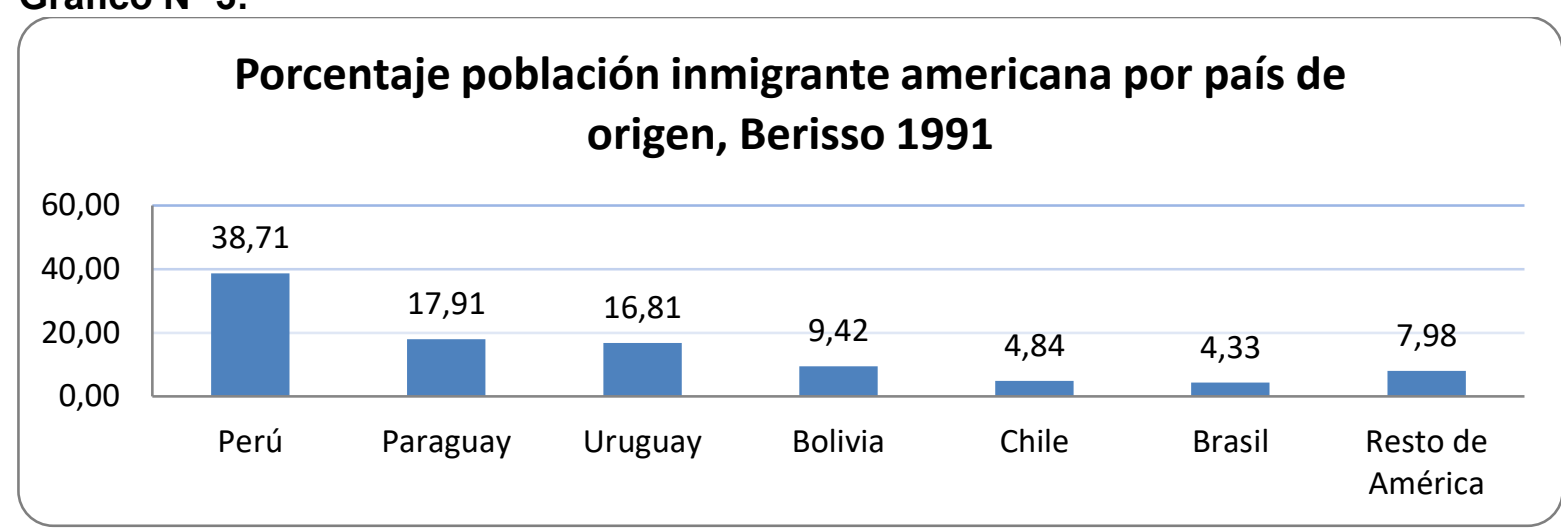

Fuente: Propia, en base al Censo Nacional de Población y Vivienda, 1991. Procesado por la Dirección Provincial de Estadística base de microdatos (datos inéditos)

De los 2.043 inmigrantes europeos, 1.191 eran mujeres y 852 hombres. De los 1.178 inmigrantes americanos, 617 eran hombres y 561 mujeres.

\section{Gráfico No 4:}

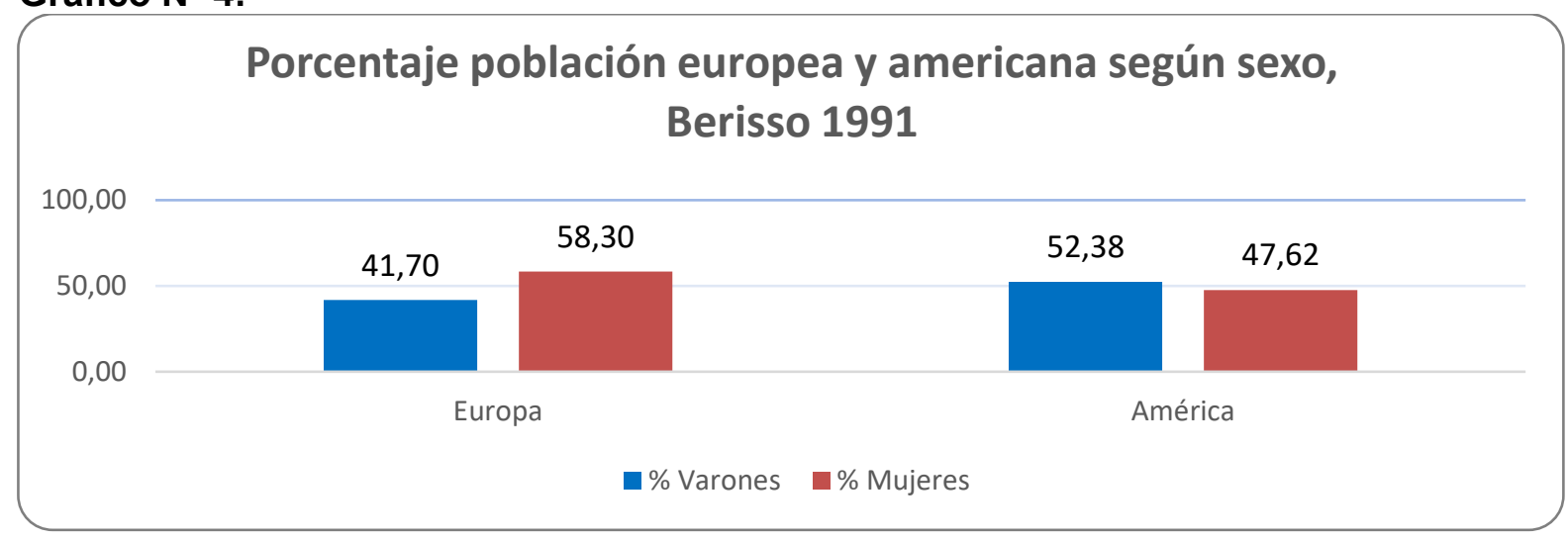

Fuente: Propia, en base al Censo Nacional de Población y Vivienda, 1991. Procesado por la Dirección Provincial de Estadística base de microdatos (datos inéditos)

De los 2.043 inmigrantes europeos, 16 tenían entre 0-14 años, 711 tenían entre 15 y 64, y 1.316 tenían 65 años o más. De los 1.178 inmigrantes americanos, 67 tenían entre 0-14 años, 1.013 tenían entre 15 y 64, y 98 tenían 65 años o más.

\section{Gráfico № 5:}

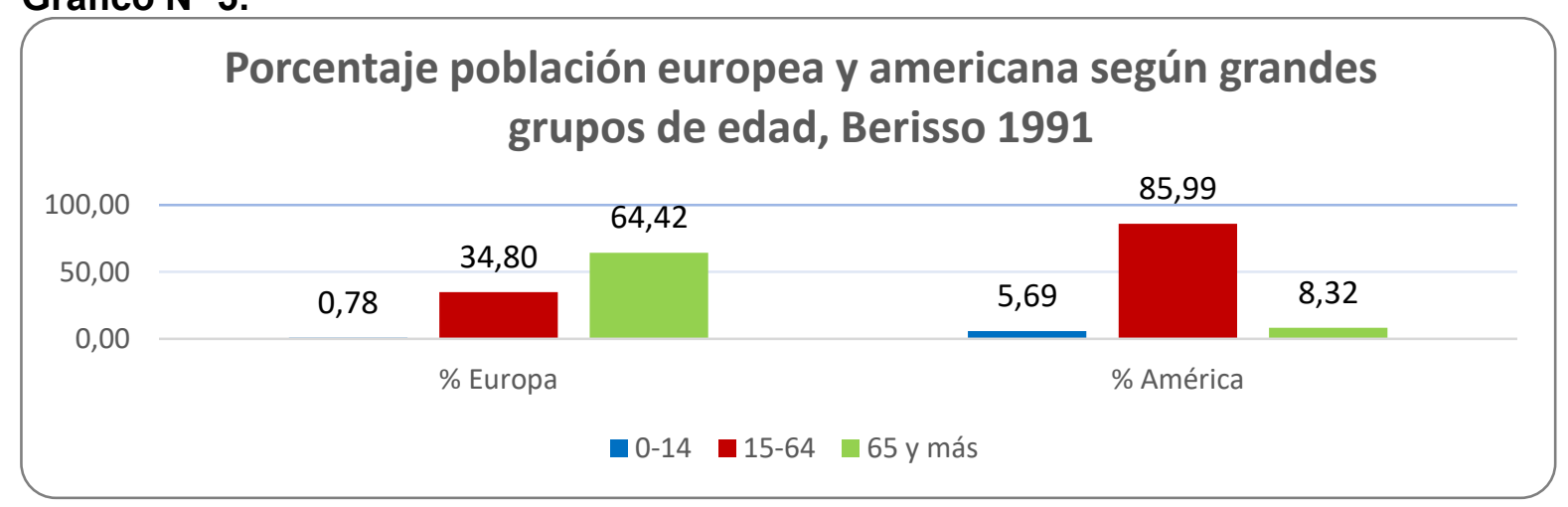

Fuente: Censo Nacional de Población y Vivienda, 1991. Procesado por la Dirección Provincial de Estadística base de microdatos (datos inéditos). 


\begin{tabular}{|c|c|c|c|c|c|c|c|c|c|}
\hline \multicolumn{10}{|c|}{$\begin{array}{l}\text { Población total nacida en el extranjero por lugar de nacimiento según sexo y grupo de } \\
\text { edad, Berisso, } 2001\end{array}$} \\
\hline \multirow{3}{*}{ Lugar de nacimiento } & \multirow{3}{*}{$\begin{array}{c}\text { Población } \\
\text { total nacida } \\
\text { en el } \\
\text { extranjero }\end{array}$} & \multicolumn{8}{|c|}{ Sexo y grupo de edad } \\
\hline & & \multicolumn{4}{|c|}{ Varones } & \multicolumn{4}{|c|}{ Mujeres } \\
\hline & & Total & $0-14$ & $\begin{array}{l}15- \\
64\end{array}$ & $\begin{array}{l}65 \text { y } \\
\text { más }\end{array}$ & Total & $0-14$ & $\begin{array}{l}15- \\
64\end{array}$ & $\begin{array}{l}65 \text { y } \\
\text { más }\end{array}$ \\
\hline Total & 3841 & 1779 & 143 & 1295 & 341 & 2062 & 127 & 1363 & 540 \\
\hline AMÉRICA & 2687 & 1297 & 132 & 1110 & 55 & 1390 & 119 & 1196 & 75 \\
\hline Países limítrofes & 1030 & 493 & 48 & 407 & 38 & 537 & 43 & 436 & 58 \\
\hline Bolivia & 112 & 68 & 5 & 59 & 4 & 44 & 1 & 43 & 0 \\
\hline Brasil & 50 & 14 & 2 & 9 & 3 & 36 & 4 & 24 & 8 \\
\hline Chile & 88 & 43 & 1 & 33 & 9 & 45 & 1 & 36 & 8 \\
\hline Paraguay & 551 & 263 & 34 & 221 & 8 & 288 & 32 & 232 & 24 \\
\hline Uruguay & 229 & 105 & 6 & 85 & 14 & 124 & 5 & 101 & 18 \\
\hline $\begin{array}{l}\text { Países NO limítrofes } \\
\text { (América) }\end{array}$ & 1657 & 804 & 84 & 703 & 17 & 853 & 76 & 760 & 17 \\
\hline Perú & 1627 & 788 & 84 & 688 & 16 & 839 & 76 & 748 & 15 \\
\hline Resto de América & 30 & 16 & 0 & 15 & 1 & 14 & 0 & 12 & 2 \\
\hline EUROPA & 1073 & 444 & 3 & 165 & 276 & 629 & 8 & 164 & 457 \\
\hline Alemania & 2 & 0 & 0 & 0 & 0 & 2 & 0 & 2 & 0 \\
\hline España & 137 & 65 & 1 & 29 & 35 & 72 & 1 & 20 & 51 \\
\hline Francia & 8 & 3 & 0 & 2 & 1 & 5 & 0 & 2 & 3 \\
\hline Italia & 543 & 243 & 0 & 94 & 149 & 300 & 0 & 93 & 207 \\
\hline Resto de Europa & 383 & 133 & 2 & 40 & 91 & 250 & 7 & 47 & 196 \\
\hline ASIA & 12 & 3 & 1 & 0 & 2 & 9 & 0 & 2 & 7 \\
\hline China & 0 & 0 & 0 & 0 & 0 & 0 & 0 & 0 & 0 \\
\hline Corea & 0 & 0 & 0 & 0 & 0 & 0 & 0 & 0 & 0 \\
\hline Japón & 5 & 1 & 1 & 0 & 0 & 4 & 0 & 1 & 3 \\
\hline Líbano & 3 & 1 & 0 & 0 & 1 & 2 & 0 & 0 & 2 \\
\hline Siria & 2 & 0 & 0 & 0 & 0 & 2 & 0 & 1 & 1 \\
\hline Taiwán & 0 & 0 & 0 & 0 & 0 & 0 & 0 & 0 & 0 \\
\hline Resto de Asia & 2 & 1 & 0 & 0 & 1 & 1 & 0 & 0 & 1 \\
\hline ÁFRICA & 4 & 2 & 0 & 1 & 1 & 2 & 0 & 1 & 1 \\
\hline OCEANÍA & 0 & 0 & 0 & 0 & 0 & 0 & 0 & 0 & 0 \\
\hline Otros & 65 & 33 & 7 & 19 & 7 & 32 & 3 & 22 & 7 \\
\hline
\end{tabular}

Fuente: Elaboración propia en base a datos del Censo Nacional de Población, Hogares y Viviendas 2001; INDEC, Celade Redatam + SP. 
De los 3.841 extranjeros, 1.073 eran europeos, 2.687 americanos, 12 asiáticos y 4 africanos. Las 65 personas restantes (cercano al $2 \%$ ) aparecen en la categoría "Otros (Desconocido)" y Oceanía aparece sin representación.

\section{Gráfico N 6:}

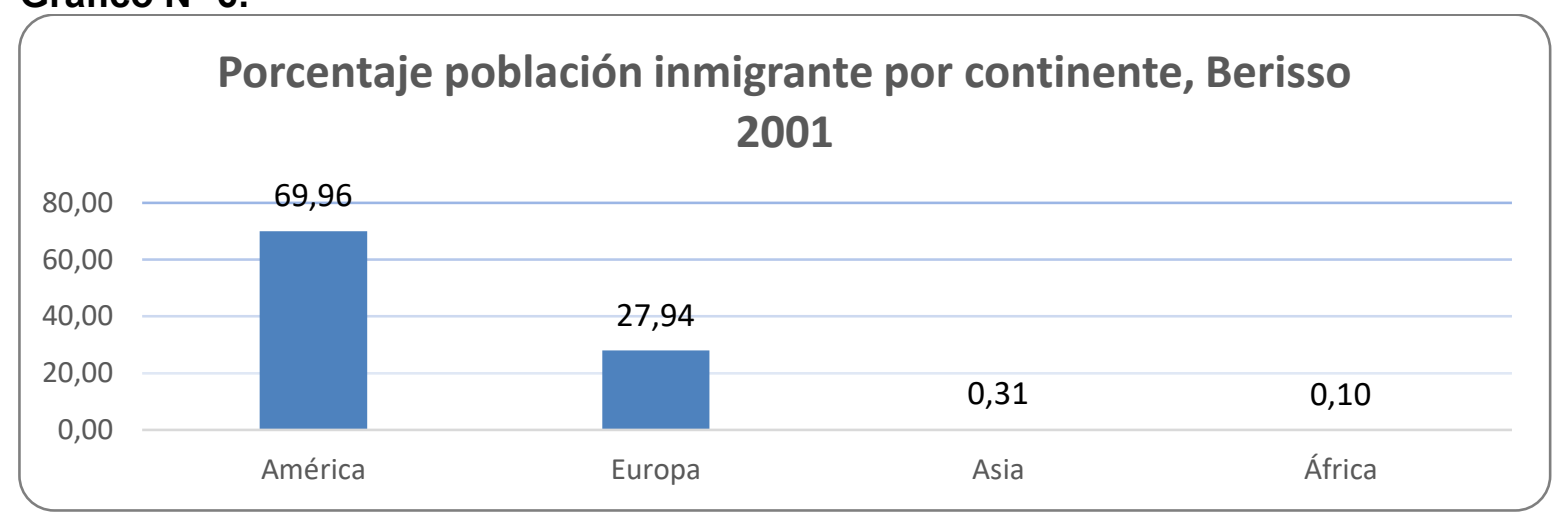

Fuente: Elaboración propia en base a datos del Censo Nacional de Población, Hogares y Viviendas 2001; INDEC, Celade Redatam + SP.

De los 1.073 inmigrantes europeos, 543 eran italianos, 137 españoles, 84 polacos, 55 ucranianos, 30 serbio/montenegrinos, 28 búlgaros; y 196 están agrupados en la categoría Resto de Europa (representando el 18,26\%). Es de aclarar que de los 196 inmigrantes incluidos en esta categoría, República Checa (25), Grecia (23), Croacia (23), Lituania (22), Rusia (20) y Portugal (18) son los países con mayor peso porcentual.

\section{Gráfico No 7:}

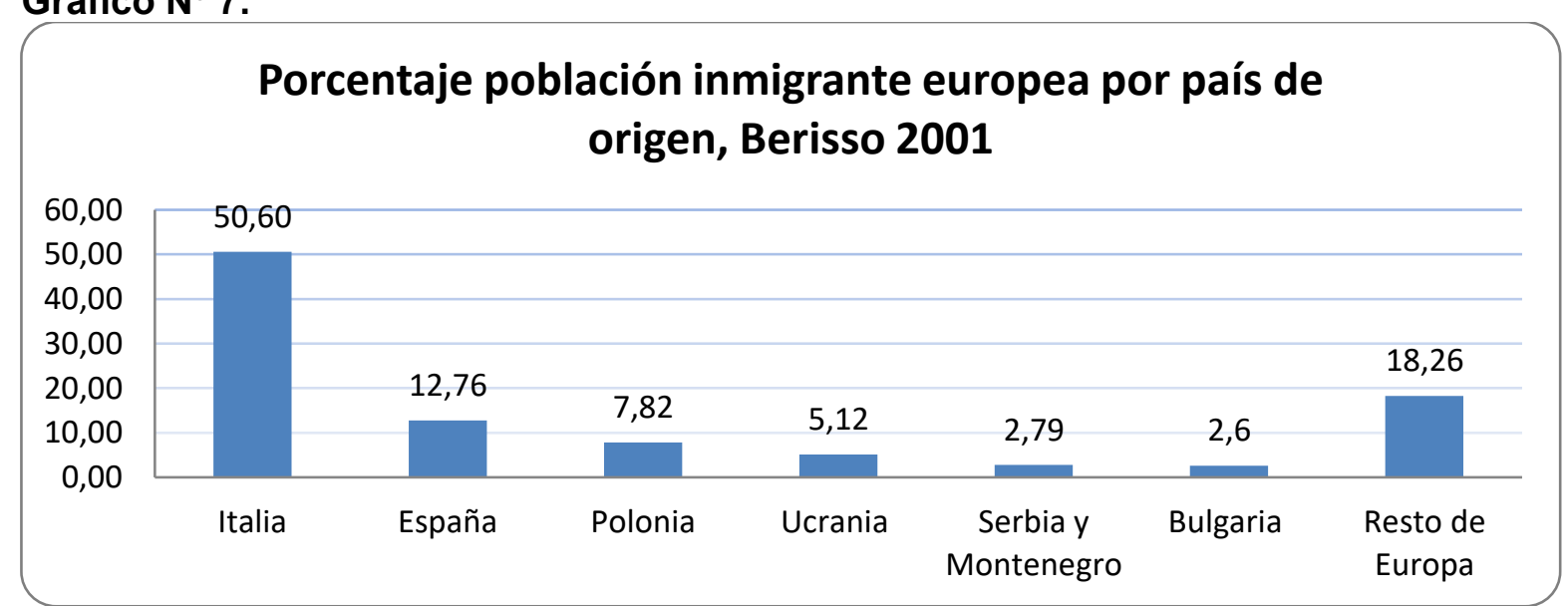

Fuente: Elaboración propia en base a datos del Censo Nacional de Población, Hogares y Viviendas 2001; INDEC, Celade Redatam + SP.

De los 2.687 inmigrantes americanos, 1627 eran peruanos, 551 paraguayos, 229 uruguayos, 112 bolivianos, 88 chilenos, 50 brasileros y de las restantes 30 personas $(1,12 \%)$ se encuentran agrupados en la categoría "Resto de América". 
Gráfico Nº :

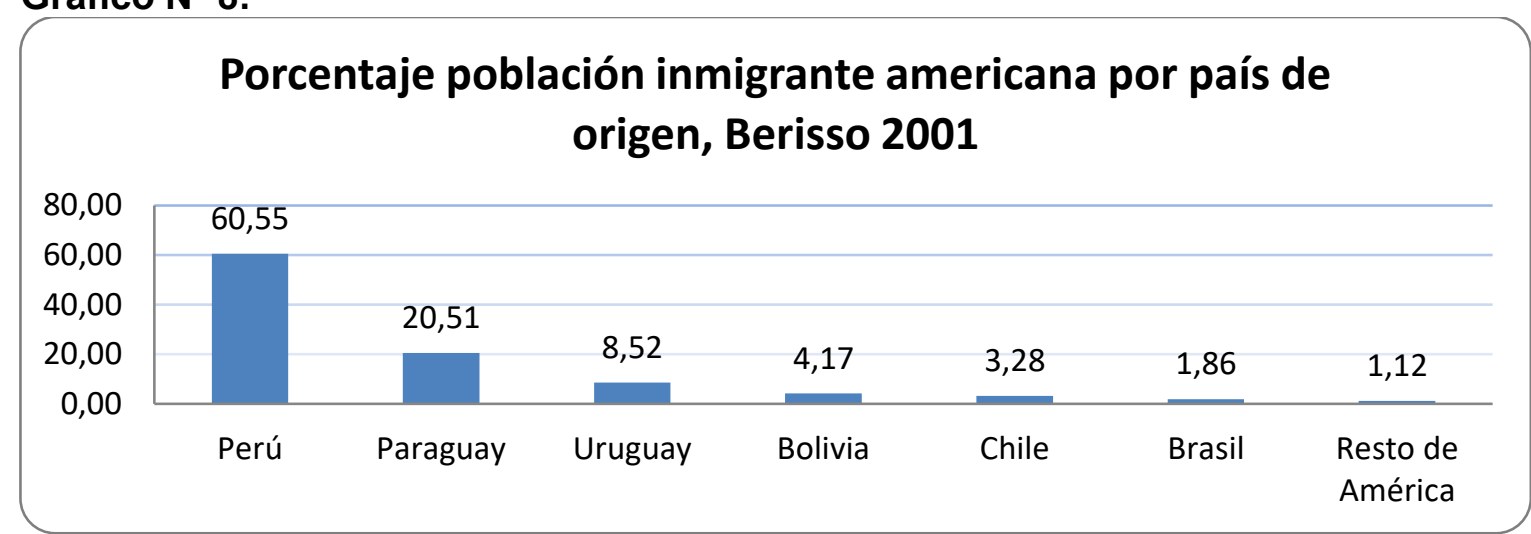

Fuente: Elaboración propia en base a datos del Censo Nacional de Población, Hogares y Viviendas 2001; INDEC, Celade Redatam + SP.

De los 1.073 inmigrantes europeos, 629 eran mujeres y 444 hombres. De los 2.687 inmigrantes americanos, 1297 eran hombres y 1390 mujeres.

Gráfico N ${ }^{\circ}$ :

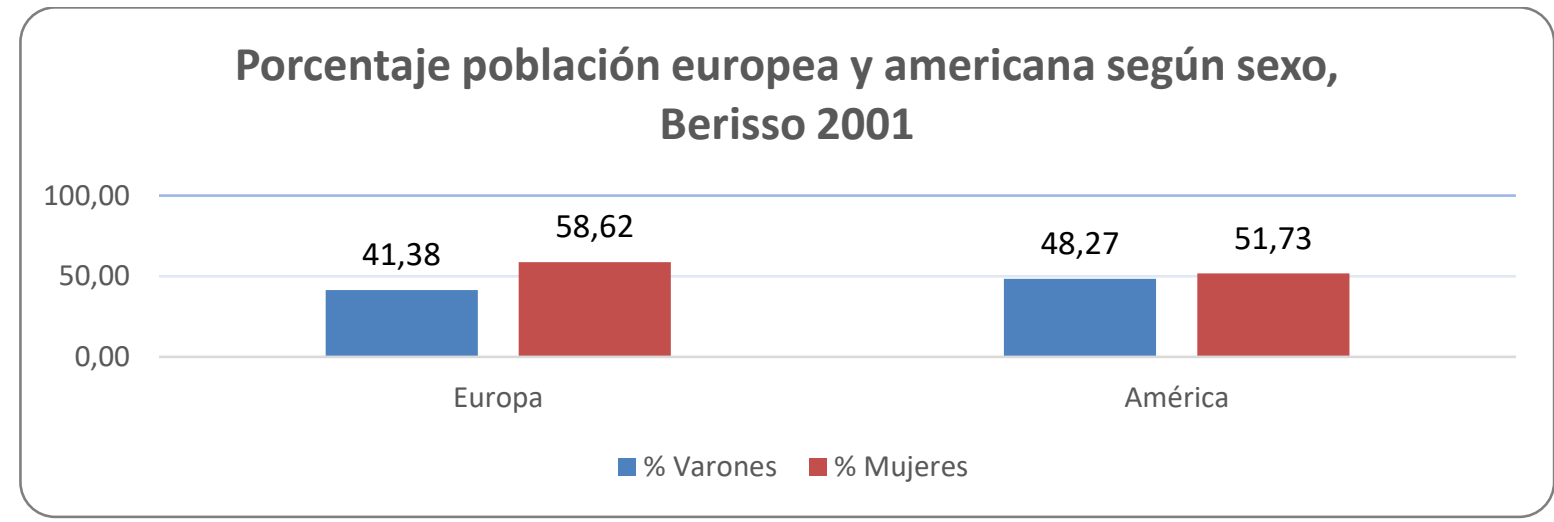

Fuente: Elaboración propia en base a datos del Censo Nacional de Población, Hogares y Viviendas 2001; INDEC, Celade Redatam + SP.

De los 1.073 inmigrantes europeos, 11 tenían entre 0-14 años, 329 tenían entre 15 y 64, y 733 tenían 65 años o más. De los 2.687 inmigrantes americanos, 251 tenían entre 0-14 años, 2306 tenían entre 15 y 64, y 130 tenían 65 años o más.

Gráfico $\mathbf{N}^{\circ} 10$ :

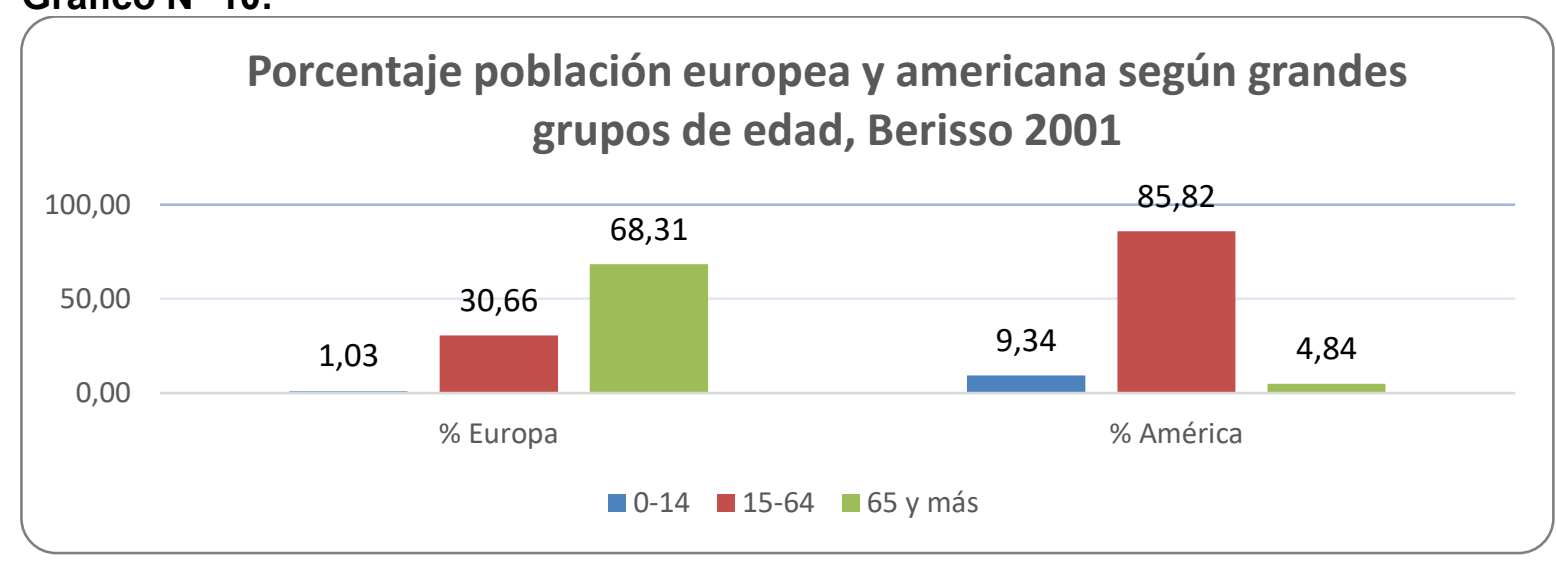

Fuente: Elaboración propia en base a datos del Censo Nacional de Población, Hogares y Viviendas 2001; INDEC, Celade Redatam + SP. 
2010

\begin{tabular}{|c|c|c|c|c|c|c|c|c|c|}
\hline \multicolumn{10}{|c|}{$\begin{array}{c}\text { Población total nacida en el extranjero por lugar de nacimiento según sexo y } \\
\text { grupo de edad, Berisso, } 2010\end{array}$} \\
\hline \multirow{3}{*}{ Lugar de nacimiento } & \multirow{3}{*}{$\begin{array}{c}\text { Población total } \\
\text { nacida en el } \\
\text { extranjero } \\
\end{array}$} & \multicolumn{8}{|c|}{ Sexo y grupo de edad } \\
\hline & & \multicolumn{5}{|c|}{ Varones } & \multicolumn{3}{|c|}{ Mujeres } \\
\hline & & Total & $\begin{array}{ll}0- \\
14\end{array}$ & $\begin{array}{c}15- \\
64 \\
\end{array}$ & $\begin{array}{l}65 \text { y } \\
\text { más }\end{array}$ & Total & $\begin{array}{ll}0- \\
14\end{array}$ & $\begin{array}{l}15- \\
64 \\
\end{array}$ & $\begin{array}{l}65 \text { y } \\
\text { más }\end{array}$ \\
\hline Total & 4827 & 2233 & 206 & 1748 & 279 & 2594 & 180 & 1971 & 443 \\
\hline AMÉRICA & 4200 & 1981 & 201 & 1667 & 113 & 2219 & 176 & 1894 & 149 \\
\hline Países limítrofes & 1643 & 741 & 96 & 591 & 54 & 902 & 83 & 722 & 97 \\
\hline Bolivia & 264 & 132 & 22 & 101 & 9 & 132 & 15 & 110 & 7 \\
\hline Brasil & 54 & 22 & 2 & 19 & 1 & 32 & 2 & 28 & 2 \\
\hline Chile & 89 & 42 & 1 & 36 & 5 & 47 & 1 & 30 & 16 \\
\hline Paraguay & 1011 & 454 & 70 & 364 & 20 & 557 & 63 & 455 & 39 \\
\hline Uruguay & 225 & 91 & 1 & 71 & 19 & 134 & 2 & 99 & 33 \\
\hline $\begin{array}{l}\text { Países NO limítrofes } \\
\text { (América) }\end{array}$ & 2557 & 1240 & 105 & 1076 & 59 & 1317 & 93 & 1172 & 52 \\
\hline Perú & 2497 & 1212 & 98 & 1058 & 56 & 1285 & 86 & 1147 & 52 \\
\hline Resto de América & 60 & 28 & 7 & 18 & 3 & 32 & 7 & 25 & 0 \\
\hline EUROPA & 606 & 244 & 5 & 75 & 164 & 362 & 4 & 71 & 287 \\
\hline Alemania & 4 & 2 & 0 & 1 & 1 & 2 & 0 & 1 & 1 \\
\hline España & 80 & 30 & 4 & 13 & 13 & 50 & 2 & 13 & 35 \\
\hline Francia & 5 & 1 & 0 & 1 & 0 & 4 & 0 & 2 & 2 \\
\hline Italia & 350 & 156 & 0 & 42 & 114 & 194 & 1 & 34 & 159 \\
\hline Resto de Europa & 167 & 55 & 1 & 18 & 36 & 112 & 1 & 21 & 90 \\
\hline ASIA & 16 & 4 & 0 & 3 & 1 & 12 & 0 & 5 & 7 \\
\hline China & 0 & 0 & 0 & 0 & 0 & 0 & 0 & 0 & 0 \\
\hline Corea & 0 & 0 & 0 & 0 & 0 & 0 & 0 & 0 & 0 \\
\hline Japón & 5 & 0 & 0 & 0 & 0 & 5 & 0 & 3 & 2 \\
\hline Líbano & 1 & 0 & 0 & 0 & 0 & 1 & 0 & 0 & 1 \\
\hline Siria & 6 & 2 & 0 & 1 & 1 & 4 & 0 & 0 & 4 \\
\hline Taiwán & 0 & 0 & 0 & 0 & 0 & 0 & 0 & 0 & 0 \\
\hline Resto de Asia & 4 & 2 & 0 & 2 & 0 & 2 & 0 & 2 & 0 \\
\hline ÁFRICA & 5 & 4 & 0 & 3 & 1 & 1 & 0 & 1 & 0 \\
\hline OCEANÍA & 0 & 0 & 0 & 0 & 0 & 0 & 0 & 0 & 0 \\
\hline
\end{tabular}

Fuente: INDEC. Censo Nacional de Población, Hogares y Viviendas 2010

Nota: se incluye a las personas viviendo en situación de calle 
De los 4.827 extranjeros, 606 eran europeos, 4.200 americanos, 16 asiáticos y 5 africanos. Oceanía aparece sin representación.

\section{Gráfico No 11:}

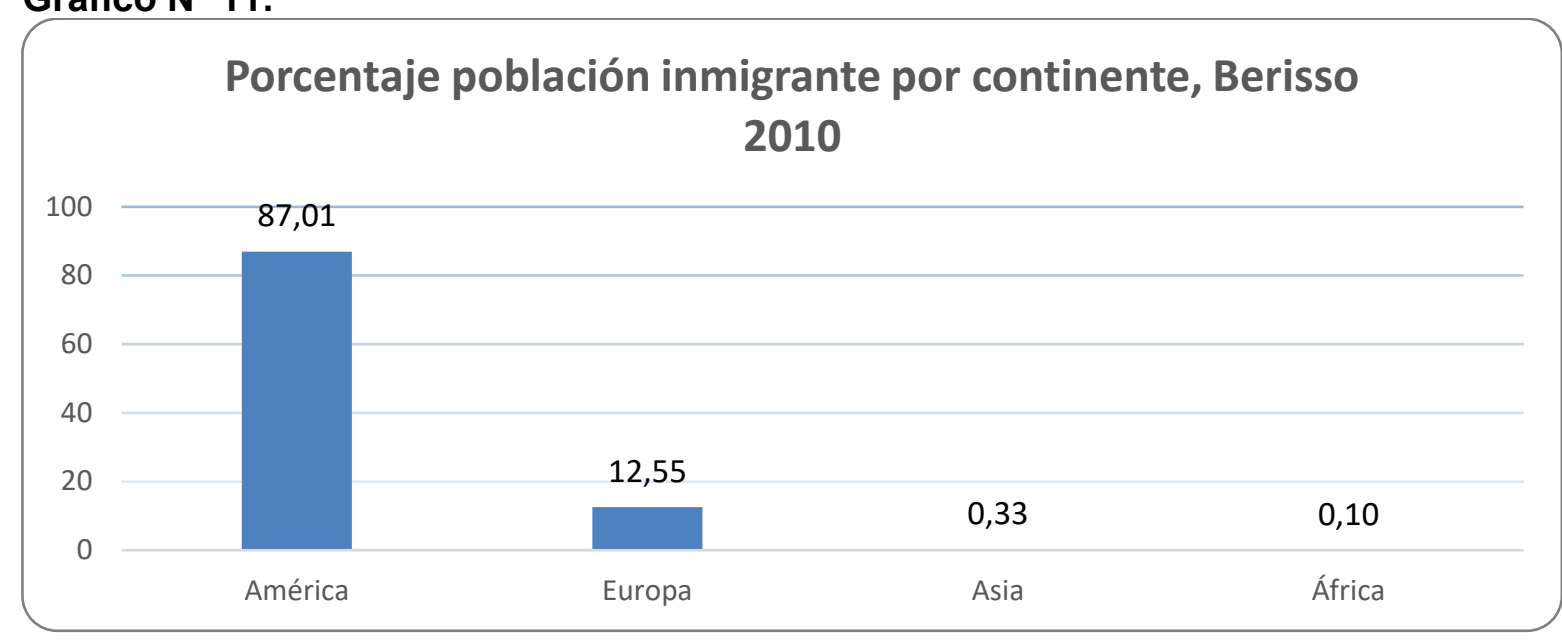

Fuente: Censo Nacional de Población, Hogares y Viviendas, INDEC, 2010

Los 606 inmigrantes europeos estaban compuestos de la siguiente manera: 350 italianos, 80 españoles, 39 polacos, 15 rusos, 15 ucranianos y 13 griegos, y 94 están agrupadas en la categoría Resto de Europa. Entre los países agrupados en dicha categoría, Portugal (11), Croacia (11) y Montenegro (10) son aquellos con mayor representación.

\section{Gráfico No 12:}

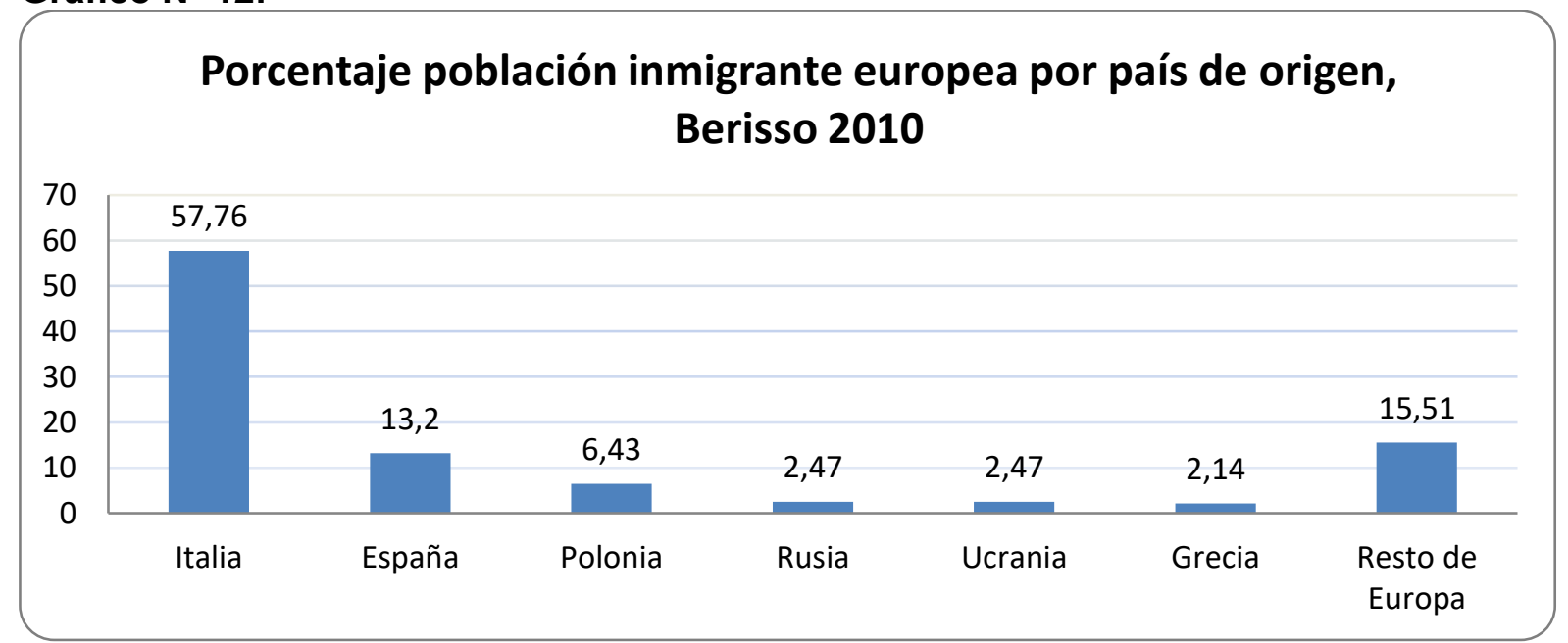

Fuente: Censo Nacional de Población, Hogares y Viviendas, INDEC, 2010

De los 4.200 inmigrantes americanos, 2.497 eran peruanos, 1.011 paraguayos, 225 uruguayos, 264 bolivianos, 89 chilenos, 54 brasileros y de las restantes 60 personas $(1,43 \%)$ se encuentran agrupados en la categoría "Resto de América". 
Gráfico N 13:

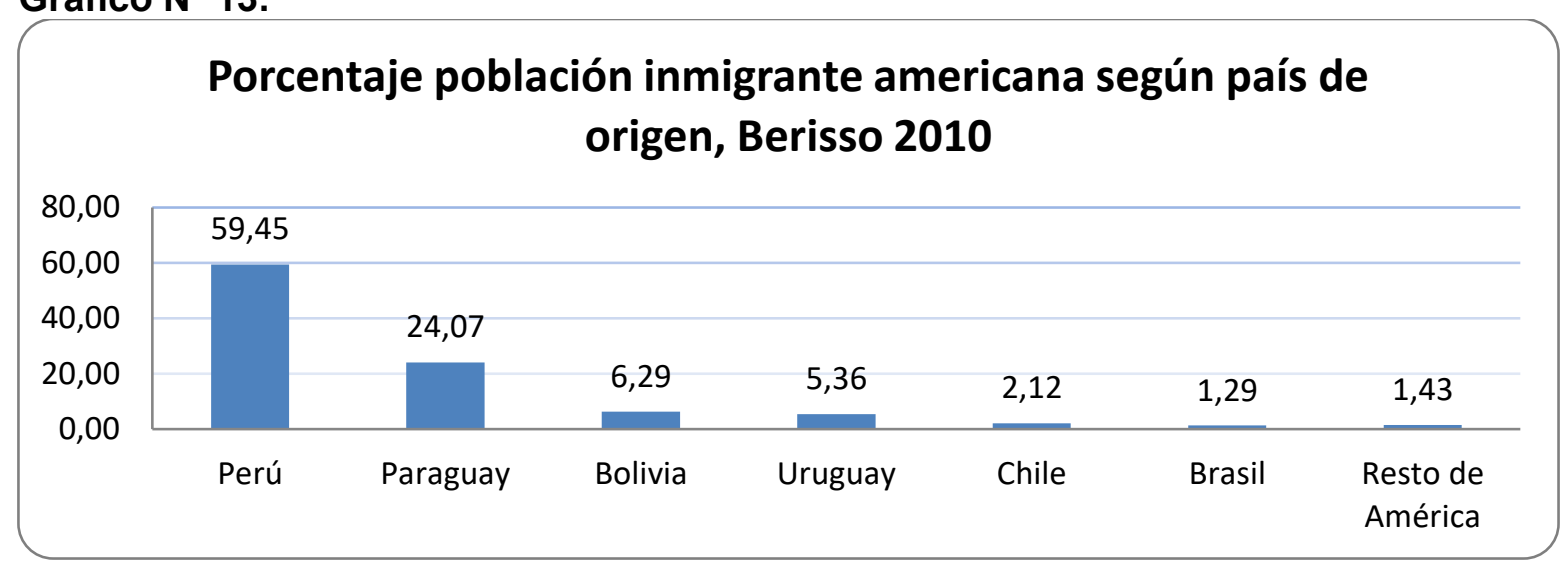

Fuente: Censo Nacional de Población, Hogares y Viviendas, INDEC, 2010

De los 606 inmigrantes europeos, 362 eran mujeres y 244 hombres. De los 4.200 inmigrantes americanos, 1.981 eran hombres y 2.219 mujeres.

Gráfico N 14:

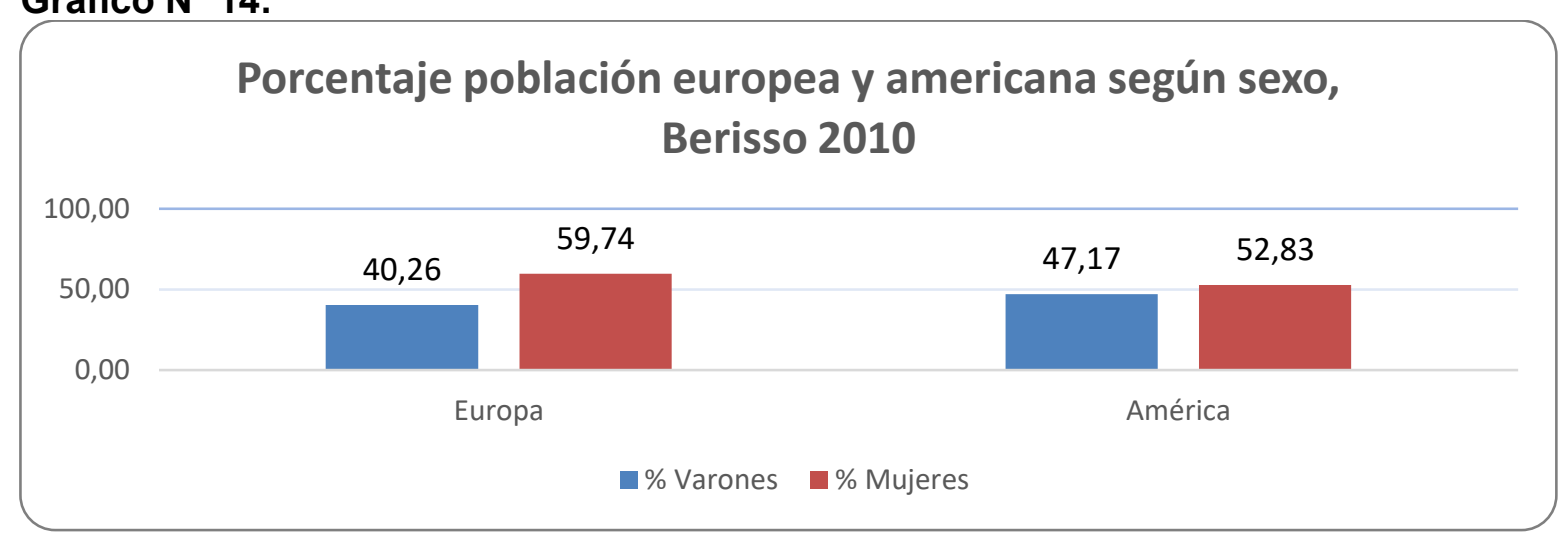

Fuente: Censo Nacional de Población, Hogares y Viviendas, INDEC, 2010

De los 606 inmigrantes europeos, 9 tenían entre 0-14 años, 146 tenían entre 15 y 64, y 451 tenían 65 años o más. De los 4.200 inmigrantes americanos, 377 tenían entre 0-14 años, 3.561 tenían entre 15 y 64, y 262 tenían 65 años o más.

\section{Gráfico No 15:}

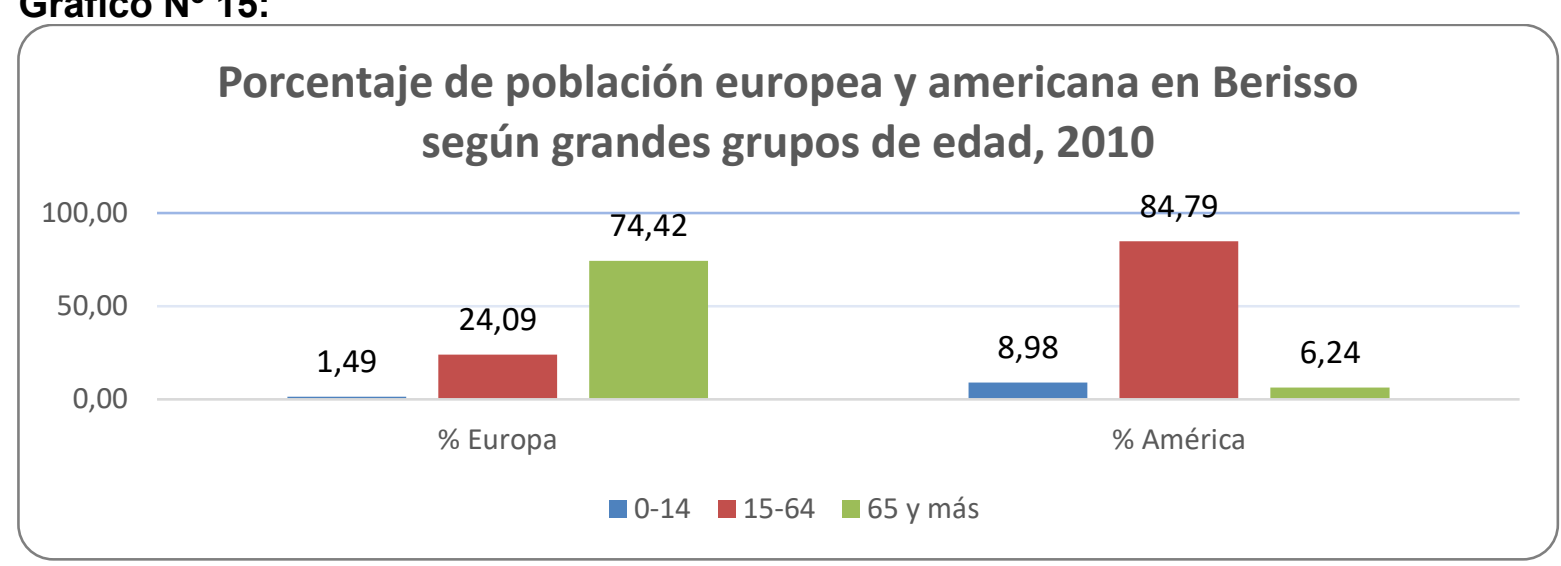

Fuente: Censo Nacional de Población, Hogares y Viviendas, INDEC, 2010 


\section{Anexo N4: Georreferenciación de la población de origen extranjero}

residente en Berisso (censo del 2010)

Mapa №1: Porcentaje de Extranjeros sobre el Total de Población de Berisso (2010). Medido porcentualmente en cada radio censal

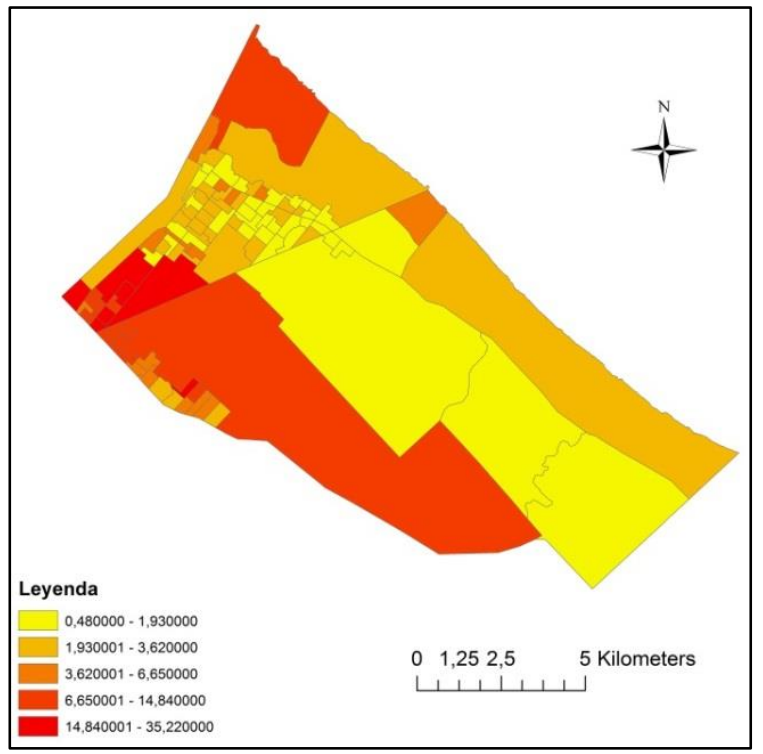

Fuente: elaboración propia en base a Indec, Censo Nacional de Población Hogares y Viviendas 2010.

Base de datos Redatam y cartografía censal. Método: cortes naturales

\section{Mapa N²: Distribución Espacial de los Extranjeros en Berisso (2010). Medido} porcentualmente en cada radio censal

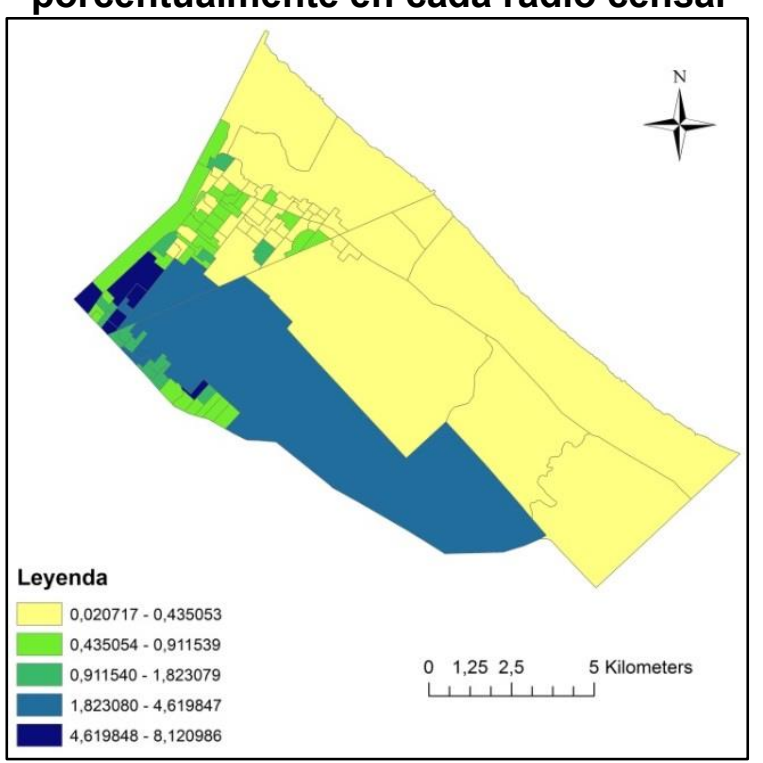

Fuente: elaboración propia en base a Indec, Censo Nacional de Población Hogares y Viviendas 2010.

Base de datos Redatam y cartografía censal. Método: cortes naturales

Cruzando los datos de la base censal y el mapa anteriormente indicado vemos que el $53,34 \%$ de los inmigrantes que viven en Berisso (2574 personas) está distribuido en solo 10 de los 99 radios censales de la ciudad (indicados en azul claro y azul oscuro). 


\section{Mapa N³: Distribución Espacial de los Inmigrantes Europeos en Berisso (2010).}

Medido porcentualmente en cada radio censal

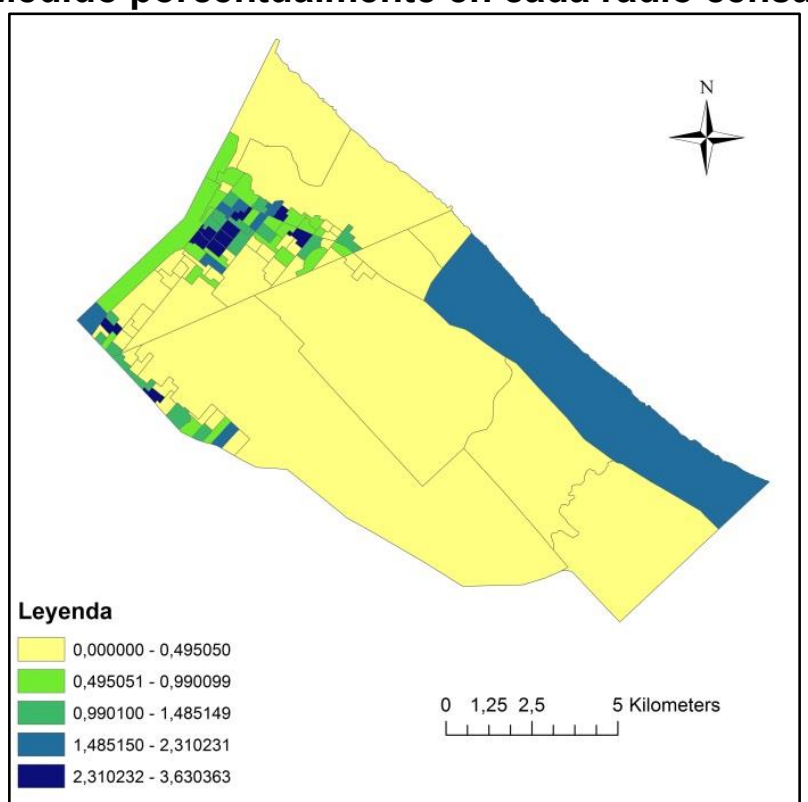

Fuente: elaboración propia en base a Indec, Censo Nacional de Población Hogares y Viviendas 2010.

Base de datos Redatam y cartografía censal. Método: cortes naturales

Cruzando los datos de la base censal y el mapa anteriormente indicado vemos que el 49,66\% de los inmigrantes europeos (301 personas) está distribuido en 18 de los 99 radios censales de la ciudad (indicados con azul claro y azul oscuro).

\section{Mapa N4: Distribución Espacial de los Inmigrantes Americanos en Berisso (2010). Medido porcentualmente en cada radio censal}

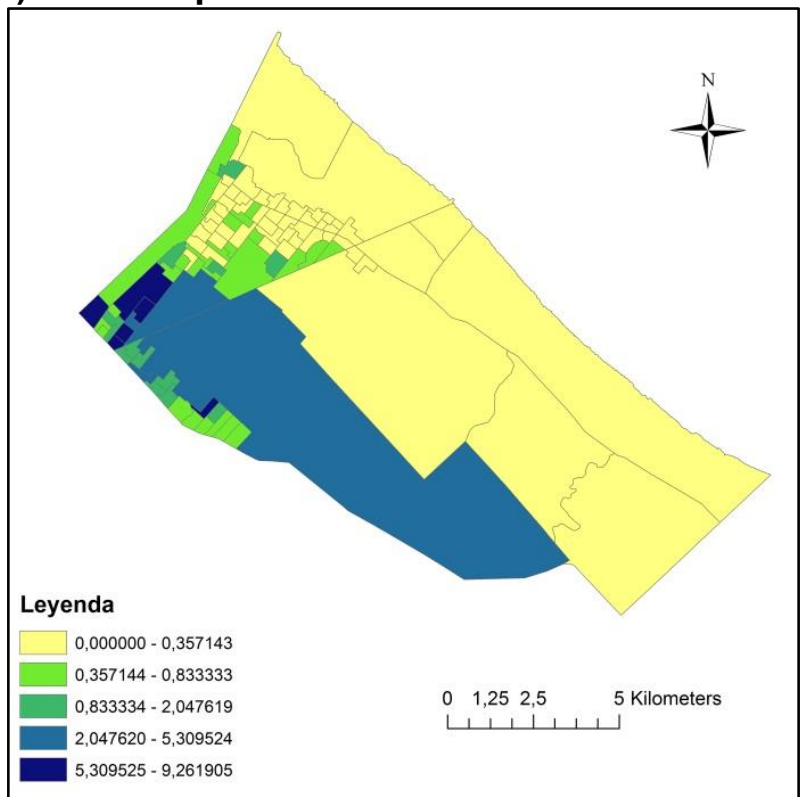

Fuente: elaboración propia en base a Indec, Censo Nacional de Población Hogares y Viviendas 2010. Base de datos Redatam y cartografía censal. Método: cortes naturales

Cruzando los datos de la base censal y el mapa anteriormente indicado vemos que el $60,45 \%$ de los inmigrantes americanos (2539 personas) está distribuido en tan solo 10 de los 99 radios censales de la ciudad (indicados con azul claro y azul oscuro). 


\section{Mapa № 5: Distribución Espacial de los Inmigrantes Italianos en Berisso (2010).}

Medido porcentualmente en cada radio censal

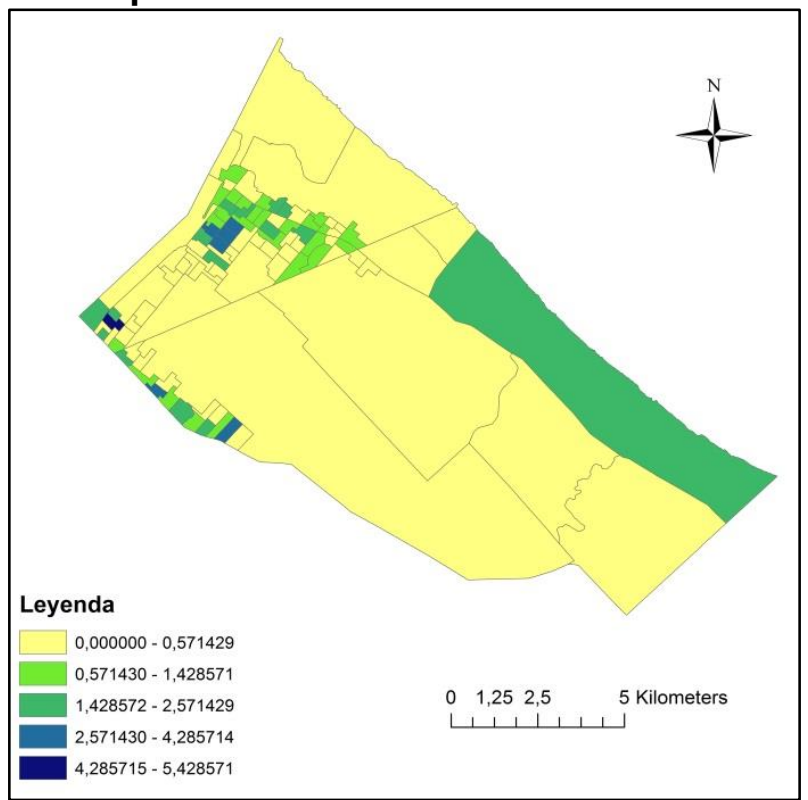

Fuente: elaboración propia en base a Indec, Censo Nacional de Población Hogares y Viviendas 2010.

Base de datos Redatam y cartografía censal. Método: cortes naturales

Cruzando los datos de la base censal y el mapa anteriormente indicado vemos que el $64,28 \%$ de los italianos (225 personas) se encuentra distribuido en 22 de los 99 radios censales que tiene la ciudad (indicados en azul claro y azul oscuro)

Mapa N6: Distribución Espacial de los Inmigrantes Españoles en Berisso (2010). Medido porcentualmente en cada radio censal

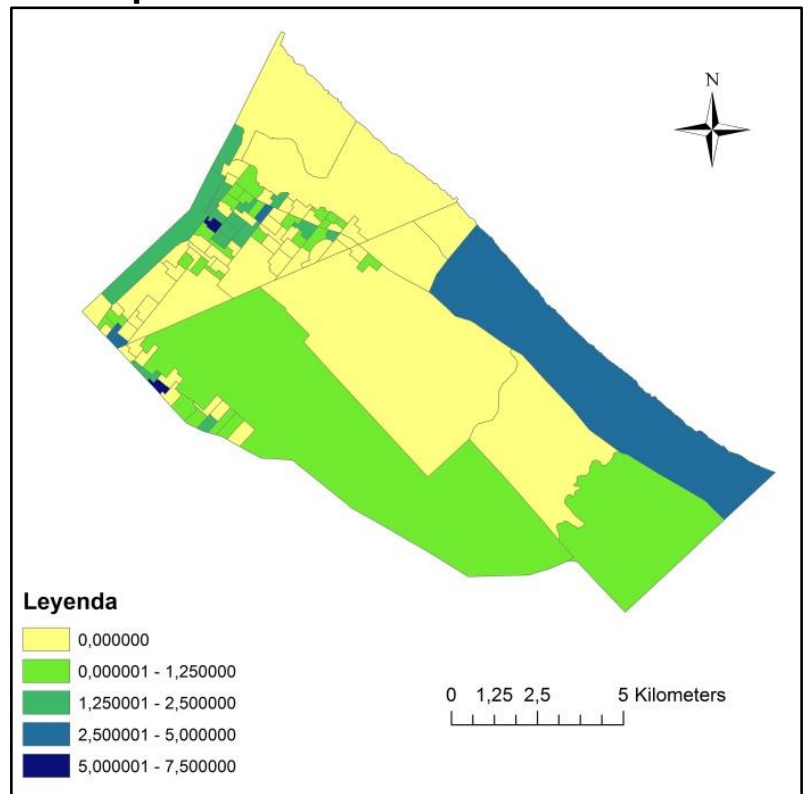

Fuente: elaboración propia en base a Indec, Censo Nacional de Población Hogares y Viviendas 2010. Base de datos Redatam y cartografía censal. Método: cortes naturales

Cruzando los datos de la base censal y el mapa anteriormente indicado vemos que el $67,5 \%$ de los españoles (54 personas) se encuentra distribuido en 20 de los 99 radios censales que tiene la ciudad (indicados en verde oscuro, azul y azul oscuro) 
Mapa N07: Distribución Espacial de los Inmigrantes Polacos en Berisso (2010). Medido porcentualmente en cada radio censal

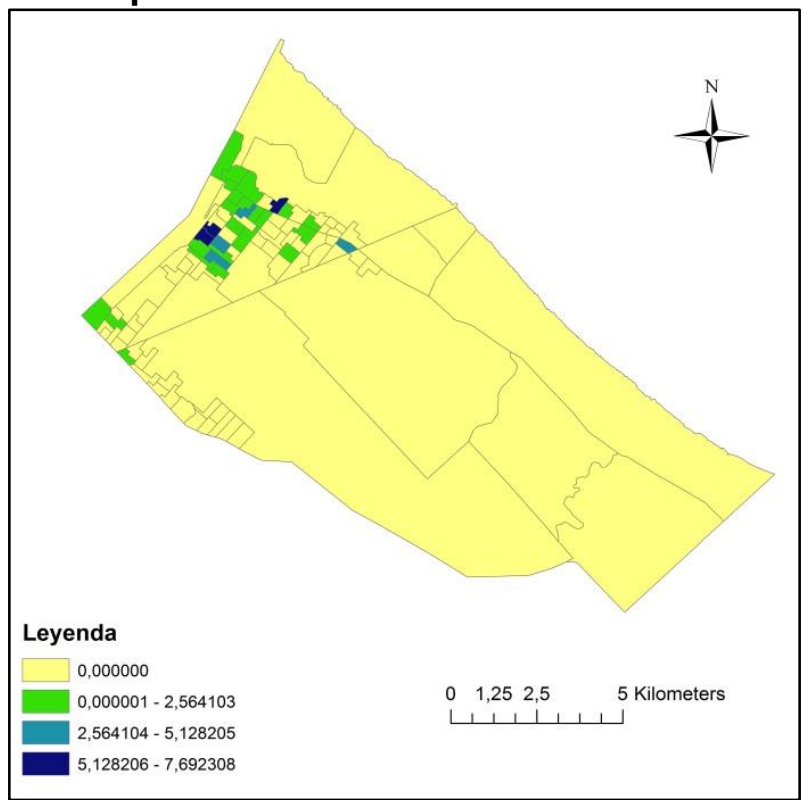

Fuente: elaboración propia en base a Indec, Censo Nacional de Población Hogares y Viviendas 2010. Base de datos Redatam y cartografía censal. Método: cortes naturales

Cruzando los datos de la base censal y el mapa anteriormente indicado vemos que el $56,42 \%$ de los polacos (22 personas) se encuentra distribuido en 22 de los 99 radios censales que tiene la ciudad (indicados en verde).

Mapa N8: Distribución Espacial de los Inmigrantes Peruanos en Berisso (2010). Medido porcentualmente en cada radio censal

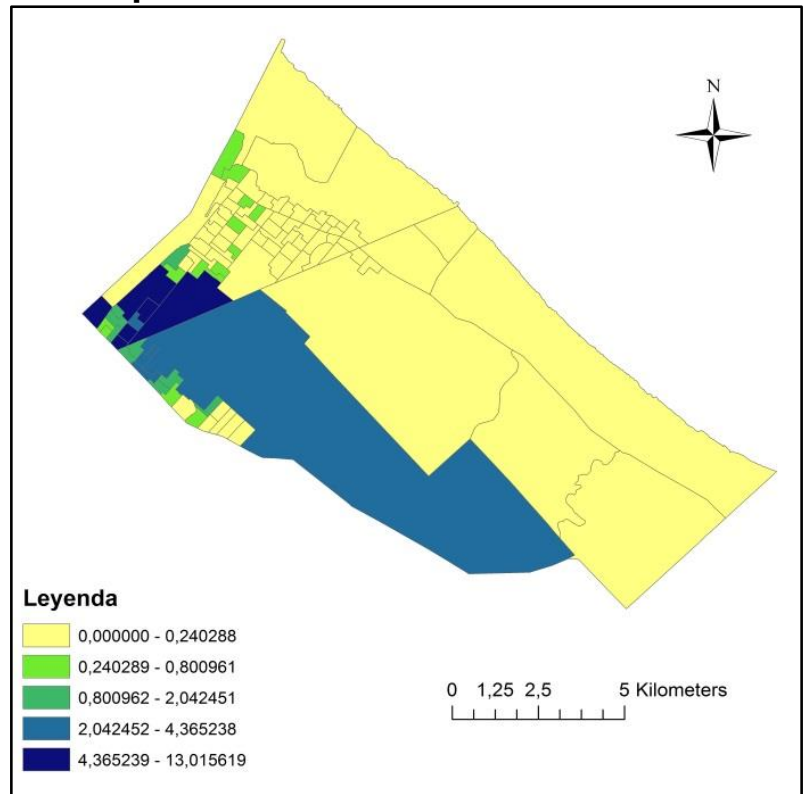

Fuente: elaboración propia en base a Indec, Censo Nacional de Población Hogares y Viviendas 2010. Base de datos Redatam y cartografía censal. Método: cortes naturales

Cruzando los datos de la base censal y el mapa anteriormente indicado vemos que el $64,11 \%$ de los peruanos (1601 personas) se encuentra distribuido en tan solo 6 de los 99 radios censales que tiene la ciudad (indicados en azul oscuro). 


\section{Mapa N9: Distribución Espacial de los Inmigrantes Paraguayos en Berisso (2010). Medido porcentualmente en cada radio censal}

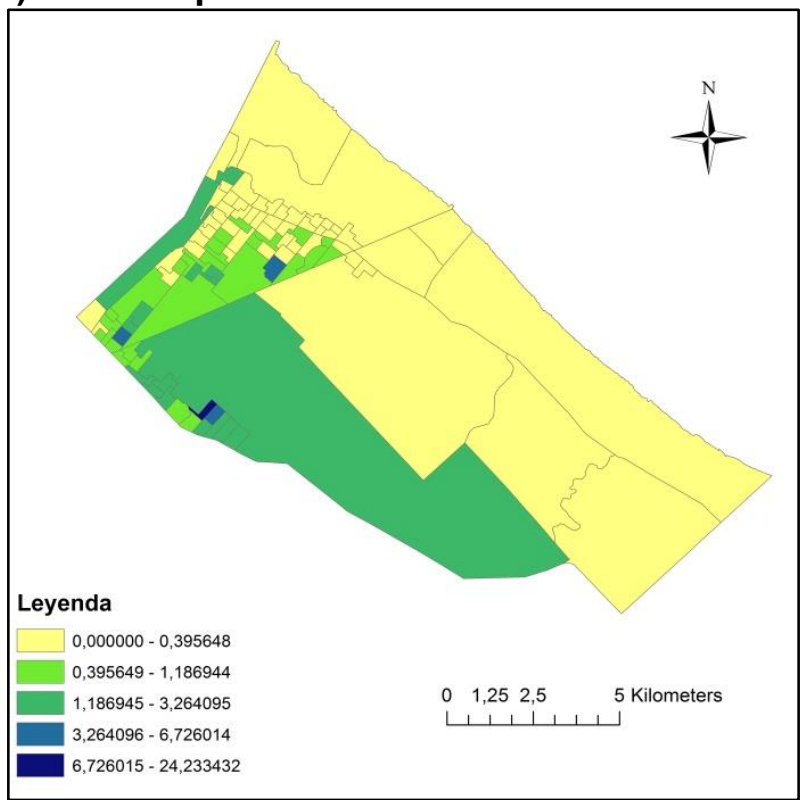

Fuente: elaboración propia en base a Indec, Censo Nacional de Población Hogares y Viviendas 2010.

Base de datos Redatam y cartografía censal. Método: cortes naturales

Cruzando los datos de la base censal y el mapa anteriormente indicado vemos que el $39,86 \%$ de los paraguayos (399 personas) se encuentra distribuido en tan solo 4 de los 99 radios censales que tiene la ciudad (indicados en azul claro y azul oscuro)

\section{Mapa No 10: Distribución Espacial de los Inmigrantes Bolivianos en Berisso (2010). Medido porcentualmente en cada radio censal}

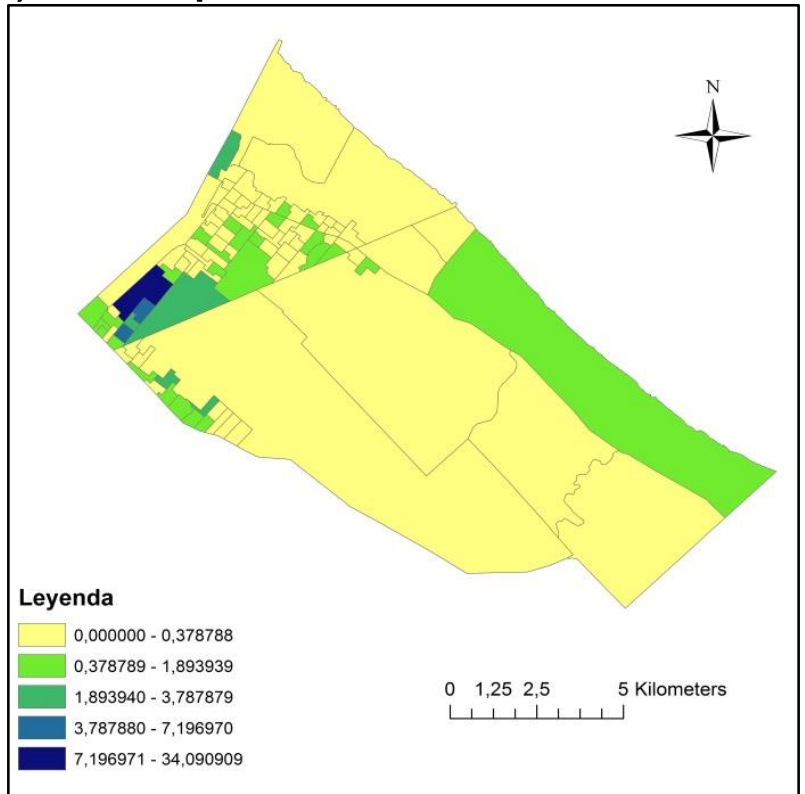

Fuente: elaboración propia en base a Indec, Censo Nacional de Población Hogares y Viviendas 2010.

Base de datos Redatam y cartografía censal. Método: cortes naturales

Cruzando los datos de la base censal y el mapa anteriormente indicado vemos que el $46,59 \%$ de los bolivianos (123 personas) se encuentra distribuido en tan solo 3 de los 99 radios censales que tiene la ciudad (indicados en azul claro y azul oscuro). 


\section{Mapa №11: Geomorfología del Suelo en Berisso}

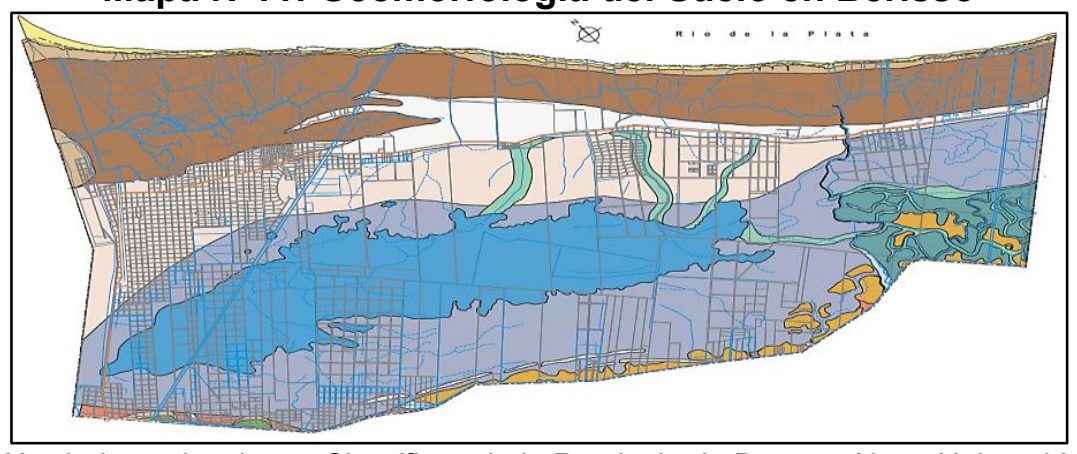

Fuente: Comisión de Investigaciones Científicas de la Provincia de Buenos Aires, Universidad Nacional de La Plata, Facultad de Ciencias Naturales y Museo, Instituto de Geomorfología y Suelos.

Leyendas Seleccionadas:

Origen del Área: Marino

Unidad: Cordón Litoral
Origen del Área: Marino

Unidad: Llanura de Fango

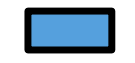

Origen del Área: Marino

Unidad: Bañado

\section{Mapa N¹2: Riesgo Natural de Inundación en Berisso}

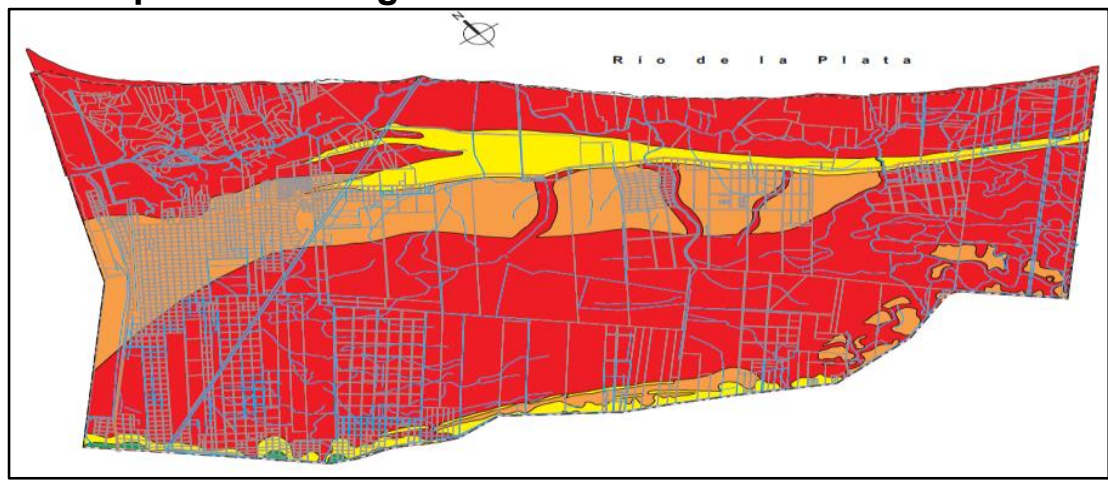

Fuente: Comisión de Investigaciones Científicas de la Provincia de Buenos Aires, Universidad Nacional de La Plata, Facultad de Ciencias Naturales y Museo, Instituto de Geomorfología y Suelos.

Leyendas Seleccionadas:

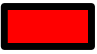

Máximo

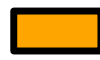

Medio

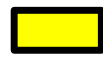

Mínimo 


\section{Anexo № 5: Asociación de Entidades Extranjeras (AEE)}

Primera Comisión directiva de la AEE

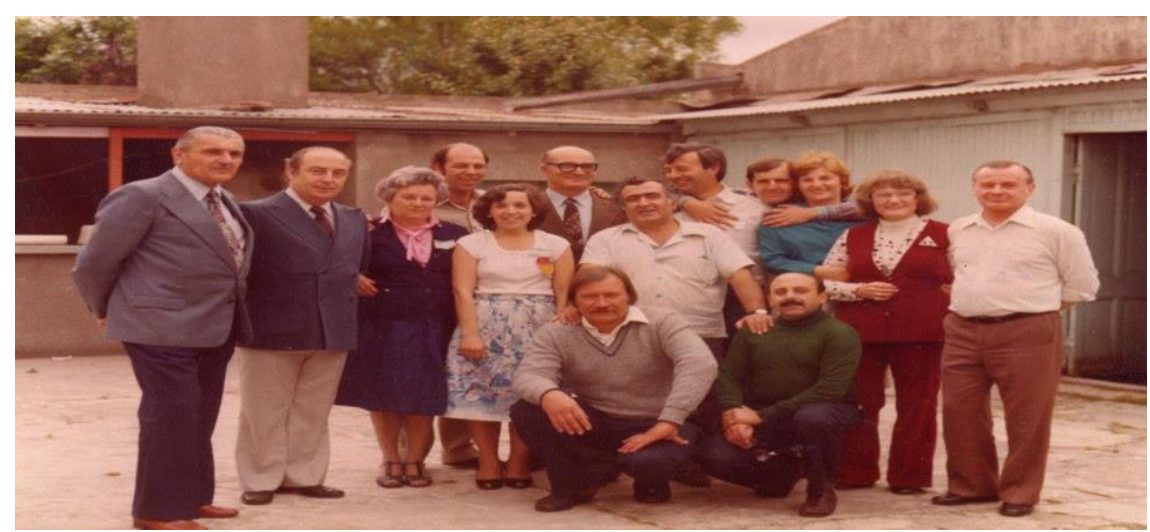

Fuente: Gentiliza Stella Loholaberry, 1981.

Situados en la sede de las Asociación Búlgara, de izquierda a derecha, en la fila trasera se encuentran Hugo García, Dr. Juan Minoian (de traje marrón y anteojos, presidente, colectividad armenia), Antonio Ortiz (colectividad lituana), Juan Petcoff (colectividad búlgara) y Valeria Wroblevsky (colectividad polaca).

En la fila del medio se encuentran Antimo Gallo, Néstor Ruiz (colectividad checoslovaca), Sofia Rapi de Petroff (colectividad albanesa), Stella Loholaberry (colectividad española), Garo Torossian (colectividad armenia), Ana Barich y Fero Drobny (colectividad eslovaca)

Agachados están Alfredo Dulke (colectividad lituana) y Dario Desimone.

Indicamos solamente las pertenencias a las asociaciones étnico-nacionales de aquellas personas que hemos podido confirmar. 


\section{ESTATUTO FUNDACIONAL DE LA AEE, 1980}

- ASOCIACIÓN FUNDADA: el 28 de Noviembre de 1979

- ESTATUTO APROBADO: el 5 de Diciembre de 1980.

Del nombre, domicilio y objeto de la Asociación

ARTICULO 10: Se adopta el nombre de ASOCIACIÓN DE ENTIDADES EXTRANJERAS DE BERISSO, con domicilio provisorio en la calle Montevideo $\mathrm{n}^{\circ} 841$ de la Ciudad de Berisso, Partido del mismo nombre, Provincia de Buenos Aires.

ARTICULO 20: Siendo Berisso decretada "Capital Provincial del Inmigrante", el objeto de esta Asociación, es fomentar el espíritu de unión entre las distintas colectividades, esencialmente en todas aquellas manifestaciones en que las entidades fundadoras y/o titulares, participen en su totalidad y en conjunto como en las celebraciones del Mes del Inmigrante; vincular estrechamente las colectividades entre ellas como así también a los argentinos, difundir la cultura social e intelectual de cada nación manteniendo viva la llama de las tradiciones y sostener los mismos vínculos con las distintas colectividades establecidas en la provincia y en el país.

Disposiciones generales

ARTICULO 30: Para los fines de la Asociación, La Comisión Directiva podrá arbitrar todos los elementos legales y recursos de todo tipo destinados a controlar el desarrollo de las actividades por ella, sean de carácter social, cultural y deportivo.

ARTICULO 4: Todo tipo de inversión deberá ser decidida por la Comisión Directiva, salvo en aquellos casos en que sea necesario tomar una urgente resolución, la cual adoptará la Mesa Directiva compuesta por Presidente, Secretario y tesorero, dando cuenta de esa gestión en la primera reunión de Comisión Directiva que se realice.

ARTICULO 50: Esta Asociación carece de filiación política, tanto en su local como en sus reuniones, no será permitido mantener discusiones de carácter político, adoptando el mismo criterio para razas y religiones. El incumplimiento podrá ser penado por la Comisión Directiva de la Asociación, con la expulsión del o de los delegados y hasta de la colectividad o colectividades que incurran en la falta, ya sea por un tiempo determinado o definitivamente, siendo comunicada esta pena a la entidad representada.

ARTICULO 6: La Comisión Directiva de esta Asociación resolverá todos los casos no previstos en el presente estatuto.

ARTICULO 70: El presente estatuto podrá ser reformado en cualquier tiempo, en Asamblea convocada para tal fin, a iniciativas de la Comisión Directiva, o de la tercera parte de las colectividades Extranjeras inscriptas en esta Asociación, esta Asamblea podrá tomar decisión con la aprobación de los dos tercios de los presentes.

ARTICULO 8: En caso de disolución de la Comisión Directiva, por renuncia e impedimento de la mitad más uno de sus miembros, la minoría existente convocará a Asamblea Extraordinaria para proveer los cargos que regularicen su función. Si la acefalía de la Comisión Directiva fuera total, la Asamblea Extraordinaria será convocada por el veinte por ciento $(20 \%)$ de las Colectividades inscriptas como Asociados Fundadores y/o Titulares y con el objeto de la elección total de nuevos miembros de la Comisión Directiva.

De los asociados, sus derechos y obligaciones. 
ARTICULO 90: Esta Asociación se compone de Asociados Fundadores, Titulares y Adherentes, dividiéndose estos últimos en activos o no activos.

ARTICULO 10 : Serán admitidos como Asociadas todas a aquellas colectividades Extranjeras afincadas en el partido de Berisso o cualquier partido de la provincia de Buenos Aires y que estén dispuestos a atenerse a los objetivos de esta asociación. Serán admitidos como representantes de cada Colectividad, no admitiendo división por regiones, la Sociedad, Centro o Club que sea admitido ejercerá la representación de su Colectividad.

ARTICULO 110: La solicitud de ingreso como asociado deberá ser dirigida por escrito al presidente de la asociación, firmada por presidente y secretario de la colectividad interesada y donde además deberán constar los nombres y cargos si los tuvieran, de los dos postulantes a Delegados ante esta Asociación. Dicha solicitud será estudiada por la Comisión Directiva en pleno. Rechazada una solicitud, no podrá ser considerada otra del mismo interesado hasta pasado seis meses al de la fecha en que hubiera sido desaprobada la anterior. El asociado fundador, titular y/o adherente, activo o no activo, expulsado no podrá reingresar hasta después de dos años de la expulsión y siempre que su solicitud fuera aceptada por los dos tercios de la Comisión Directiva reunida a pleno.

ARTICULO 120: El socio fundador o titular, que por causas imputables a fuerza mayor de su colectividad, se retirara de la Asociación sin comunicación escrita, será considerado renunciante de la Asociación, perdiendo por lo cual, todos los derechos.

ARTICULO 13: Bajo las mismas circunstancias referidas en el párrafo anterior, previa solicitud de licencia, la cual tendrá una duración de un (1) año, pudiendo ser ampliada por la Comisión Directiva, en el término que crea menester, medie o no solicitud de ampliación de plazo por la Colectividad solicitante. En la nota del pedido de licencia, la Colectividad peticionante informará si participará y en que forma se adherirá a los festejos organizados por la Asociación, quién determinará sobre el particular. La Colectividad encuadrada en éste y el anterior artículo pasará a revistar como Socio Adherente, con los derechos expresados en el artículo $18^{\circ}$ (dieciocho) de este estatuto.

ARTICULO 14\%: Son Asociados Fundadores y/o Titulares, todas aquellas Sociedades, Centros o Clubes Extranjeros radicados en el Partido de Berisso y que tomen en número uno por colectividad su representación ante ésta Asociación. Estos asociados tendrán derecho a integrar la Comisión Directiva de la Asociación de Entidades Extranjeras y por lo tanto tendrá voz y voto. El voto será en número de uno por Colectividad, haciendo uso del mismo el delegado titular, cualquiera sea el cargo que ocupe dentro de la Comisión Directiva y en caso de ausencia asume el voto el delegado suplente. En caso de que se registre un empate en el cómputo de votos es el Presidente el que decide.

ARTICULO 15: En el caso de una votación, los revisores de Cuentas, titulares o suplentes pueden ejercer el derecho a voto siendo delegado titular de la colectividad que representan y en su ausencia este derecho lo ejerce el delegado suplente.

ARTICULO 16\%: Son asociados Adherentes Activos o no Activos, todas aquellas Sociedades, Centros o Clubes Extranjeros que no estando radicados en el partido de Berisso y que en número de uno por Colectividad, siempre que no estén representados en la asociación, tomen su representación ante esta 
asociación. Estos asociados tendrán derecho a presenciar las reuniones de la Comisión Directiva con voz pero sin voto.

ARTICULO 17: Los asociados fundadores y/o titulares, tiene derecho a gozar de todos los beneficios ofrecidos por la asociación, cuidando de hacerlo en forma tal que no perjudique los mismos derechos de los demás asociados y de acuerdo a las disposiciones de la Comisión Directiva y reglamentos internos.

ARTICULO 18: Los asociados adherentes activos o no activos, tienen derecho a participar en los festivales o cualquier tipo de acto organizado por esta asociación al igual que los asociados fundadores y/o titulares, pero a diferencia de estos, solo obtendrán beneficios en las ocasiones que la asociación lo determine.

ARTICULO 19: Las colectividades que no se encuentren inscriptas como asociados fundadores, titulares, adherentes activos o no activos, no tendrán derecho a exigir participación de ninguna especie en aquellas circunstancias en que hubiera sido invocada esta asociación, ya sea en actos oficiales o privados, quedando a criterio de la Comisión Directiva el concederles el permiso de participación, pero sin beneficio alguno y bajo el cumplimiento estricto del presente Estatuto y reglamentos internos.

ARTICULO 20: Los asociados adherentes activos, son todos aquellos que al no tener representación en la asociación, son admitidos por la Comisión Directiva en calidad de oyentes. Este tipo de asociados podrán ser titulares, luego de transcurrir en su calidad de asociado adherente activo un mínimo de (3) tres años y en actividad con la Asociación. Una vez obtenida la titularidad, con el voto de los dos tercios de la Comisión Directiva, estarán habilitados para integrar dicha comisión.

ARTICULO 210: Los asociados están obligados a cumplir y respetar los reglamentos y disposiciones de este estatuto y a conducirse con la mayor corrección y decoro, bajo pena de apercibimiento, suspensión o expulsión, según la gravedad de la falta. El apercibimiento, suspensión o expulsión es facultad exclusiva de la Comisión Directiva, con solo el derecho de interponer recurso de reconocimiento ante ella por el interesado. Llegado a la definición, la misma será irrevocable.

ARTICULO 22: Cada colectividad integrante de esta asociación, mantendrá su autonomía en cuanto a su actividad habitual sin tener que notificar de sus actos a esta asociación.

Comisión Directiva

ARTICULO 23: La Asociación estará formada por dos representantes de cada colectividad, (uno titular y otro suplente). Estos representantes podrán ser o no miembros de las comisiones directivas de sus respectivas Sociedades, centros o clubes extranjeros, ex componentes de las mismas o cualquier socio mayor de edad capacitado para tal fin, los que serán renovados o ratificados anualmente, total o parcialmente

ARTICULO 24: Inciso 10: De la comisión revisora de cuentas, sus atribuciones, derechos, obligaciones y deberes.

a) Controlar mensualmente la contabilidad de la Asociación, dejando constancia de ello.

b) Vigilar que el ingreso y egreso de los fondos se efectúen dentro de las buenas normas y que la contabilidad sea llevada en forma clara y uniforme.

c) Solicitar Asamblea Extraordinaria cuando detecta anomalías de importancia. Este pedido deberá ser resuelto dentro de un término no mayor de treinta días 
y si no se tomase en cuenta la petición o se negase infundadamente podrá elevarse el o los antecedentes a la Dirección de Personería Jurídica.

d) Refrendar con su firma el Balance General, Inventario y Cuentas de Ganancias y Pérdidas y vigilar que estos documentos sean fijados en la Asociación en un lugar visible con quince días de anticipación a la fecha de la Asamblea.

ARTICULO 25: La Comisión Directiva La Comisión Directiva se reunirá por convocatoria del Presidente o de cualquier asociado activo, por lo menos una vez al mes.

ARTICULO 26: La Comisión Directiva podrá sesionar con la presencia de la mitad más uno de sus miembros como mínimo y sus resoluciones serán tomadas por simple mayoría salvo al tratarse de ingreso, renuncia, pedido de licencia, obtención de titularidad, apercibimiento, suspensión o expulsión de un asociado donde deberán sesionar con la totalidad de sus miembros.

ARTICULO 27: Las reuniones de esta asociación se podrán realizar en la sede provisoria o en la sede de cualquiera de las colectividades que en carácter de asociado fundador y/o titular integren la asociación.

ARTICULO 28': Aquellas colectividades que dejaran de asistir a (4) cuatro reuniones consecutivas sin aviso, ni causa justificada, a juicio de la Comisión Directiva se entenderá que han renunciado a esta asociación. A este fin, el prosecretario llevará un libro de asistencia donde firmarán los que concurren a cada reunión.

ARTICULO 29: Son atribuciones de la Comisión Directiva:

a) La admisión de nuevos asociados.

b) Exigir la observancia del Estatuto y de los reglamentos internos que se dictaren.

c) Cuidar todo lo relativo a la administración de la Asociación, dictando los reglamentos necesarios.

d) Convocar a reunión cuando sea necesario.

e) Nombrar Subcomisiones especiales para el desempeño de algún trabajo, pudiendo estas, estar formadas por delegados de asociados fundadores y/o titulares y/o adherentes activos o no activos.

f) Aplicar las penas de disciplina (apercibimiento, suspensión o expulsión).

g) Resolver los casos no previstos en el estatuto cuidando de no apartarse de los fines que persigue la Asociación.

h) Nombrar y reemplazar los empleados que crea necesario de acuerdo a las circunstancias.

i) Aprobar las cuentas de gastos de la Asociación y autorizar su pago conforme a lo establecido en el estatuto.

j) Aprobar la Memoria y Balance Anual las que serán presentadas a las respectivas colectividades asociadas activas.

Del Presidente.

ARTICULO $30^{\circ}$ : Son atribuciones del Presidente:

a) Presidir todos los actos de la Asociación.

b) Resolver provisoriamente los asuntos de carácter urgente, debiendo dar cuenta a la Comisión Directiva en la primera reunión que se celebre.

c) Convocar a la Comisión Directiva a todas las sesiones que crea necesario.

d) Firmar las actas de las sesiones y Asamblea, Memoria, cheques y correspondencia juntamente con el Secretario o Tesorero según los casos.

e) Poner el visto bueno al Balance Mensual que formulará el Tesorero. 
f) El presidente no tiene voto, a excepción de aquellas ocasiones en que se encuentre ausente su Subdelegado y en los casos de empate como se mencionara en el artículo decimocuarto y decimoquinto. En ocasión de tratarse temas inherentes y/o de interés de la colectividad que representa, delegará la Presidencia en el Vicepresidente, que, en caso de ausencia se regirá acorde a lo estipulado en el artículo trigésimo séptimo, para ese único caso de votación. Del Vicepresidente.

ARTICULO 310: El Vicepresidente reemplazará al Presidente en caso de impedimento, renuncia o inhabilitación con iguales atribuciones y deberes. A diferencia del Presidente el Vicepresidente, sí tiene voto, con excepción de ejercer la Presidencia.

Del Secretario.

ARTICULO 320: Son deberes y atribuciones del Secretario:

a) Redactar las notas.

b) Refrendar la firma del Presidente.

c) Cuidar el perfecto orden del archivo.

d) Elevar el registro de asociados fundadores, titulares y adherentes, activos o no activos.

ARTICULO 33: El Prosecretario reemplazará al secretario en caso necesario, siendo su obligación la de llevar el libro de asistencia.

ARTICULO 34: El Secretario de actas reemplazará al prosecretario en caso necesario, siendo su obligación la de llevar el libro de actas y leerlo en cada reunión de Comisión Directiva.

Del Tesorero.

ARTICULO 35': Son atribuciones y deberes del Tesorero:

a) Recibir los fondos de la Asociación y depositarlos al día siguiente en un banco, del modo que disponga la Comisión Directiva.

b) Pagar las cuentas aprobadas por la Comisión Directiva y autorizadas por el presidente y secretario.

c) Firmar con el presidente y el secretario los cheques.

d) Dirigir y ordenar administrativamente todo lo relacionado con la contabilidad.

e) Presentar un estado trimestral de cuentas que será puesto de manifiesto ante la Comisión Directiva.

f) Firmar los Balances generales Anuales que presentará a la Comisión Directiva para acompañar la Memoria y así ambos ser presentados a las distintas colectividades asociadas fundadoras y/o titulares.

g) Ser responsable de todos los valores y cantidades de dinero que reciba perteneciente a la Asociación.

h) Confeccionar el inventario de los bienes de la Asociación que será agregado a la Memoria Anual.

ARTICULO 36․ El Pro tesorero remplazará al tesorero en caso necesario y colaborará en todos los casos con él.

ARTICULO 37: En caso de ausencia del presidente y vicepresidente presidirá la reunión el primer vocal titular y así sucesivamente hasta el sexto vocal titular. ARTICULO $38^{\circ}$ : Inciso $1^{\circ}$ : El cierre del ejercicio se efectuará por el período correspondiente al lapso comprendido entre el $1^{\circ}$ de Abril y el 31 de Marzo.

ARTICULO $38^{\circ}$ Bis: De las asambleas Ordinarias y Extraordinarias. Las asambleas serán Ordinarias y Extraordinarias, debiendo las primeras verificarse dentro de los tres meses posteriores al cierre del ejercicio económico, que se clausurará el 31 de Marzo de cada año. Las 
Extraordinarias, toda vez que lo disponga la Comisión Directiva por sí, o por solicitud de cuatro (4) miembros socios de la Asociación, debiendo concretarse los puntos a tratarse a fin de que los socios puedan estudiar los temas antes de la Asamblea. Las asambleas Ordinarias y Extraordinarias funcionarán con quórum formado por la mitad más uno de sus asociados con derecho a voto en primera convocatoria y una hora después en segunda convocatoria con los asociados que se encuentren presente, que no deben ser inferior a cuatro (4) representantes titulares de las colectividades que conforman la asociación.

ARTICULO 39०: Se llamará a Asamblea Extraordinaria cada vez que la Comisión Directiva lo crea necesario o ante el pedido fundamentado presentado por el delegado de una Colectividad componente de dicha Comisión Directiva.

ARTICULO 40\%: En caso de disolución total se realizará una Asamblea Extraordinaria con todos los titulares de la Asociación de Entidades Extranjeras. Los bienes y Capital se distribuirán en forma proporcional entre todos los asociados titulares de la Entidad.

LA PLATA, 16 DE MAYO DE 1985.- EXPEDIENTE: 2215-29749.- LEGAJO №: 36350.- NOMBRE DE LA ENTIDAD: "ASOCIACIÓN DE ENTIDADES EXTRANJERAS DE BERISSO".- DOMICILIO: Calle Montevideo $n^{\circ}$ 841.LOCALIDAD: Berisso.- PARTIDO: BERISSO.- FOJAS EN QUE OBRA EL ESTATUTO: 4/10 y conformaciones de fs. 55/56.-

VISTAS estas actuaciones en las que la entidad recurrente solicite el otorgamiento de personería Jurídica y aprobación de su estatuto societario; atento lo dictaminado por la Dirección de Legitimaciones, cumplimentadas las exigencias establecidas por la ley $8671 / 76$ y su Decreto Reglamentario 284/77 y en ejercicio de las facultades conferidas por los artículos $3^{\circ}$ y $6^{\circ}$ de la Ley citada, EL DIRECTOR PROVINCIAL DE PERSONAS JURÍDICAS RESUELVE: ARTICULO 10: RECONOCER en el carácter de persona jurídica a la entidad recurrente y apruébase su estatuto societario, cuyo texto obra en las fojas indicadas en el epígrafe de la presente.

ARTICULO 20: COMUNIQUESE, Regístrese, Dése el Boletín Oficial, tómese nota y remítase a la Escribanía General de Gobierno para que se extienda testimonio de los estatutos. RESOLUCIÓN No: 0595.

Hay una firma ilegible y un sello aclaratorio que dice: Dra. EUGENIA GIRADLES, Director de Legitimaciones, Dirección Provincial de Personas Jurídicas.

CERTIFICO, Que es copia fiel de las piezas originales de referencia que obran de fojas cuatro a fojas diez vuelta y fojas cincuenta y nueve, del Expediente $\mathrm{N}^{\circ}$ : 2215-29749/84 del Ministerio de Gobierno, doy de para la entidad denominada: ASOCIACIÓN DE ENTIDADES EXTRANJERAS DE BERISSO; con domicilio legal en la Localidad de BERISSO, Partido del mismo nombre, expido el presente "Testimonio" en ocho fojas simples que firmo y sello en la Ciudad de La Plata, a los diecinueve días del mes de Agosto del año mil novecientos ochenta y cinco. 


\section{REFORMA AL ESTATUTO DE LA ASOCIACIÓN DE ENTIDADES EXTRANJERAS DE BERISSO APROBADO EN LA ASAMBLEA EXTRAORDINARIA, BERISSO, 19 DE DICIEMBRE DEL 2006}

\section{TITULO PRIMERO}

\section{DENOMINACION, DOMICILIO, OBJETO, CAPACIDAD y PATRIMONIO}

ARTICULO 1: Continua con el nombre de ASOCIACIÓN DE ENTIDADES EXTRANJERAS DE BERISSO, la entidad de carácter civil y de bien público, fundada el 28 de noviembre de 1979, con Personería Jurídica reconocida por la Dirección Provincial de Personas Jurídicas de la Provincia. De Buenos Aires, por Resolución № 595 del 16 de Mayo de 1985 e inscripta bajo el Legajo $1 / 36.350$, que tendrá su domicilio social en la ciudad y Partido de Berisso, siendo su sede social el local ubicado en Avenida Montevideo (ruta provincial 15) $N^{\circ} 604$ de la ciudad de Berisso, o donde la Asamblea Anual Ordinaria disponga establecerla dentro de los límites del referido Partido, y la que tendrá por objeto:

a) Atento a que la ciudad de Berisso ha sido declarada "Capital Provincial del Inmigrante", por Ley Provincial 12.913, en reconocimiento a su conformación poblacional migratoria, incrementada durante los años de su plena actividad industrial, esta entidad se propone reunir a todas aquellas colectividades extranjeras, que expresen o hayan manifestado una actividad cultural y social, por medio de sus componentes inmigrantes o descendientes que radiquen o se hayan radicado en Berisso, Ensenada y La Plata y que a su vez, cada una de aquellas, se encuentre representada por una entidad organizada.

b) Fomentar el espíritu de unión entre las distintas colectividades, esencialmente en todas aquellas manifestaciones en que la entidades fundadoras $y / 0$ titulares, participen en su totalidad y en conjunto en las celebraciones del Mes del Inmigrante y en otros acontecimientos o celebraciones que lleven a cabo y se considere conveniente la participación de esta Asociación.

c) Vincular estrechamente las colectividades entre ellas, como así también con las otras entidades de bien público establecidas en el Partido de Berisso.-

d) Difundir todas las manifestaciones culturales de las naciones y pueblos de las colectividades, dentro de un marco de respeto, tolerancia y comprensión hacia las otras colectividades

e) Procurar la obtención de recursos con el fin de destinarlos a la adquisición de bienes y servicios, para atender las necesidades de su actividad

f) Relacionarse con Entidades de iguales características, Organismos Municipales,

Nacionales, o Internacionales, Públicos o Privados, para el logro de sus finalidades.

g) Desarrollar un ambiente de cordialidad y solidaridad entre sus asociados. 
ARTICULO $2^{\circ}$ : La asociación se encuentra capacitada para adquirir bienes inmuebles, muebles y semovientes; enajenarlos, hipotecarlos, permutarlos, venderlos, como así también para realizar cuanto acto jurídico sea necesario o conveniente para el cumplimiento de su objeto

ARTICULO $3^{\circ}$ : Constituyen el patrimonio de la asociación: a) las cuotas que abonen sus asociados; b) Los bienes que posea en la actualidad y los que adquiera por cualquier título en lo sucesivo, así como las rentas que los mismos produzcan; c) Las donaciones, legados o subvenciones que reciba; d) El producido de beneficios, rifas, festivales y cualquier otra entrada siempre que su causa sea licita.

ARTICULO 40: Esta Asociación carece de filiación política. No será permitido a sus asociados, cualquier tipo de manifestación, verbal, escrita, gráfica o de cualquier otro tipo de exteriorización, ni mantener discusiones, todas ellas de naturaleza política, racial y/o religiosa; tanto en su local, como en sus reuniones, dentro del ámbito de actividad propia y/o participada de la Asociación de Entidades Extranjeras de Berisso. El incumplimiento de lo establecido en este artículo será sancionado, de acuerdo a la gravedad del caso, de conformidad al procedimiento y demás medidas previstas en los artículos 19 a 21 inclusive del Título Segundo, Capítulo de los Derechos y Obligaciones de los Socios.-

\section{TITULO SEGUNDO}

\section{DE LOS ASOCIADOS}

ARTICULO 5': Habrá 3 (tres) categorías de asociados: Titulares Fundadores, Titulares Activos y Provisionales Adherentes.--

ARTICULO $6^{\circ}$ : Son socios titulares fundadores, aquellos que constituyeron esta Asociación a la fecha de su fundación, y son los siguientes: a) La Asociación Patriótica Albanesa, por la colectividad Albanesa; b) Hogar Árabe Argentino, por la colectividad Árabe; c) Sociedad Armenia de Berisso, por la colectividad Armenia; d) Club Social y Deportivo Vostok, por la colectividad Bielorusa; e) Sociedad Cultural Búlgara "Ivan Vazov", por la colectividad Búlgara; f) Club Eslovaco Argentino, por la colectividad Eslovaca; g) Sociedad Española de Berisso, por la colectividad Española; h) Sociedad Italiana de Berisso, por la colectividad Italiana; i) Sociedad Cultural Lituana y de Socorros Mutuos "Nemunas", por la colectividad Lituana; j) Sociedad Unión Polaca de Berisso, por la colectividad Polaca; k) Centro Yugoslavo Argentino, por la colectividad Yugoslava.

ARTICULO $7^{\circ}$ : Son socios titulares activos a la fecha de la aprobación de esta reforma de estatutos las siguientes entidades representativas que de acuerdo a la fecha de ingreso a la asociación, las entidades que se consignan son las representantes de las siguientes colectividades:

a) Club Germano Argentino de La Plata, por la Alemana

b) Asociación Ucrania de Cultura Prosvita de Berisso, por la Ucraniana

c) Colectividad Helénica y Platón de Berisso, La Plata y Ensenada, por la Griega 
d) Colectividad Irlandesa San Patricio de Berisso, La Plata y Ensenada, por la Irlandesa

e) Asociación Raíces Istrianas de La Plata, Berisso y Ensenada, por la Croata

f) Asociación Caboverdeana de Ensenada, por la Caboverdeana

g) Asociación Eslovena de Berisso, La Plata y Ensenada, por la Eslovena

h) Colectividad Portuguesa "Virgem de Fátima", de Berisso, por la Portuguesa

ARTICULO 8 : Serán Socios Provisionales Adherentes, a partir de la fecha de aceptación como tales por la Comisión Directiva, quienes cumplan los siguientes requisitos:

a) Aquellas entidades que representen a colectividades y que reúnan las condiciones establecidas en el artículo $1^{\circ}$ inciso "a" del presente Estatuto.-

b) Poseer personería jurídica y/ o estar reconocida como entidad de bien público.-

c) Presentación de una nota peticionando la entidad su admisión como socia y la manifestación de conocer y aceptar el estatuto de la Asociación y sus reglamentaciones suscripta por el Presidente y Secretario de la peticionante.

d) Junto a la solicitud deberá acompañar la nómina de la Comisión Directiva, copia de sus estatutos, y la constancia de inscripción que indica el inciso "b".

e) Abonar la cuota mensual por adelantado de acuerdo al monto fijado por la Asamblea.

f) De la decisión de la Comisión Directiva por su aceptación deberá contar con la aprobación de las $2 / 3$ de sus integrantes ,debiéndose dejarse constancia en el Acta. En caso de rechazo, solo deberá quedar constancia de ello sin que sea obligatorio expresar las causas. El aspirante podrá reiterar su solicitud de ingreso, luego de transcurrido un lapso no menor de un año desde la fecha de la reunión en que se resolvió el rechazo.-

ARTICULO 9': Una vez admitida la colectividad, a través de la entidad que la representa, como socia adherente, se integrará a la Asociación de Entidades Extranjeras de Berisso, lo hará al igual que las demás entidades asociadas, por medio de un Delegado Titular y un Delegado Suplente, designados previamente por la Comisión Directiva o Asamblea, de acuerdo a lo que prevea estatutariamente la entidad representada.

ARTICULO 10 ${ }^{\circ}$ : Las entidades asociadas, para participar en las reuniones de Comisión Directiva y en las Asambleas, deberán presentar una nota suscripta por las autoridades representativas, en donde se consigne, los nombres y apellidos completos, como sus circunstancias personales y documentos de identidad, de sus respectivos Delegado Titular y Delegado Suplente.

Para las Asambleas Ordinarias y/ o extraordinarias la entidad asociada, mediante nota especial al efecto, deberá expresar que los Delegados designados, se encuentran investidos para representar a la entidad en la respectiva Asamblea .Las referidas notas serán presentadas al Presidente, 
quién entregará constancia de su recepción, con diez días hábiles anteriores a la fecha de la Asamblea. Con las notas recibidas dentro del plazo fijado, procederá a la confección de una nómina de las entidades asociadas, con los nombres de la colectividad a las que pertenece y de sus respectivos delegados, disponiendo la exhibición de la nómina confeccionada, en un lugar visible de la sede social de la Asociación, durante ocho días hábiles anteriores a la Asamblea.

ARTICULO 11': Los asociados provisionales adherentes serán admitidos a las reuniones de la Comisión Directiva, exclusivamente, en calidad de oyentes y derecho a voz, pero sin voto. Pasarán a revestir el carácter de socio titular activo, una vez transcurrido tres años de actividad y asistencia a las reuniones en forma reglamentaria, y previa incorporación en tal carácter por decisión de la Comisión Directiva con una aprobación de los $2 / 3$ de sus integrantes.-

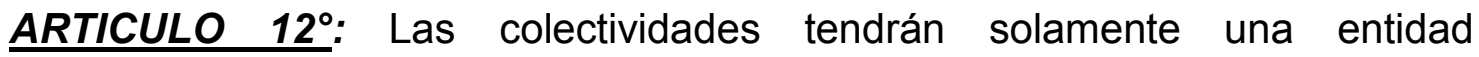
representativa de aquella, que podrá revestir el carácter de socia fundadora , activa o adherente. No se admitirá colectividades divididas por región. Las entidades representativas de una colectividad no podrá arrogarse la representación de otra que no sea la propia.

En cualquiera de las actividades organizadas por la Asociación de Entidades Extranjeras de Berisso las instituciones, únicamente podrán exhibir los elementos representativos (banderas, escudos insignias, etc.) de la nación o regiones que la integran, estando prohibido el uso de carteles, banderas, escudos, emblemas, leyendas identificatorias de partidos, movimientos $u$ organizaciones políticas.

ARTICULO 13 ${ }^{\circ}$ : Las colectividades y sus entidades que no se encuentren inscriptas y asociadas a la Asociación, no tendrán derecho a exigir participación en la misma en las actividades que esta desarrolle, por propia iniciativa, compartida con otras instituciones, o intervenir desde la Asociación en actos públicos u oficiales. Sin perjuicio de ello la Asociación a través de su Comisión Directiva podrá formularles la pertinente invitación a tales efectos y su concurrencia y/o participación no implica reconocimiento de derecho o beneficio similares a los otorgados a los asociados a la Asociación

ARTICULO 14. ${ }^{\circ}$ : Cada colectividad y su entidad representante, integrantes de esta Asociación, mantendrá su autonomía en cuanto a su actividad total y propia, sin tener que notificar de sus actos a esta Asociación, con excepción de aquellos en que se encuentren relacionados con su carácter de socia de la misma.

\section{DERECHOS Y OBLIGACIONES}

ARTICULO 15: Son derechos de los Socios:

a) Gozar de todos los derechos que les acuerden este Estatuto y los Reglamentos siempre que se hallen al día con Tesorería y no se encuentren cumpliendo con penas disciplinarias. 
b) Proponer por escrito a la Comisión Directiva todas aquellas medidas o proyectos que consideren convenientes para la buena marcha de la Institución.

c) Solicitar por escrito a la Comisión Directiva una licencia hasta un plazo de un año y siempre que la causa invocada se justifique ampliamente. En la nota del pedido de licencia, informará si participará y en que forma en las actividades de la Asociación, quién determinara sobre el particular. Durante la licencia el Socio no podrá concurrir a las reuniones y Asambleas de la Asociación, salvo que le fuera requerida expresamente su asistencia por la Comisión Directiva.

d) Presentar por escrito su renuncia en calidad de Socio a la Comisión Directiva, la que resolverá sobre su aceptación o rechazo si proviniera de un Asociado que tenga deudas con la Institución o sea pasible de sanciones disciplinarias.

ARTICULO 16: Las altas y las bajas de los asociados se computaran desde la fecha de la sesión de la Comisión Directiva que las aprueba. Hasta tanto no se haya resuelto la baja de un asociado estarán vigentes par el mismo todos los derechos y obligaciones que establece el presente Estatuto.

ARTICULO 17 ${ }^{\circ}$ : Son obligaciones de los Asociados:

a) Conocer, respetar y cumplir las disposiciones de este Estatuto, Reglamentos y Resoluciones de Asambleas y de Comisión Directiva.

b) Abonar mensualmente y por adelantado las cuotas Sociales.

c) Aceptar los cargos para los cuales fueron designados.

d) Comunicar dentro de los diez (10) días corridos todo cambio de domicilio a la Comisión Directiva.

ARTICULO 18: El Socio que no diera cumplimiento al inciso b) del ARTICULO anterior y se atrasase en el pago de tres mensualidades, será intimado de manera fehaciente a regularizar su situación. Pasado un mes de la notificación, sin que normalice su mora, será separado de la Institución, debiéndose dejar constancia en Actas. Todo Socio declarado moroso por la Comisión Directiva, a raíz de la falta de pago de tres cuotas consecutivas y por lo tanto excluido de la Asociación por ese motivo, podrá reingresar a la Institución cuando hubiere transcurrido menos de un año desde la fecha de su exclusión, abonando previamente la deuda pendiente a los valores vigentes, en el momento de la reincorporación, no perdiendo así su antigüedad. Vencido el año se perderá todo derecho y deberá ingresar como Socio nuevo.

ARTICULO 19: Los asociados y/ o sus delegados cesarán en su carácter de tales por las siguientes causas: renuncia, cesantía o expulsión.

Podrán ser causa hasta de cesantía: Faltar al incumplimiento de las obligaciones previstas en el ARTICULO $17^{\circ}$ incisos "a", "b" $y$ " $d$ " por partes de los asociados y / o sus representantes y/ o delegados según corresponda.-

Serán causa hasta de expulsión cuando los delegados representantes de las entidades incurran en los siguientes actos: 
a) Observar una conducta inmoral o entablar o sostener dentro del local social o ámbito de actividades de la Asociación o formando parte de delegaciones de la entidad, graves discusiones de carácter religioso, racial o político, o participar en la realización de juegos prohibidos o de los denominados "bancados".

b) Haber cometido actos graves de deshonestidad o engañado o tratado de engañar a la Institución para obtener un beneficio económico a costa de ella.

c) Hacer voluntariamente daño a la institución, provocar graves desordenes en su seno u observar una conducta que sea notoriamente perjudicial a los intereses sociales.

d) Asumir o invocar la representación de la asociación en reuniones, actos de otras Instituciones Oficiales o Particulares, sí no mediare autorización o mandato expreso de la Comisión Directiva.

En caso de cesantía de la entidad, la sancionado podrá solicitar su reingreso luego de transcurrido un término mínimo de un (1) año, previa consideración y aceptación de la Comisión Directiva, con una mayoría de la 2/3 parte de sus integrantes, como socio adherente.

La expulsión de la entidad asociada representará la imposibilidad de reingreso, hasta transcurrido (2) dos años en la que podrá solicitar su admisión como socio adherente, previa consideración y aceptación de la primera Asamblea que se constituya y que obtenga su aceptación con una mayoría de las $2 / 3$ parte de sus integrantes.

En ambos casos los plazos que se aluden se computaran desde la fecha en que quedó firme la medida adoptada.

Durante el plazo establecido para la readmisión o suspensión , ninguna otra entidad podrá asumir la representación de la colectividad ejercida por la entidad sancionada.

ARTICULO 20\%: Las sanciones que prevé el ARTICULO anterior así como las de suspensión o amonestación serán aplicadas por la Comisión Directiva, la que previo a ello deberá intimar al imputado a comparecer a una reunión de dicha Comisión en la fecha y hora que se indicará mediante notificación fehaciente, cursada con una anticipación mínima de diez (10) días corridos, conteniendo la enunciación del hecho punible y de la norma presumiblemente violada, así como la invitación a realizar descargos, ofrecer prueba y alegar sobre la producida. La no comparecencia del interesado implica la renuncia al ejercicio del derecho de defensa y la presunción de la verosimilitud de los cargos formulados, quedando la Comisión Directiva habilitada para resolver.

Las suspensiones no podrá, ser superiores a 180 (ciento ochenta) días.-

ARTICULO 21: De las Resoluciones adoptadas en su contra por la Comisión Directiva, los Asociados podrán apelar ante la primera Asamblea que se celebre, presentando el respectivo recurso en forma escrita ante la Comisión Directiva, dentro de los quince (15) días corridos de notificación de su sanción.-

\section{TITULO TERCERO}

DE LA COMISION DIRECTIVA Y COMISION REVISORA DE CUENTAS, SU ELECCION 
ARTICULO 22: La Institución será dirigida y administrada por una Comisión Directiva compuesta de: un Presidente, un Vicepresidente, un Secretario, un Prosecretario, un Tesorero, un Protesorero, un Secretario de Actas, y hasta un numero de vocales que se integrará con los representantes de la entidades asociadas en su carácter de fundadores o activos.

Correspondiendo un cargo a cada socio titular, con derecho a voz y voto por colectividad, que será ejercido por el Delegado titular de la entidad asociada.. El titular en caso de ausencia, podrá ser reemplazado por el Delegado Suplente de su misma colectividad para los casos de revestir los cargos en ejercicio de la vicepresidencia, prosecretario, protesorero, secretario de actas y vocales.

Habrá asimismo una Comisión Revisora de Cuentas compuestas por tres asociados titulares que revestirán como miembros Titulares y a su vez se designarán dos miembros reemplazantes en caso de renuncia, ausencia o cualquier causa impediente.

El mandato de los miembros de la Directiva y de la Comisión Revisora de Cuentas durará un año.

El cargo de Presidente no podrá ser ejercido por persona que haya ocupado el mismo puesto en representación de una colectividad distinta a la que lo hizo anteriormente, hasta después de haber transcurrido el plazo de cinco años.-

ARTICULO 23: Los miembros de la Comisión Directiva y Comisión Revisora de Cuentas, son las entidades asociadas en su carácter de fundadoras 0 activas, quienes enviaran cada una de ellas un Delegado Titular y uno Suplente, los que podrán ser sustituidos por la entidad representada, y comunicado en la forma prevista en el articulo $10^{\circ}$ del presente Estatuto, en cualquier momento durante el periodo del ejercicio en curso.

El mandato de las respectivas Comisiones será anual, dentro del ejercicio económico financiero, para el que han sido designados, debiendo permanecer en los cargos hasta la Asamblea Anual inmediata siguiente.-

ARTICULO 24: Los integrantes de la Comisión Directiva y Comisión Revisora de Cuentas se conformará con todos los socios Fundadores y Activos de la Asociación a través de un procedimiento especial que posibilitará a todas las entidades con una antigüedad superior a cinco años como asociada a participar en la Presidencia de la entidad, conforme a las siguientes bases y condiciones:

a) Entre los Socios Titulares Fundadores establecidos en el Artículo 6 del presente Estatuto, se efectuará un sorteo, por el cual de acuerdo al número de orden que obtengan se ubicarán para los siguientes cargos: $1^{\circ}$ )Presidente; $2^{\circ}$ ) Vice-Presidente; $3^{\circ}$ )Secretario; $4^{\circ}$ ) Pro Secretario: $5^{\circ}$ ) Tesorero; $6^{\circ}$ ) Pro Tesorero; $7^{\circ}$ ) Secretario de Actas; $8^{\circ}$ ) Primer Vocal; $9^{\circ}$ ) Segundo Vocal; $10^{\circ}$ ) Tercer Vocal; $11^{\circ}$ ) Cuarto Vocal.-

b) Entre los Socios Titulares activos establecidos en el articulo $7^{\circ}$ del presente Estatuto, se procederá a sortear el orden que le corresponderá 
ocupar en los cargos de Vocales a continuación de la nómina establecida en el el inciso anterior.-

c) A los efectos del sorteo se convocará a una Asamblea Extraordinaria dentro de un plazo de 90 (Noventa) días corridos a partir de la aprobación de estos Estatutos, con participación de todos los asociados fundadores y activos. A tal fin se anunciará con anticipación de treinta días en un periódico de la ciudad de Berisso la referida convocatoria, además de las notificaciones dirigidas a todos los asociados, en forma fehaciente.

d) En dicha oportunidad se procederá a efectuar el sorteo público por ante un Escribano con Registro en el Partido de Berisso para proceder a extraer los nombres de los socios enunciados en los incisos a) y b).-

e) Del acta labrada por el Notario, debidamente protocolizada, su testimonio será parte integrante del presente Estatuto y se comunicará a Persona Jurídica para su inscripción como Anexo I.-

f) La nómina confeccionada será la correspondiente a la Comisión Directiva para el año 2007. Para los sucesivos períodos anuales, esa nómina se modificará a través del desplazamiento del orden de los cargos, atento a que la colectividad que ejerció la Presidencia, se ubicará en el último lugar de la lista.

g) Para el supuesto, que alguna de las colectividades no acepte el cargo que le resulte asignado tanto por el sorteo o por la ubicación en los sucesivos desplazamientos, pasará a ocupar el último lugar de la lista, procediéndose al corrimiento ascendente de los cargos subsiguientes.

h) Asimismo para el supuesto que durante el período anual, se produzca el cese o renuncia del Presidente, Secretario, Tesorero y Secretario de Actas, y deba reemplazarlo el que le sigue en el orden; el ejercicio de esos cargos en ausencia del titular, no le impedirá acceder al cargo previsto para el período inmediato siguiente.

i) Los miembros de la Comisión Directiva asumirán sus respectivos cargos en ocasión de la celebración de la Asamblea Anual Ordinaria.

j) Los miembros de la Comisión Revisora de Cuentas, serán sorteados entre los vocales que integran la Comisión Directiva, en ocasión de la Asamblea Anual Ordinaria. Para el supuesto que durante el ejercicio anual el vocal asuma alguno de los cargos previstos en el inciso a), deberá ser sustituido en la Comisión Revisora de Cuentas por otro Vocal.-

ARTICULO 25\%: La Comisión Directiva se reunirá ordinariamente, por lo menos, una vez por mes, por citación de su Presidente y Extraordinariamente cuando lo disponga el Presidente o lo soliciten tres de sus miembros, debiendo en estos casos realizarse la reunión dentro de los cinco (5) días hábiles de 
efectuada la solicitud. La citación en los dos casos, deberá ser en forma fehacientemente efectuada al último domicilio conocido de cada uno de los delegados integrantes o de la entidad que representa. Los miembros de la Comisión Directiva que faltaren a tres reuniones consecutivas o cinco alternadas, sin causa justificada, serán separados de sus cargos en reunión de Comisión Directiva previa citación fehaciente al miembro imputado para que efectúe los descargos pertinentes y a la entidad que pertenezca el representante.

ARTICULO 26: Las Reuniones de Comisión Directiva se celebrarán válidamente con la presencia como mínimo de la mitad más uno de sus miembros titulares, requiriéndose para las resoluciones el voto de la mayoría simple de los presentes, salvo los casos que se requiera los $2 / 3$ de sus integrantes. El Presidente tendrá voto y doble voto en caso de empate. Para las reconsideraciones, se requerirá el voto favorable de los dos tercios de los presentes en otra reunión constituida con igual o mayor número de asistentes que en aquella que adoptó la resolución a reconsiderar.

\section{TITULO CUARTO}

\section{DEBERES Y ATRIBUCIONES DE LA COMISION DIRECTIVA}

ARTICULO 27\%: Son deberes y atribuciones de la comisión Directiva: a) Cumplir y hacer cumplir este Estatuto y los reglamentos; b) Ejercer en general todas aquellas funciones inherentes a la dirección, administración y representación de la sociedad, quedando facultado a este respecto para resolver por sí los casos no previstos en el presente Estatuto, interpretándolo, si fuera necesario, con cargo de dar cuenta a la Asamblea más próxima que se celebre; c) Convocar a Asambleas, y ejecutar las resoluciones de las Asambleas; d) Resolver sobre la admisión, amonestación, suspensión, cesantía o expulsión de Socios; e) Resolver todos los casos de renuncia o separación de los miembros de Comisión Directiva, la incorporación de suplentes; f) Crear o suprimir empleos, fijar su remuneración, adoptar las sanciones que correspondan a quienes los ocupen, contratar todos los servicios que sean necesarios para el mejor logro de los fines sociales; g) Presentar a la Asamblea General Ordinaria, la Memoria, Balance General, Cuadro de Gastos y Recursos e informe de la Comisión Revisora de Cuentas correspondiente al ejercicio fenecido, como asimismo poner copias suficientes a disposición de todos los asociados, en Secretaría, con la debida anticipación; h) Realizar los actos para la administración del patrimonio social, con cargo de dar cuenta a la primera Asamblea que se celebre, salvo los casos de adquisición, enajenación, hipoteca y permuta de bienes inmuebles, en que será necesario la previa aprobación de una Asamblea de asociados; i) Elevar a la Asamblea para su aprobación las reglamentaciones internas que se consideren a los efectos del mejor desenvolvimiento de sus finalidades.

ARTICULO 28: Son deberes y atribuciones de la Comisión Revisora de Cuentas: a) Examinar los libros y documentos de la sociedad por lo menos cada tres meses; b) Asistir con voz y voto a las sesiones del órgano directivo ; c) Fiscalizar la administración comprobando frecuentemente el estado de la caja y la existencia de los títulos acciones y valores de toda especie; d) 
Verificar el cumplimiento de las Leyes, Estatutos y Reglamentos; e) Dictaminar sobre la Memoria, Inventario; Balance General y Cuadro de Gastos y recursos presentado por la Comisión Directiva; f) Convocar a Asamblea General Ordinaria cuando omitiera hacerlo el Organo Directivo; g) Solicitar la convocatoria a Asamblea Extraordinaria cuando lo juzgue necesario, poniendo los antecedentes que fundamenten su pedido en conocimiento de la Dirección Provincial de Personas Jurídicas cuando se negare a acceder a ello la Comisión Directiva; h) En su caso, vigilar las operaciones de liquidación de la sociedad y el destino de los bienes sociales. La Comisión Revisora de Cuentas cuidará de ejercer sus funciones de modo que no entorpezca la regularidad de la administración social, siendo responsable por los actos de la Comisión Directiva violatorios de la Ley o del mandato social, si no dan cuenta del mismo a la Asamblea correspondiente, o en su actuación posterior a ésta, siguieren silenciando u ocultando dichos actos. Deberán sesionar al menos una vez por mes, y de sus reuniones deberán labrarse Actas en un libro especial rubricado al efecto. Si por cualquier causa quedará reducida a dos de sus miembros, una vez incorporado los Suplentes, la Comisión Directiva deberá convocar, dentro de los quince (15) días a Asamblea para su integración, hasta la terminación del mandato de los cesantes.

\section{TITULO QUINTO}

\section{DEBERES Y ATRIBUCIONES DEL PRESIDENTE Y VICEPRESIDENTE}

ARTICULO 29 ${ }^{\circ}$ : El Presidente y en caso de renuncia, fallecimiento, licencia o enfermedad, el Vicepresidente, hasta la primera Asamblea Ordinaria que designará su reemplazante definitivo, tiene los siguientes deberes y atribuciones: a) Cumplir y hacer cumplir este Estatuto y los Reglamentos que en coincidencia con sus disposiciones se dicten; b) Presidir las Asambleas y Sesiones de la Comisión Directiva; c) Firmar con el Secretario las Actas de Asambleas y Sesiones de la Comisión Directiva, la correspondencia y todo otro documento de la Entidad; d) Autorizar con el Tesorero las cuentas de gastos, firmando los recibos y demás documentos de Tesorería, de acuerdo con lo resuelto por la Comisión Directiva, no permitiendo que los fondos Sociales sean invertidos en objetos distintos a los prescriptos por este Estatuto; e) Velar por la buena marcha y administración de la asociación, haciendo respetar el orden, las incumbencias y buenas costumbres; f) Suspender previamente a cualquier empleado que no cumpla con sus obligaciones, dando cuenta inmediatamente a la Comisión Directiva; g) Adoptar por sí y "ad referendum" las resoluciones de la Comisión Directiva impostergables en casos urgentes ordinarios, absteniéndose de tomar medidas extraordinarias sin la previa aprobación de la Comisión Directiva h) Convocar a los Presidentes de las entidades asociadas, cuando se requiera una colaboración especial y extraordinaria de estas, para el mejor desenvolvimiento de la entidad y sus actividades y/o se estime conveniente informar respecto a su resultado. I) Representar a la Institución en las relaciones con el exterior.-

\section{TITULO SEXTO}

\section{ATRIBUCIONES $Y$ DEBERES DE LOS OTROS MIEMBROS DE LA COMISION DIRECTIVA DEL SECRETARIO}


ARTICULO 30 : El Secretario en caso de renuncia, fallecimiento, ausencia o enfermedad, quien lo reemplace, hasta la primera Asamblea Ordinaria que designará su reemplazante definitivo, tiene los siguientes deberes y atribuciones: a) Asistir a las sesiones de la Comisión Directiva, redactando las Actas respectivas, las que asentará en el libro correspondiente y firmará con el Presidente; b) Firmar con el Presidente la correspondencia y todo otro documento de la Institución; c) Citar a las sesiones de la Comisión Directiva de acuerdo con el ARTICULO $26^{\circ}$ y notificar las convocatorias a Asambleas; d) Llevar de acuerdo con el Tesorero el Registro de Asociados.

\section{DEL TESORERO}

ARTICULO 31: El Tesorero y en caso de renuncia, fallecimiento, ausencia o enfermedad, quien lo reemplace, hasta la primera Asamblea Ordinaria que designará su reemplazante definitivo, tiene los siguientes deberes y atribuciones: a) Llevar de acuerdo con el Secretario el Registro de Asociados, ocupándose de todo lo relacionado con el cobro de las cuotas sociales; b) Llevar los libros de Contabilidad; c) Presentar a la Comisión Directiva Balance Mensual y preparar anualmente el Inventario, Balance General y Cuadro de Gastos y Recursos que deberán ser sometidos a la aprobación de la Comisión Directiva, previo dictamen de la Comisión Revisora de Cuentas; d) Firmar con el Presidente los recibos y demás documentos de Tesorería efectuando los pagos resueltos por la Comisión Directiva; e) Efectuar en los Bancos oficiales o particulares que designe la Comisión Directiva a nombre de la Institución y a la orden conjunta de Presidente y Tesorero los depósitos de dinero ingresados a la caja social, pudiendo retener en la misma hasta la suma que anualmente determine la Asamblea, a los efectos de los pagos ordinarios y de urgencia; f) Dar cuenta del estado económico de la Entidad a la Comisión Directiva y Comisión Revisora de Cuentas toda vez que lo exija.-

\section{DEL SECRETARIO DE ACTAS}

ARTICULO 32 ${ }^{\circ}$ : El Secretario de Actas o el que lo reemplace en caso de renuncia, fallecimiento o enfermedad hasta la primer Asamblea Ordinaria. Tiene los siguientes deberes y atribuciones: Llevar los Libros de Actas de Asambleas y Sesiones de la Comisión Directiva.

\section{DE LOS VOCALES TITULARES}

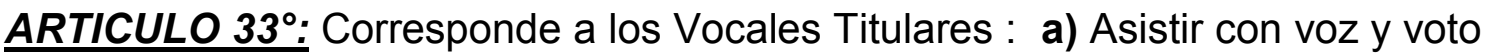
a las Sesiones de la Comisión Directiva; b) Desempeñar las comisiones y tareas que la Comisión Directiva les confíe; c) Asumir en caso de renuncia ,fallecimiento o enfermedad hasta la Primera Asamblea Anual Ordinaria, en la medida que se produzcan, del vicepresidente, prosecretario, protesorero, 0 secretario de actas.

.ARTICULO $34^{\circ}$ : Si el número de miembros de la Comisión Directiva quedare reducido a menos de la mitad más uno de la totalidad, a pesar de haberse incorporado a todos los Suplentes, la Comisión Directiva en minoría deberá convocar dentro de los quince (15) días a Asamblea Extraordinaria para su integración hasta la terminación del mandato de los cesantes. 


\section{TITULO SEPTIMO}

\section{DE LAS ASAMBLEAS}

ARTICULO $35^{\circ}$ : Habrá dos clases de Asambleas Generales: Ordinarias y Extraordinarias. Las Asambleas Ordinarias tendrán lugar un vez al año y se convocarán con treinta (30) días de anticipación, y dentro de los tres meses posteriores al cierre del ejercicio económico que se producirá el día $3 \mathrm{l}$ de diciembre de cada año; a) para la asunción a sus respectivos cargos los miembros de la Comisión Directiva y Comisión Revisora de Cuentas en la forma prevista en el Artículo $24^{\circ}$ incisos e), f), g), i) y j); b) para tratar la consideración de la Memoria, Balance General, Inventario, Cuadro de Gastos y Recursos e informe de la Comisión Revisora de Cuentas, que correspondan, de acuerdo a lo previsto en el TITULO TERCERO de estos Estatutos; c) En ambos casos se podrán incluir en el "Orden del Día" de la Convocatoria, otro asunto de interés que deba ser resuelto por la Asamblea de Socios.-

ARTICULO 36 : Las Asambleas Extraordinarias serán convocadas con treinta (30) días de anticipación, por resolución de la Comisión Directiva. También podrá ser convocada por la Comisión Revisora de Cuentas o cuando lo solicite el diez por ciento $(10 \%)$ de los Socios con derecho a voto. La solicitud deberá ser resuelta dentro de un término no mayor de diez (10) días corridos. Sí no se resolviera la petición o se la negare infundadamente, podrán elevarse los antecedentes a la Dirección Provincial de Personas Jurídicas, solicitando la convocatoria por el Organismo de Contralor en la forma que legalmente corresponda.-

ARTICULO 37\%: Las Asambleas se notificarán con veinte (20) días de anticipación, mediante avisos en la sede Social y notas cursadas a cada uno de los Socios al último domicilio conocido en la Entidad, por dos (2) publicaciones periodísticas, realizadas con la anticipación dispuesta en periódicos de circulación en el partido donde tiene su domicilio la Entidad, y avisos en la sede Social. El Secretario deberá documentar el cumplimiento en término del procedimiento adoptado. En el momento de ponerse el aviso en la Sede, se tendrá en secretaría, con el horario que fije la Comisión Directiva y siempre que deban ser considerados por la Asamblea: un ejemplar de la Memoria, Inventario y Balance General, Cuadro de Gastos y Recursos e Informe de la comisión Revisora de Cuentas. En caso de considerarse reformas se tendrá un proyecto de las misma a disposición de los Asociados.

ARTICULO 38 : En la primera convocatoria las Asambleas se celebrarán con la presencia del cincuenta y un por ciento $(51 \%)$ de los Socios con derecho a voto. Una hora después, podrá sesionar en segunda convocatoria con no menos del veinte por ciento (20\%) de los Socios con derecho a voto.

ARTICULO 39०: En las Asambleas las resoluciones se adoptarán por simple mayoría de los votos emitidos y en forma nominal, salvo los casos previstos en el Estatuto que exigen proporción mayor. Ningún Socio podrá tener más de un voto y los miembros de la Comisión Directiva y Comisión Revisora de Cuentas se abstendrán de hacerlo en asuntos relacionados con su gestión. 


\section{DEL PADRON DE SOCIOS}

ARTICULO 40 : Con treinta (30) días con anterioridad a toda Asamblea, como mínimo, estará confeccionado por la Comisión Directiva, un listado de los Socios en condiciones de votar, el que será puesto a disposición de los Asociados en Secretaría, a partir de la fecha de la convocatoria. Se podrán oponer reclamaciones hasta cinco (5) días hábiles a la fecha de la Asamblea, las que serán resueltas por la Comisión Directiva dentro de los dos (2) días hábiles posteriores. Una vez que se haya expedido la Comisión Directiva sobre el particular, quedará firme el listado propuesto. A este solo podrán agregarse aquellos Socios que no hubieren sido incluidos por hallarse en mora con Tesorería y que regularicen su situación hasta veinticuatro (24) horas antes de la Asamblea. A estos efectos la comisión Directiva habilitará horarios amplios durante tres días anteriores al cierre de pagos.-

ARTICULO 41 ${ }^{\circ}$ : Para reconsiderar resoluciones adoptadas en Asambleas anteriores, se requerirá el voto favorable de los dos tercios de los Socios presentes en otra Asamblea constituida como mínimo con igual o mayor número de asistentes al de aquella que resolvió el asunto a reconsiderar.-

\section{TITULO OCTAVO}

\section{REFORMA DE ESTATUTOS, DISOLUCION, FUSION}

ARTICULO 42 : Estos Estatutos no podrán reformarse sin el voto favorable de los dos tercios de los votos emitidos en una Asamblea convocada al efecto y constituida en primera convocatoria con la asistencia como mínimo del cincuenta y un por ciento $(51 \%)$ de los Socios con derecho a voto y en segunda convocatoria con el Quórum mínimo previsto en el ARTICULO 38.-

ARTICULO 43: La Institución sólo podrá ser disuelta por la voluntad de sus asociados en una Asamblea convocada al efecto y constituida de acuerdo a las condiciones preceptuadas en el Artículo anterior. De hacerse efectiva la disolución se designarán los liquidadores que podrán ser la misma Comisión Directiva, o cualquier otro u otros Asociados que la Asamblea resuelva. La Comisión Revisora de Cuentas deberá vigilar las operaciones de liquidación. Una vez pagadas las deudas sociales, el remanente de los bienes se destinará a la Sociedad de Bomberos Voluntarios de Berisso, con domicilio en la ciudad de Berisso, Provincia de Buenos Aires, reconocida como Persona Jurídica bajo Matrícula $\mathrm{N}^{\circ} 1.057$ y Legajo $\mathrm{N}^{\circ} 1.618$ de la D. P. P. J. de la Provincia de Buenos Aires.

ARTICULO $44{ }^{\circ}$ : Esta Institución no podrá fusionarse con otra u otras similares.

\section{DISPOSICION TRANSITORIA}

ARTICULO 45 : Quedan facultados el Presidente y el Secretario, para aceptar las modificaciones que la Dirección Provincial de Personas Jurídicas, o que cualquier otro organismo formule a estos Estatutos, siempre que las mismas se refieran a simples cuestiones de forma y no alteren el fondo de las disposiciones establecidas.- 


\section{Anexo No 6: Bandera y Escudo de Berisso $^{207}$}

\section{Bandera de Berisso:}

En el año 2003 se efectuó un llamado abierto a la comunidad para presentar proyectos de diseños para designar una Bandera que identifique al Distrito. El diseño elegido fue presentado por la joven Marilina Hortel y en un acto llevado a cabo el 5 de diciembre de 2003 en el Centro Cívico, se izó por primera vez la insignia local.

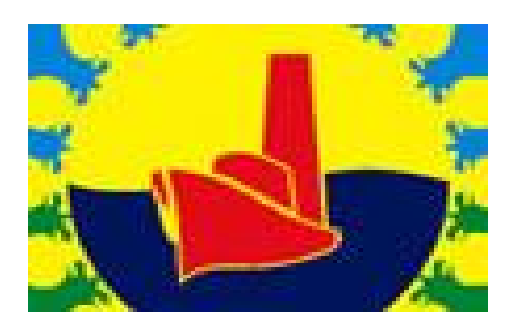

\section{Elementos constitutivos:}

- La torre o chimenea

Símbolo de una ciudad pujante donde el trabajo en los frigoríficos fue una actividad por excelencia, constituyendo una de las principales fuentes laborales para la mano de obra extranjera.

- El barco

Símbolo de la afluencia de los inmigrantes que llegaron a este suelo con la esperanza de construir un futuro propicio y en paz.

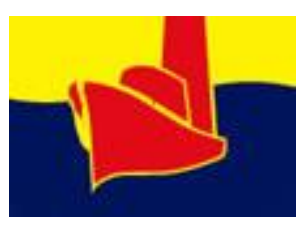

- El sol

Símbolo de una ciudad naciente que ilumina a todos sus habitantes.

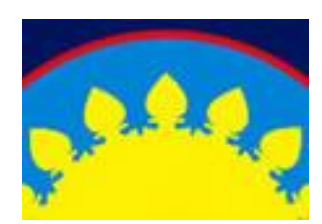

- Las cenefas

Determinadas por los rayos del sol configuran los elementos ornamentales que se colocaban en las viviendas y las cuales constituyen el patrimonio arquitectónico de nuestra ciudad.

\footnotetext{
${ }^{207}$ Fuente: http://www.berisso.gov.ar/historia.php
} 


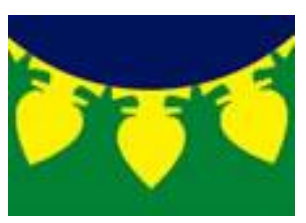

\section{Función simbólica de los colores:}

El color Rojo simboliza todo aquello que fue creado por el hombre y está ligado al principio de la vida, la fuerza y la energía. El Amarillo es un color que posee connotaciones características de nuestra ciudad: fuerza activa, radiante y expansiva. El color Azul es el símbolo de la profundidad solemne que suscita una predisposición favorable.

\section{El escudo de Berisso}

El 13 de julio de 1967, por Decreto $\mathrm{N}^{\circ} 593$ se llamó a concurso público promoviendo la presentación de proyectos para diseñar el Escudo de la ciudad. Así, por el Decreto 632 del 29 de septiembre de 1967 se adoptó como Escudo de la ciudad de Berisso el proyecto presentado por Luis Sixto Romano, bajo el seudónimo "las 14".

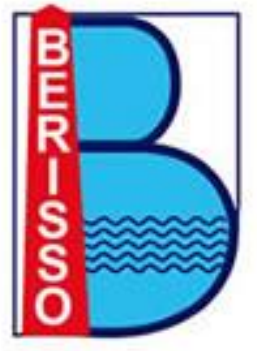

Se trata de un escudo de campo rectangular con una sus esquinas redondeadas. En el interior del mismo contiene una letra B mayúscula simbolizando la primera inicial del nombre de nuestra ciudad, cuyo fondo es azul. En el margen izquierdo de dicha letra se sitúa una forma que representa a una chimenea, que hace referencia a la actividad fabril que se desarrolló durante años en la ciudad. En el interior del ojo de la letra $B$ se encuentran cinco líneas ondulantes en blanco. Estas hacen referencia de una ciudad ribereña.

La forma rectangular y su partición son atípicas a todos los escudos de distintas nacionalidades debido a que Berisso es un verdadero crisol de razas. El cielo e inicial del apellido del fundador va esmaltado de azul claro, por ser éste, color propio y simbolizar justicia, verdad y lealtad. Una nube blanca es la luz pura del esplendor. La chimenea de ladrillos rojos nos habla de energía representando en éste caso el saladero San Juan, punto de partida de la industria carnea a cuya sombra creció la ciudad. Las cuatro líneas onduladas son simbólicas de los cursos hidrográficos, que cruzan el partido formado el Delta del Santiago. 


\section{Anexo N7: Fotográfico de la Fiesta Provincial del Inmigrante}

1) Misa Inaugural

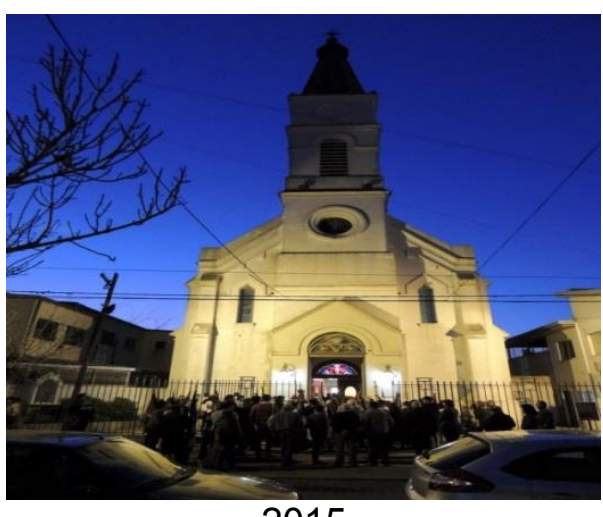

2015

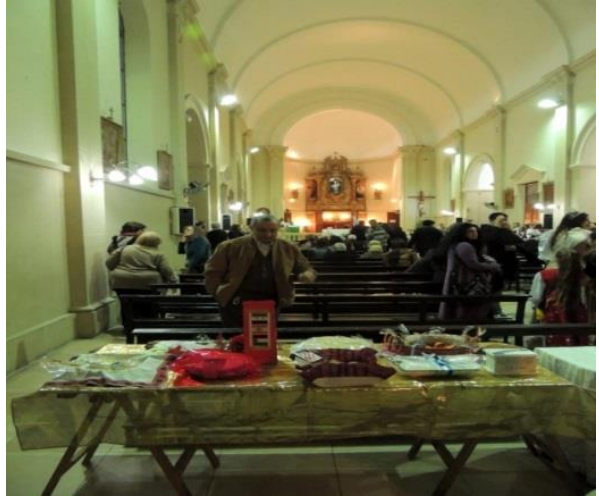

2015

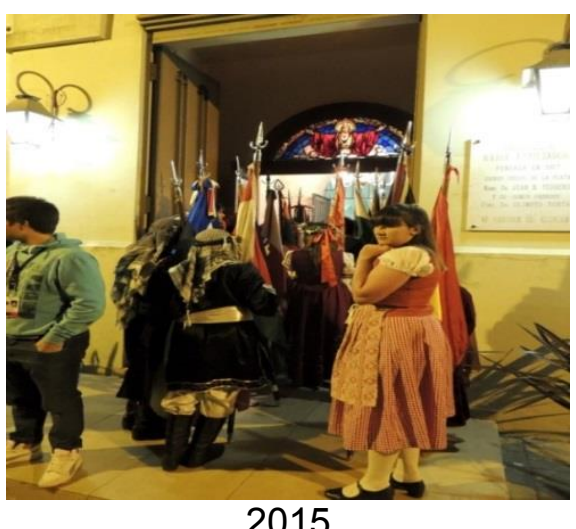

2015

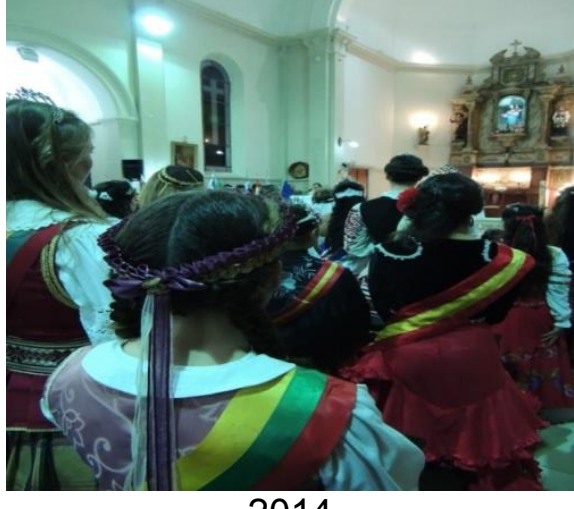

2014

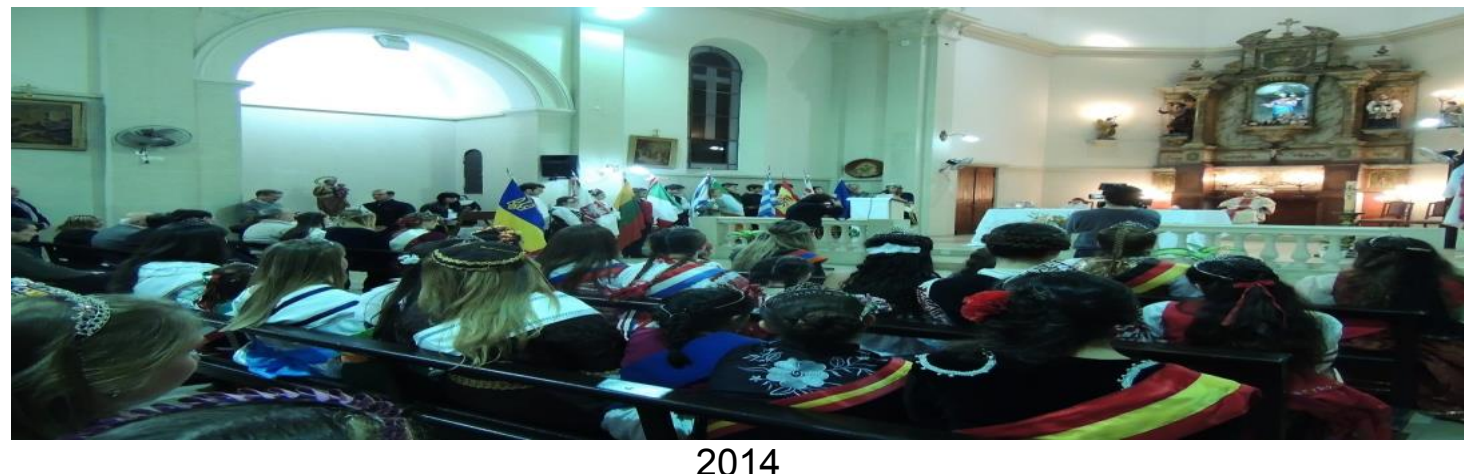

2014

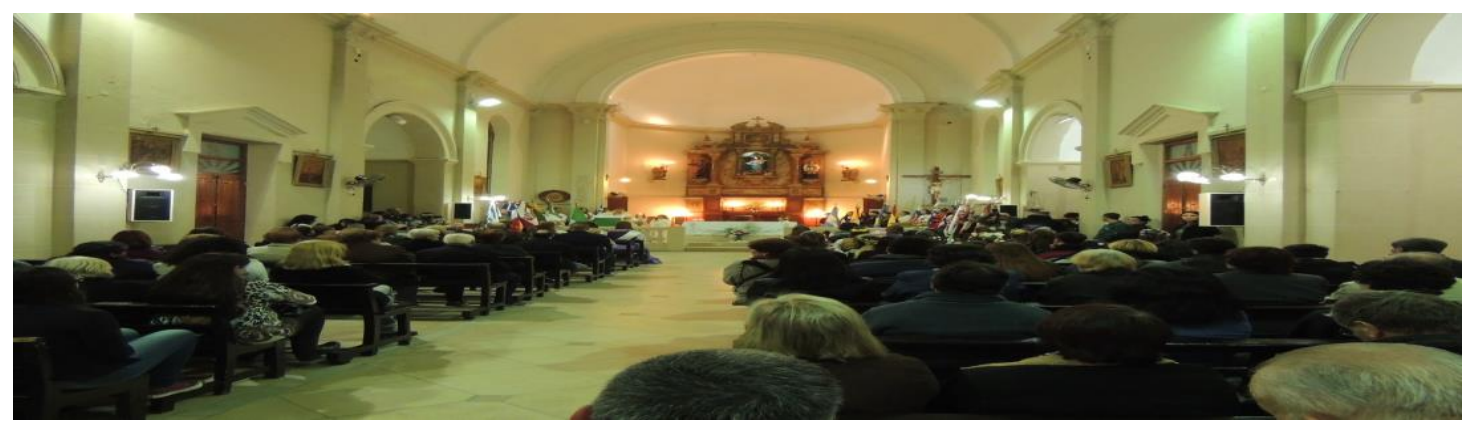

2015 
2) Encendido de la Lámpara Votiva y Posta del Inmigrante
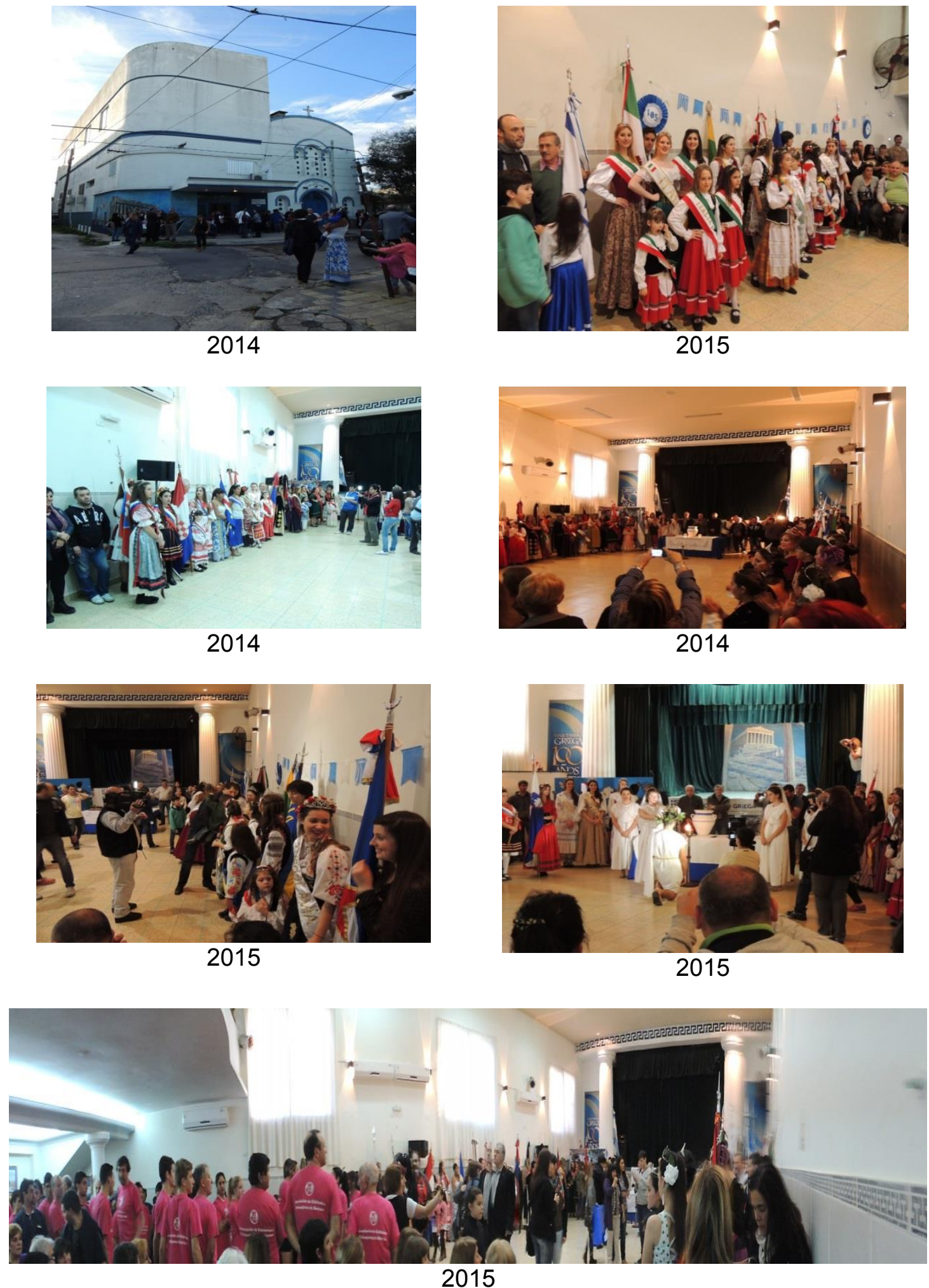

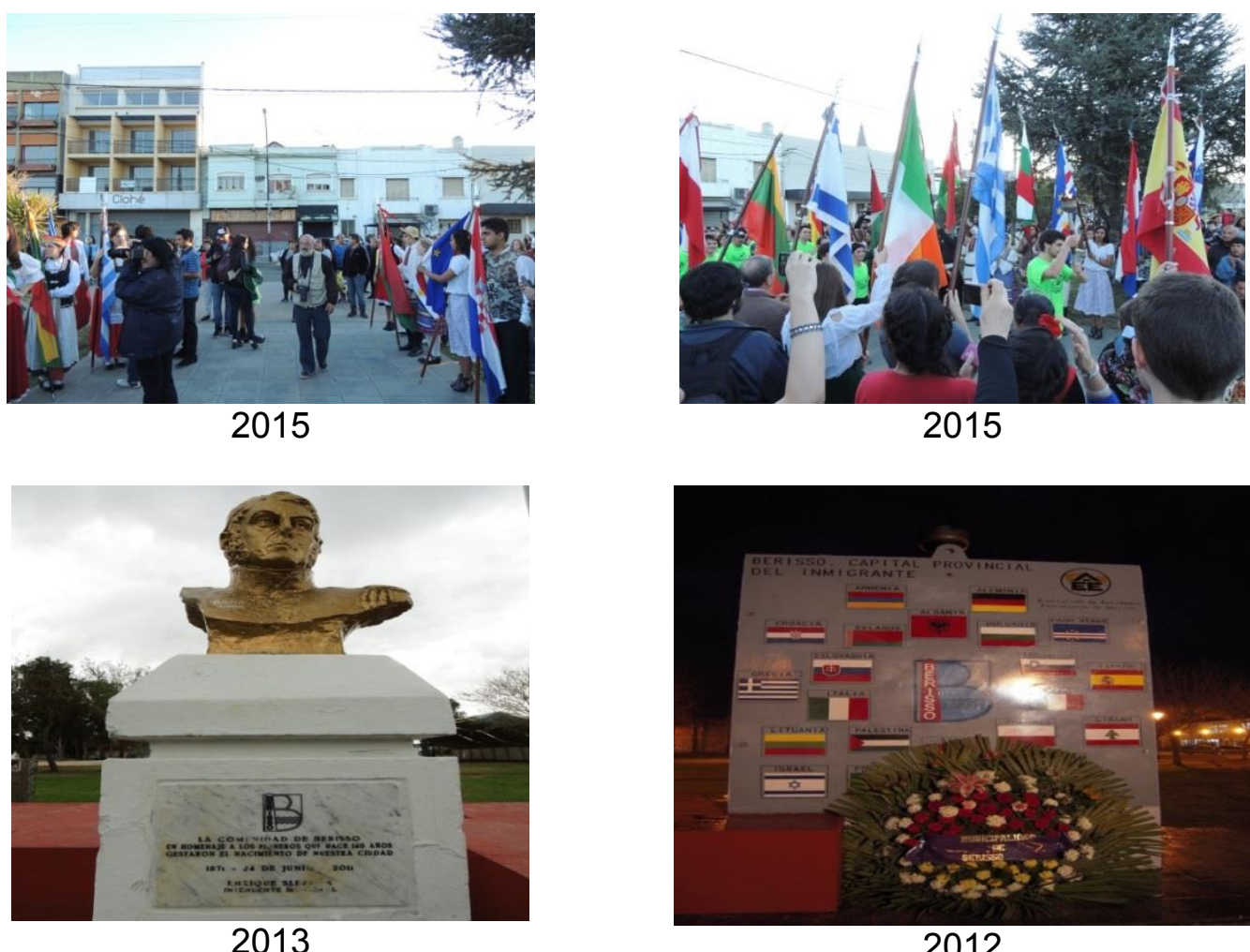

2012

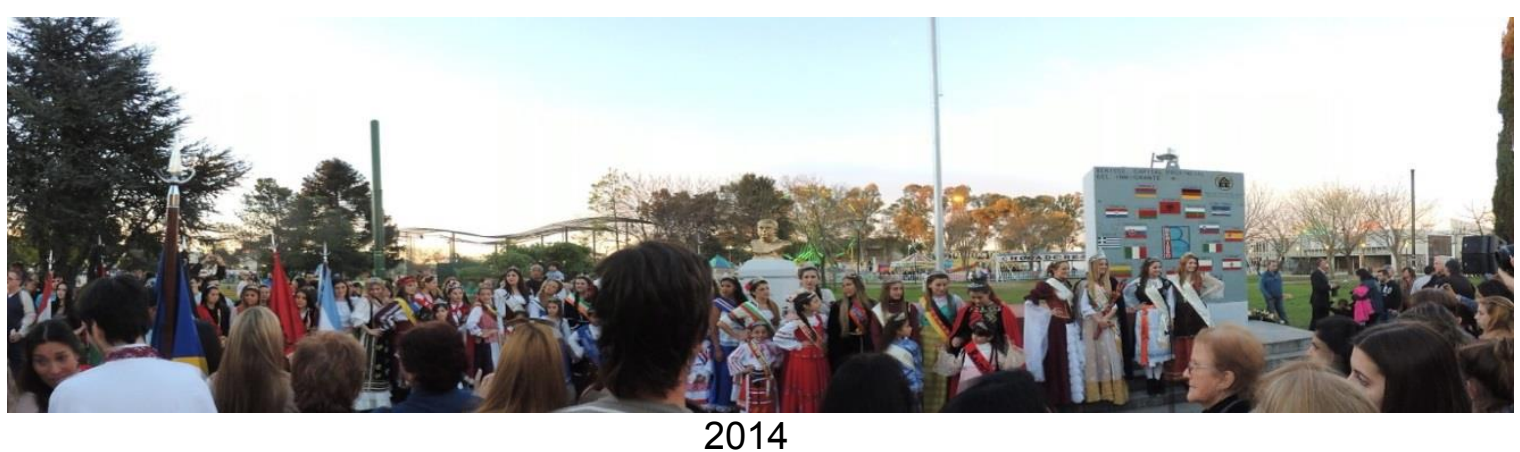

3) Desembarco

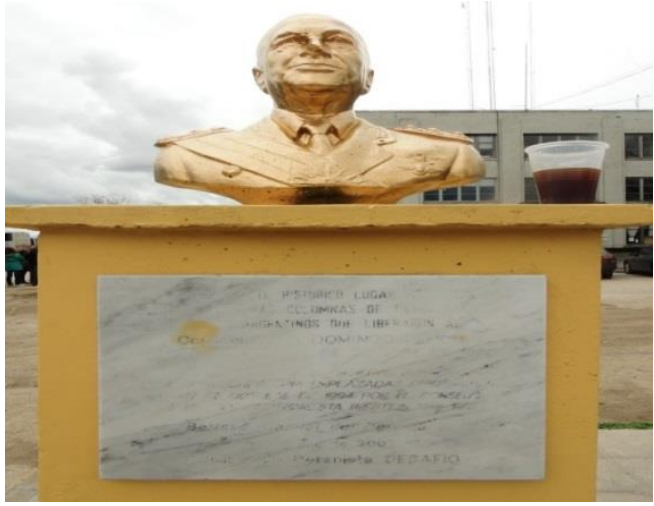

2013

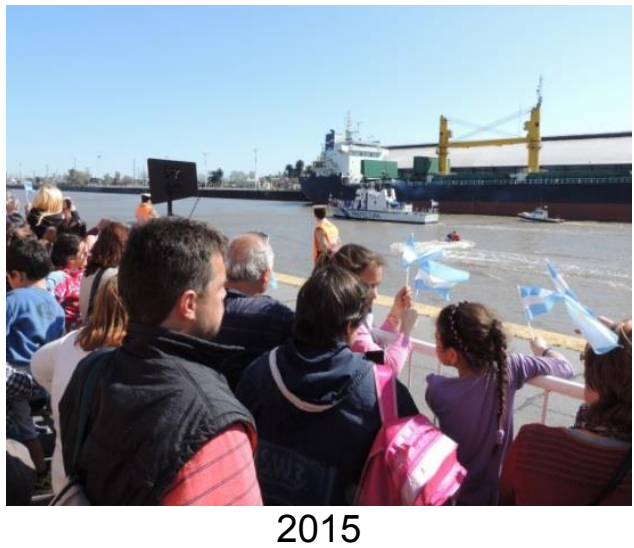



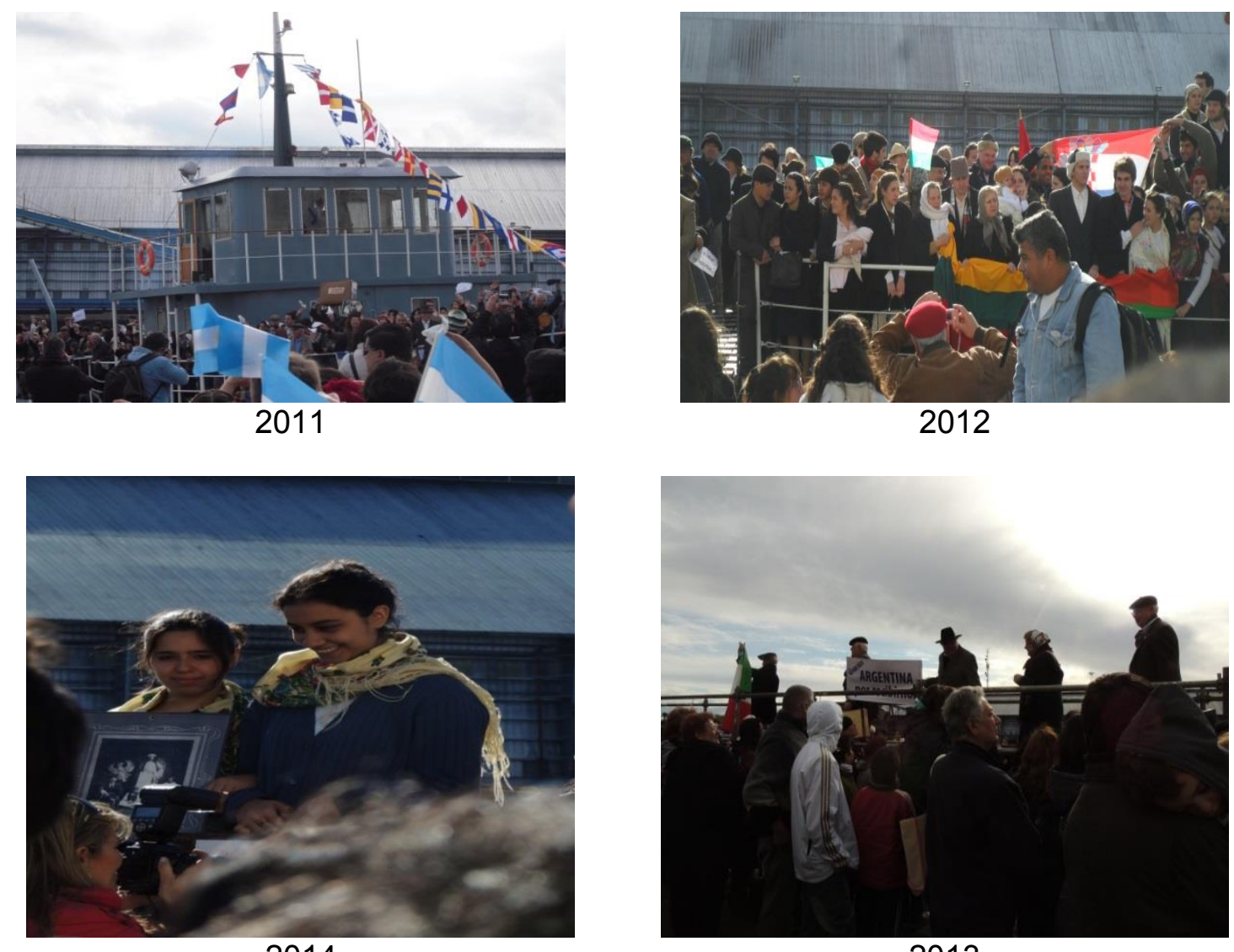

2013

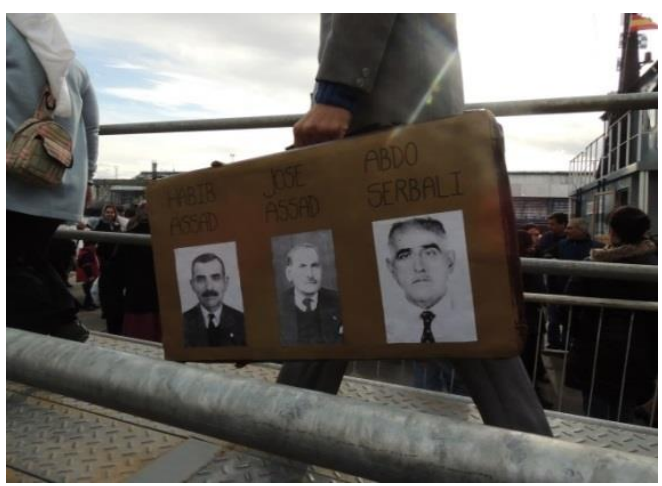

2013

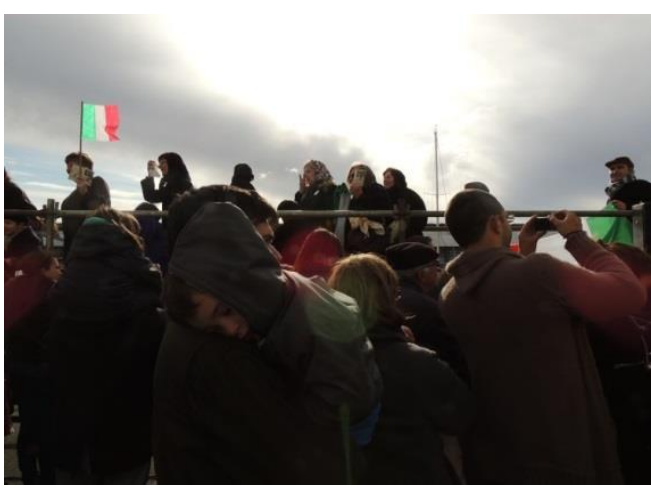

2013

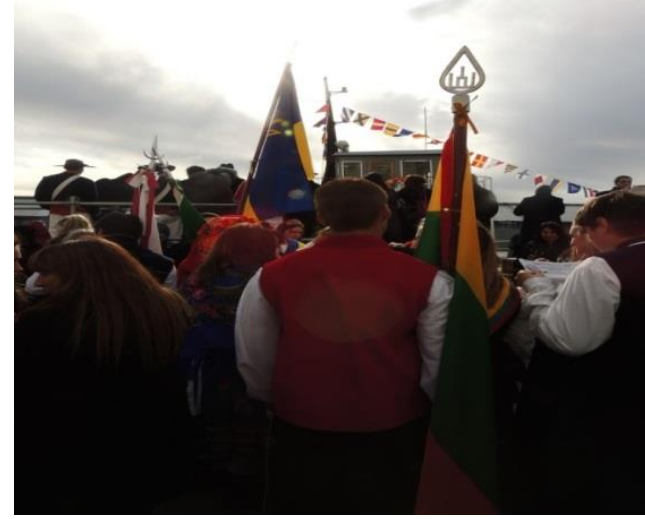

2013

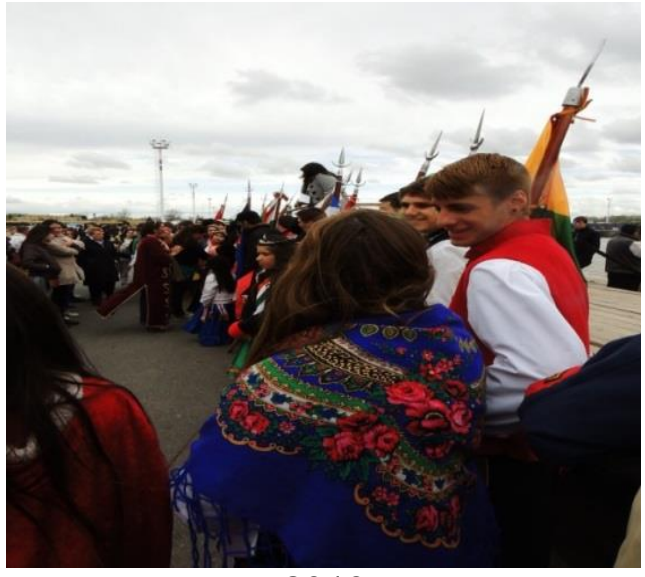

2013 


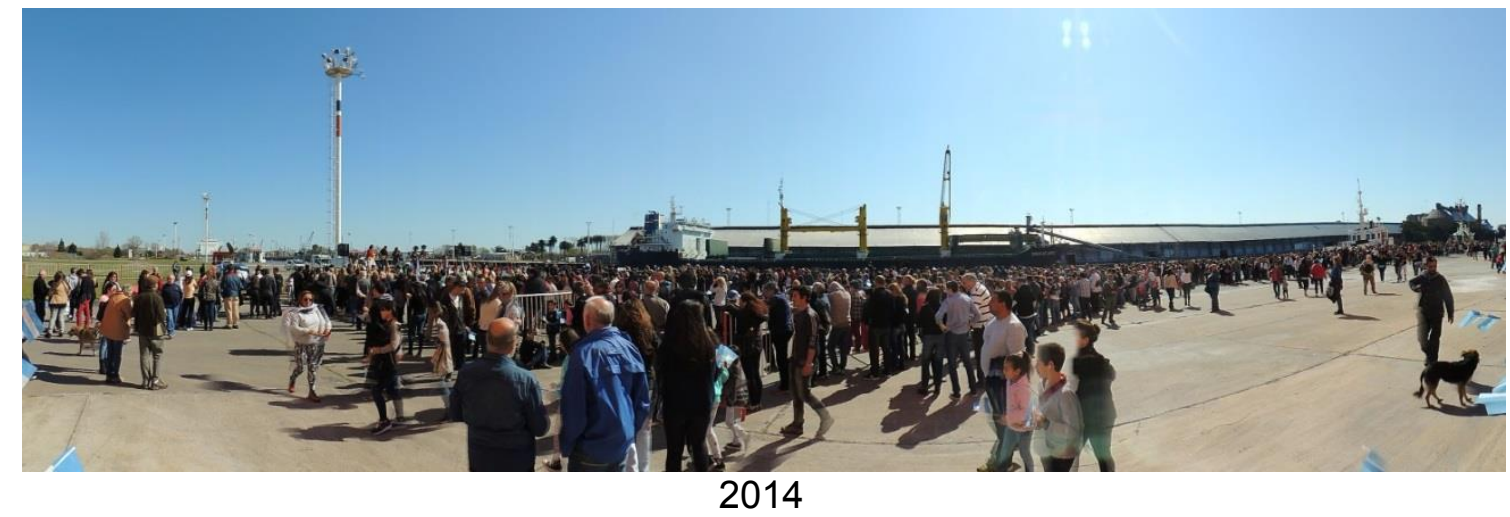

4) Sobre el Centro Cívico: Carpa de las Colectividades

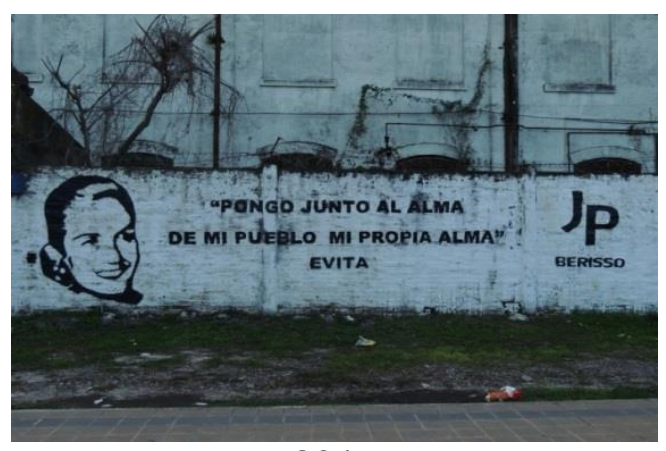

2015

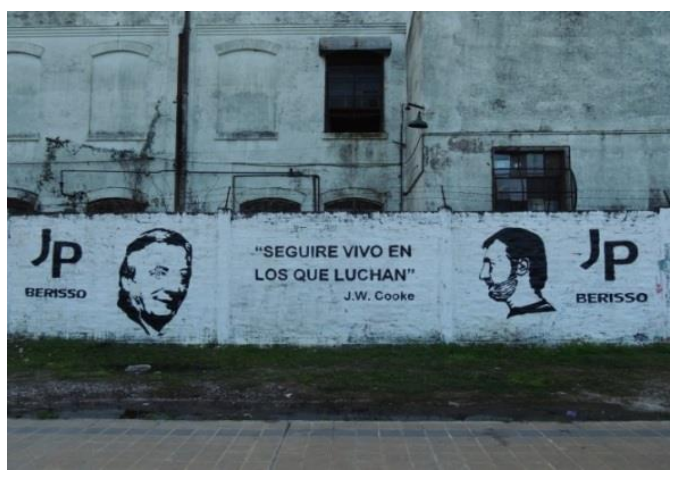

2015

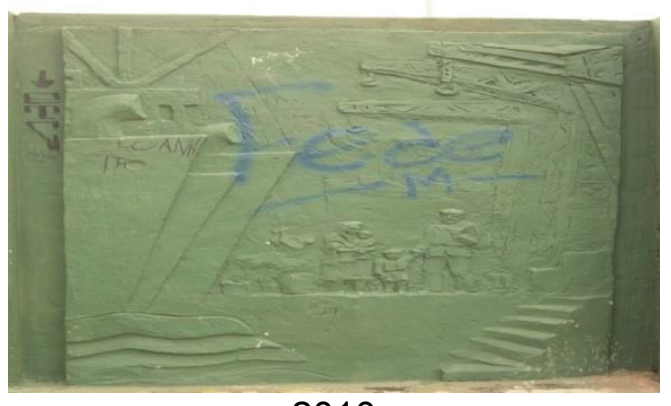

2010

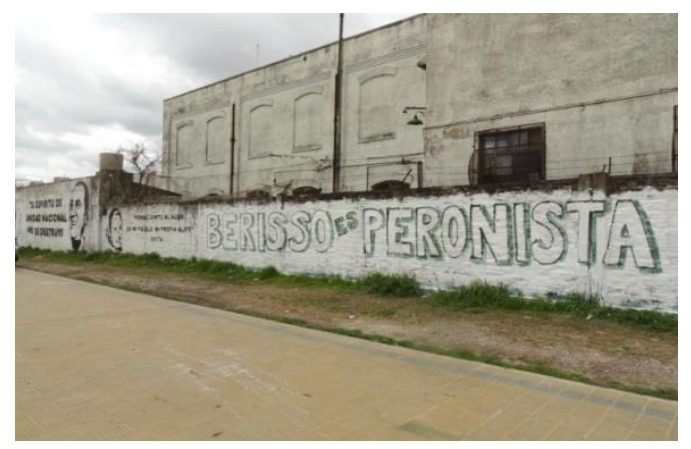

2013

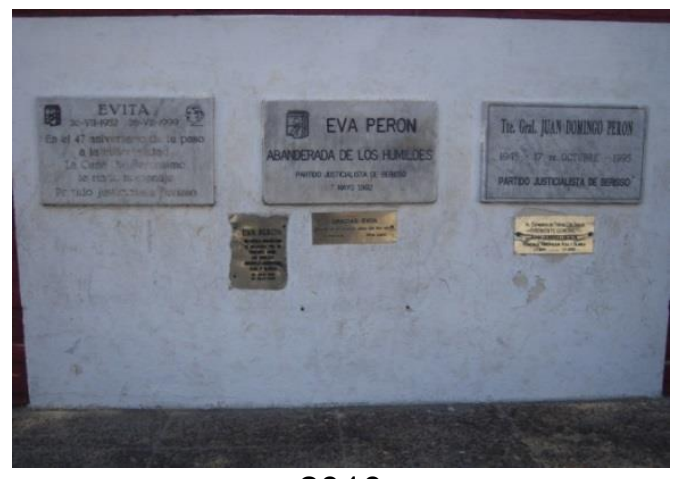

2010

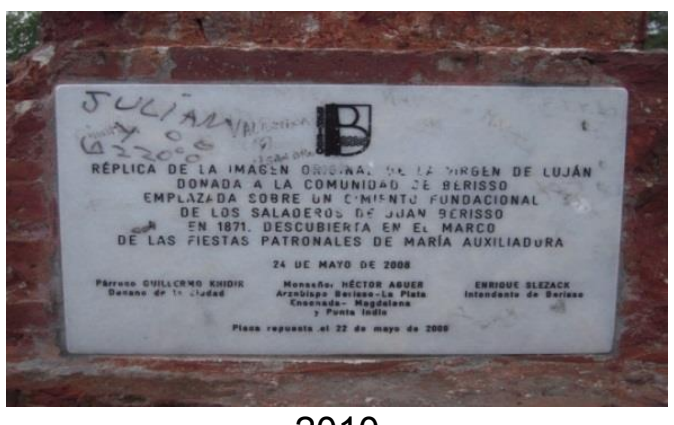

2010 


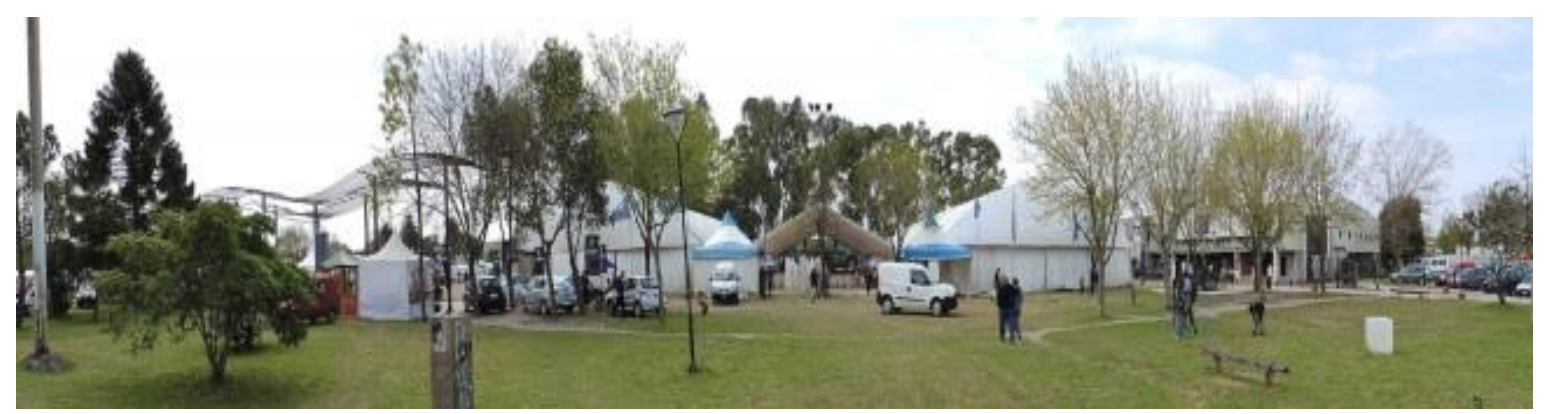

2013

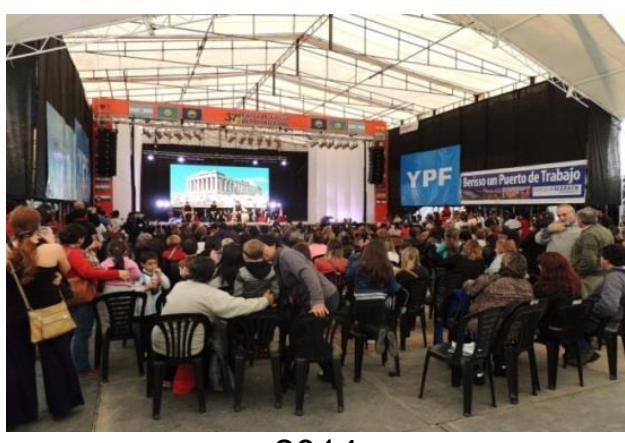

2014

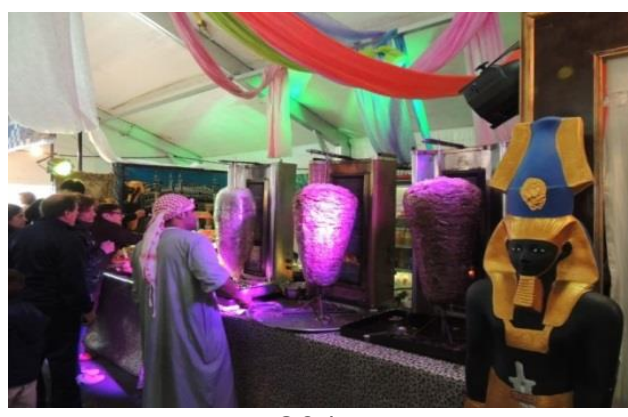

2015

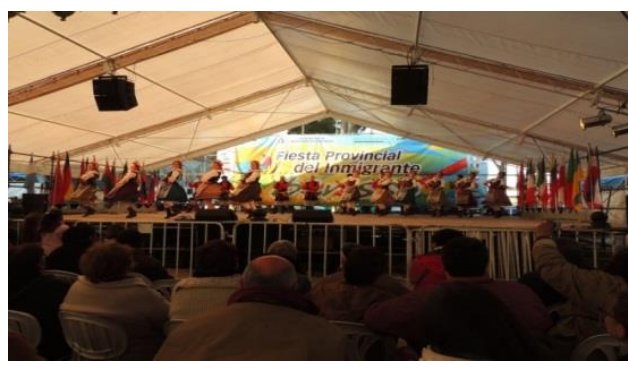

2013

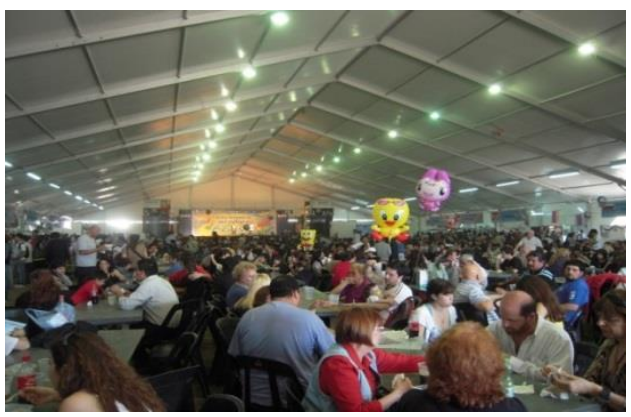

2010
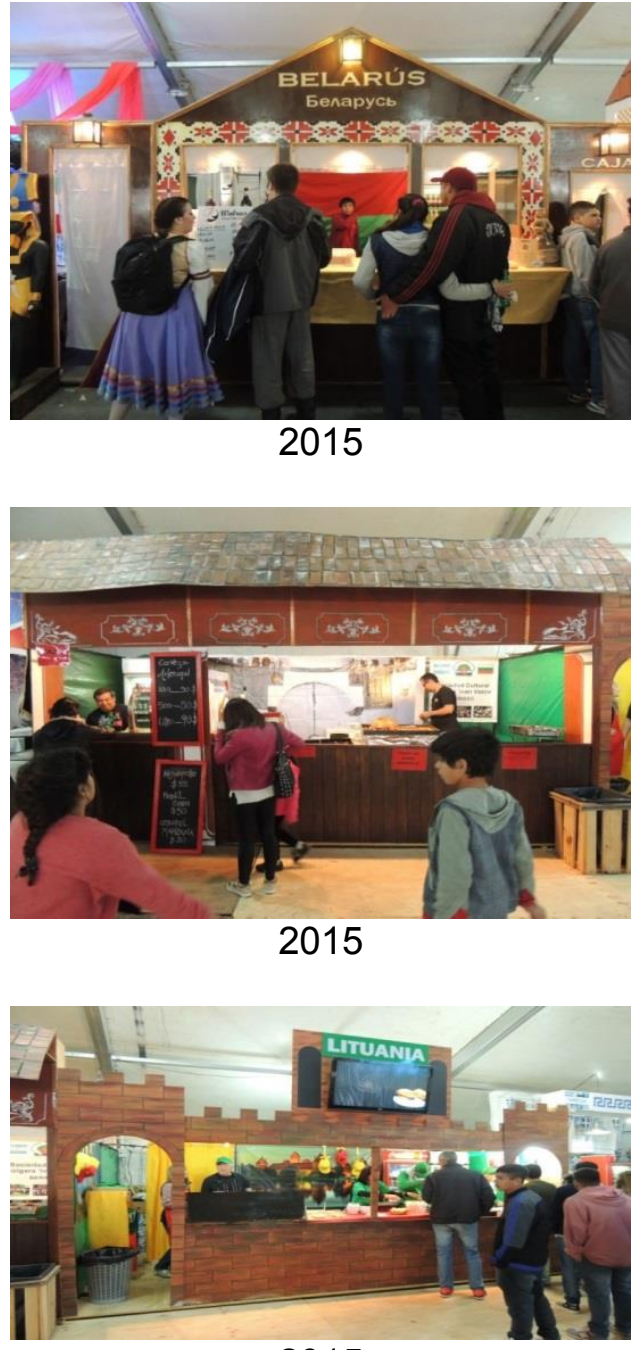

2015

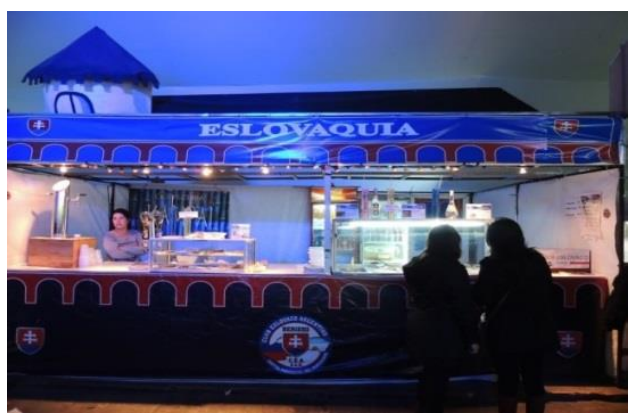

2014 

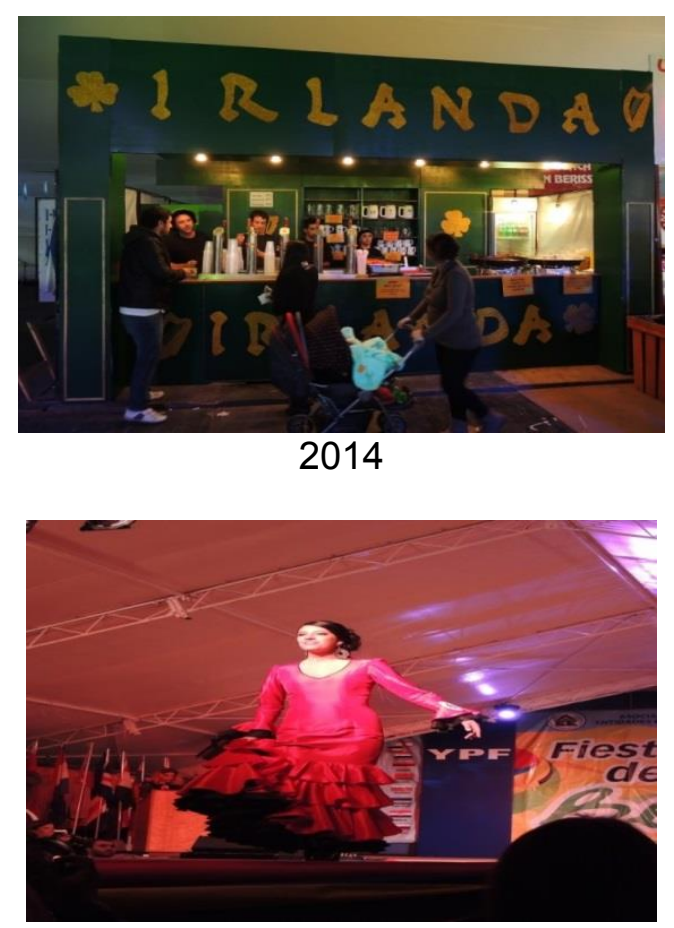

2013

5) Desfile de Clausura
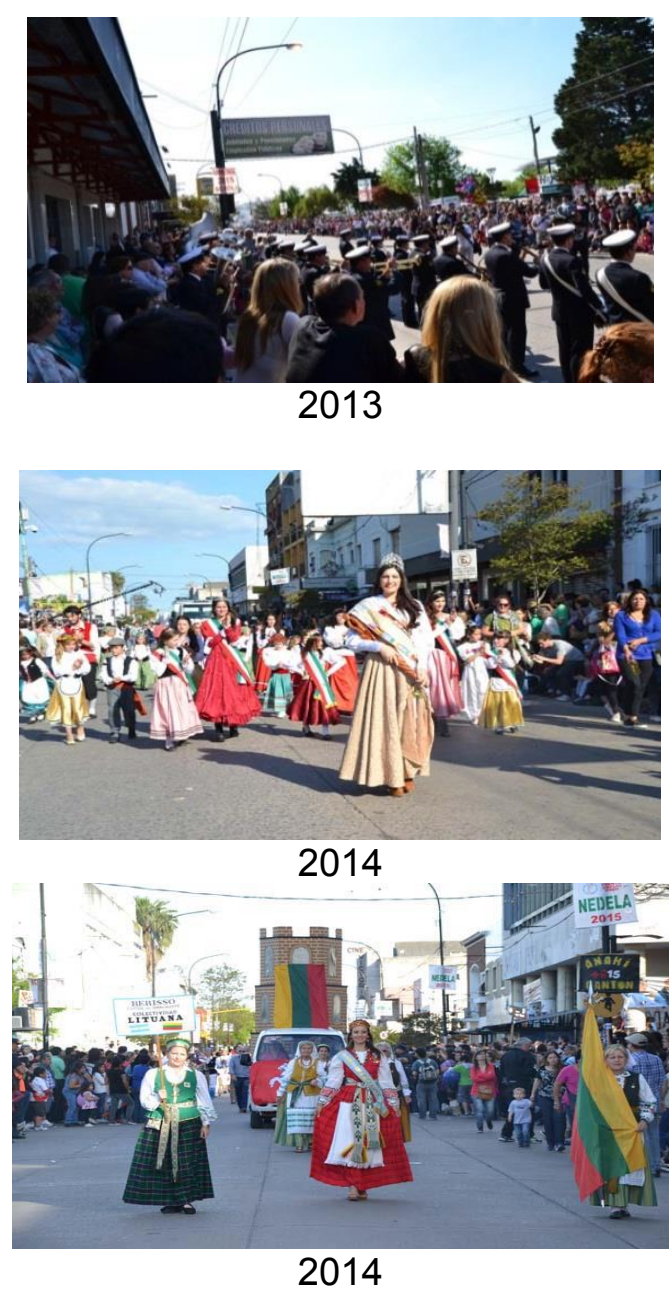
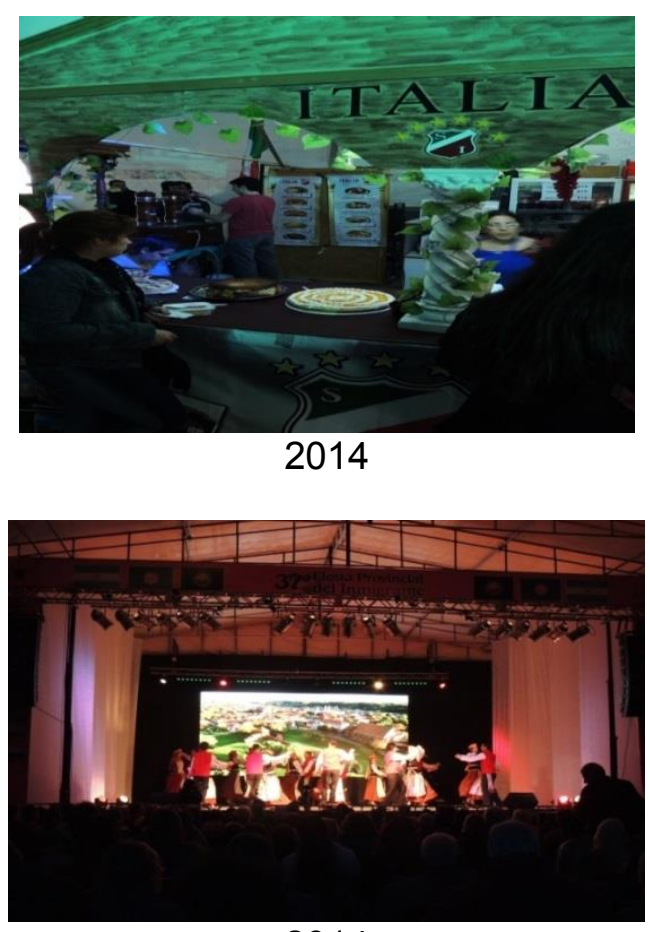

2014

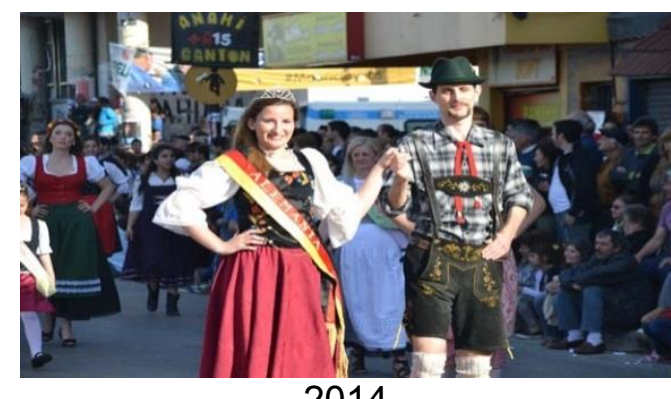
2014
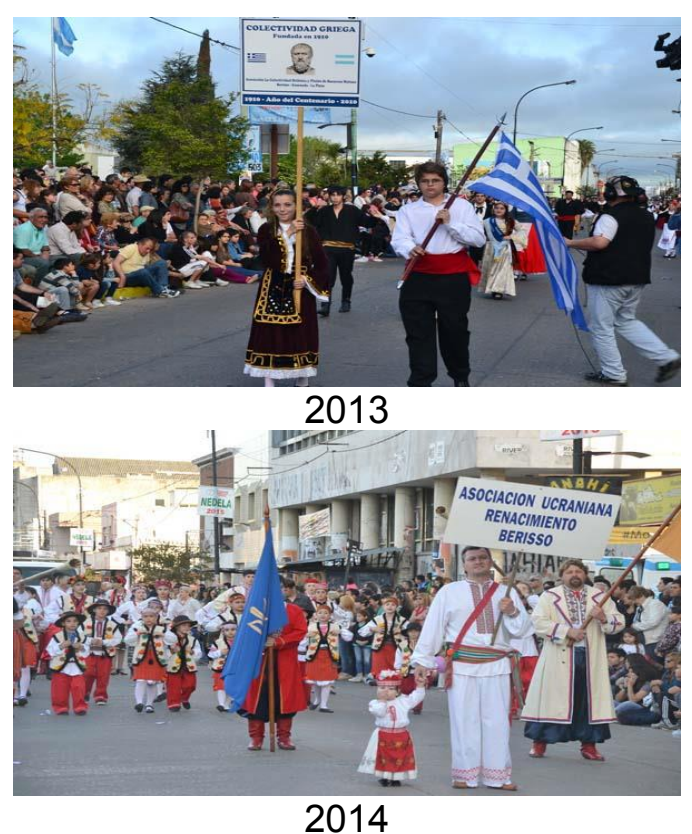


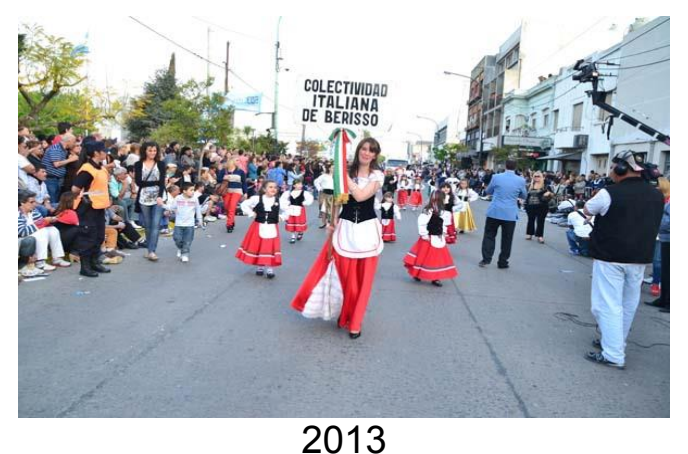

6) Banderoteca
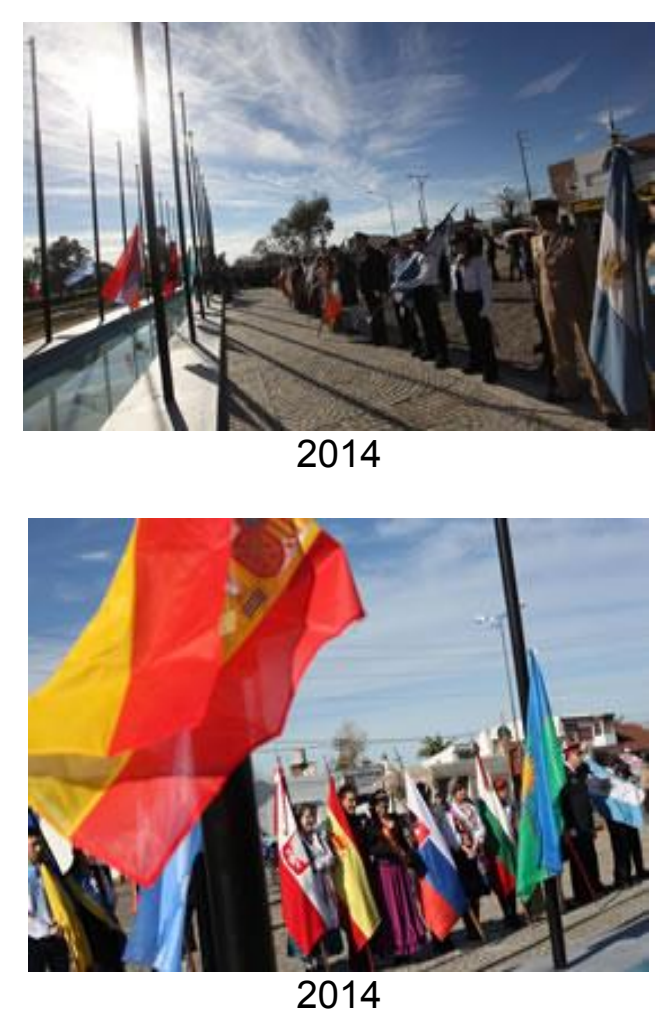
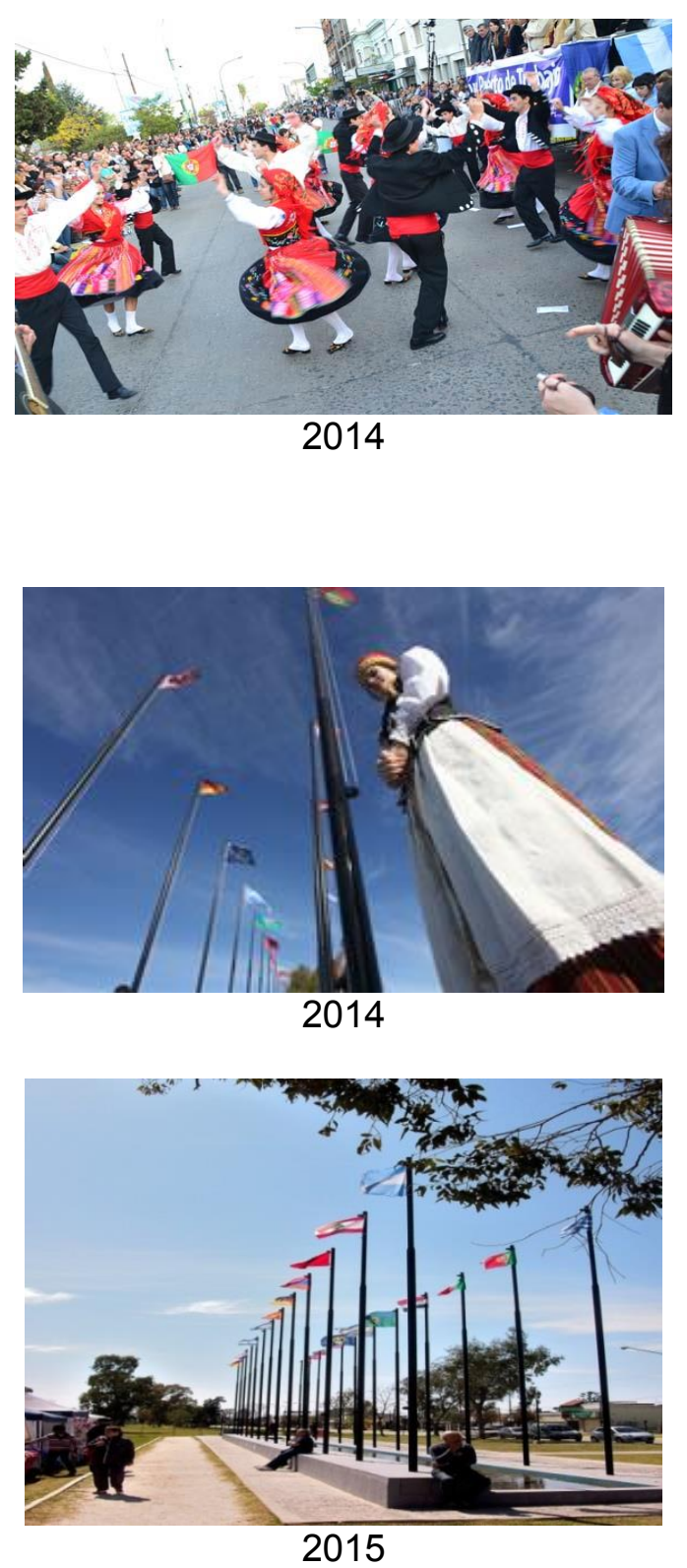